
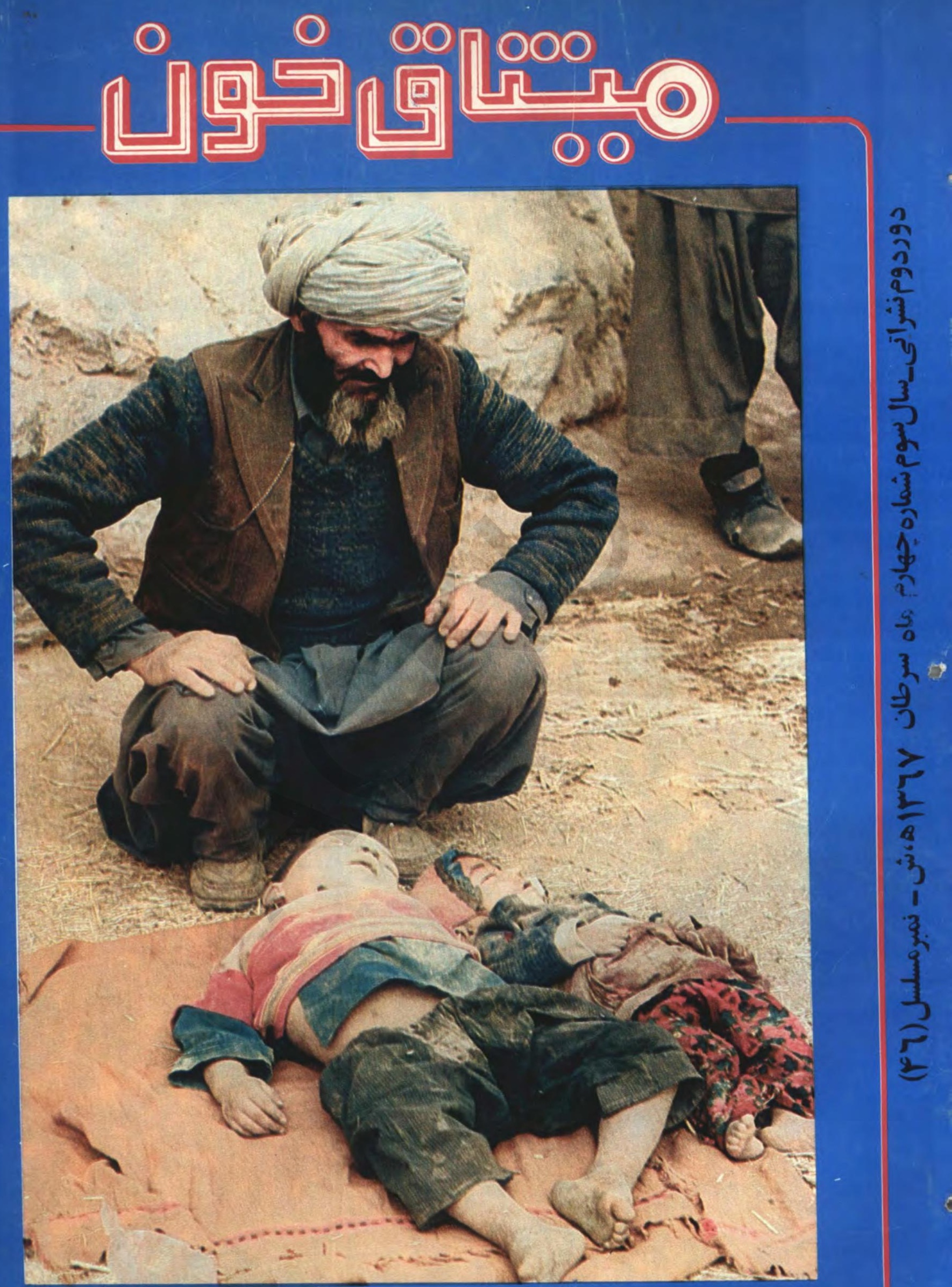


\section{الههى فرمسان}

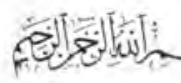

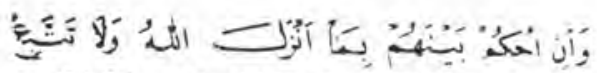

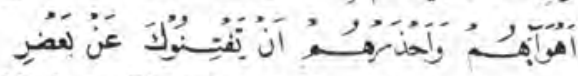

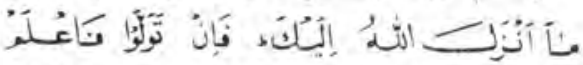

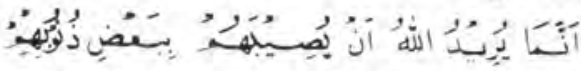

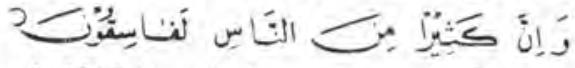

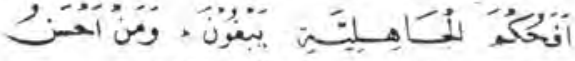

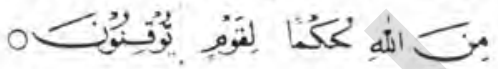

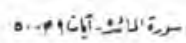

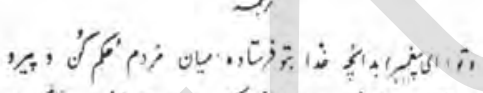

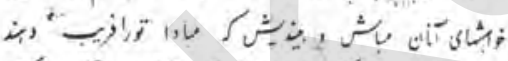

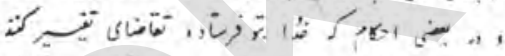

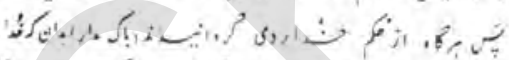
itr, , il

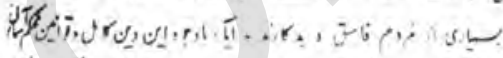
لز ؟11 -

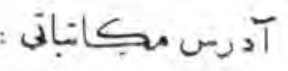

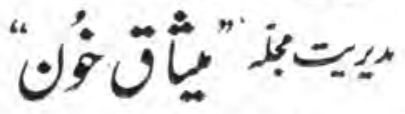

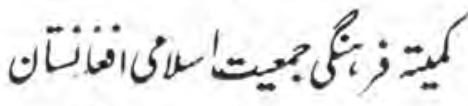

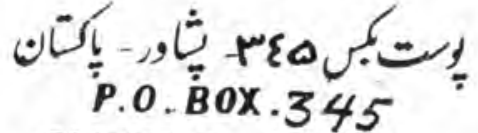
P.O. BOX. 345
PSHAWAR - PARISTAN 

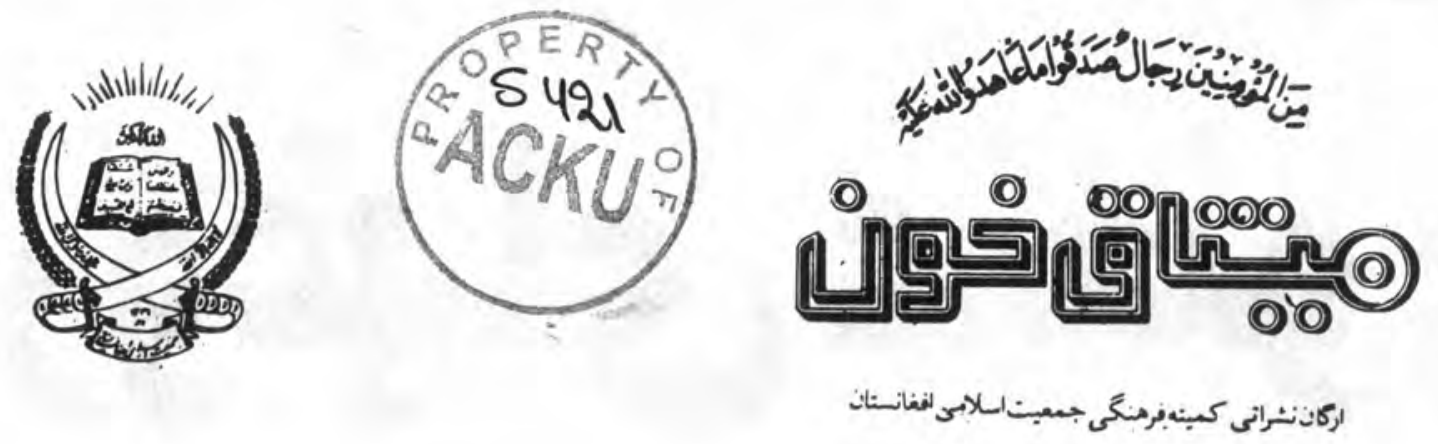

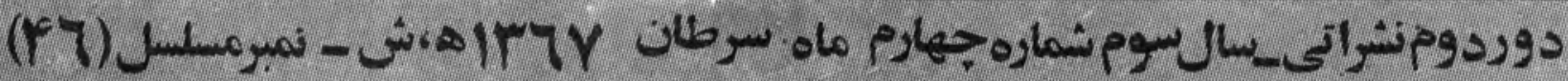

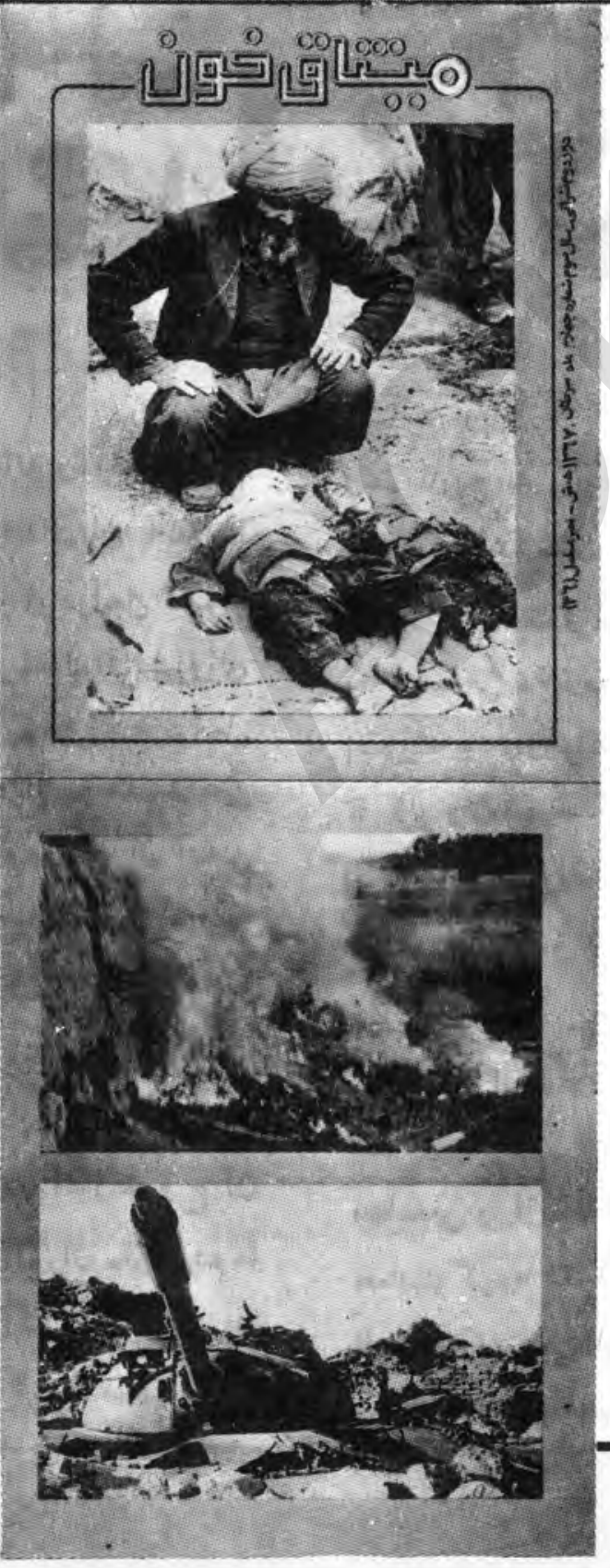

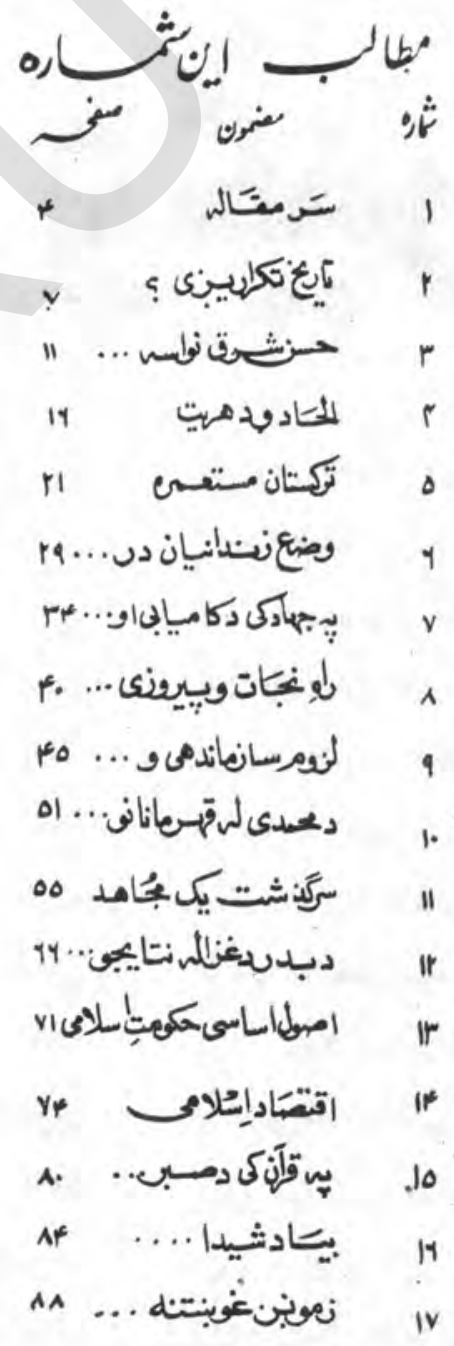

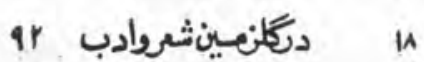

19 

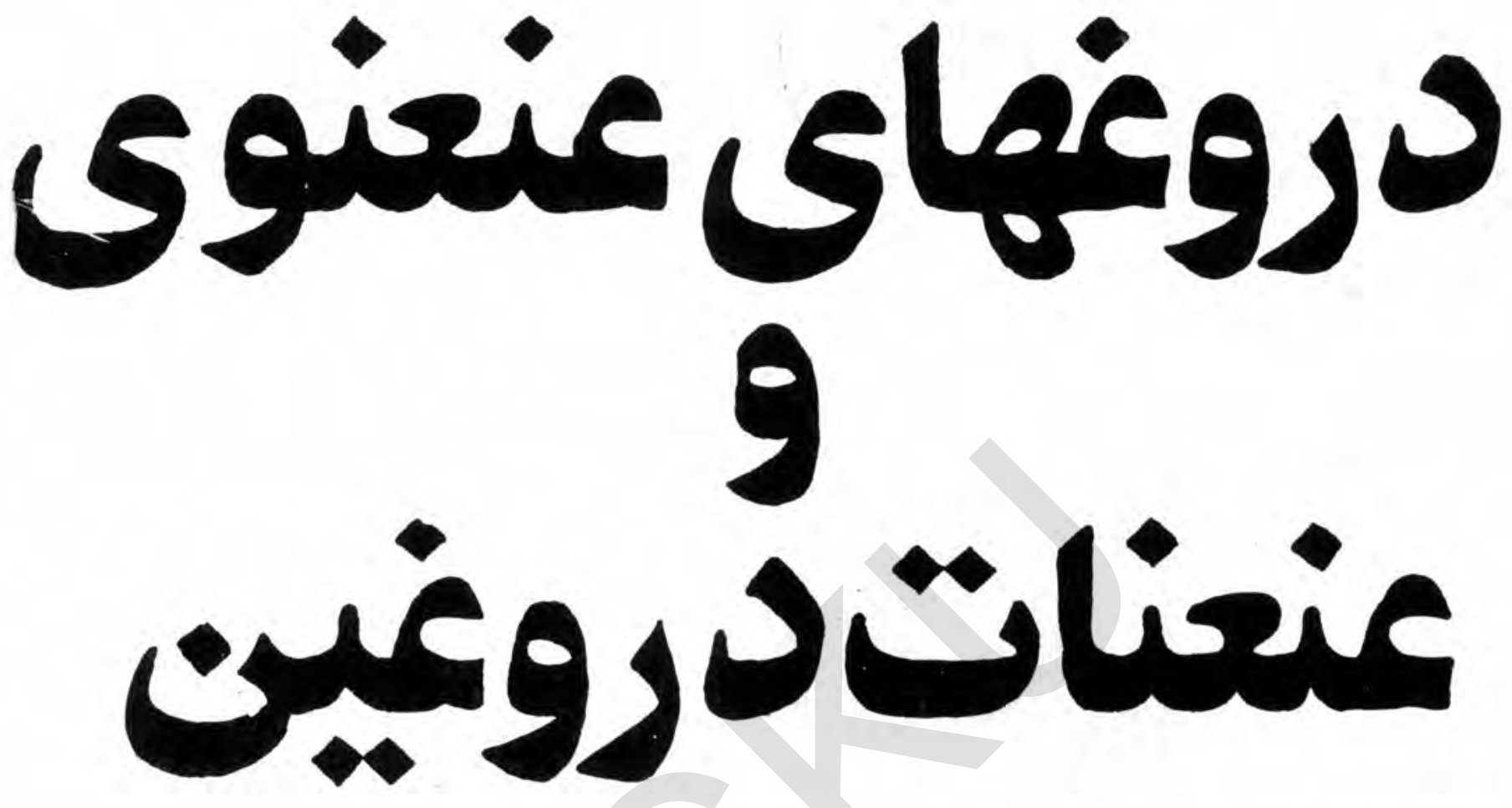

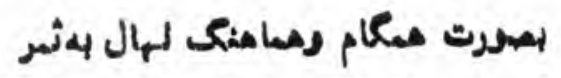

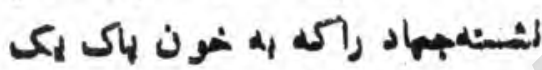
لميم بليونث مهيد كمكون كفن ازلهقرين

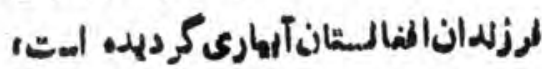

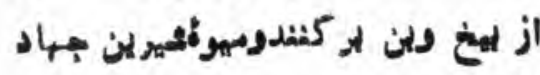

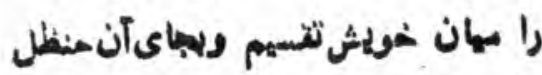

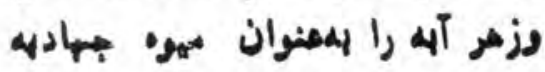
مودم ما ليغررائيد.

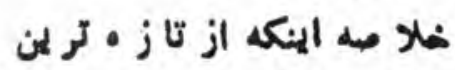

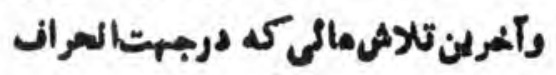

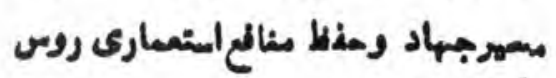

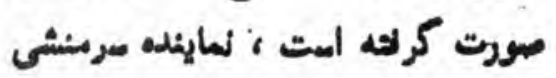
ملل متعد اتاى كوردوليز بلمهاجرين

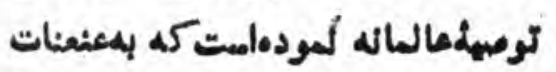
حميش رجوبلهالئدومسايلومسفنلات

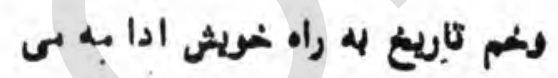

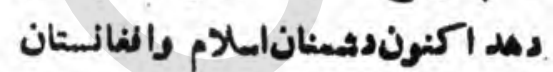

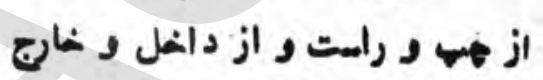

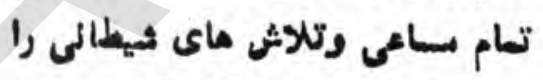

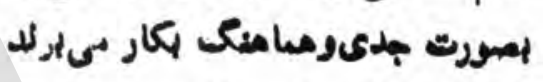

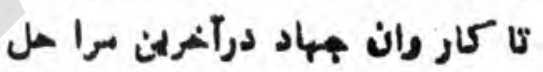

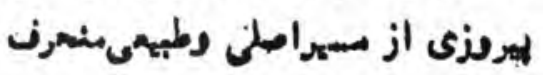

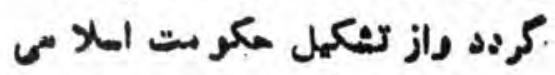

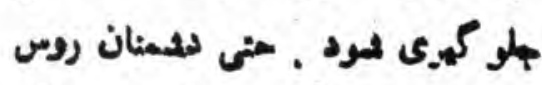

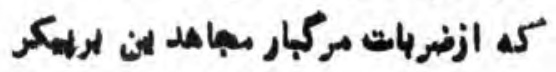

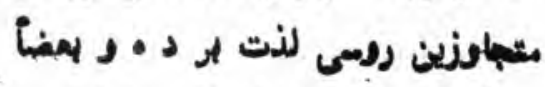

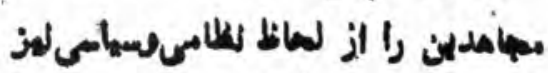

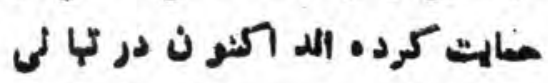

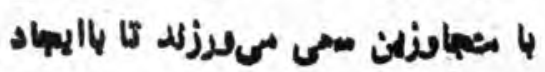

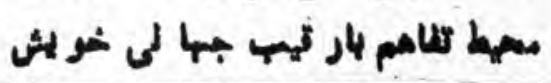

بهاد مسلعاله وخونلار مردم مهامل ولهاعماسته الفالهتان باكذثت ده مال دام وكذر از مرامل ددوار

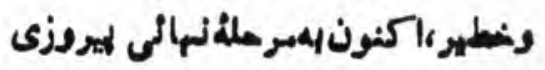

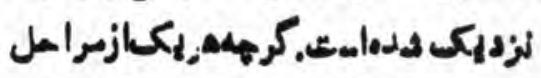

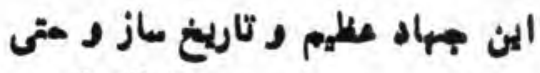
مر هالل ، مر ماه وهر روز آن آلهين

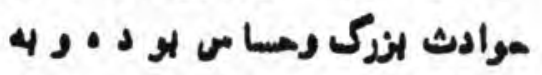

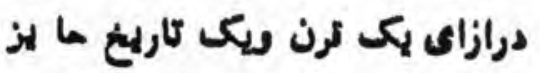

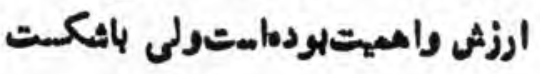
تواى شنهاوز وجنايت كار ردم دره

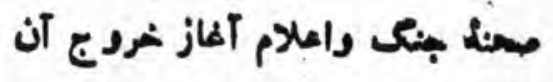

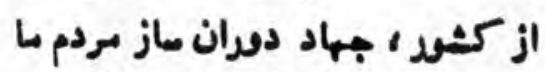
ارد مرحله بس انزرك ومساس كرديده.

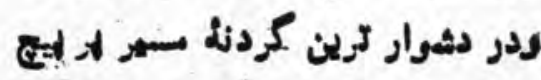


لعباميم و الدامات دان رواج بالهه اهت له عنوان مغعنه "الهالهم مردم

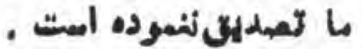

V. كنتهنباله كذاثةت كمهساب

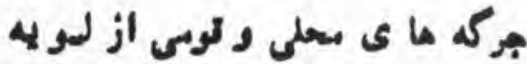

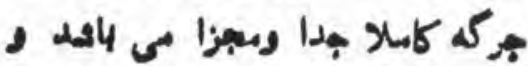

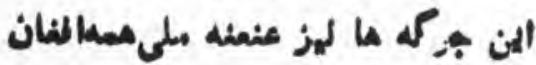

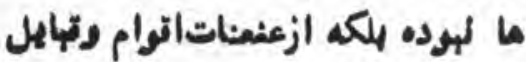

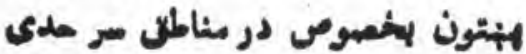

هر مل و بنول كمور ما مى لادـد

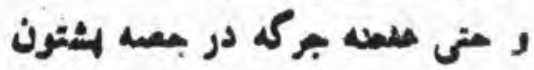
نشين امسورت كل وجود لدارد كابل

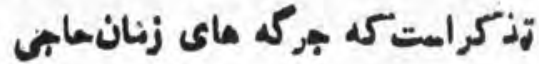

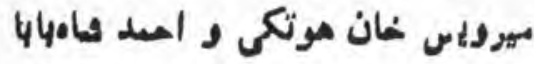

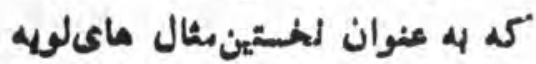

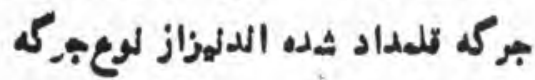

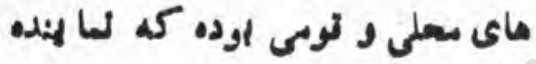

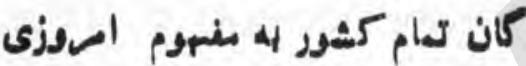

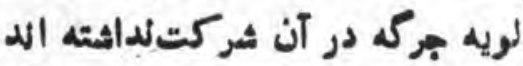

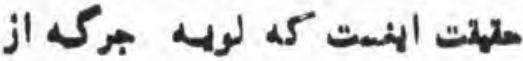

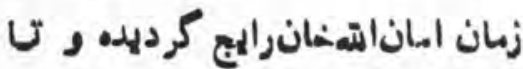
امروز هم رثيم ها از آن به. هندوان

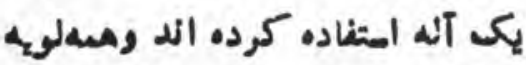

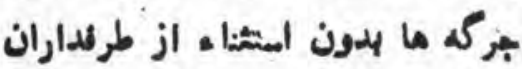
و مدامانرزيم ما متثكل بودهاست

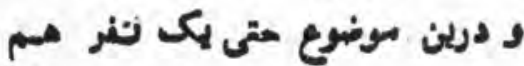

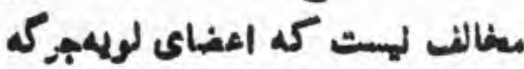

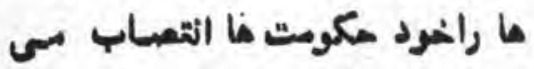

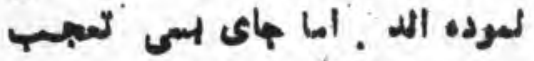

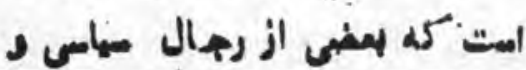

ازلين لارمت د دراز لمسودن د مـت

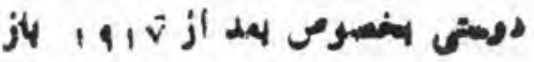

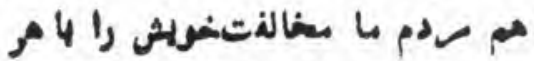
الدام مبنى لر لزدهلكى و دوستى 4

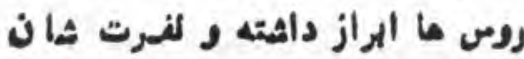

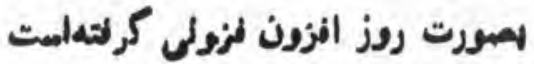
هدران ما روس ما را باير، متعكار،

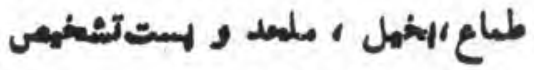
داده و مديثه آلان را دثمندانسته

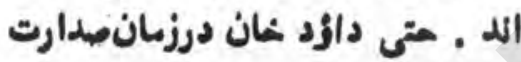

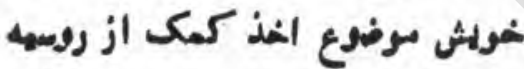

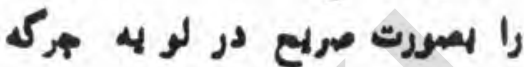

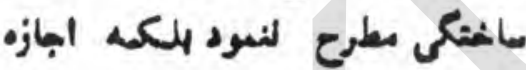
كرفت كا ازهر منبعى كم مناسبهلاثلد

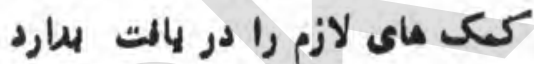

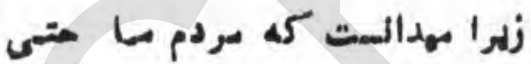

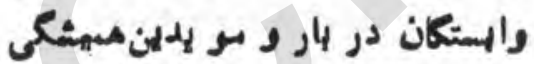

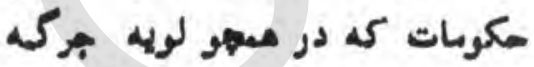

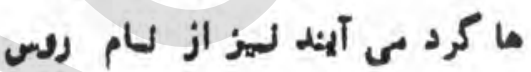

خلامه الينكه ثمار دوستى

منعنوى الففان ها و روس ها ها هكىاز

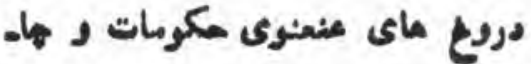

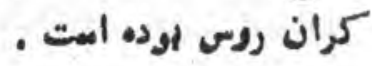

4ه معن مورت ه لويه جركمه

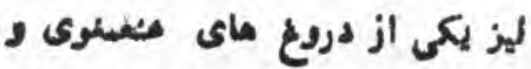

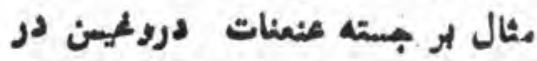

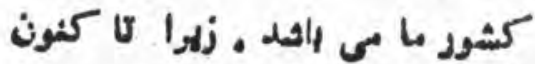

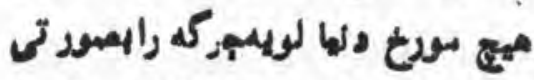

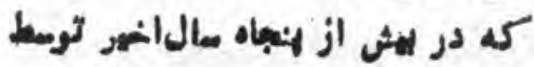

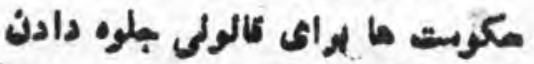

را از آن طر يلى مل كميد معهيا ن ممزمان 14 ملام طرح بهديد كور دوليز مبنى الر تلدوبر لوبه جزكم، راديوماى

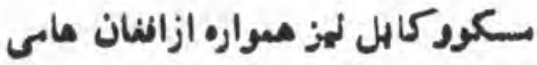

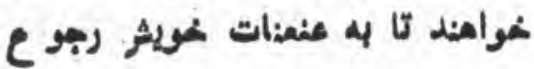
لمايند ويك تصداد از الفان ما أيكه دفالف رزالم كمولستى كابل مستيد

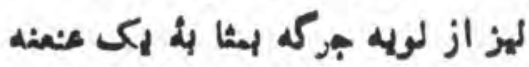
كلى وراهعل لهائى تضميهاديى لهائده. قبل ازينكه درمورد عسلىبودن

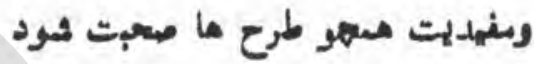

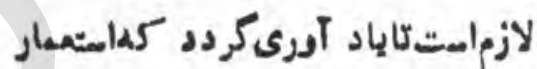
كران خار جى، رثلم هاى امتبدادى

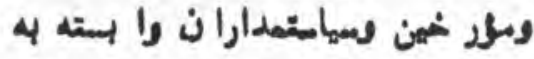
دربار وامتعمار مهواره كو لههد • ائد كاتداريخ درجال كثورمارامسيخلمايند وايراى مردم تلربهخ ، عنعنات وكلثور دروهمن وسامتكى البازيد. بطور مثال

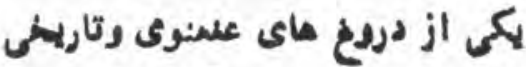

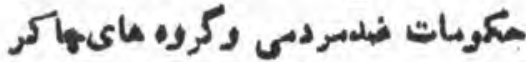

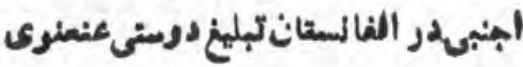
اففانسزوس مس بلدهد رلهيب مردور

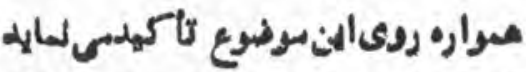
كم اماس دوسنم 4 روس را لهدران

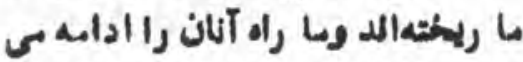

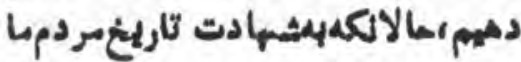

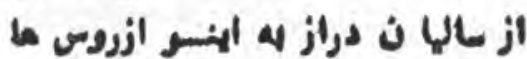
لهرت دالهته د مركز درله دوصتم 4 روس لهوده المه متى درهزايطدشوار

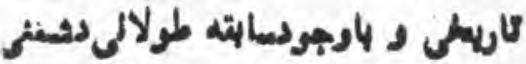

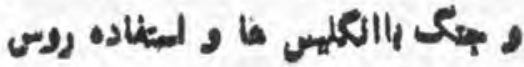




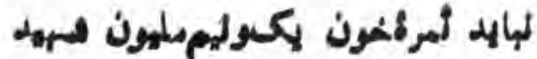
هنم آزادى و أهات كثوريه د داسان

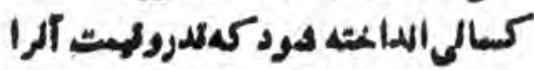

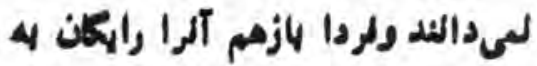

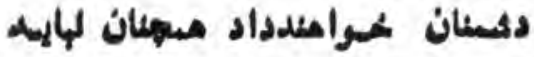

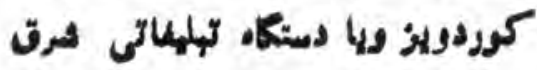

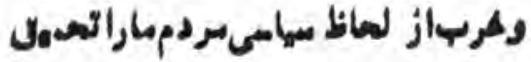

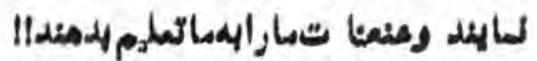

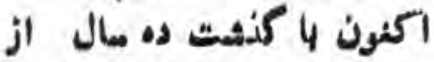

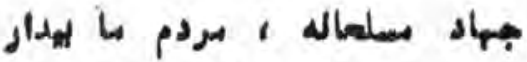

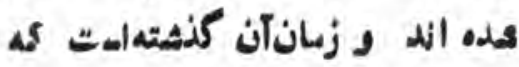

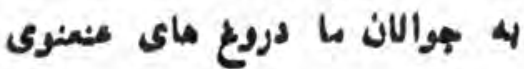

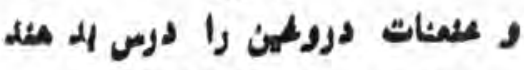

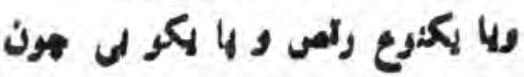

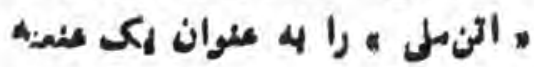

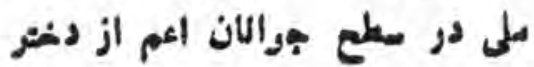

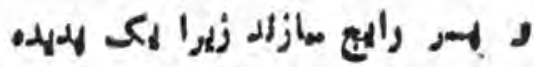
زمالىهلمىللقدى وكرده كه تعام مردم

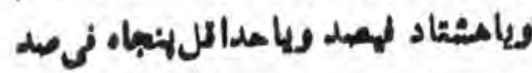

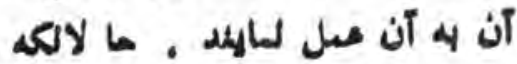

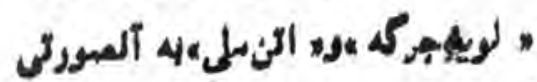

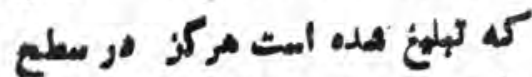

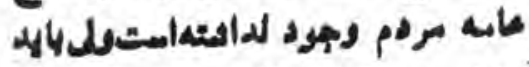

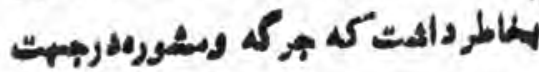

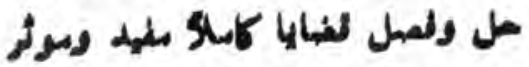

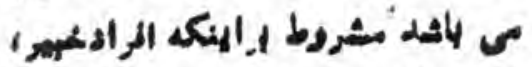

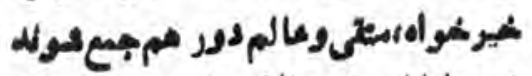

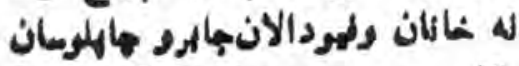
هكو مت و دوم اليكك هركمد دهرا

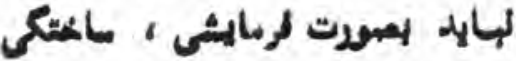

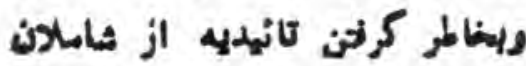
IIT )

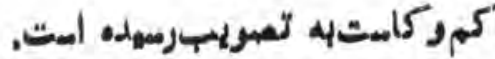

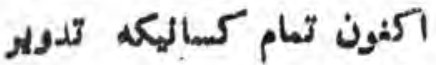

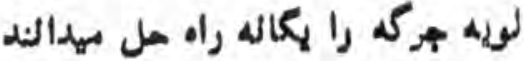

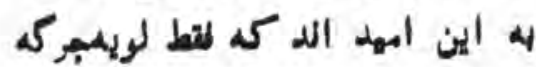

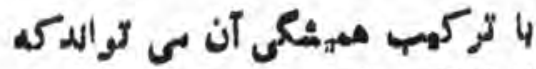

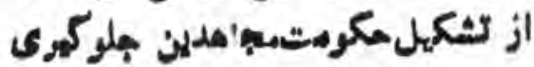

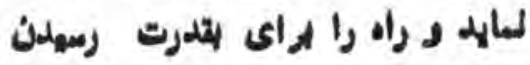

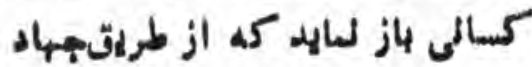

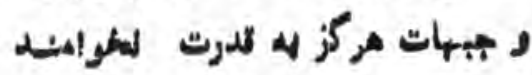

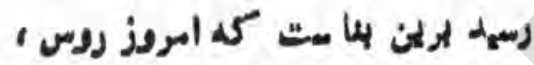

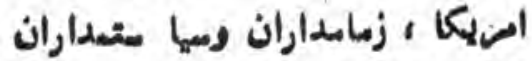
قبلى 2 طركلداران لهان ازلميله هركم

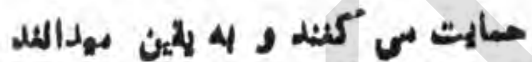

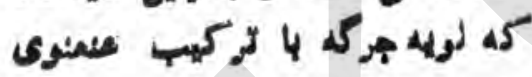

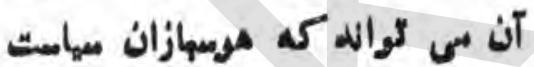

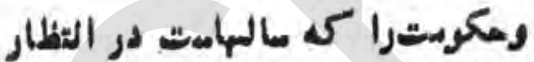

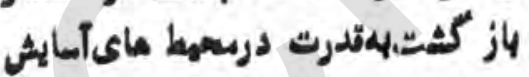
و آراس و مزاران بهل دور ازسيكر

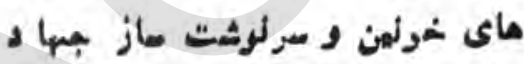

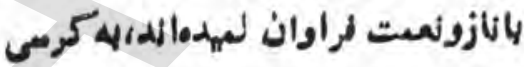

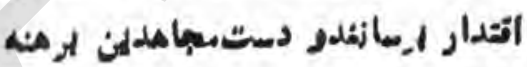

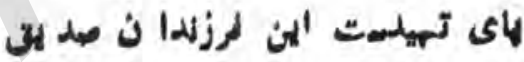

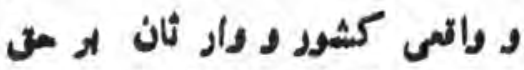

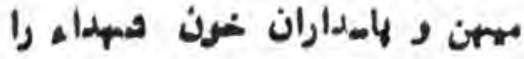

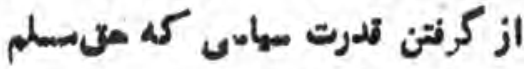
ثان است كوتاه لفالهد .

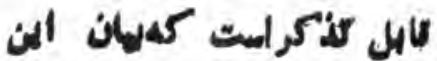

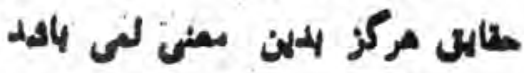

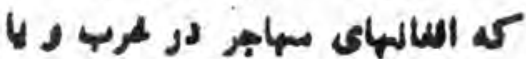

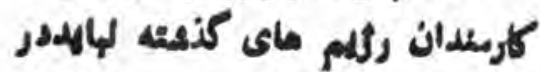

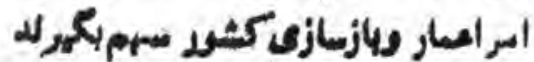

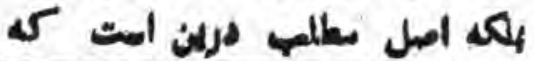

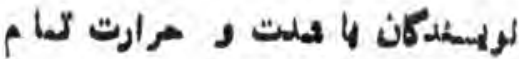

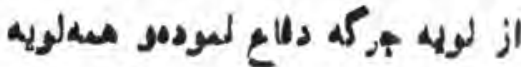

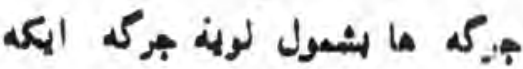

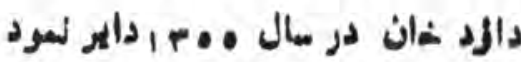
را له عنوان مظهر ارادة ملت ثائهد

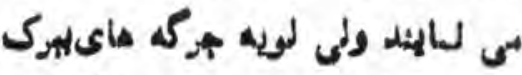

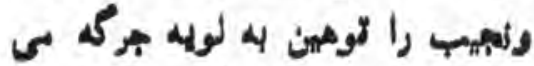

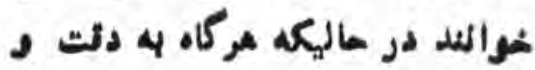

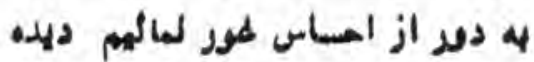

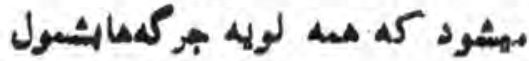
لوله جزكم نههب از إكلقاش اوده.

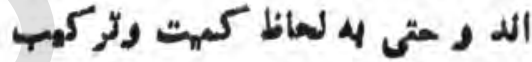

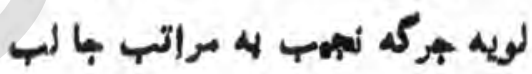

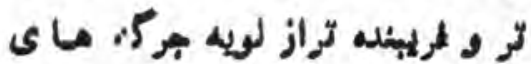

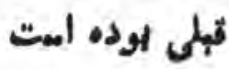

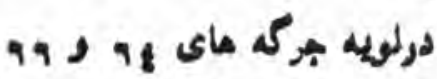

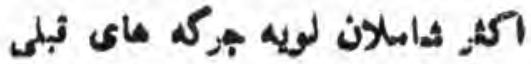

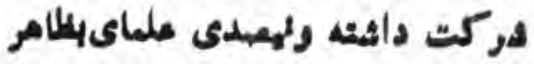

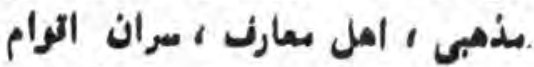

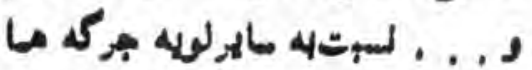
الهثة اوده اهت

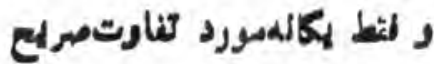

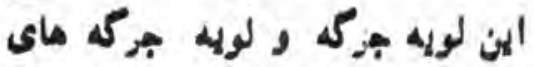

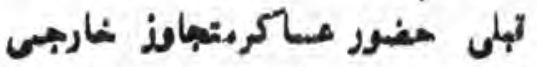

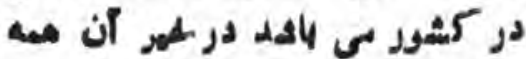

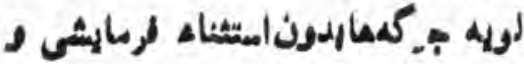

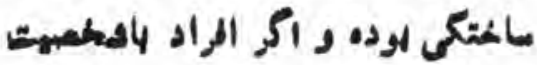

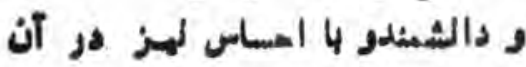
ثهاسل بودمائد ، جرات لها صلاسهي

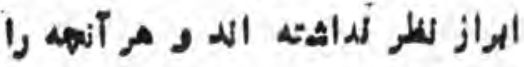

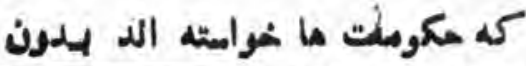




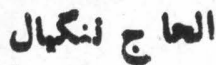

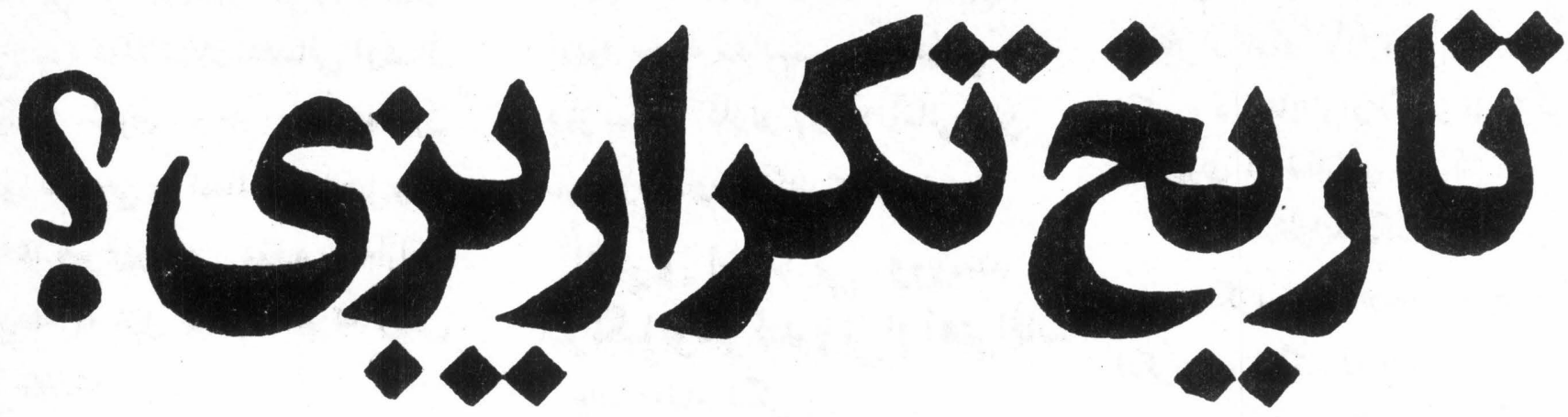

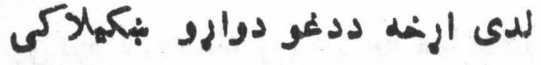

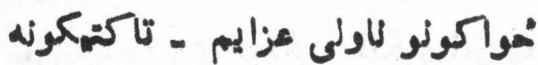

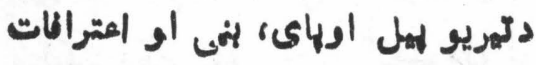

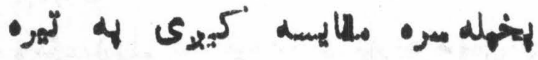

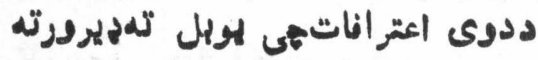

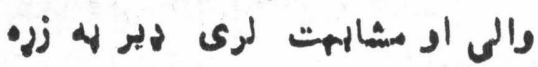

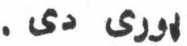

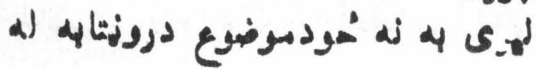

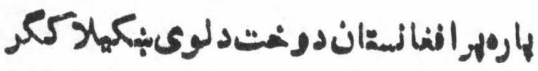
توت فيرنكى لوميرى ثيرى يولهم مل

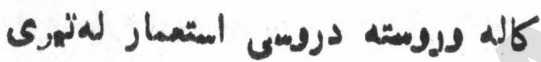

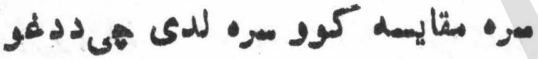

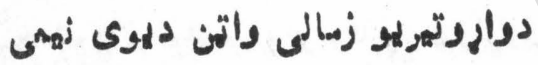

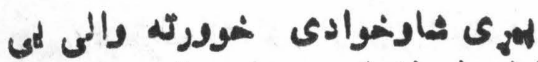

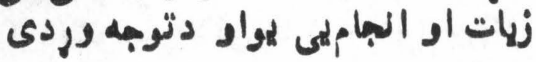

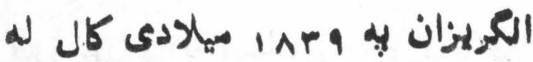

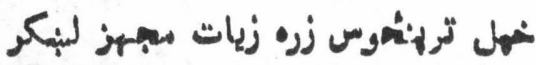

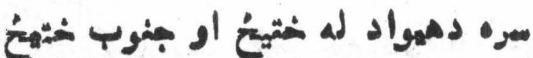

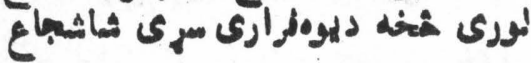

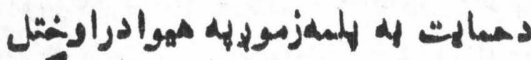

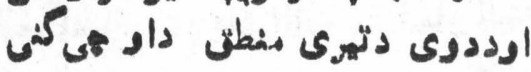

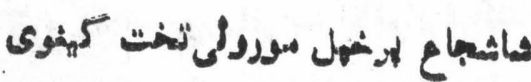

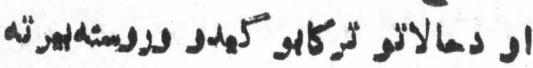

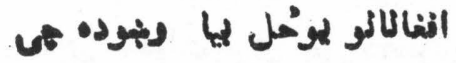

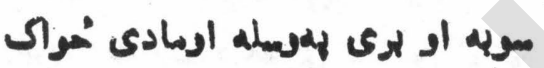

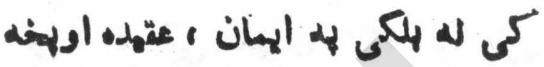

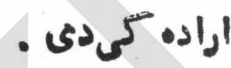

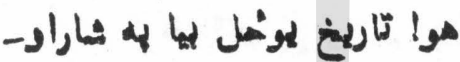

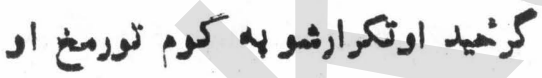

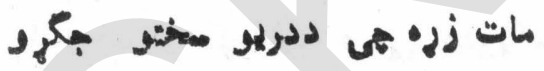

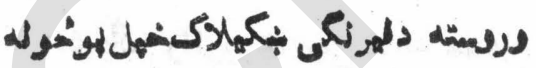

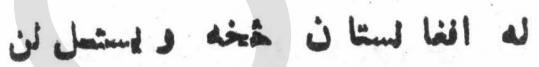

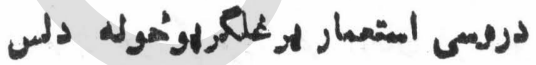

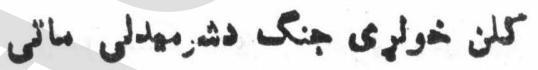

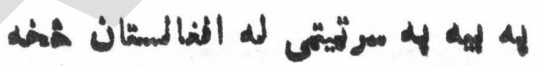
- 4

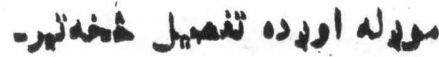

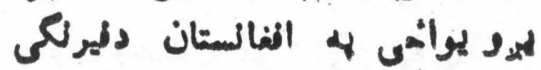

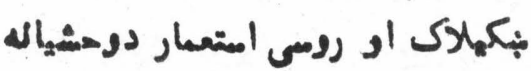
كيرى اوثرمهدلى ماتىدانغاز اوالهام له اره ددوى خمواره واره لاداهمتونه،

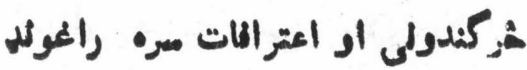

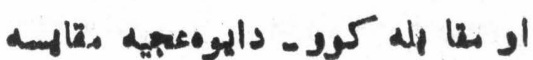
ارسشانهت دى ثن له كنو مواردو

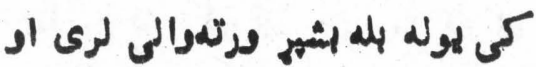

تارين يوخل لها تكرار شو او

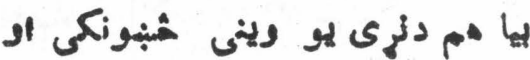
وحشى نبكيلاك دافغانستان دمبهاهد

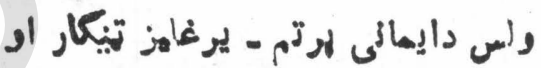
تند.يز مقاومت لروراندنى له كونئد ثمو او دخثل وحثيانه تيرى 4 لاى كى دثرميدلى ماتى الهام تمورمهيد .

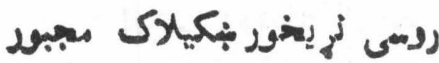
ثمو وروسمته لدى ثي دخهل ودمثت ، ايريريت ، توطيو او دميسو ثاكمىلهى ثخارى ته زيندى شموه له ا اففانسيان

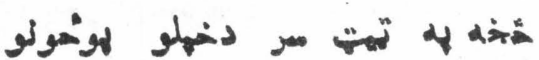

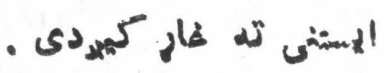

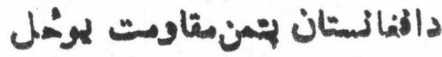
هيا ديخوده ثي دولسونو دآزادى

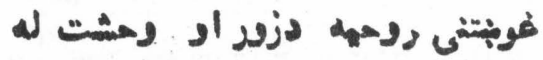

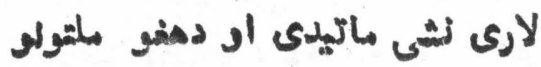

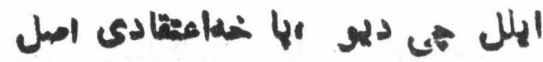

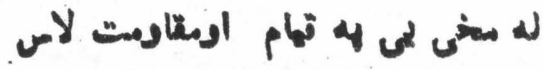
هورى كرى وى لشى كولى دزون

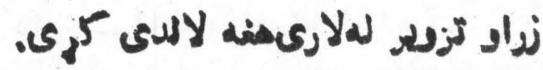


عندى لر اففانستاندانكريزىلبنكرو

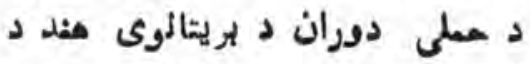

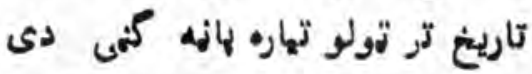
ليكى :د الفالانواوالكريزانو جنكوله لهاله

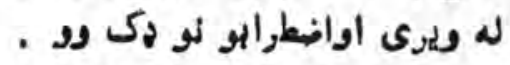

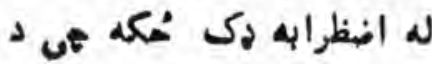
دغو جنكونو له الرخه كوم زيله الكريزى لبكروله واوبت ثيرزيات

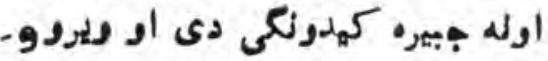

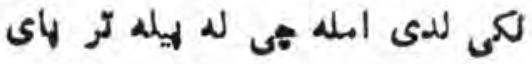

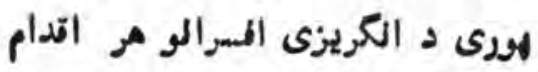

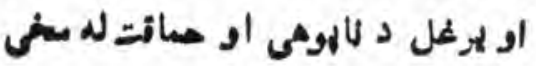
لنه لهوله.

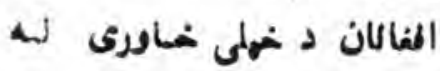
آزادى سره هى كهى او ليولى بهيها

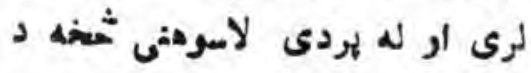

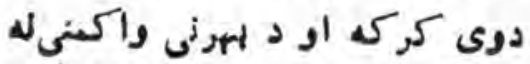

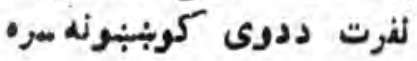

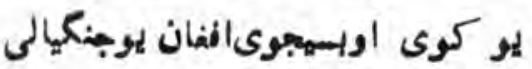

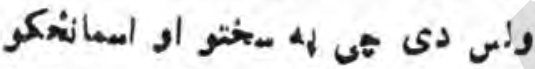

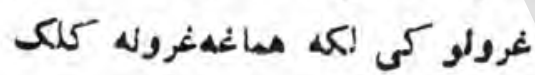

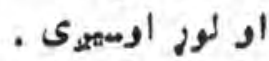

كله ثي الكريزائو ها هـ كال

ver

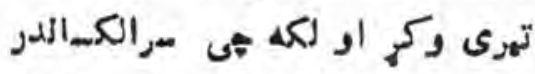

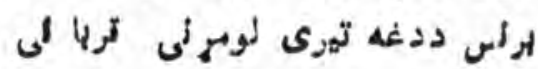

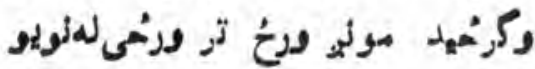

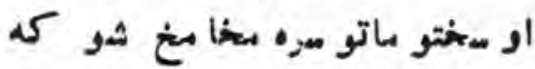

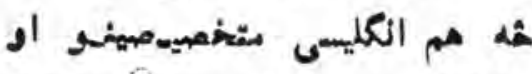

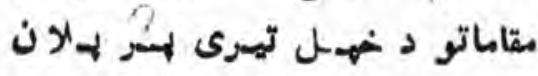

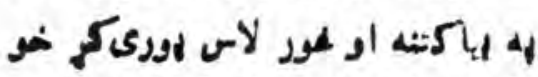

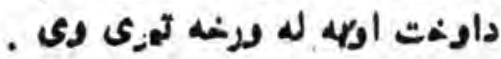

اليل اونائكى سره دلمنلول شي اد

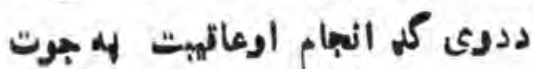

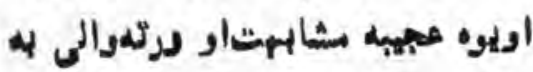

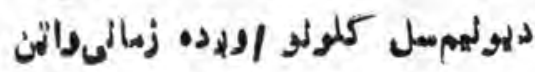

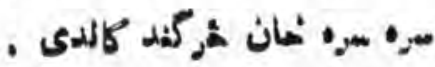

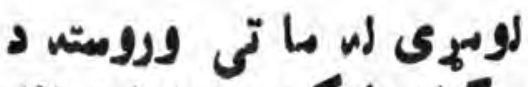

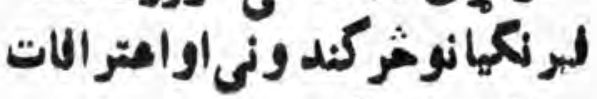

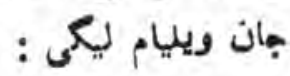

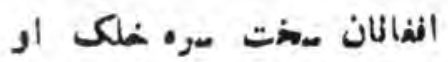

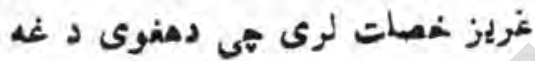

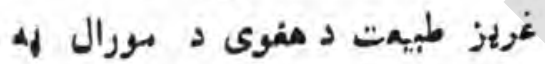

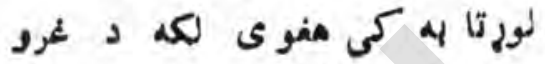

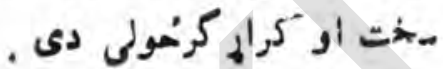

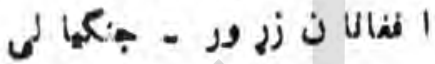

"

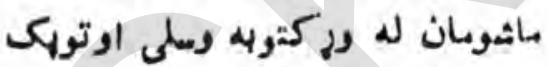

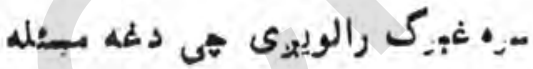

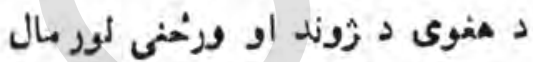

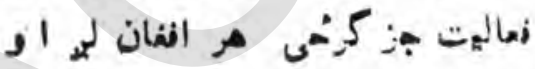

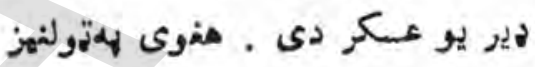

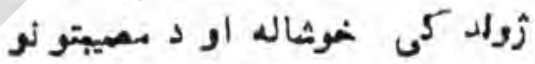

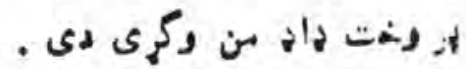

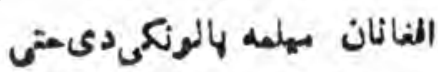
ددوى دبنمنان هم ددوى له هله لهاكى مطمين رولد تيرولى شمددورى روريه

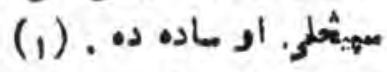

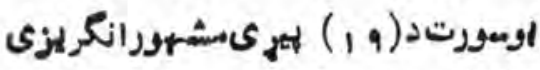
ليكوال انخهل كقاب " : نلار دلارنس

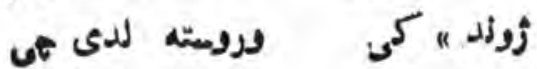
د الكريزالمو له جنكى لهلاذونواوتقثو

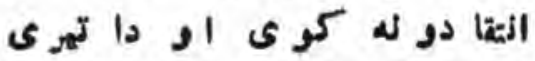

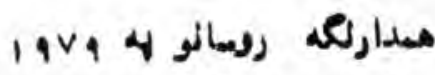

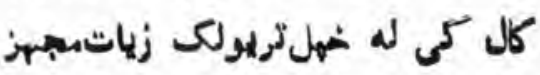

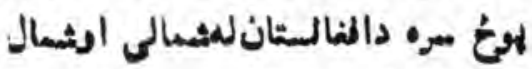

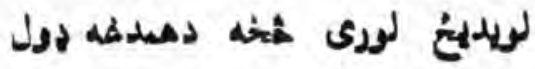

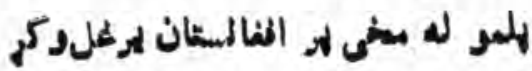

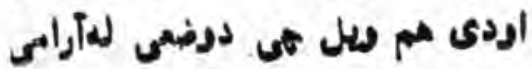

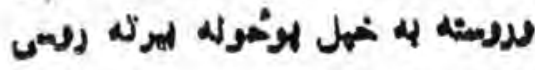
تله متنوى . خهره لتهبه كى دغودواروتهريو يوه لاروومله رومائو 4 مشاعهلار

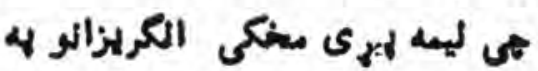

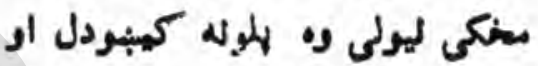

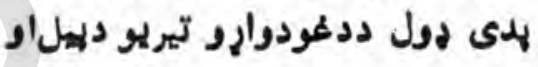
لاى ثكمى مره ولنبتل .

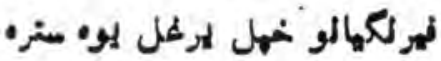

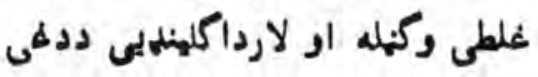

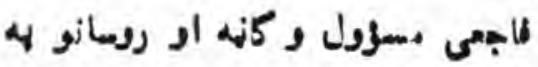

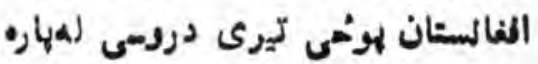

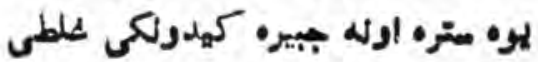

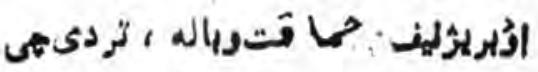

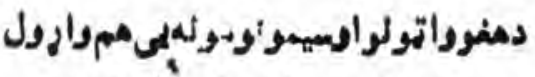

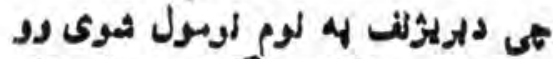

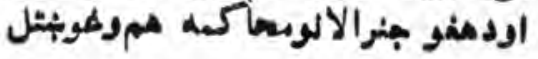

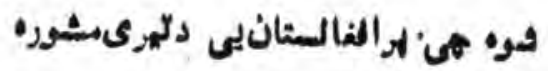

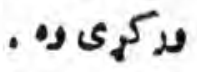

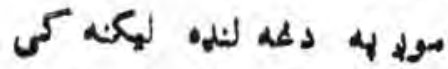

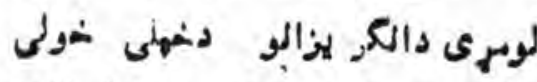

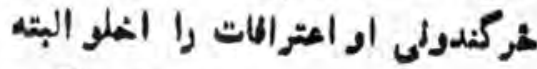

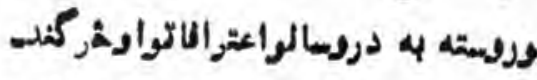

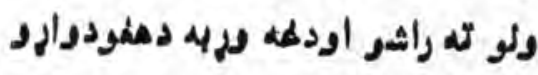

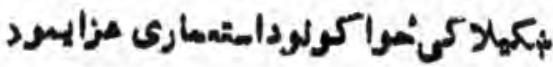


الفاناند(لاالمالالهم) (انهاكير)

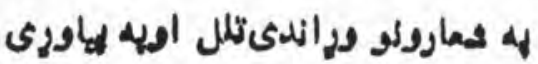

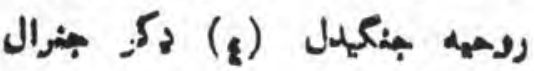

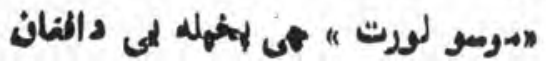

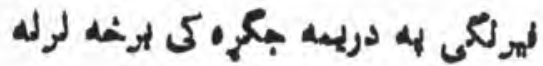

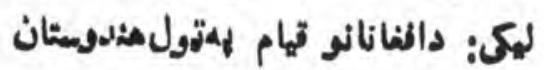

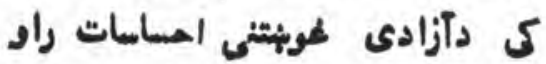

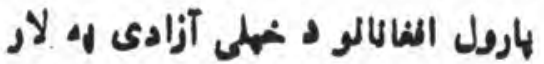
كى هردول تربالهم اوخطروكلوته هاره هاره كيبوده اوجنك لمى وكاته .

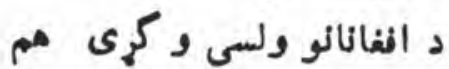

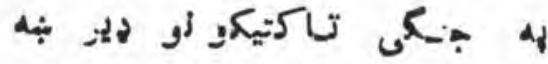

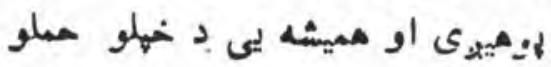

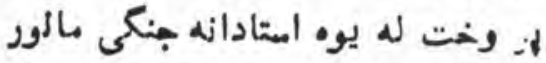
مخهد كار اخيست افغان ولس يو زه هاتيدونكى قوت دى ، دوىدآزادى ليه كه هر يله

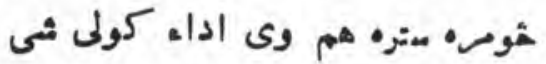

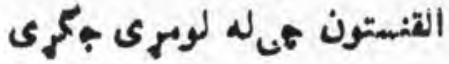

3 . وديل كمدانكلهس لبككرى ددلاهووتلفاكي

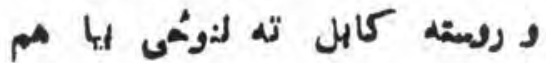

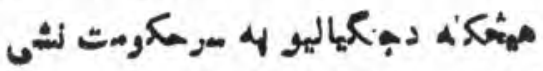

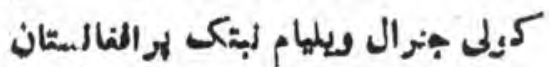
دالكريزى لبكرو تيرى لاوهمثره اثثبا

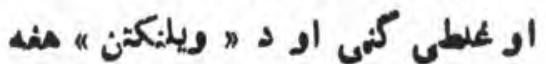

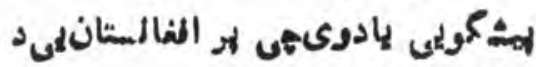

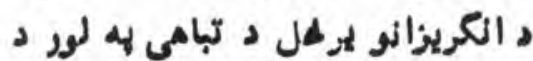

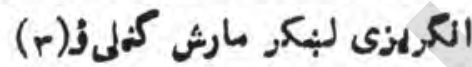

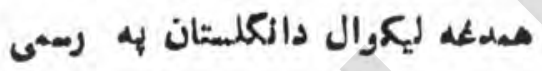
خهروله كى لهكى: الفالزان كمه عسكي.

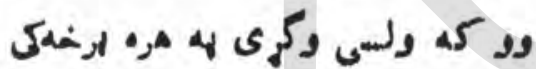

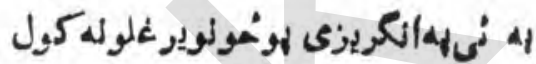

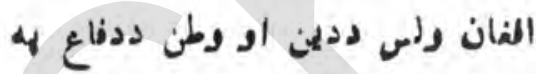

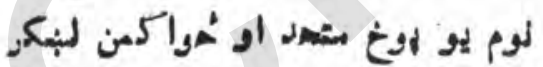

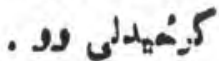

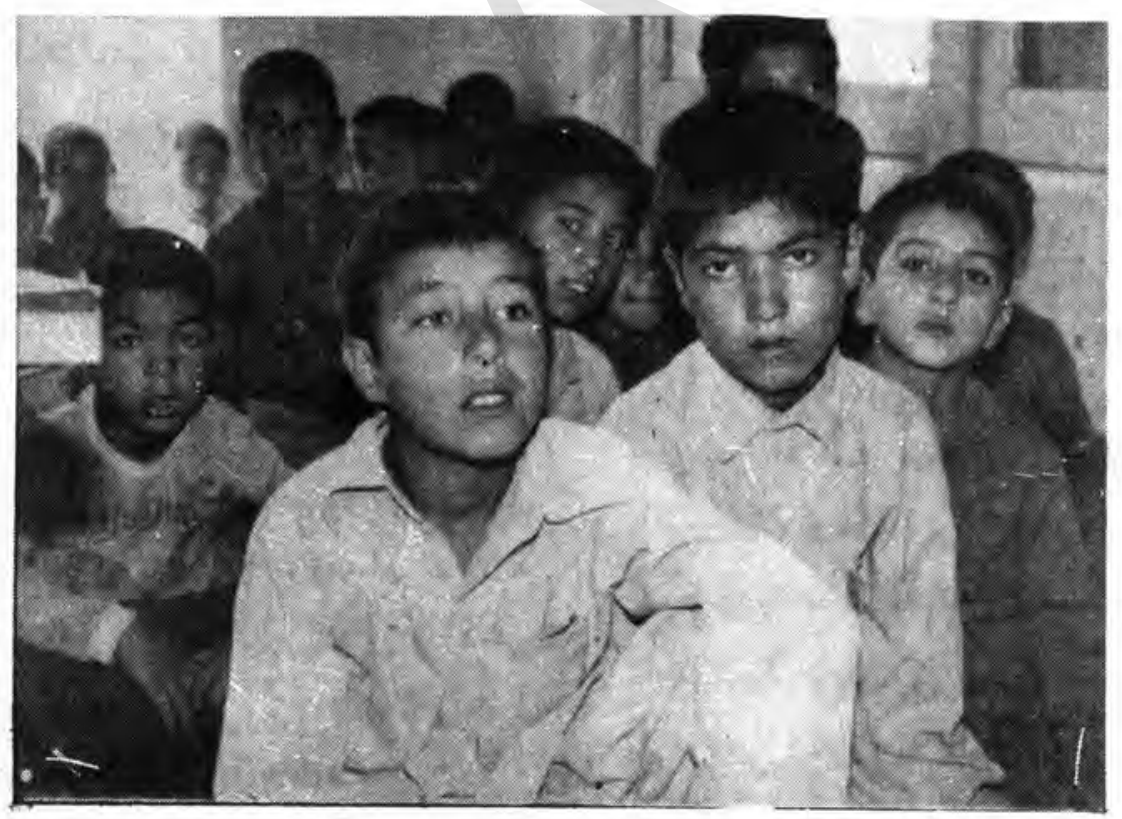

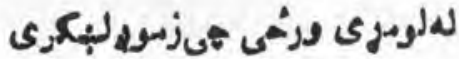
المالمسا ن ته لنوتى دهغو لاوره او

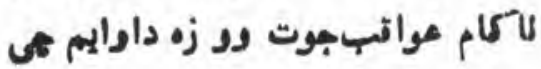

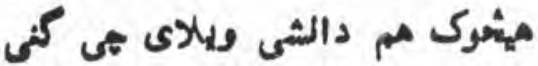

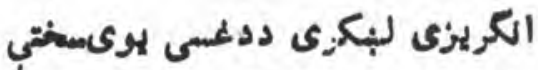

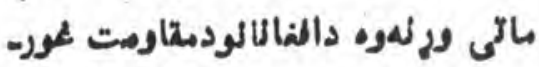

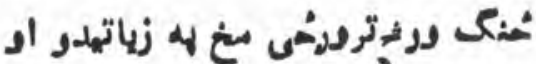

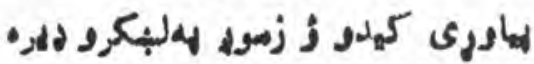

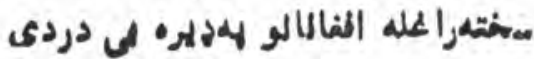

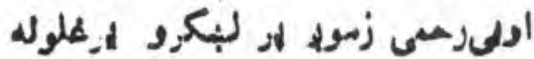

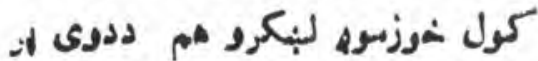

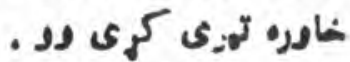

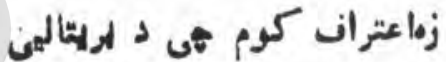

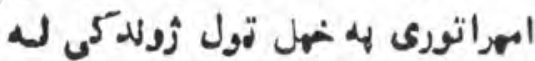

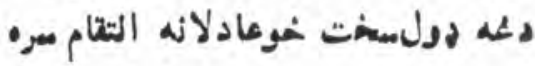

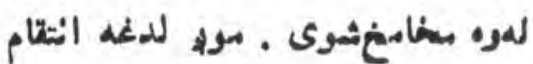

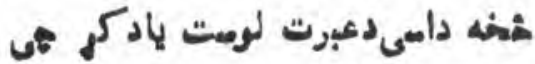

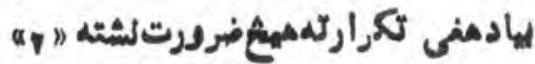
ارثياليه لوريزى لهيل كتاه

لدالفالانوجكرىه كى ليكى دالفاناد

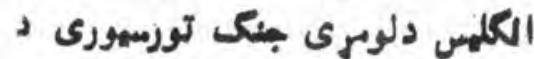

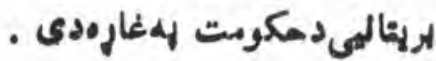

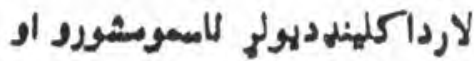

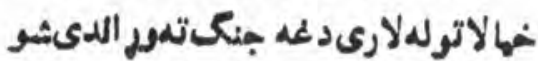

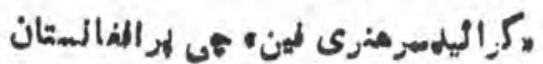

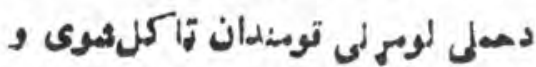
لر المالمتان له تهرىسره خهل سمخالنت

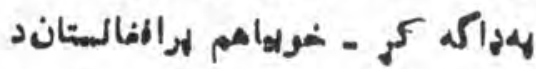
الكريزيى لبككرو بريدترمسره شهو كمثه

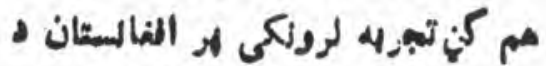

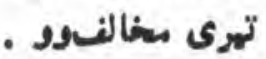


يو الكويز طبهب ددبتو له

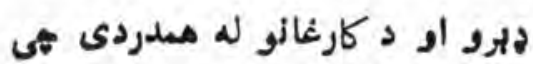
دده ـاندى اوزكيروى ليخهلو كوكم

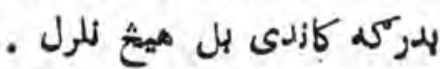

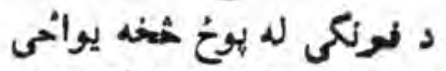

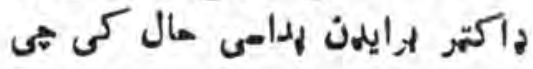

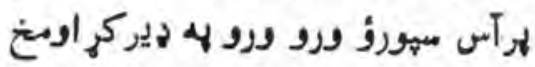

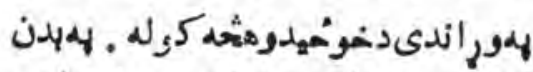

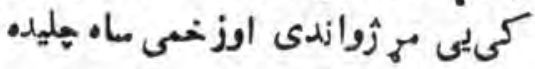
تردى ثي لهر آس لهى دئان تنكيدو

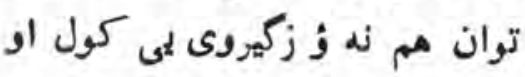
هيه خجل تور بخت يلى لعنتونه ويل.

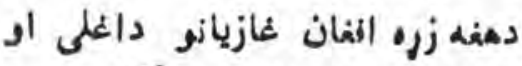

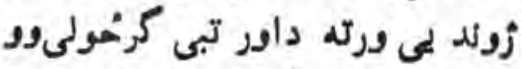
كله بل لهى د مرص الهيراختيا

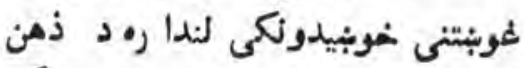

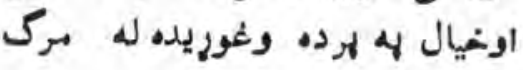

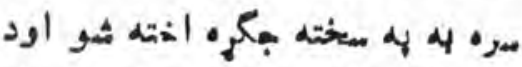
خهل، امتهمارى زوند ديوى ثيهى

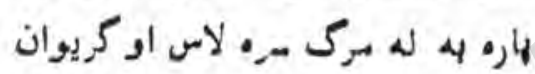

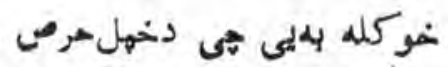

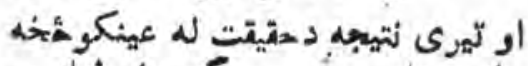

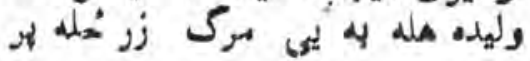

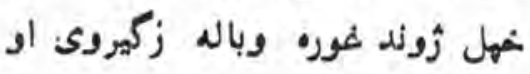

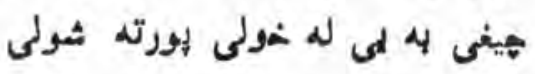

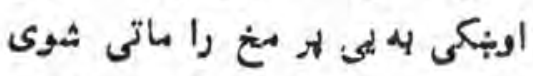

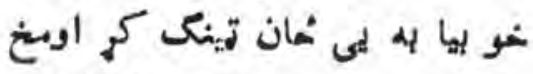
لروز اندى لبليى دهركت هثمه كوله

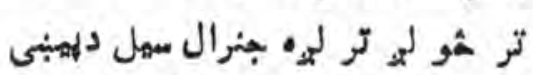

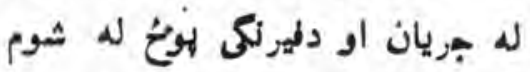
انجام مُخهل خبر كازدى .

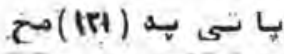

تنداره درلوده افغانانوإخهلوخمليدوتكو تورو خهلى له واورو بوبنلى دبنتى اوغرونه ددبنمن يهزاياكو ولهنو تكيه

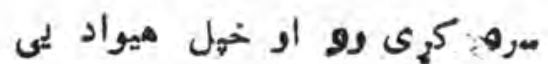

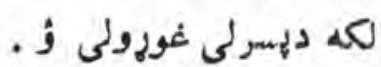

دتوب اوتورهى لهز زوونكو مزو

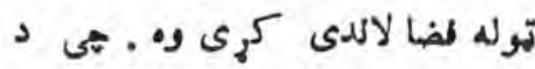
عاقت نه سنجبوونكو انكريزى لبنكرو دوزند ستنى يلى لهزولى .

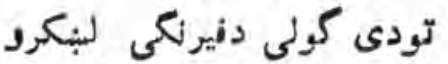

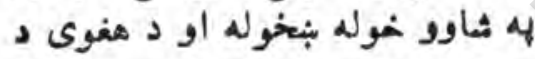

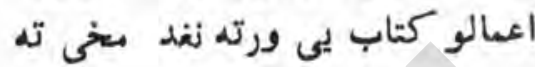

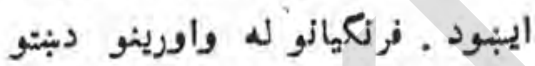

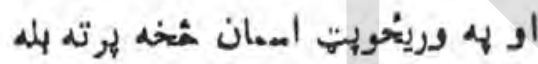

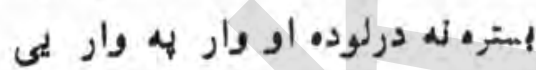

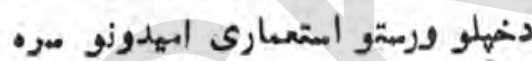

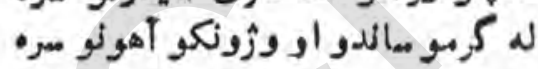

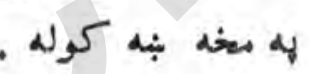

دخهل تول هرص ، دوكى او

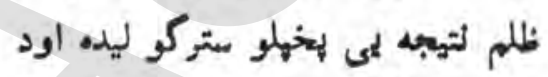
مسرت ماكهو وار نه وركاوه .

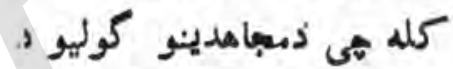

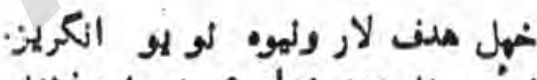

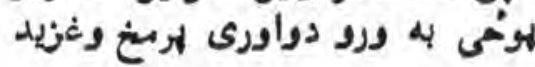

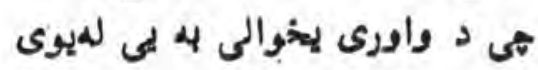

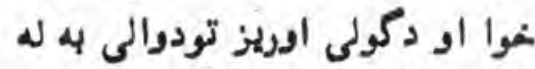

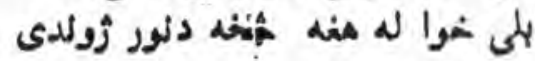

$$
\text { هاتى كيدو وخت ولوته . }
$$

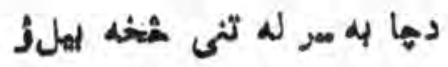

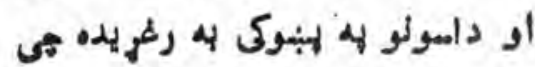

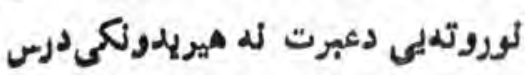
وركار.
لمه حقبةت كى افغانان هلهآزادى زوزندى

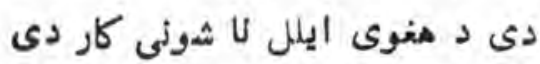
داولس ليهل او اليجلى خمصوصيات

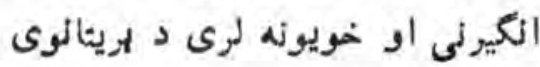

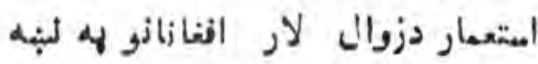

$$
\text { (0) } 0,250,1+9
$$

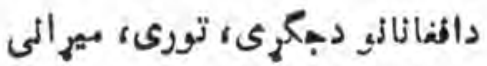

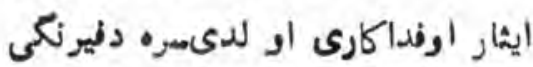

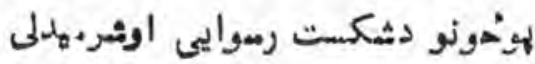

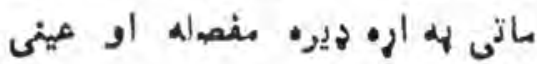
ليكنه د جنرال سمل دمالندينى ياداشتونه دى جى اله خمورا دفيقه توكم

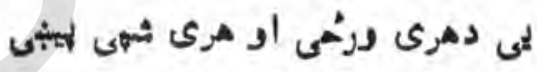

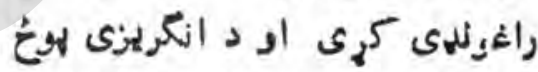

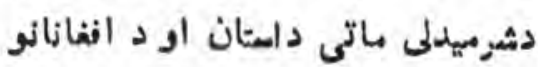

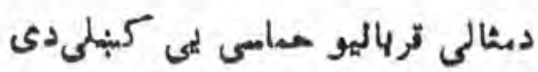

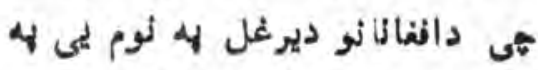

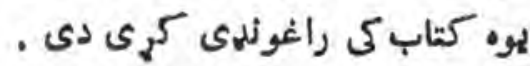

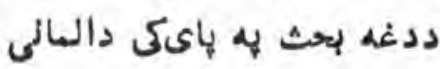

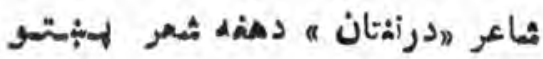

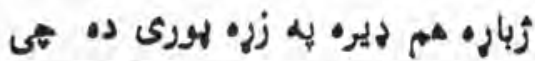

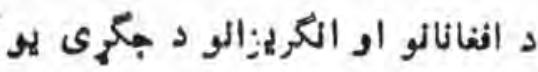

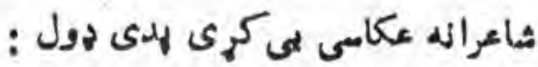

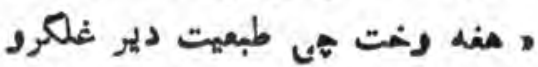

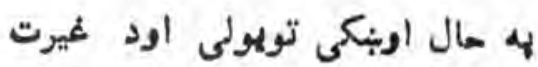

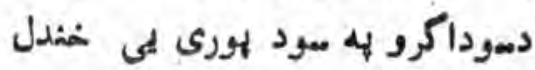

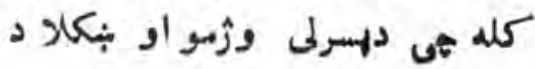

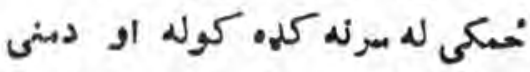

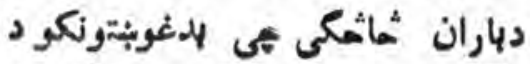

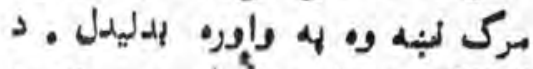

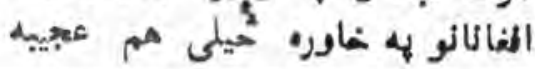


رك ما و عر وق "كارل ماركس"

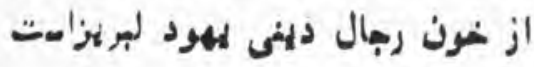

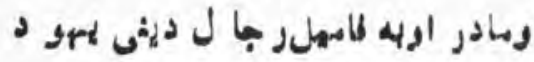
رسموبالوده ومشهنهن لهدر اوازهماندان

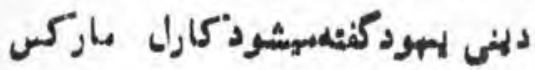

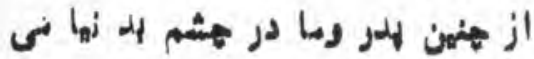

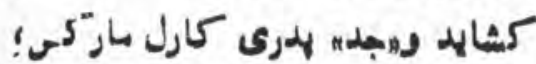

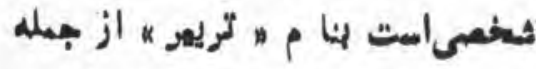

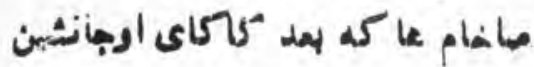

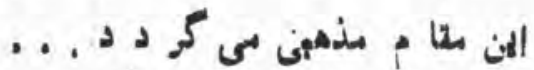

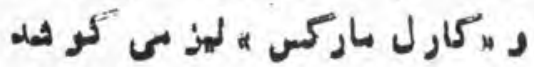

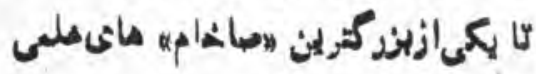

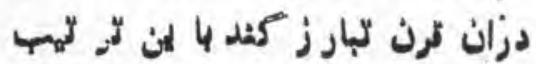

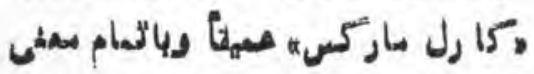

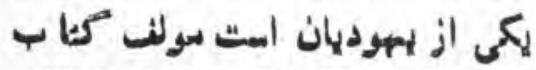

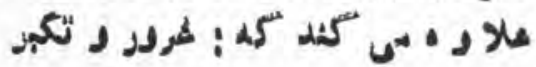

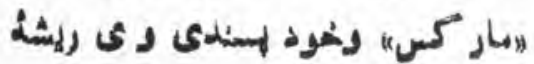

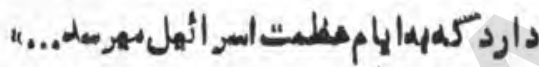

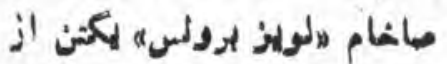

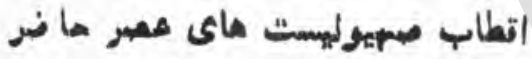

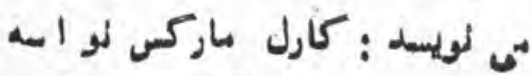

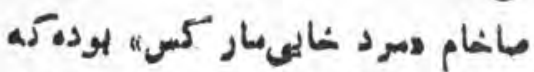

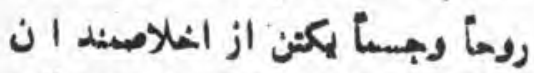

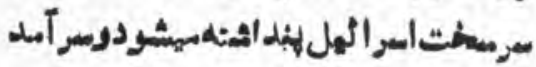
مهان كسالى است كمه درراه اسيحكام

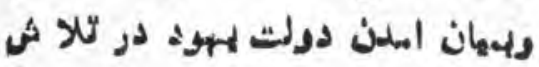

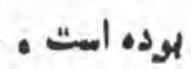

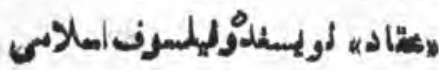

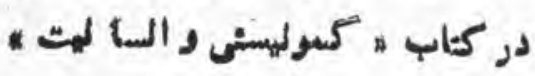

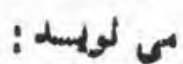

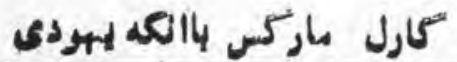

كمولنتئى دهوت لمودمولماليت آلمها

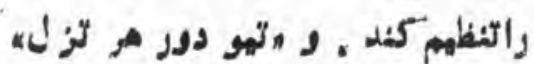

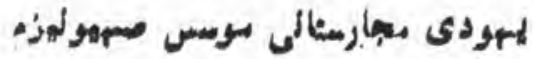

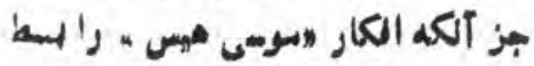

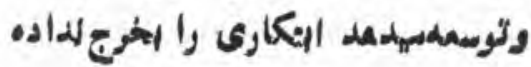

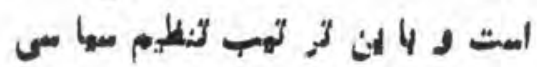

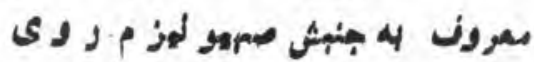
ليظر يات "مسوس بهسب، امساس كذادئه ميثود .

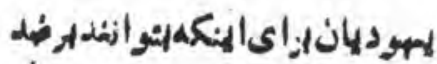

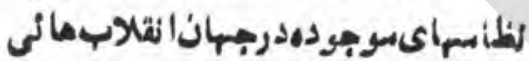

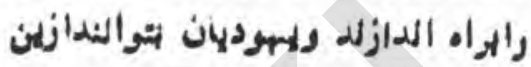

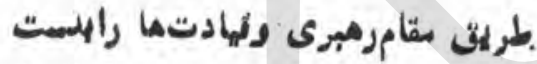

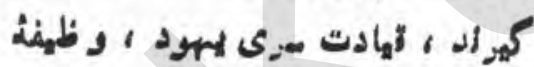

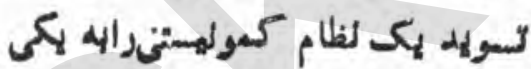

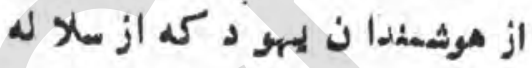

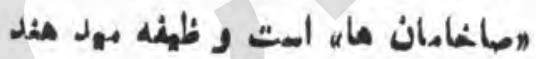

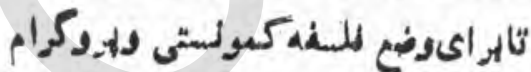
وروش على ايوبود آهدذ الثلابها،

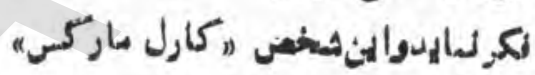

كارل ماركس ' لهودى الهالى

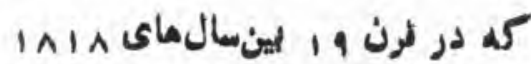

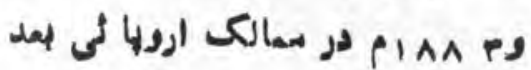

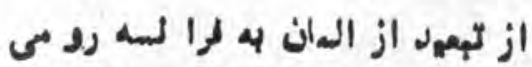

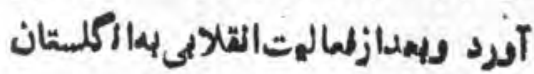

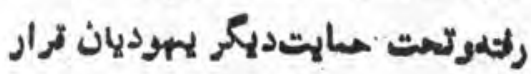

"ارمون ولسونه دركثابهود

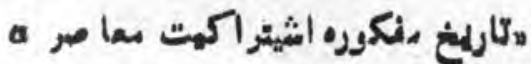

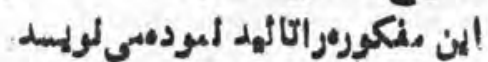

جذه مايى حولين را دربهان الممان

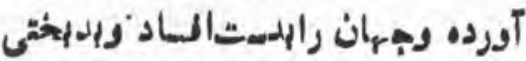

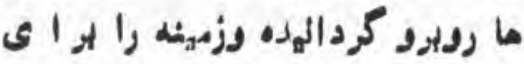

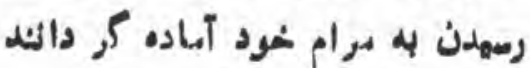

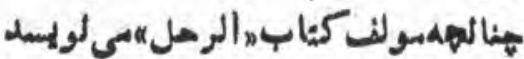

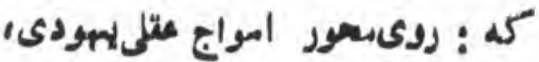
"روتسكى بهتطب دنفى' وضاوتثشيله"

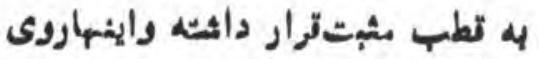
تضغاد درممكور ه سمى بى د ر زليدلد تاجبان را بهانهم المدازئد وليهدليت وليت قرن لهستم شاتعه دبمنده . روى شعهن تدليو سعرى شيعث

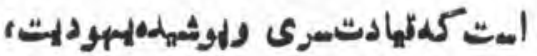

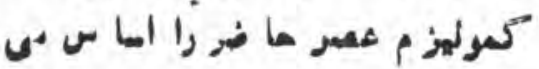

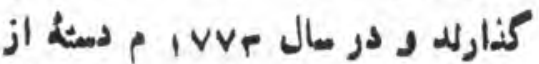

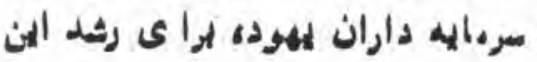

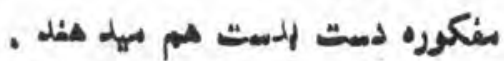

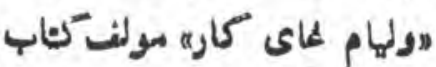

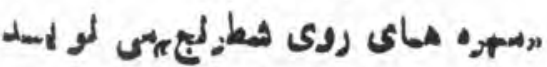

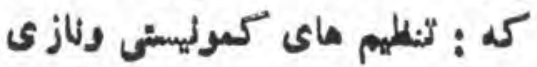

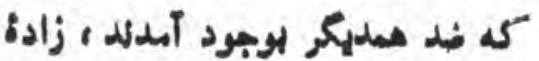
مغكورة لبهان كذاران لهبودى لودئه

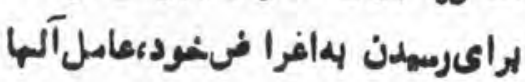

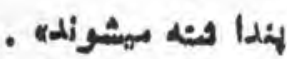

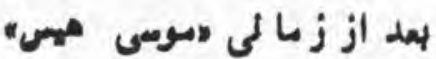
يكتن از إمهوديان الماندراواسطط ترن

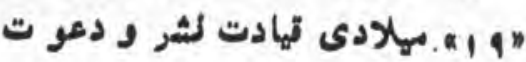

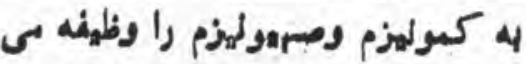

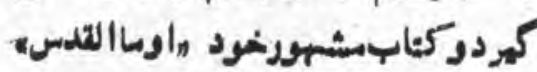

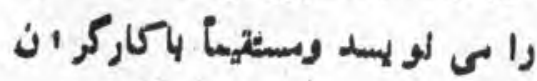

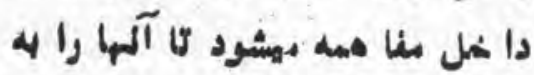




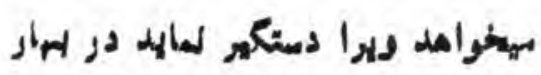

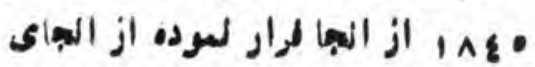

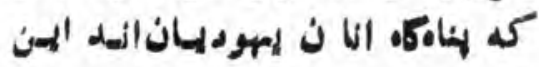

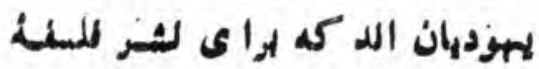

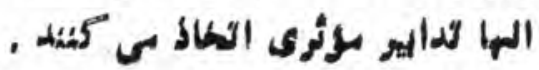

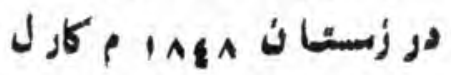

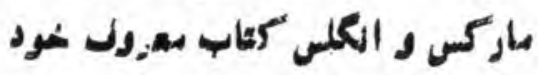

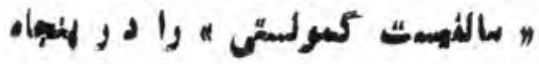

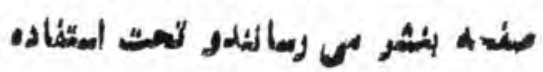

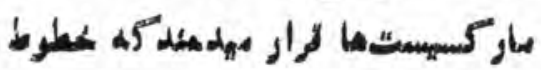

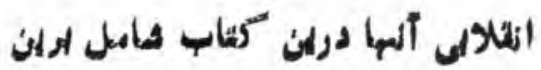
س. " سعن دور واه دكر كون ماختن

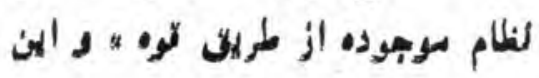

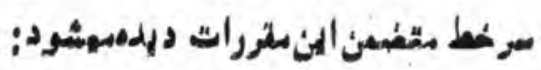

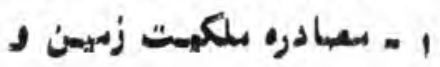

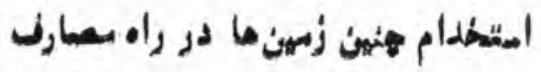
دولك .

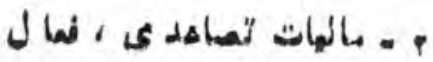

$$
\text { . A ر ر ر ر }
$$

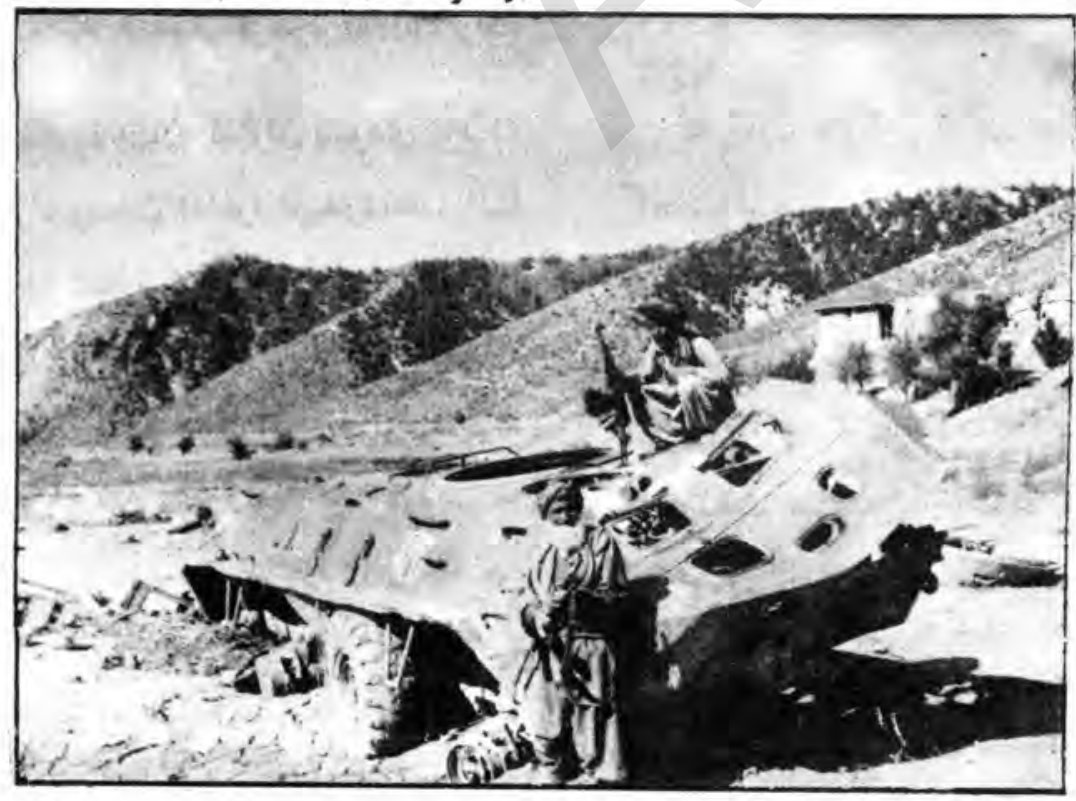

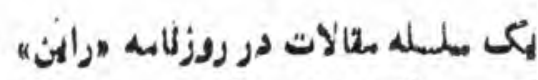

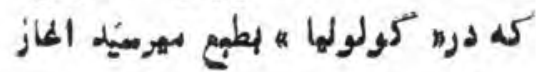

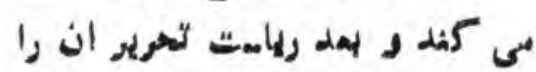
الدست بم كميد ود روى معرلثه بلده

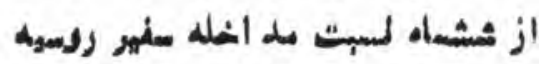
كم أر مكوبت تهير الئقاد لمسوده

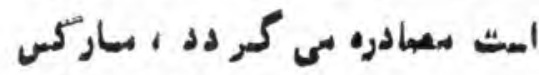

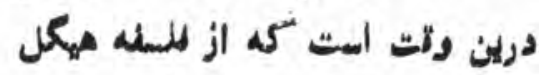

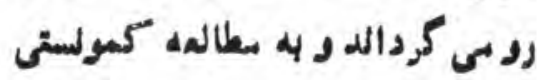

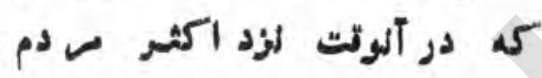

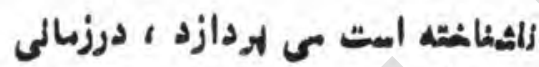

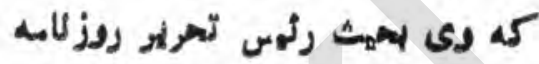

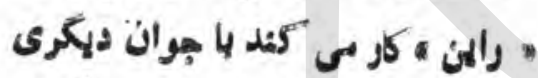

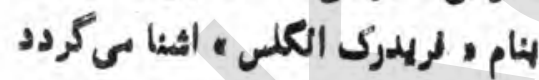

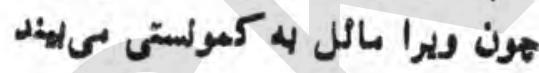
4 ونى ظرح دوصنى سىالكمند .

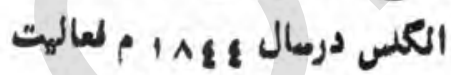

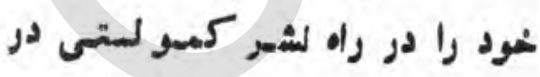

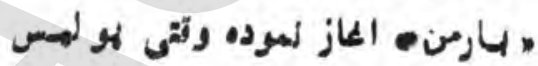

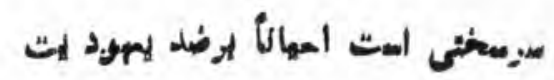

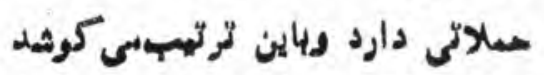

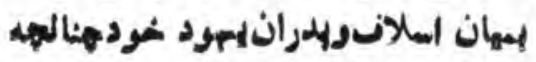
وصف آنها در ثلمو آسده الهت تبارز كملد ري رلش ومو ماى سر حمدد را

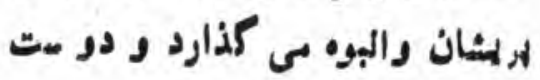

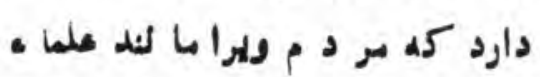

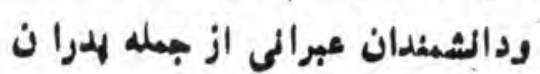

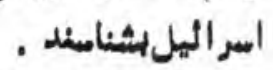

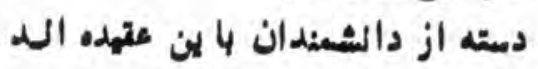

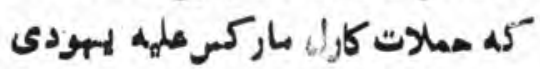

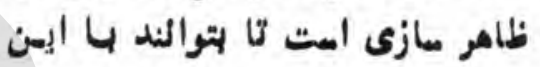
روله ، مسامهاى ليهود را از طريله

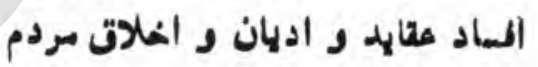

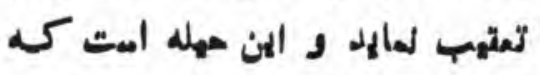

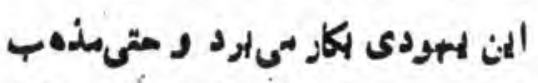

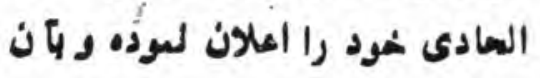

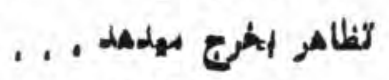

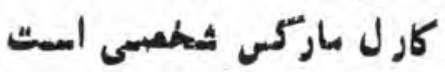

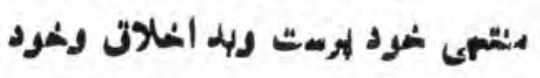

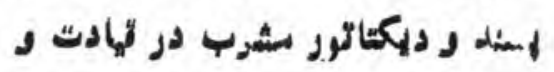

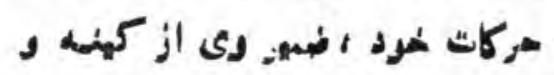

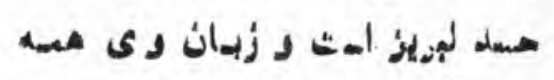

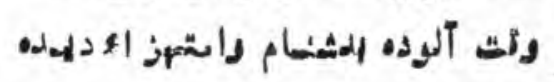
.

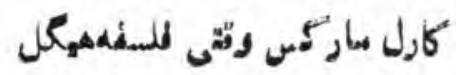

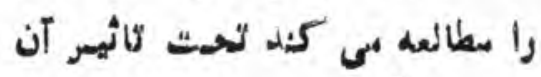

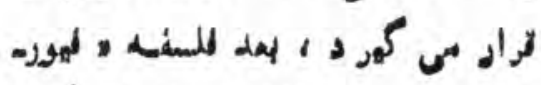

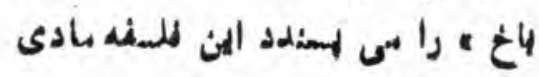

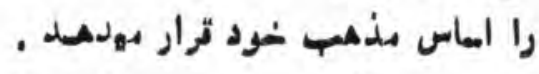

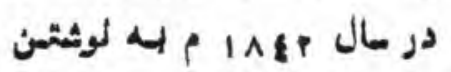


آزادى هزته كاركر " ثرار مي كهرلد.

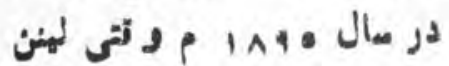

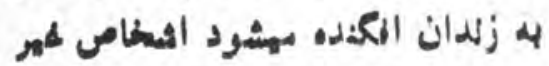

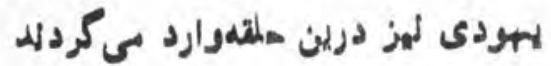

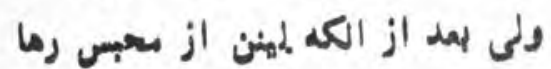
مىكردد ، عنامبر هير المهودى رالزين

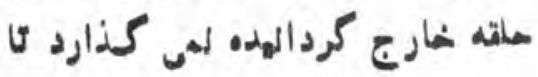

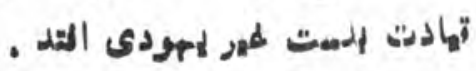

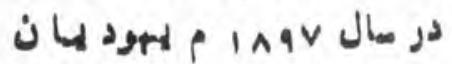

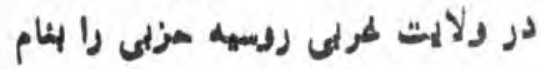

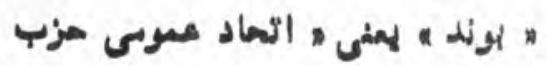

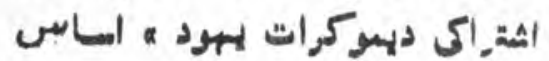

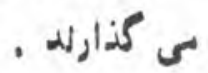

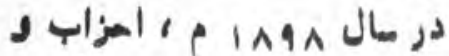

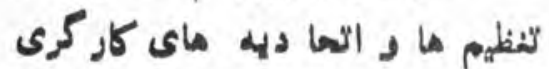

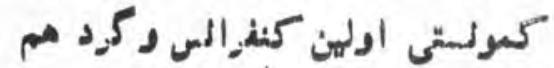

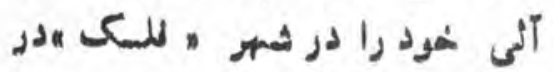

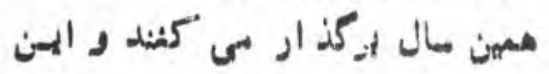

ثاسل مى كردد و ايز مسان لهوددى

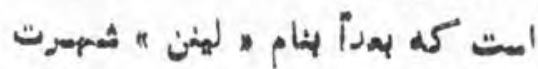

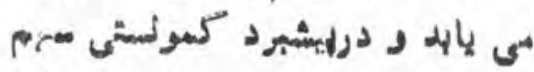

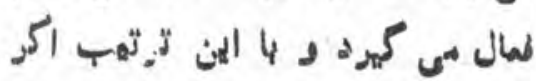

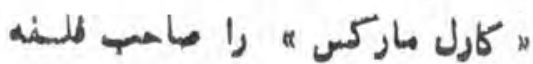

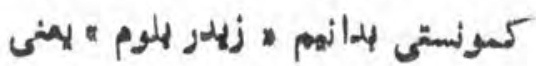

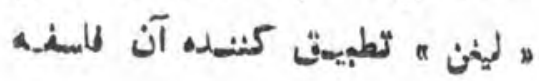

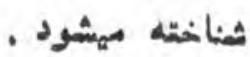

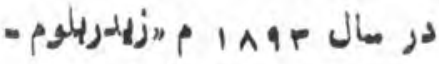

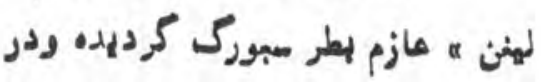

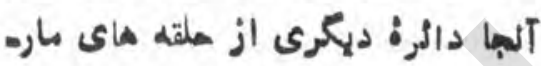
كسمهزمرابه همكارى يكتمداد النهوديان

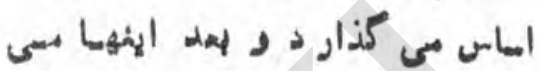

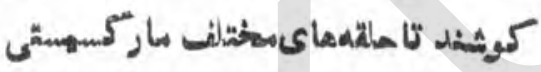

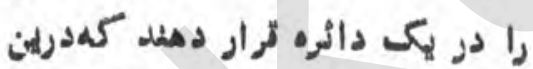

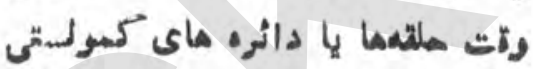

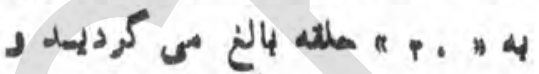

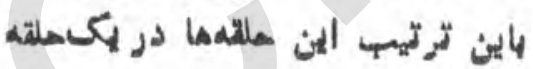

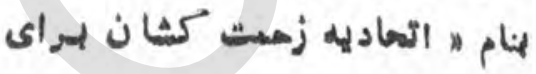

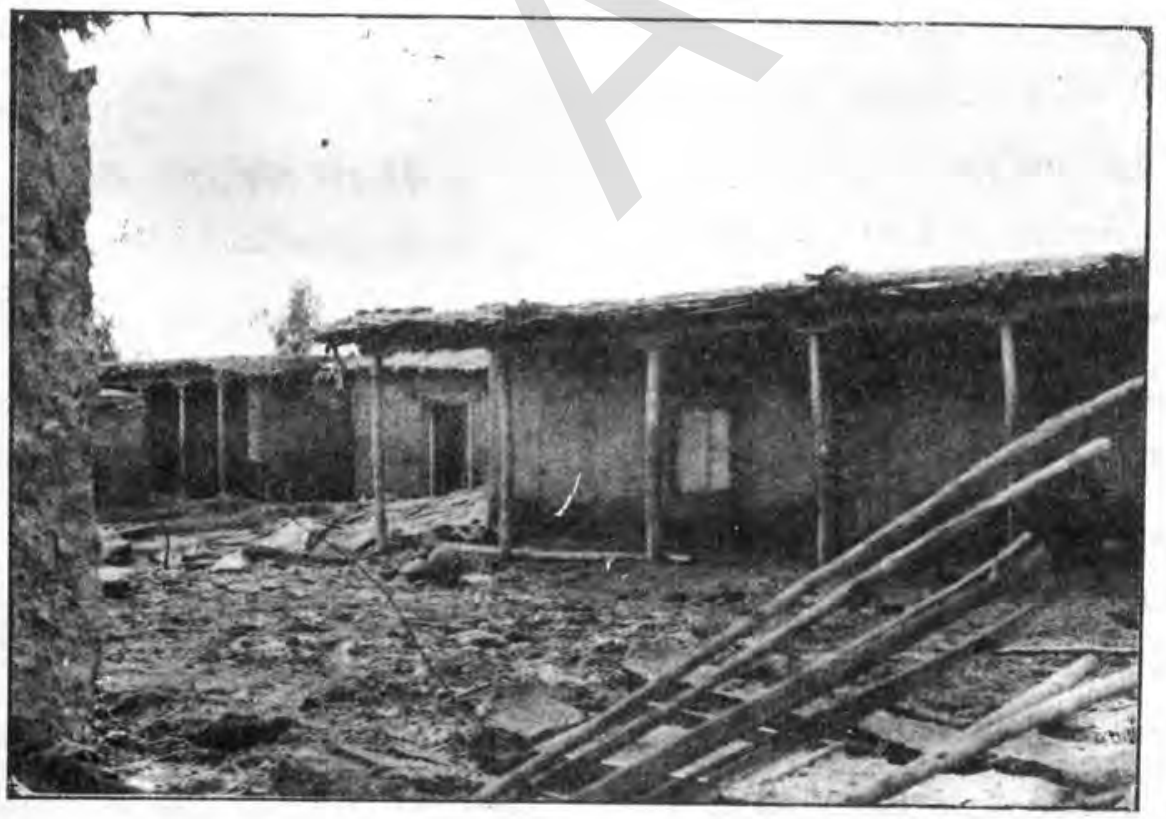

$$
\text { r. الفايى هل همراث }
$$

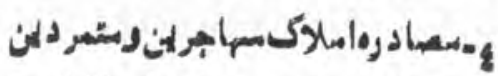

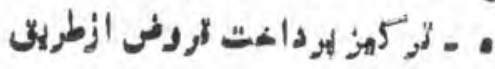

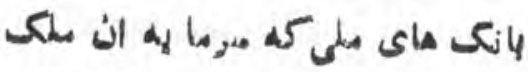

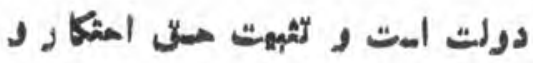

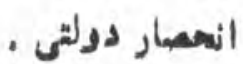

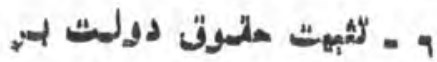

$$
\text { لوسائل بوامهلات . }
$$

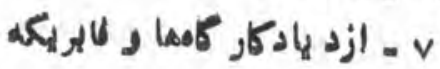

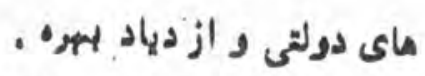

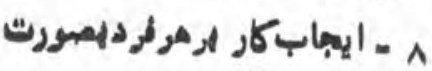
كئساوى د بهمان آدردن اردويى كار

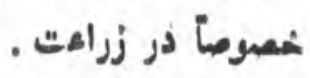

ه - تعشيم زراعت در دمات دمات

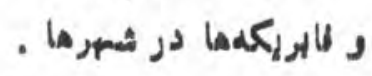

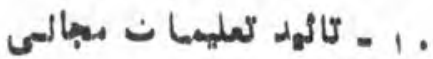

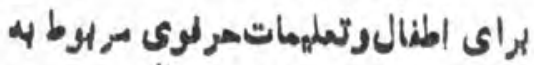

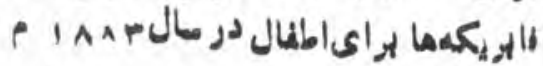

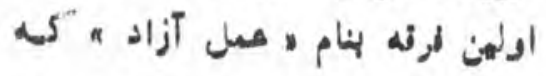

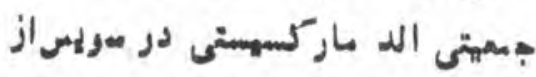

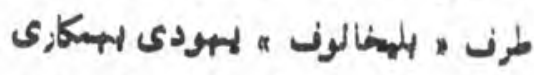

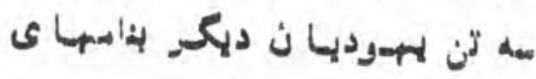

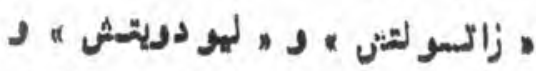

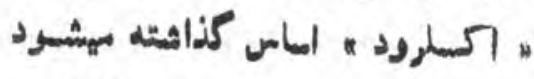

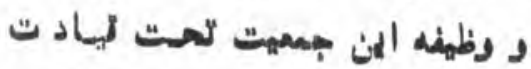

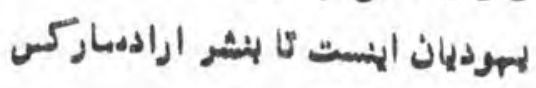

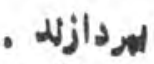

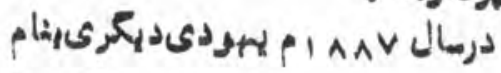

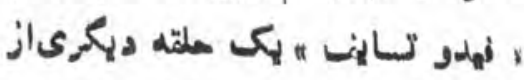

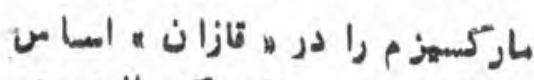

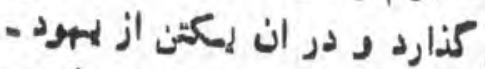

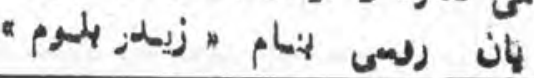


ا - در مراحل الفى وظهيه حزب

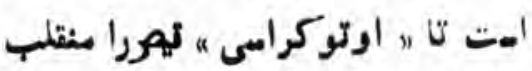

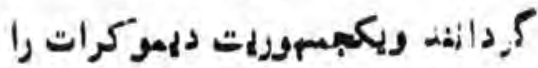

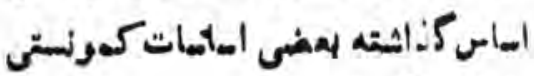

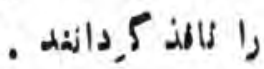

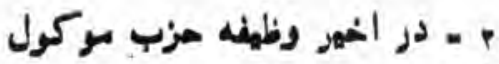

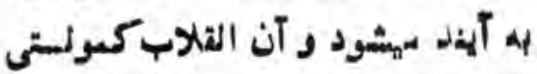

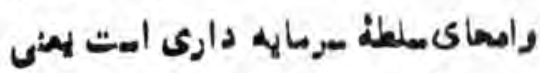

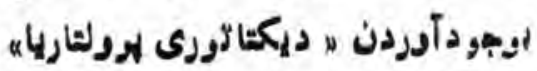

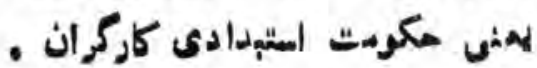

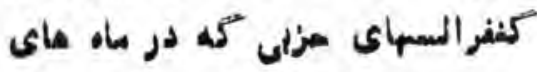

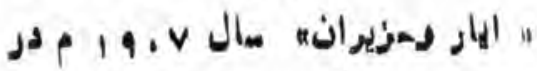

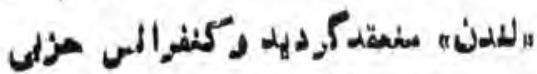

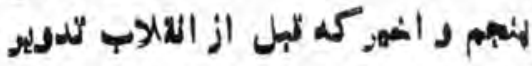

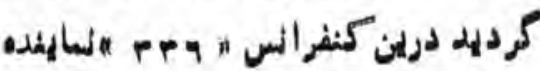

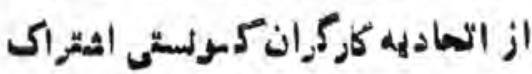

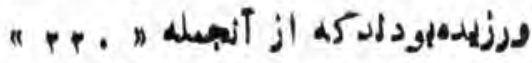

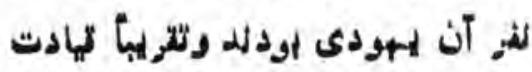

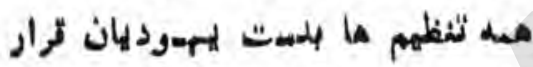

داثت

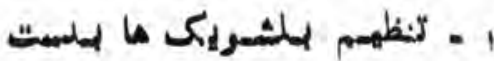

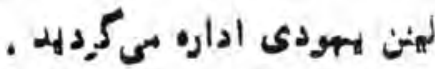

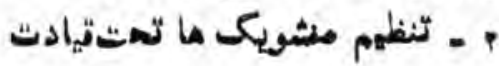

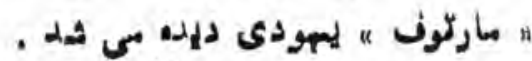

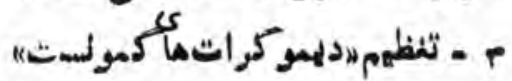

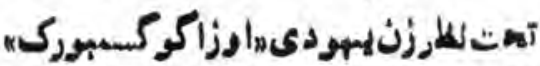

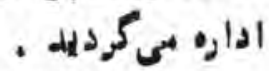

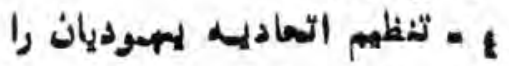

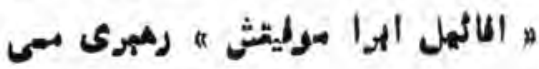
لمود م

بغيهدرصفحد (III)
دو س الدهادهله كار كران كمو لمهت

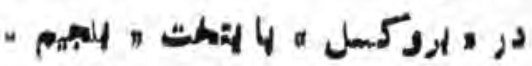

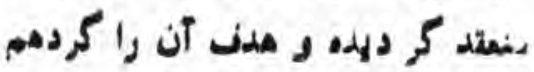

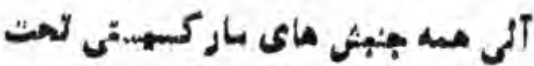

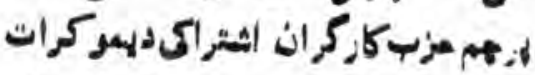

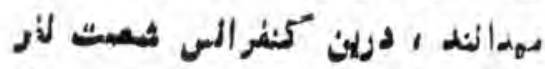

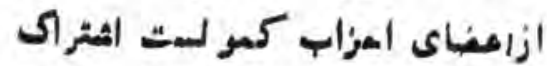

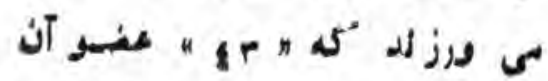

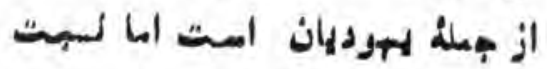

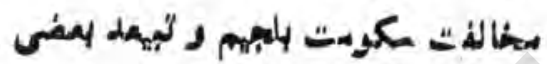

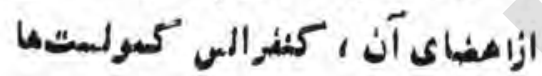

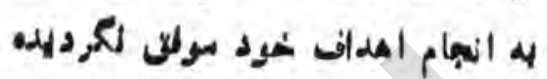

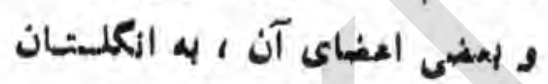

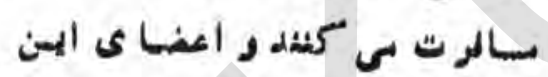
كنفرالس دكرد مم آلى بلدو دسثم

$$
\text { تلسيه بمثولد . }
$$

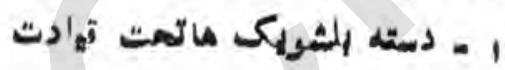

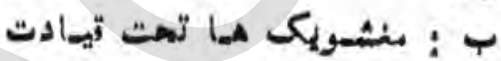

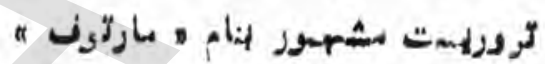

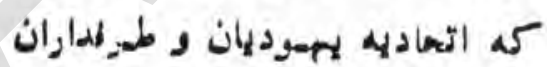

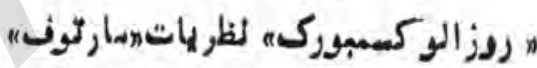

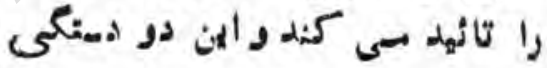

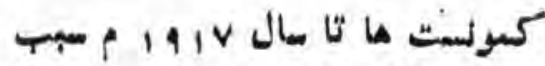
انشماب آنها سى مرددولىدراخير معمين

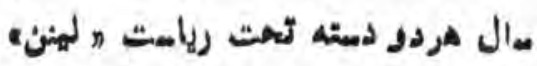

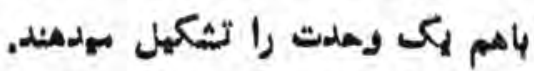

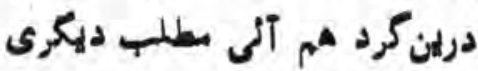

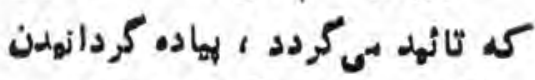

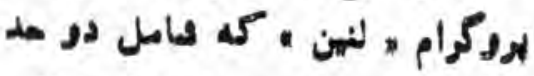

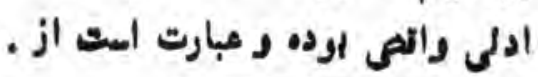

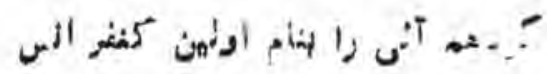

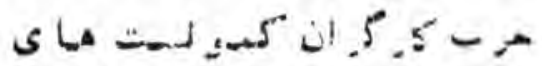

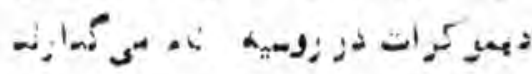

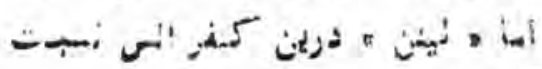

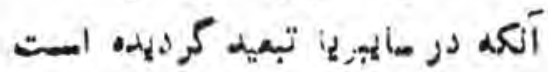

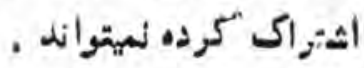

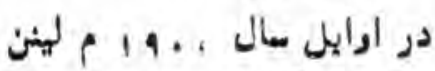
از تبعهد بلز بى كردد و اولينه:هيدة

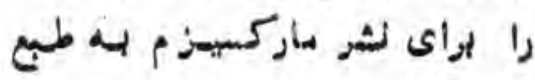

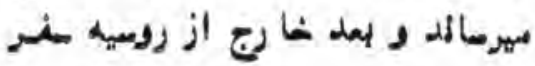

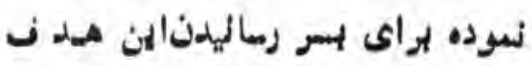

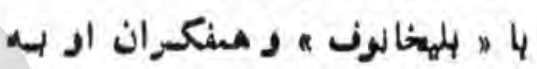

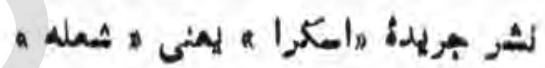
مى التدازلد و اوليهنشماره آن درمال

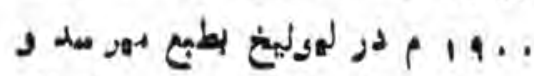

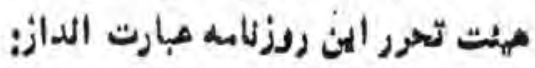

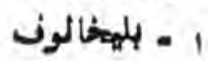
ب : زاتسو لهيّ - يهمودى

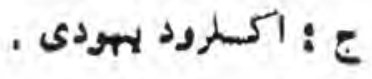
د: : 'ينز المهودى

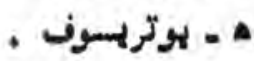

و - مأرلون الهو

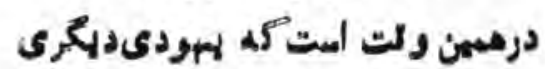

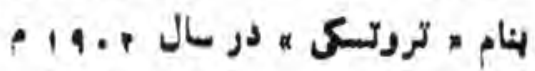

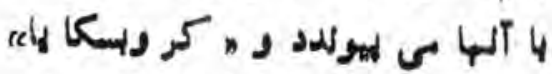
همسر لهن لهزباآلها بشاركتمىدرزده.

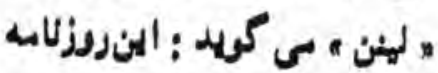

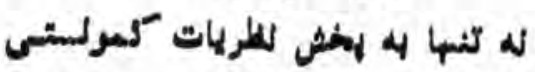

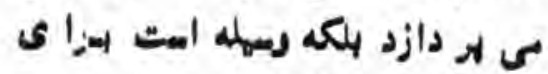

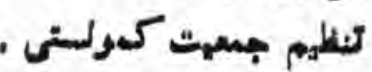

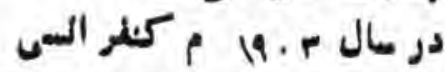


ترجمه : ب-لكل فرهيخته

انود كه در تر كستان رياليزه (آب) لمى ثد ، و ممين هم علت تقليل

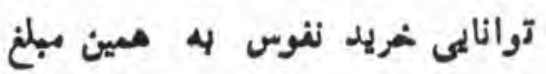

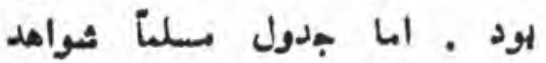

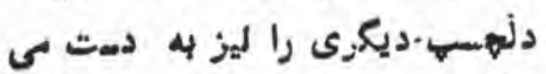

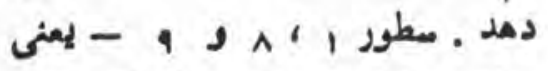

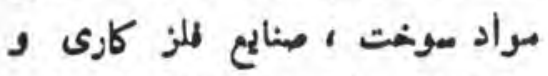
معدن در منطقه خهيلى نعالى الد . اين تصوير آن بنان يك وضع مكثدون ر آشكا. است كه منطفه تشارك كنيد

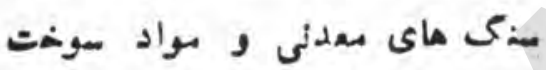

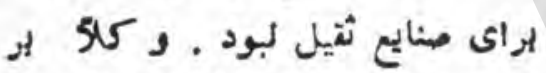

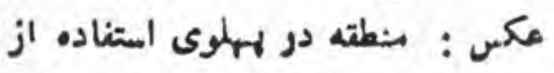
أزاوردهماى منايع فلزكارى ، سعصوت

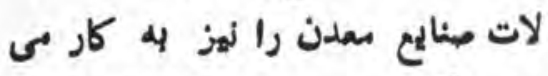

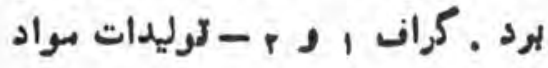
هذايع و علد باب نهز براى منطئه

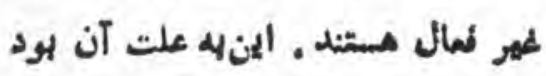

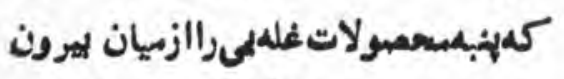

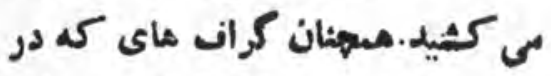

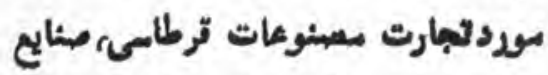

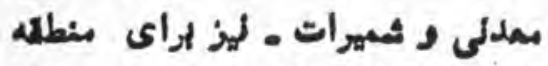

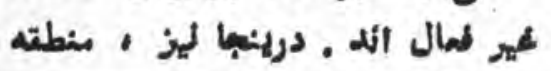

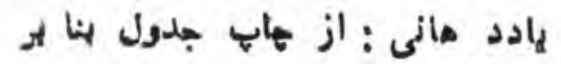

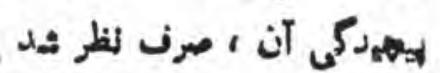
در بلمغى كسنها ، الطور مثال

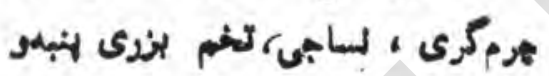

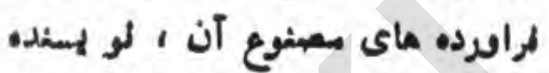

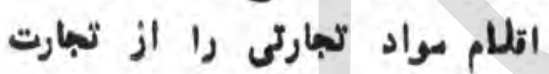

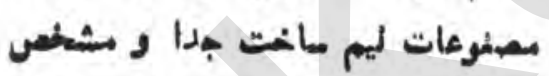

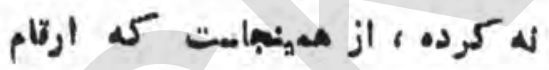
جدول امل مسثله را در لرده الهبام

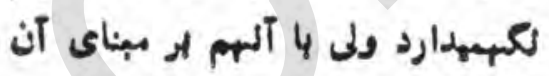

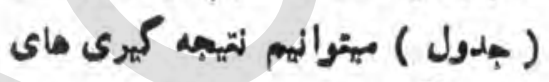

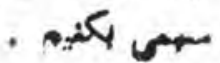

نخست از همه بايد خاطر نشان

هاخت كه مادرات منطقه بيشتر از رارداتش بود . هنعقه ، هنكاميكه 4 مبلغ معينى مواد

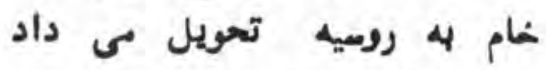

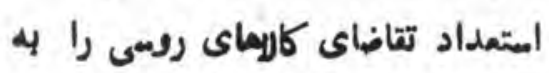
همين مبلغ نداثت . در لين صادرات و واردات تفاوتى بهالدازه مى ملهون روبل وجرد داثت ايثثتر قسمت آن مود مرمايذ تهارى و بالكهاى روسى
يراى نتيجه كيمرى از مسلة

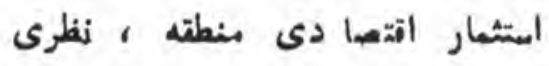

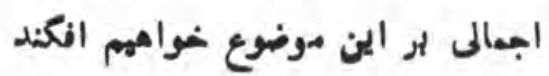

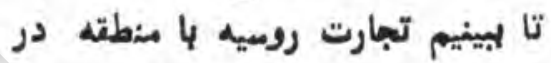
اين مرهله در هه وضع قرار دادت. در بلا ديدايم كمه بكوله هيورفرا

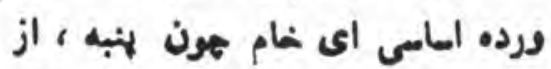

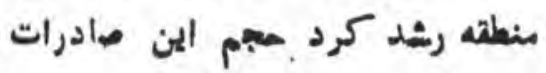
در لايان همله مورد مطاله از ماز ......

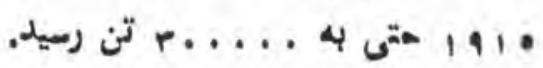

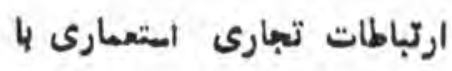

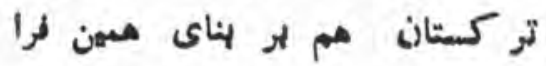
درده ي "اساسى رثد ميكردمدورمواد

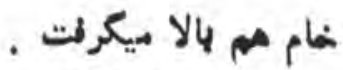
آنون 4 كردش ماى تجارت در اتلام ديكر طادراتى و وارداتى ماتى

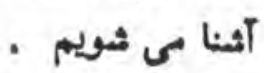

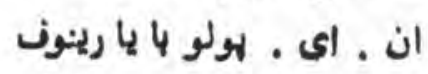
آمار آتى را

ازكردش تهارت خاربى منطقه 4 روسيه و دمالك مبهوار آن در مال

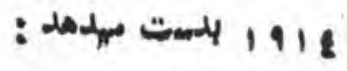




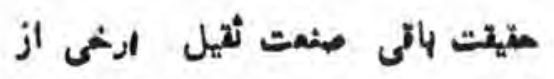

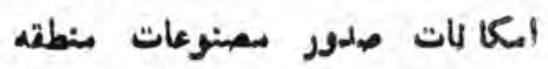
بلدت آورد ، الها سواد سورنت

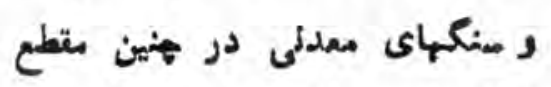
زمانى بلست نياورد .

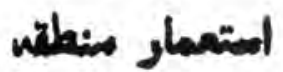

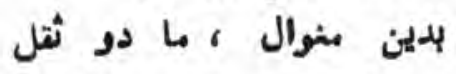

استعمارى راكم بر دوش منطقه ثرار

$$
\text { داثت الرمى كرديه. }
$$

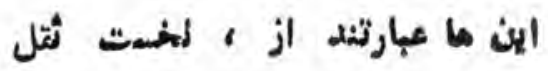

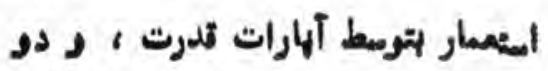

دهيكر ـ ثثل استعار تبارى و بالكى

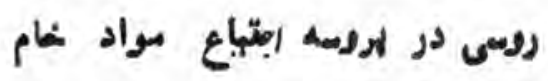

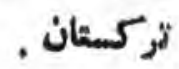

ما ، در دمل متئعى ، آمار

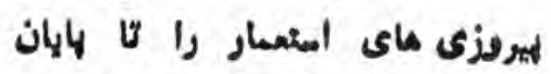

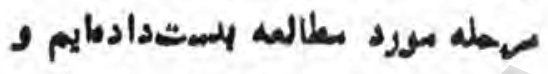

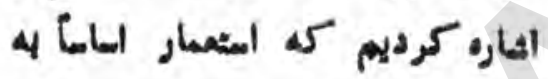
سوى سناطل كوبهى لكين توجيه شيد

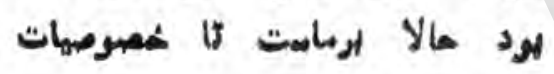

أستعارى مكوميت و عم خعصوميت

مهود استعمار رأ الرس كنهم .

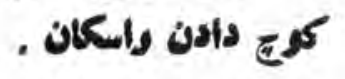

سملك بورد بطلالعه ، مهمله

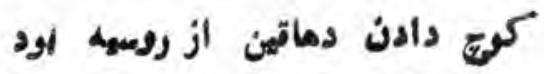

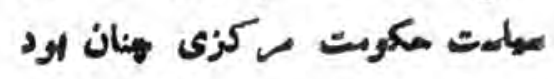
كع باليد تعداد لهثثر مانواده دهائين

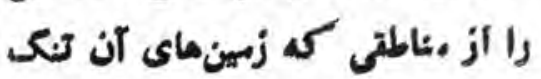

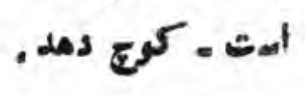

هـرجين از مها ن نويسنده

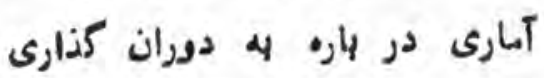

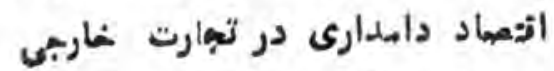

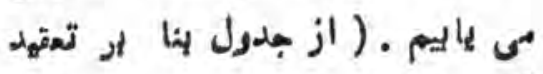
آن مرن نظر بميثود ،

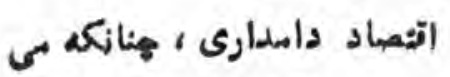

الهينيم ، متىجوالكوى تقاضياى دانلي

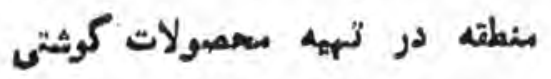
ليست . منطثه از اين سمعيو لات

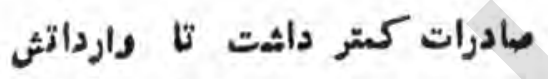
دولى درباايل درهين اتلام مادراتى

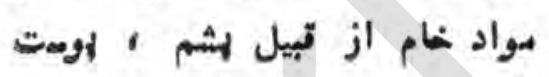
كوسنغد فره تل وغهره ، سنطقه بهينّر هادرات دارد تا واردات : م ازلين

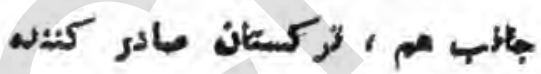
مواد شام له روسوه أست . بداين ترتيب / تهبارت روايط

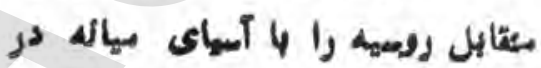

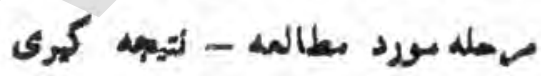

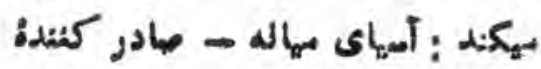

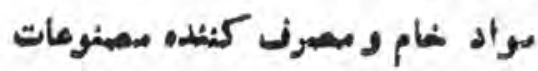

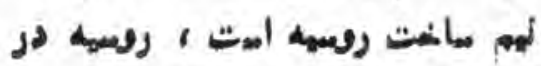

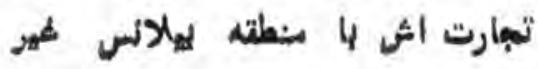

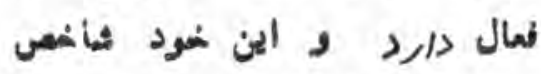
مقياس هاى المثمار استمهارى است

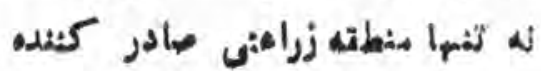

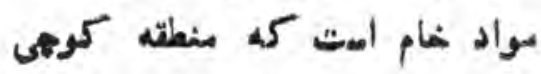
كمئن نيز ، ولح تركستان ، اكنون

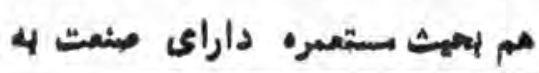

ستبهلى سمعنوعات ليمسانت است . تنها در آلهاكمواد شام ثشاسل

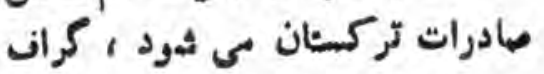

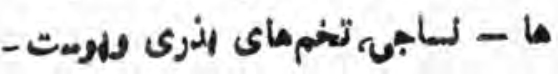
مادرات تركستان ايشتر از واردات آن مى الثد ، إعنى در بهلانس

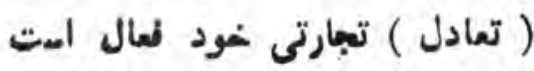

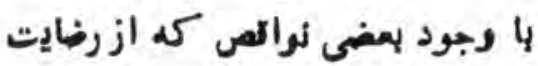

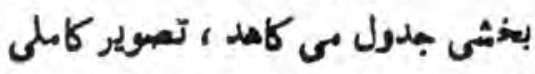

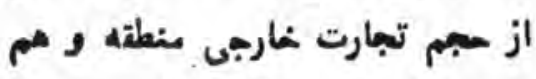
در باره خصوميت آن ازطريق جدارد

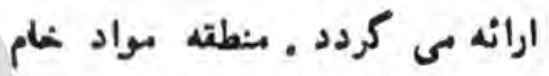

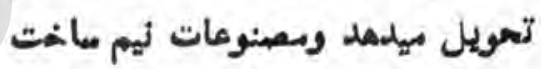
بلدست بى آورد : منطثه بيلانس تبار تى تيجيك ( شود د ويثر ) استمارى دارد :

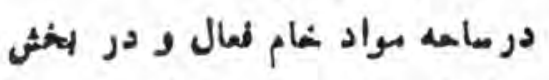
مواد ليم ساخت غير كمال ادت .

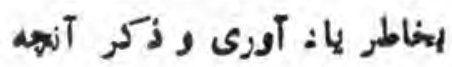
اين تجارت در انشش زياد يخودتهارت

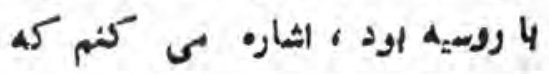
طبق آمار ممان نويسنده كردش هاى

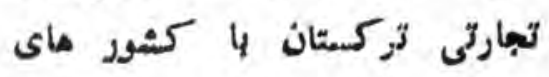

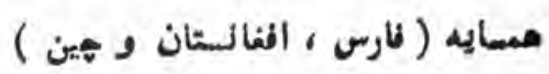

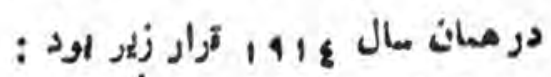

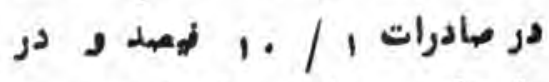

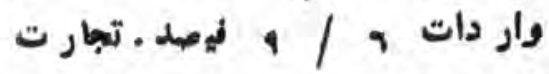

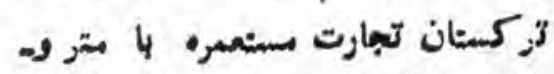
اوليت (كثوراستمار كر ) ) روسيه . 29! 


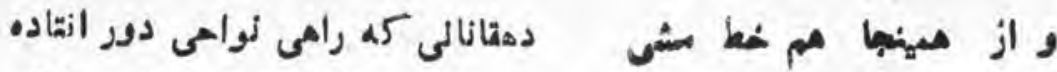

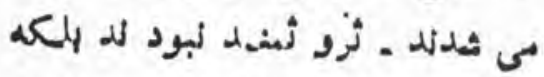

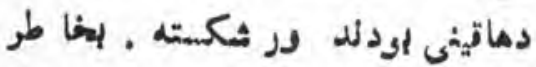

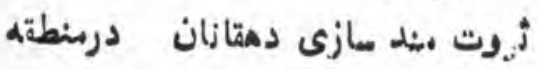

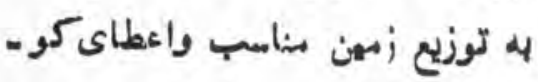

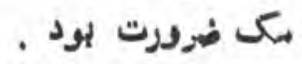

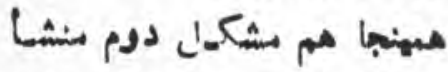

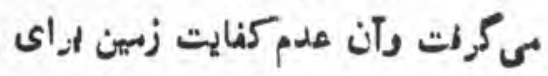

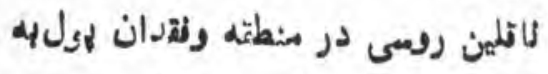

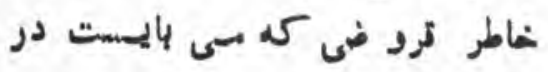

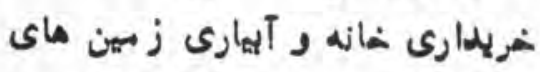

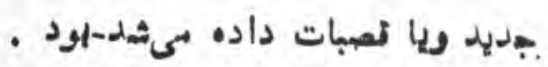

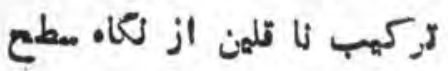

$$
-\because \cdot)^{\circ}
$$

لخست دارائى ناقلين روسى را.

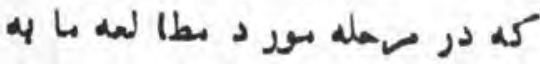

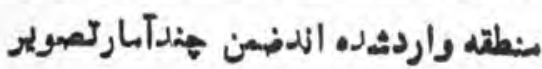
سيكنيم) آسارتعقيقات درمورده 1 ر اقصهبه

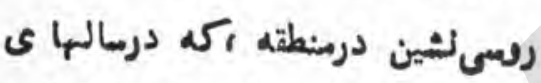

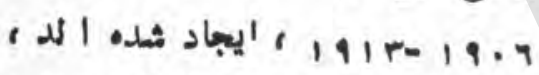
كبت درمبدى آتى را از كروبهماى الهاد شعده زارع لظر له مزار ع آلها در د طن لهن

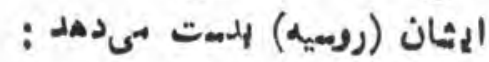

جمعأ تعداد بمجوعى لمصبا ت
لاثلين ثروتمئد نتهيهه مى ثد. تمعبات

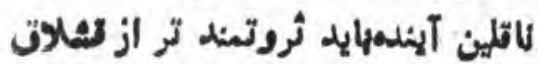

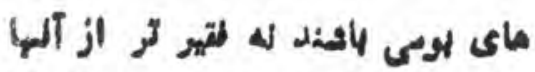

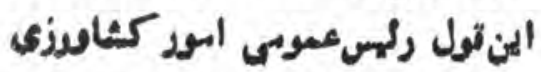

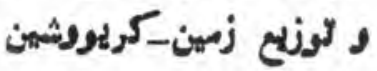

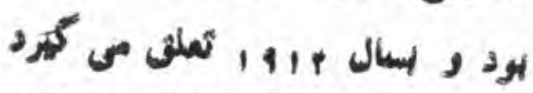

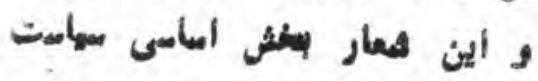

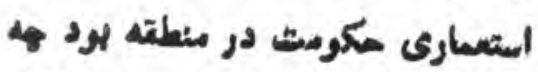

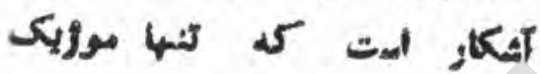
( دمثانان و كار كران كثير روسيه )

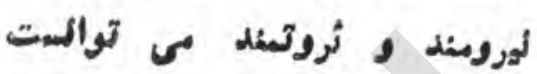

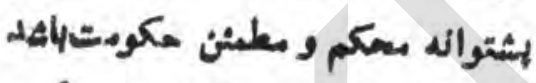
و لنها ثروتئد بى توانست كأمين

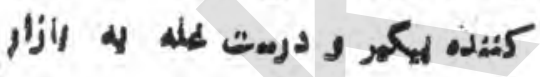

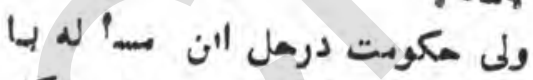

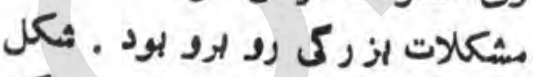

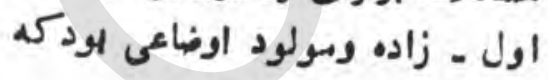

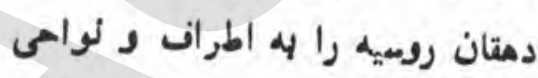
دور انتاده راهى بىساخت : دهمانان

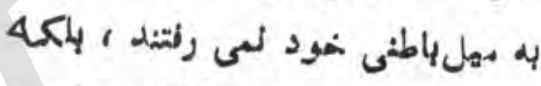
تفكى وتلت زبهين وادارثان دهيساخت

$$
\text { شماره اتتصادهاتى كه دروطن }
$$

هنهن الو د مشى ( مكوبدت

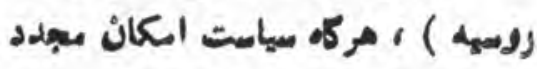

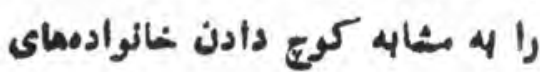
دماتين روس از روسهه در شكل للاب

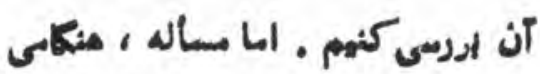
كه "وجه مان را لهمستعمره معطوف كنم

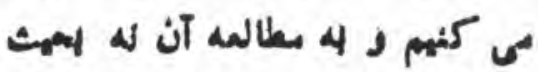

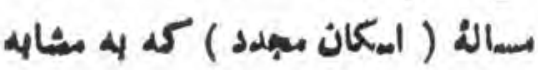

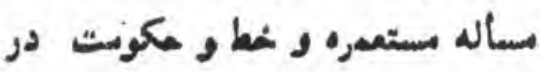
امكان منطقه توسط لنوس روسى آغاز

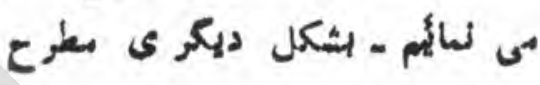
مهثود . مال

درينجا 4 امداف جديد ميأمت

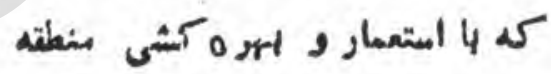

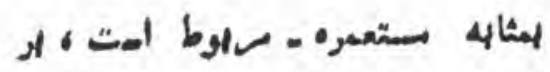
بى خوريم لاثل روسى لخست بلايد

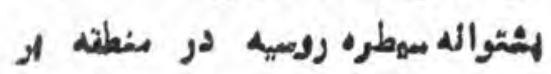

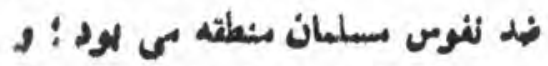

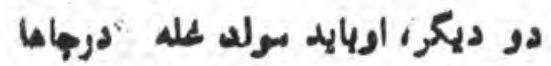

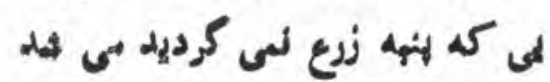

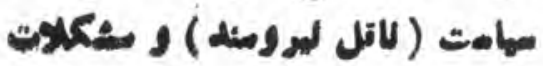
: آن

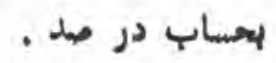

\begin{tabular}{|c|c|c|c|c|c|}
\hline & ivv & • cp & 1098 & pqv & PAP \\
\hline 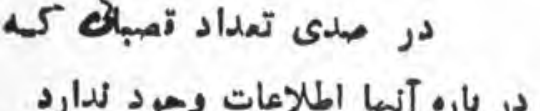 & et. & $180 \mathrm{~g}$ & $6 \varepsilon^{\prime} \cdot$ & i1'. & 1.19 \\
\hline ر باره آهبا اطلغعات وجود مارد & .14 & $1 V^{\prime} 8$ & optr & $11{ }^{\prime}$ & $1 A^{6} 1$ \\
\hline
\end{tabular}

$$
\text { داراى مززوعهبوده الد . }
$$

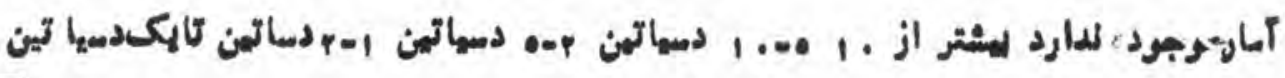




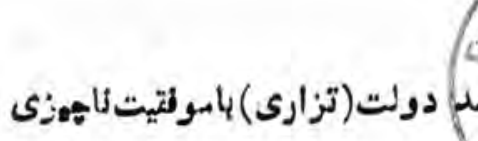 \\ ر) راه تمبات هنطقه \\ بدول زير(نسبت عنهد}

از آن مرفرنظر بىشود ) الئنه روزى

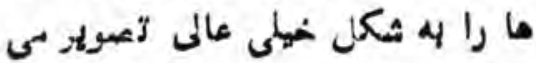

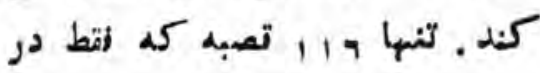
مسمله مدهيان وليزره نسب ت به صندوق

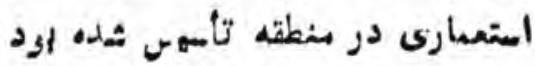

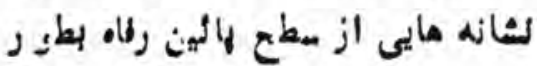

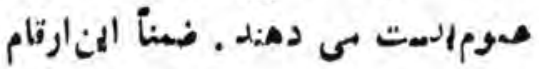

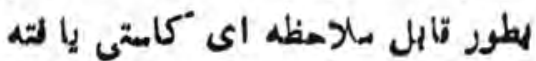

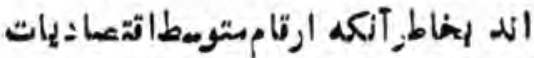
هوبو د كسو داده ثـده الد ، ولم

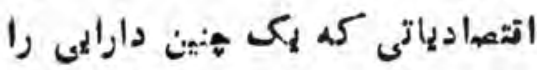
داثمته الد .ولى هi:كاتى كمه به تمبات

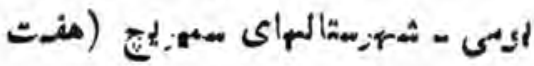

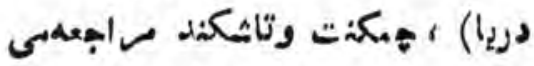

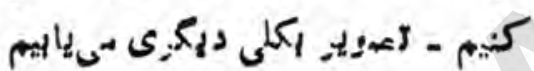
درلههلوى تأبين أوقالعاده زيادزيمهن

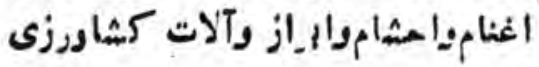

\section{rz}

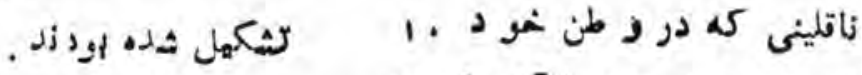

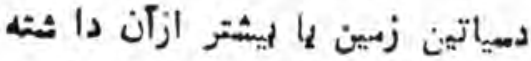

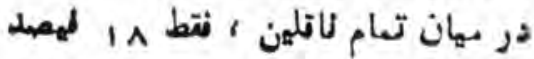
را مى سأزلد . ايثتمر ين لمدا د را لاتلين كثكيل بى د هد كد كتمر از

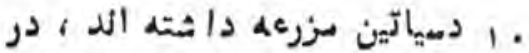
ماليكه إيشثقر از نصف تمداد نا قلين

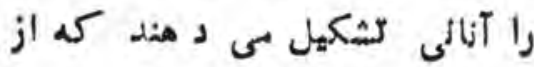

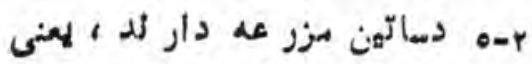

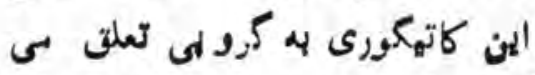

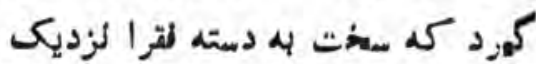

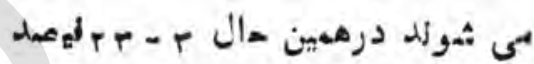

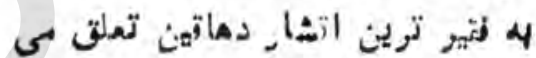
كم اين رلاء لوت المعاده زاميز الهت

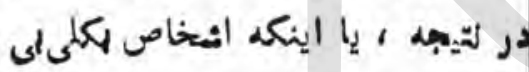
كر ند

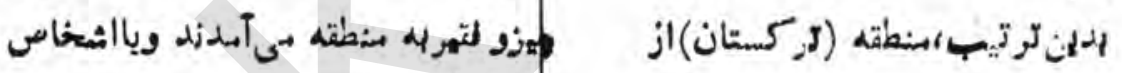
.

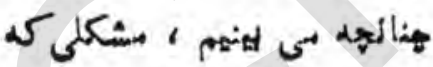

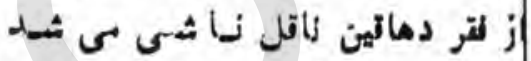

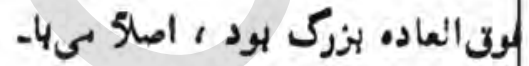

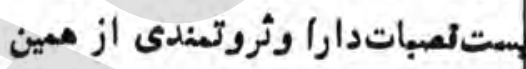

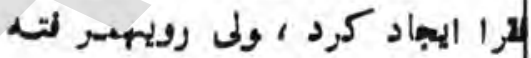

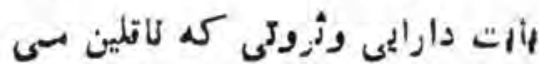

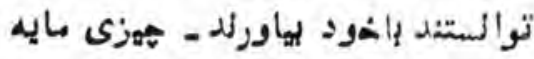
خوثشى وافتخارنداثيت . اينها(لاتلهن)

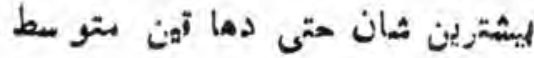

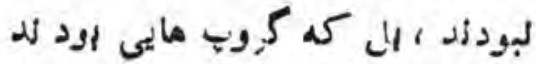

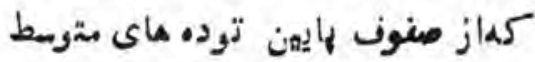

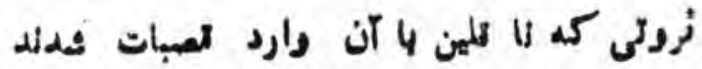

1 ا تصبه شمهرمتان مبكنت م

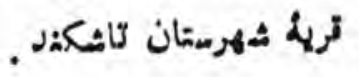

متدار روبلى

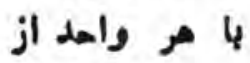

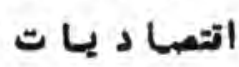

تومط لU تلهن

$$
\begin{aligned}
& \text { } 11 \text {, تصبه كم در مدالهاى }
\end{aligned}
$$

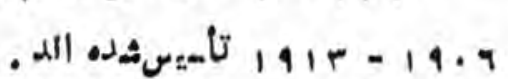

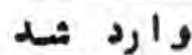

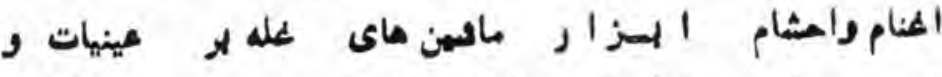

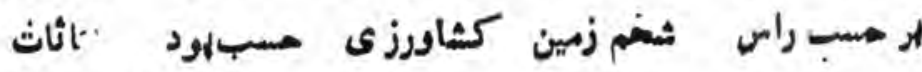
البيت

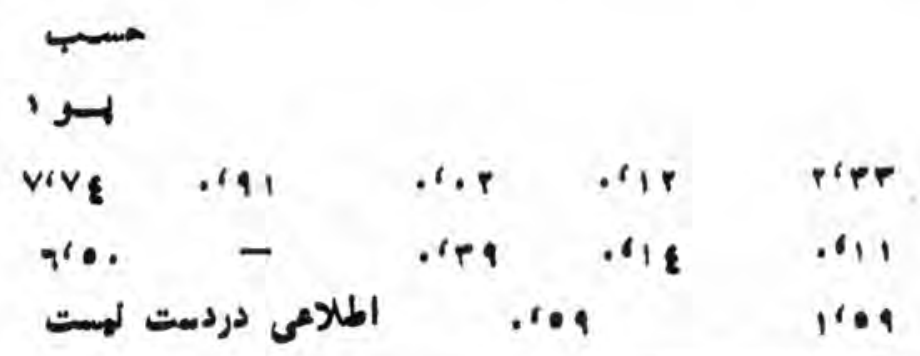


دارد، كم نشان بى دهد كم مزارع

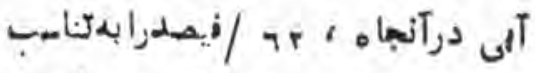
4اسامه عموبى تهتزرع بى مانت.

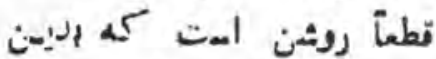

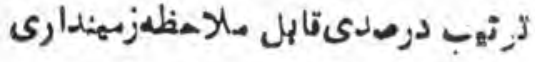

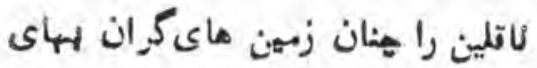

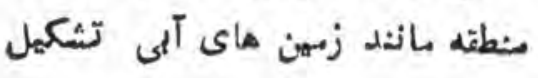

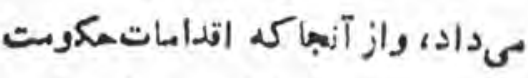

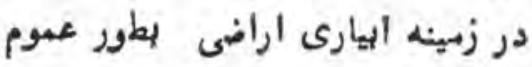

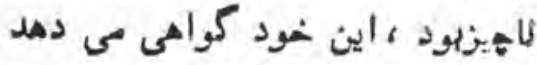

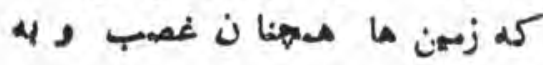

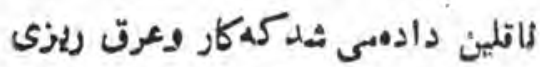

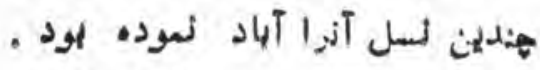

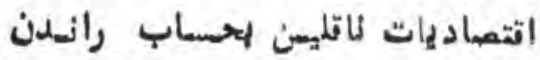

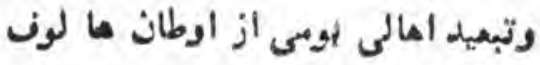

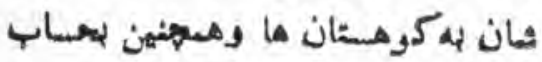

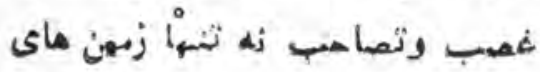

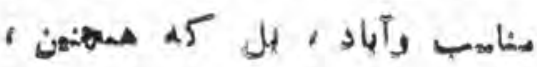

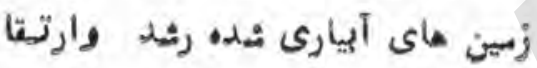
بي كري 3

سباهت امتعمارى همكومت تزار بدين سنوال، شيوهجديد ديكر المتمار وبهره كسى رابكار مى كرفت وآن تصاهب مستقهم زمينهاى بوبى 4 نفع ملاكى روسيه كه طرفدار امكان هرجه إيشتر دمقانان روميه بود، وبله

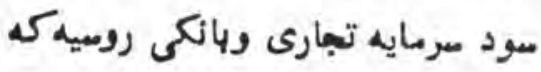

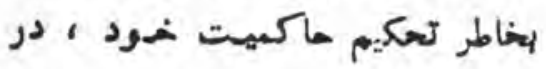
منطقه تصبات ايجاد كرده بود- هود.

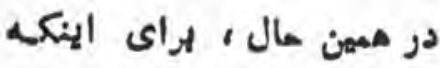

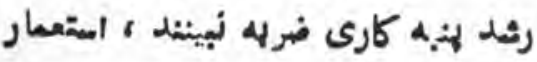

لعهاهي وغمسب اراضم بهثاله

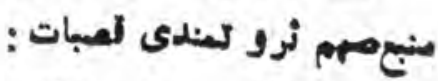

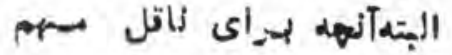

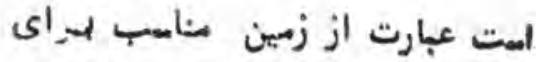
اهكان اومىياثد, هكومت اري نملفانه اين اراضى رالز بومى هان و باتئدكان

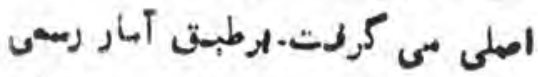

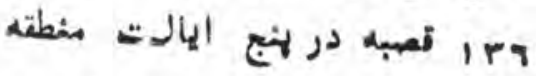

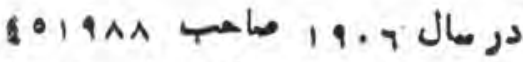

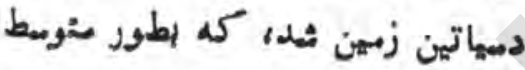

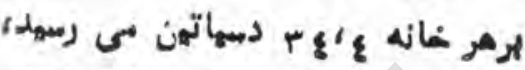

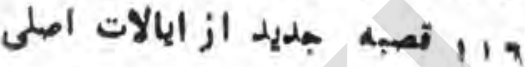

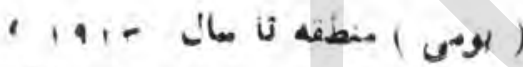

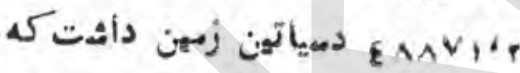

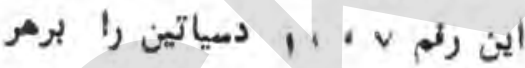

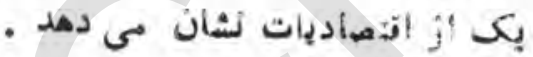

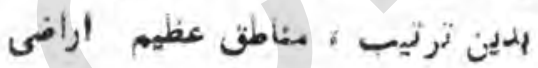

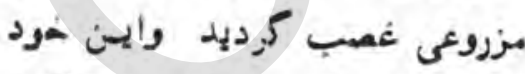
امهاس ولانه رفاميت ناقلين را لتشكيل

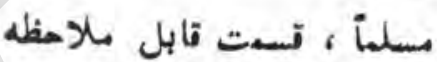
اين اراضى زمين ماى آلى بود: زمين الهيل

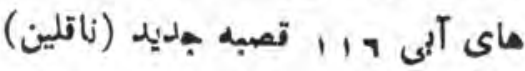

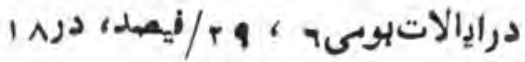

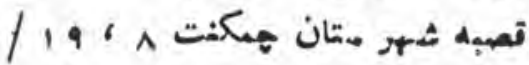

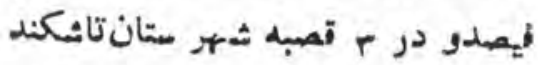

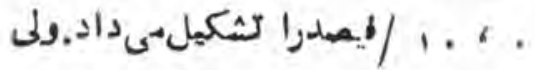

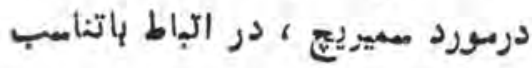

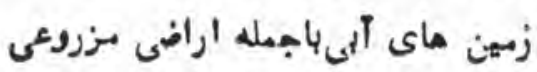

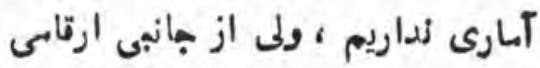

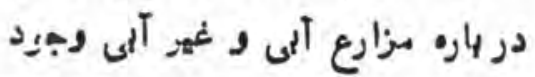

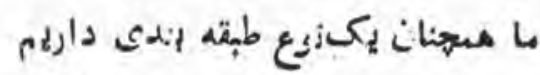

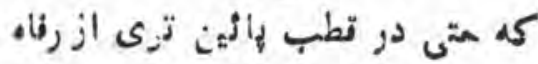

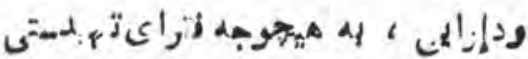

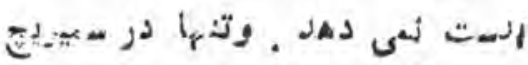

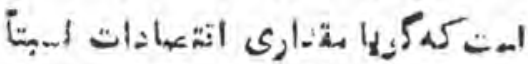
مهن درز دو كروب زرعى بى دهد.

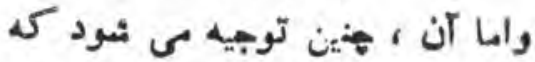
درآلها (سمير الهج) درصنى المرك بهامطلاح اتصهاديات ايكانه يهنى اقتصادياتى كم هنوز از جانب اداره (مديريت)

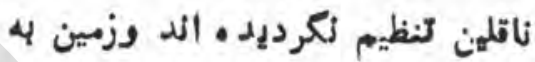
ايشانتقسميم نثده امته، واين وضعيت لهه طور قالل ملاوفظه اي ار قام رفاه مهانى ( تقوسط ) را درمسمريج تنزل مى دماند

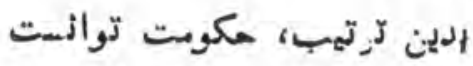

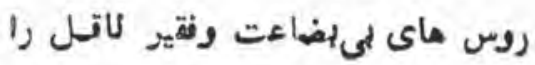
در ثنان شرايطى بكذاردكم يزودى يتوانيد اتتعهاد خود را رشد بدهند . أمباتى كه ساتق جريان اسكان در

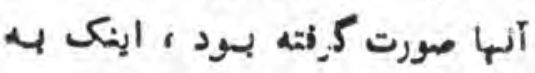
هثتوانه نهروسند اتتعادى ماكميت روم در منطقه تبد إلبل مى ثيدنيد وتعبات جديد ( ناتلهن روس ) در همين مسير قرار داثمتئن دارايى آنها

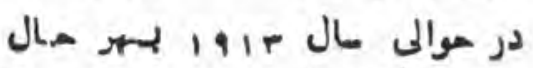

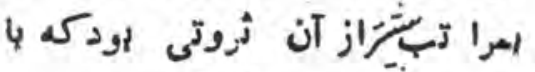
آن وطن خودزا تزى كنيند .

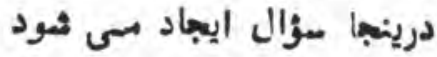

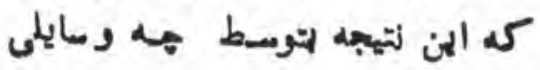

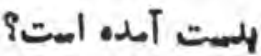


در عين هال ، ليبثتر بوميها را أحيث كاركر اجير امتخدامبيكنيد.

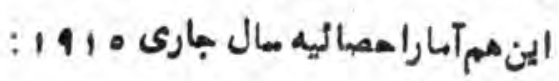
لدر ملى كاركران اجير

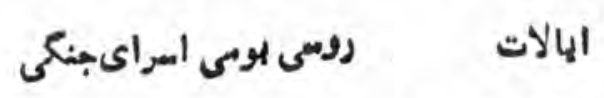

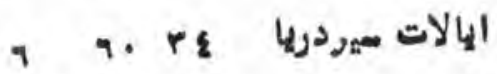

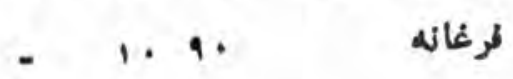

- Mr ra

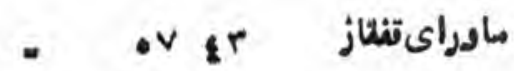

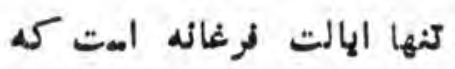

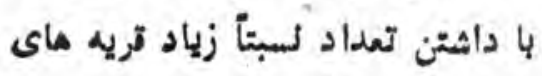
روسى لتض لايحه را بلمست مهيدهد

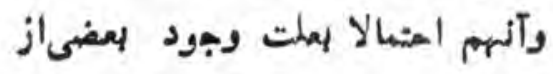
كادر هاى ناتلين روسى كه منهوز

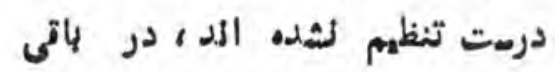
ايالات اكثرأ لوبى ها رات المتهخدام

\section{YY}

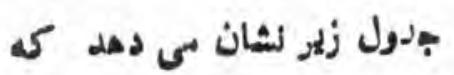

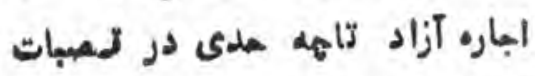

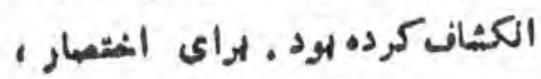

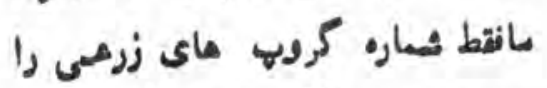

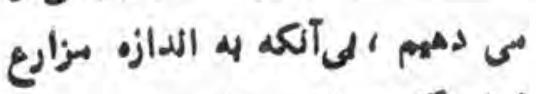

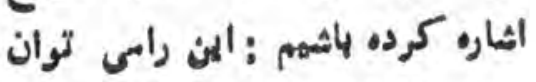

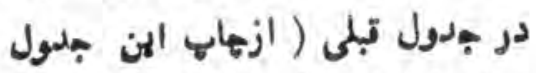

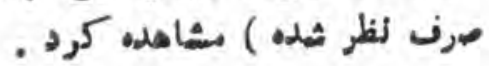

ارقام تمام كرانها كواه بربكار

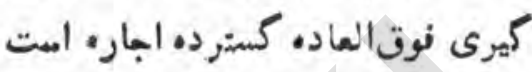
وروى معر نته نهتنها كرويهاى كماعلاى زرعى اجاره بى كنين كم كروفيهانى بايين نيز حتى زاقلهن لسبتآ كم ثروت

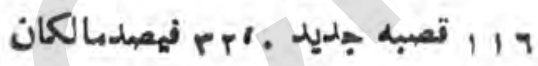

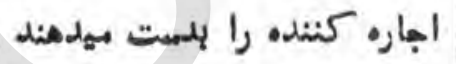

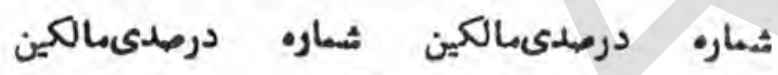

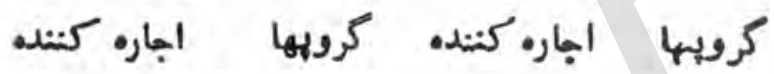

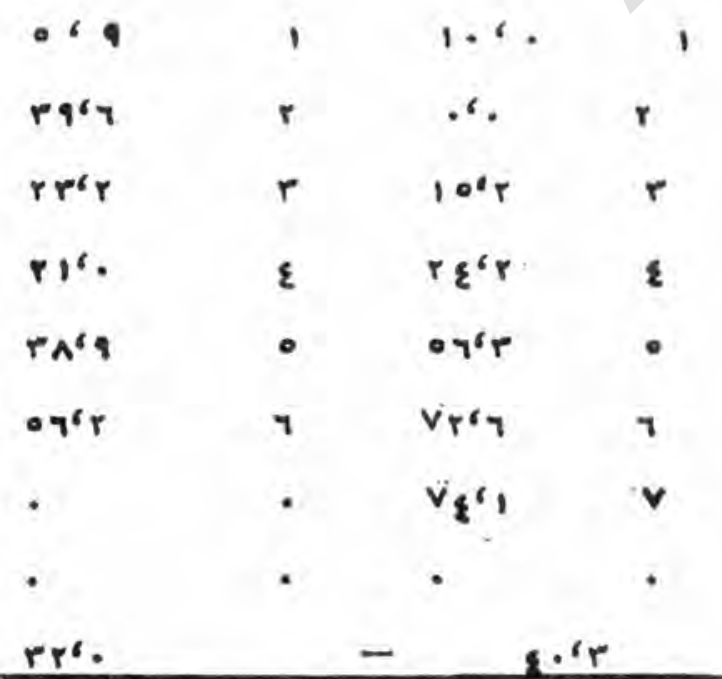

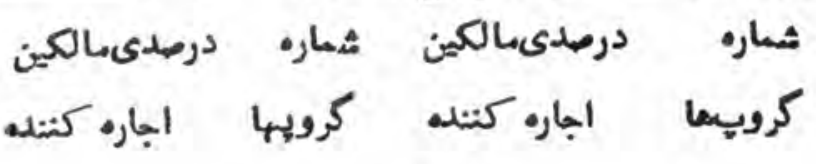

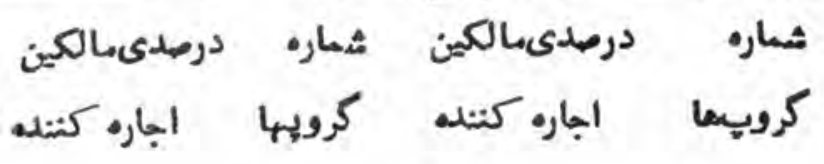

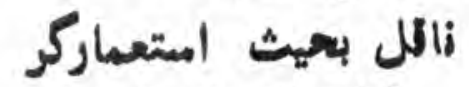

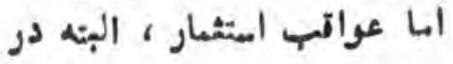

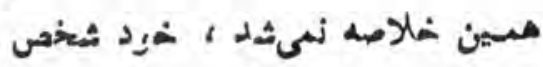

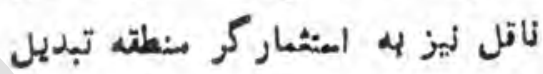

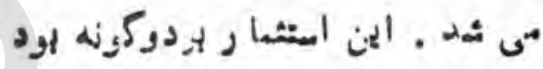

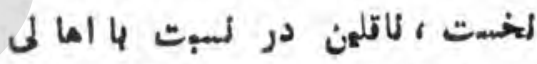

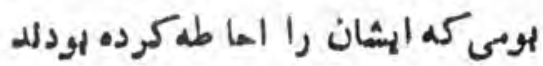

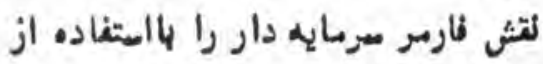

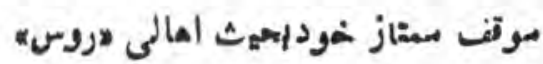

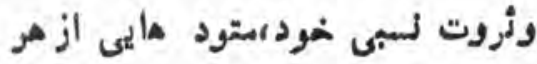

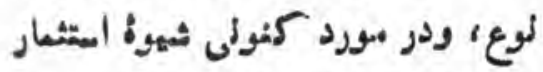

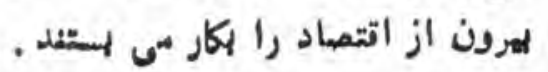

\begin{tabular}{|c|c|c|}
\hline - & , & $\bullet$ \\
\hline 0 & $r$ & 04 '. \\
\hline AIOV & $r$ & OACy \\
\hline Aviq & $\varepsilon$ & $7 \Lambda^{6} \wedge$ \\
\hline צ' & - & r'A' \\
\hline $9 \cdot 6$ & 7 & 9.61 \\
\hline 9A'T & $v$ & $906_{1}$ \\
\hline $90<4$ & $\wedge$ & $9 \Lambda^{61}$ \\
\hline
\end{tabular}

- vvio - $-\varepsilon^{i} r$ 
روسى) كاوماى لر خود راكمهريض

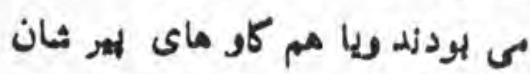

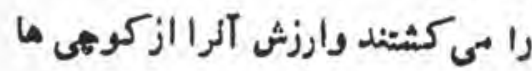

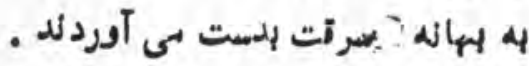

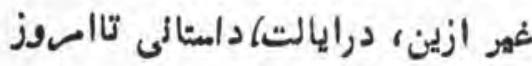
هنظ ثده است مبنى اراينكه، هكونه موزيكهاى ايكى از دمات ، زمستئان

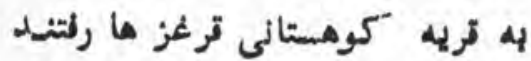

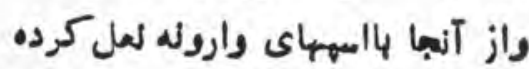

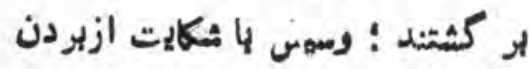

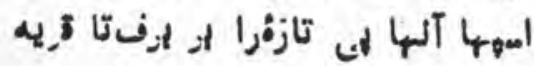

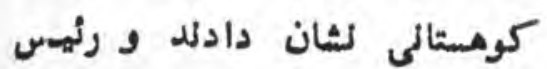
ثهرستان (ولسوال) ترغز را سجيبود

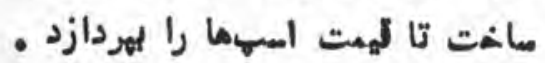
"

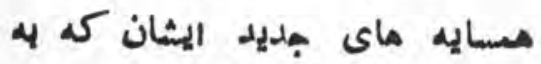

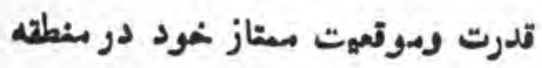

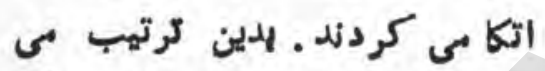

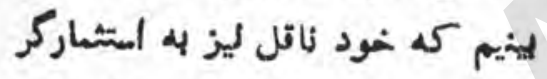

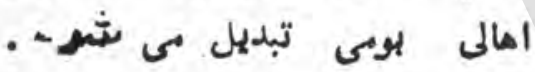

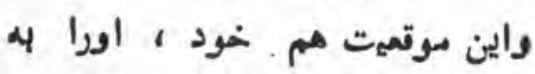

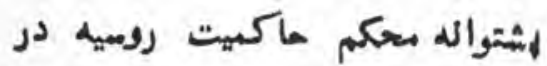
منطثه تبديل بى لمود، ير او(راقل)

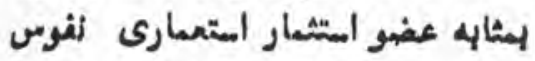
الوسى تكميه مسى كردنيل .

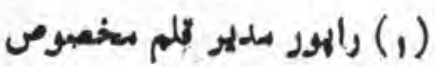

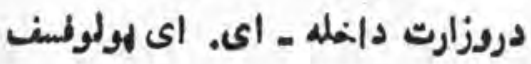

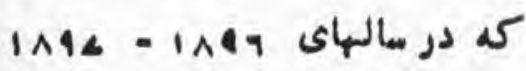

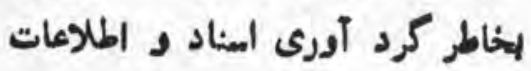

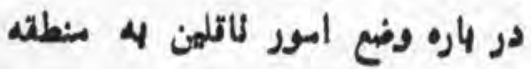

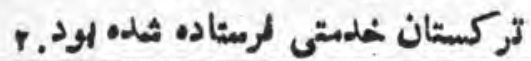

ويكاله مدف از هراء انداختنت آن كثنن هند روبل از ترعز و استفاده

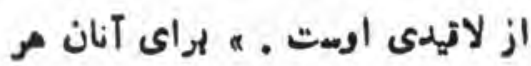

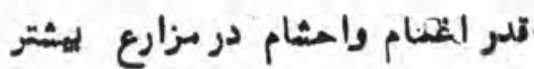

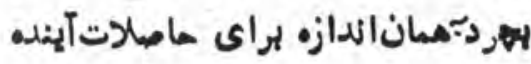
فعل درو و كثت الهارى المتير

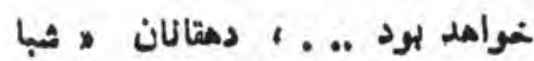

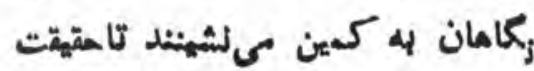

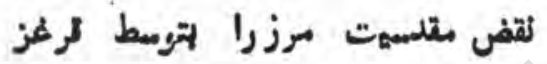

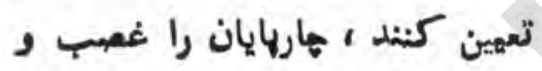

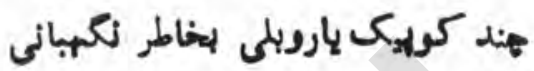
". .

قرغز ما به هنهن تعدى مايى

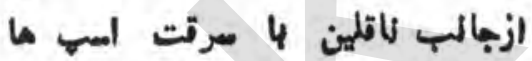
جواب مى دادند كم آنكاه والمكل

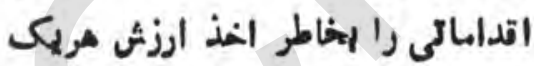
از اسمهاى مسروق از ترغز باشيند.

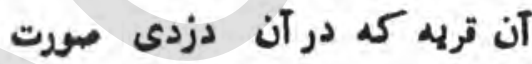

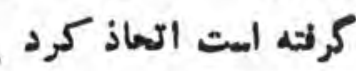

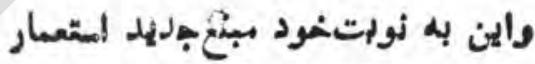

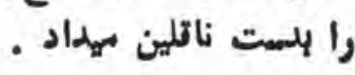
هولولهن POLOr Cer المالى سميرائه ثمين بم كويد : در كام موارد ارزش دابى راكدقرغزها

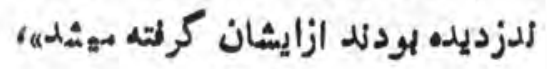

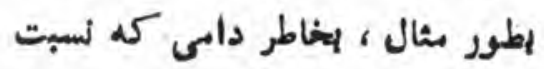

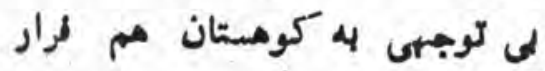

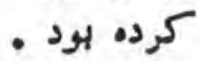

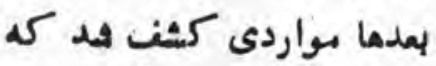

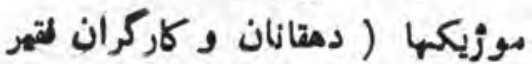

بى كنيد واين بشكل روشن وواضrىى در ايالات عير دريا كم ليشترين ليثاتلين روسهادران مستقر ثمدالديهان ميشود. در مورد سميريج درئرسىاين

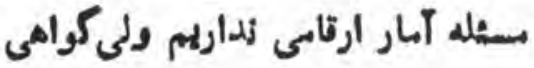

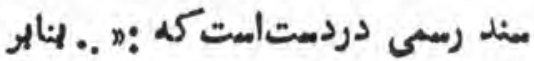

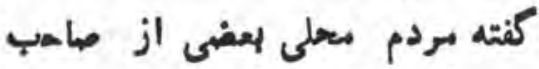

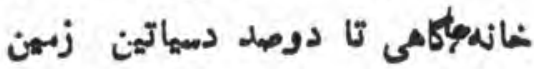
وهتى لهيثتر از آن دارلد و بشكل ملاكان زندى مى كثين وتعدادمعينى از كاركران ارزان ترعزى ردا نكاء

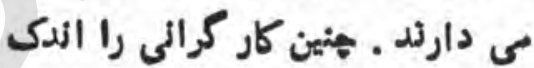

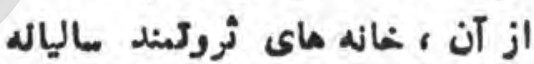

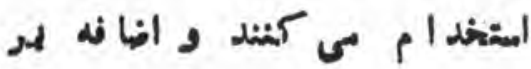
آن اين كوله امتشخدام كاركران ابير

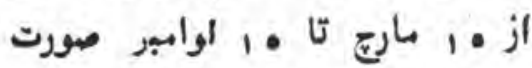

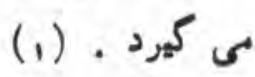

بداين ترتيب ، زاقل روسى

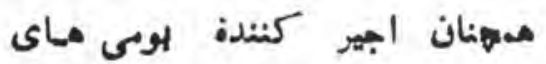
ورثكسته است ؛ در لرومئه رثـد

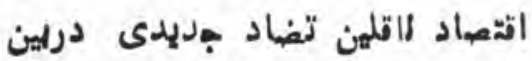

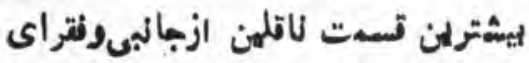
بومى از جالب ديكر الوجود آسد كمعبارت بود ازتفهاد در بهان اجير واجير كمنده . منه هبsiين امتشارغهر مرمايدارى

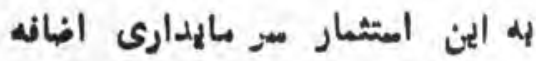

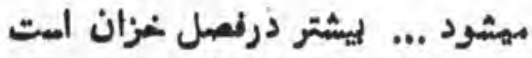

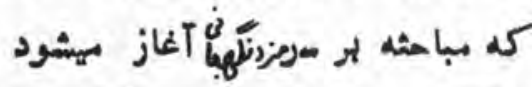




\section{rA}

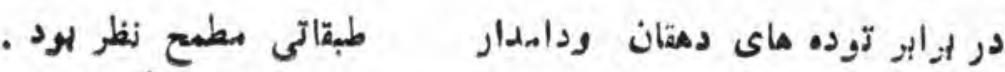

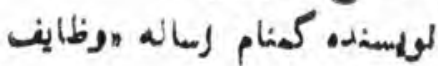

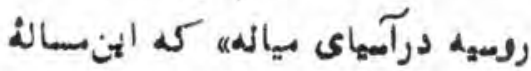

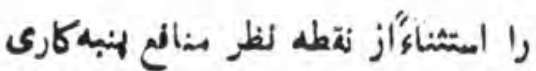
الر رسى مى كرده، منوز درسال. . 19

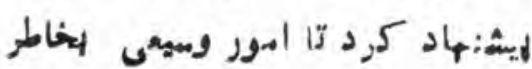
آيارى بحساب بول دولت سازمان داده ثود وله لميخاجوجه توريد

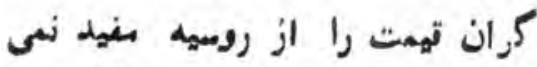

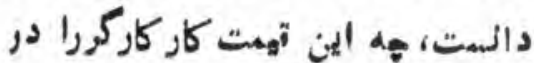

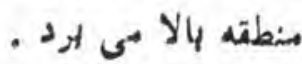

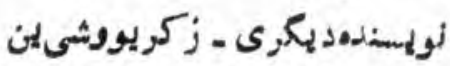
مد KRIVOSHIN

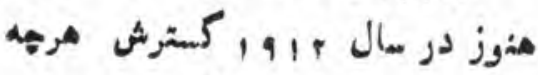

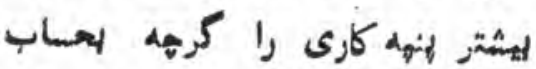

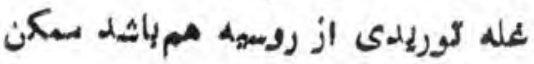

$$
\text { دانست } 6 \text { هم : }
$$

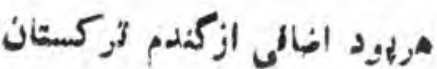

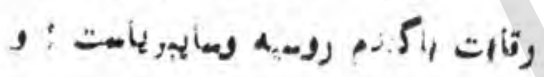

ظهور لمود كم عبارت بود از مبارزه

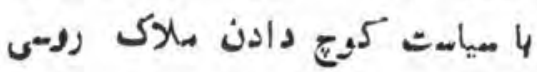
ضمناً در تصبات روسى (روس لشين )

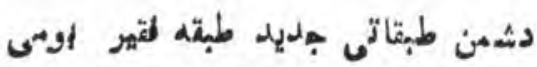
رشده ثى كر: وآن كاقل استشهاركزيهود.

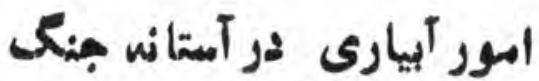
9

ثتأيزوكى المور آيهارى

pde -

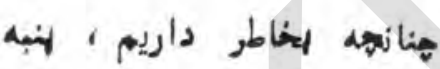

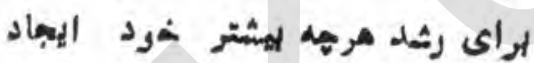

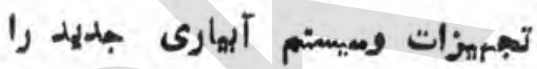
تقاضا مى كرد وائن وضميت ازمهان

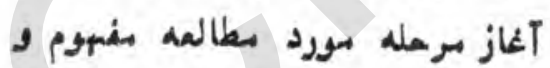

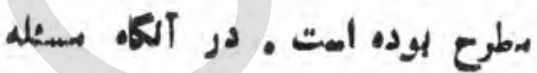

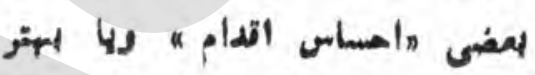

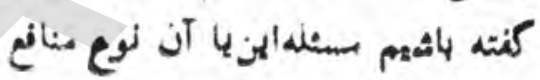

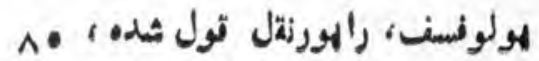
لتيبهد كبرى هاى منوا ن:

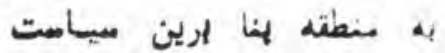
المتعهارى هلثه سوم را در امتشهار

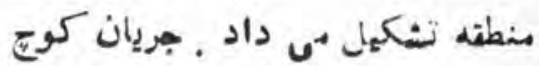

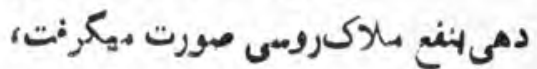
واسكان قصبات ثُزوتمند بلمسودمرمايه بالكى ولهارى بود واين ممه براهالى

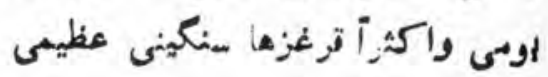

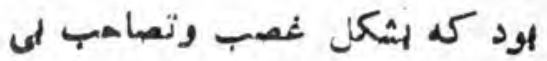

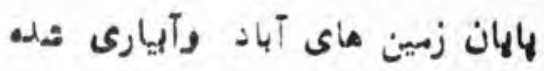

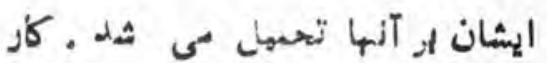

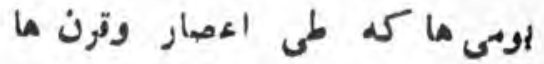

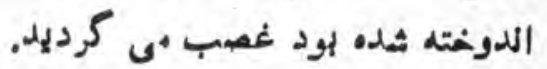

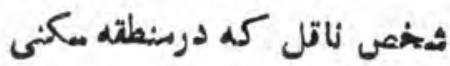
كزيده بود ، المتشماركر اوبى اي ثمد

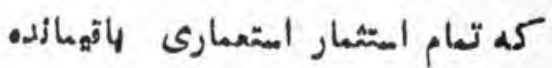
هم:هان اورا بوردمسله ترار دادهلوده.

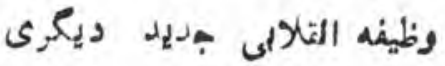

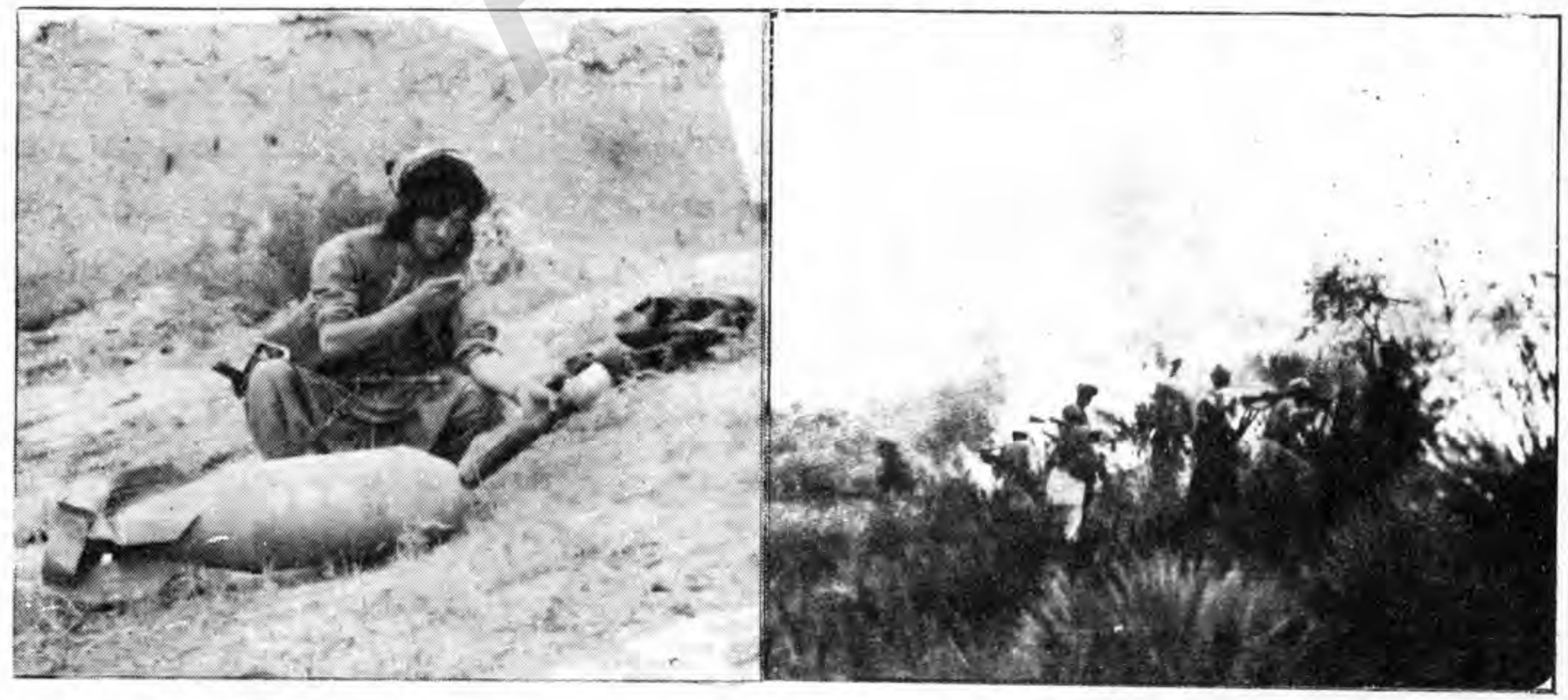




\section{وضعزندانياندراردوكاه هاى}

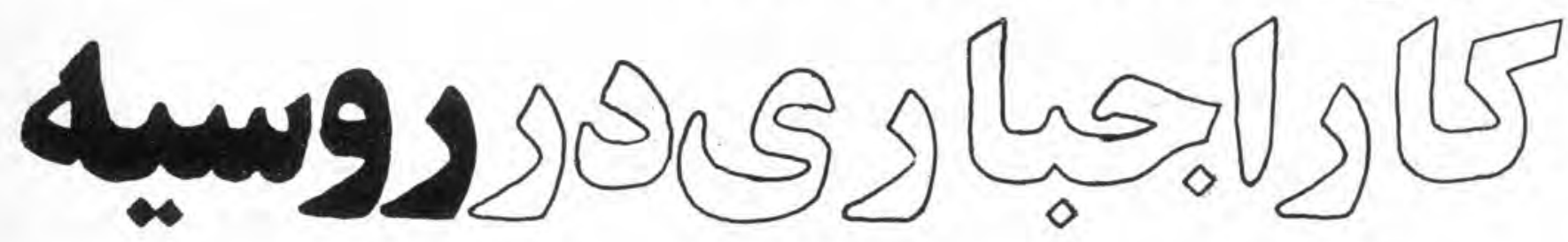

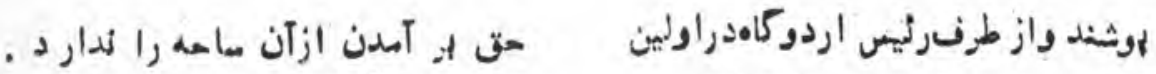

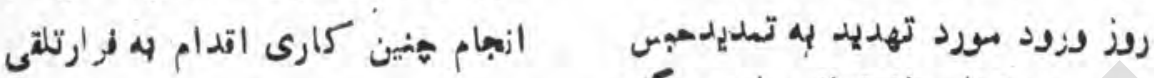
شده ومورد فيو سحافظ قرار سى كهرد.

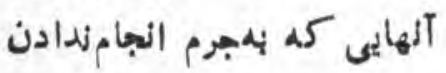

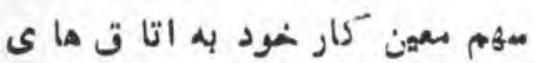

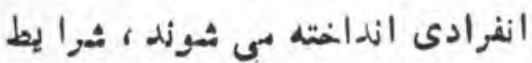

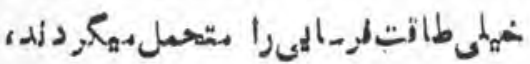

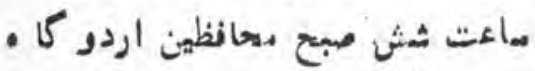

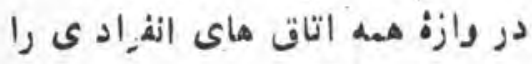

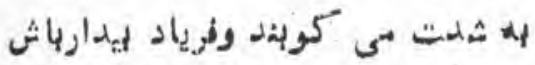

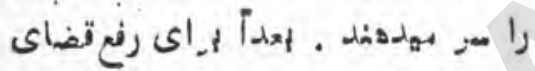

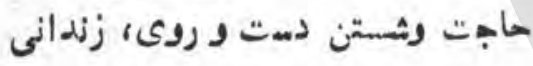

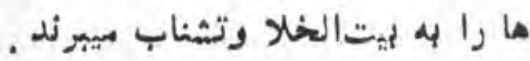

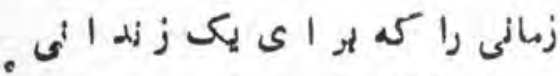

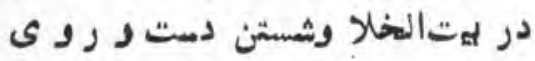

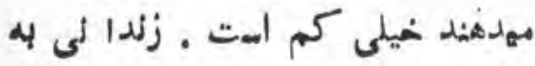

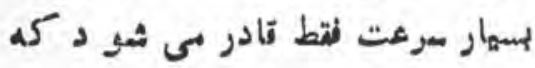

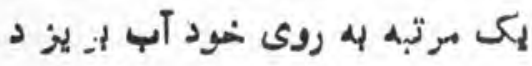

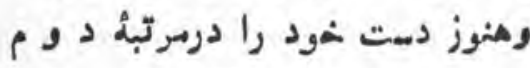

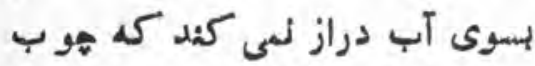

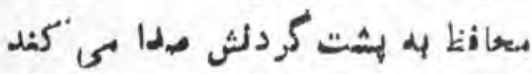

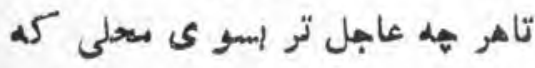

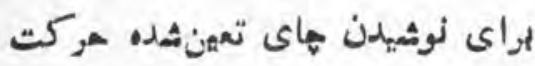

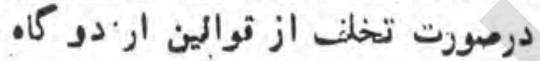

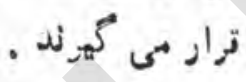

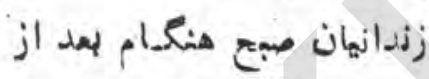

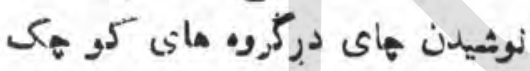

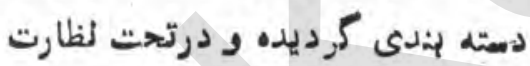

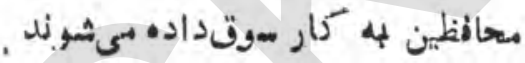

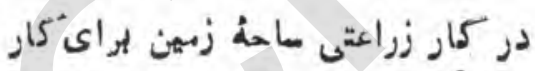

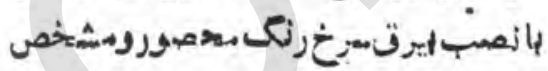

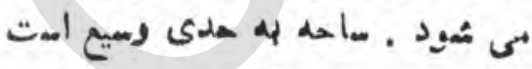

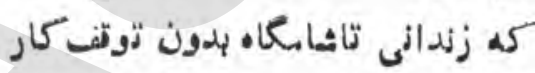

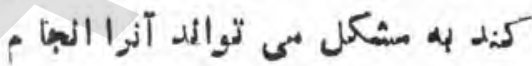

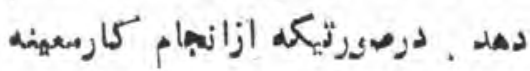

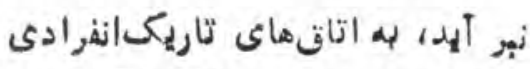

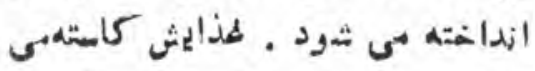

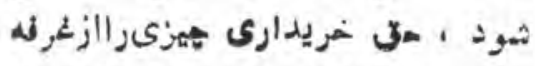

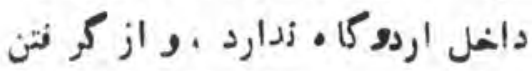

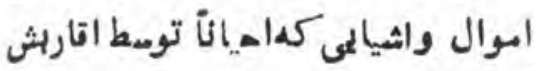
آورده شود شعروم.يمكردد . الجام ندادنسهميدُ كار وامتشناع از رنتن به كار مجازات بالاتر ازاين ها را نيز بدلبال دارد ــ وتقى ماحلة

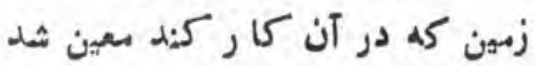

وضع زنها زلها

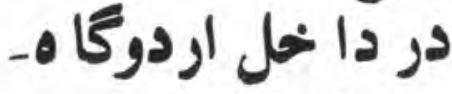
هاى كاو, اجمبار كى

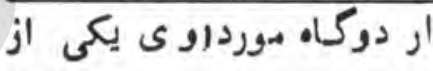

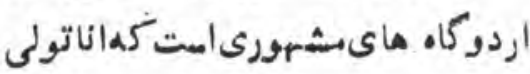

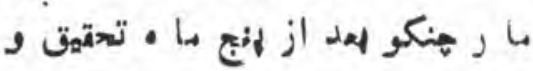

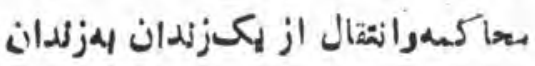
ديكر درآن آورده بىشود. اودرمورد

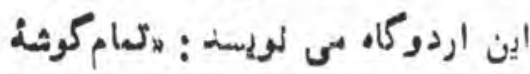

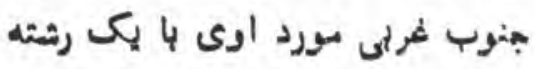

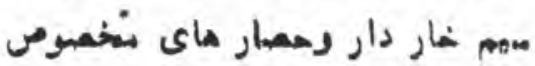

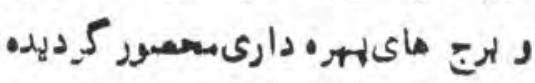

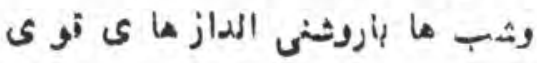

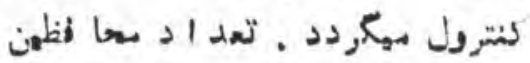

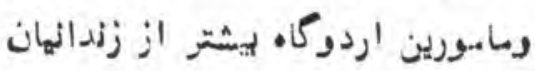

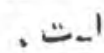

شعار زفظا.يان وماهب دنهصبان خياى زياد است . مسكومين از بليت ماى مائلف ولقاط مشختلف متى كثشور

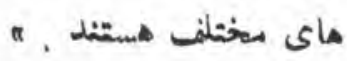

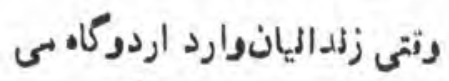
تولد ، لباسمغموص اردوكاء رابى زئى 
در اتاق انقرادىدريكدوره يجازات اخافه از بانزده روز نمى ماند و البيّه

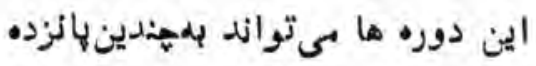

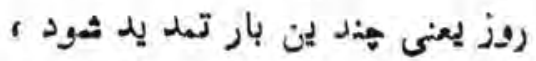

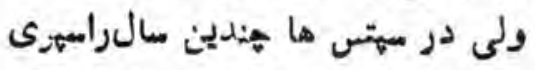
مى كيند ومثى تعام عر را .

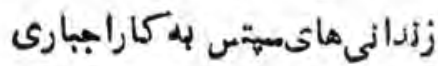

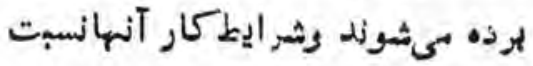

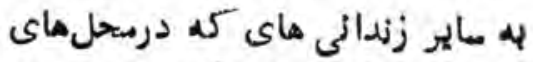

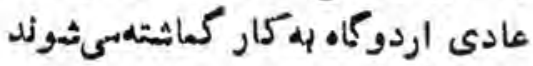

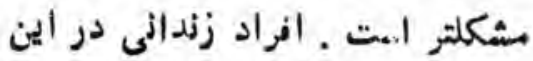

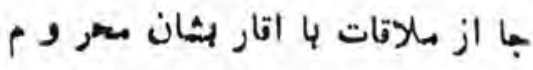

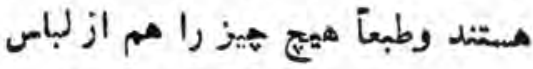

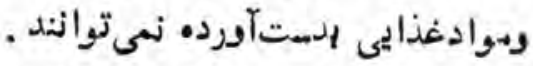

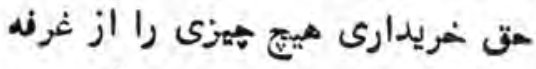

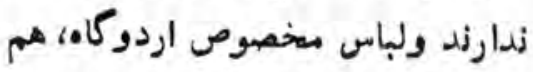

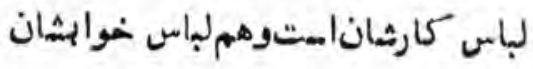

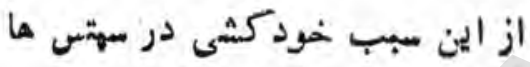

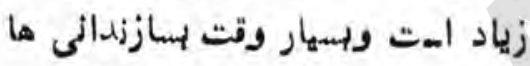

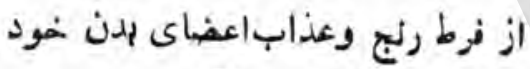

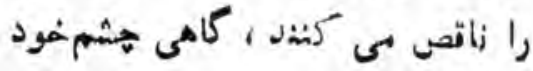

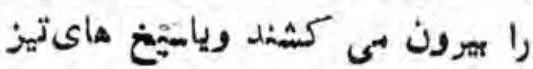

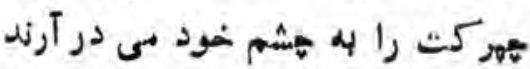

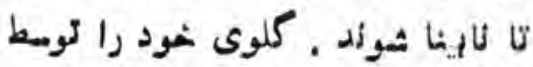

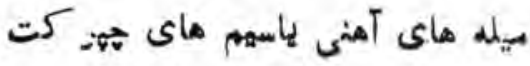
تطع بى كثنيد وكاهى رك هائ الدهن خود را نيز تطع بى نمايند تا ازئون ريزى زياد بهملاكت إرمندوازعذاب

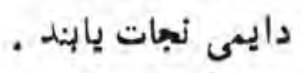

كار ديكرى كم زندانىمانير ائى

تسكين عقده وامسامات محود دريرائي
نثط افزائ سجازات را منثظر باثهد .

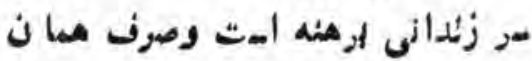

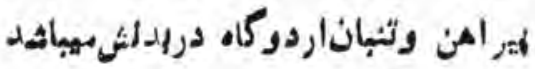
و درهير ائن لهيد اهن هقداشل كردن

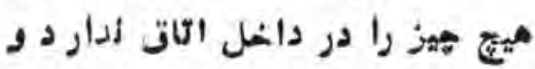

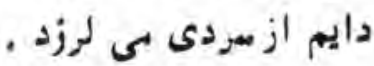

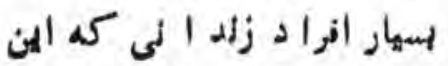
شرايط را نمى توانيدتحسل كنئددست

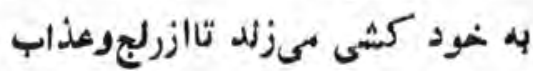

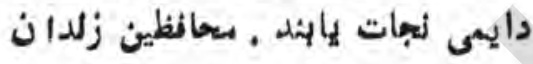

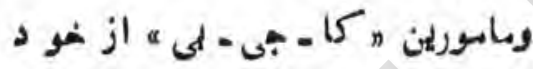

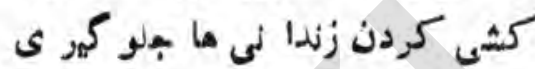

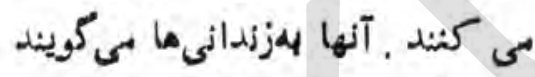

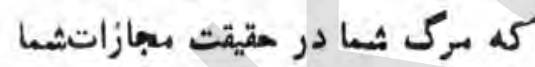

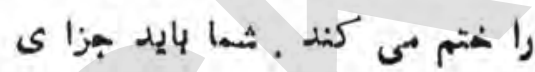
خود را بيهنيد ، هر وقتى از زندا نمان

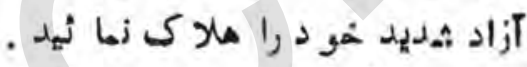

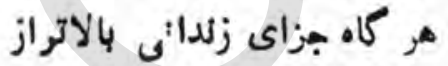

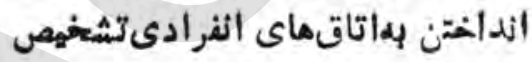
داده شود ، آنكاه زندانى را درمتحل

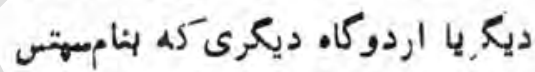

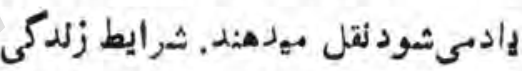

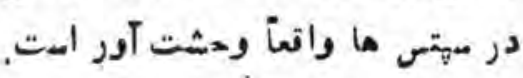

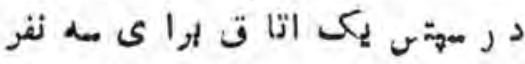
زندانى تخصيص داده شيده است. اين

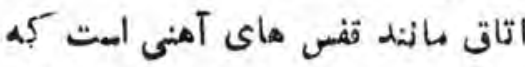
دا، باع وحشر هيوانات درئدمرادرآن نكهدارى بى كميثد ــ زندانى ازاتاق

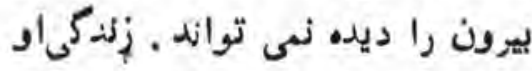

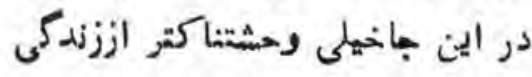

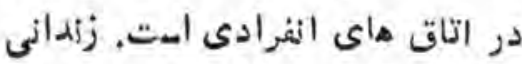

نمايد . آنحه كمهنامهاى دادةبىشود

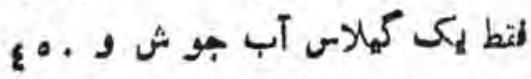

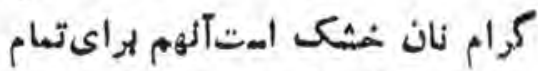
روز و زئدانى از خوردن نان هاثيت اهرت

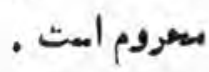

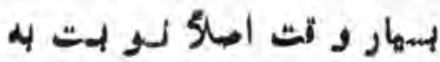

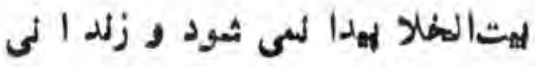

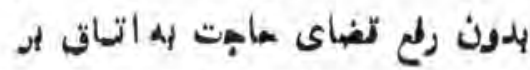

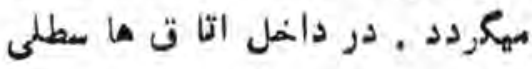
قرار داره كه زندانى مىتوانددرآنها

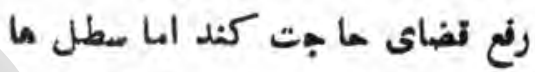

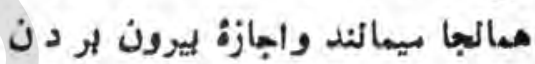

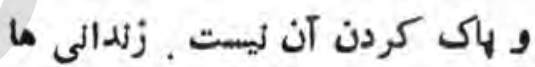

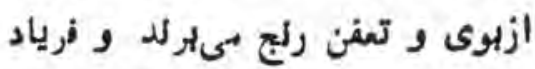

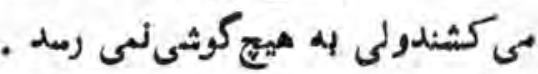

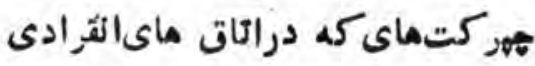

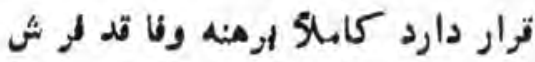

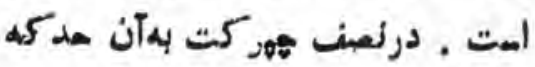

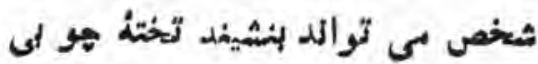
قراردارد ولتصف ديكر هيركت كتداراى

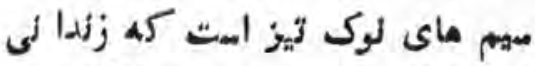

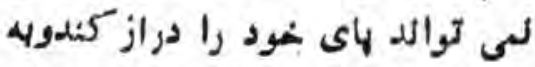

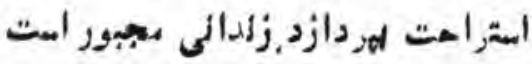

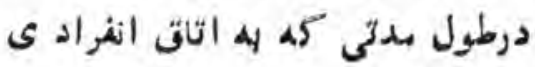
ميجبوس است لاكىها خود رابمع نموده

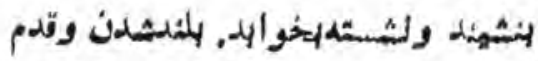
زدن مم بهاز نهست ـ علاوه الراينكه

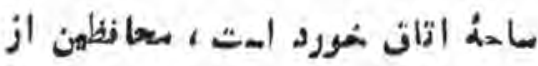

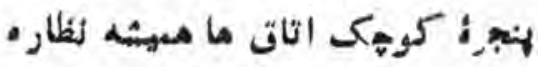

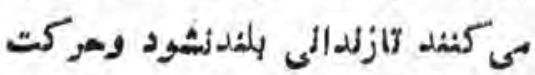
كنيد أكر هنهين كارى را العام دالد 
مزدمواى احساس ايهروانهكثبهميوانى كمونيزم ديكرانسانى دربراير مدنوغ

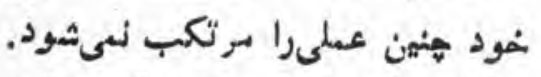
بايد كزندكان صهرا ودرندكانجنكل ها وحشث و درزندكىرا از كمونيست

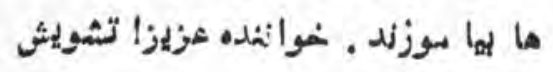

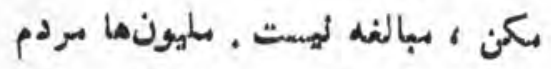

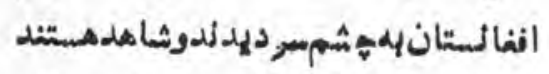

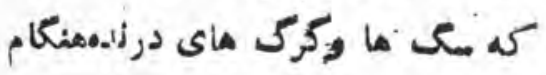

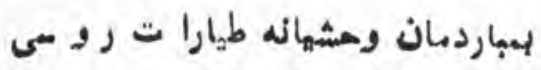

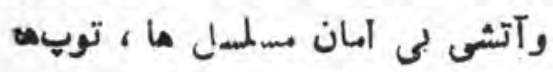

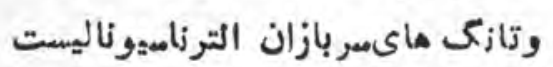

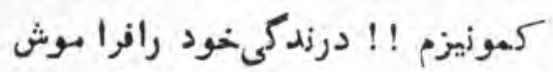
كرده واز وحثت وهراس دركودال

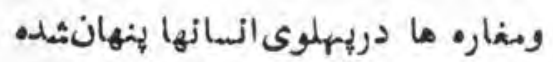
اند ـ برعلاوة آنكد زندانيان اردوان انهاء

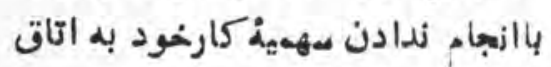

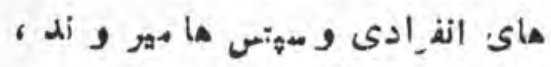

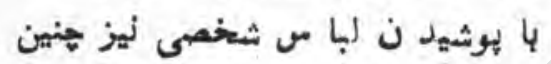

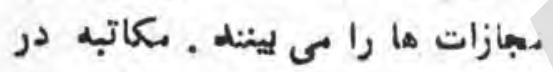

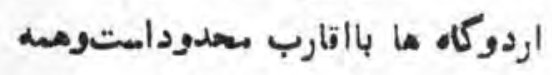
زامهعادورد سانسور ومطالعه مامورين (5ا جى له) قرار بى كيرد. مبحافظين

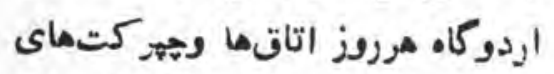
ززندان هارا تلاثشى مى كمندواكروباس

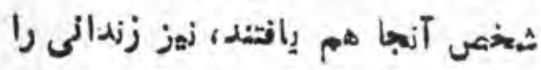
زندانى در اردوكاه بهدا زمهرى

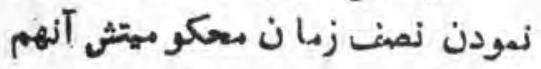

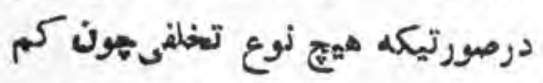
كارى لوشثيدن لباس شخصىى، هفمور

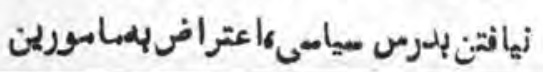

همكذرد دركتاب نمود درآغا ز أخش

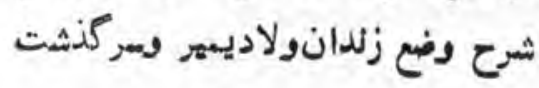
زنداليان جمله را از كر يبا يد و ف زوإسنده وشأعر روسىهنين بى آورد:

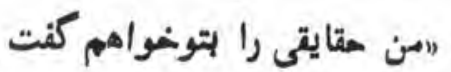
كم از هر دروغى وحششتناكتر استه

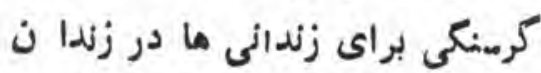

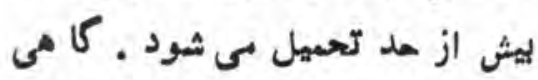

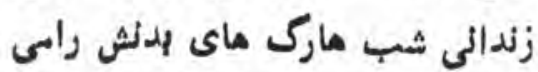

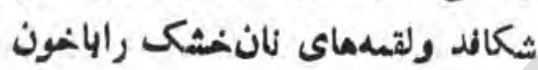
كم از رك مايش مى آيد تر بلى كثلد

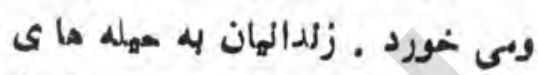

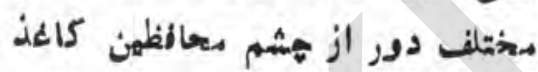
وكوكرد تهوه مى كمند، شبدرواتلاق

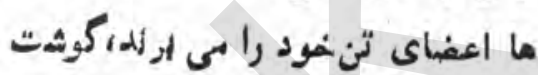
ران ، كوشت شكم، دست وانكشمثان

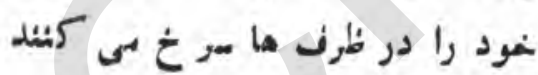
ومى خورند . به بر إيض مأى رومى ود ايواله

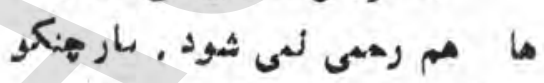
سى كويد : "امن در زلندان ولا ديهمير مريض روهى را ديلدم كه د ايمبواد

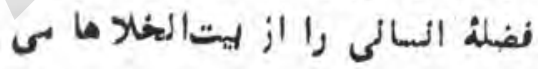

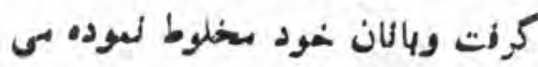
خورد وآنرا هيش دهن هركس بهرد

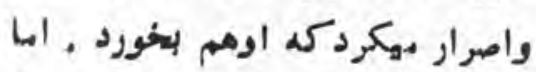
ماكسانكمونيست اورا سالهاى سال

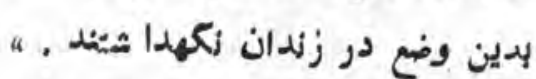
واقعاً كه جنايات كمونهزم در تاريخ

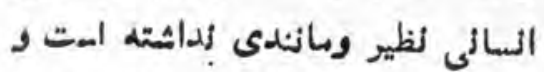

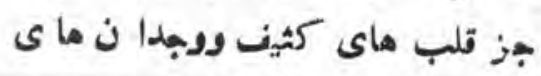

نظالم وشكنجهماىهاكسان كموزهزم

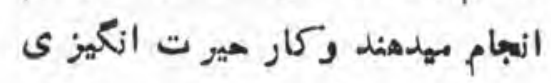

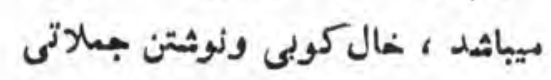

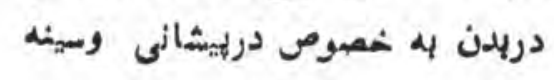

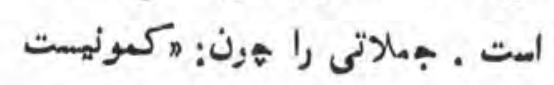

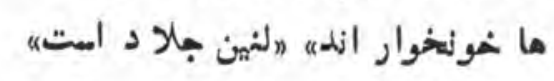

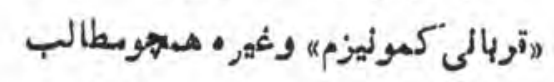

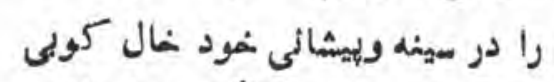
مى كنئد ـ البته كمباين عمل بازهم

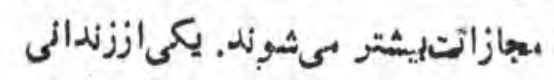

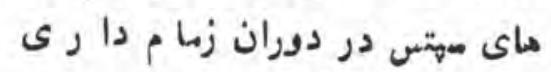

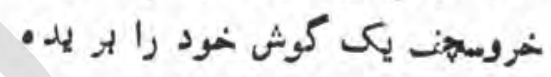

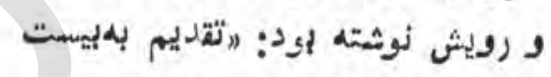

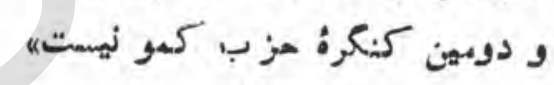

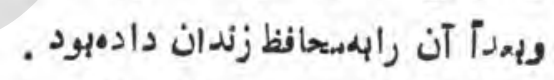
هركاه سجازات زندانى بالاتر از اتاق الفرادى و.نهت هاتئخيص دادمثرده،

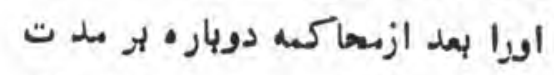

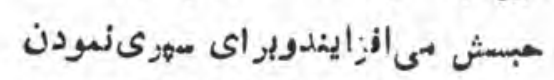

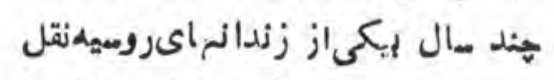
ميدهند.شر ايط زندكى ، عذابوشكنجن

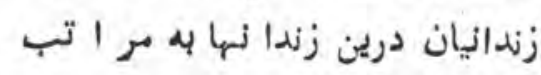

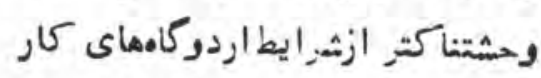

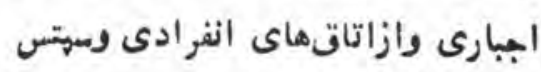

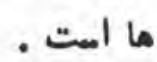

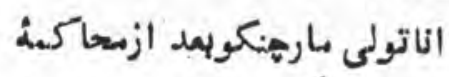

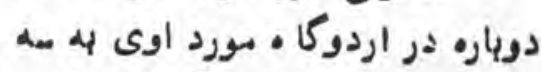

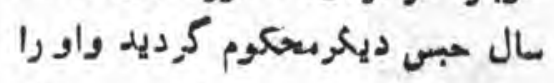
ليراى سهرى لمودن الين سه سال

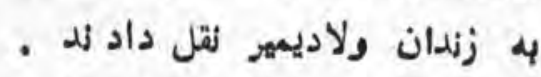

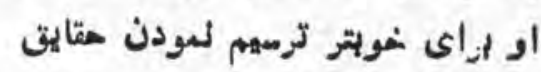

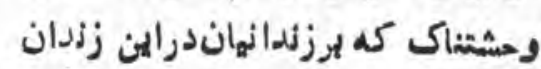


ترار دارد بثشنود 9 !! سفاكى و لن رعى كموليزم را زندالى ها نه تنها ومان 45

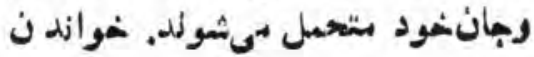

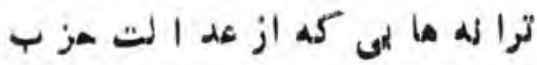

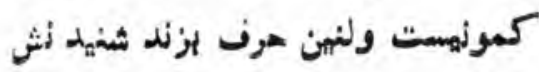

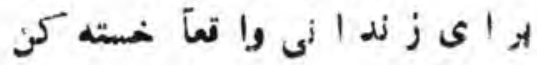
و دلفراش استلهاضافة زبر كرهنكى كه زلدائان به آن دهار مستخد. بقاه كنسرت ما واجراى كار منرى بدكنهد

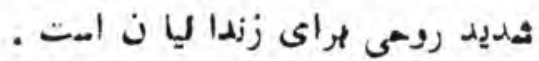

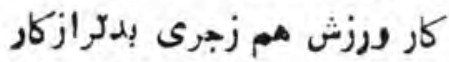

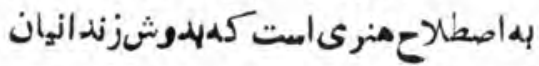

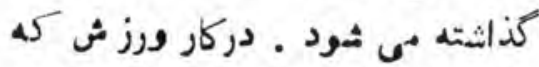
إيشتر آنرا دويدنوخيز كرفثن تنذكيل

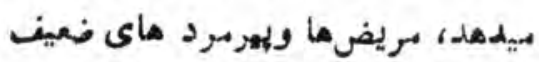

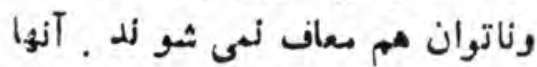

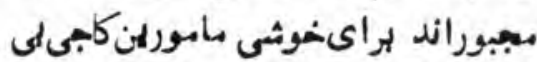
بدوند وخيز بكيرند . بوان كار دهكر شعبن آموزش سياسى، وخيك
تعليموآموز ش دراردوكاه ها :

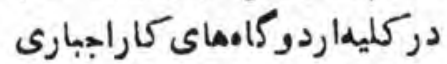

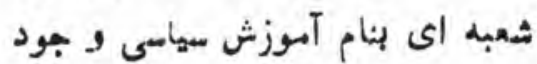

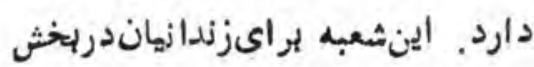
به امطلاح هنرجون رتص وخواندن،

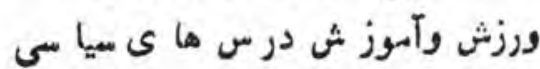

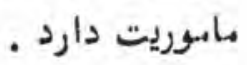

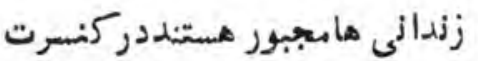
كم توسط شعبd آبوز ش سياسى تهمهي وترتيب مى شود اشتر اك كمند. آواز

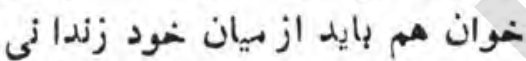

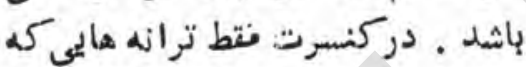

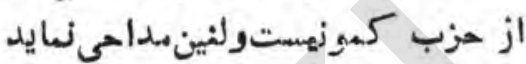

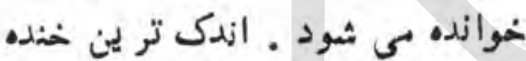

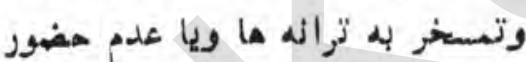

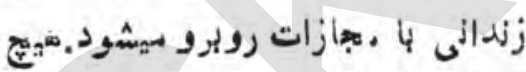

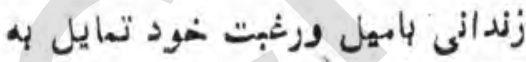

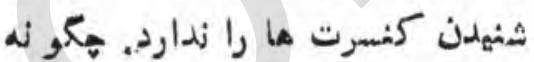

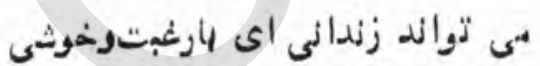

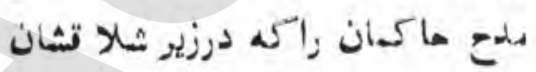

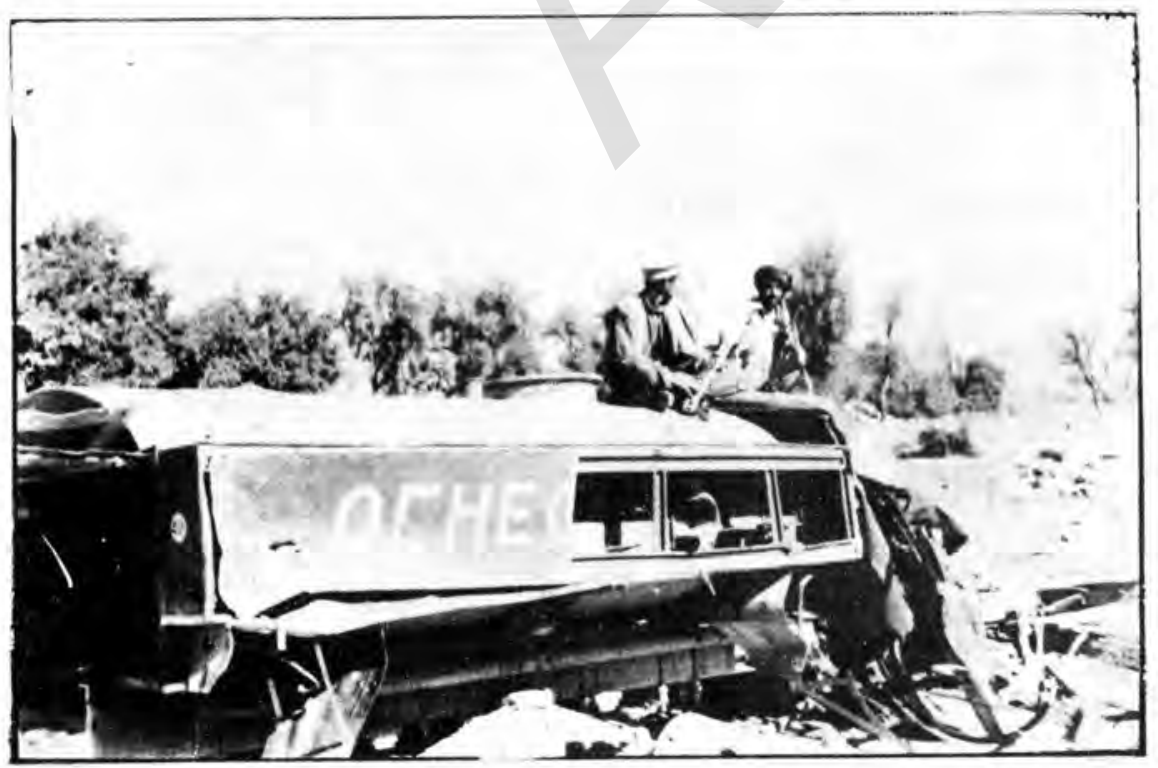

وامثال آن از اوسرنزده باشدمىتواند

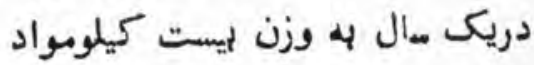
از اقاريث در يافت كيد ـ ـ و اكثرآ ايخ مقررات هم رعايت نميشودوفقطط

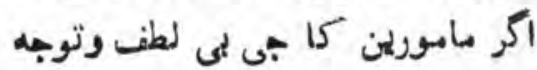

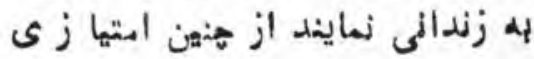

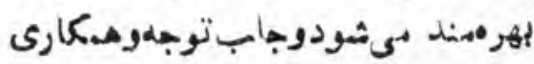

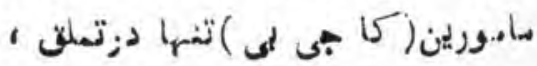

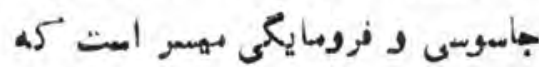

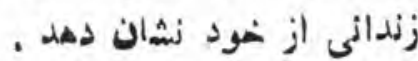

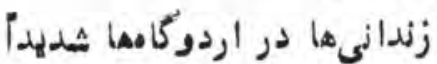
استثشار هيشوند، كار طاقت فرسابهىرا

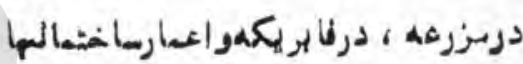

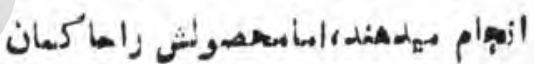

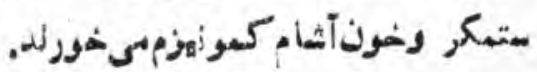

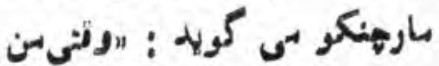

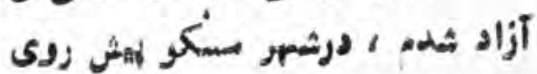

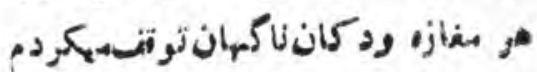
ونظرء را اجناسواشيايى بهخودجلب ميكرد كه تومط ززدازيان دراردوكا.

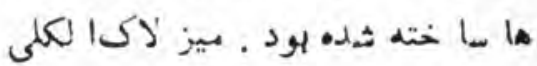

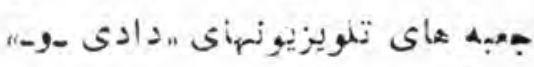

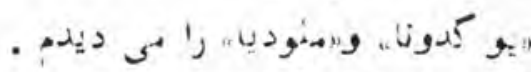

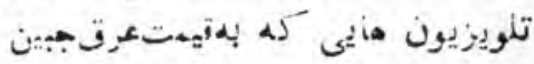

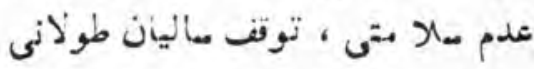
در زير برف وباران ود در.حل تقسيم توفي

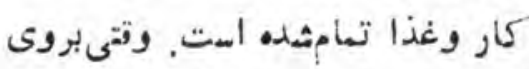

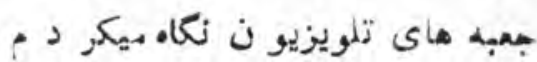

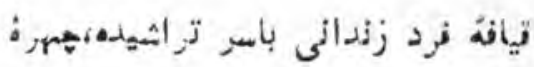

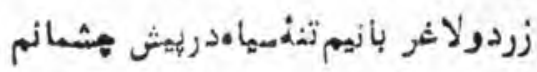

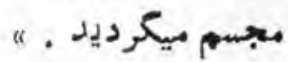




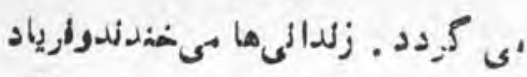

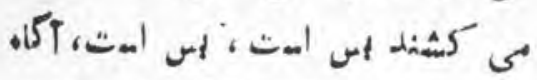

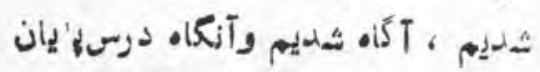

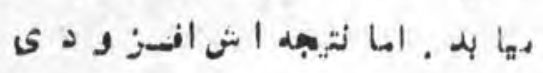

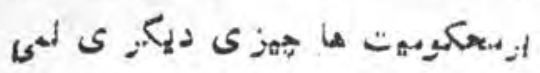

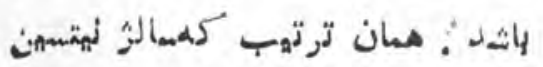
نويسمدة روسنزمالى مبحكوم دراردوكاه كار اجبارعايود إيكى ازماسمورين بلند

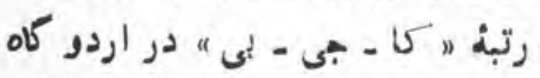

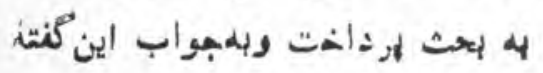

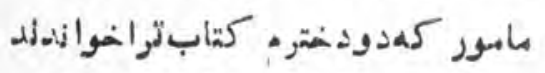
وهر شب برا زيو سوال و اعثراض

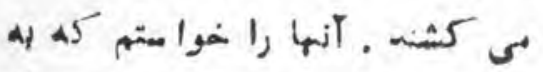

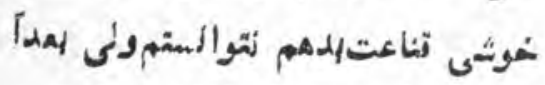

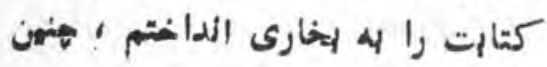
كمت :

" لنى ! شما هميشهل يك رامعل تاطع داريه ، كتابرا لهليخارى وسارا

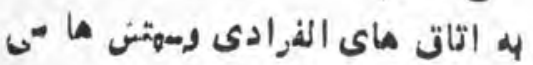
المدازبلد .

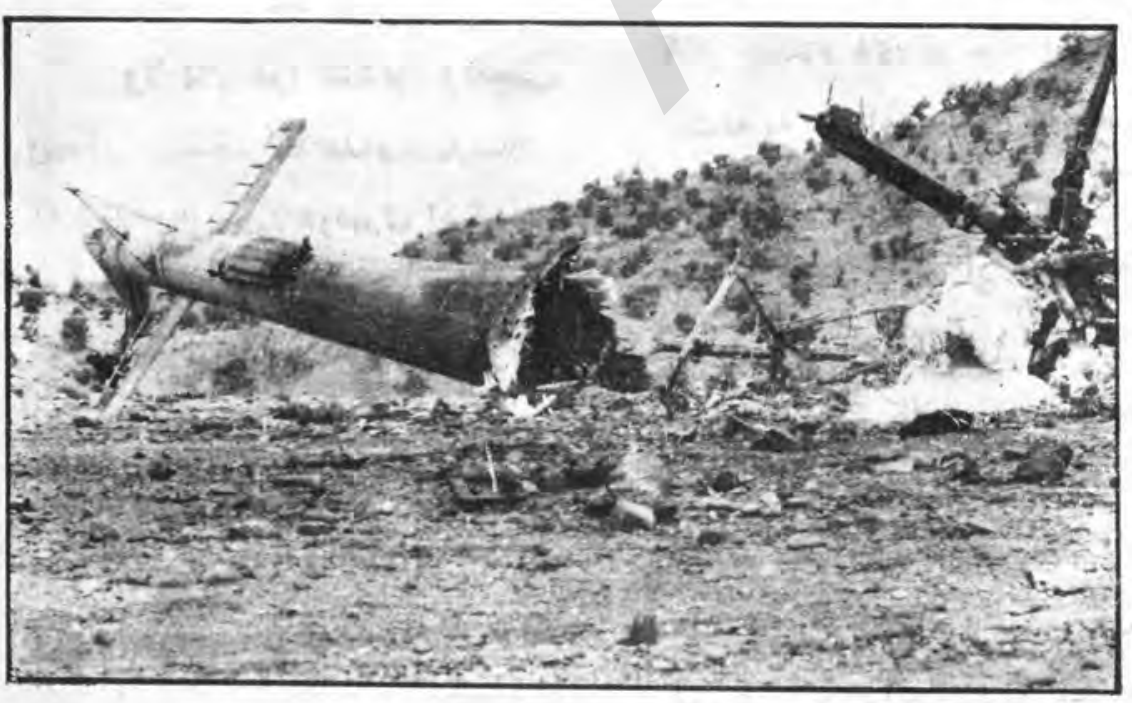

خود اهغباركرد تالورا تعتميق نهايد.

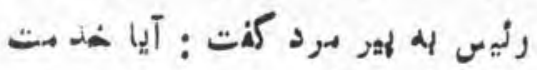

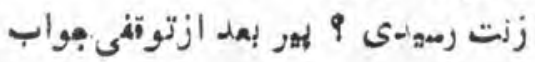

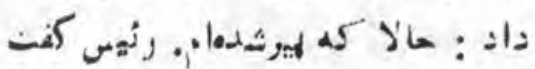
اكر خودت نمى تو الستى مر ا صداد

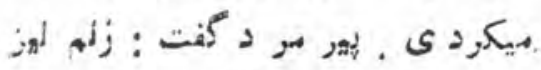
لير الهت رنيه بلهاوكفت هانعى زلهارد " 15

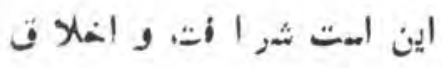

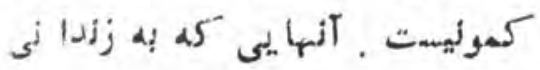

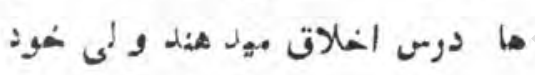

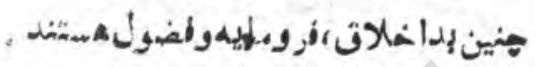

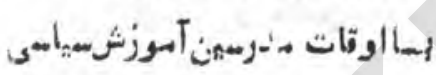

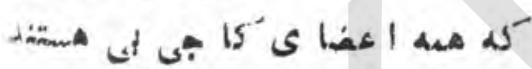
توسط زندانى ها به مسجخره و إستهزيا

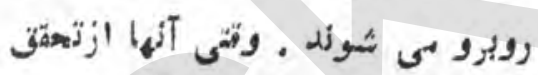

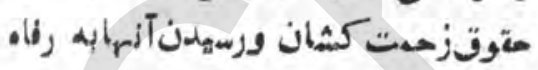

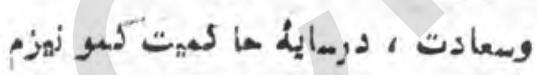

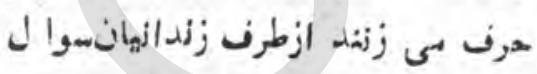

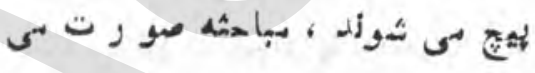

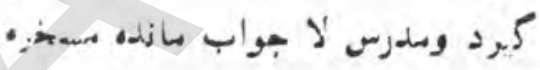

دادن درسسياسي درهنتة يكروز براى

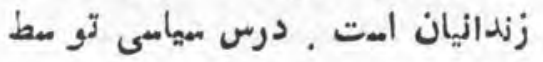

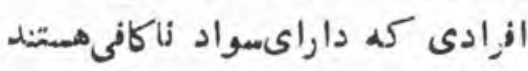

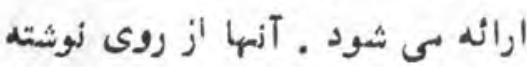

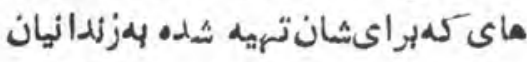

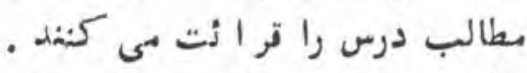

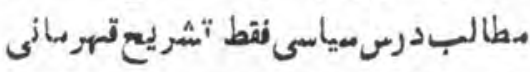

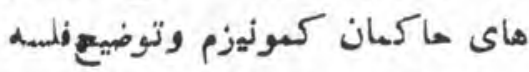

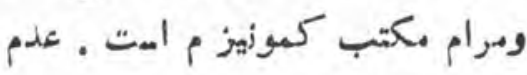
هضور زندانى دردرس مياسى ودجازات

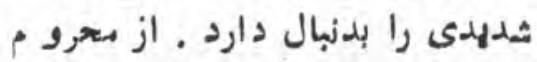

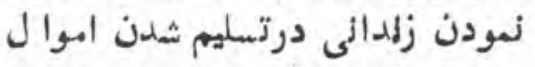

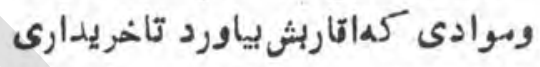

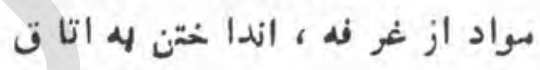

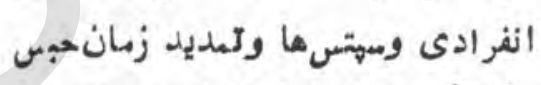

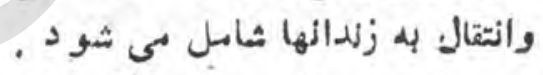
در درسهاى بيأسى، كسونيزم

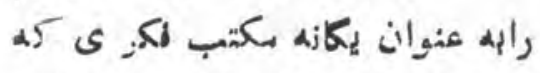

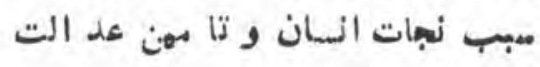

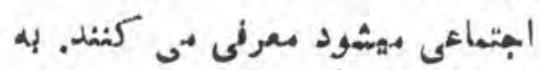

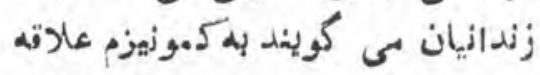

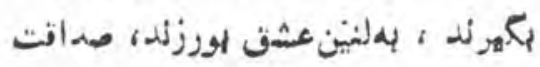

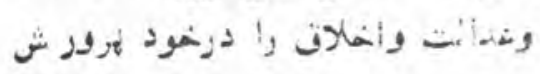

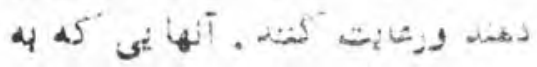

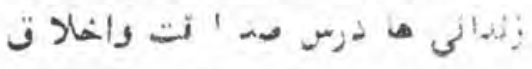

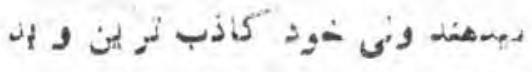

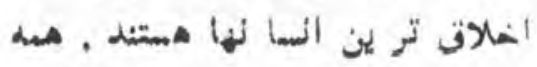

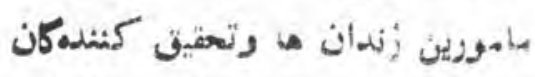

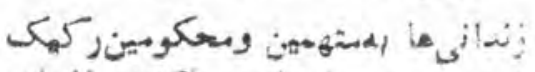

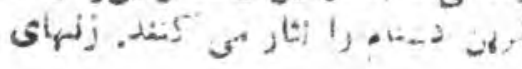

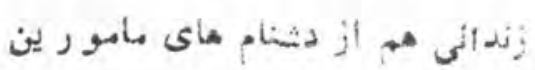

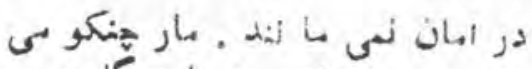

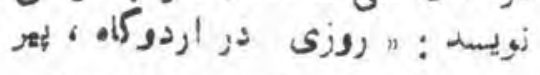

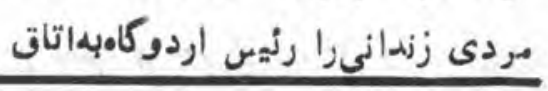


ثترجم : كل آثا " شائق "

\section{يهججهادكى دكاميابىاوبرلاسكيكيدو}

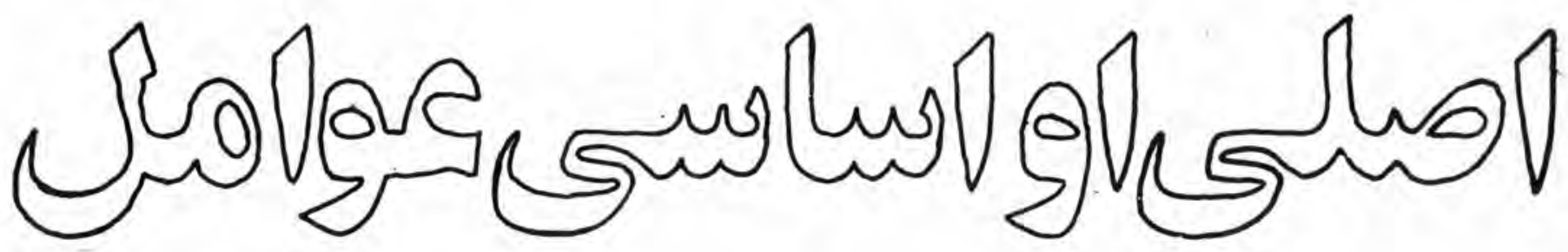

دى او دا معيت له اله (ج) مأخهم

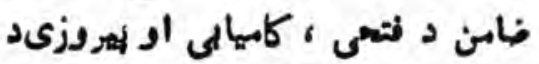

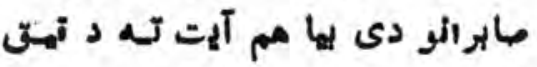

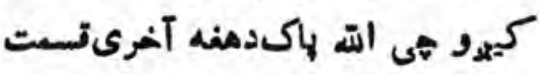

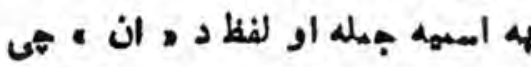

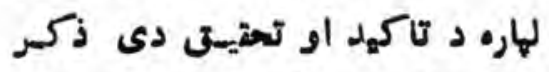

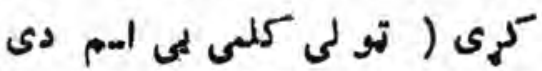

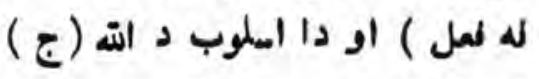

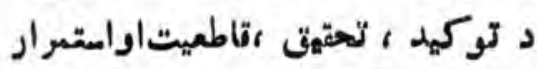

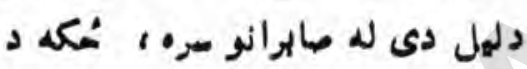

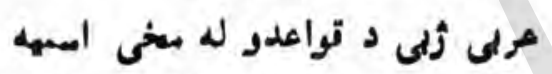

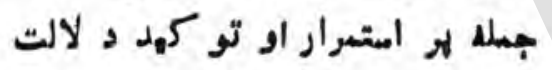
كوى او اله داسى مال كى إثى دالته (ج) لمعرت او كمى لهسئكرونوكى اونى

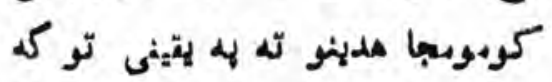
لوسميدى نوذكر شوى دهاهدين متئاً

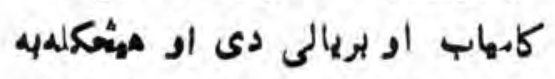

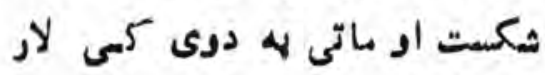

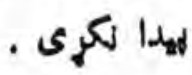

له بله طرفه د هر يهت علداوالهى

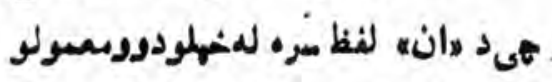

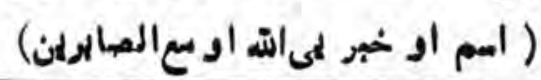

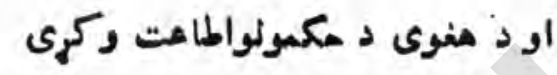

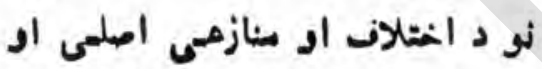
اساسى سبب او ماسل هتمأ له لهينه اله هاك د آيت به آخر كى us

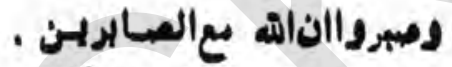

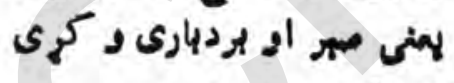

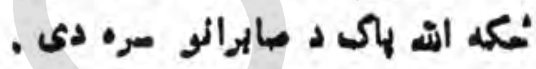

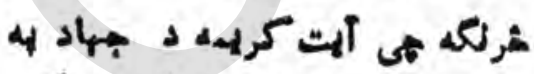

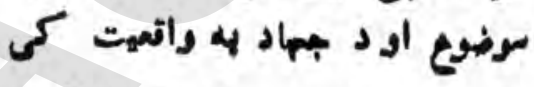
دى او جباد د مبر،تعمل اوتكايف

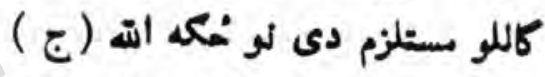

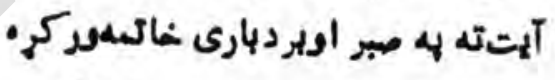

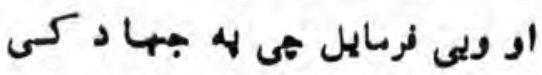

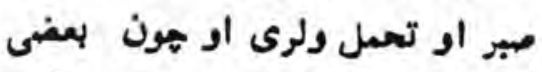

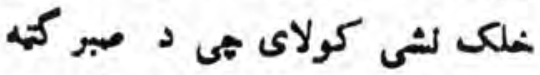

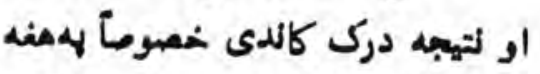

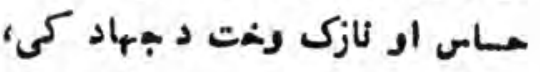
لو اله (ج) وفرمايل هي قايده دصبر

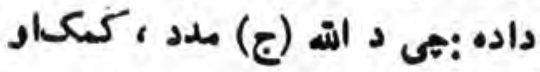

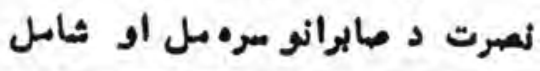

ثهيد مهد قطب د في ظلالمى لى القرآن له تفسهر كى ددى آيت له

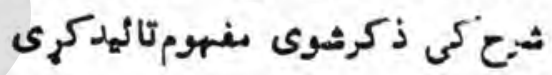

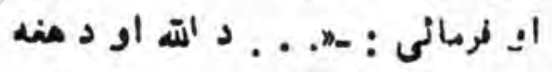
د رسول (ص) اطاءتد جهاديهمالت

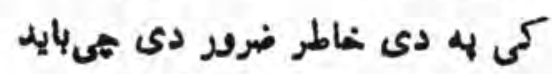

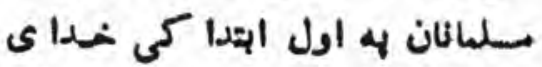

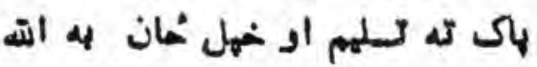

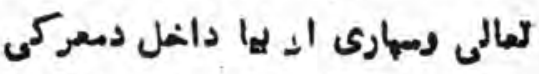
ثي او د انثلاف او مشازعى لاملوله

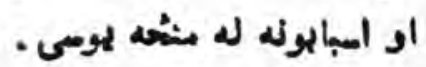

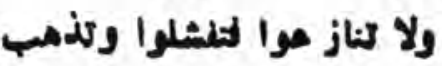

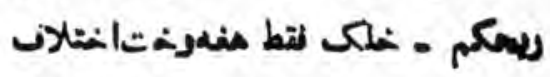

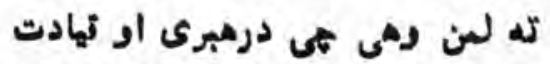

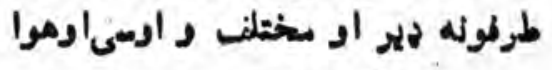

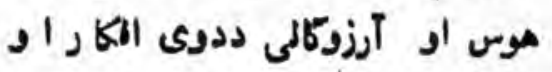

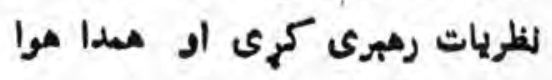

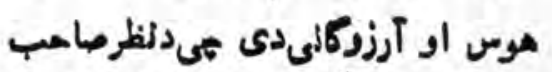

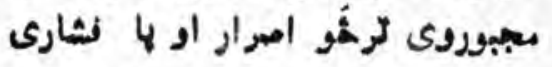

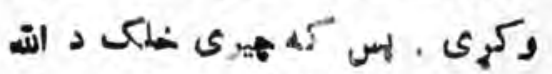

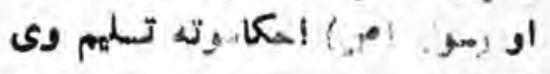




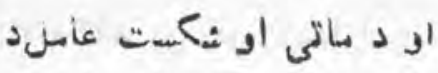

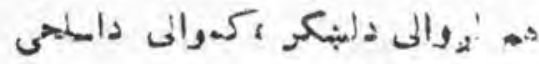

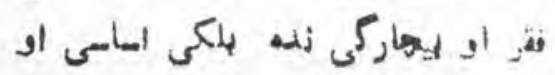

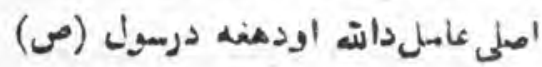

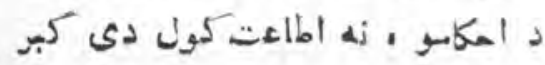

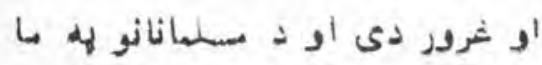

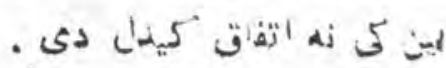

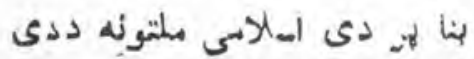

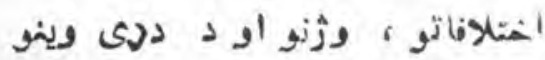

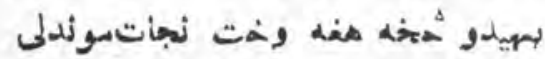

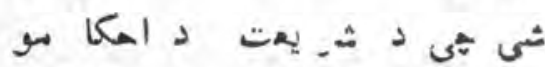

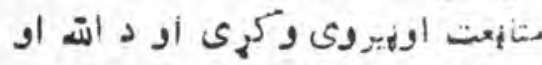

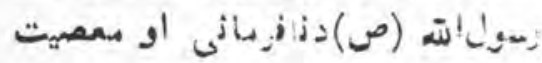

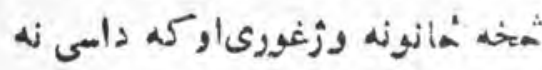

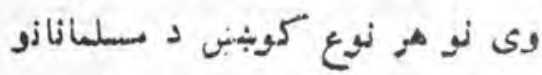

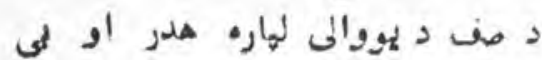

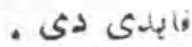

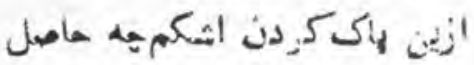

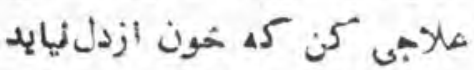

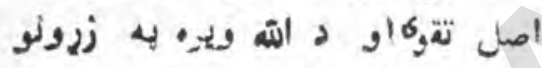

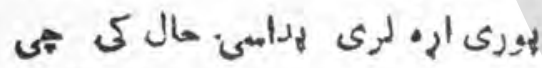

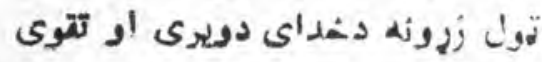

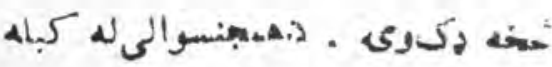

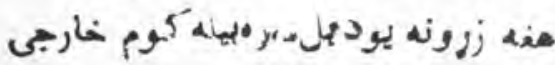

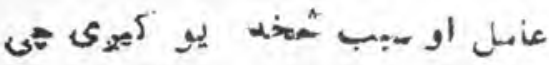

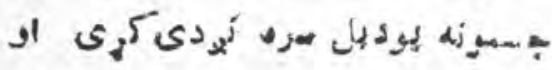

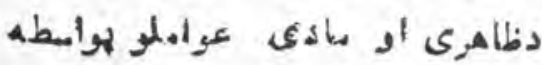

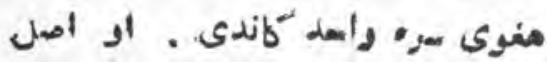

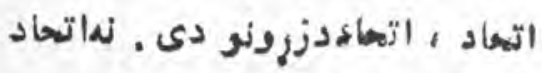

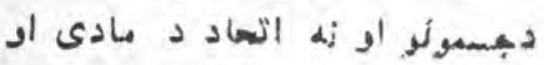

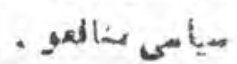

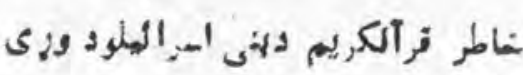

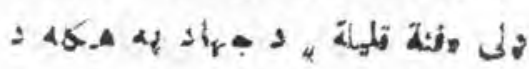

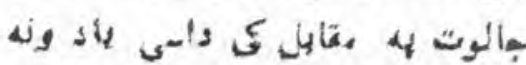

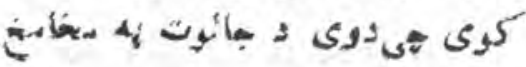

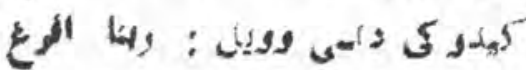

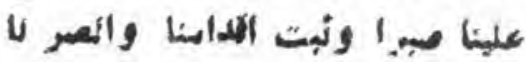

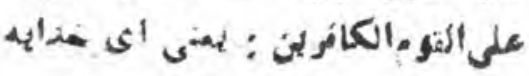

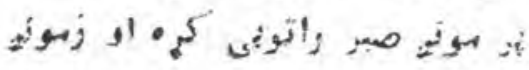

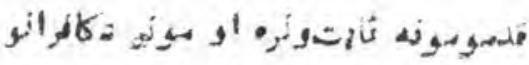

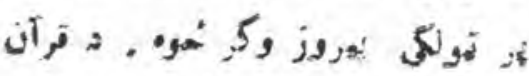

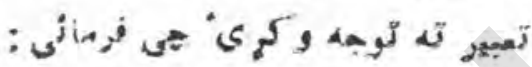

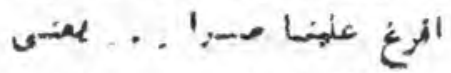
S

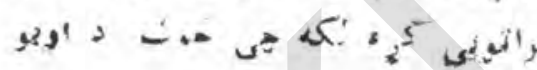
كوزن دبي، هابه ميروتويوتي': كنايه :

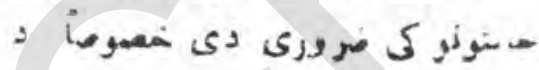

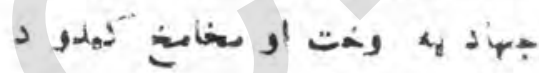
غدار دبنهن كلى .

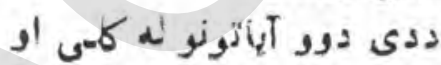

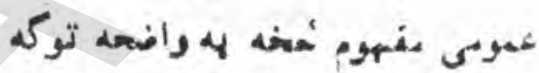

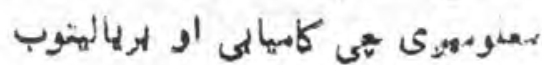

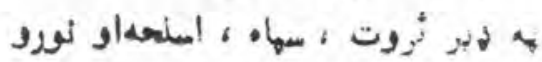

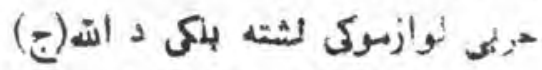

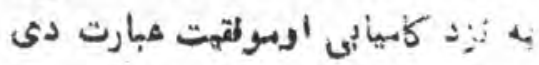

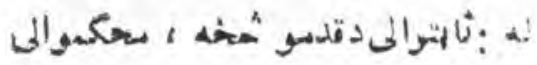

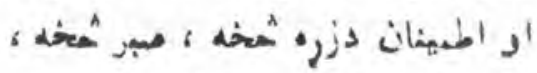

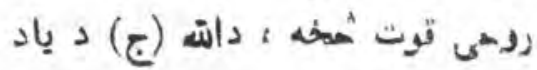

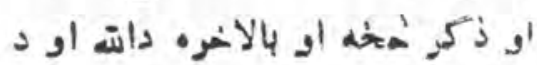

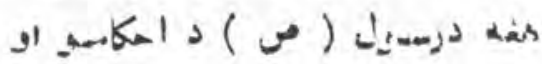

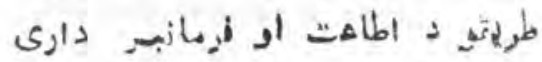

علت دى لهاره د امرمايلى (امبروا)

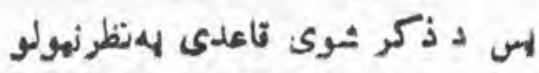

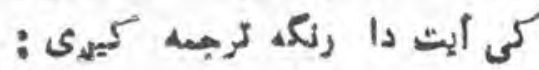

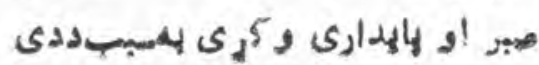

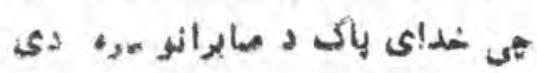

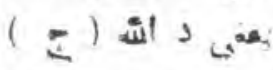

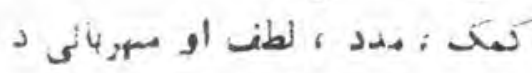

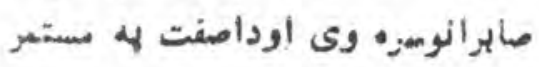

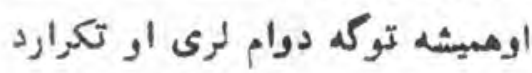

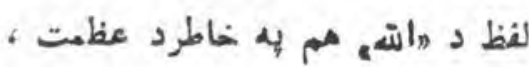
جلاليت او مطلقه قدرت د ده ذبكر

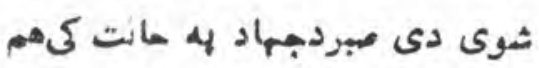

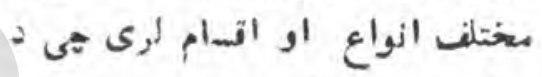

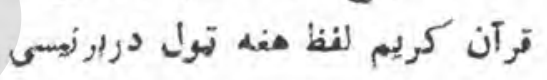

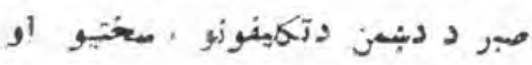

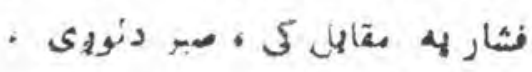

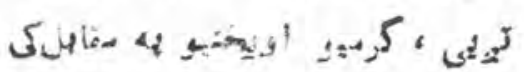

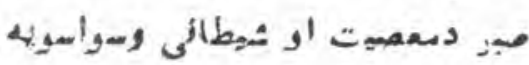

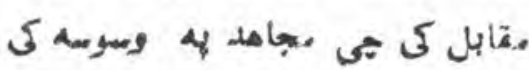

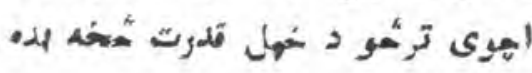

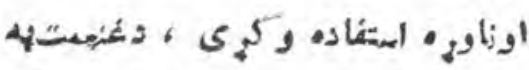

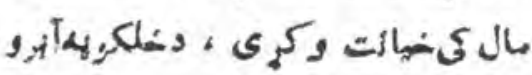

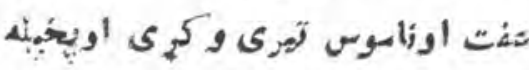

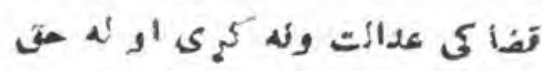

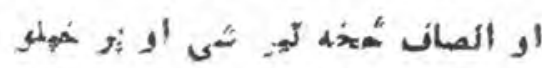

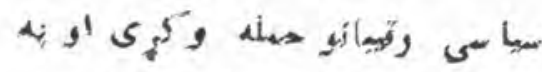

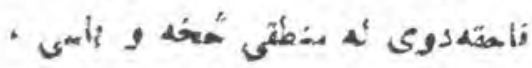

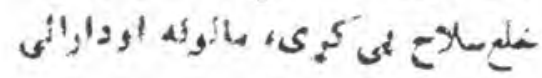

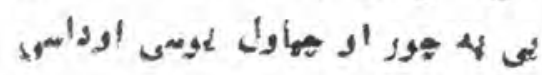

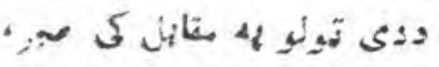

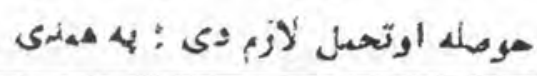




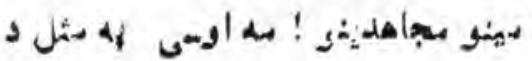

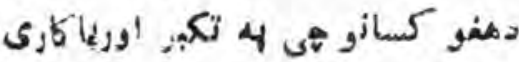

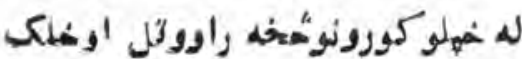

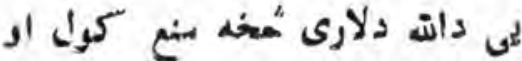

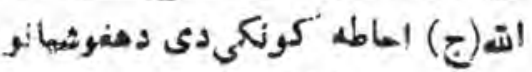
.

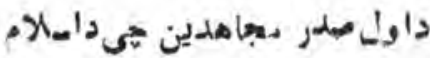

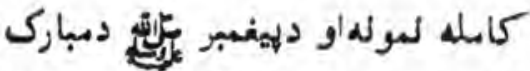
لاس ترئيه شوى ليالكى وو اوله ريا اوتكبر ثخته بيى لهز رمنكونو فاطله زهولى وه دجهاد او الهّ (ج) دابو

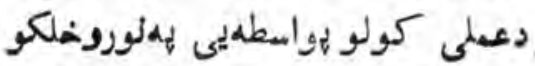

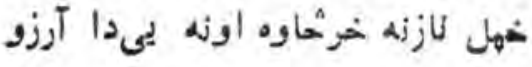

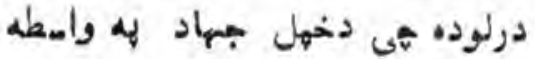

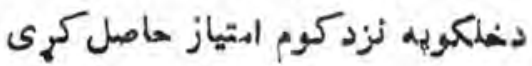

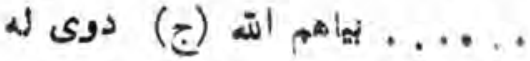

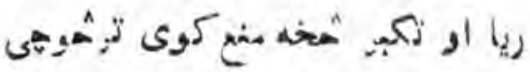

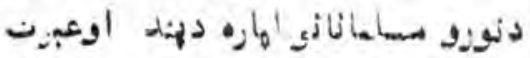

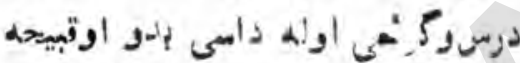

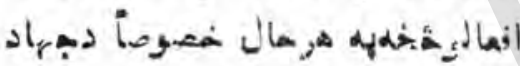

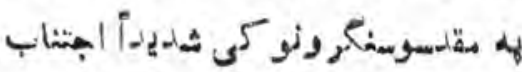

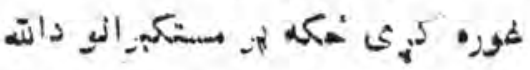

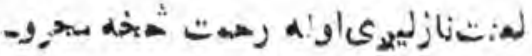
ثيهي . لمنت اورحت داسيى دوه

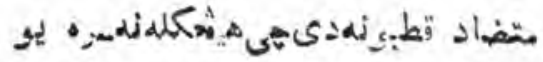
$\sqrt{4 \times 2} 5$

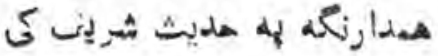

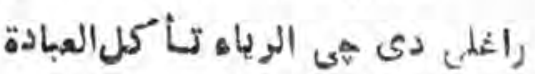

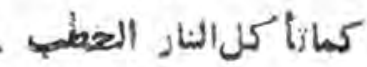

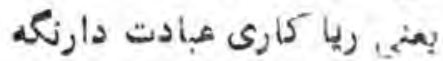
خورى لكه هي اور لركى خورى او
كشى تول املانى شحيطونه هارئر وزيولآن تردى هيى نزماسداراو هاكم

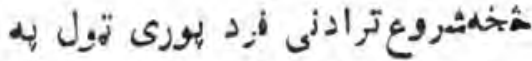

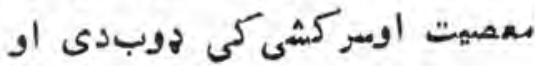

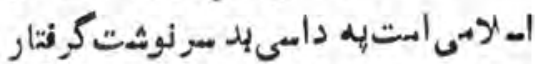

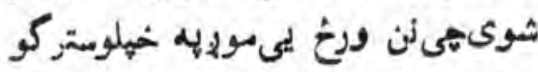
وينو ولى إهوره دافسوس ثمائى دى

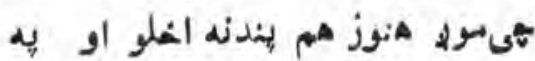

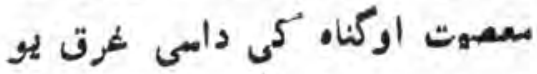

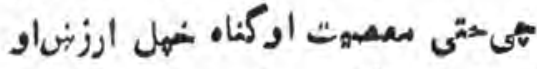

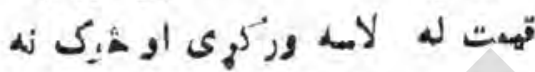

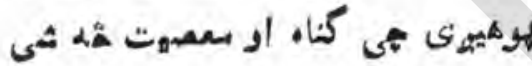

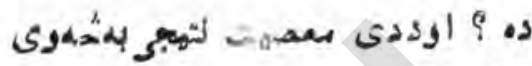

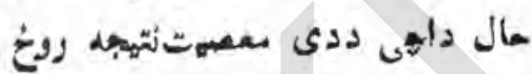

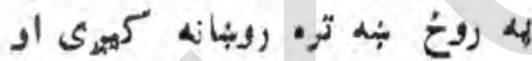

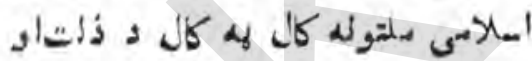

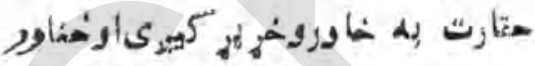

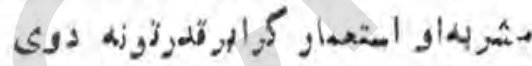

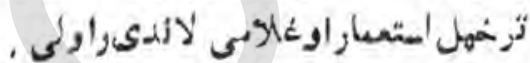

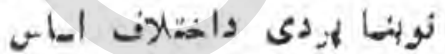

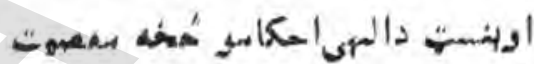

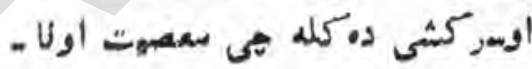

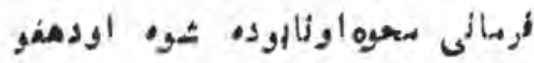

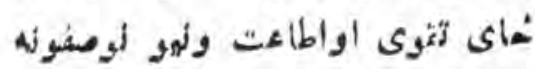

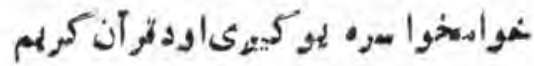

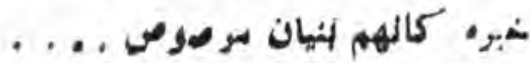

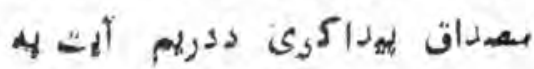

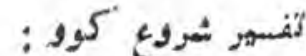

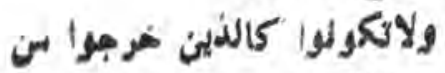

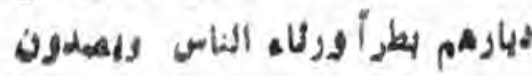

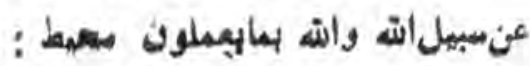

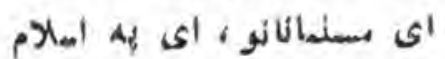

كرو ذره كاندلين ارض وسما امت

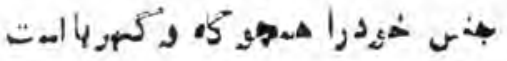

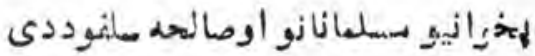
اـت ؛ =ىدمريمت داواهرو اطاعت

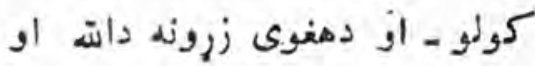

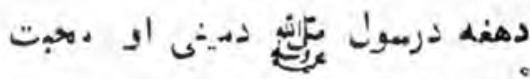

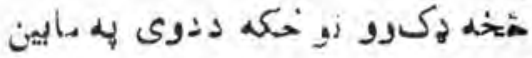
كى كوث اختلاثه. وبود زهدرلود

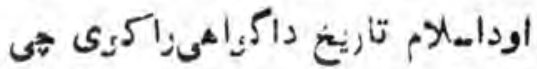
له هنه وخت راليديخوا به إهله

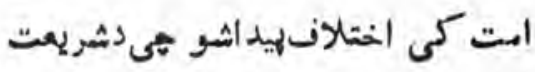

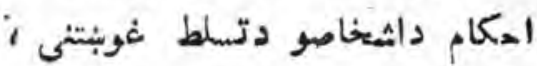
هكم روائى اوثنه ت طلبى دآرزوكانو

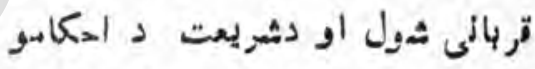
'مانى شيخصى اومادى آرزو كانو' منفمت هيتمنى اوخدودخواهى وزهو . هله اونافومالىدمشريمت دامكاسو داكلاءت

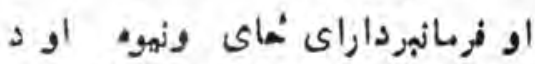
زمامدار خجره إخههله ثريمت وكرخيده. اود خداى (ج) دنامه له عبوض دده

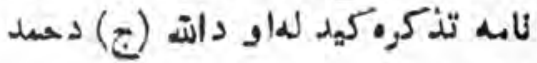

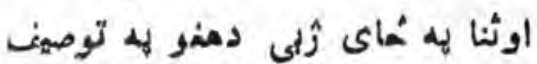

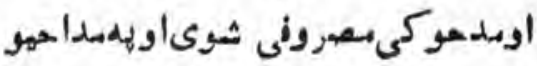

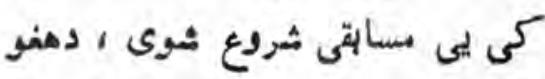

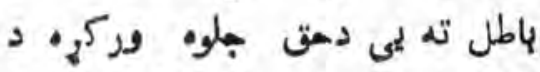
آباتونو اومليثونو لهغلط تأوبل هُخحه لمى دمغل أفل ته شرعى شكل إولئه

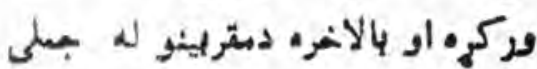

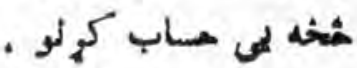

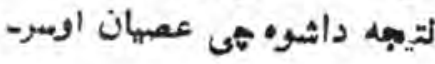




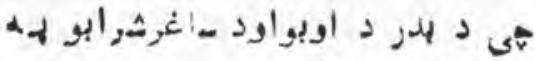
عوض كي دمبزك نجاسينو هله بجنبلو

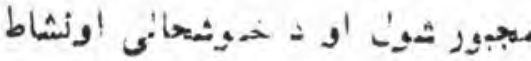

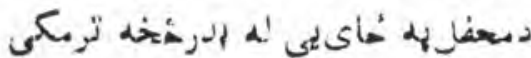

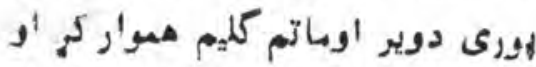

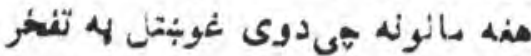

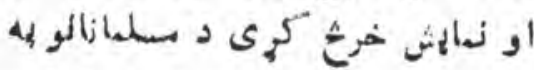
غنهت ورغلل او د ايدان او توهمه

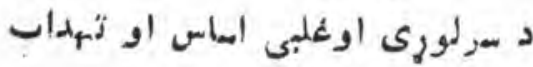

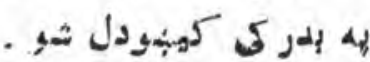

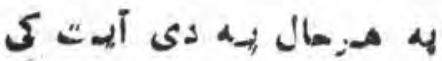

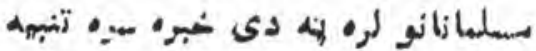

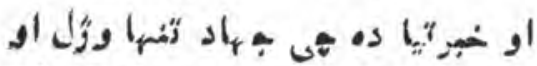

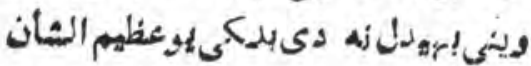

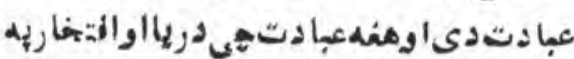

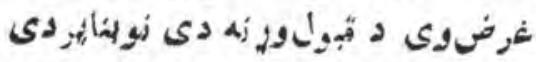

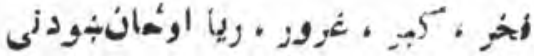

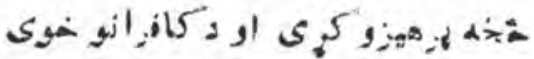

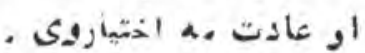

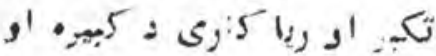

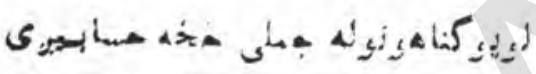

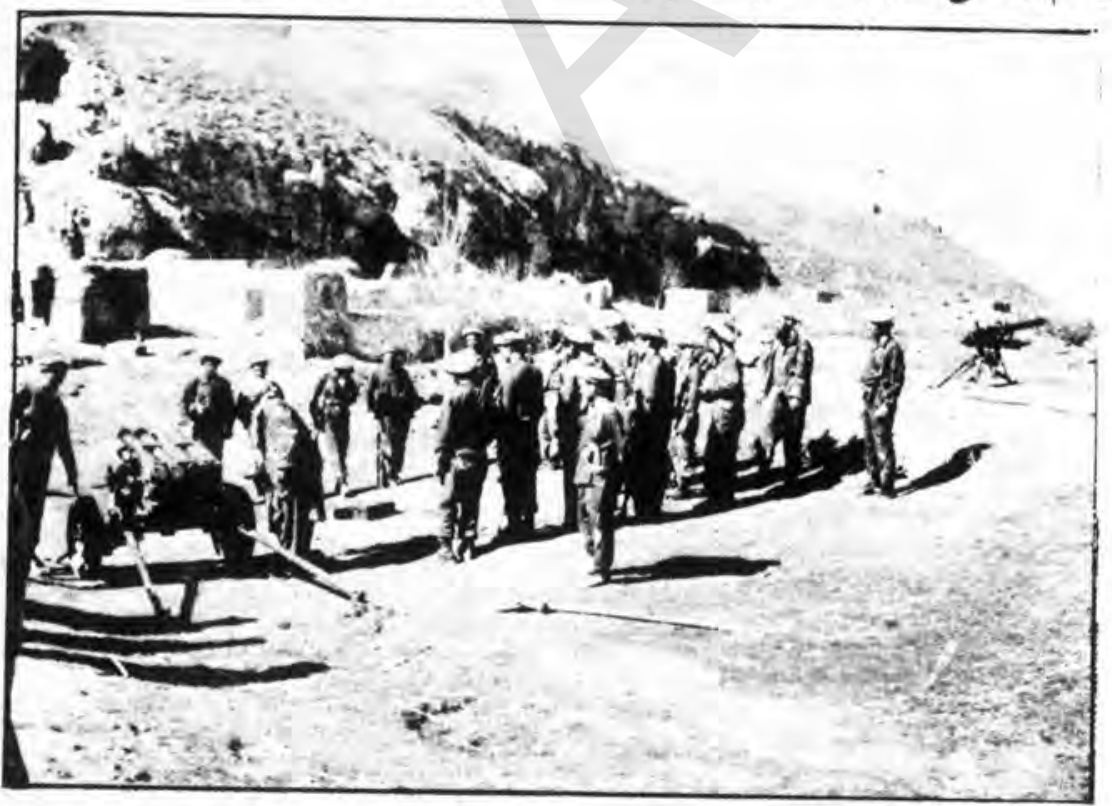

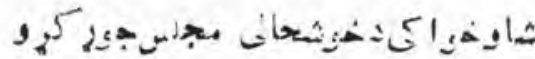

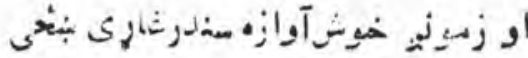

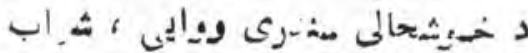
وهبنو او هم نزونه واخلو اوتز دريو

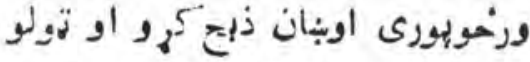

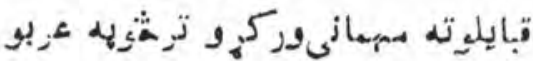

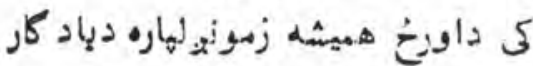

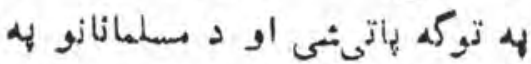

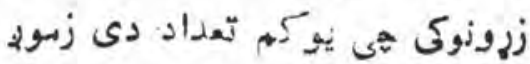
رعب او همت خدأى ونيسى ترشويه

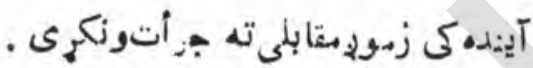

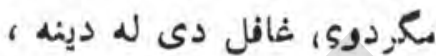

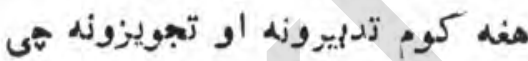
دوى سنجوى دهنوى واتع كيدل او

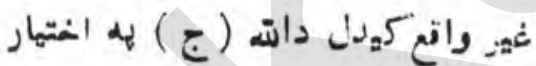

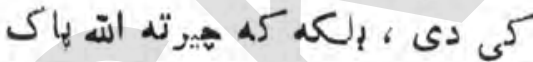

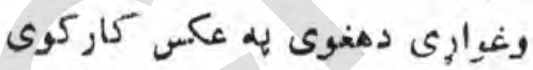
اوددوى تدبعرونه اوبدزيتونه دهمدوى لهدي

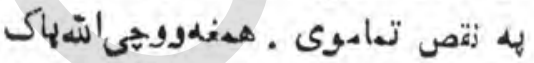

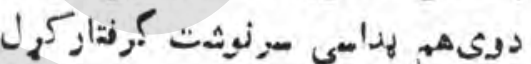

جا د د به خهله عبا دت دى د نديزو

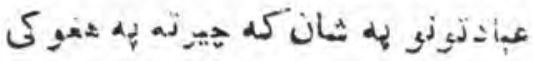

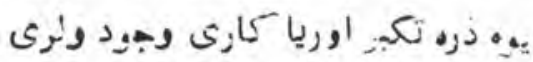

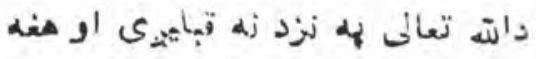

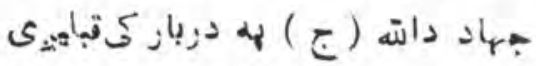

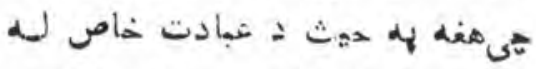

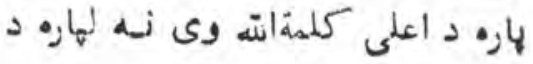

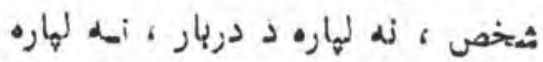

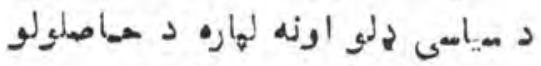

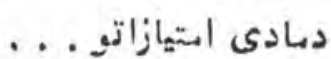
داله دلارى بمجا هايدين دي د

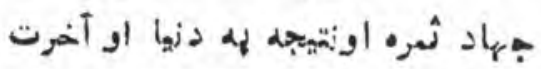

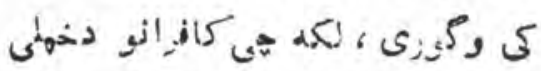

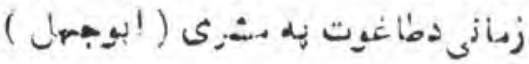

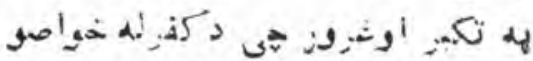

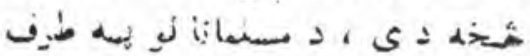

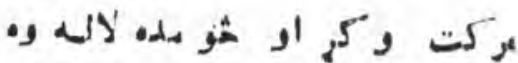

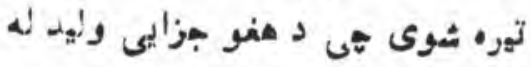

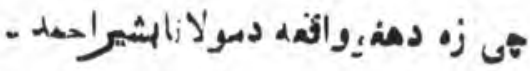

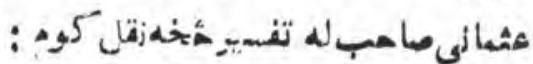

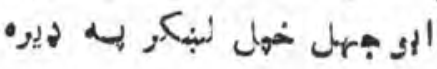

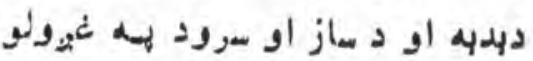

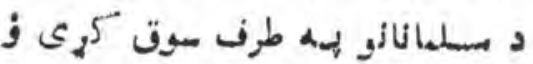

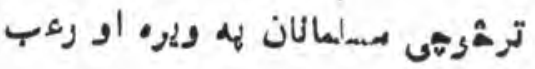

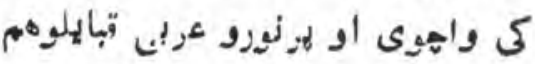

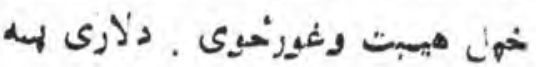

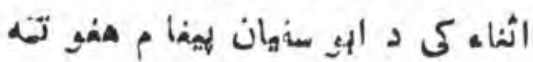

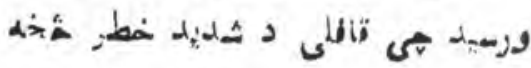

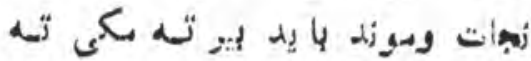

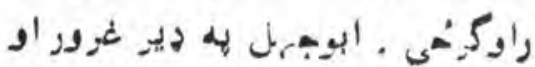

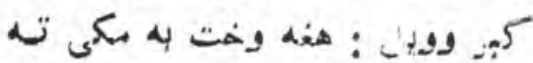

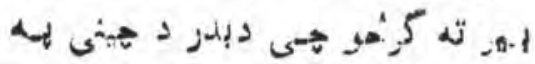




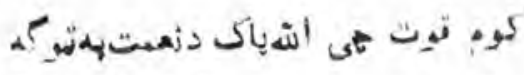

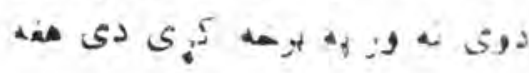

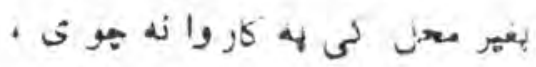

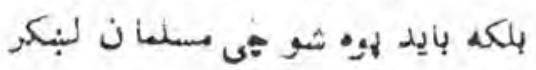

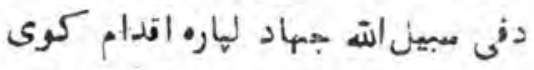

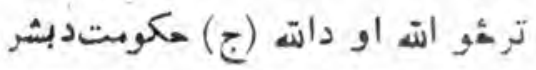

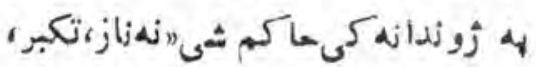

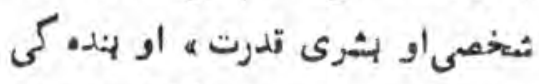
خاص بايد لهاره داته وكرثي لهلهياره

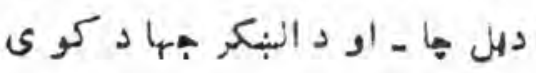

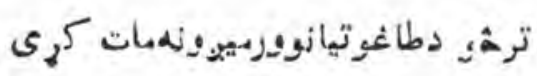

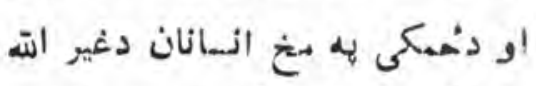

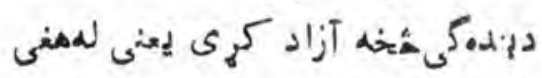

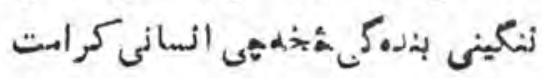

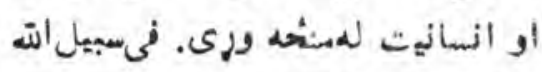

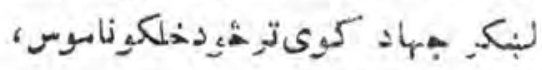

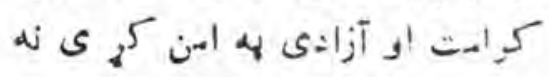

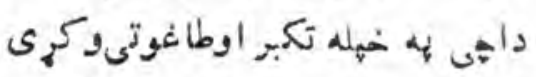

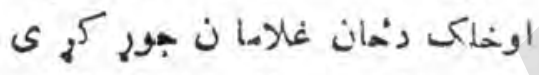

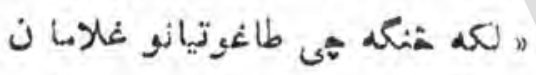

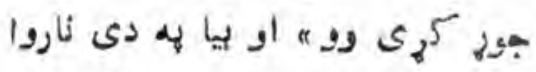

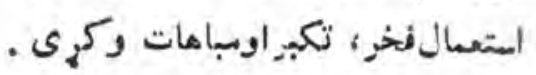
دافى سبيل الته لبنكر هغلوخت

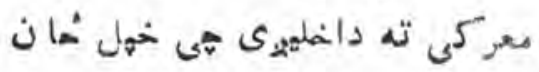

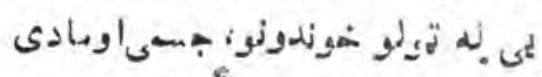

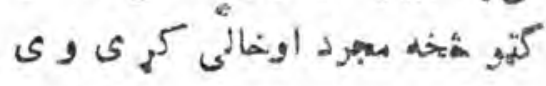

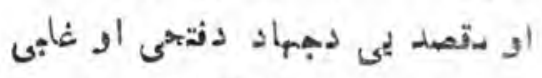

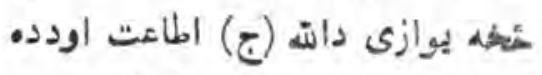

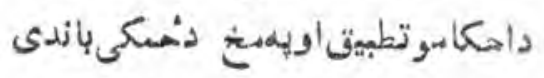

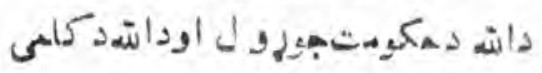

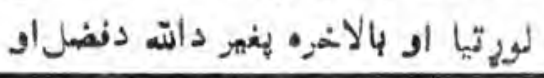

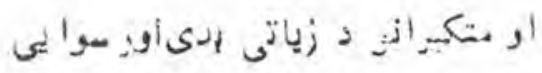

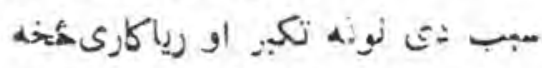

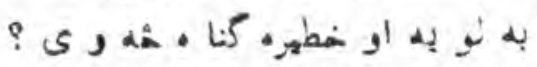

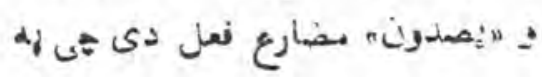

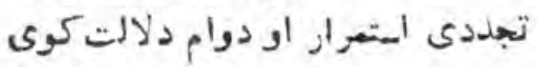

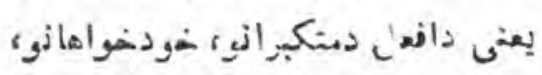

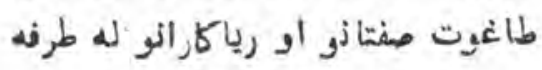

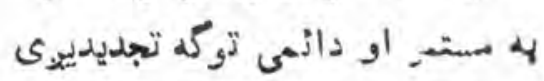

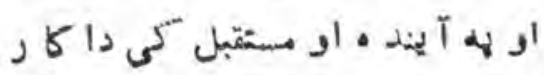

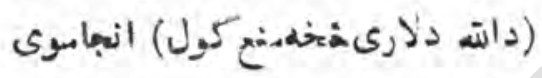

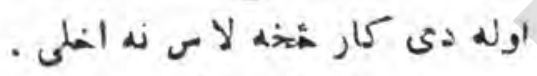

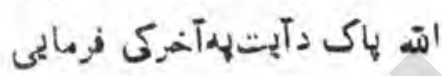

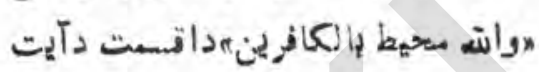

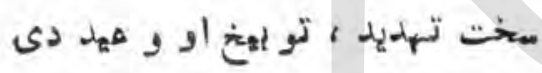

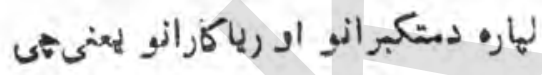

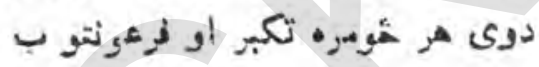

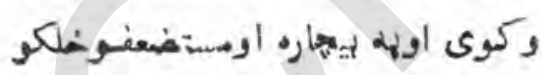

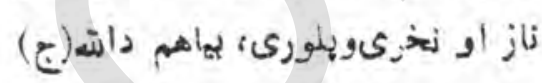

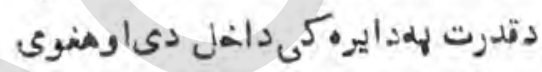

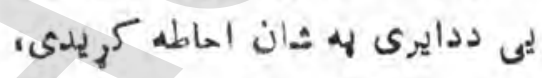

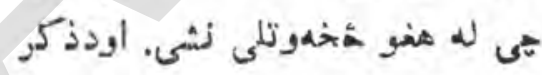

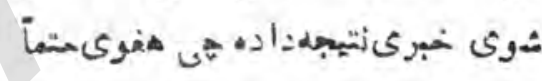

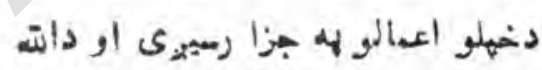

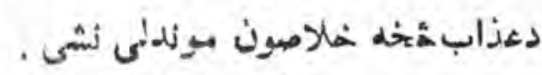

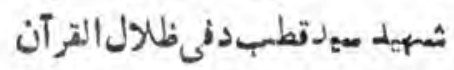

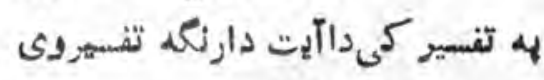

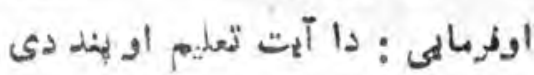

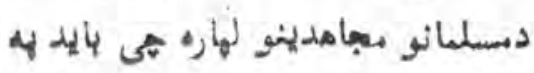

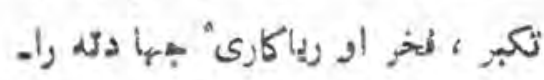

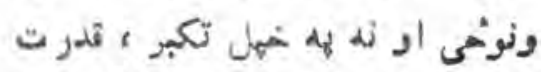

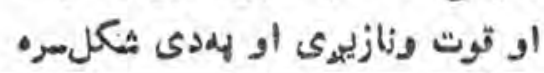

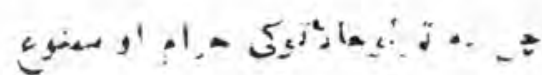

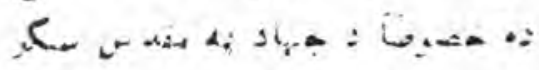
ئ

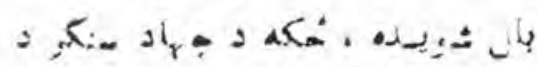

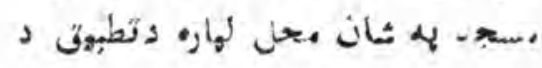

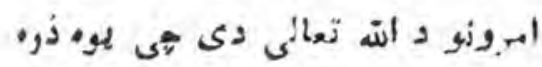

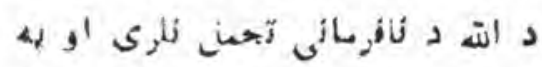

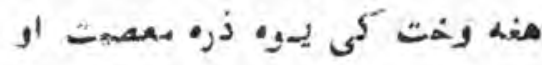

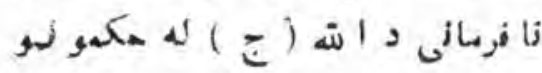

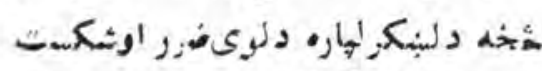

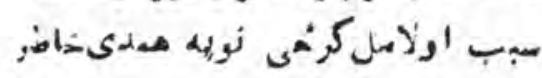

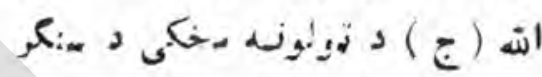

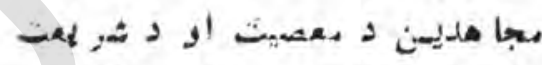

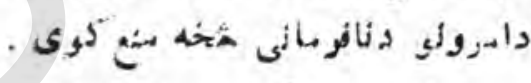

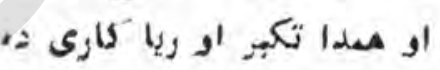

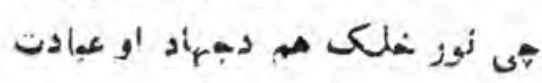

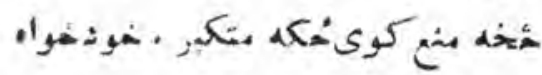

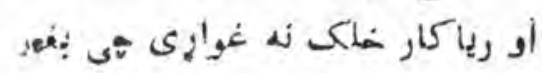

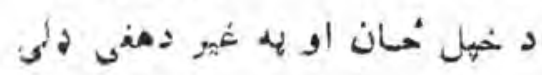

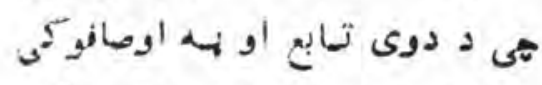

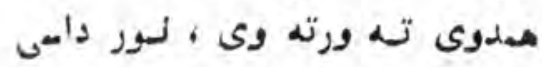

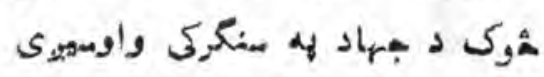

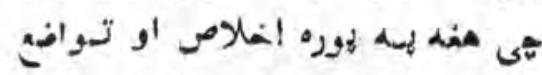

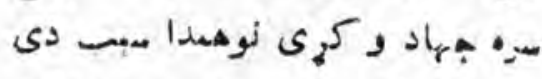

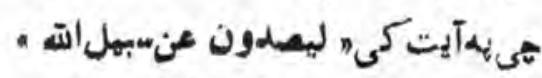

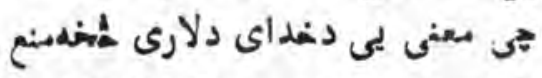

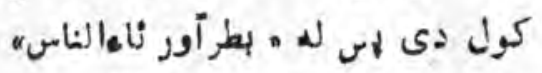

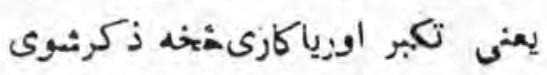

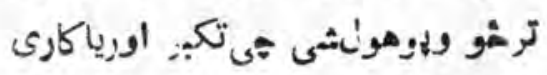
ددى خبزى سبب اوباعثدى جيىنور

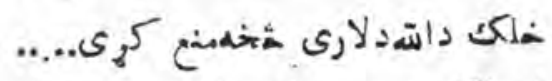

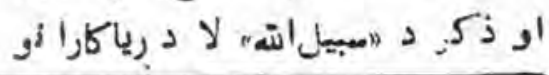


درسوزه دى اود اته د لارى مجاجهدين

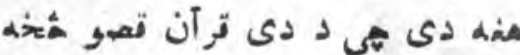

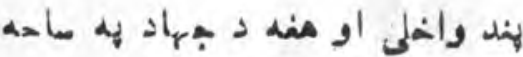
كى ثي د تطعيق ساحه ده عملىكاندى او خهل "مان د واتعىمجا هد بهاخلاقو او اوصافو داسى مزين او آراستهكي

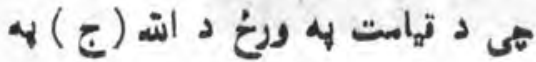
عضوركى سرفراز اوكامياب به وى وله نه دا يق خجل او مر كـوزى وى مُكه د قيامت هيهـ ورخُ دا كبر او عرور او دا مهامس رقايتسونه او ريا

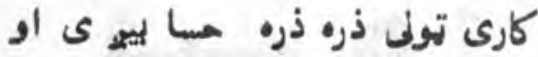

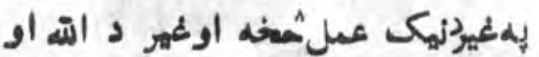
د هغه د رمول د اطاءت او لهزئى

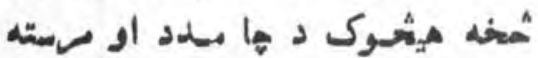

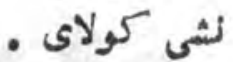
يومرلاينفغ مالولالئونالاسن اتىاته تقلب مثلميم . والمهلام

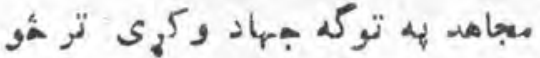

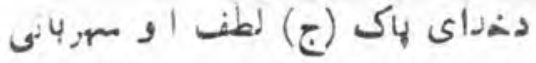

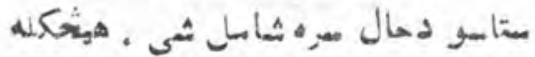
دا خبره مه كوى كه هيرته له هملى مدرنى مالح س-ه رنطقى ته ورسيثيو فلانكى خيل يا خهل سياستى

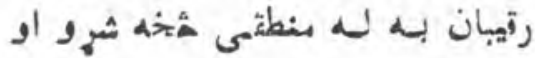
داسى ضربه به وزكوو ثيى د أبه لهاره وزته ليند وى او د هله وحرت لهائره

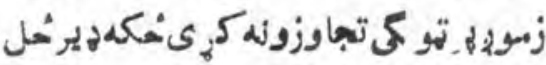
لهدل شو ى او اوريدل ثوى دى ثيى

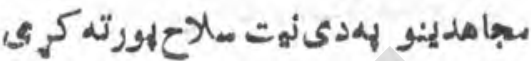
اويه:ى ليت يمزيات تعلداد مجاهدين

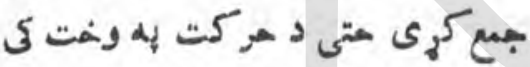

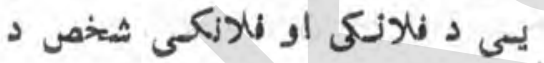

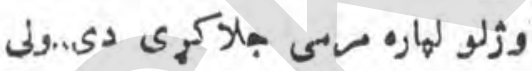
هتأسفانه يا هنوى منطقى ته لا رميده

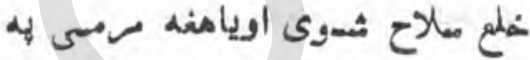

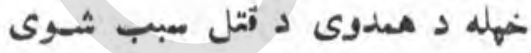
دى.قرآنى تصى تيولى د هند او عبرت
أحسان لتمولو مُخديل هطلبوزلهلرى

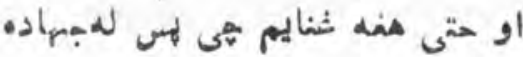

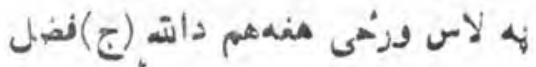
اراحسان ونولى لانهيتهيجهدخهلقندرت، مهارت او دخهل بت زوره.

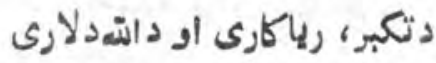

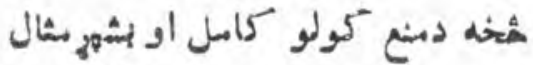

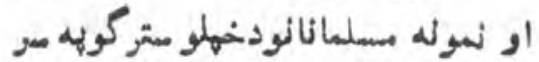

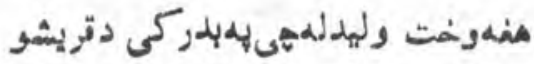

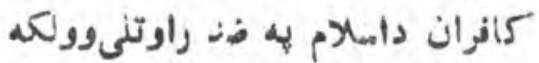

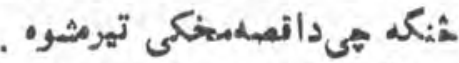

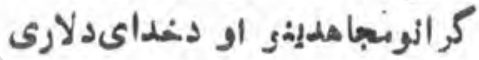

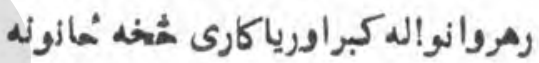
وساتى او:اقرآنى قصىلهنهيلوسنكرونو

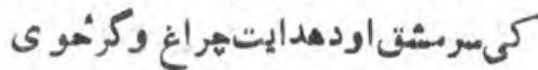
او به خهله ريا كارى او تكبر نوربى

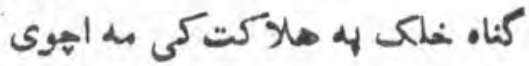
او دواقعى مباهد به او مافو ليعنى

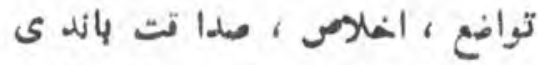

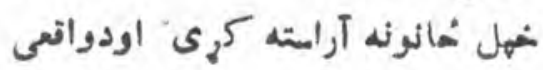
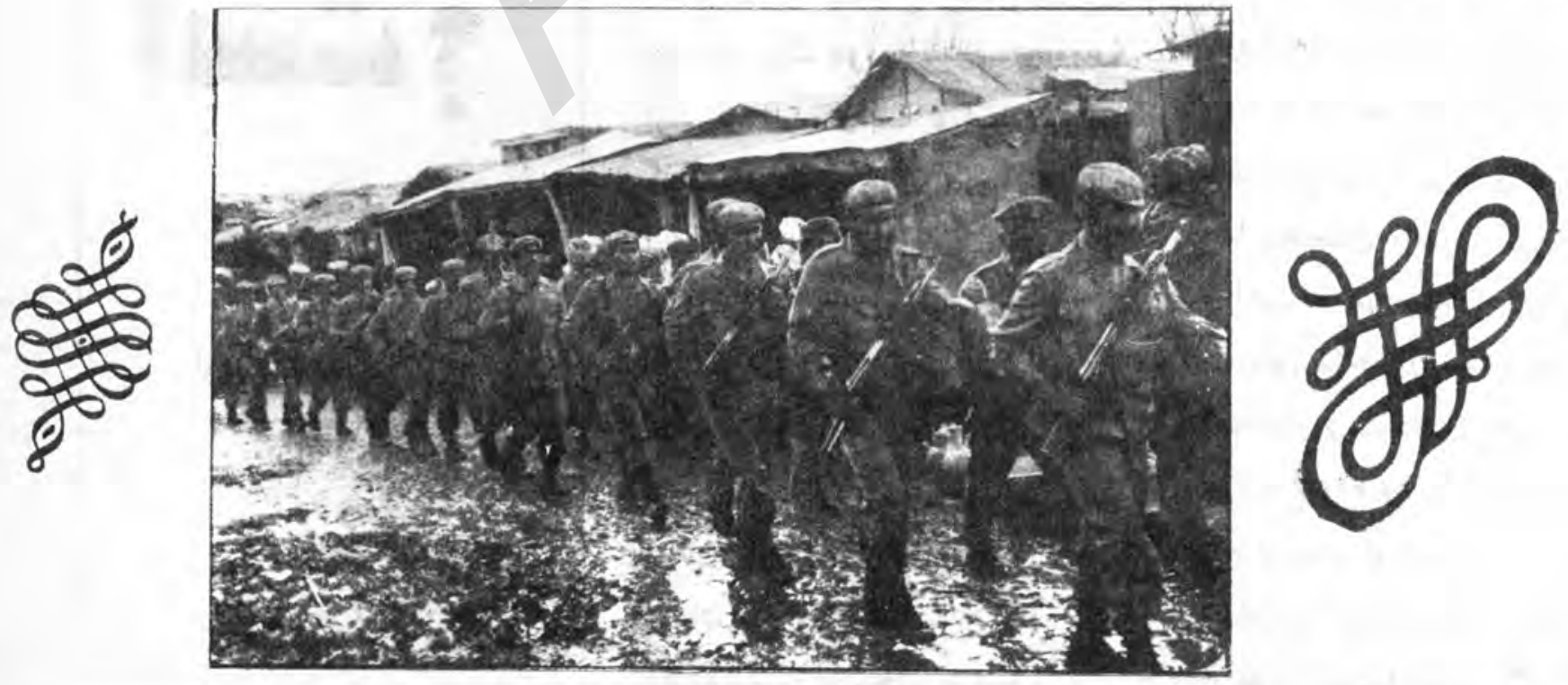


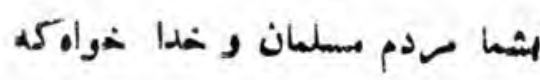
عمه هيز خوددرا فدا مانتهد و أزهمه

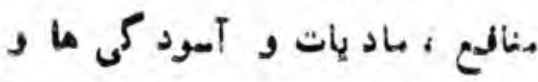

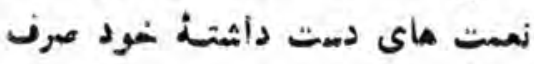

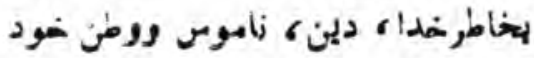

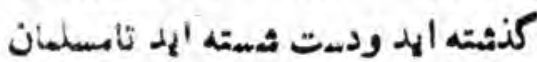

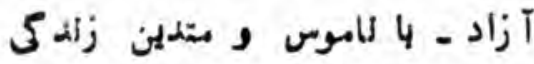

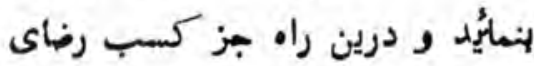

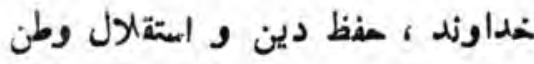

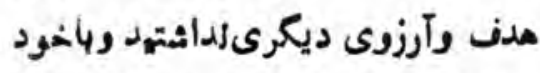
وخداىخودنيصله كرده بوديدكه بهن ونيز

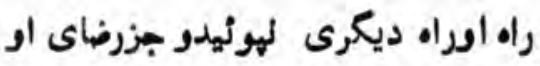
مقصد ديكرى نجوئهد تا بدليا وآخرت لكيوم حشر لهث خحداوئد وممه ريندكان

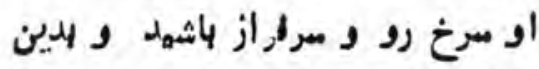

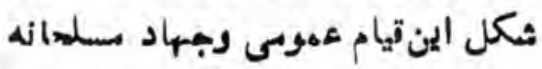

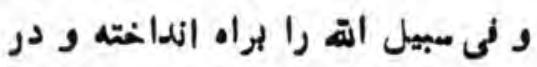

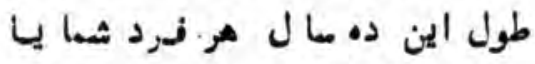
لزبان ، يا بهال و يا بهان در صف درد

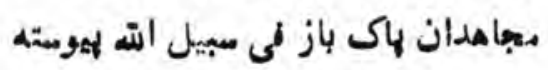

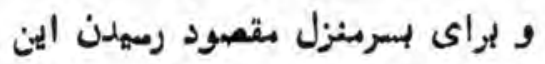

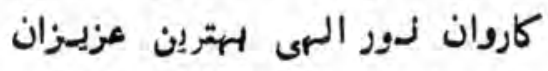

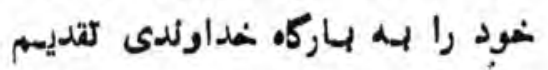

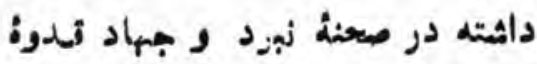

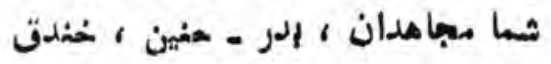

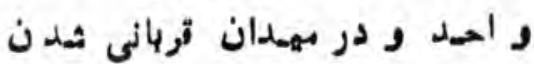

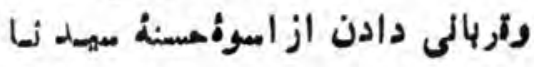

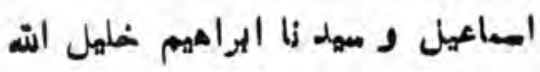

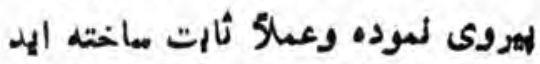

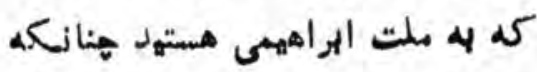

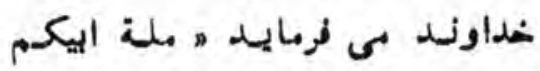

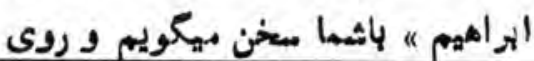

راليسوم يئس النذين كفروا مسن

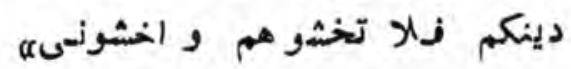

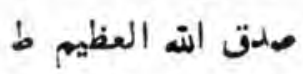

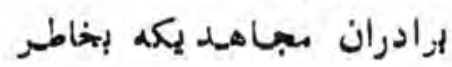

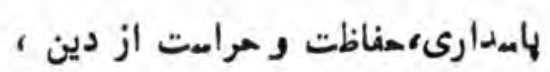
وطن و ناموس :غويش و ازمم +ميهنان

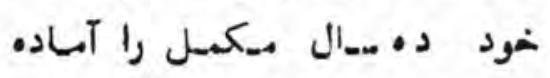

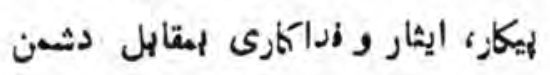

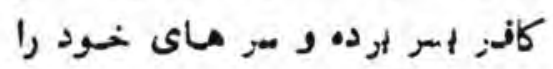

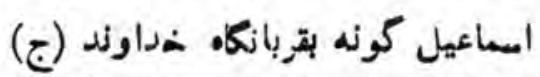
إخاطر مصول رضاى او ونجبات كثئور إملاسى تان بكذكزفته ودرين جريان

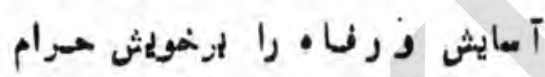

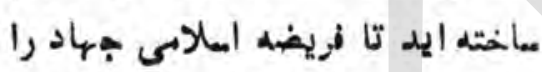

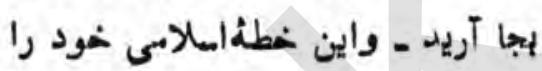
از يوغ كفر د كمونيزم و ليخدانى

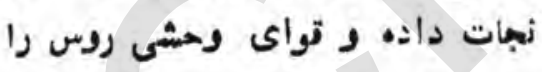

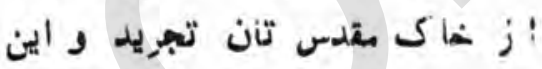

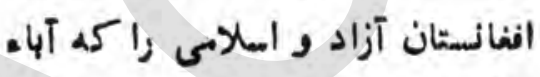

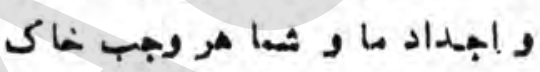

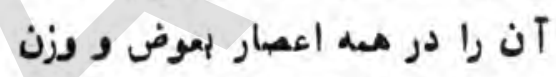
خونهاى لاكى خود ازتسلط هتجاوزان آزاد كردانهده و بها و شمها بهيراث

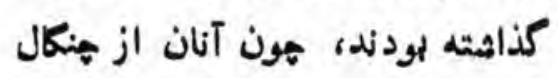

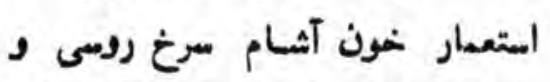
نوكران ثرن باخته وناخداى ايشان استقلال لخشيده و كومر عنت زئن

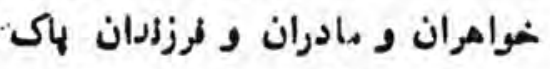

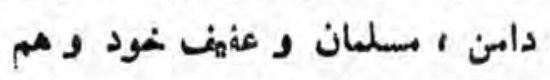
وطنان خودرا ازتجاوز و بهامال ثيدن رومان ود روس لرمستان در المان لكاه

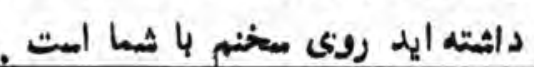

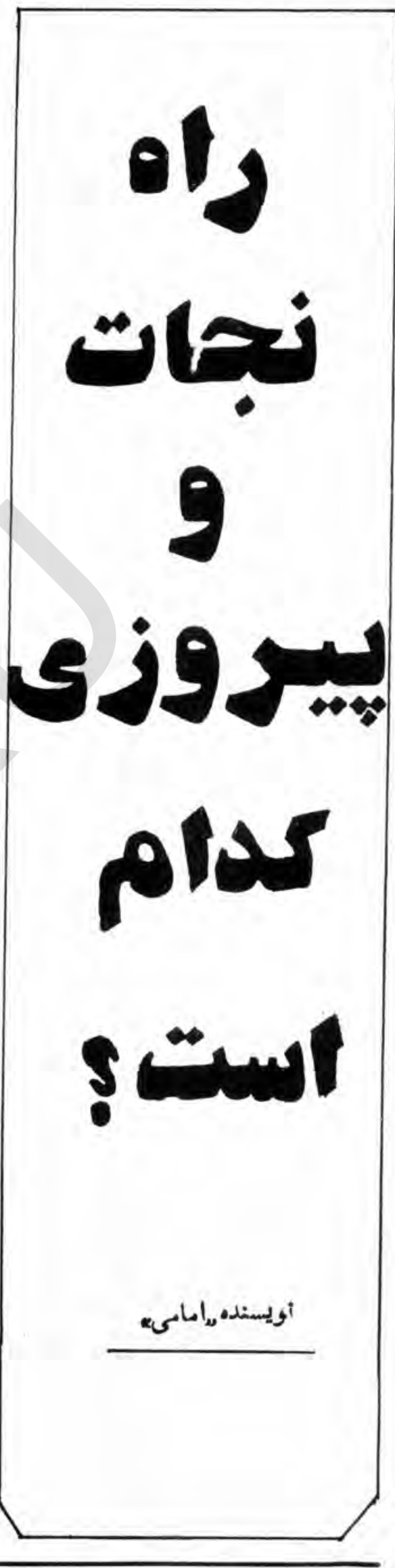


عقب نشينى واخراج قواى شمود را

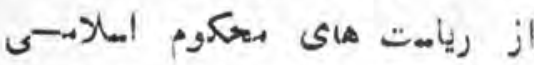

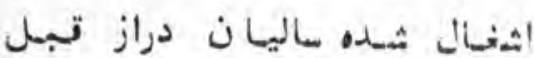

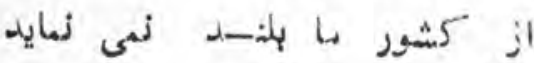
واعلام ميـدارد كمه تعيين و. ندوع

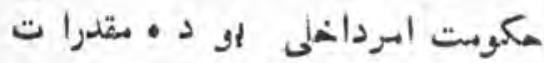

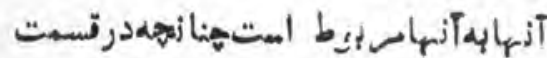
افغانسيان درين روز ها ناله سر داده

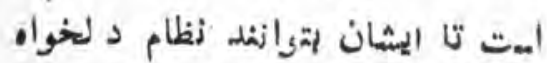

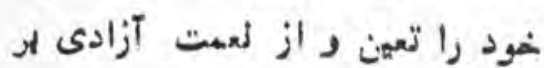

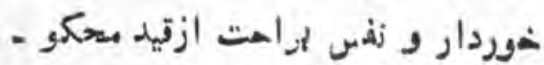

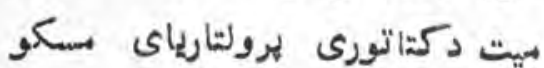

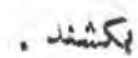

انس هرا تنها روسيه جهانهوار

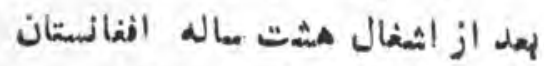

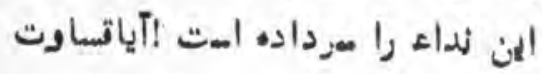
تلبي كموئيزم زوسى به ترحم تبديل

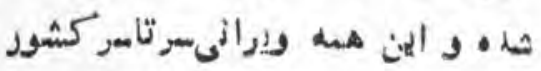

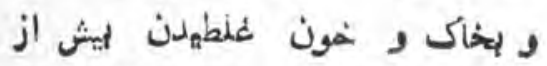

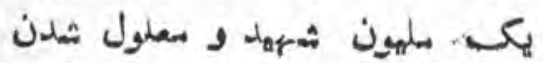

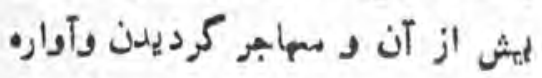

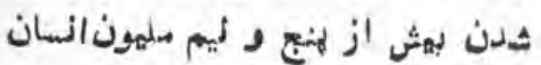

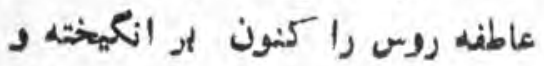

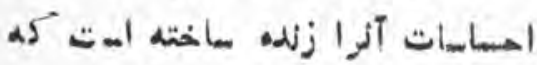

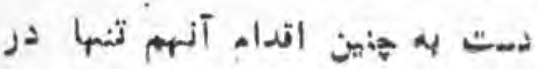

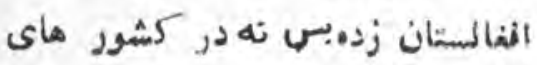

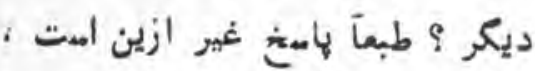

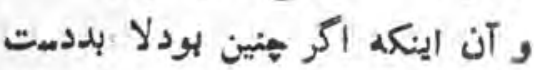

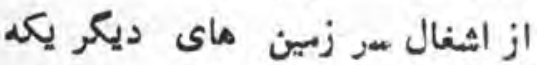

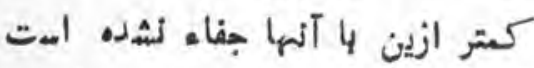

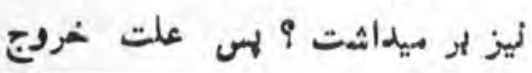

و ان جندلالهم المنعهو:وذ وبعل

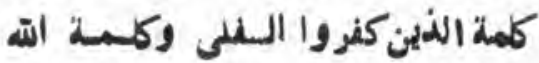
هم المليا الاانهزبانه مثم الغالبون

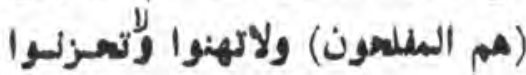

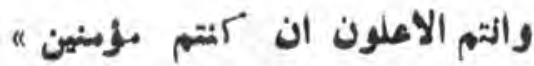
مجتقى سانت هبطه وضايع نكردانيد وسز ازنجام دثمن كافر باهـه كميد ومكر هانى شيطانى وآنهمه زرقوبرق

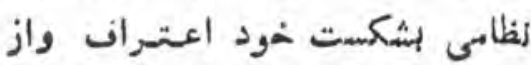
تسلط يافتن لبر ثهها و كثور اسلامى بهرد

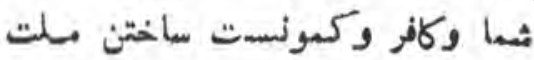

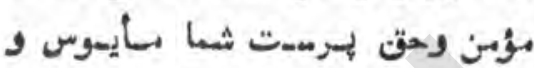

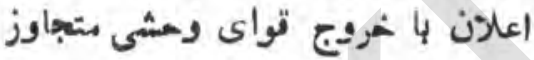
و اشغالمكرش از مرز وبوم امسالامسى مواس وكثور مسلسان هيرور ما نموده اهت.

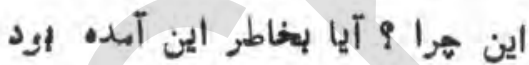

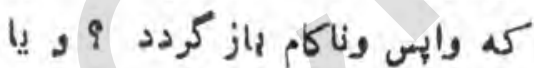

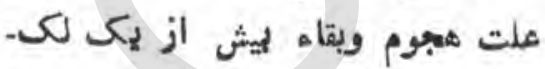
ولنجاه هزار زيزوى زظابى لـجهر 4

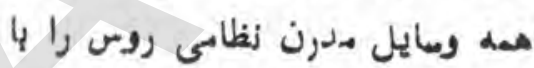

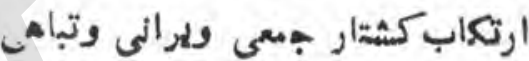

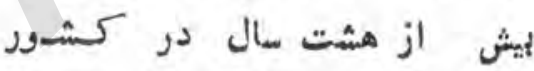
وياريكمقدرترسأندن دهالة المزدوران

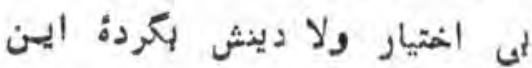
ملت درخلال دممال تعوإه وتبديل

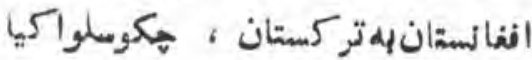
تاجكسيتان ونغره كشيور هاى الشغال

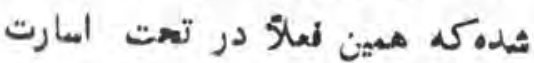
ودمكوميت آن لسر بى برئد ه إوده يا هيزى ديكرى ؟ واكر هين لبن لبودي

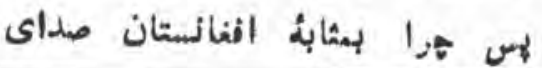

مرفم با ثماك ادت .

وبلاخره با شما رهبران جمهاد افتخار

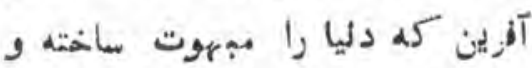

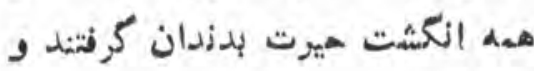

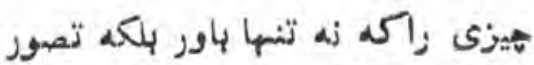

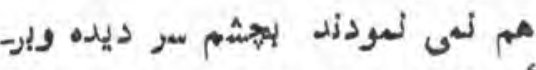

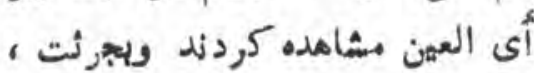
شمبامت ، غيرت وبردانكى اين ملت الت

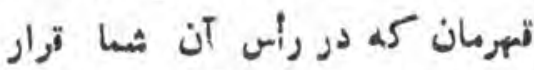

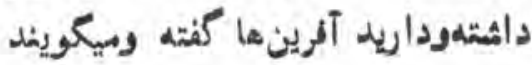

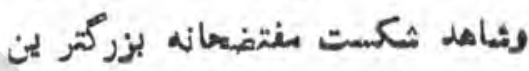
قدرت وطاقت تابدئدان بجنهز ومسلح بنح عصر كنونى در مقابل شها أزد تهو تلاش خسته كى نابذير شبا روزى دئ

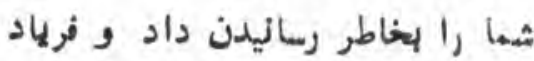
ملت خود ، وومشث و بربريت

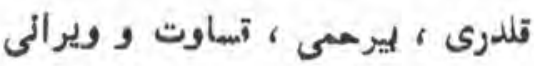

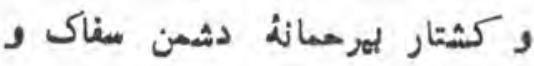
درخخيم تان بكوش جهان ود جهبانيان

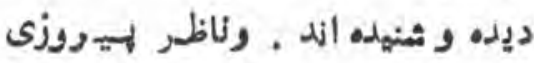

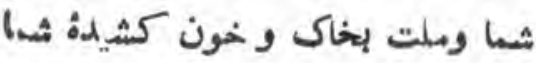

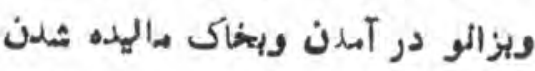
لهوزه روسيه غدارو.كاربمقاب بل شماقافله داران جهاد كثشور الدد بل شماصعهت

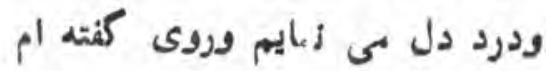

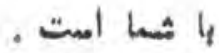
وآن ايفكه خداوند وعدةُخود را اسميز در خصوم ثمها وملكت دردميند وآواره وسركردان وبمجامدين

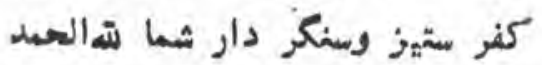
طبت فرسوده ماىخويش : 
EY

وأي

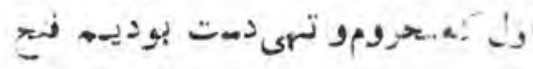

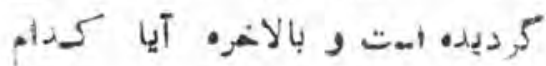

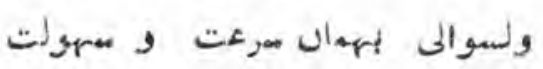

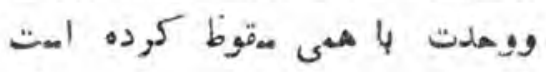

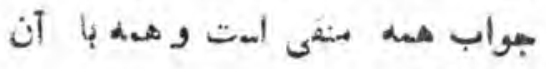

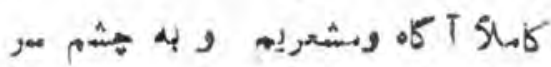

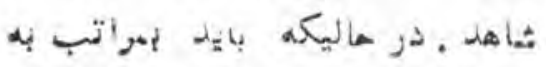

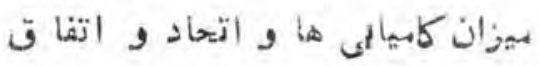

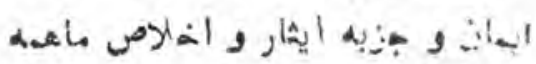

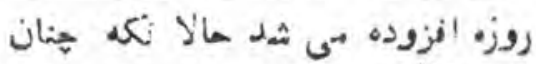

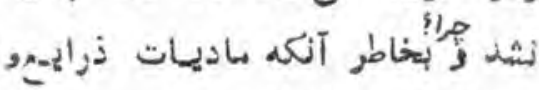

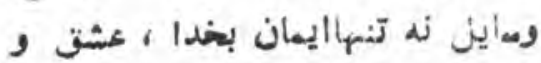

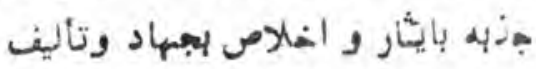

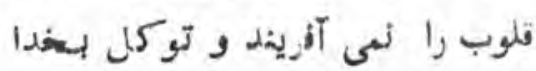

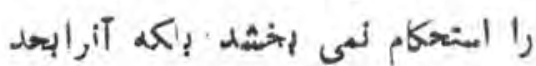

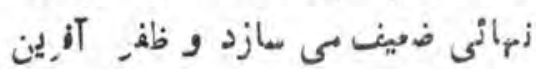
زيست نتع و ظفريكه ببنى و اماسى

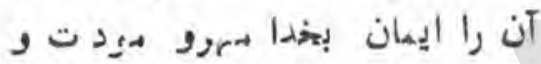
اتحاد اخلاص جنزبه ايثاز و أفدا كارى درواه دين خخداوند تشكيل ميدهدكم

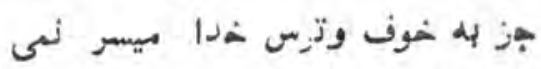
شود خه ترس وعشق بشخداوزلد اسهت

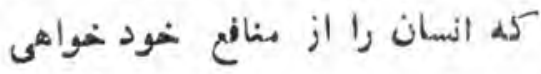

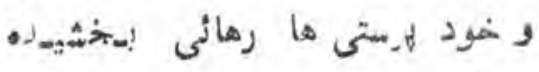

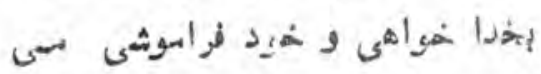
distas

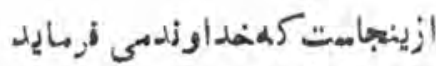

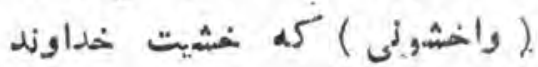

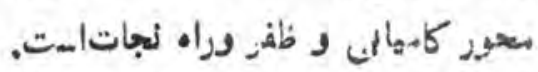

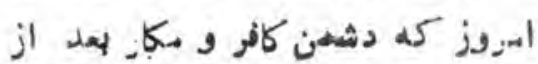

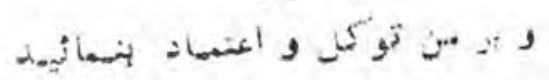

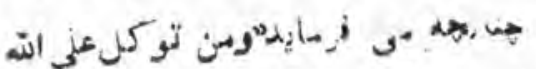

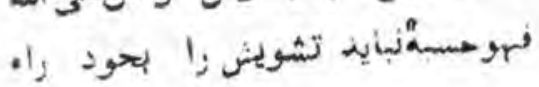

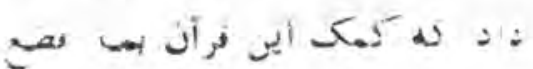

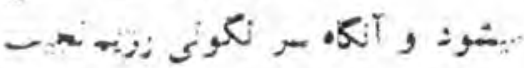

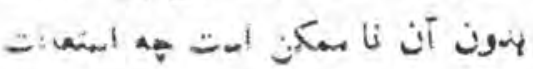

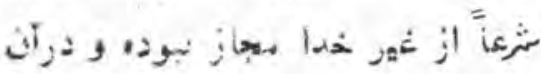

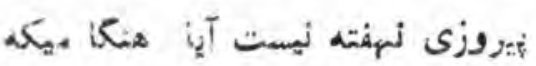
غةل المسلمار ، فرقه نههوين فرقه هرات اكثر مساكز ولايات كثمور و مهن

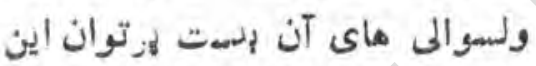

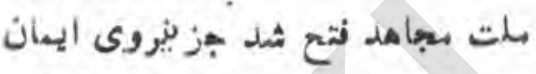

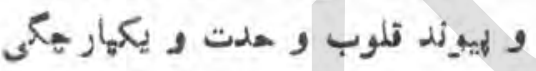

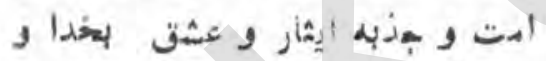
دين كدام كوبهك الهرونى ديكر

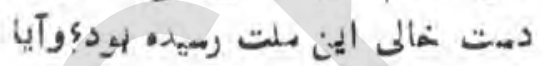

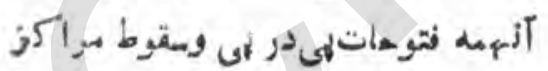
دولتى يكى لبمد ديكردر نتيمبه كذام

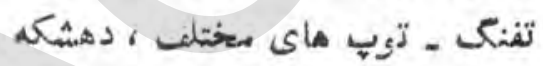

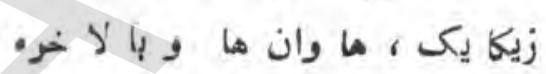

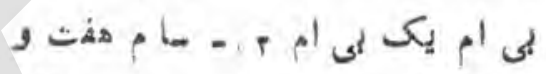

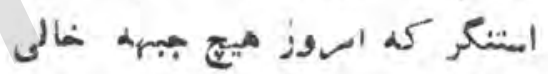

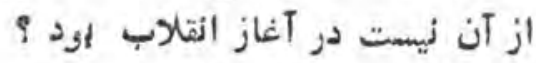
هز المتغاته جستن ازخداولندوتوكل

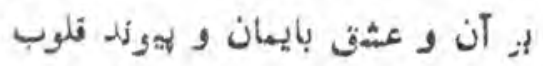

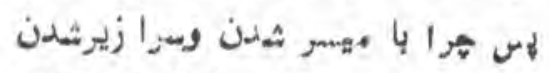

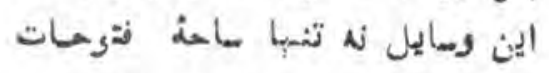

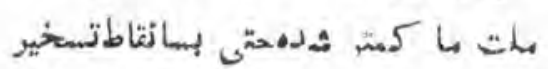

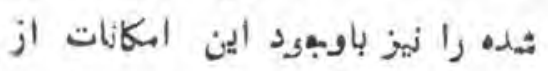

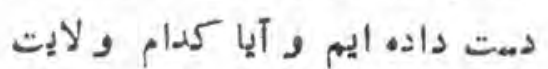
لم از دست رسى باين و سايل هون
واى زوس بعد ازين همه ثاك ريتكرى

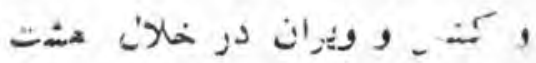

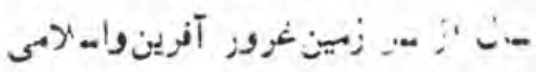

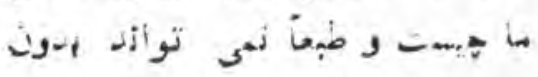

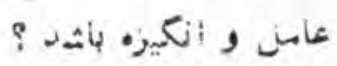

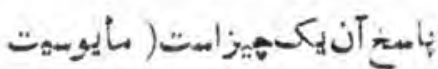

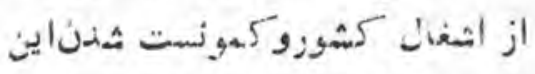

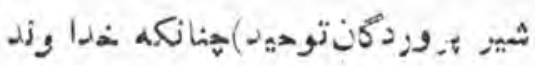

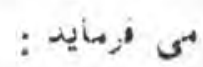

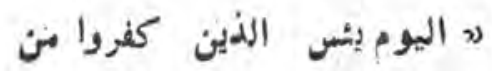

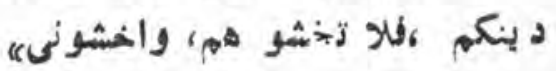

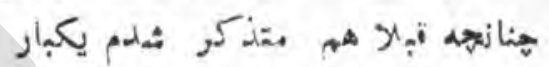

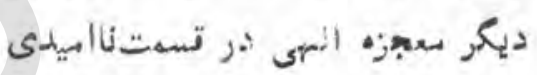

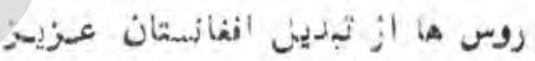

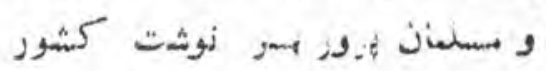

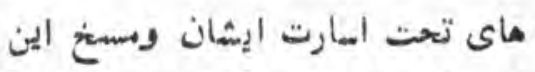
هلت كله در هيدد آن بود وهمكوند

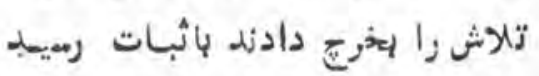
دصدق الته المعثى العظيم.4،

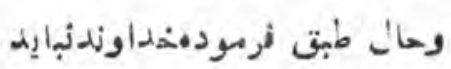
هراس اخوف ور عبىاز روس وعهال

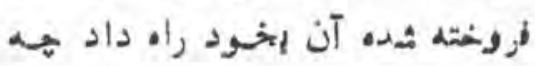

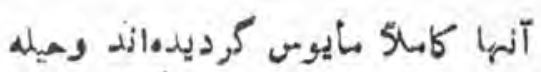

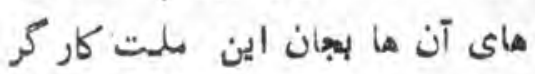

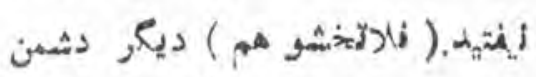

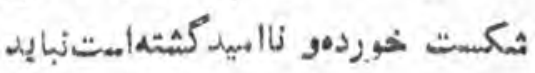

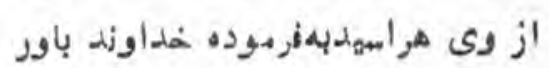
وايمان داثت اذذعان ويقين كيرد و رضاى سخن در الين فرسوده خداوزد

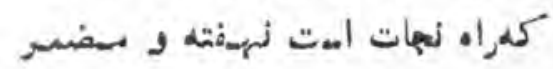

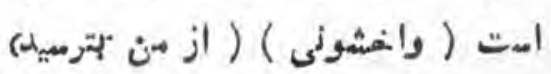


خودو كشوروملتخود رادرطراز اول

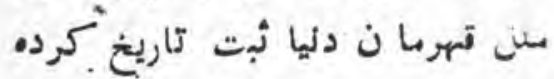
ايد : ميخواهم عاجزاندياشما مشوره ليمايم تصور لكنيد كها|لسان از مشوره

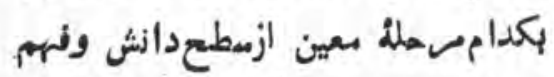

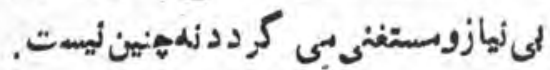

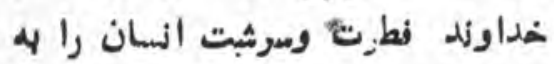

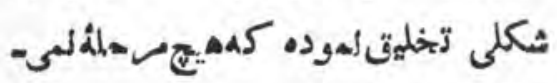

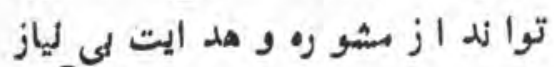

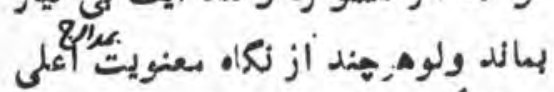

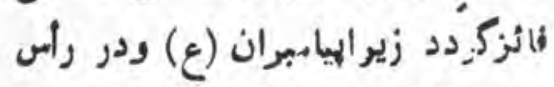
ايشان كه بيابثربزركوار اسلامازميث وديث فضيلت قرار دارد خداوند 4 و خطاب الخاب

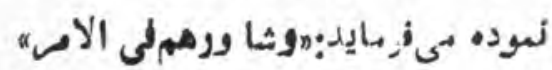

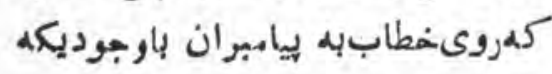

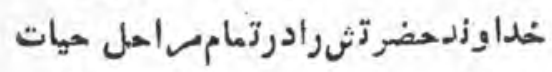

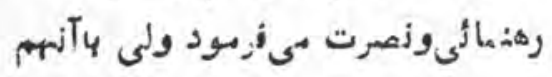

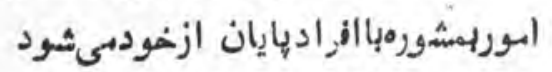

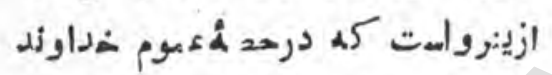

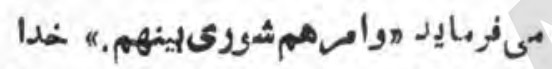
لهزابزركانماهم بششور. طبيعتأ وفطر تهات

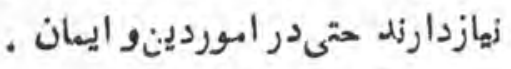

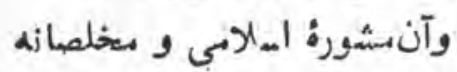

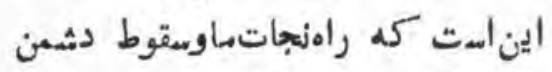

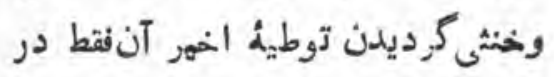

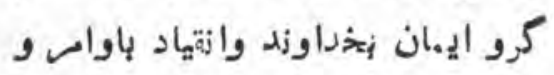

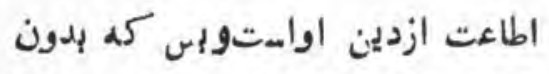

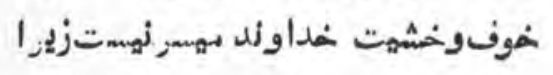
دزيورت عدمخوف ورجاه ازمخداوند

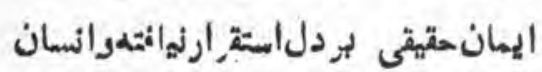

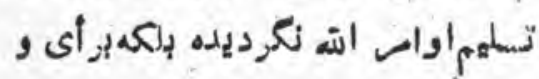
نقلخود كارنسوده وتسلمهموا دهوب الهب
ماركسيستى را بركردة ملتما حاكم

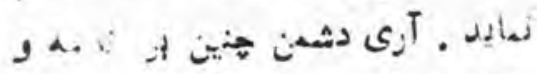

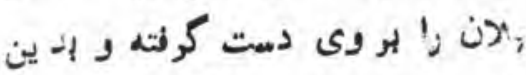

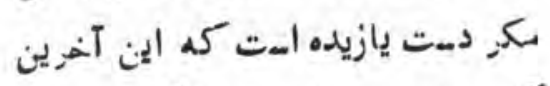
كيد دثمن شيا دو حيله كر اهت .

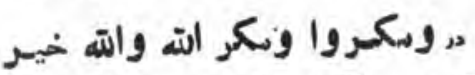

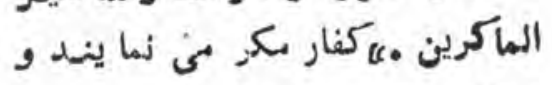

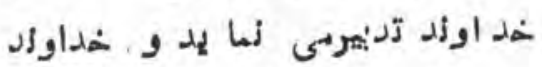

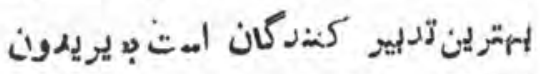

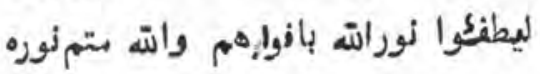

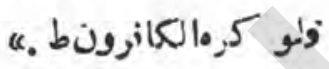

بمخواهند نور خداوند را باهيخ

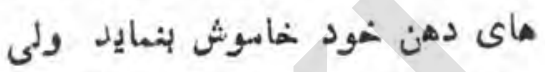

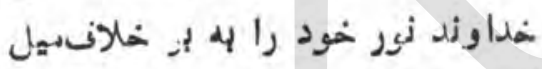
كفار با شيها بى روسازد.

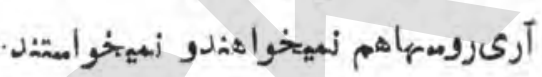

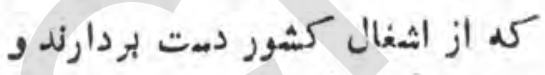

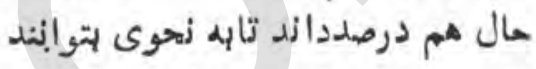

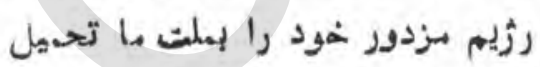

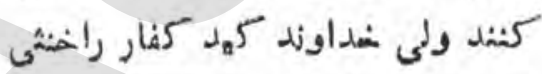

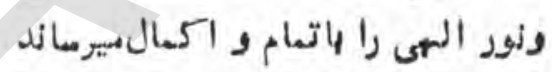
آنهم له بوسملف ديكران لبكه تو سيط

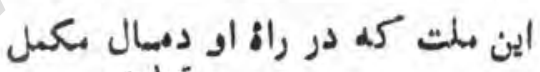

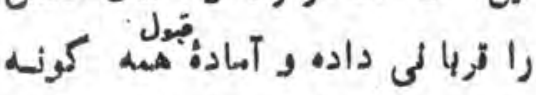

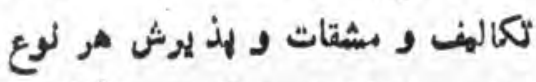

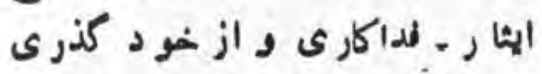
شيده الد.

اي مجاهدين دلير و با ايهان

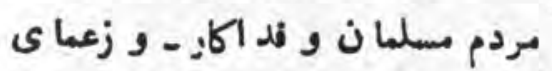

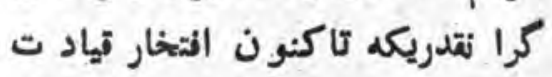
كاروان نوررابدوش كثيده واستوائيراليد

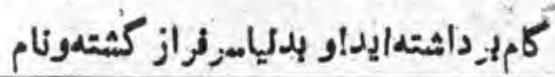

يورش و غارتكرى هثت ساله فنان

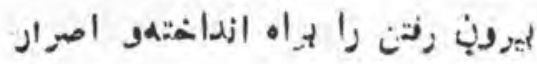

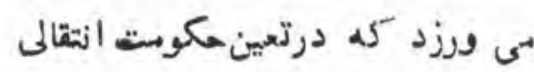

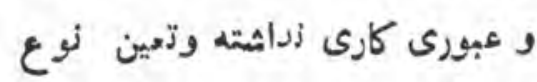
هكوبت امه داخلى هدمافنغالستان و وظيفه آنها است .

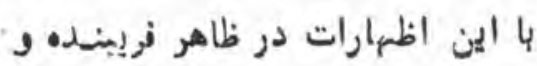

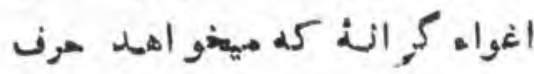

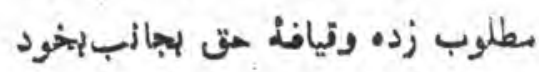
اختيار ك:د در زيز إيرده اين ستخنان

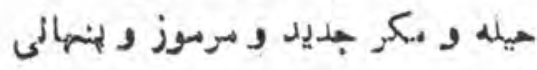

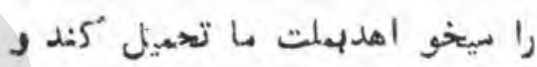

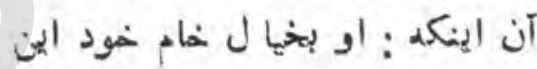

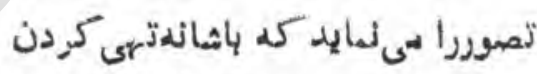

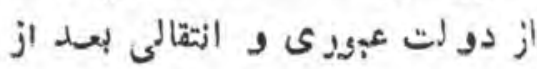

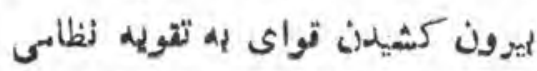

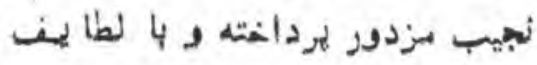

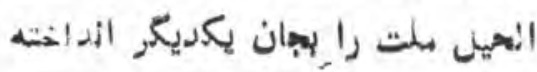

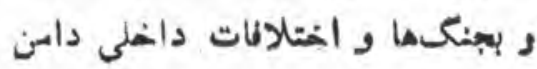
زده وجنك رادراز مدت ينمايد تزري

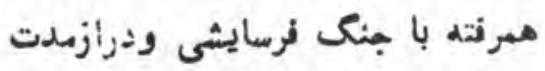

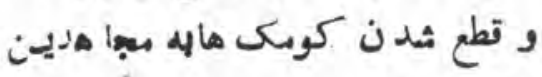

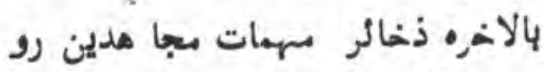

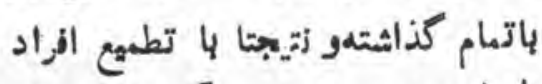

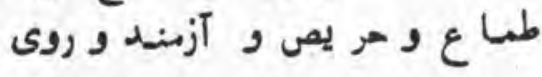

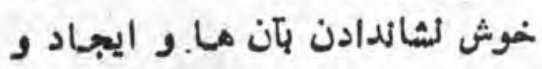

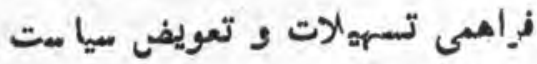

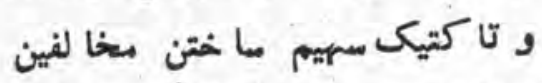

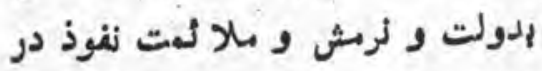

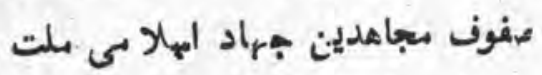

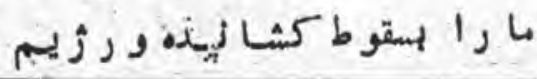


را كمه ابهان شان متزوج با يقيه و

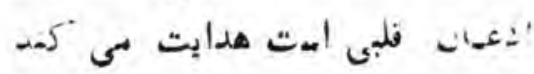

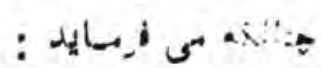

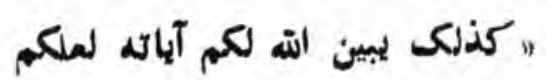

$$
\text { "لهتdون }
$$

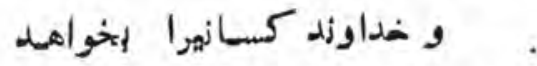

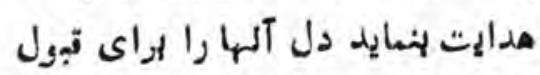

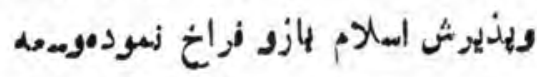

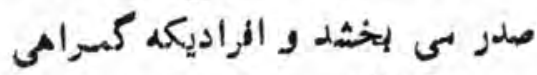

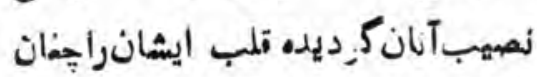
تنك و بـى ظرفهت بىهازد كمهتكليف

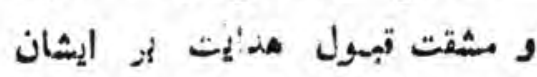

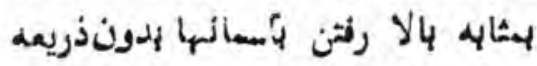

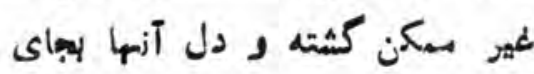

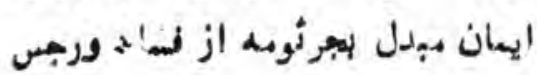

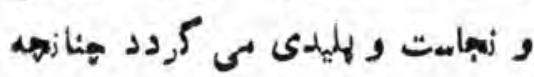

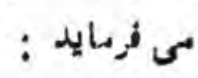

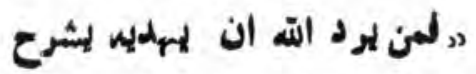

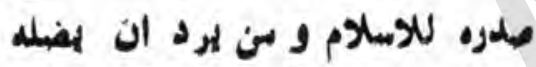

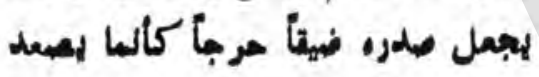

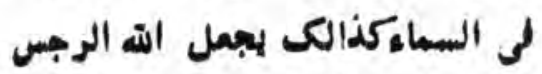

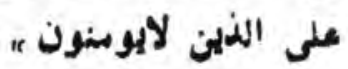
!

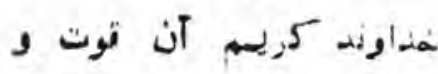

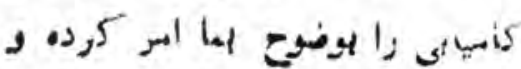

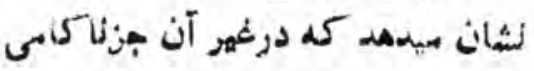

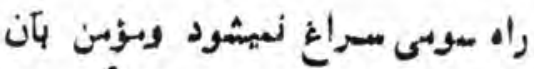

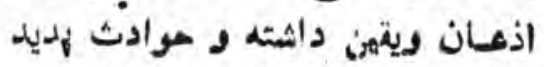

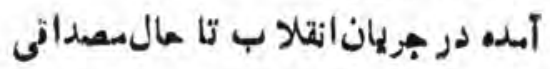
هقيلم آن است ” ولا تناز موا التلثبلوا

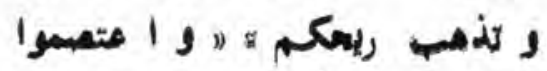

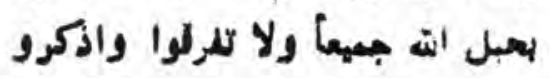

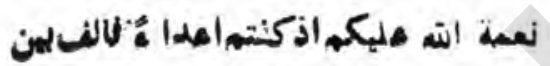

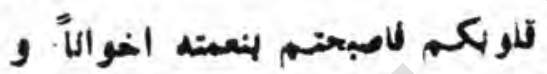

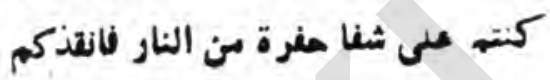

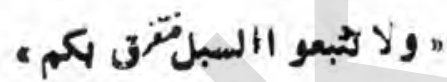

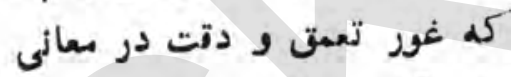

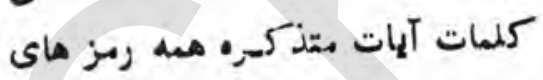
هيهروزى و شكمت را بها نشان دمهى مى نهايدد . و خداونه بوسيله آيـات بيينات

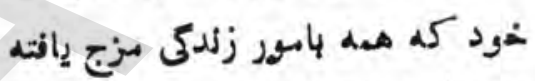

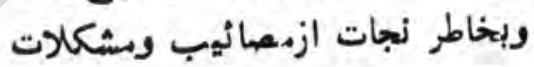

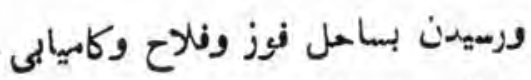

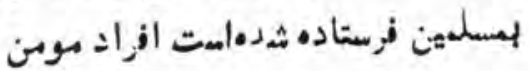

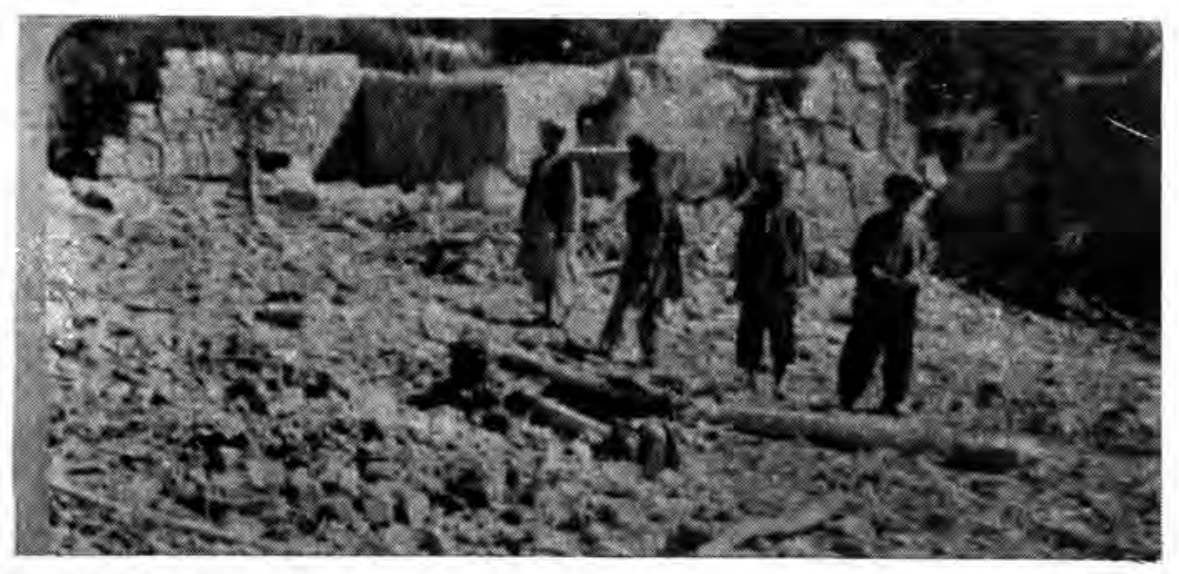

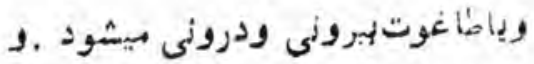

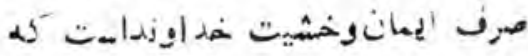

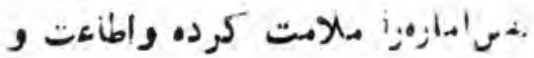

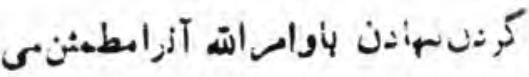
سأزد واختيأوتدرت وآرزوى رادرجاى كه امرخداوند تاطعروصريح باثهد از وآروى رادري وىسلب مىكند تا بهخواستعقل و لانذس تنودرندهد اين امسبا ايسانتوأم

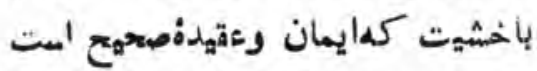
همكن اهت نمدرغيزآن كهآيات شريفة

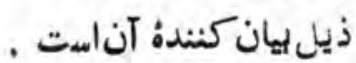

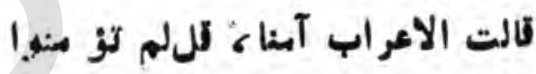
ولكن الولوا:أسلهنا، ولمايدخل الايهان

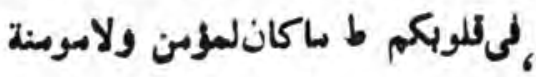
اذاتضى اله ورسوله ا مرآات إكون لهم الخيرة من امس مهمط

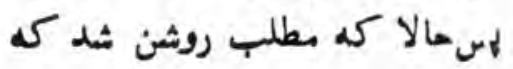

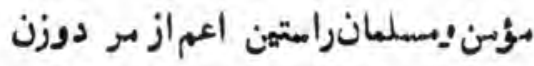

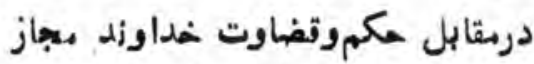

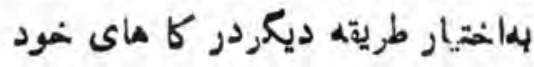

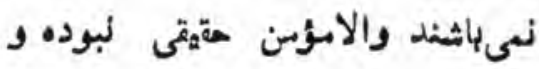
ايهان در دل ايشان المتقرار لهيدا

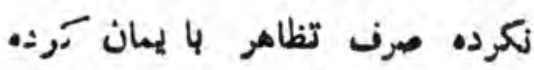

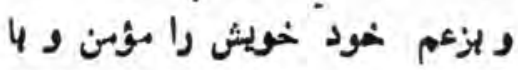

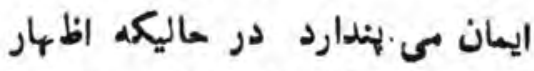
ايسان إدون امتحان وآزمائش به باركاه

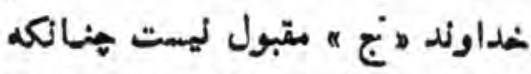

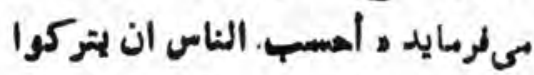
أن يقولوا آهنا و مم لايفتنون

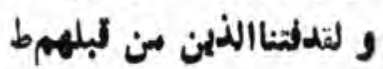




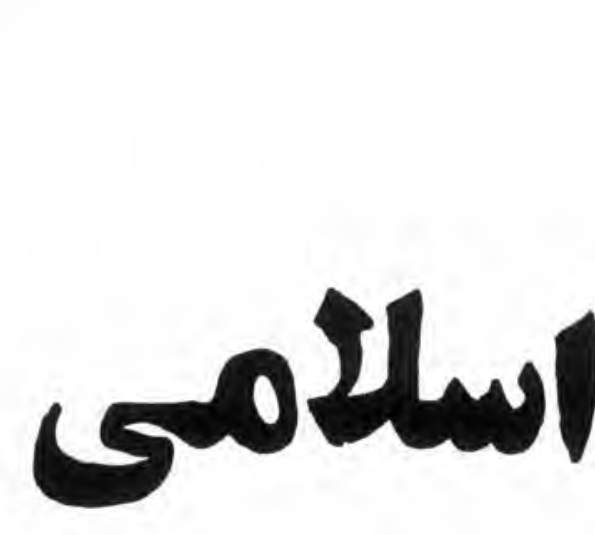

\section{لزوم سازماندهى وكلارتشكيلاتى $\int 3$}

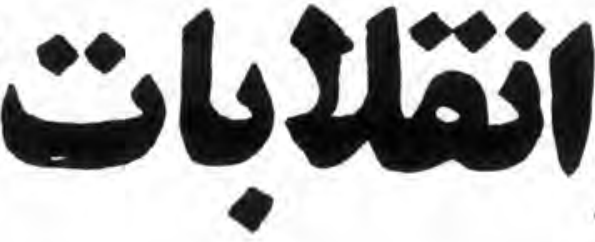

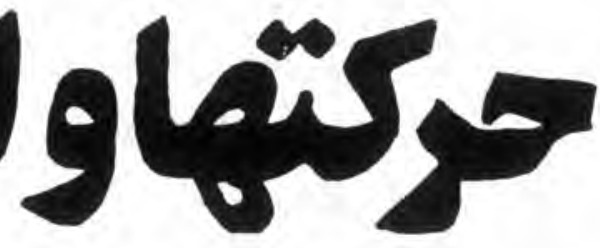

انتظام يافتهازئ واطور مم آهنكيراى

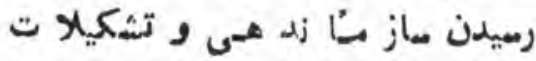

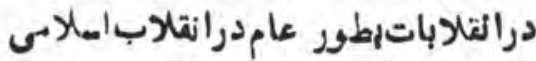
يطورخاص يكىفن السياردمبم وبا ارزش امت. تشكيلات بهدردم زظمى بهدهد كد از طريق آن نظم كار زيادومؤثر به مهولت النجام بى يابد واين خهود

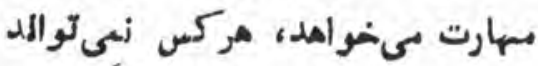

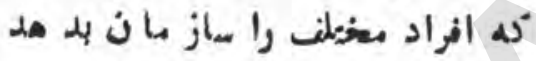

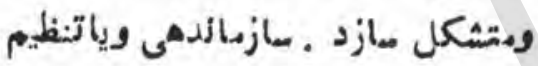
وتشكيل انواع واتسام مغتلف دارد.

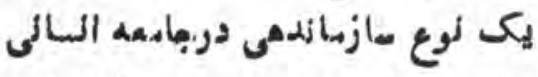

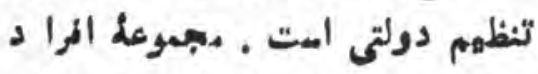

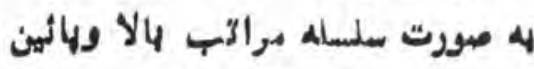

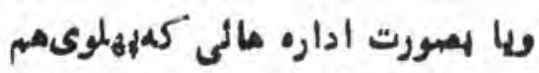

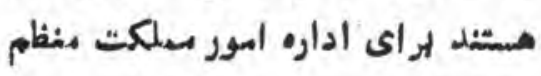
و .تشكل شيده الده كم آنر ا تشكهل

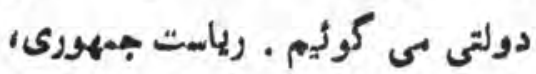

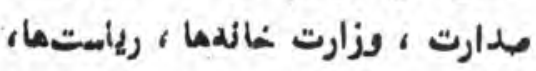

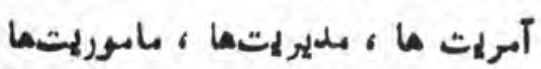

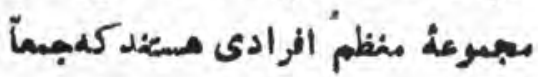

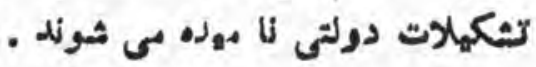

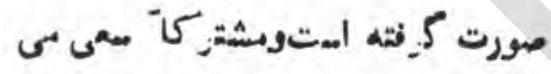

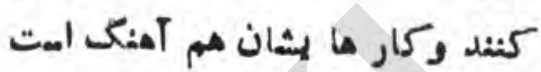

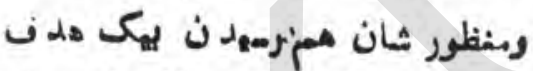

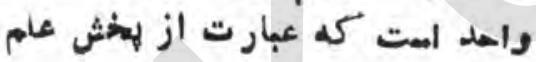

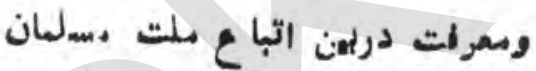

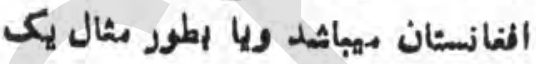

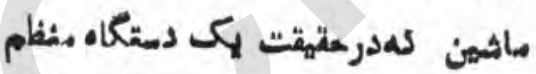

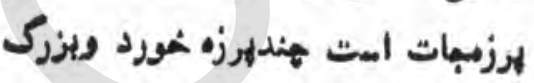

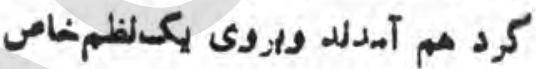

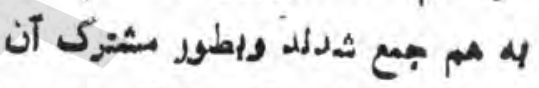

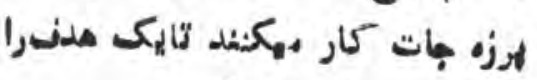

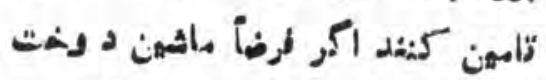

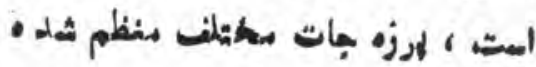

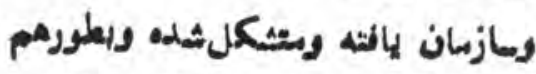

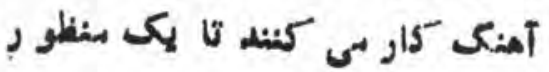

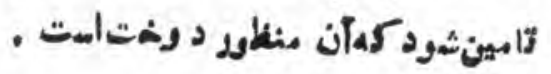

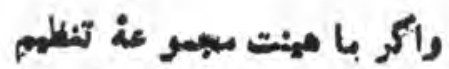

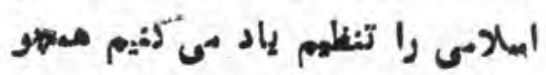

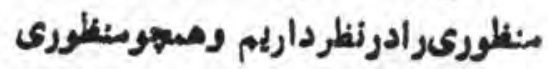
رأ اراله مى كثئد : عدة إز المراد 4

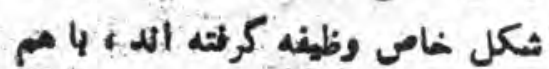

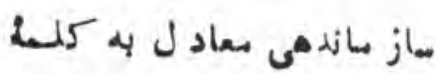
تنظهم وياتشكيلاست. تنظيم بلمعنى

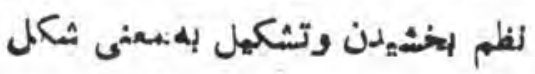

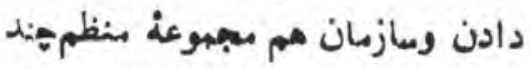
فرد السانى امت كم به بهنظور رمديدن

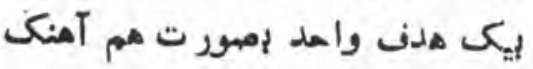

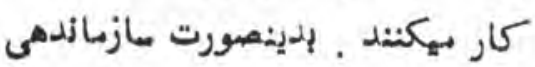
وتشكيل غبارت از نظم دادن برهند

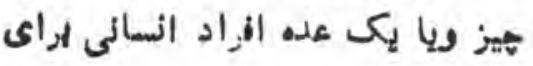

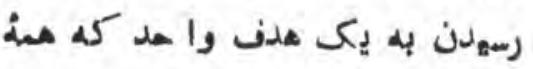

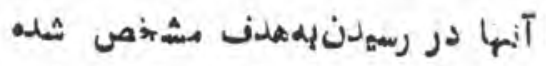

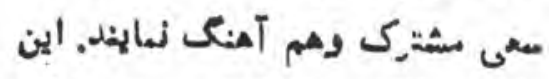

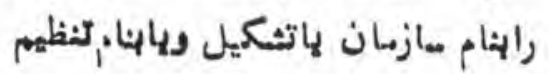

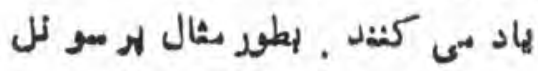

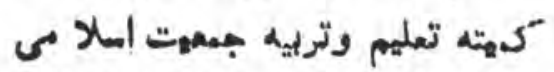

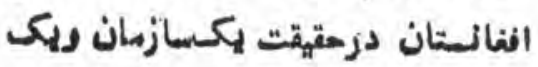

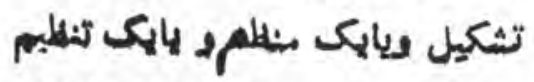

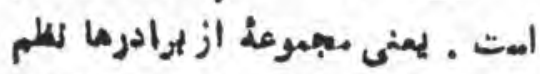

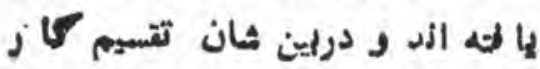


روى زمين اختيار كرده اهت ازمهان

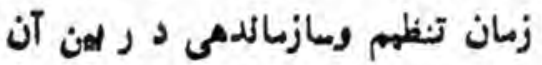
رواج لهدا لموده است . معصوصأتوت

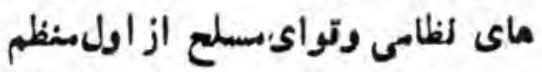

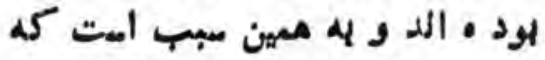
اردو :حرالظام ياد مي كيند درالفالستان

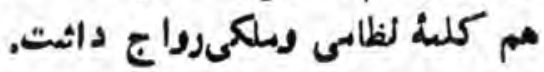

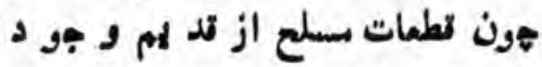
داثتند وداراى للمم خام وتثكيلات بودلد از الئ سبب اردو رابنام لظطام

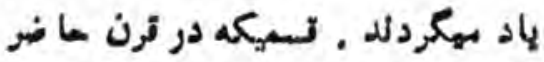

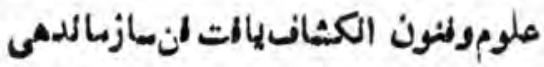

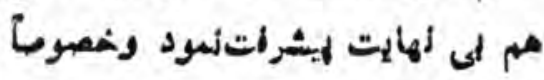

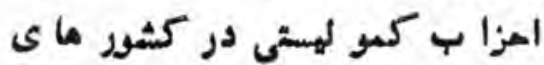

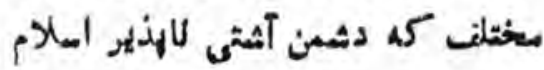
د مسلمعين مستثلد الطو ر خهيلى بنظم وسازمان يالثه كار بهكنئد د درمقرون اخمر. اولين كروه سهاسى كه تواذست

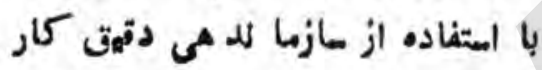

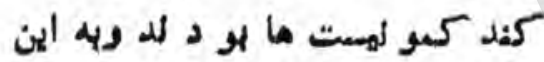

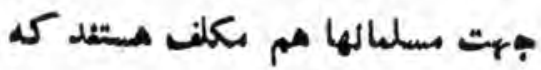

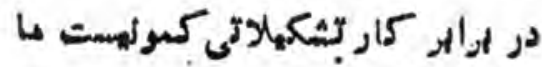
كار تشكيلاتى شيظم و مازمان ليالته داشيته باشغد .

كار تشكيالاتى را دربكس كثيور

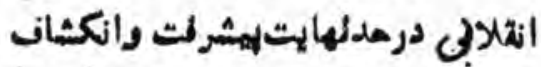

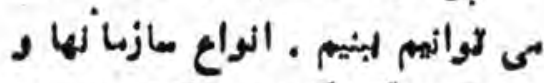

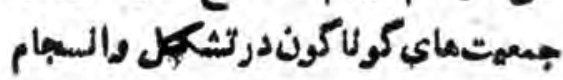

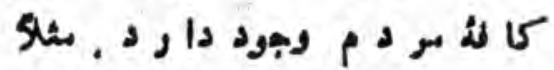

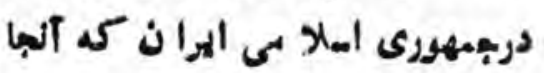

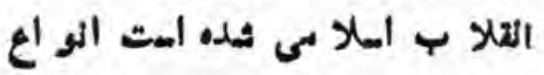

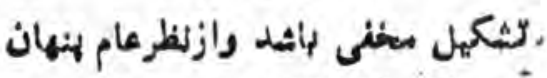

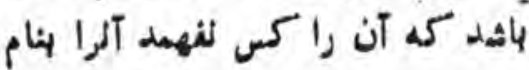

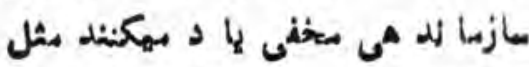

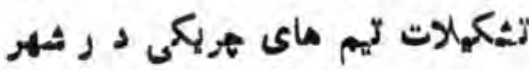
كابل. كرومأى هريكى ثومعط جبهات

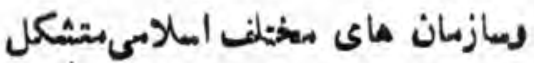

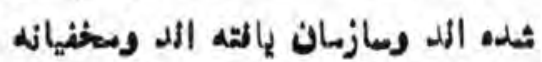

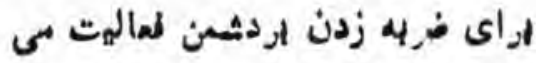

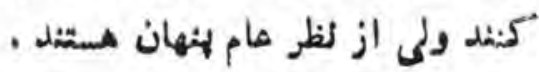

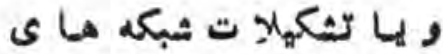

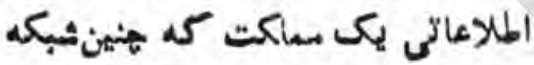

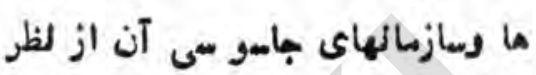

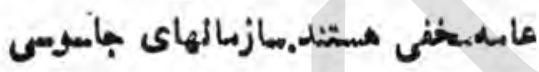
تشكيلات لنهانى دزيو زميينى مهداثيته

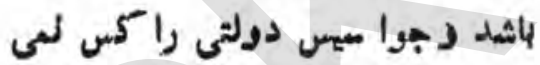

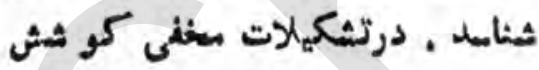

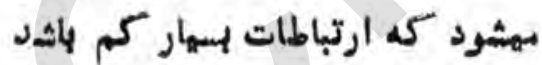

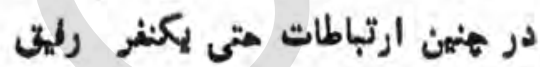

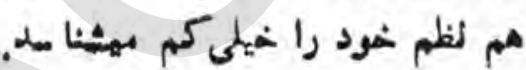

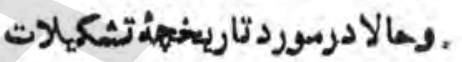

نظر اندا ز ى بى كنيه . لز وقتهكه

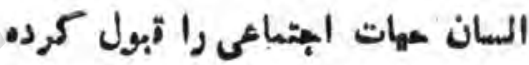

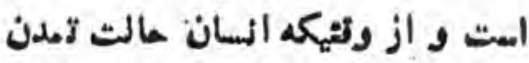

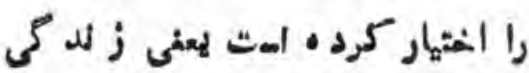

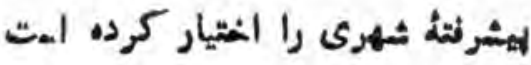

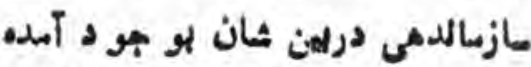

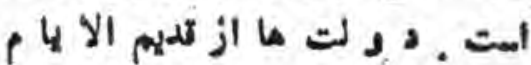

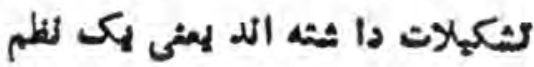

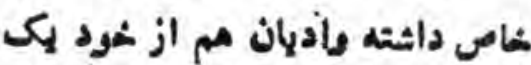
لظممخاص داثيههالد. ازمهان زنا لهكيه

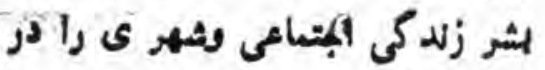

ليكنوع ديكر ازتنظم وياتثكيل، تنظيم سها سى كثنه مى شو د د . ـثل

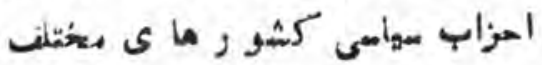

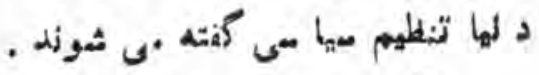

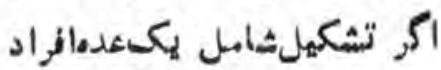

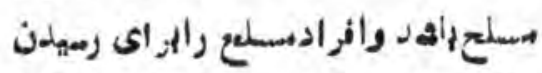

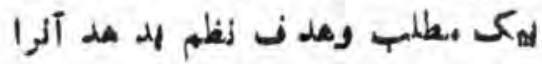

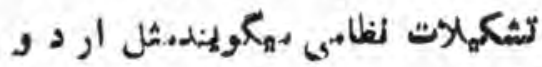

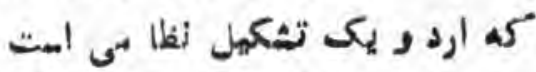
والراد سملعدرآن سازمان هيأبدواكي

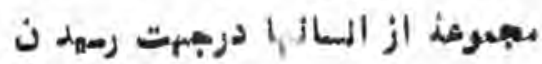

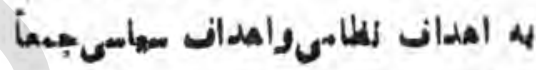

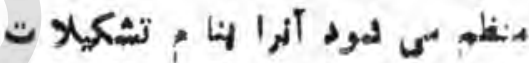

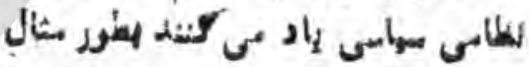

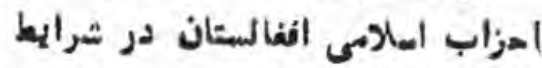
لعلى تثكيلاتسياسى لكلا مى مستيد

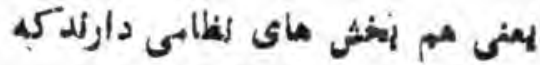

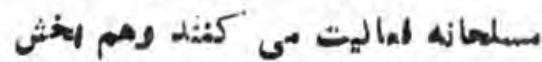

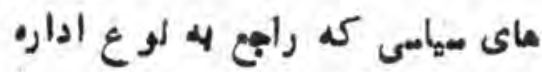

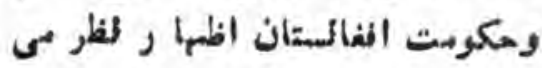

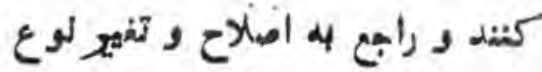

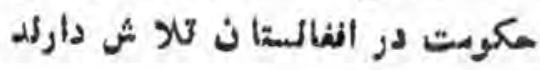

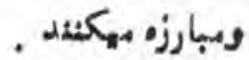

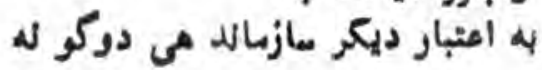

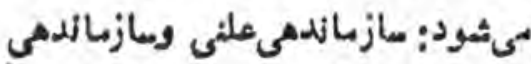
بخفى لطور مثال كميته تعلهم وتربه

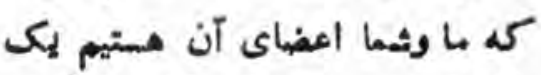

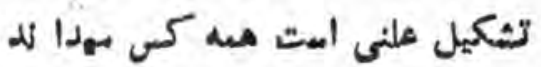

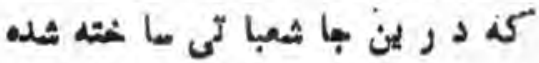
و الرادى درآن ثعبات جاليجاكرديده.

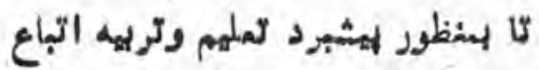

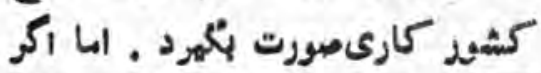


تشكيل ثدد و بعد 4 جزير ة العر ب

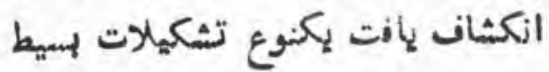

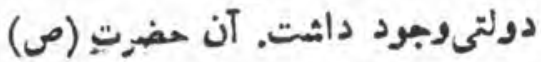

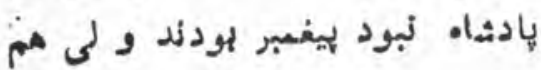

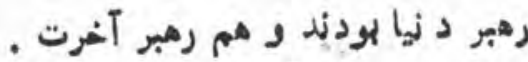

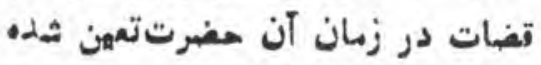

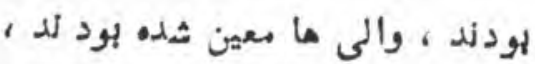
هيئت جمع آورى زكوة معين كردين معديد

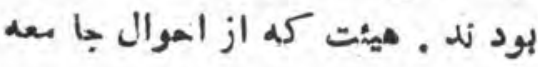

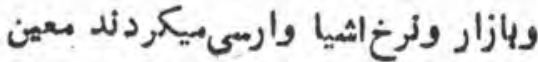

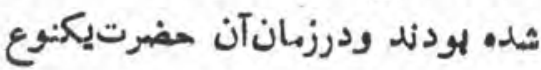

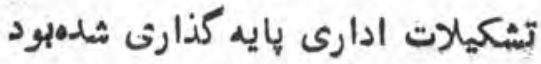

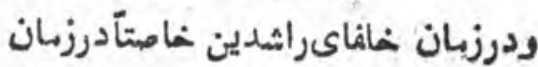
مضرت عمر (رض) تشكيلات ادارى

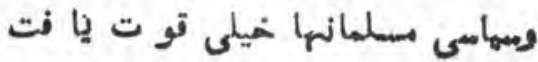
وانكثافنمودوهتى هضرتعـ.(رض)

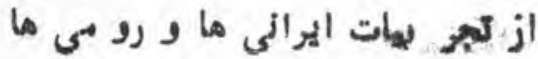

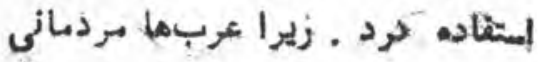

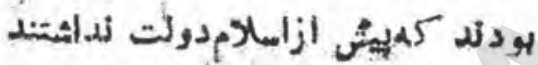

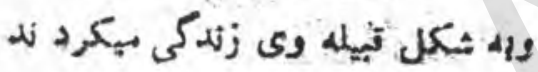

راكه ابروز كموليستهابنام مازبان

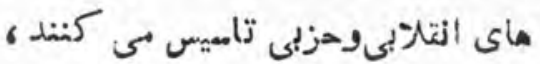

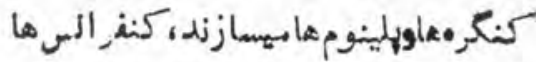

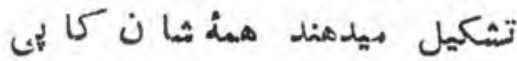
تقليه خود آكاه يا زاخود آكاه ازجنه تشكيلات املام است. كردهم آبدن بردم يـمسحلدزريك مسجد واقتداى

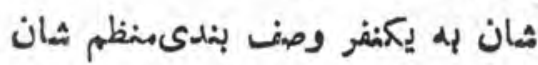

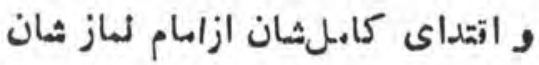
خود يكنوع سازماندهى وتنظيم انراد دركارعبادت لرودردكاراست. هم هنان

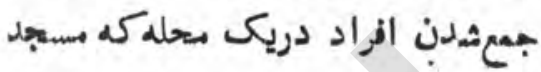

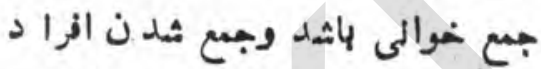
در مال دوبار بخاطر خواندن نمازعيد همه اينها كار هاى تشكيلاتىوسازمان

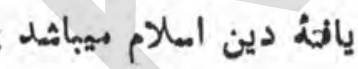

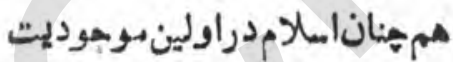
هود تثكيلات دولتى داثتة امت .

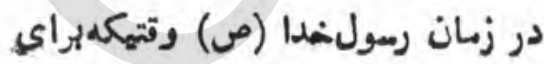

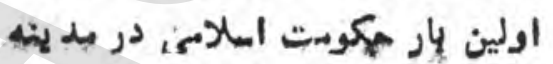

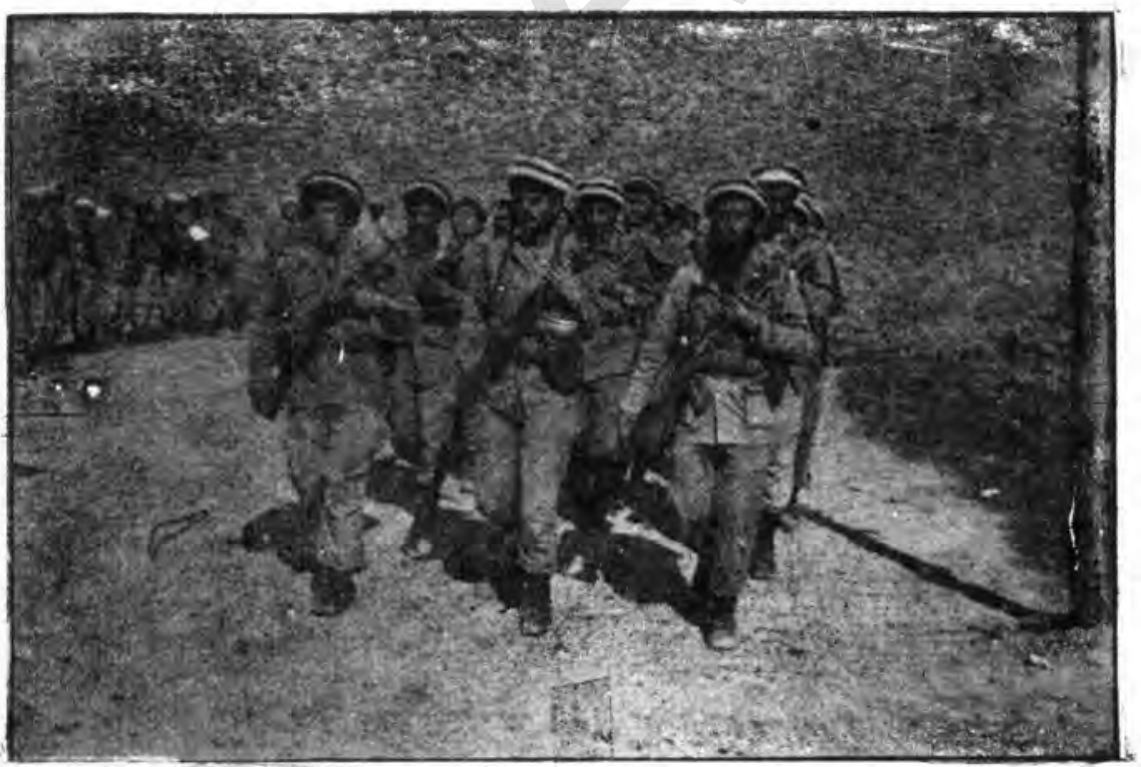

سازمانهاى كم توده مردم ايران را

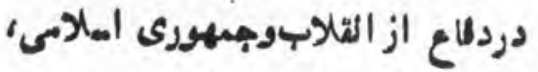

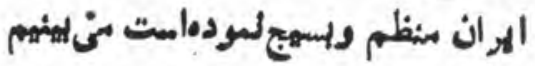

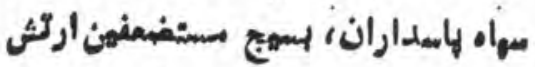

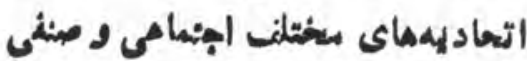

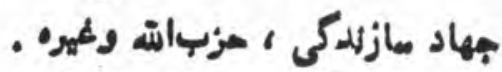

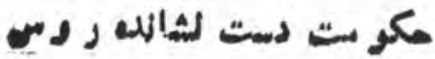
دركابل درمازمالدهى وكارتشكيلات

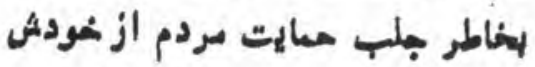

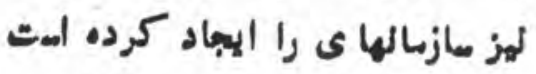

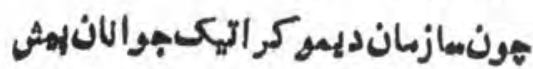
آهنكان، جمههُ هلى لهدر وطن، شئون

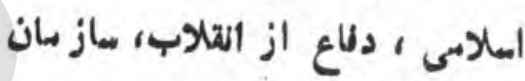
دالموكراتيكسزلان ولغيره . ولى هون

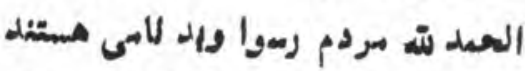
مازمالدمى وتشكمياتشثان بلدرد ثهان

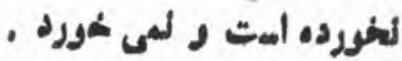
تشكميلاتى دراسلام وجود د داثتهاست

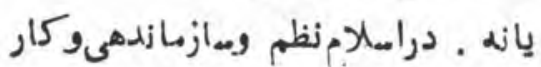

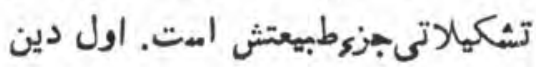
كهدر.كره زمين بهنظم إنششهدن وكار مازمان يافته شزونع كرد دين اسلام بود ـ تعبيز مسجد ها به هر قتر يه

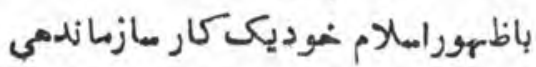

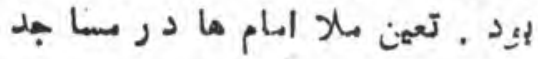
حغيز به حيث رهبر همان تريه، بناى

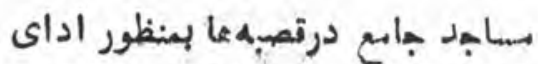
نهاز جمعه وبناى عيدكاه ما درثشبرها

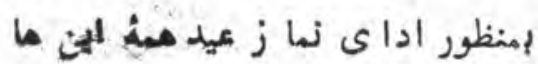
يكنوع روشن وآثكار كار تثكيلاتى مئى وسازماندهى در اسلام است . هيزي 
كم خداو ند به آن اليخشيد • است .

$$
\text { ترآنكريه ميثر مايد }
$$

لارجع البعر ملدرين

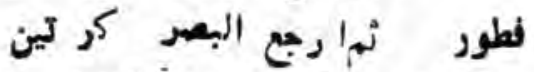
ينقلب اليك البعر خا سـأ وموسميري"

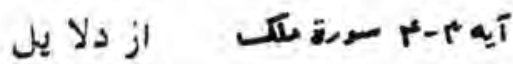

مجكم ائبات وبو د خهداوند د ر ائن دانثهمندها درعصمر حاضو برما ن نظم اله وانسان ازنظمى كله درعالمخلق

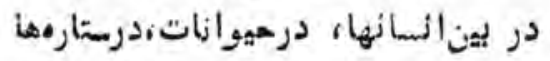
، درزمهن وهمه برجيو دا ت آورده

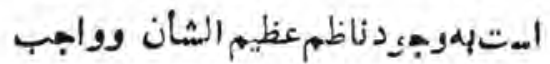

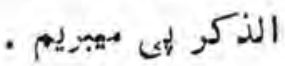
مشاك اكر نظم را درمود انسمان هطالعه كنيم بى لهينمب خثدين سلمو ل

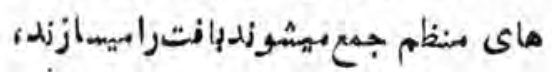

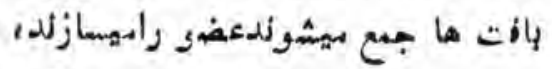
عضووها يكى دستكاه زابيسازند دستكاء ها ضمه كم از هلق، ازكلون، ازمعده. و'ز روده تشفكيل شيده اهت .

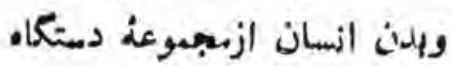
ماى هنظم ماخته ثيده المت . تواى الشرىى همل خما صيت يكى

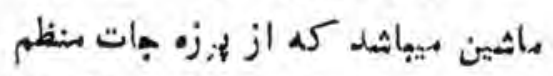
تشكيلثشدهازله وكار هنظم وممآهئى

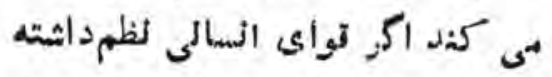
لاشهد ومنظم شودد لبعد از منظم شهدن

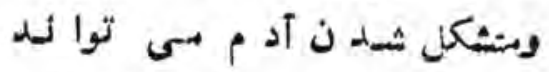

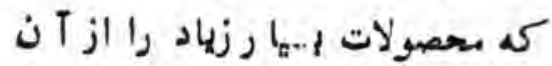
لدست بياورد ـ مثملك يكى ازوبهوه

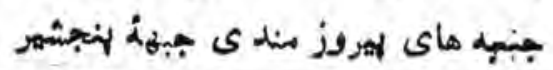

ومجموعن از لمرزه هات ــازمان يافته تتشكل امعت . هنان اين هرزه جات

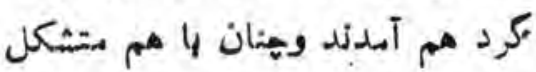

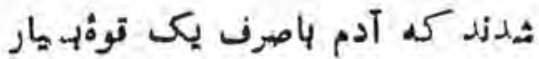
كم يكىوزن بسهار بزرك رابىتواند

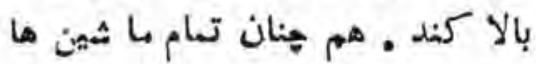
همين خاصيت را دارئد هون مجموعد

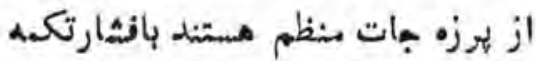
آدم بىتواندكار بسيار بزركرا انجام

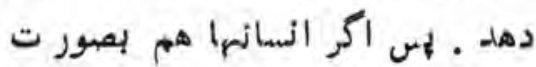

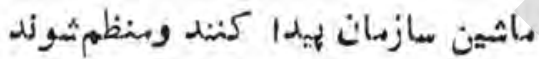
با صرف يكى قواي كم بمتواند كار

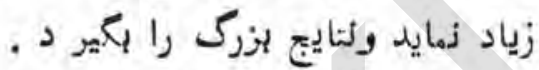
خدا وزند متعال عالم خلق وكائنا ت را إه شيكل يمى دمنكاه ــنظم سا خته

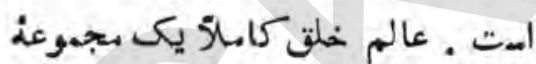
هنظم است. اتوم كم يكى ذُره است

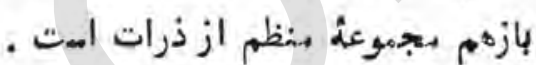

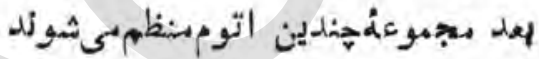

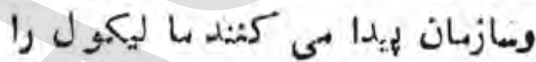

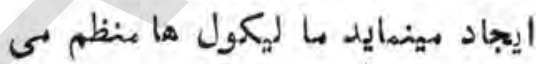

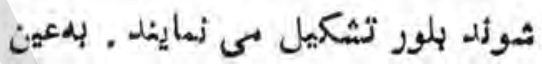
ثكل هيدينئسياره وقمرو ستاره بإدورهم جمع بى شوند لظظام شهم را تشيكيل

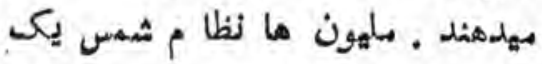
كهمثشان رابيسازند ازمبهوعن ميهون ومليارد ها كوكيثان كايثات سا خته شده امت. لمسمداوند كائغات وغالم خلقرا هانهائت نظممآريده استوتصام

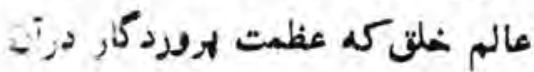

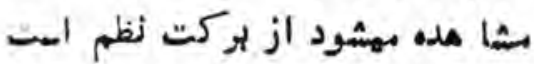

و روبى ها وابرانى ها الهزا طو ر ى

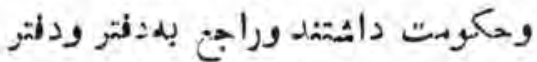
دازى تجربه داشتيد . دززهان هضرت

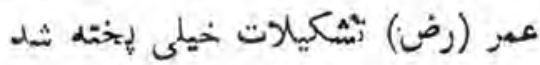
ووسعتيانتجندين دفتر وديوان مديد

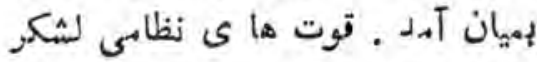
تا آنوتت ليود +وسلهانها بى جنكيدلند.

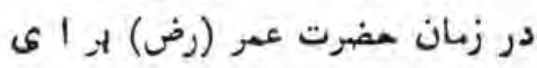
اولين بار زتووماى بسملح تشكيلثمد.

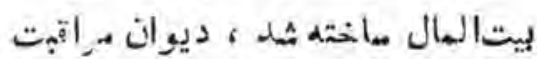
بهان آهد , ديوانى كه امربهـeروف ونهى ازمهنكر بى كثيد وبهارزة| جتهاعى

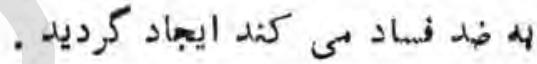

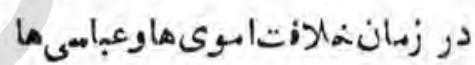

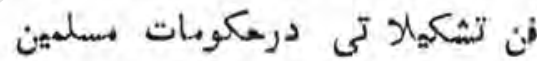

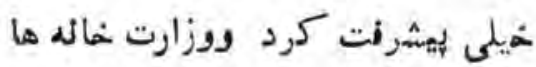

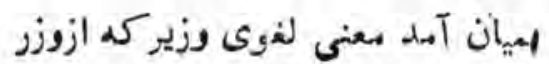

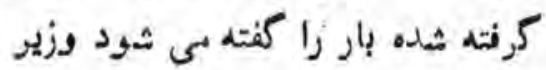
كسيكه يـى قسمت مسؤليتوركاريكى دولت را إدوش بمى كيرد و زير كفته ثى شيود' . وزارت ماى مختيلفتتنميد. وزارت تفويض و ديوا ن رد مظا لم

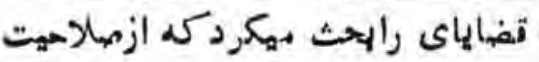
أيمبلة تاضى بالاود . مشلكً يكى وزيو جربى ميكرد كه درين مورت توسط ديوان سطاله مروسى ثميكرديد .

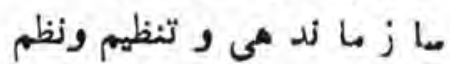
بخشيدن خهلئهم اهت. اكريجموعن از انسانها منظم شوزند باصرفلمهروى كم كار السيار الزرك انجام مىكيرد.

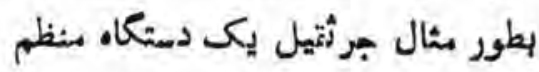




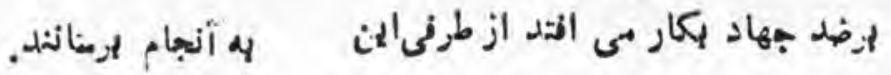

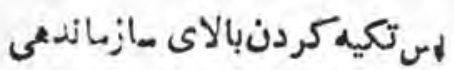

وتشكيمات بهاين معنى نيست كم مصه

كار را سازمان بكند و از آن طر يق بقدي

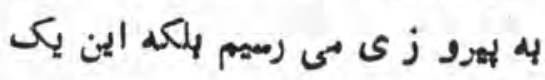

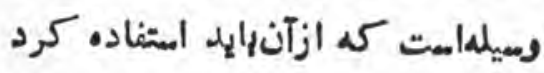
هلهروزىازجالب الهودركار استوهيون

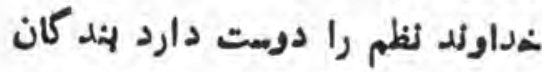
او لهز كار منظم باليد لتمايفلد .

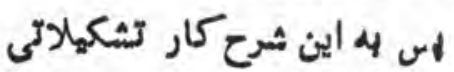

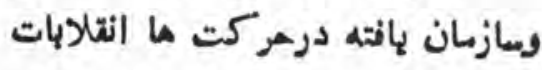
اهلاسى لهائتهم وارزلده اهت

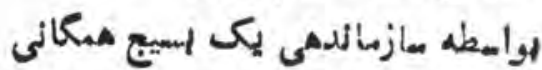

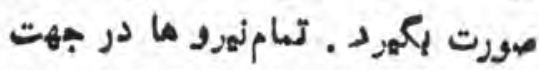
اعلاى كليهنهدا ولقوية اهمام بدكار

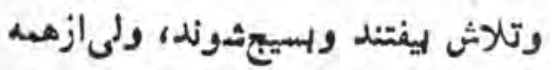

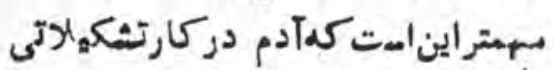

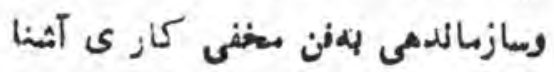

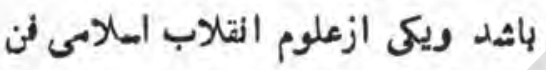

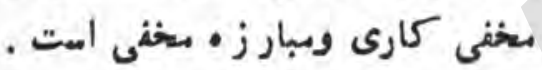

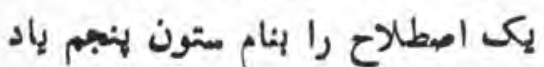
هى كبند كمسهوانيا كه دريكى ازجنى مانى جبالى لود تومائدانى ثهارجبهنه

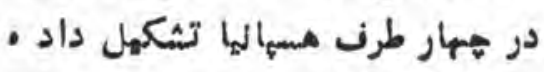
بود وتى ازآن قوماكدان سوال كرد دئد

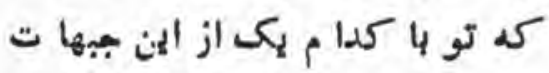

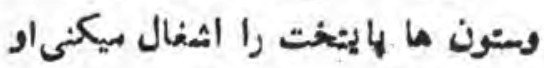

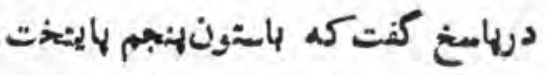

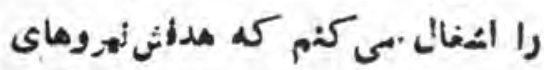

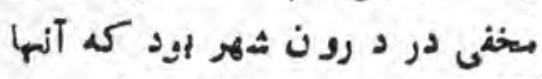

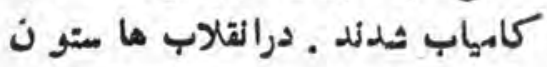

را نيزبايد درلظر كرفت كمه مازماندهى وتشكيلات همه كار را دوا نمى كند. تشكيلات يكى شرط امت ويكى وسيله

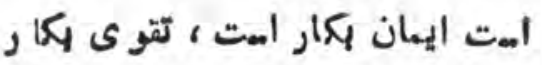

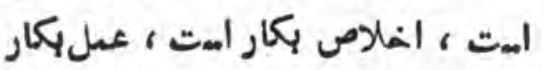
اهت ، رهبرى درمت بكار اهت ايثار ايثار

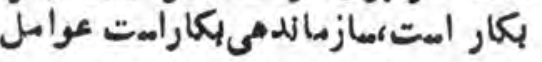
زيادى هستندكه درايهروزى لتش عهده

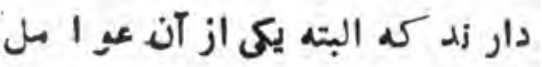

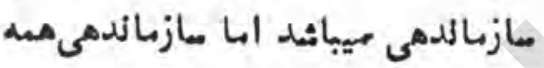

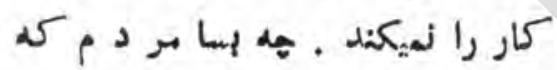
از مازمازدهى بسيار دتيق ير خوردار

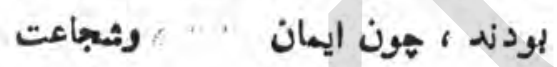

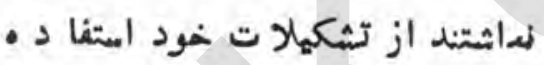
كرده نئوانستيد . مثل مجاهدين خلتق ايران كم يكى ماز ما ن خيلى مغلنى

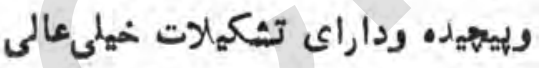

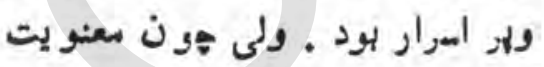

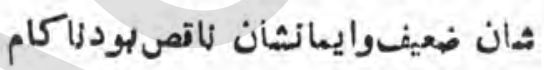

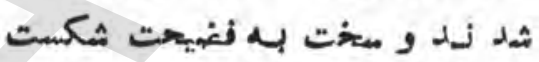
خوردند ويأسازمان آزاديبخشر فلسطين كمساز ما ن نها يدت دد قيمق الهت ولى هون فاقد ايهان ومعنويت همستيد يليش از نهم قرن الهت كمه تلا ش

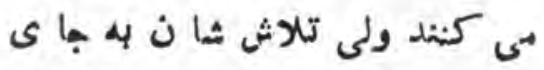

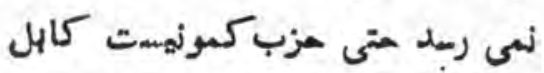
وتشكيالاتى برخوردار مست ولى تهون

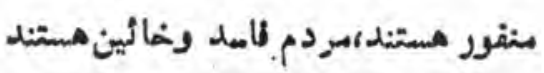
الثلوانستند از تشكهاتات شنظم كارىرا

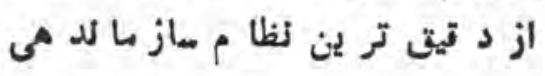

اين بودهم درآلجاكار ينظموسازمان

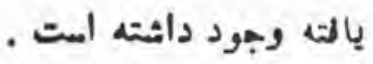
ركار تثكهالتى ونده است. يعنى

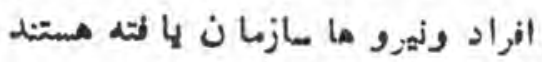

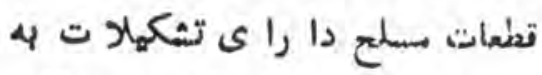

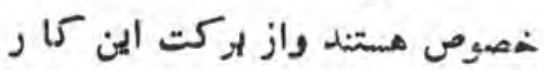
منظم ومازمان يانته وتثكيلاتمنظم

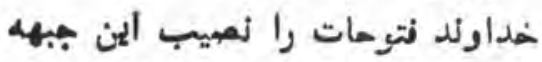

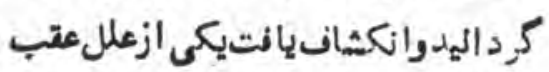
هائده كى المزاب املاهى ما وشها درو

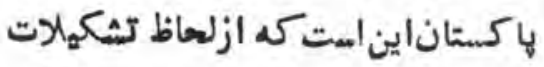

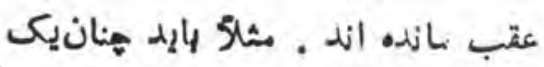
سازمان ايجاد شود وجئان تثكيلات ساخته شمود كدتمام نيروماى مسيدلمان موجود درامفازستانوخارج الفغانستان

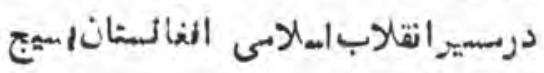

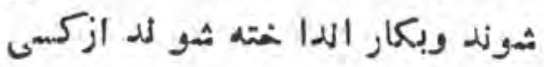

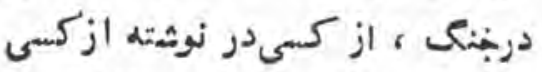

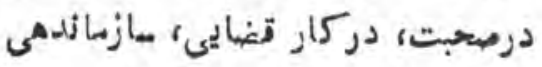

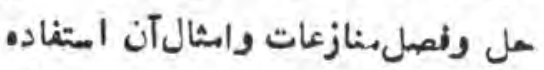
ثود ــاس اكرزيروهاى الهانىدرست

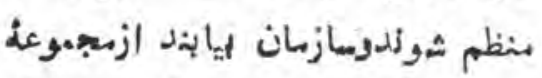
فعالهت آنها يكى كار يرثمر و ازورى

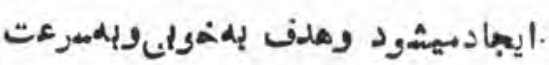

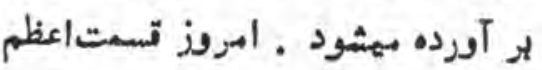

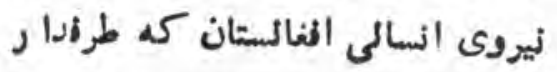
وو فادار به انتلا ب املا بى مستشند

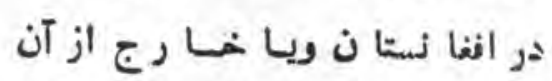
درياكستان يا در الئان يطور عاطل

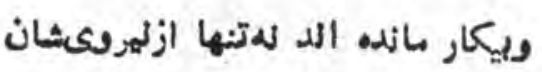
استفاده نمىثود كاهى اوقاتئيروى ماندان 
هاسل امتاسلكاسى ميانشيندرلى آكثريت

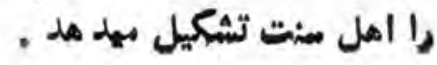

مضرت مولالا ماهب مهكويد

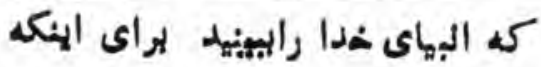

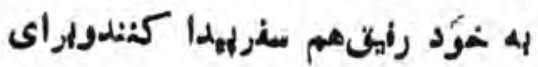

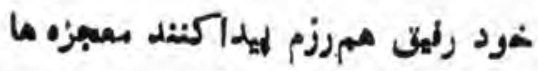

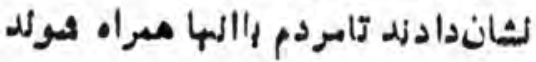

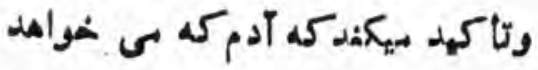

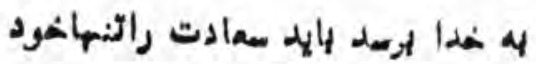

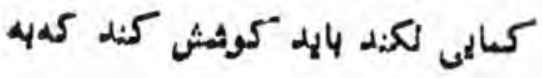

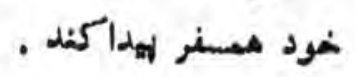



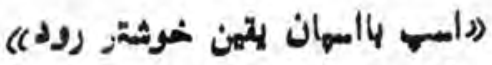

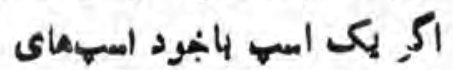

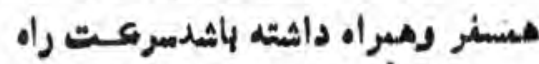

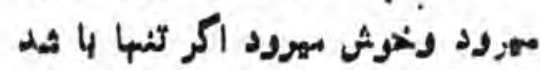

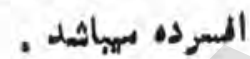
والسلام عليكم ورهمة|آه داركاله

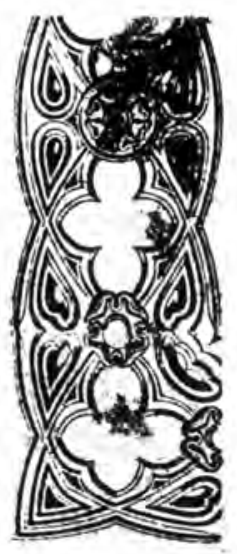

كغد به أن ميخفى كار ى لبد. لبوده.

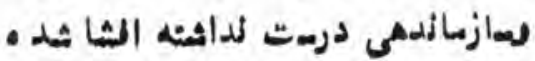

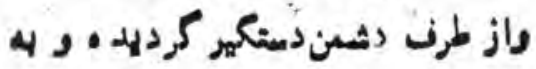
جوته ماى اعدام مهرده ثديلد .

مأحتن لكى مزب سياسىومنظم

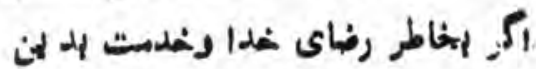

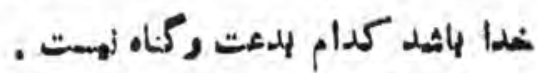

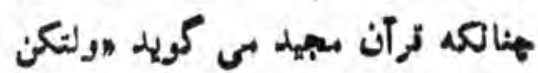
هنكم اية يدعون الى الخهرولياسرون

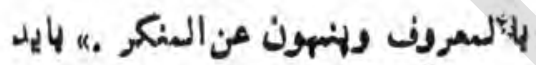

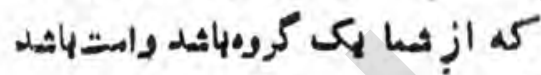

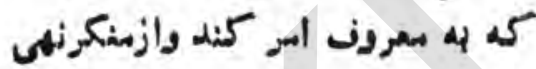

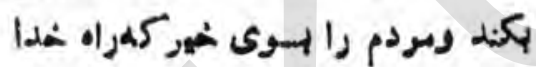

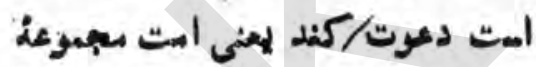

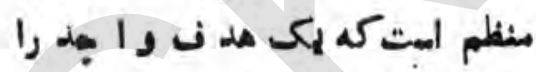

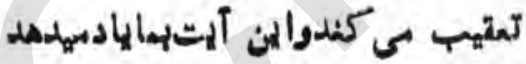

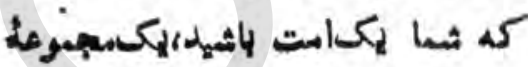

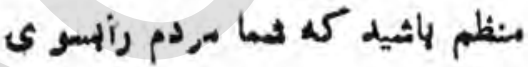
خهر دعوت كنهدوإمجورت دسنهبنمى امر به بعروث كميد ور لهى از منكر

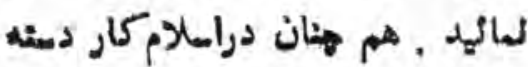

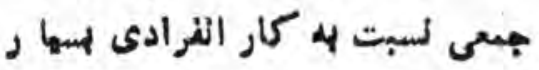

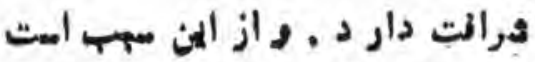

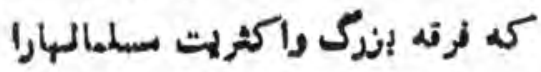

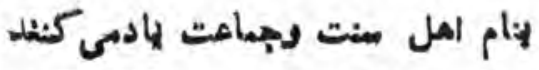
هنالهه مولانا ماحب بس كويد كم:

ه راه سنت لامباهت خوب بود.ه)

راه ما دئها راه أكثر يت أبت

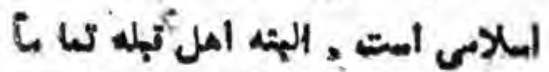

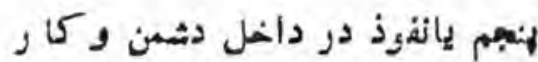

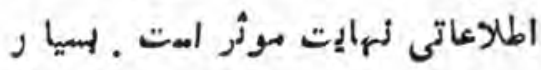

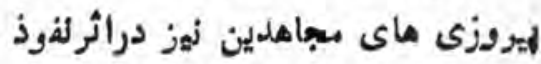

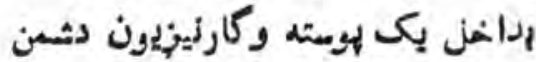

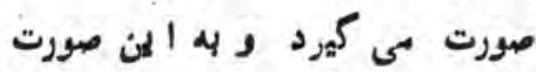

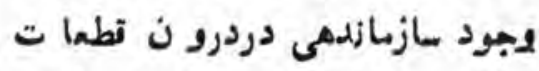
وانومتهماى دشمن كار رآسان بى كنيد

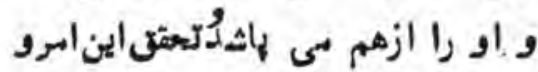

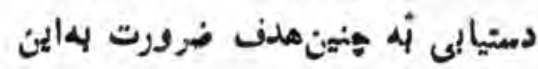

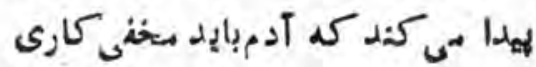

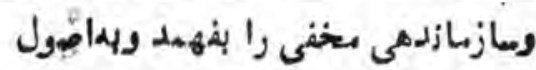

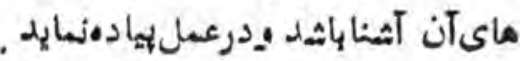

در بنفى كارى ارتباط سهدود كى 4 شد ـ الراد يكمديكز خود راكم بنم

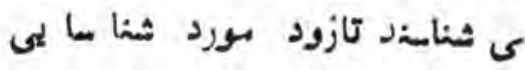
دثمن وليوليس ترار ثليرند و ائن را

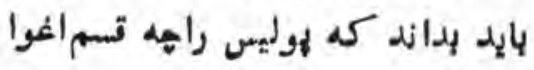
ككند وفريب دهذ.

وتلى مر كات مسلمائة اسلامى در الفالستان شروبعدئهاربير ادران

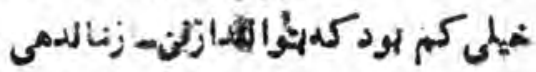
بخغياله ومبخفى كاريى اسنغاده كنيند.

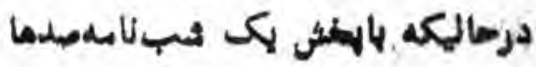

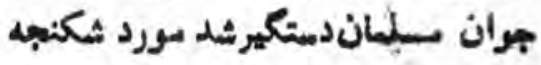
واذهت ترار كرأثئ وبشثهادترسيدند.

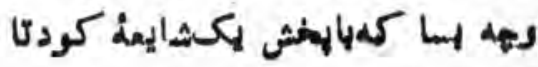

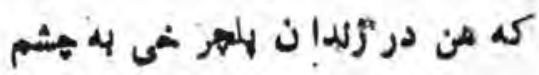

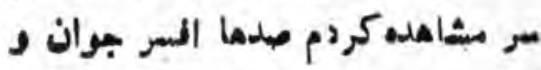

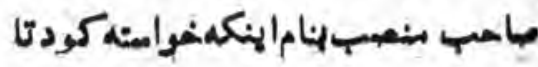




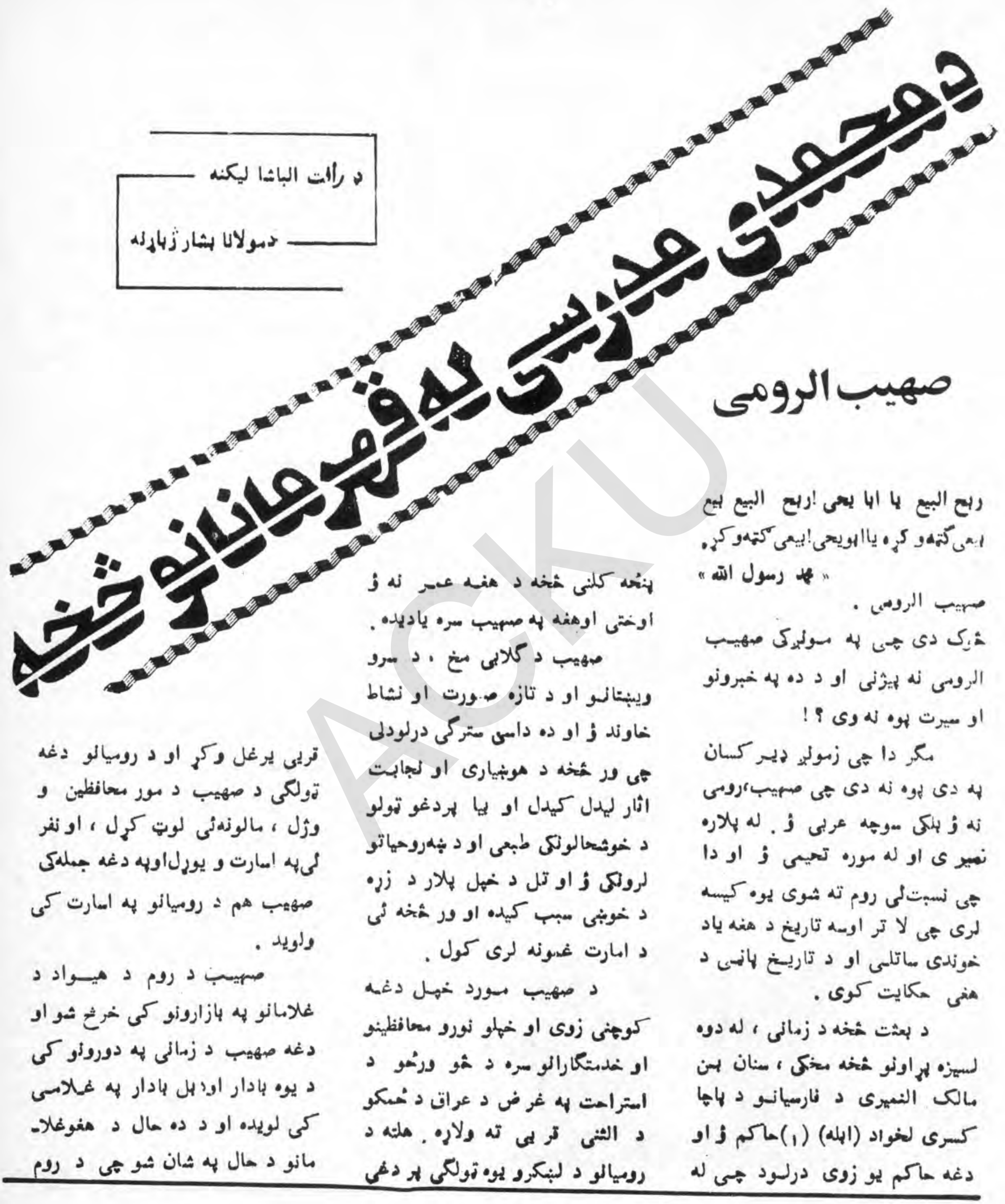




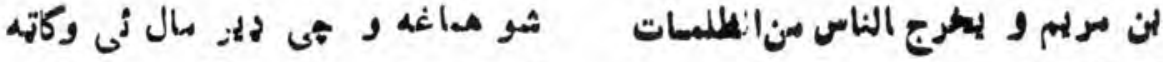

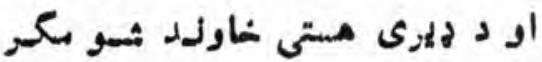

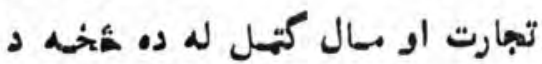

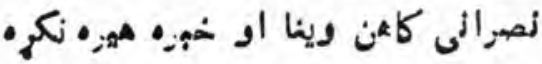

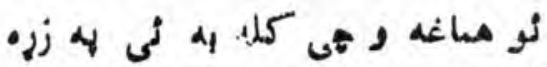

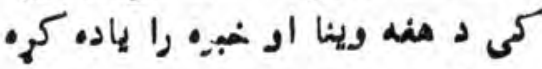

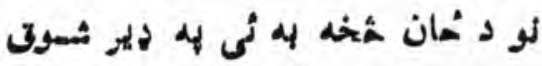

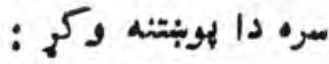

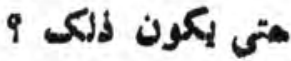

هغه به كلمه وى ؟

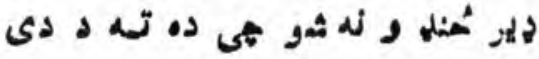

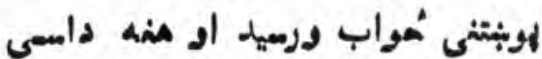
:

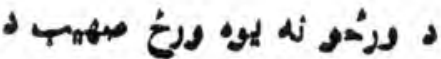

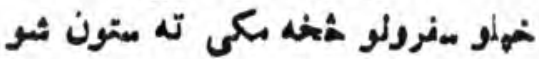

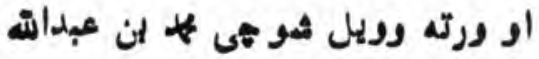

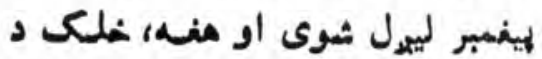

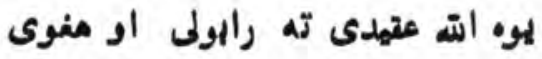
هدل او اهسان تمثثوى او دلهثاو

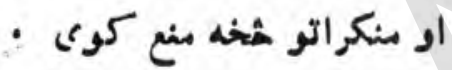

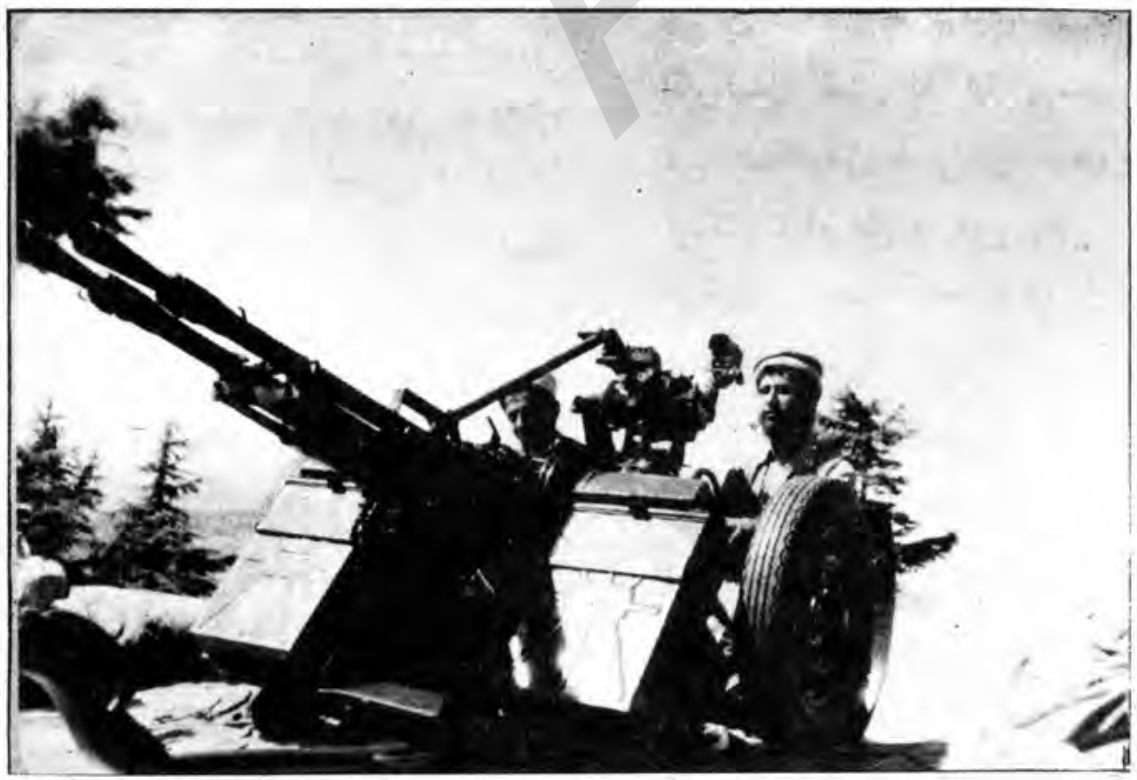

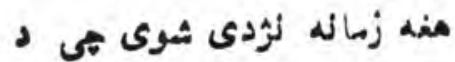

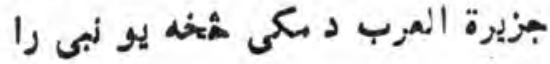

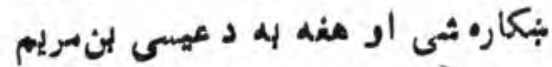
تهديق كوى ، او ملكى به له تيارو

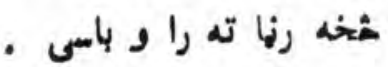
هي د خهلو بادارانو د هلابى مُخهم

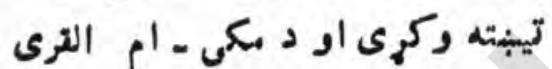

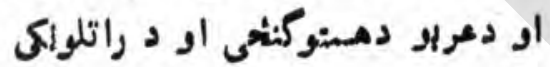

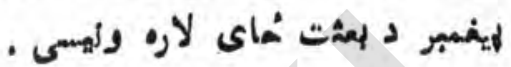
كله هي مهيب عربى ميوادته

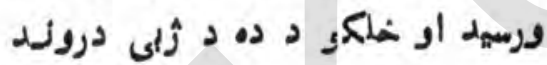

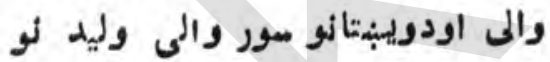
له مبهيب الروبى سره لمى و نوموه .

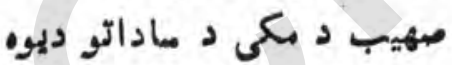

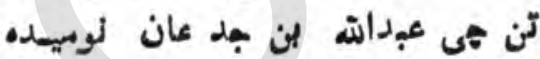

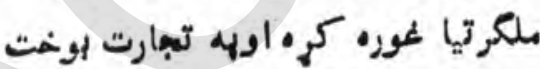

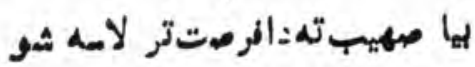

دميواد تصرونه ور ثيخه ذك وو .

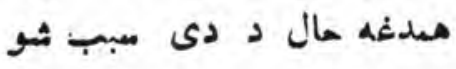

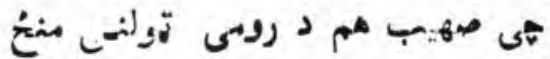

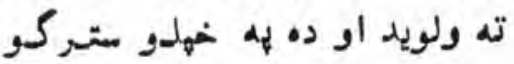
د روبى تصرونو د نارواو او نحشيشاو

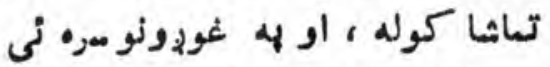
د دظالمو او مفاسدو آوازونه ، وريدل

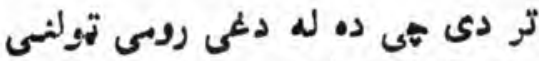

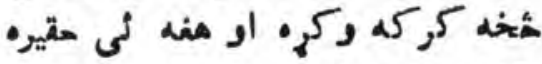

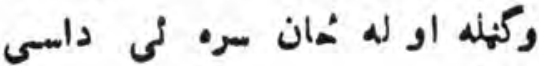
وويل : " ان ميجتمأ كهذا الايطهره الالالطولهانه

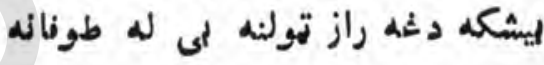

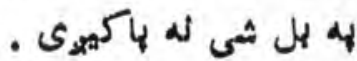

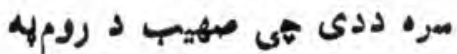

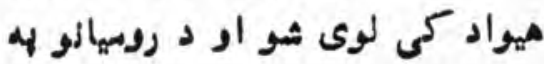

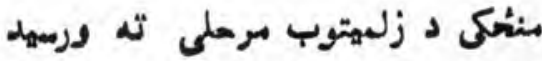

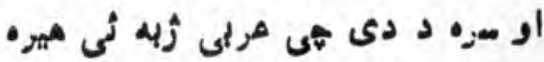

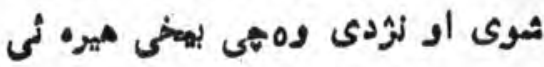

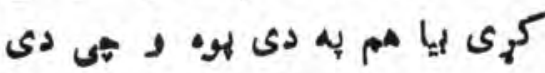

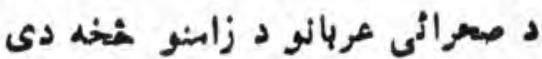

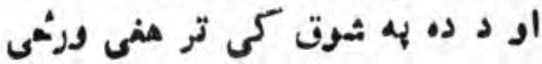

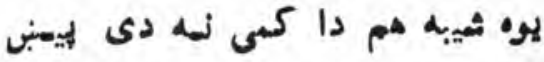

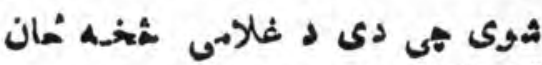

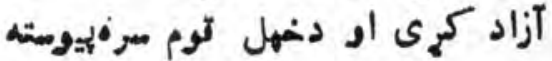
او يو 'ماى شى . ليا د ده ثوق مر له هيواد ته

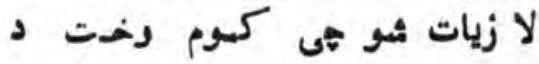

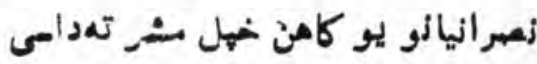
وويل. - و

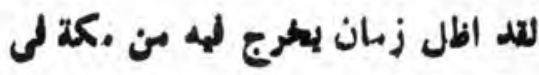

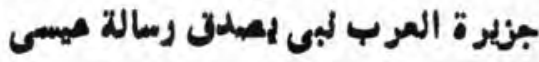


دده دهجزتمانعوكرخمدل او ورباندى

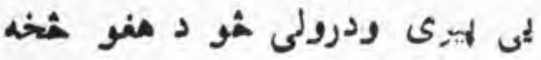
تيبته ونمكرى اودئمان سره دوتجارت

$$
\text { سمبن او مره يولسيى • ونه اودمات }
$$

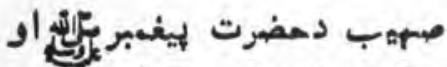

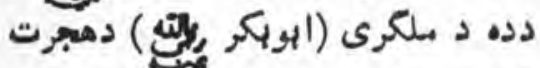

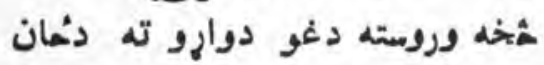
رمولو دفرصت ميندلو له فكر اوهثمه

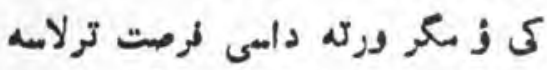

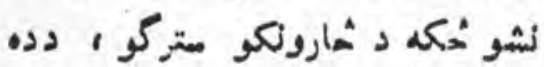

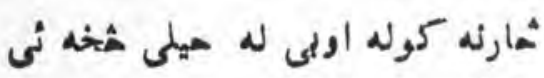

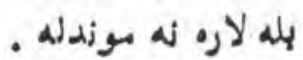

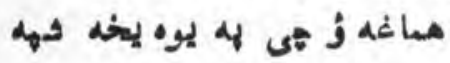

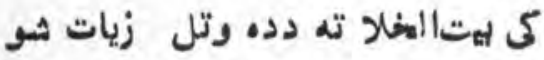

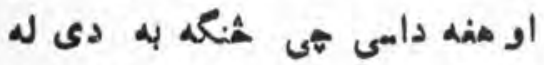

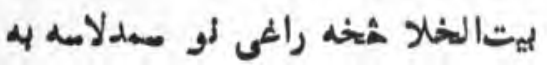

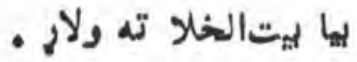

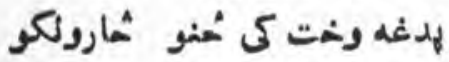

وפيل :

خوبن اوسى هى لات او مزى

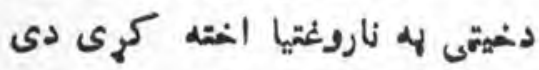

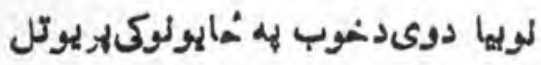

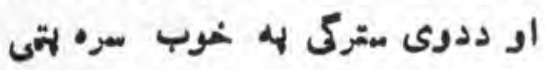

معاغهز صنهيب ددوى لمسنئمه

$$
\text { ووت او دمدينى لاره نى وليوله . }
$$

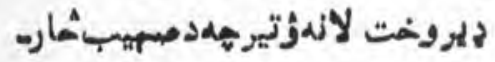

ومكودمبهيه وتلوته متوجه شولاوله

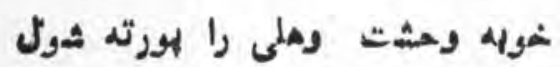

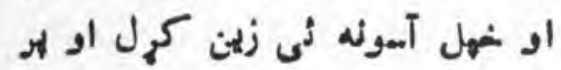

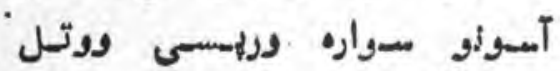
او د كيرولو به مثهد كى ني ثمول .
سز• ددوارو به سيغوكى دايطان رنا

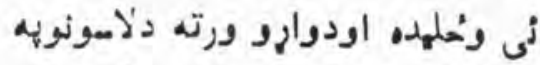

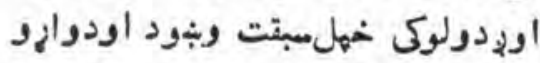

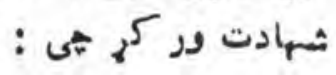

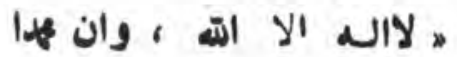

$$
\text { "مبده ورمسوله " ماله }
$$

لهيا دواره توله ورنُ د الهى

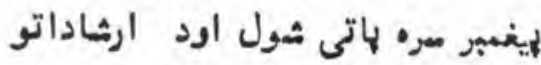

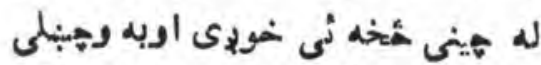

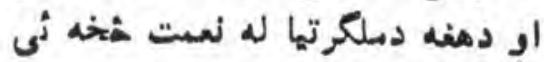

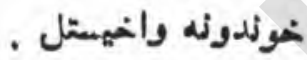
كله ثي شهه شموها او هره خموا

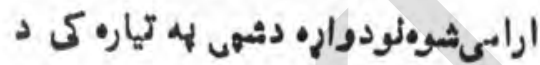

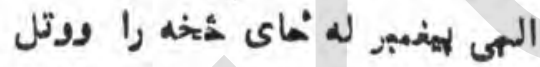

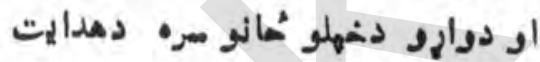

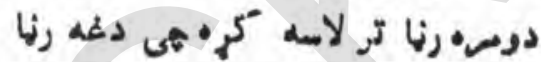
دتولىدليادرونهائها دهاره لبمتهاكوله.

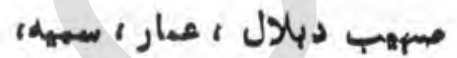

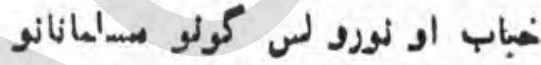

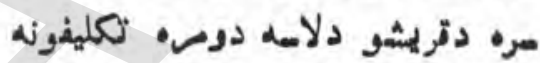

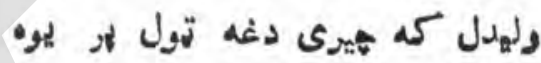
غرهبائدى نازل شوى واى نو غر

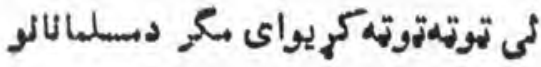

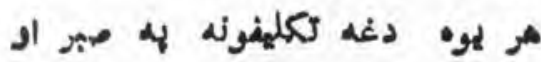

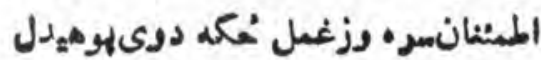

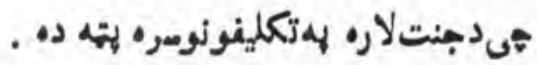
كله بهى رمول اله (ص) خهلو

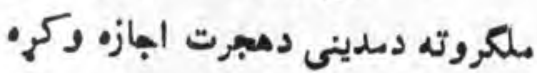

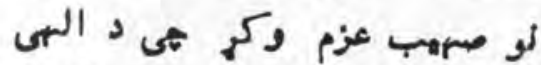

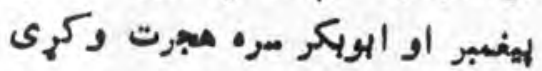

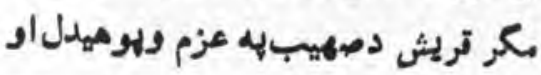

لو ولي ويل : ايا مساغهثهضص

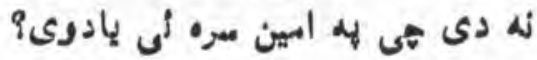
ورته وويل شو : بلى ، مقاثه دى.

نووى ويل دهنه ئمائميرته دى 9 درته وديل/ثـو : د صفا تر

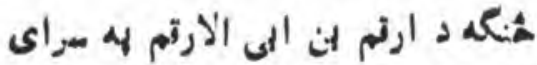

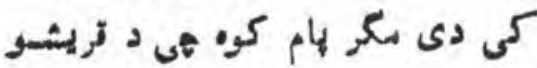

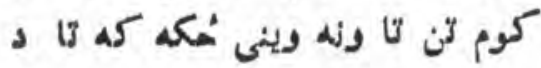
ترايشو كوم تن ودائى نو تاسره به دانس

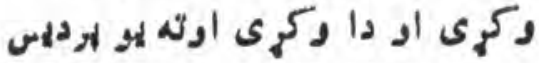

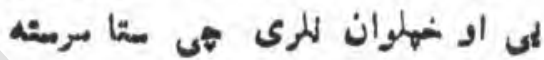
وكئ.

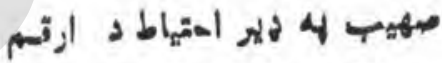

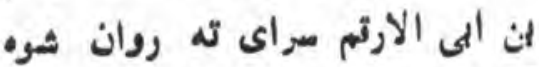

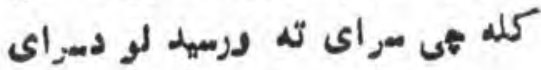

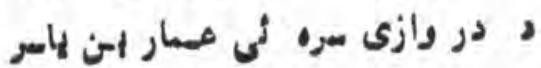

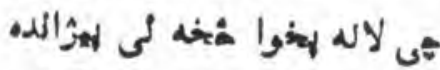

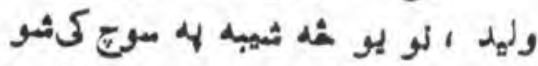

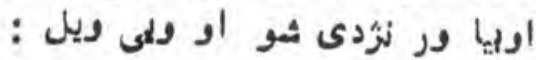

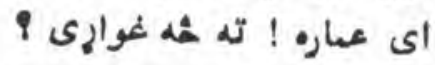

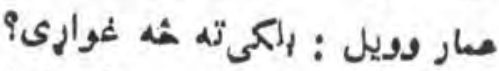

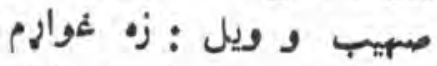

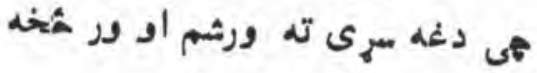

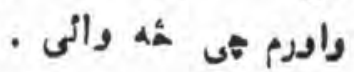
عمار وويل : زه هم معدغه نحوارم.

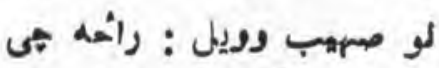

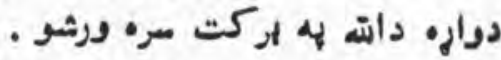

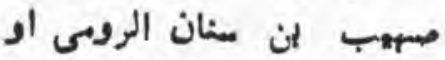
عهاربن باسر دواره رسول اله(ص) ته ورغلل اودوارودالهى يهغبمرويناواوريدلهاو دالهى|هغيبردويثا هب اوريدلو 


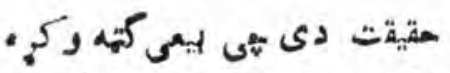

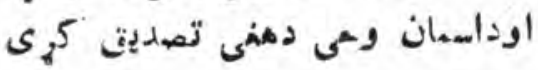

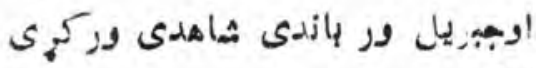

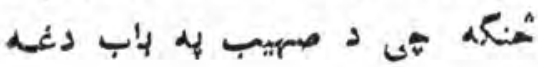

$$
\text { تول نازلا ثوى دى : }
$$

"وسنالناس من يشترى للنسه

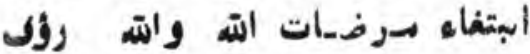

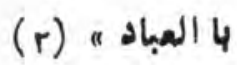

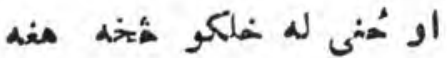

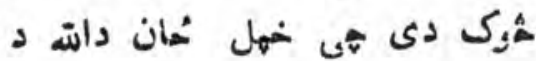

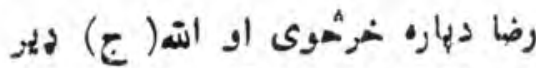

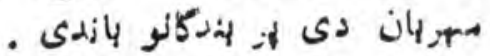
لو مهيب لهن سنسان الروسى

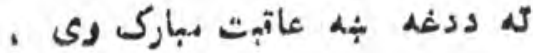

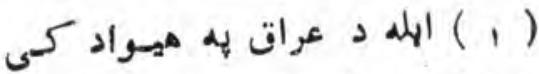

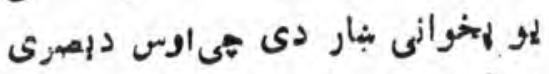
جز كزخيدلى دى .

$$
r v-\text { المبة (r) }
$$

خهلدين نى خوندى وكرخو.واود خهل

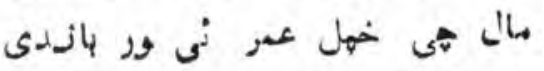

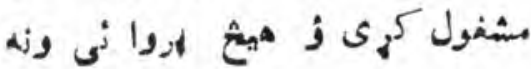
ساتله

هركله هيى به ورته سثوبالى

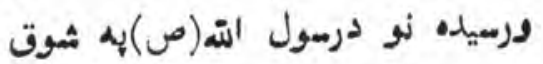
مره به دبنه نشاط او قوت شخاوند

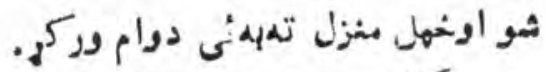

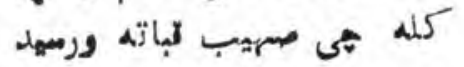
او له ده بازدي درمول اته (ص) نظار

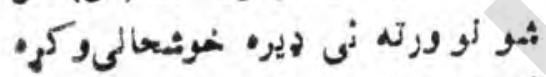
او ويى ويل :

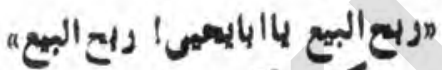

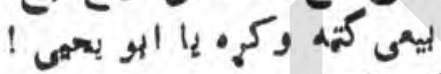

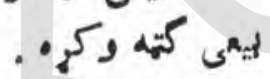

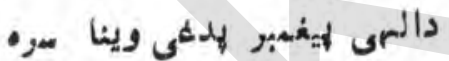

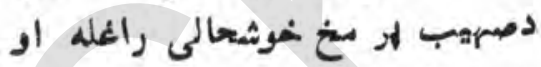
ولى ويل :

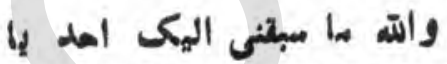

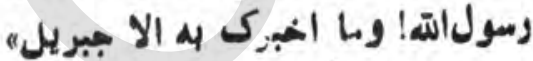

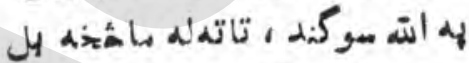

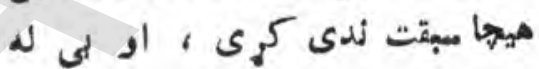

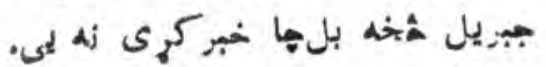

كله هه هـيمب دخهل كمر يدلو

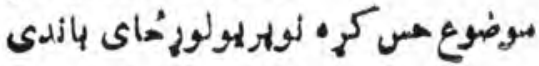

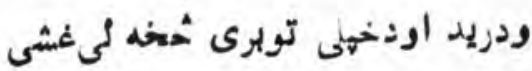
را وويستل او يو غشى نى له لينده كى كيبنود او ويى ويل :

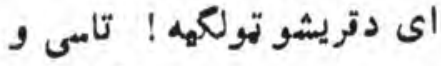

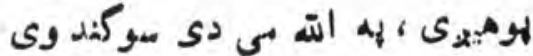

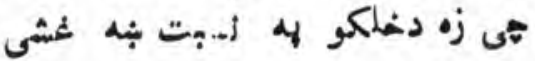

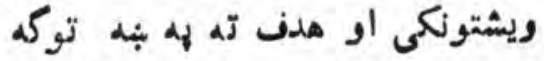

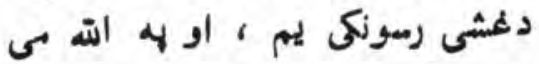

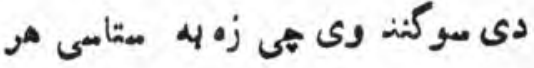

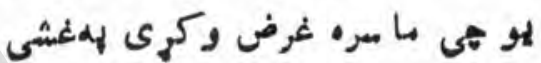

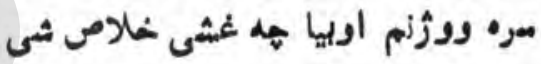

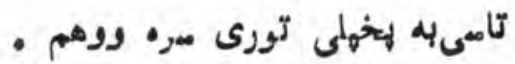

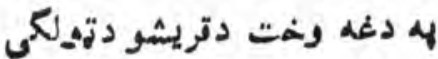

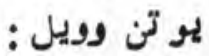
له اله دى زمونيّ سوكند وى لي

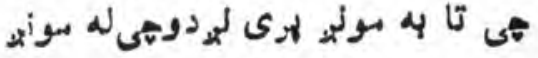

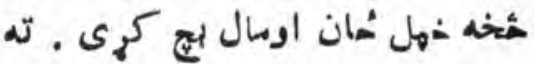

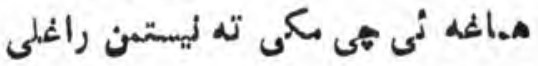

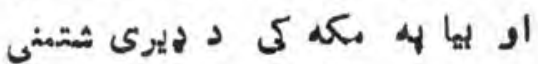

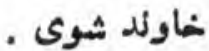

صهيب وويل : كه زه تاسى ته

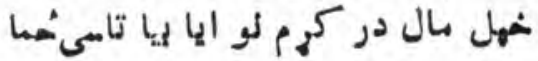
لهرينبودولكى يى هال دوى وويل : مو.

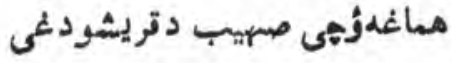
لملى تد به مكه كى دخهل بال "ماي

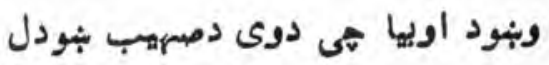

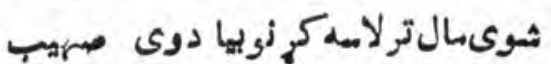
ازاد بريبنود . صبييه دمدينى لار وئيوله او 
00

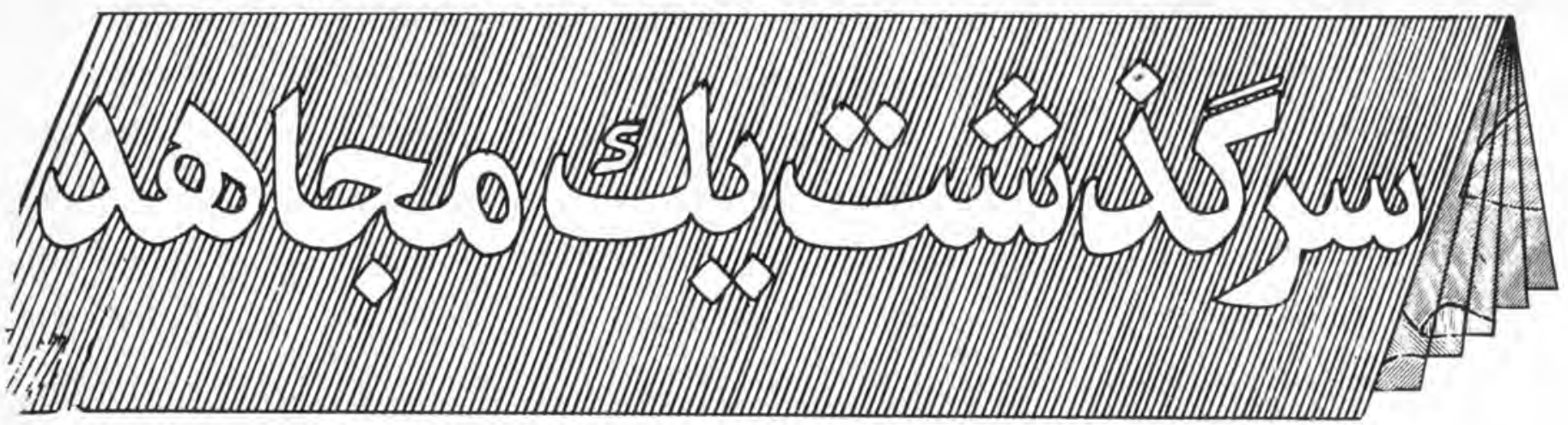

ترجم:م:ن " م. "

سامل و 4 هنزل آواز دمده ، البته

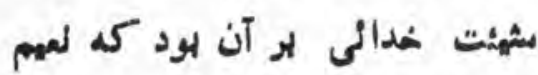
الهن كاررا انجوام دمد ، آتهزث خهلى

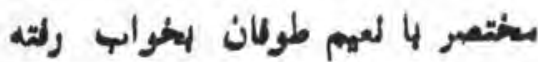
را دولاره در تله زلمئا لهدار ساخته آرزدي رهامى از لنمه الئ حادي د

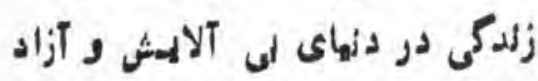

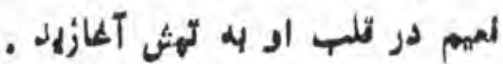

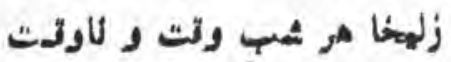

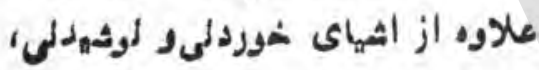

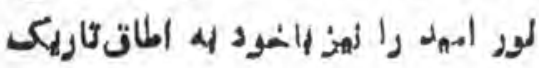

$$
\text { - SA ta }
$$

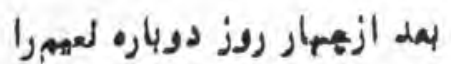

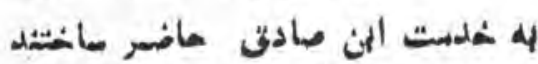

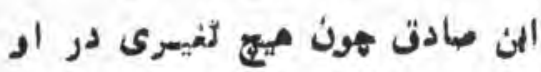
لدديد هيران كرديده كفت : تو خهيلى معتث جانهستى ، ثائه اراده خداى تو بو آن باثده كم تو زلده لهاكى اما

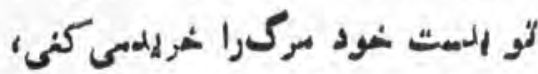

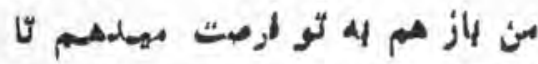

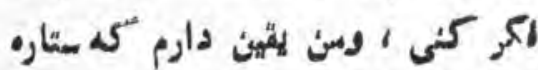

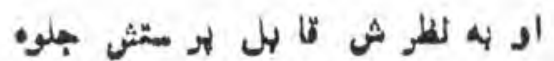
$.2,5$

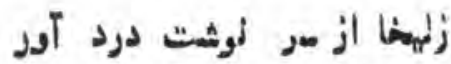

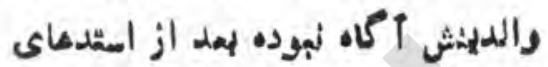
زهاد از دمال آلها ماهوب كرديده

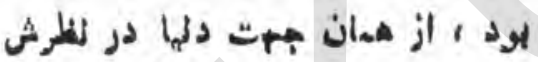

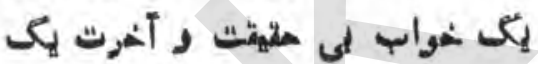

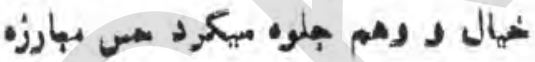

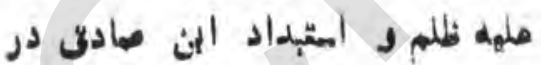

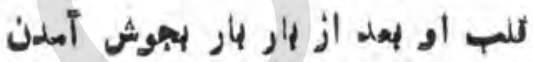

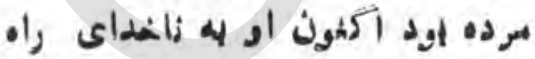

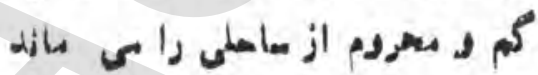
كا

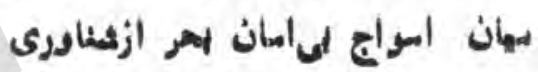

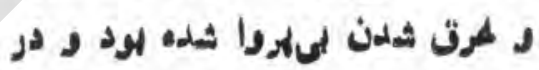

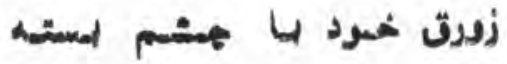
اله هر اس در مها ن اسمواج

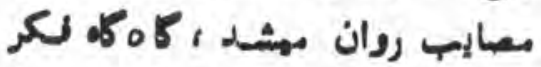

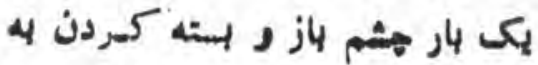
ذهذو خطور ميكرد اشا لوررأ ماهوسى

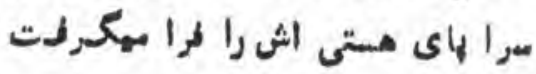

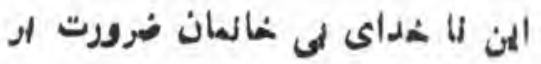

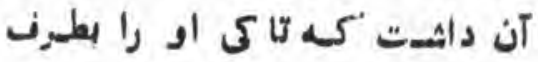

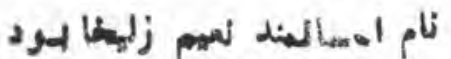
او لإهبود عهرى نهودن دالزيده هبال

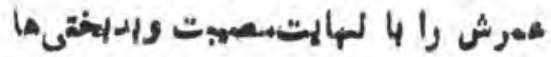

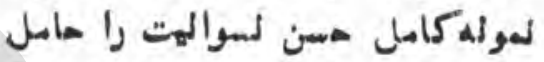
الود ، زلهما لطرتناً از هر المسانلفرت

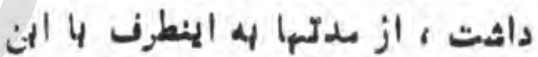

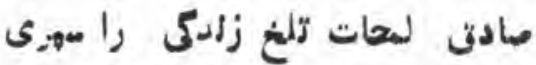

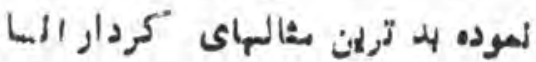

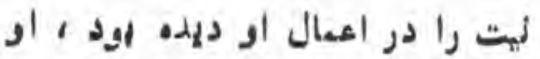

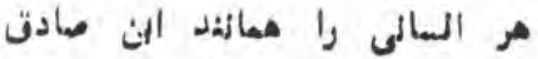

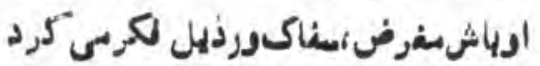

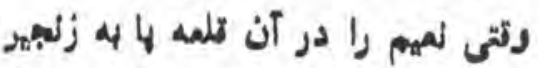

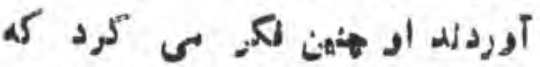

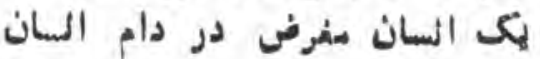

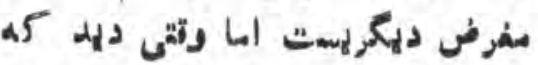

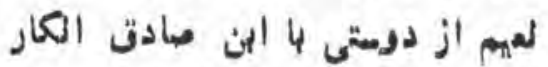

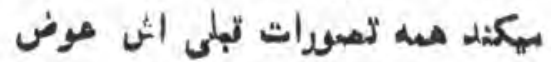

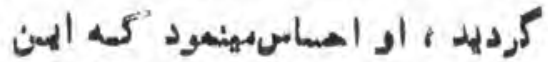

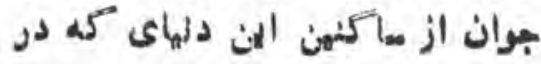

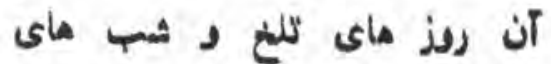

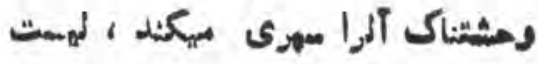

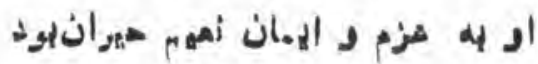

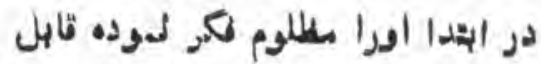

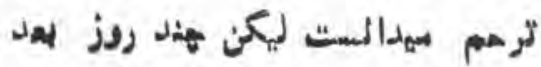




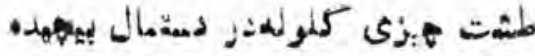

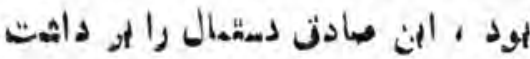

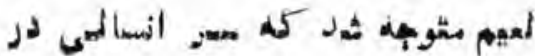
أن كذاثيته لهده ،

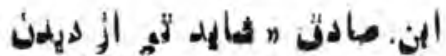

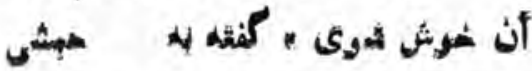

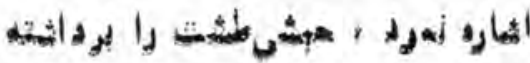

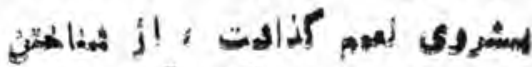

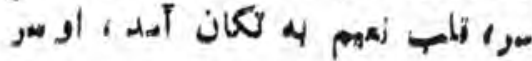

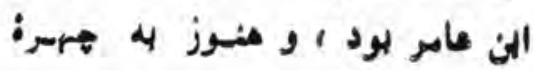

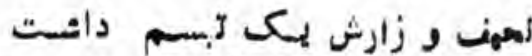

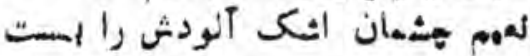
زليها كم لهثت سرالن مادت ايسيّاده. اين صعنه درد ثاك را لعاشها ميكرد

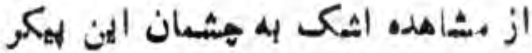

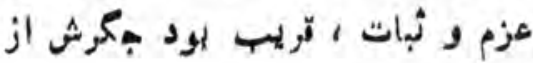

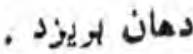

ابن مادق از مانى خود بلغيد

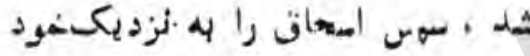

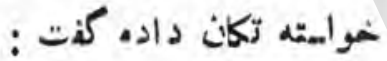

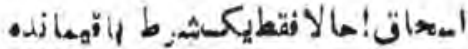

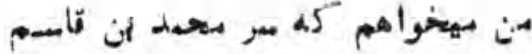

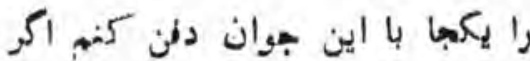

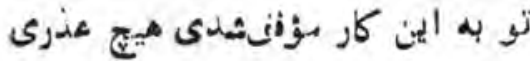

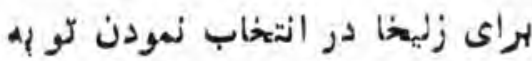

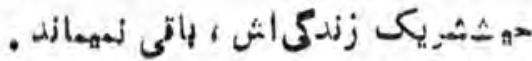
اين كثت و البن صايت روتافتنه

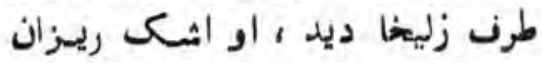

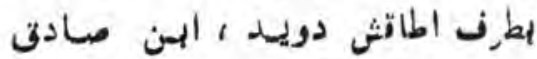

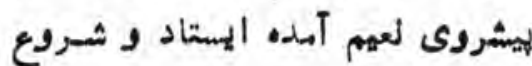

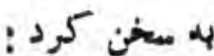

نمبم خاسوش دارد .

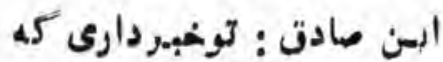

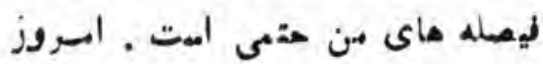
به تو مبهلت اهت تا شـام در مهيسن جا لاثى ، ازين فزمت امتفاده لموده

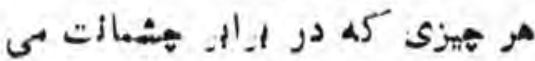

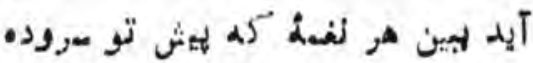

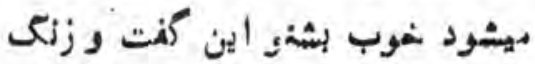

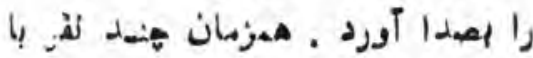

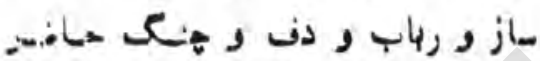

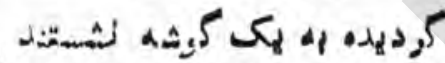
مداى لفهه آهستيه آهسته بلئلد

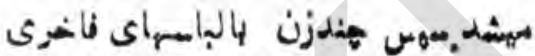

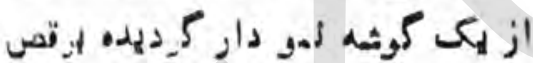

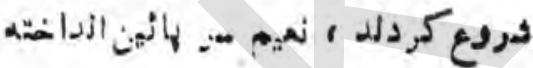

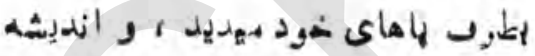

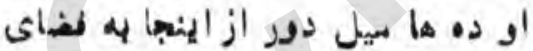

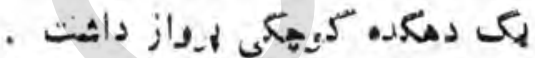
همند ساعتى از انعتاد ائمثنل

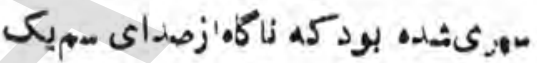

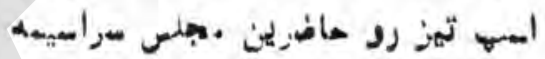

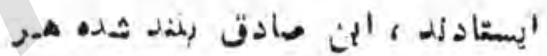

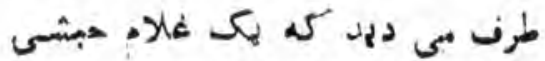

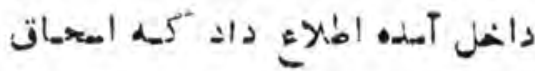
آبده .

أبن مسادت لعهبم. را خططاب

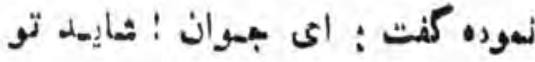

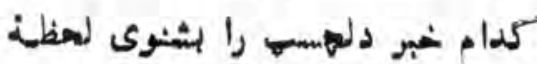

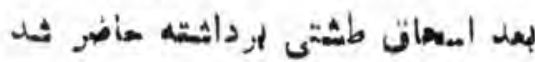

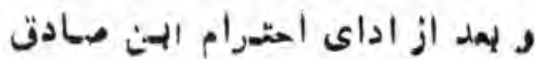

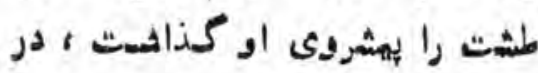

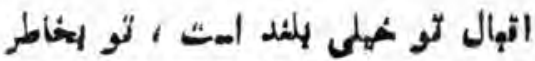

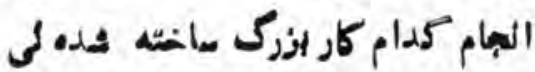

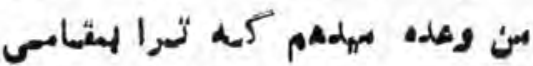

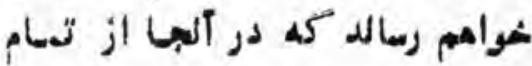

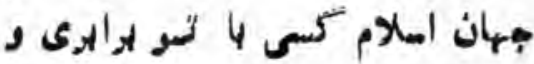

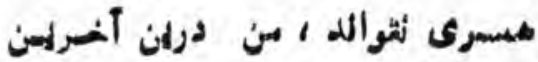

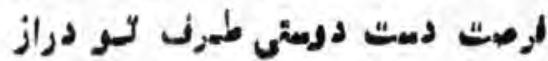

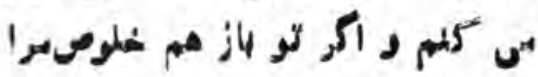

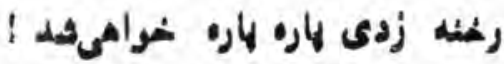

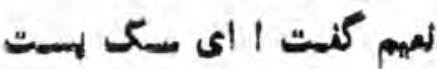

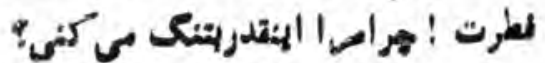

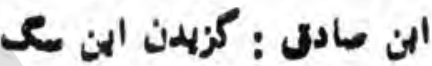

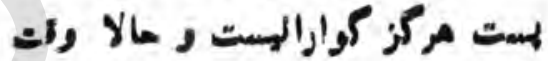

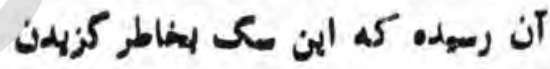
تو دمن بكثايه ، السان عالهـت

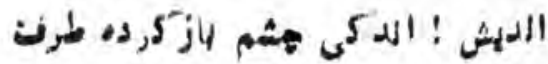

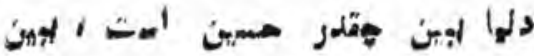

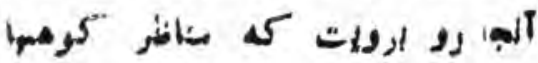

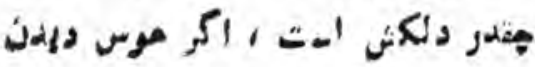

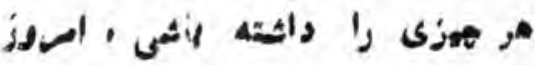

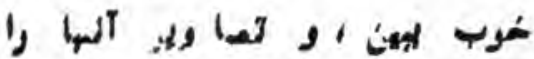

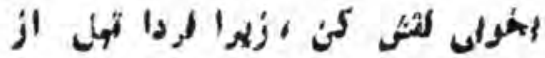

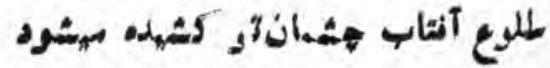

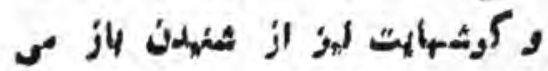

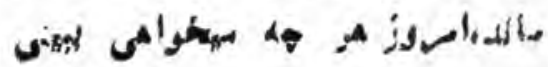

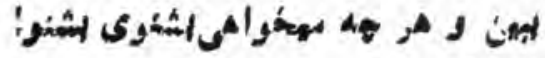

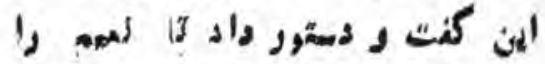

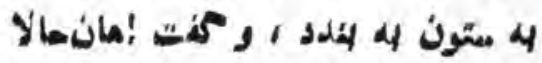

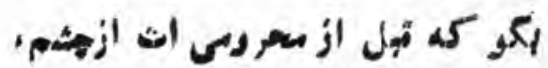

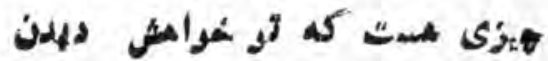

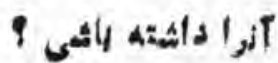




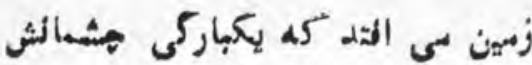

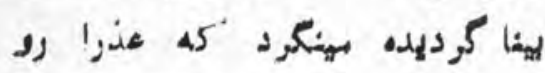

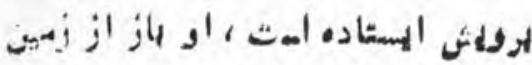

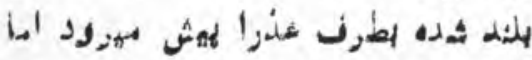

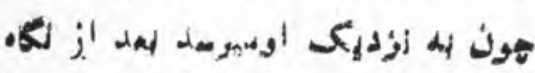

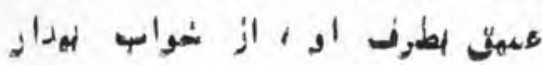

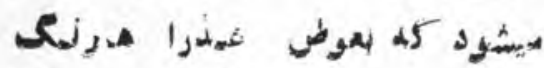
2

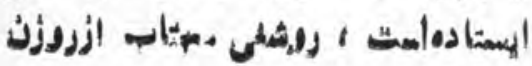

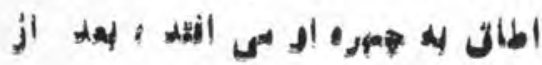

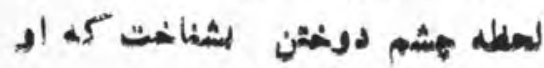
زل زلهماست

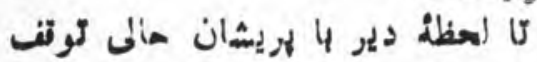

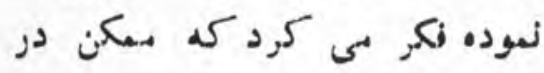

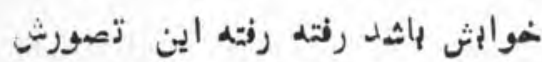

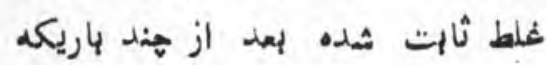

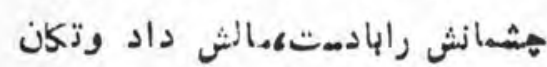

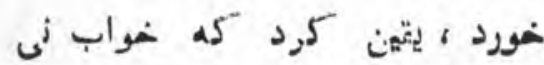

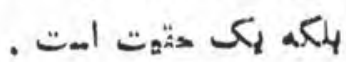

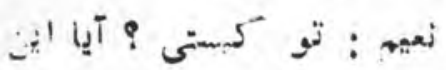

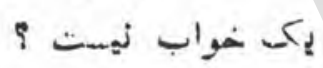

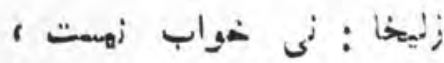

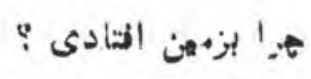

نميم : به وقت

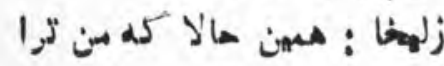

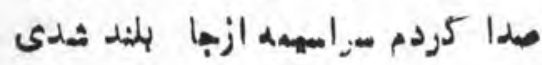

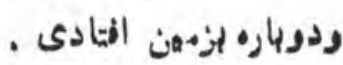

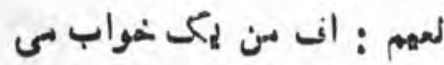
ديدم ، ديلم كم كور شهده ام وعزرا

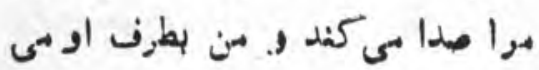

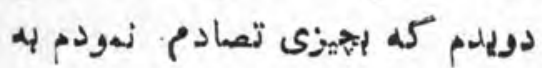

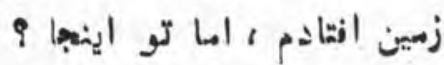

ديلد كه در هوالىمبحع او را ازاطات

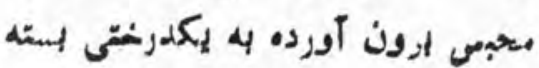

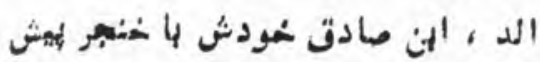

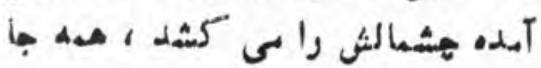

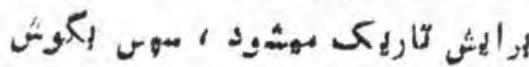

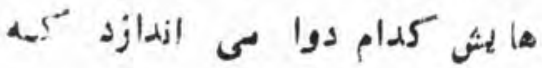

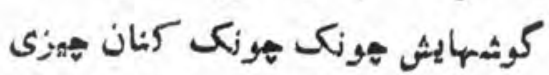

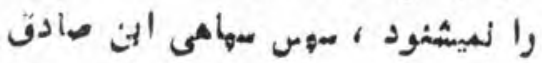

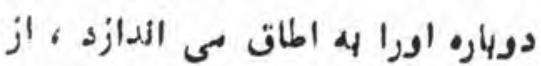

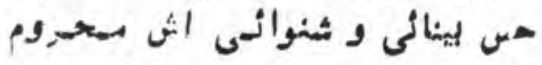

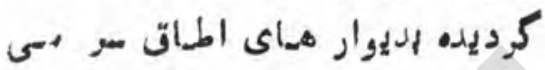

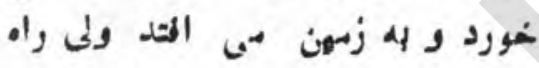

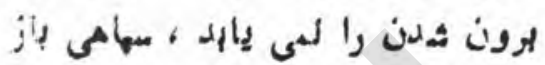

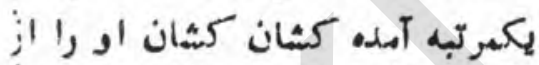

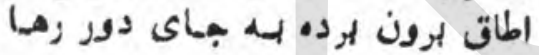

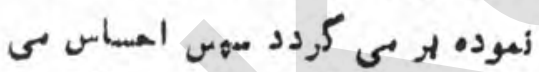

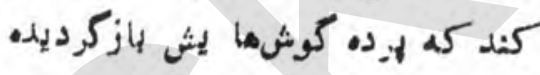

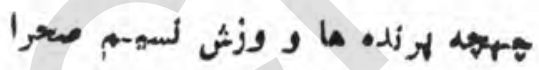

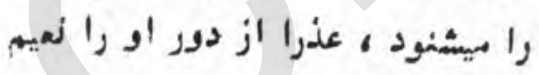

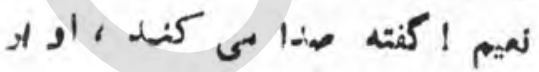

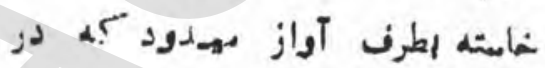

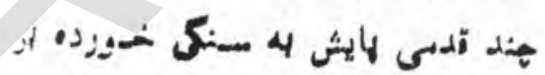

من بهدانم كه تو ابن ماسمرا

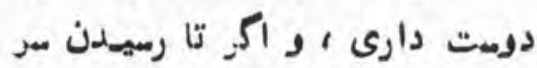

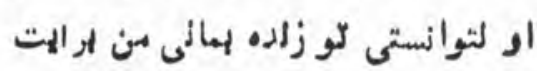

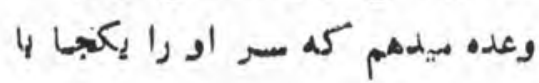

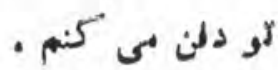

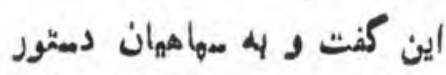

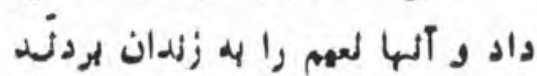

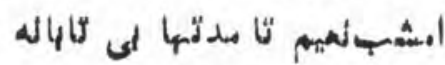

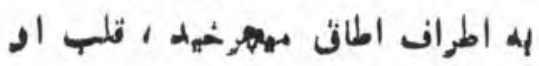

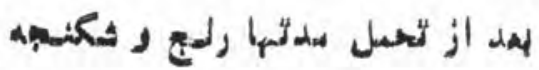

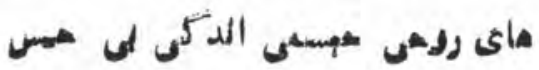

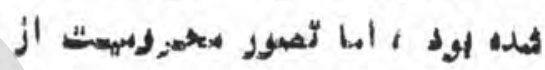

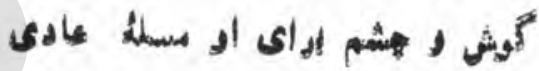

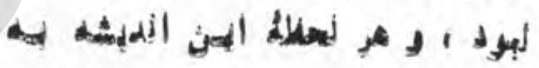

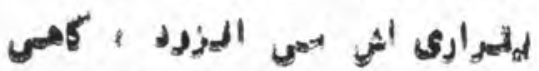

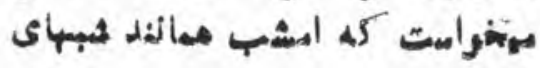

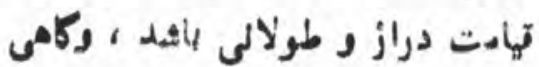

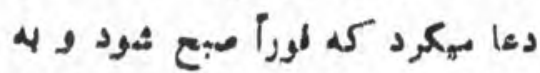

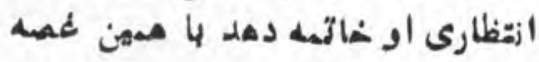

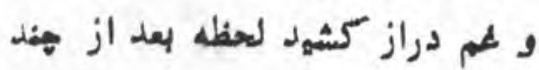

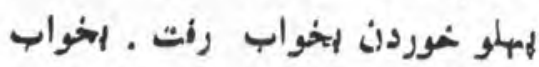

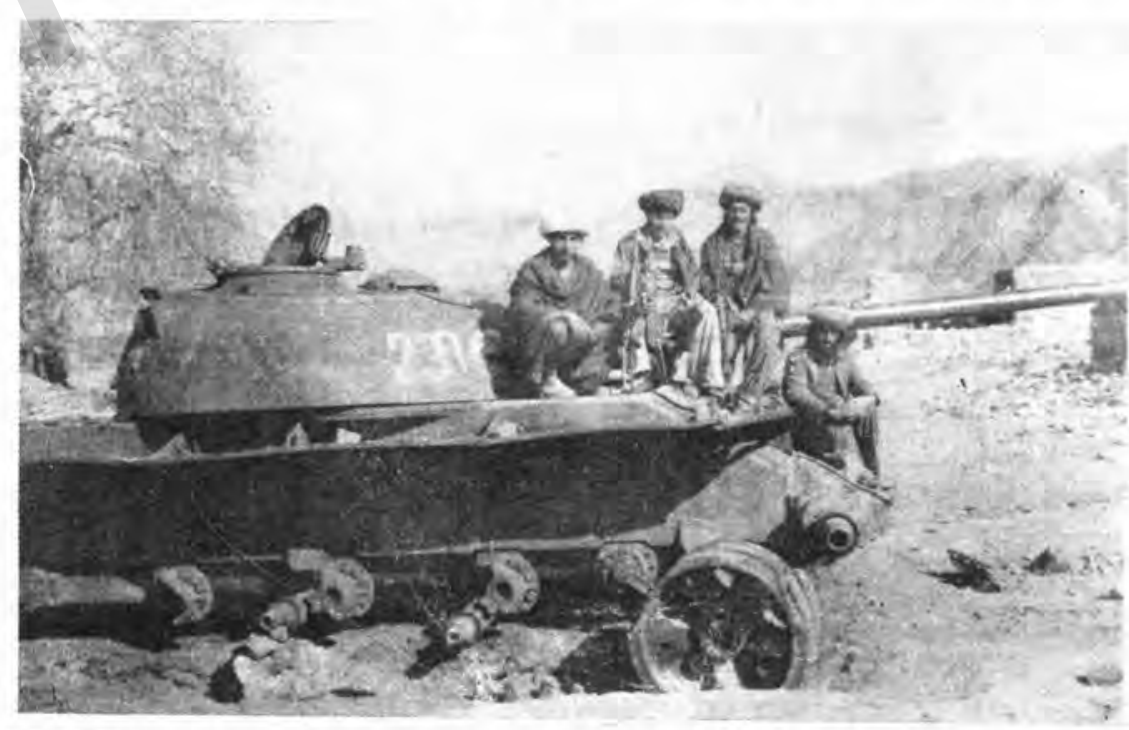


ور نزديك قلعه سهاهدديكرى

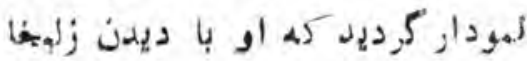

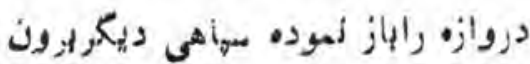

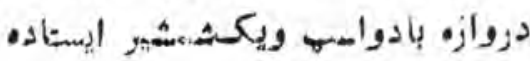

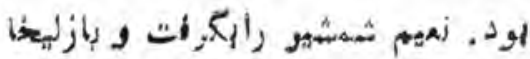

هز دو اله دو اسمب موأر شيدند ، هئد

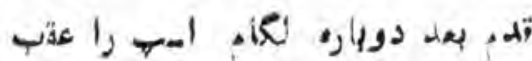

كانئ

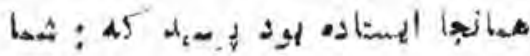

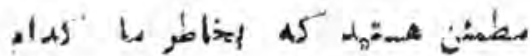

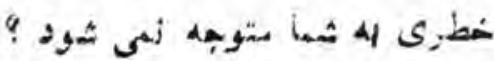

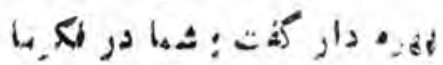

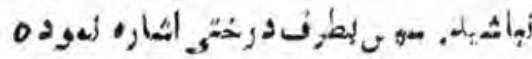

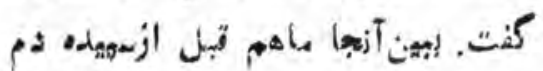

صدها ثيل از ائمجا دور خواهيم شيدة

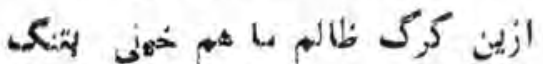

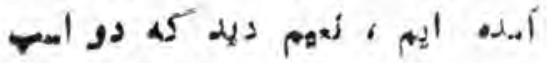

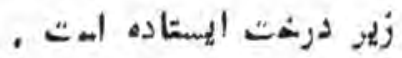

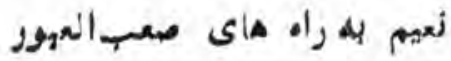

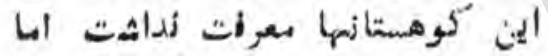

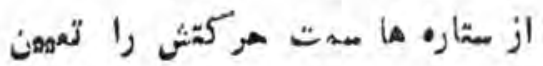

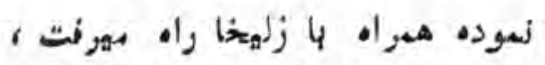

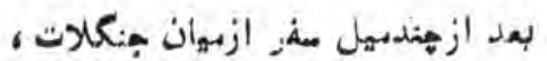

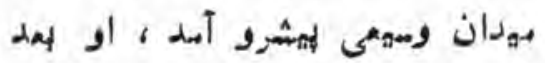

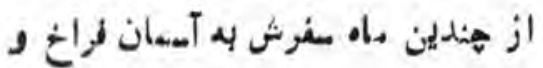

ستاركان درخشيان انتاده بود ، دوريمئ

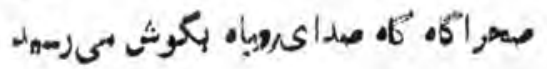

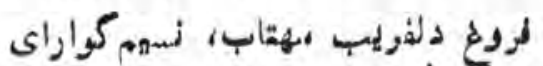

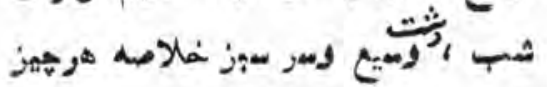

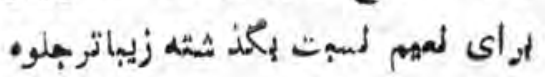

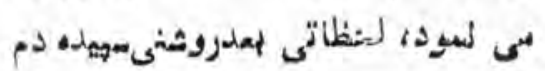

اكسحافي در آوزده وبا او وعد. كرده.

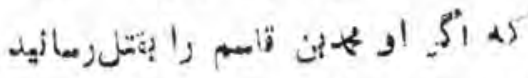

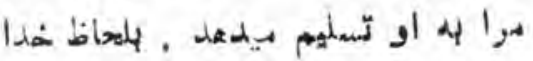

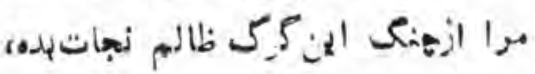

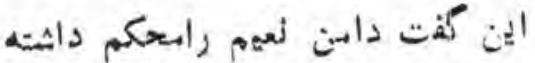

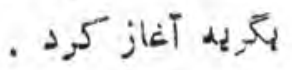

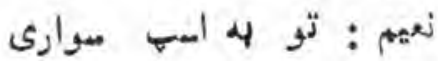

$$
\text { لدمتزمس دارى ؟ }
$$

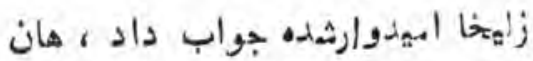

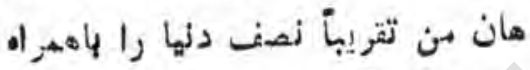

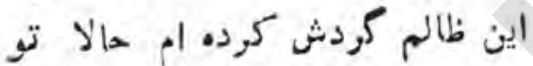

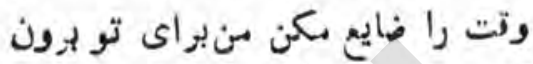

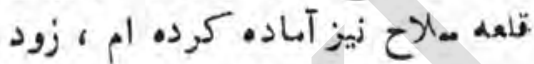

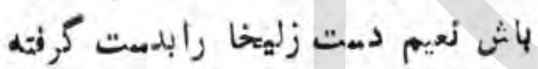

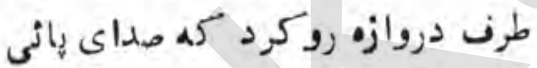

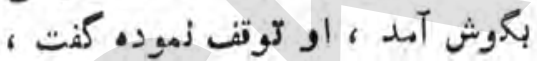

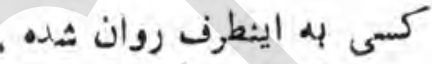

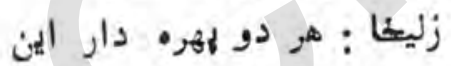

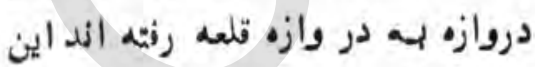

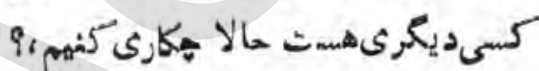

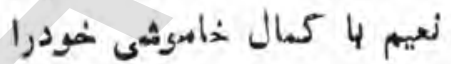

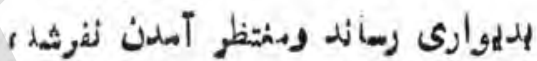

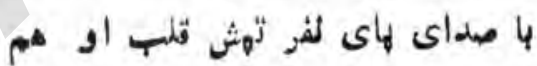
ثهدت مى كرلث

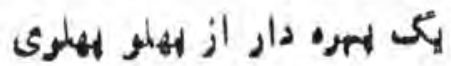

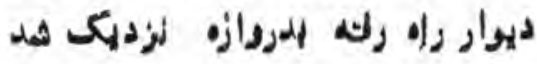

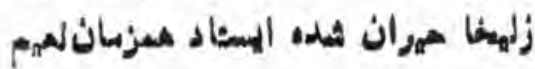

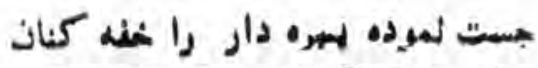

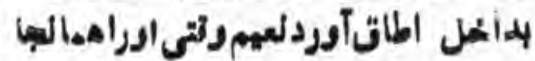
البهوش مانحت به اطات رها ل لموده خودش با زليخلا برون آهده دروازهرا aind

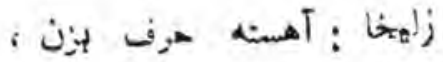

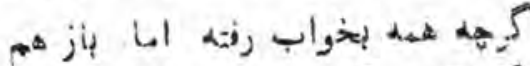

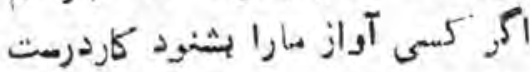

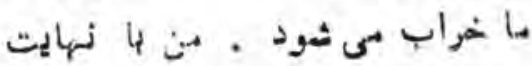

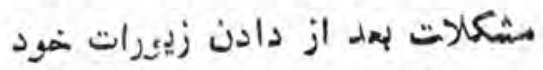

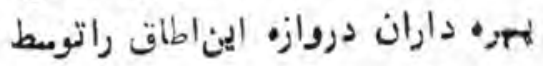

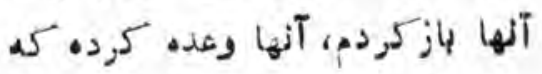

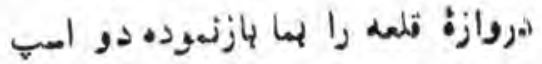

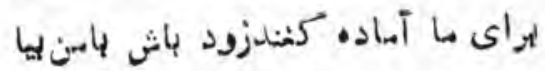

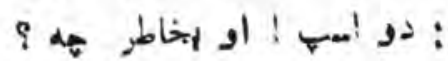

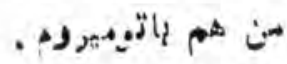

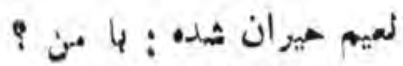

24

تو از من حهاظت بنى كنى ووالدئن

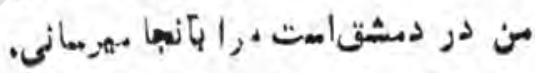

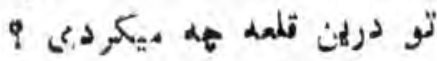

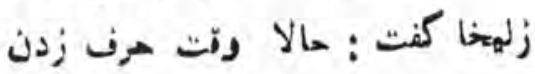

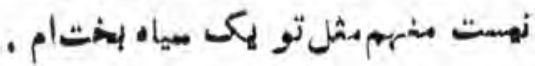

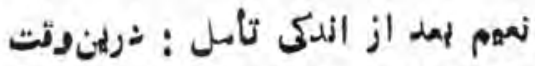

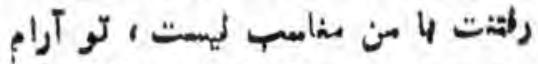

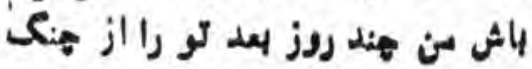
اين ظالم رما لموده 4 خودود بهورم.

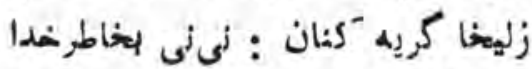

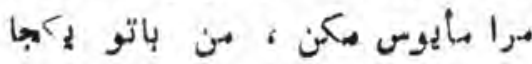

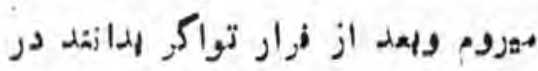

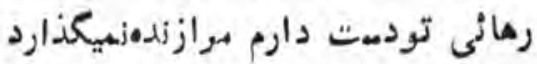

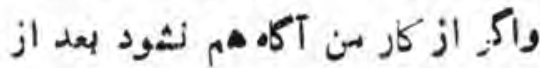

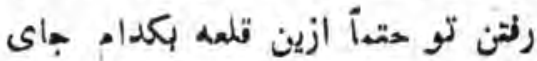

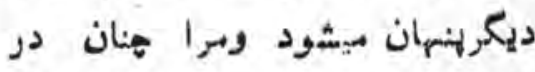

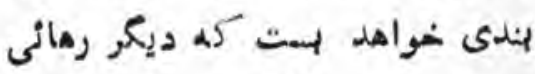

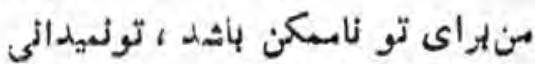

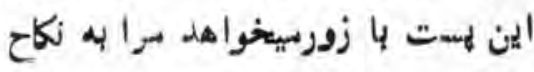




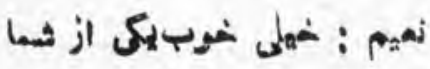

لطرف شهالثشرق برود آنها دربهان

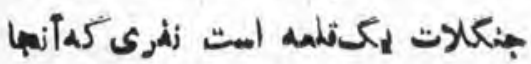

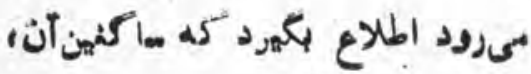

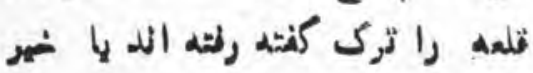

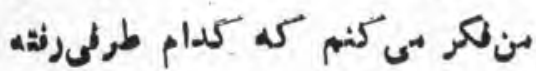

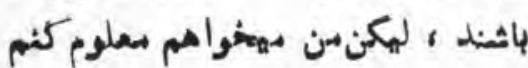
كم آنهاكدام طوف بى رولده، الهاطر

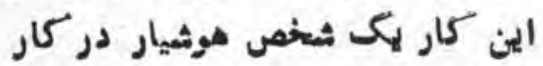

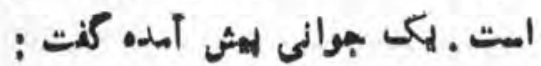

$$
\text { هن بى روم - }
$$

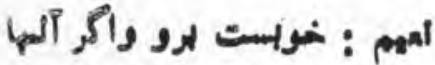

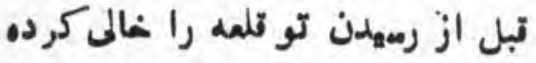

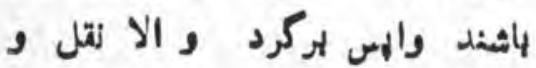

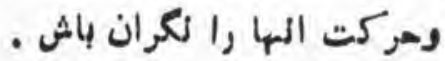
جوان .بانهد إه اسب سوار ثيدهرواله

ثد . ثرال

نعهم از مهاه باقى مالد الجنت تئرا

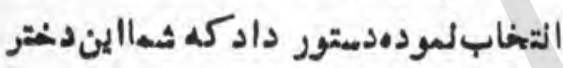

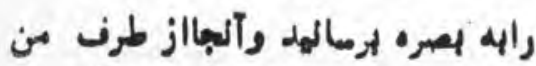

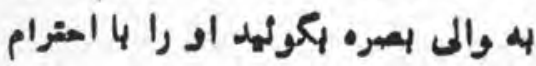

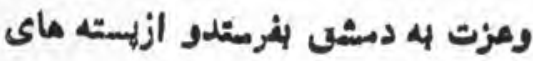

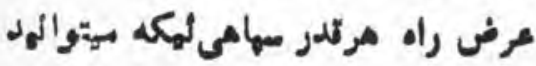

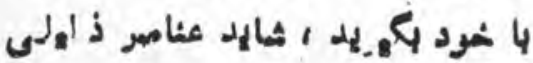

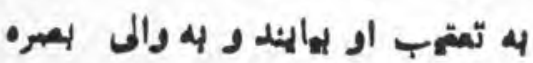

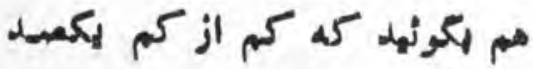

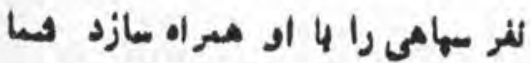

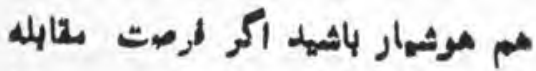

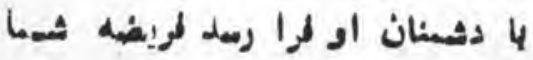
قبل از مسه نجات جان اوست ، دررراه

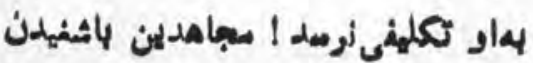

هـ كرداند ر دازيانه زد ـ زلزيخا نيز

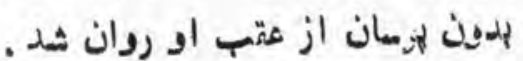

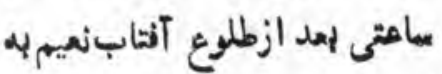

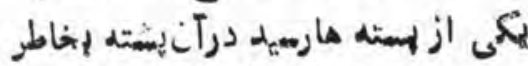

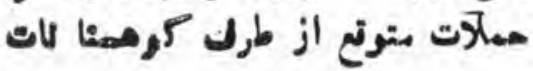

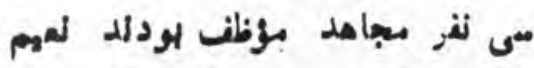

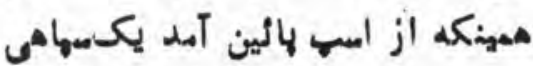

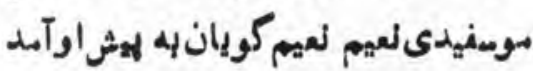

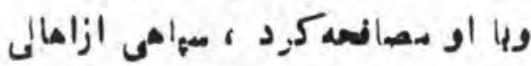

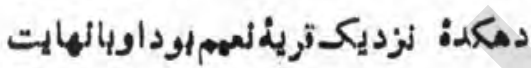

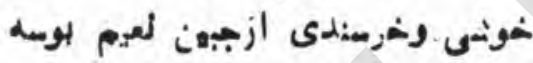

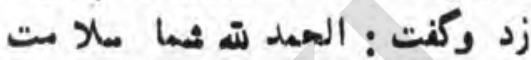

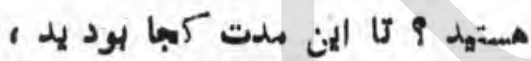

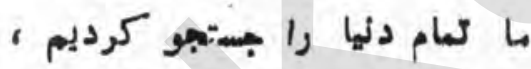

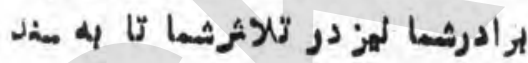

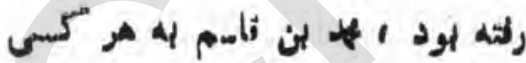

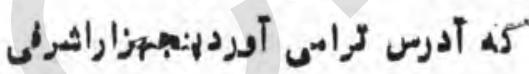

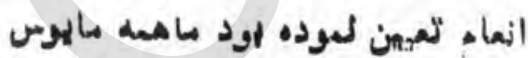

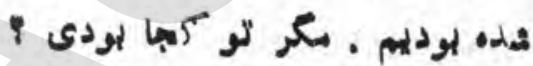

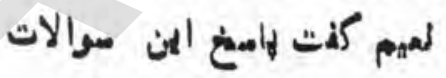

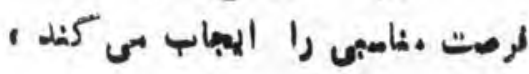

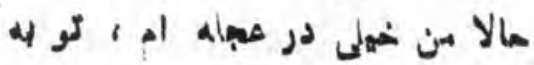

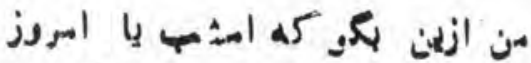

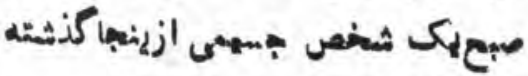

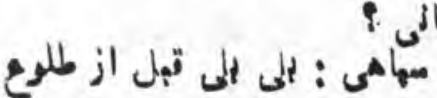

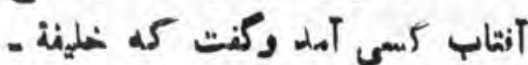

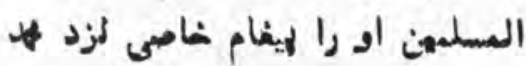

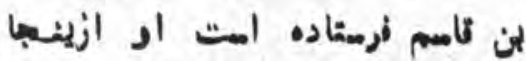

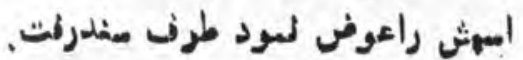

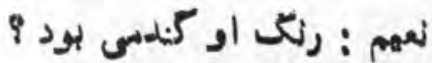

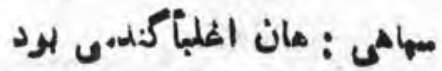

كه داثيت ها دور سواه ثمب را بدرد

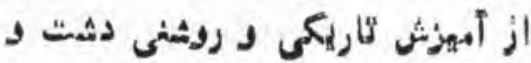

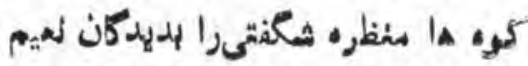

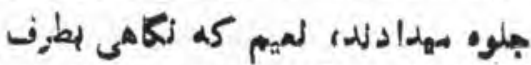

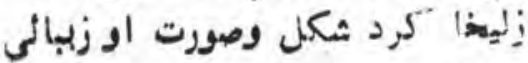
نظظ: زمم تاريك صحرا را دوهيدان

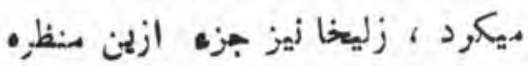

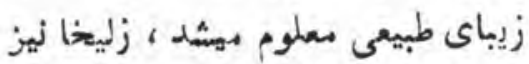
بطرف رفيقش ديد و ازحها سر إهائهن ازداخت . نعيم از او لهربيد كم بكوند

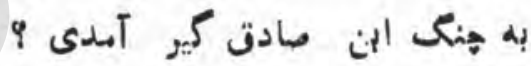
زلمهخا در جواب داستان المشاكى خود را از ايقدا تا آخر ليهان لمود ، ودر

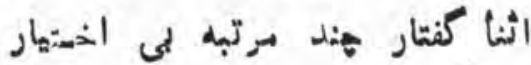

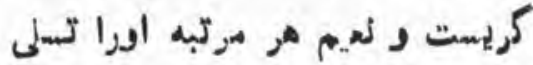

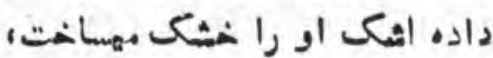
وتنىهواخوب روشن شيد آندو

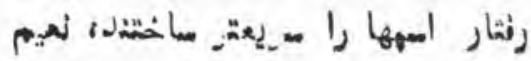

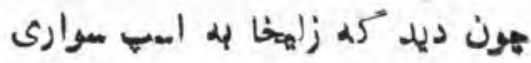

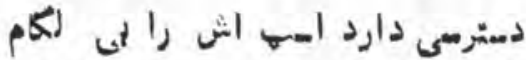

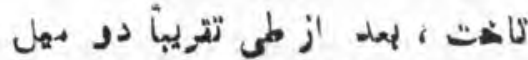

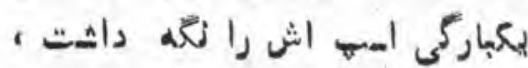

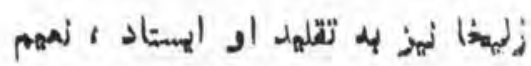

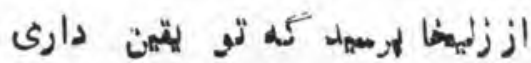

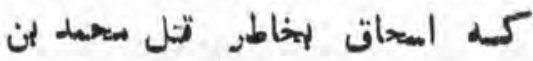

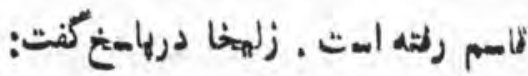

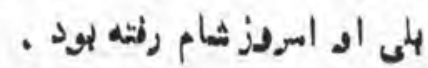

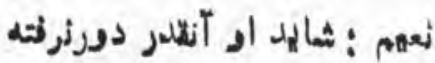

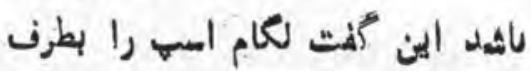


حهلي خوب الهن مهاهي ترا

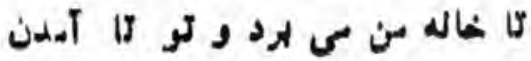

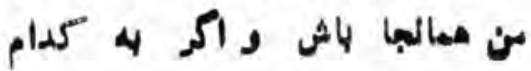

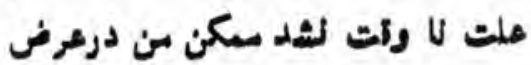

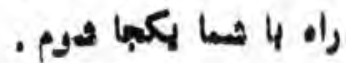

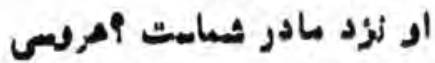

كرده الهد

لى الها لهودر اد در ماله ما ثلده .

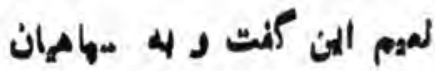

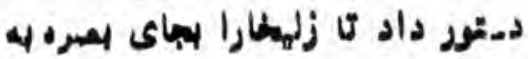
هاله أد لرمهالهد.

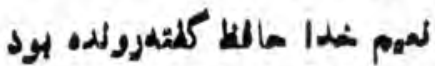

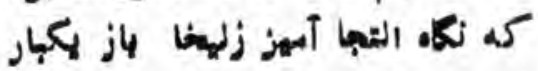

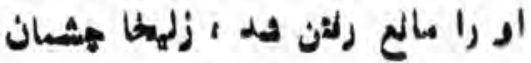

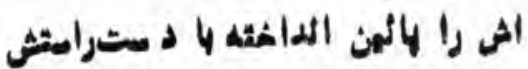

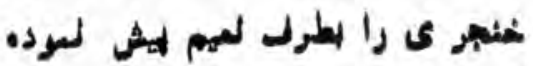

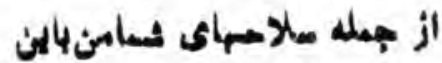

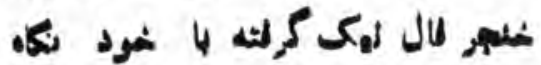

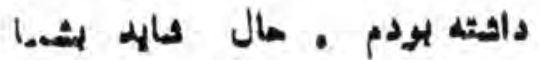

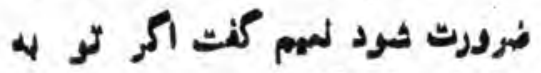

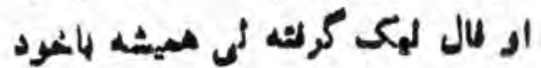

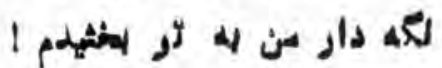

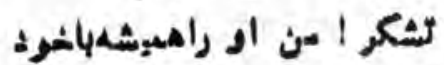

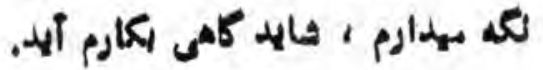

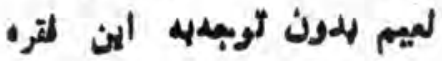
اخهير او به اسب سوار هد الها لمثلئل

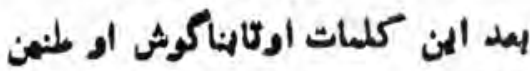
الكن هدل . المن

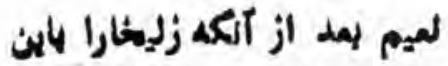

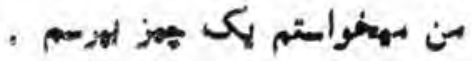
كمو لهزي

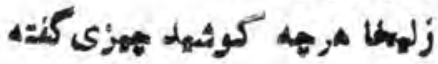

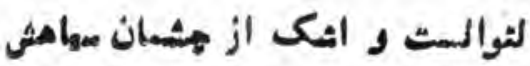

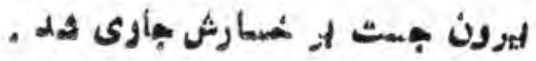

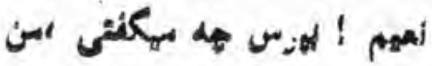

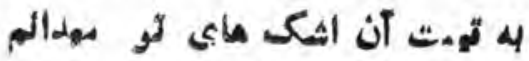

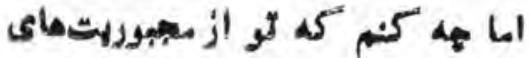

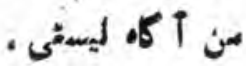

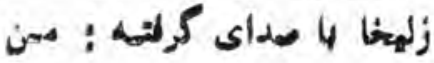

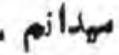

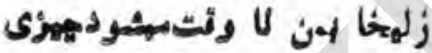

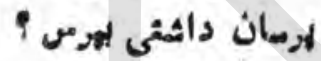

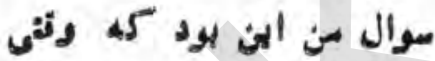

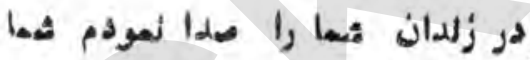

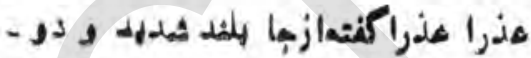

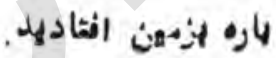

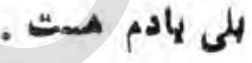

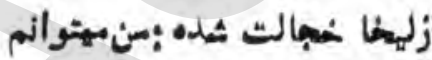

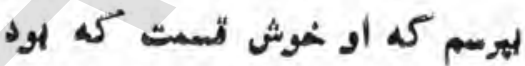

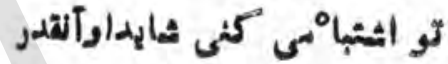
حهوش ثتست لباثهد . او زنده هـت . هما كيد كم او زنده باثددر كماهت

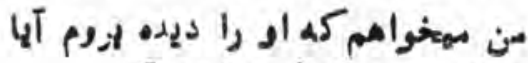
خراهن من آمول مهثرد لمسم:آلا راستى مهيغواهى ادرا 9 لبهن اكر شعا لاراض لشولهنئنيلى

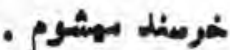

الين دساتهر سصروفسزينكردناسهها

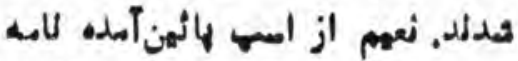

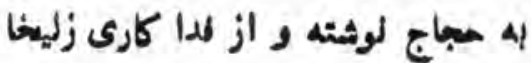

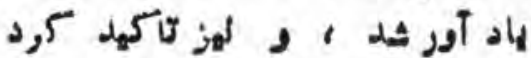

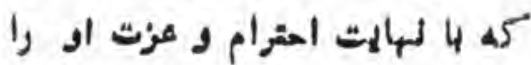

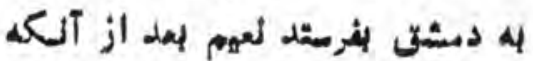

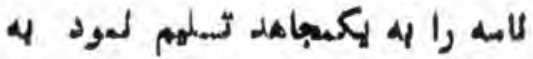

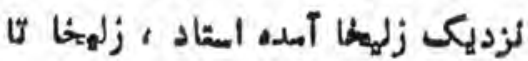

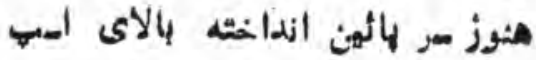

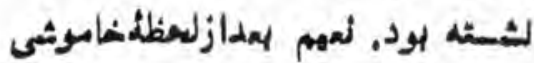

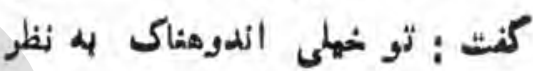

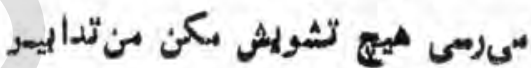

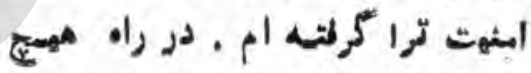

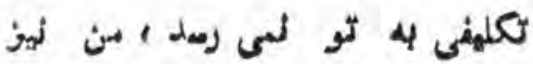

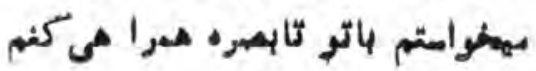

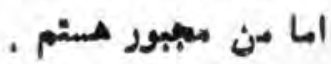

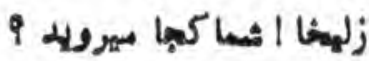

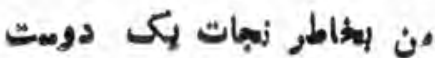
خودد.

مان

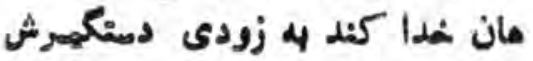

زليها دستمالف را به مشمان

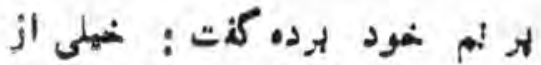

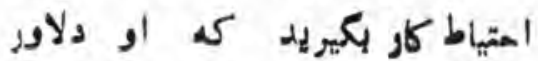

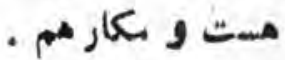

توتثويش مكن هعر امان كومثم

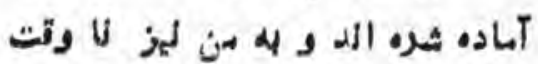

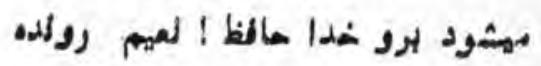

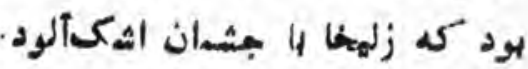

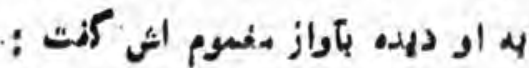




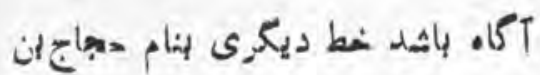

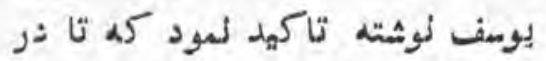

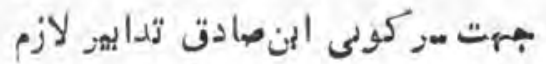

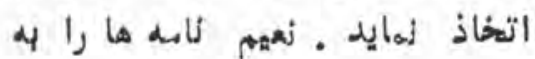
بداهدين آن لهته تحويل داده تاكيد

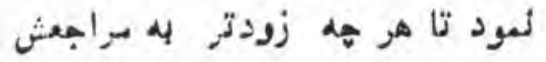

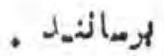
نعيم قبلكا در هدين تشئويش

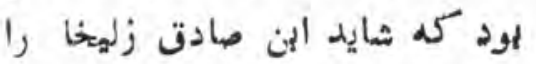

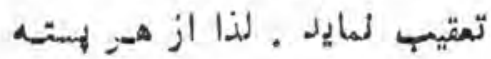

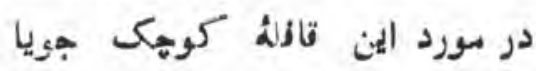

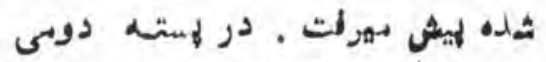

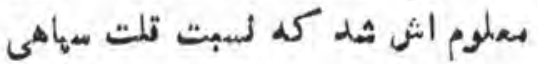
با زلميخا ايشثّر از ده لنو لركله اند .

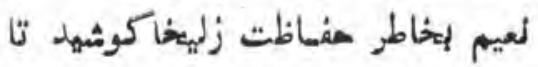

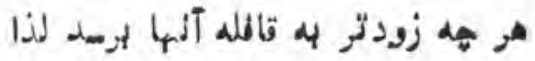
اسمثش را به سرعدت بى راند ، بدب

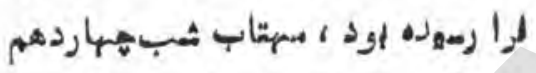

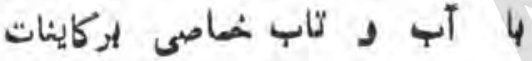

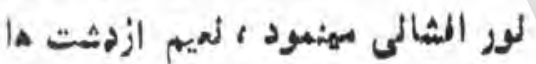

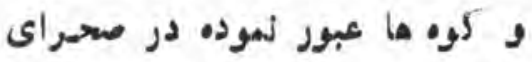

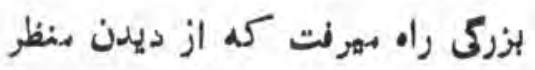
عجيب و غريبى خون در رك جانش از هركت ماند ، بالاى ريكهيا جبهد

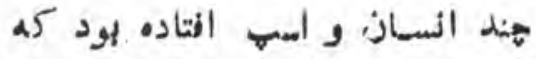

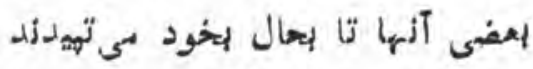

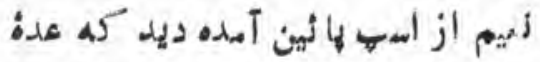

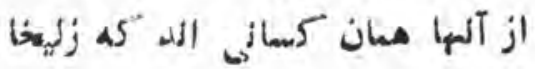

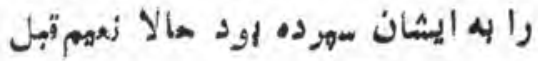

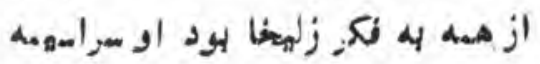

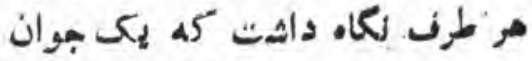

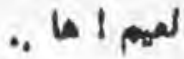

من السمالنسرأميهم

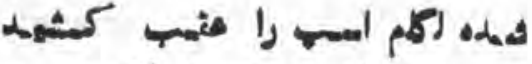

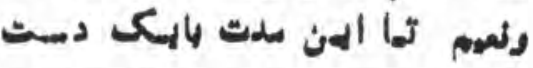

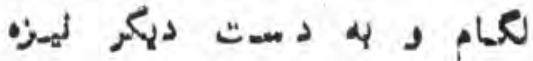

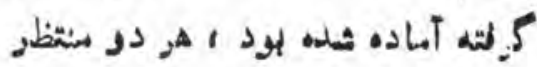

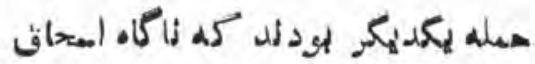
كيزه را بليد لسوده اسمه را لتكام زد .

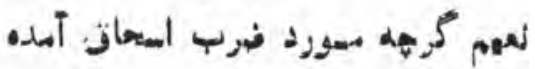

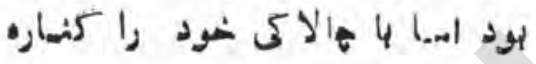

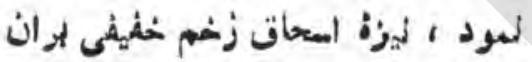

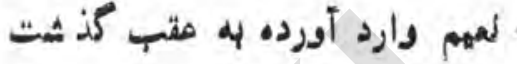

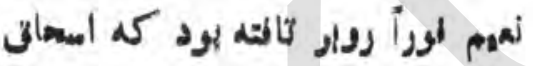

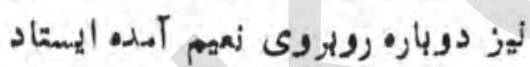

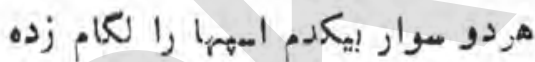
إنا زيزه حسله نمودزد نعهم باز خوددرا از ضرب اسحاق كناره لمود اما سينه

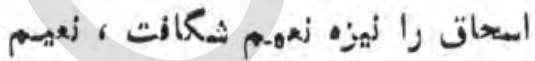

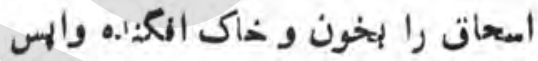

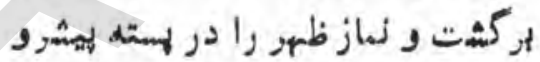

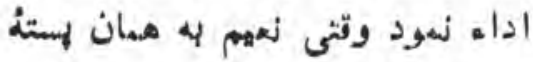

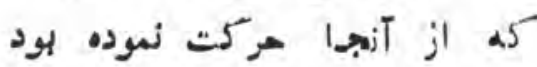

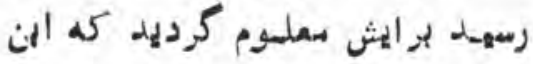

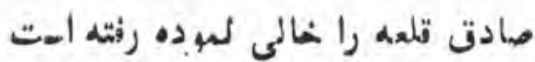

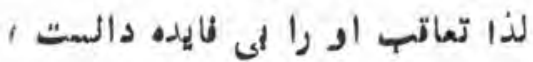

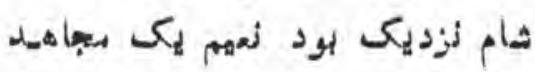
را دستور داد تا قلم و كاعدذ بهاورد

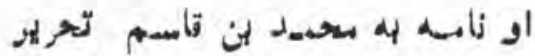

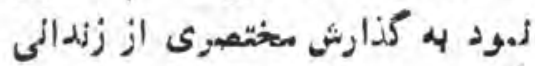

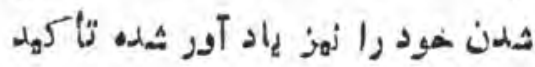

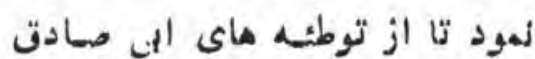

كافله كووهك اعزام كرد خودش 4

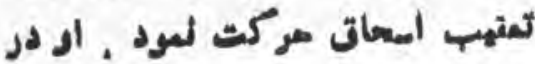
مر:سته امهس را عوم لعوده 4

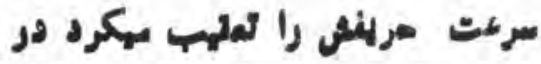
عرالز لمد ازهاقت ازدوركسىلمودار

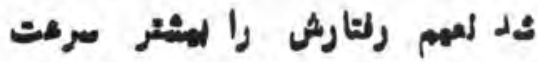

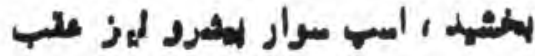

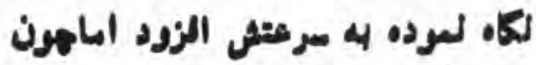
اهساس كرد اسب لفر عنى مهلىما لمسرعت راه مهرود رلكارش را آمست فيت

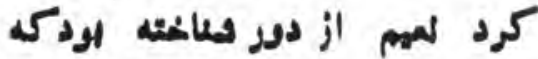

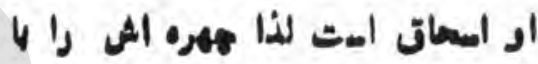
دمعال بهان لمود اسمانهيدن دلد

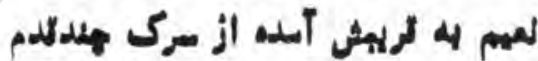

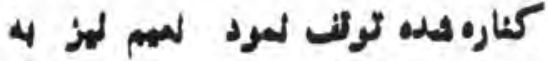

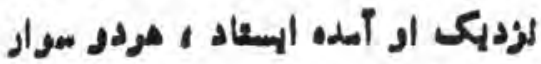

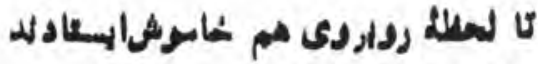

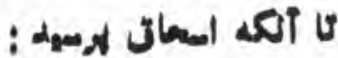

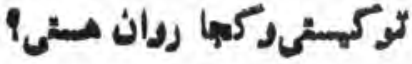

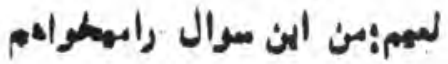
از لمّو لهرمم :

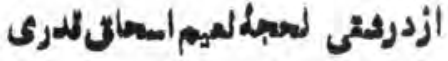

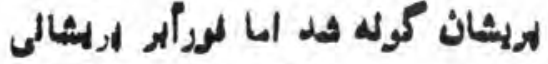

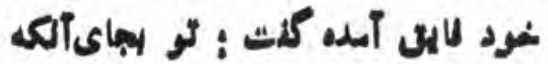

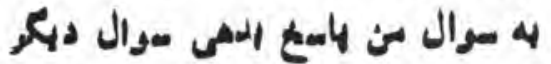
is

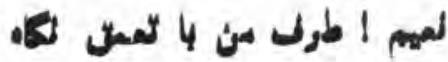
"كن هواب هر دد سوالترا درمهابى

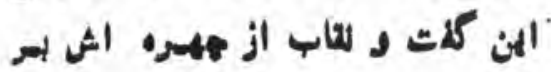
د الثك . اسماثر/لا اختياد : لعم ..لوه 
مست هون لاله آزاد وطن

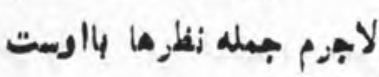

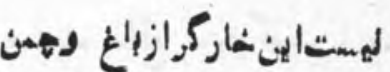

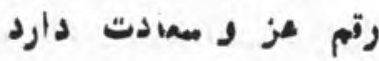

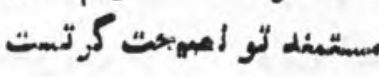

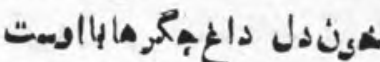

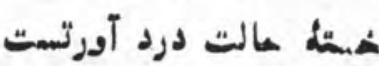

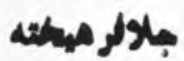

\section{نغس سكر}

الا اي رز مهبومد ! الا اى مد لU ورد !

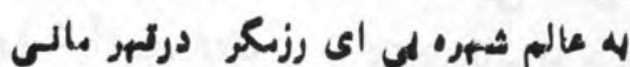

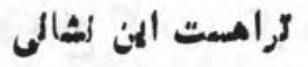

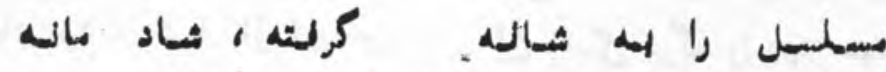

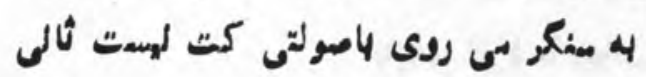

له لمروى برالى

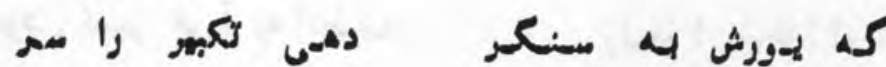
كنى سعشر هابااين سرود آسطالى

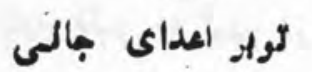

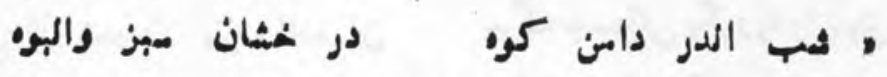

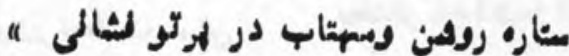

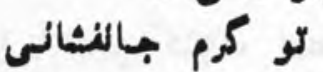

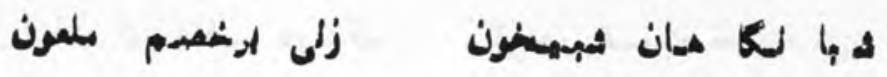

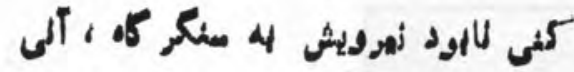
الطورنكهاكى

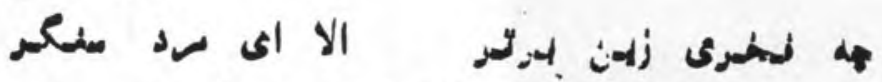

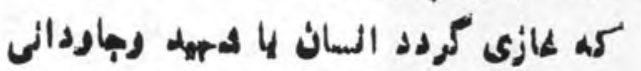

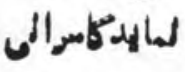

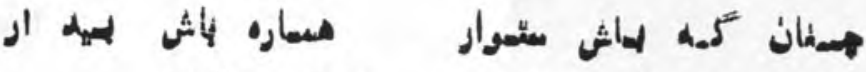

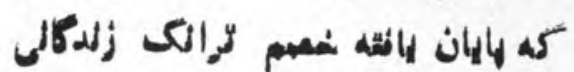

بود دمر لاتوالى

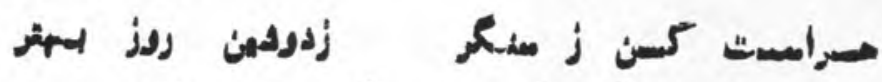

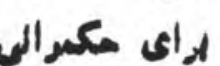

دربrان از مaه بلان كيرد

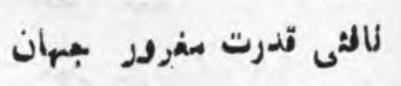

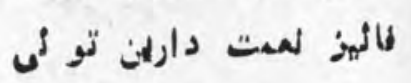

مه ابروزىواقبال وملاح

لم زمقل وخرد روثينتيت

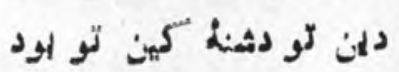

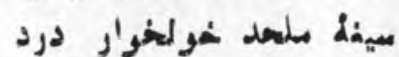

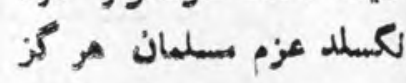

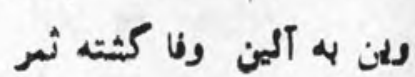

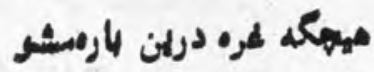

ملهدش كرده سبكساركيد

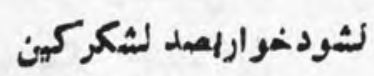

بمله زله رامكذر مهأيد

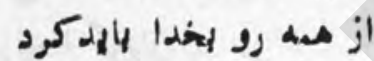

مانظ كشيور وليوان هنى

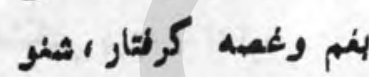

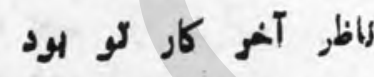
كالز ادرمشو هركز بهديعان

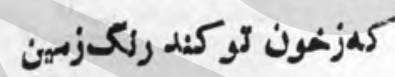

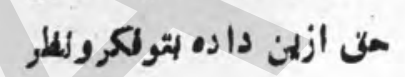

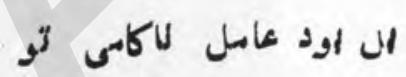

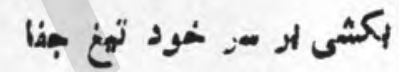
ألص وخسرانتوالمزوده ثمود

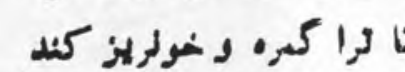

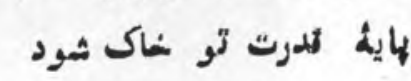

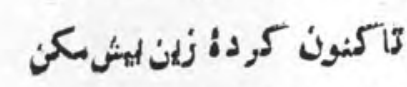

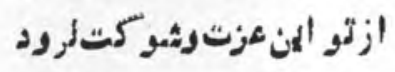

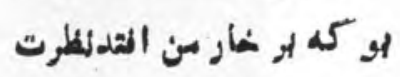

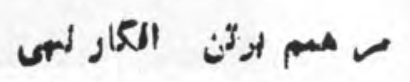

ميت رزم تو بهبالها كيرد توكى دزمآدرمشهور بهان

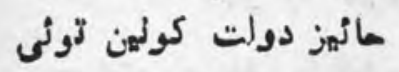

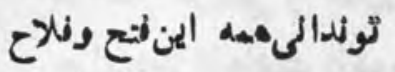

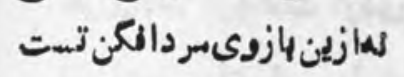

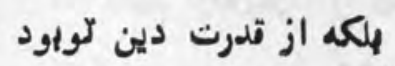

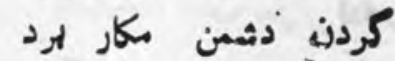
نشكند لشكر الهمان مركز

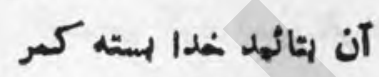

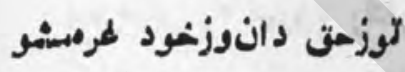
مركسى راكه مداخدواركند مركسي راكمد مد عزتدلين

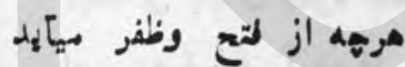

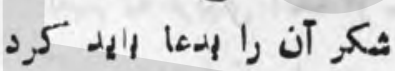

*

ائمبامد كه توهونجانمينى

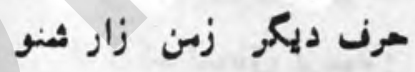

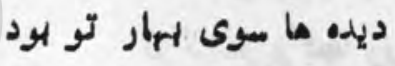
مرومركز توره كنف وشلاف

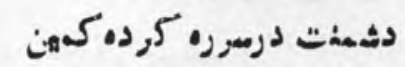

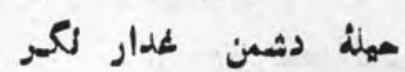

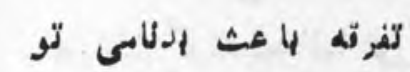

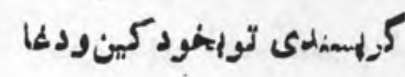
دوفميت راهتوآسموده شود

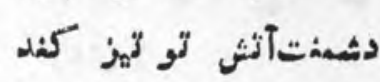
مله شئكتمتو هاكى شسود

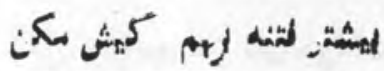

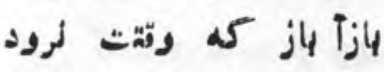

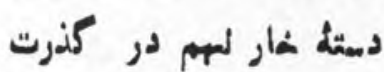
هاى كل الرسر ودمئار لنهى
موانه Sall

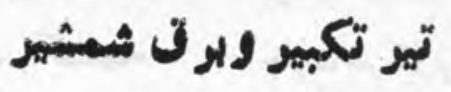

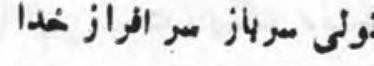

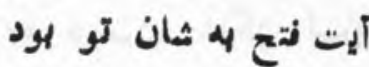

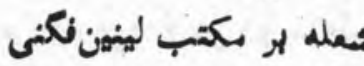
وينزخشمركهت كثيته شرر قمبر افسون ستصكر شكند ملطع مبع ظفر داده لهيام ملعدان را معه بريادىزتو دئو

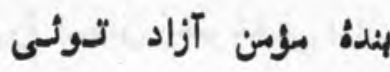

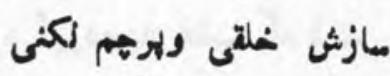
لاتوان ميله وتزولير ستم آنكبهيخواستجهان زيرنيكين

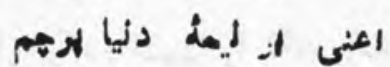

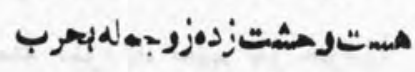

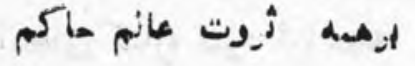
ره سوى كثور لهباورمند

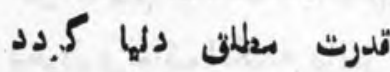

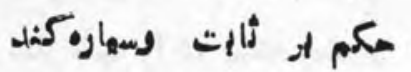
بلكمه آلمين عيا أردارد

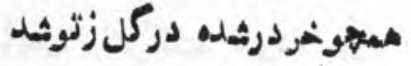
از توثد ارتش بهدادزبون

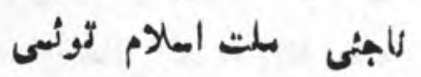

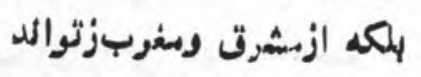

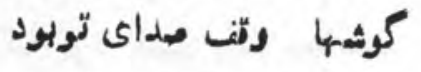

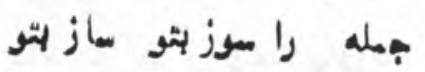

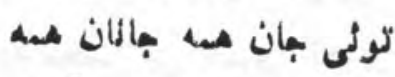

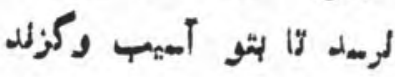
درثمت باديريثيان وهزئن ثدرت سطلنق سرمد بتو ليار
اي سبهانهدتونىسر بازمدا (ج)

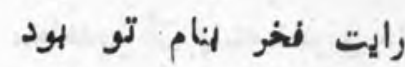

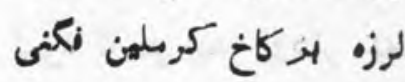
آنثد ازضرات تو خماكيهر كير تكبير تو سنكر ثكند ازت شهشئر تودر طلمتثشيام

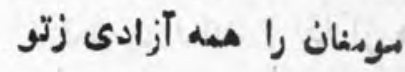

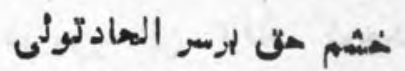

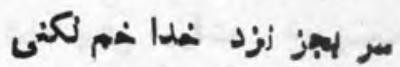

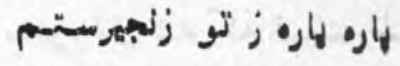

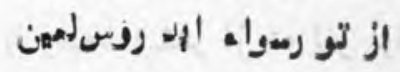

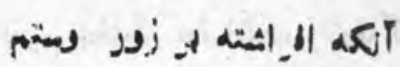

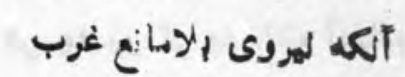

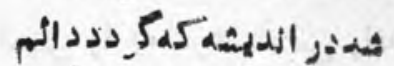

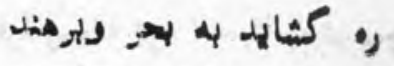
لس ازان هاكم درياككدد

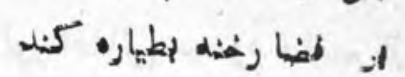
دائ ودلازمهمهجا بردارد

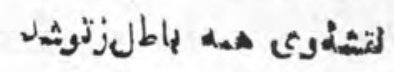

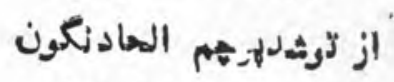

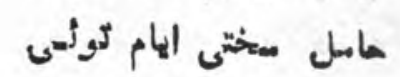
مومن مكدويثرب زتو ايلد

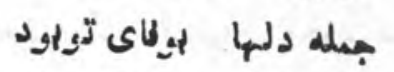

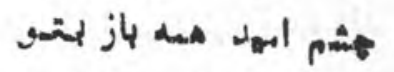

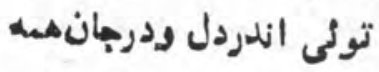
دمت ها الهر دعاء توليليد

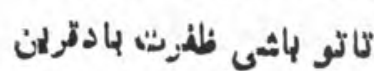
مست اعباز هـ(م)أتويار 


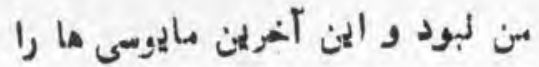

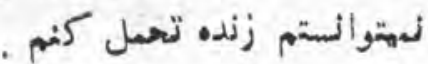

كعيم : سن خملى شيزمسارم الها

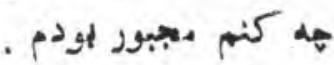

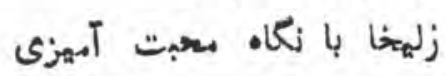

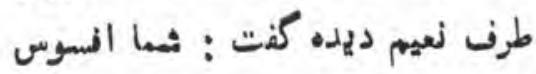

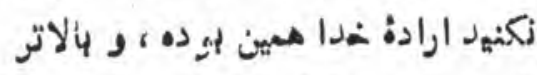

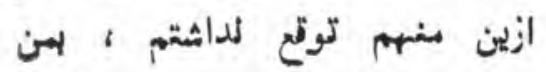

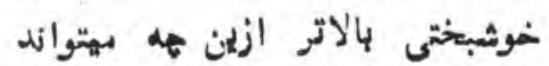

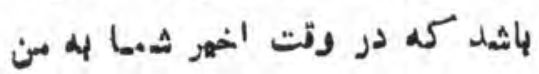

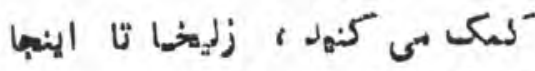

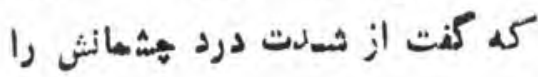

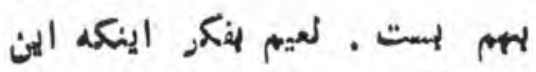

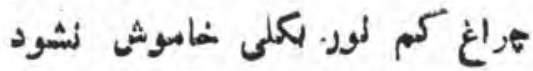

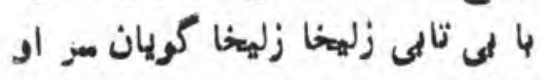

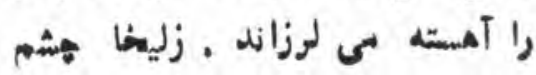

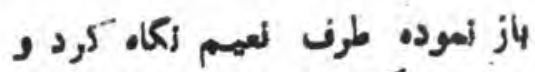

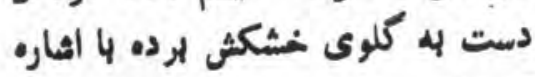

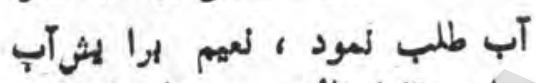

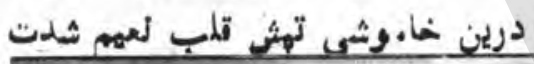

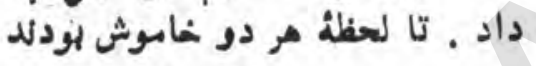

دست هالم شيده كفت ! - مالا برون

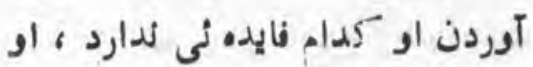

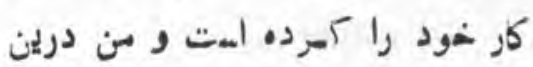

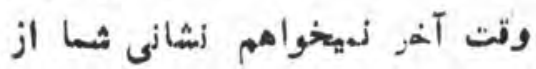
ثن دور باثشد .

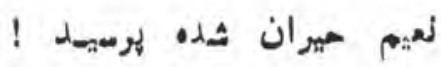
نشالى من :

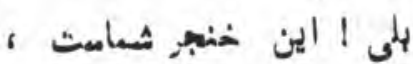

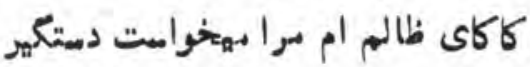

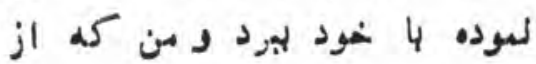

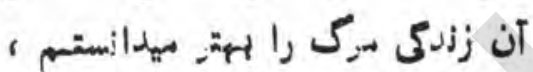
بازهم از شعا سهاس كذارم كمه خنجر

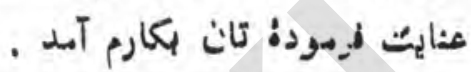

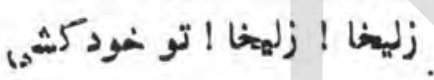

ك 9

من از مزك رومى هر روزه

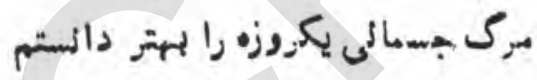

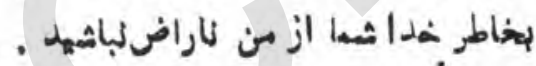

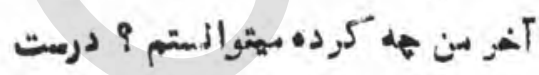

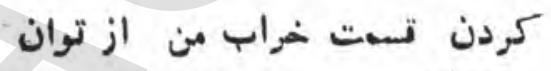

زخسى از او آب شواهت ـ لنعهم فوراً

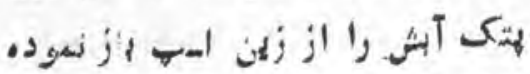

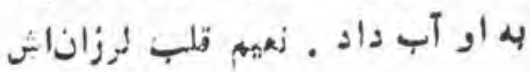

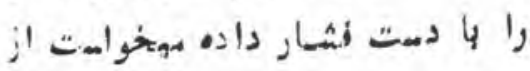

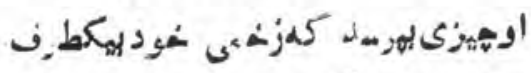
الشاره لعوده كفت :

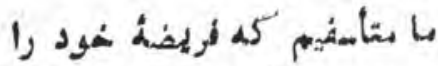

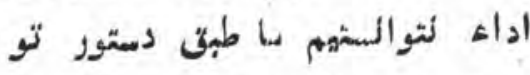

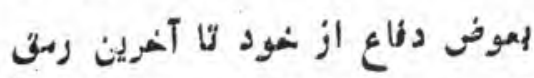

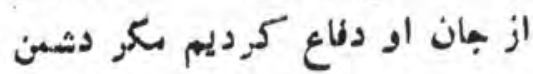

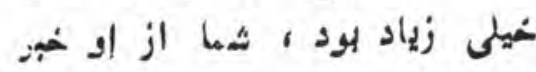
بكيريد إنبي اين كفت و باز لا دسمّش طرنى اشهار. نمود . نعيم نورآ به آنطرف

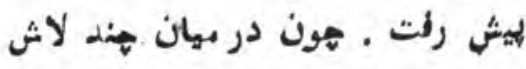
زليضا را ديد قلبس به تهش در در آمده كوثهبايش از مهنهدن لاز مالده آن

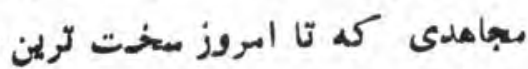
هادثات را با بمبين كثشاده امتلقبال

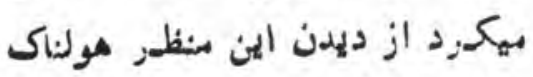

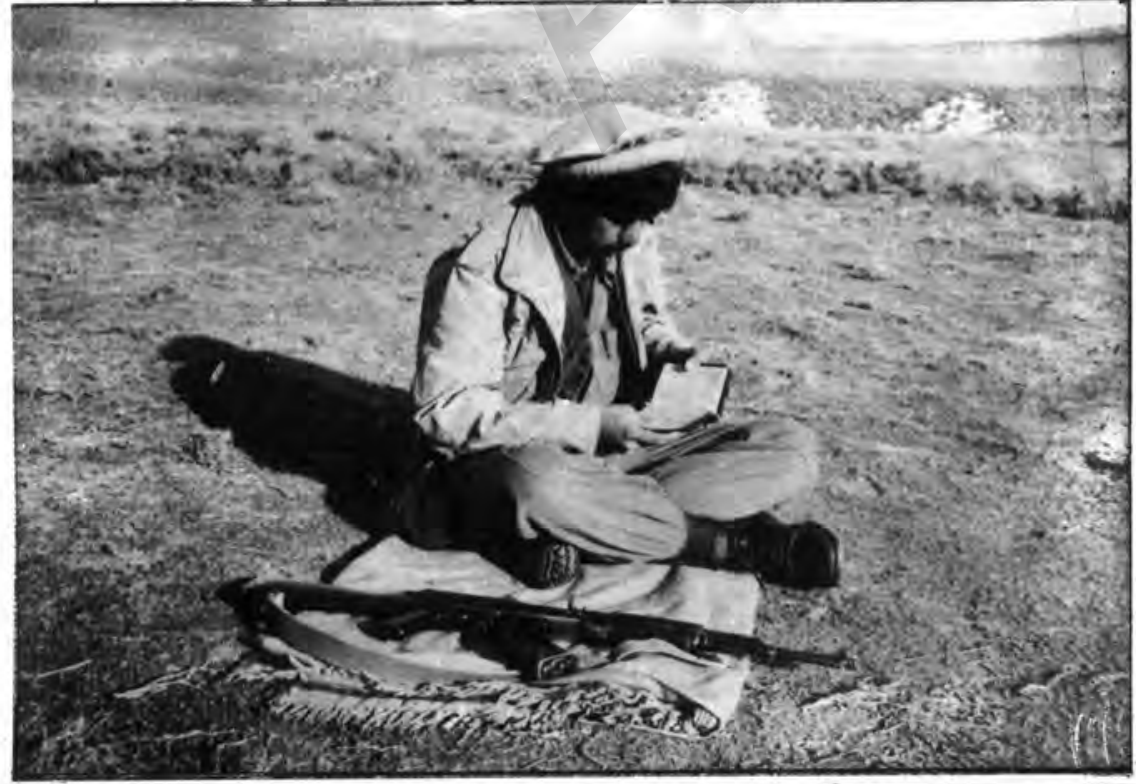

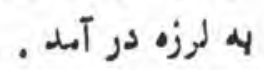
زلميخا ! زلهيخا 1 1 ترو هـم

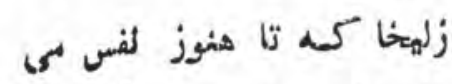

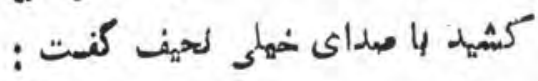
وما آميديد 9

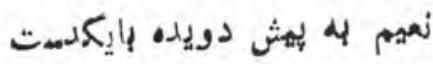

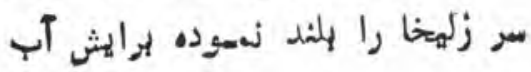

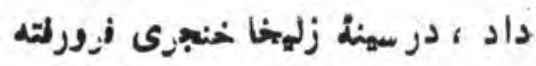

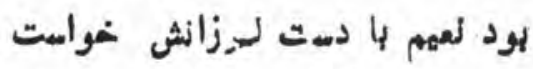

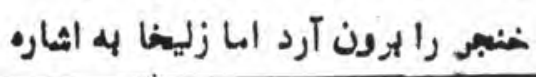


هود مشروم نسازيلد

لعهم ايني خواهش دردهميدالة

زلهخا را رد نتوانسته دوباره لهماله

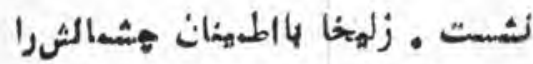

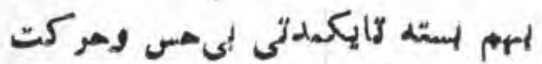

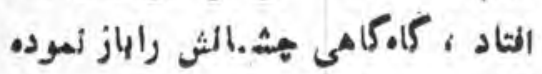

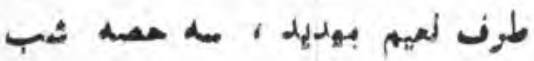

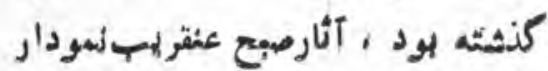

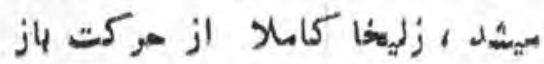

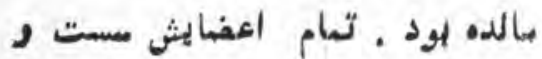

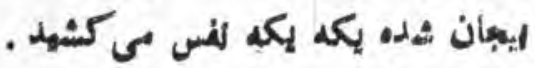

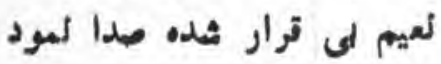

زليهiا !

زليهخا لــاى آخرين مرتبهشم

اش را بازلهوده بعد ازيكى ننسوطوين آمريل

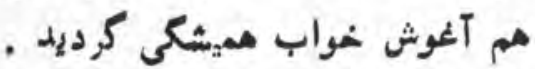

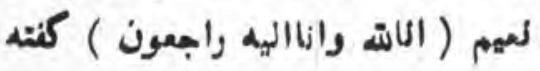

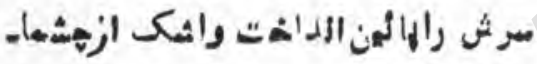

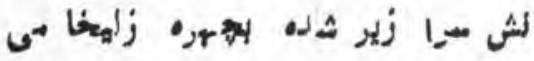

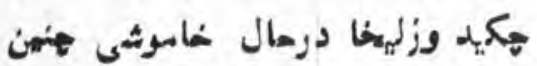

$$
\text { مىكنت } 25
$$

اى موجود شقدس ! من لهيمت

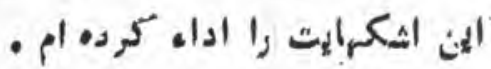

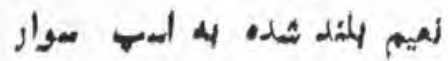

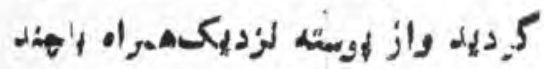

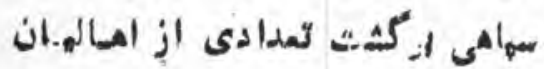

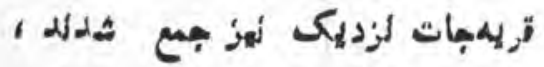

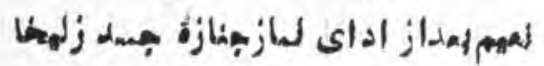

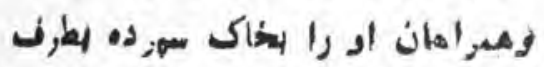

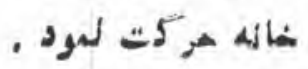
إسايه دارد
قرارى لرمهد . ككونوليد او كدام راه i

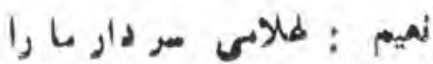

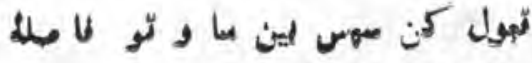
بالمى لع ماند . زلهها : من آماده ام امثامردار

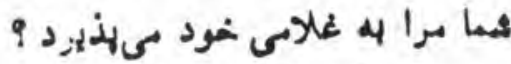
نهمب : الملى او خيلى سهربان

ز زلهخا! اما منثايدرتاهيدلهظه 1

نعيم : بخاطر اين كار وتت زياء بكار لهـت ، زلهنخا بكو ؛

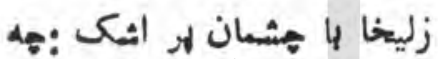

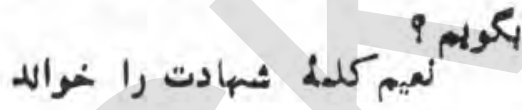
زليخا او را تكرار لمود ، زليخا باز

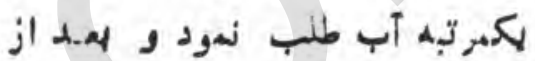

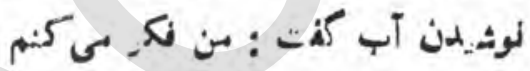
كم از تلب من بار معكينى الر داثيته

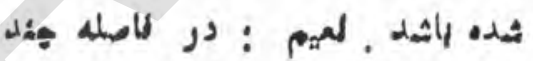

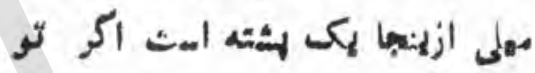

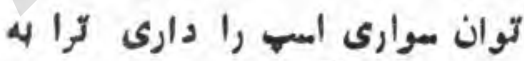

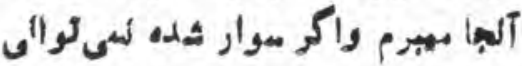

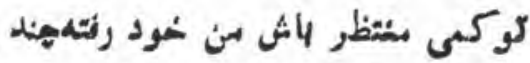

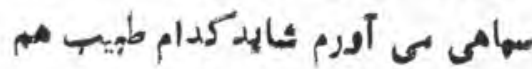

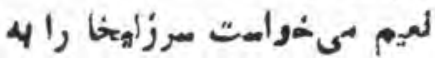
زمهتكذايته بلند شوداشا او بلادستان

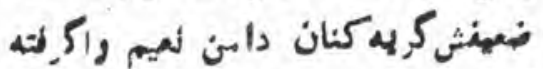

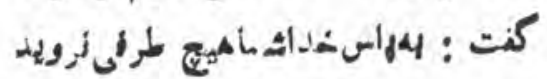

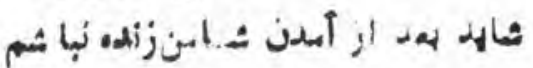

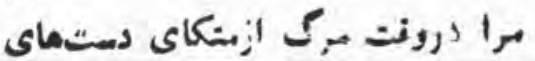

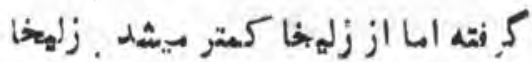

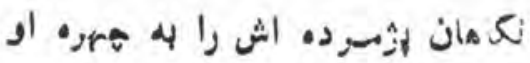

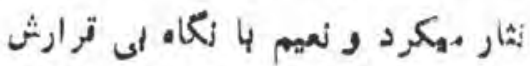

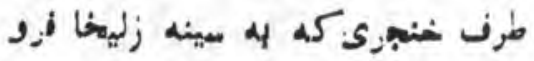

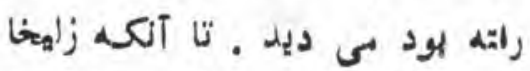

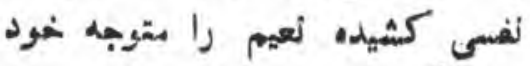

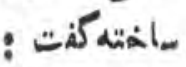

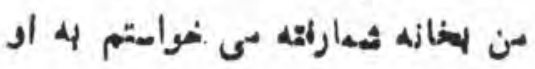

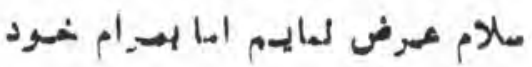
مونق نشثدم هشدا آنبا رنته سـالامبرا به اوبرساليد ، تايدينهازليهخا هاموش

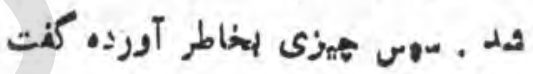

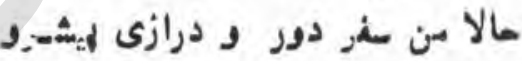

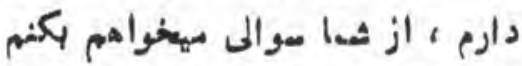

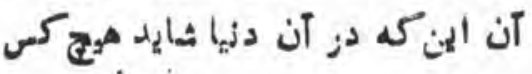

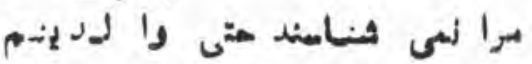

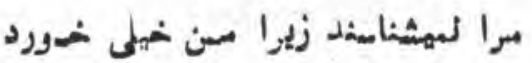

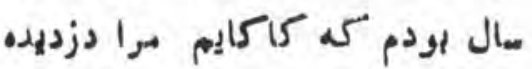

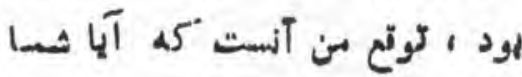

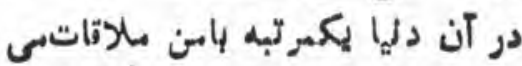

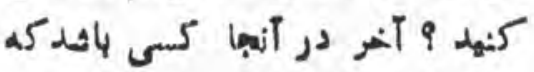

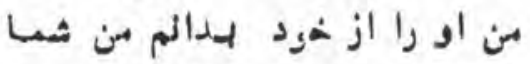

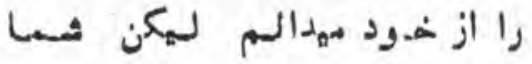

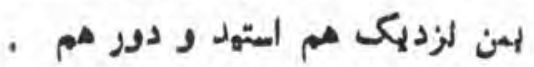

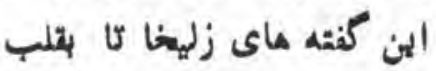

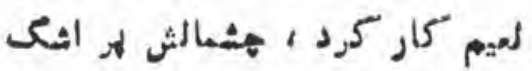

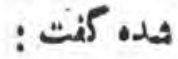

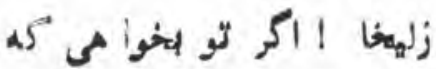

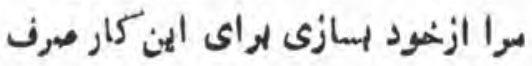

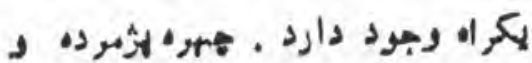

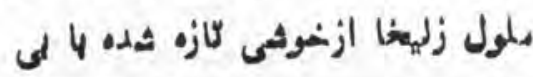


" قاضى طشعيب "

\section{دبدر دغزى' للنتايجو يوهنمونه}

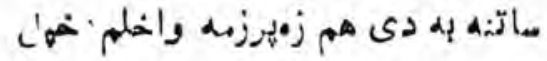

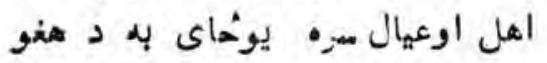

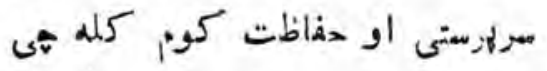
عثيز داخبره واوريده لو صفوان تهيى تهري

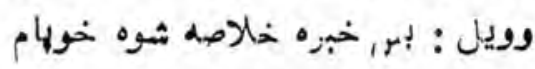

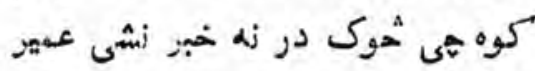

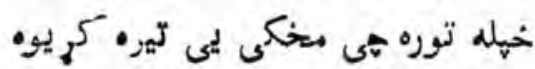

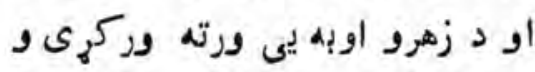

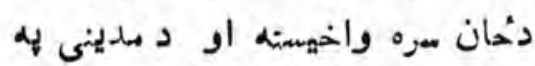

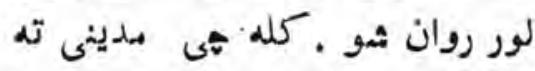

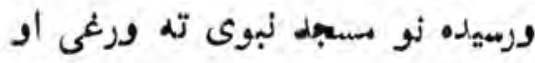

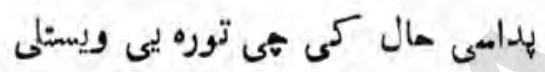

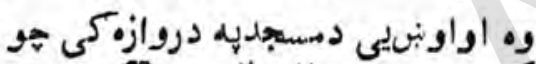

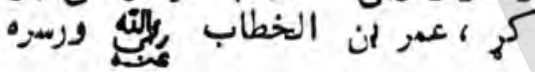

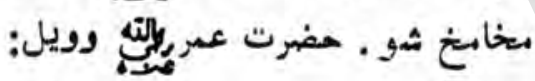

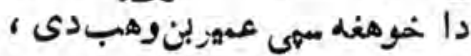

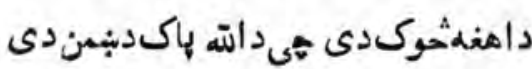

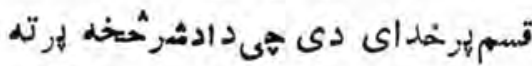

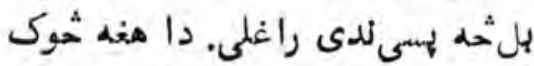

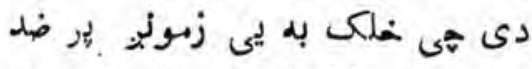

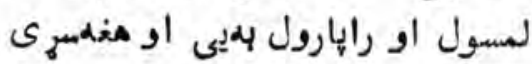

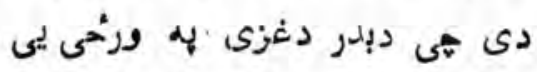

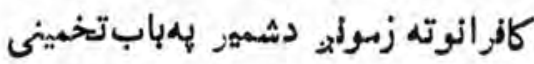
معلومات ورك, فوفيى دومس كسان

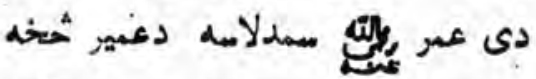

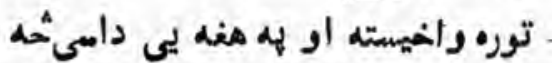

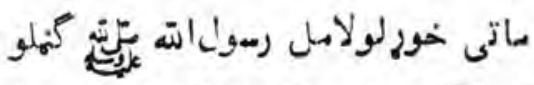

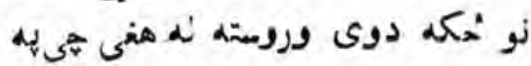

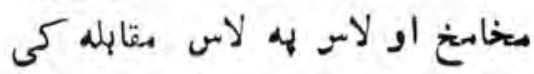

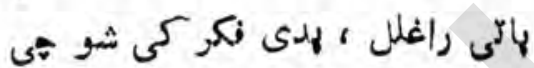

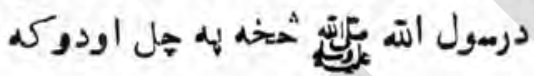

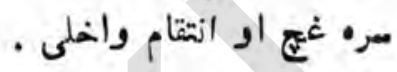
ددغو دسميسو او لهلانوزيو إنه جريان كى ثى دوام يیى درلوده يوه

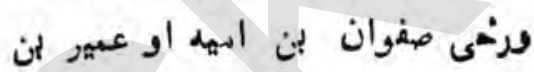

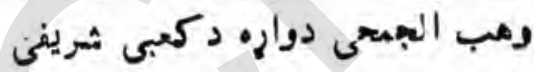

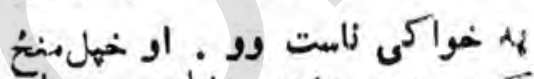

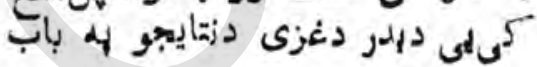
افسوس زاكى خبرى اترى اويلى اويادونه كوله

عمير وويل : له يوى خوا

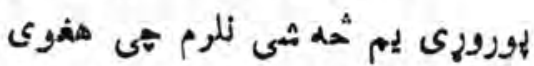

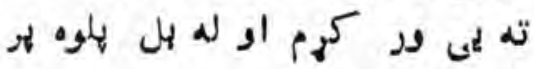

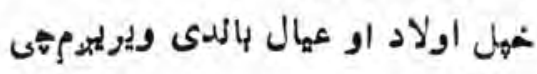

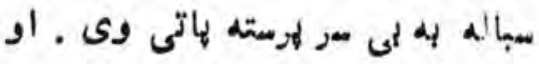

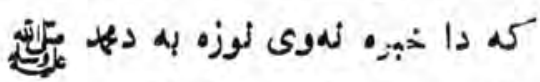

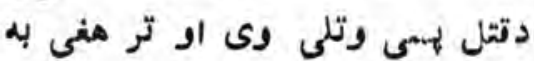

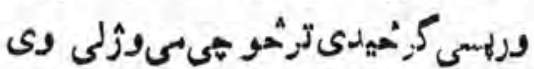

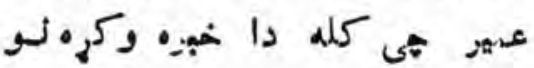
صفوان إنـاهيه ورته وويل: دترخولو

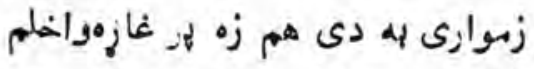
زه به يى ادا كرم اوداهل اوعله اوعيال
دإدزغزى داسلام لهه تاريخكى تر

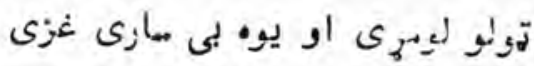

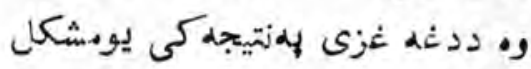

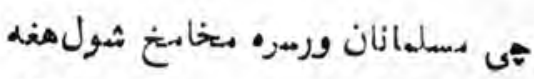

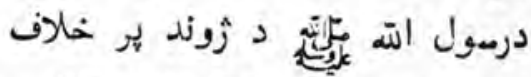
د كافرانو ددسيسو او توطيو مقابلهوه

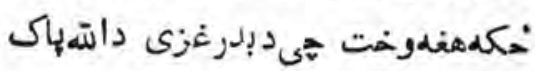

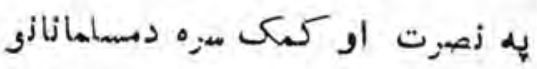
به كته مرن بايى ته ورسيده زودكافرانو.

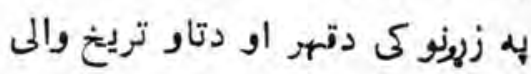

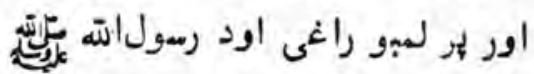

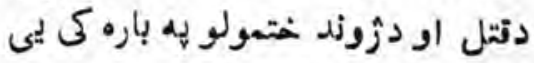

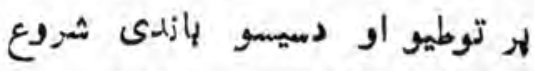
وكره او داخحكه ثي مسلمانانو دبدر

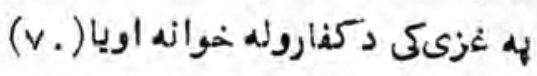

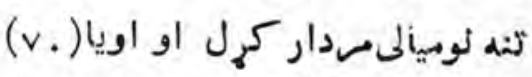
نفره نورزامتو كسانيى لثنديان وزيولا

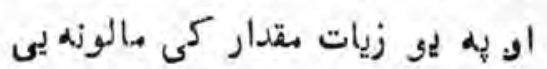

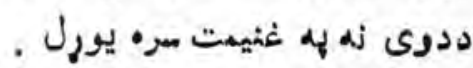

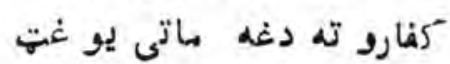

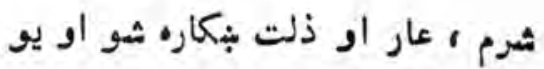

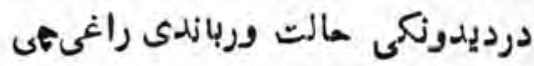

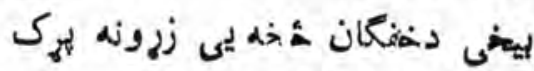

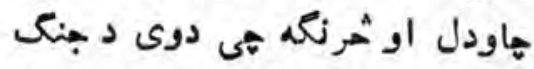

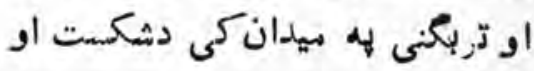




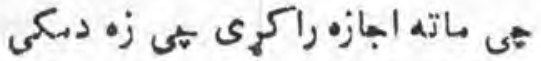

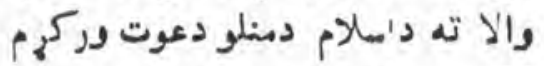

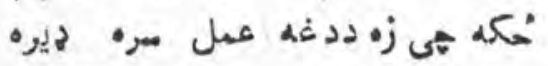

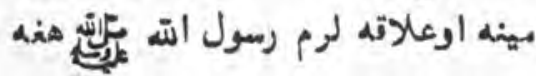

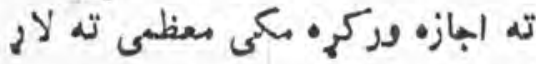

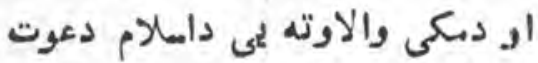

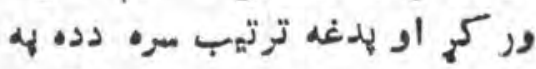

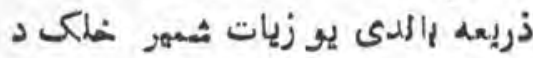

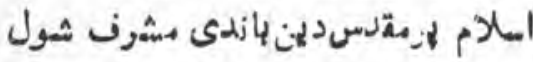
او دئ دنيخالفيهو دلورى د تكليف

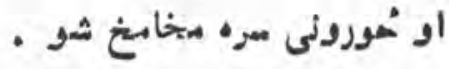

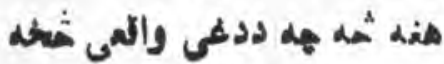

الهمبيرى .

1 - مايركرتى شتمن اومالداره

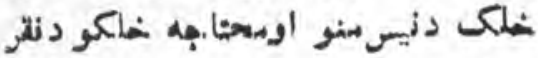

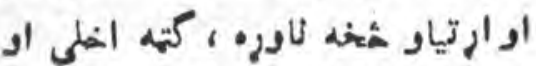

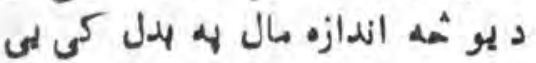
دخهلى تقاصا سره سم ديلو كار بهمرته رسولو باندى كمارى اكر ثيى د دنها كار له ترسره كولو كى هلاكى اوله له بله

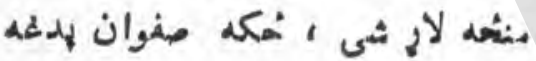

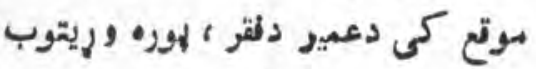

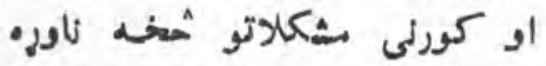
استفاده كوى اوهنه دمركىاوهلاكت لهاره لميدى يعنى دداسى يو كار المسى

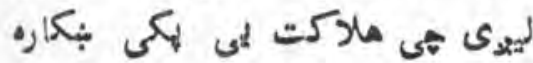

متصهور دى . مئكا

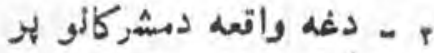

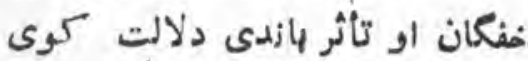

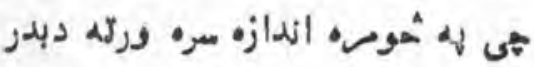

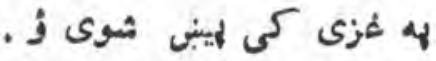

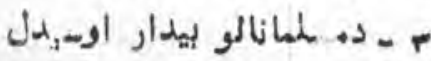

عبيرويل : داخه يشثان تورى دى

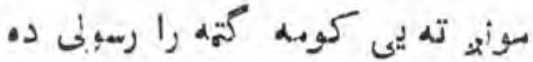

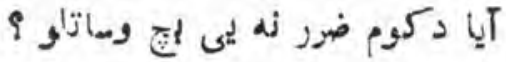

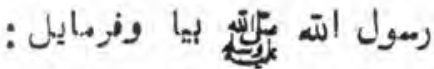
ربتيا ووايه دثشه لهاره راغلى لهى

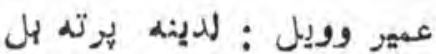

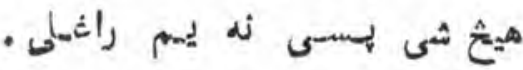

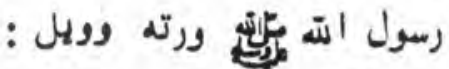

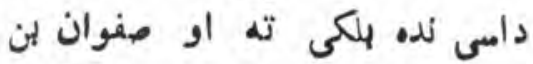

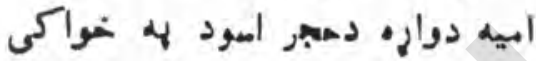
ناهت وى او دوازو دقريشو دهنو

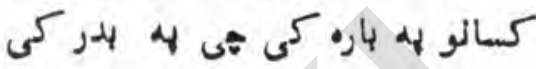

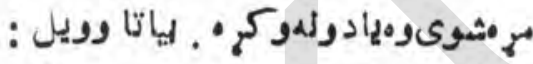
يره كم ترضويى له واى او داولاد لهاد

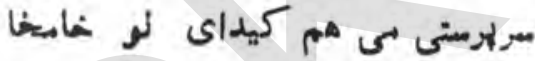

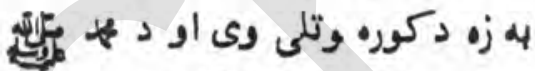

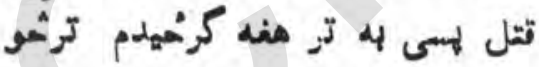

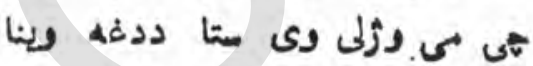

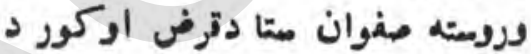

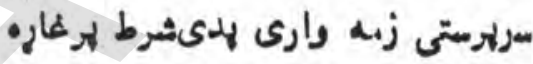

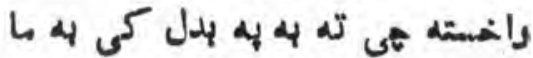

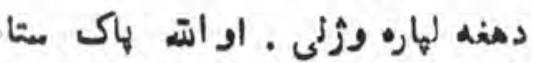

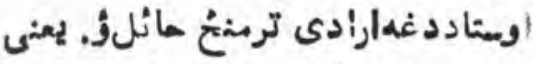

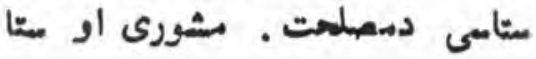
لخوا له زمه باندى د دفه وظينى

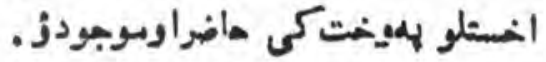

عمير (اثهبه الك رسولاته ) مانراله

داملام كلمه وويله او مسملمان شو .

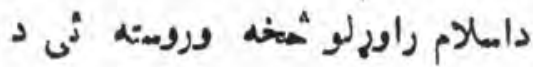

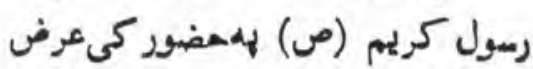

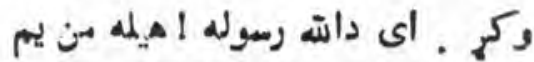

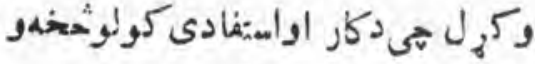

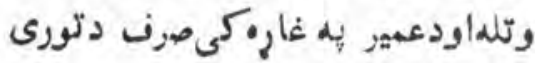

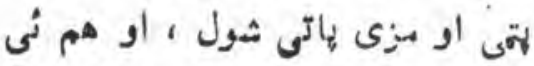

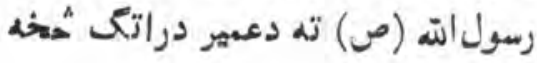

ليها عمر (رض) خهولو انصارو ملكرو ته وويل :

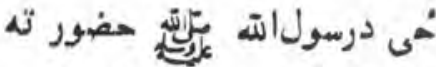

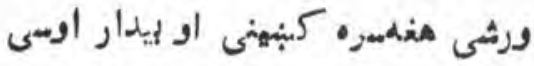
او دغٔه خبيث دلام لالدى ساتى هيى كوم ناوره اقدام ونكيرى ثمكه دايو خطرناك سيى سدى اعتبار اوباور لزيى .

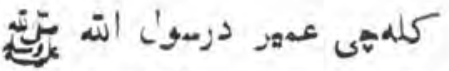
حضورتهورثى نودخهل رواج لمشخىيىد

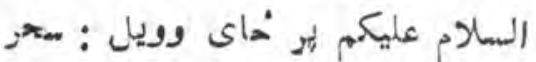

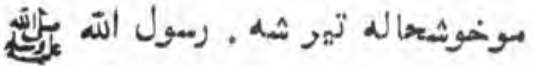

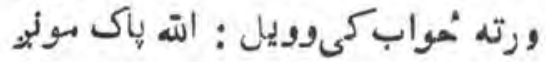

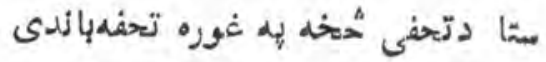

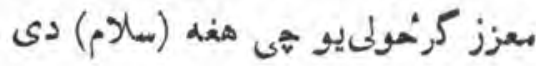
اودجنت والاو تحفه او سونات دىى

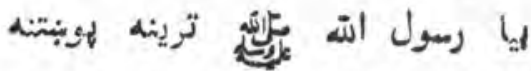
وكم، : دئه لهاره راغلى يلى 9

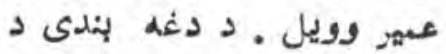

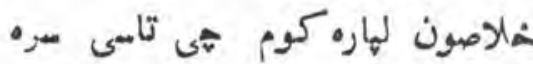

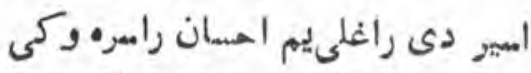

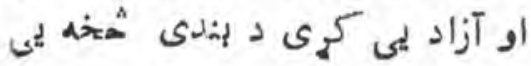
مطلب خهل "موى و .

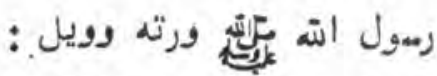
هغه غازي ته شيدى توزه بارتهوه ذولئز هiى دى مَّه كول 


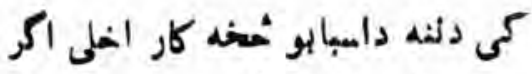

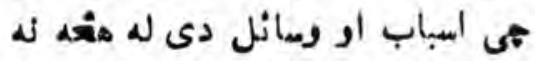

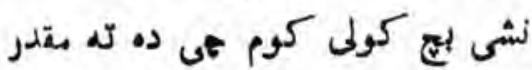

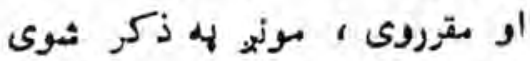

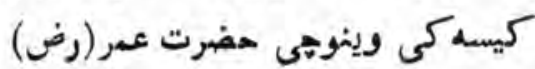

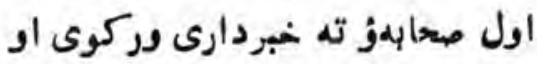

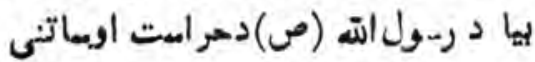

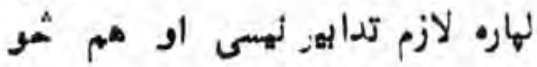

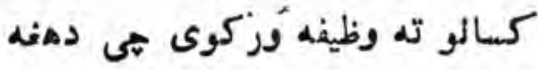

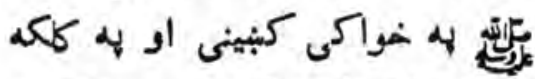

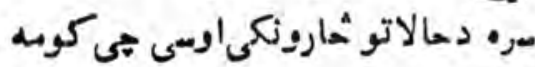

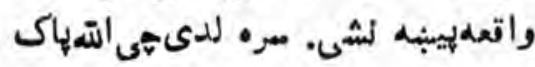

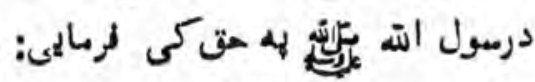
"واله يعصيمى من الناس" .

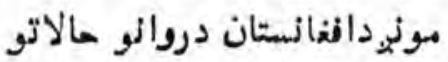

نه ارتباط دنهبل مجاهد ولس بام ديته

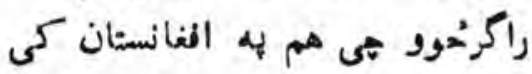

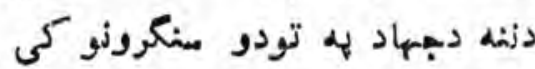

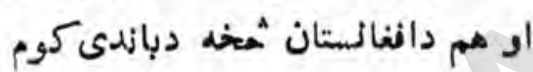

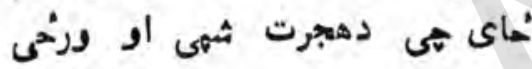

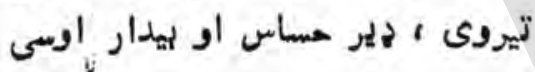

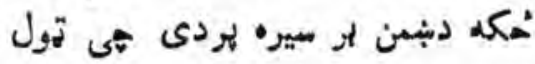

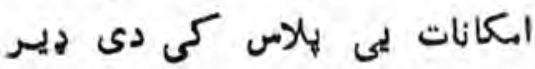

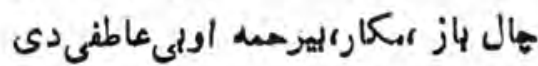
شهه اودرع فكر كوى ، دبيسى

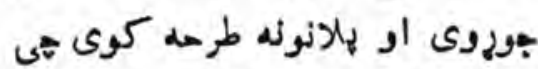

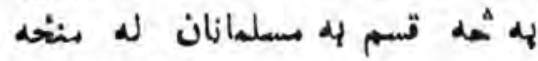

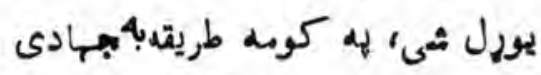

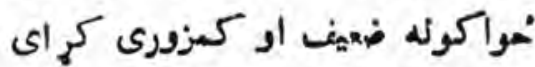

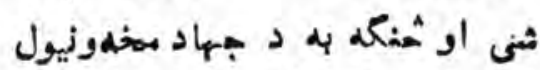

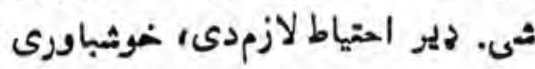

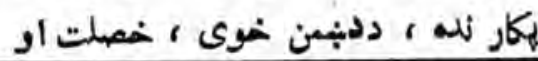

دجاسوسى وظوفهدترسره كوله لهمبدى

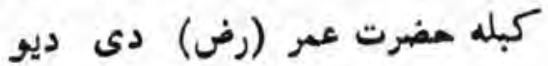
خالن له توكم خملكوته ور وايزئنده او دي

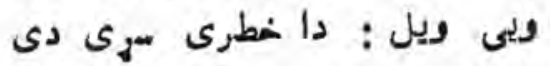

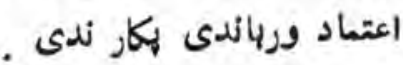

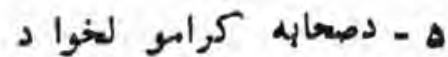

رسول اته (ض) دمناظت او ساتنىليه

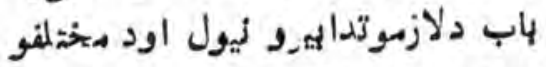

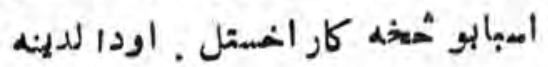

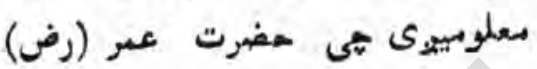

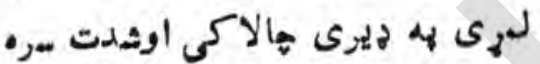

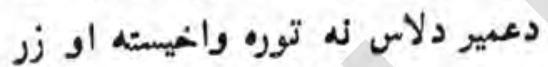

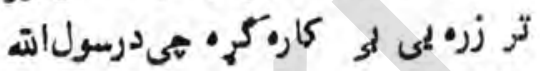

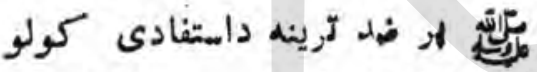

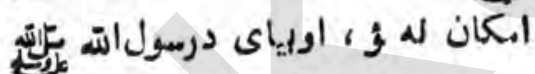

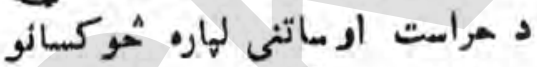

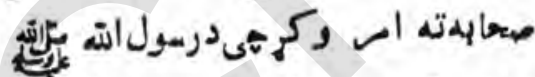
هضور ته ورشى اود هنه ـناظت 'او خهره دارى وكرى ثيى ثخوك ورته ضزر ونه رسوى . ددريم ، ثملورم او بلئحمنتبر

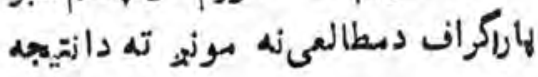

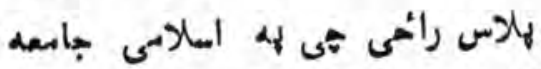

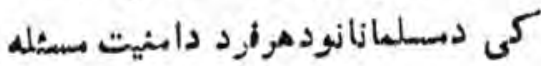

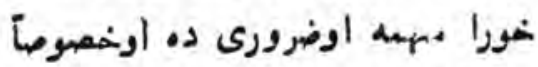

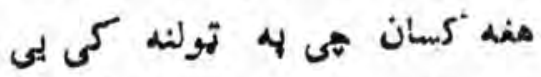

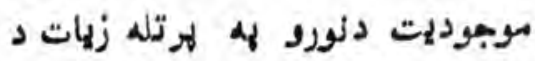

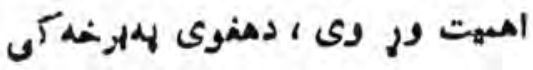
زياته توجه اواجتياط بكاردى. علاو.

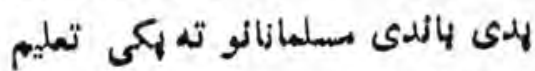
ور كمل شويدى بهى دخهلو ثمانونو

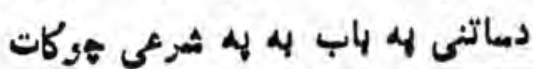

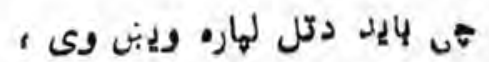

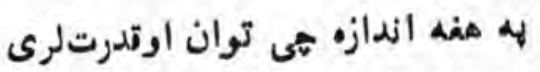

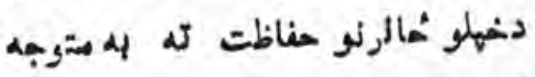

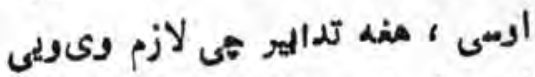

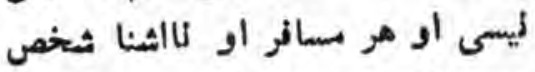

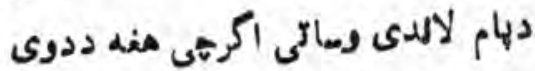

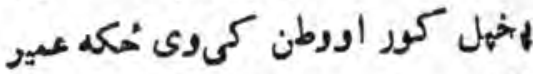

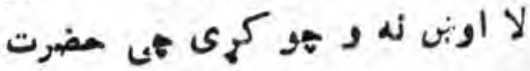
معر (دض) هفه ته ماتلتت شو اودده

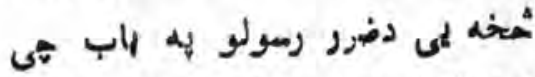

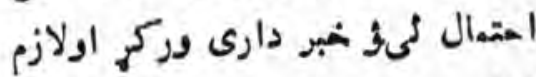
كداير يقى وليول .

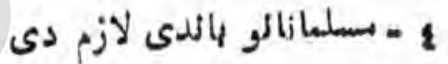

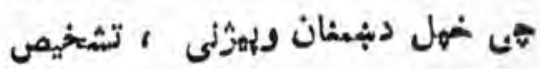

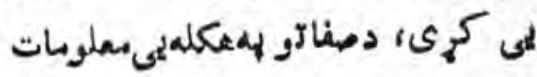

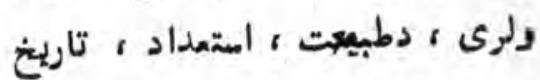

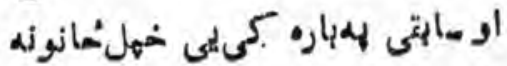
اكمه او خبردار كرى ثـكه عمر (رض) هي ثمنكه عير ائوهب وليد نوفيراً

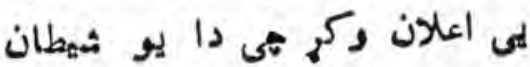

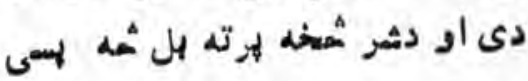

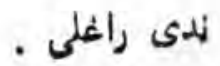

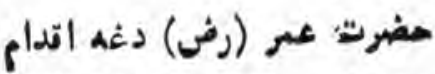

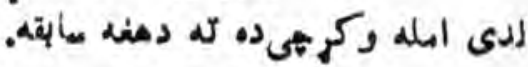

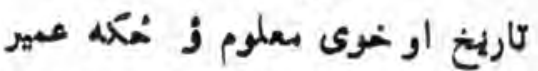

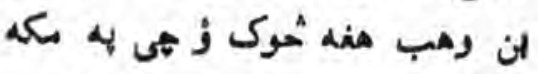
معظه كى بلهى مسلمانانالوته تكليف

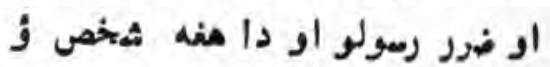

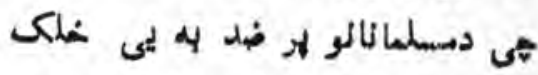

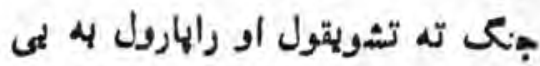

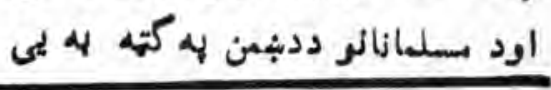


سره نشي او لبل مأه ترينه بطلبهوى

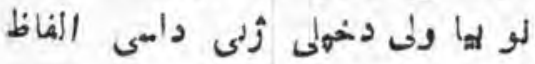

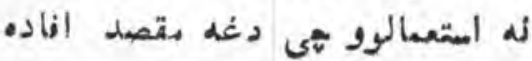

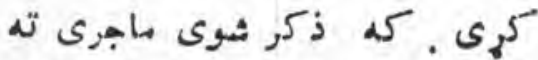

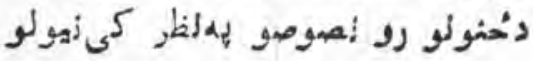

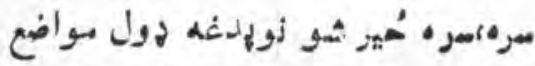

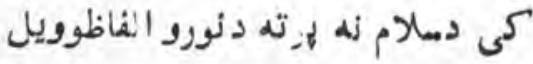

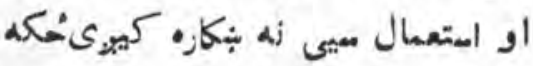

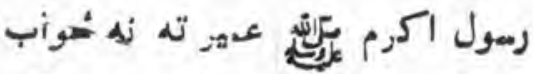

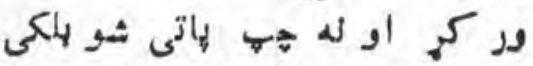
ورته ولي ويل: (كلد اكر سنااله التحية

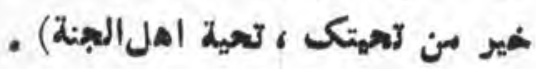

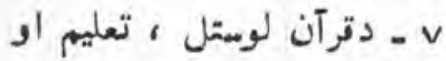

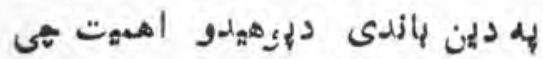

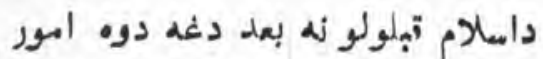

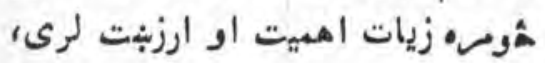

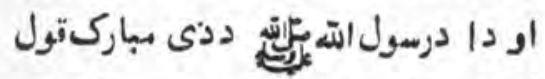

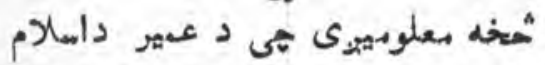

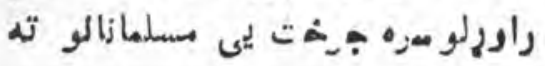

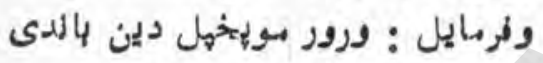

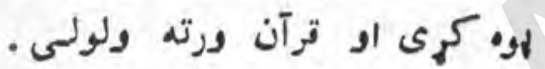

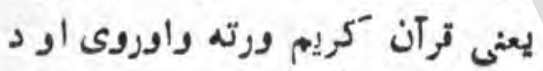

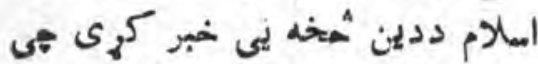

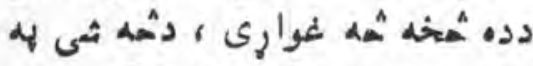

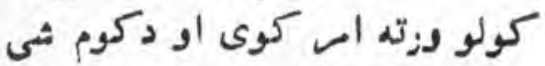

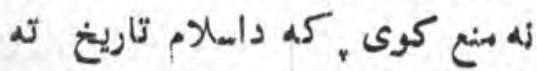

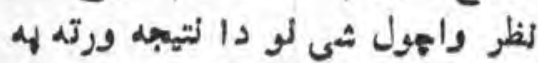

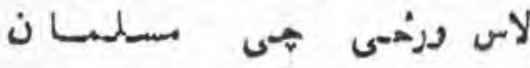

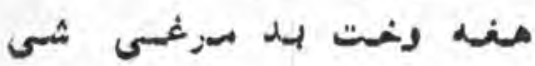

اود ملاكت كبلدى كل الريوزى ثى

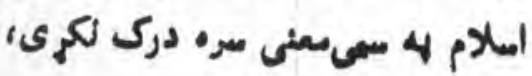

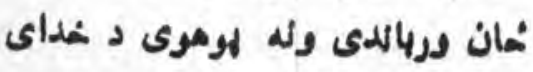

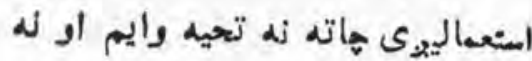

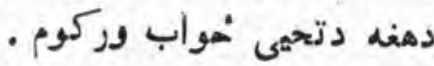

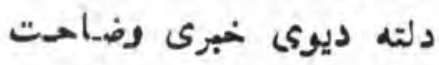

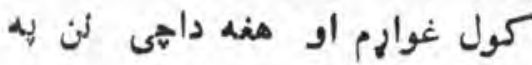

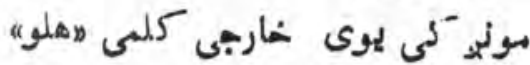

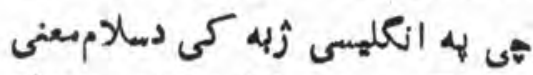

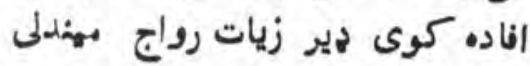

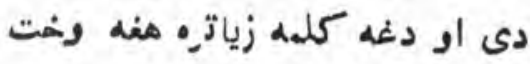

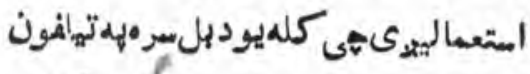

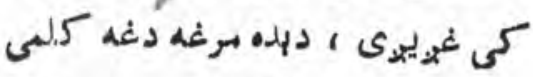

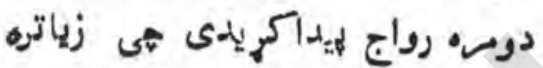
خلمى مخذكى لدى ثي تيلفون كى ريو

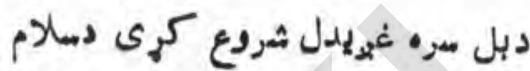

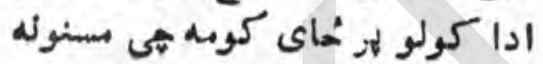

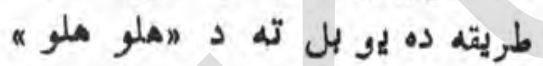

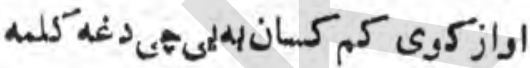

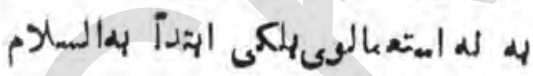

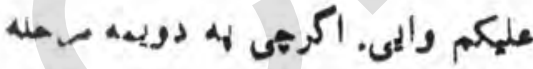

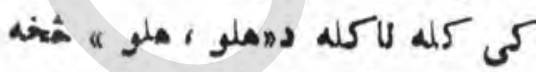

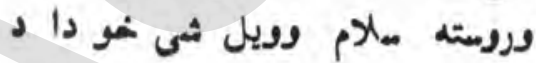

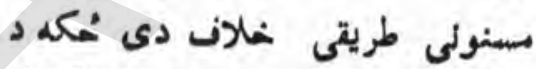

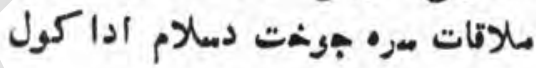
ضزورى دى .

زه دا لموايم ثي ايا دفه كالمه

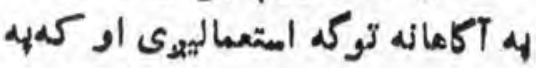

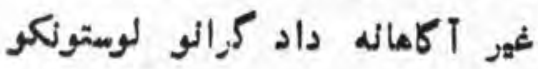

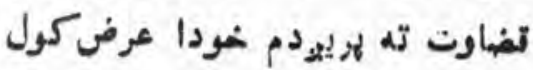

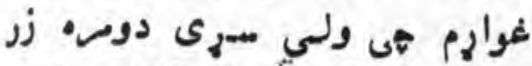

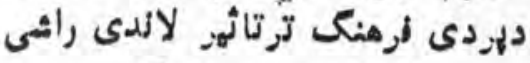

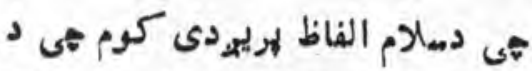

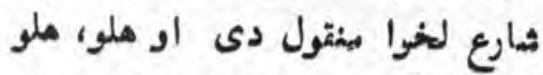

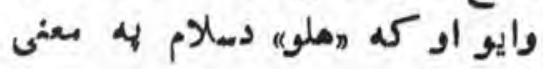

سايقه به هام كى كيول ضرورى دىى

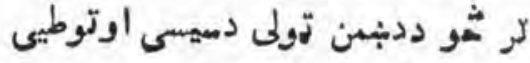

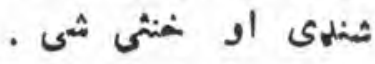

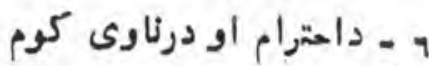
الفاظ او كلمات ثيى مسلمانان يلى

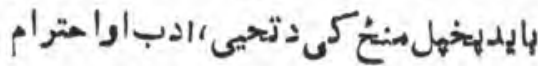

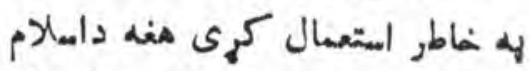

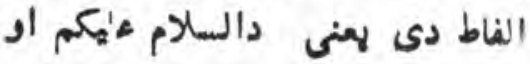

وعليكم السلام ) دى هغه تهيات الفاظ او يا هر هنه دمتور او طريته هنه

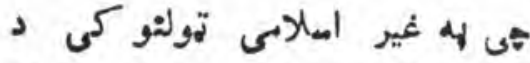

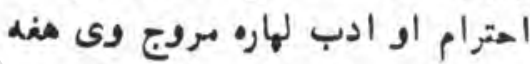

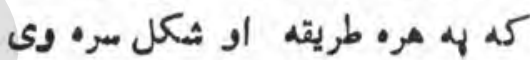

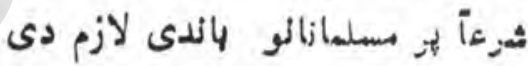

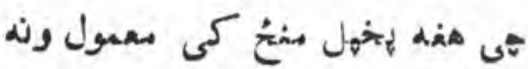
كرئشوى ترشوغير اسلانى فرهنى

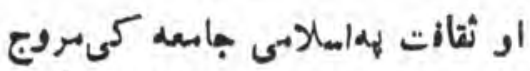

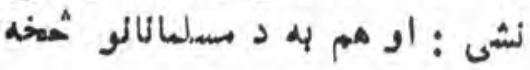

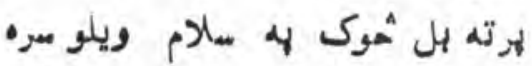

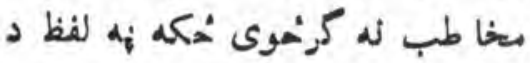

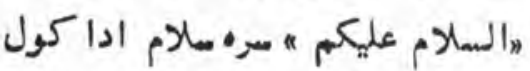
اي دهنى رد لهمه "اوعليكم السهالامبسره

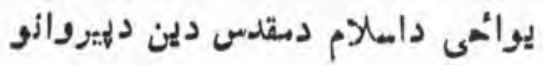

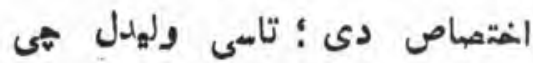
رسول كريم (ص) عميرته دهنه دتجحيى

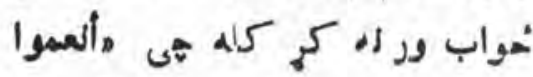

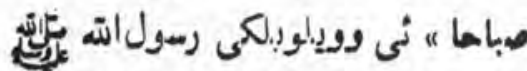

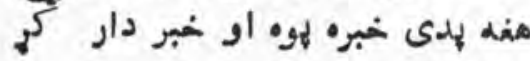

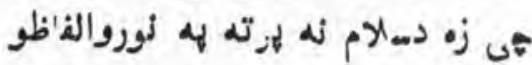

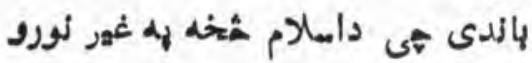

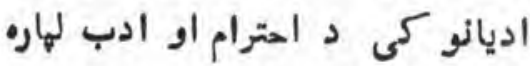


له لورى دعوت وركول دهربسلهان امساسى او مةصهدى وظينهده ثطع احساط

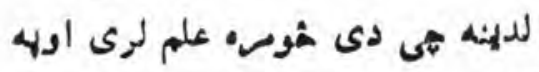

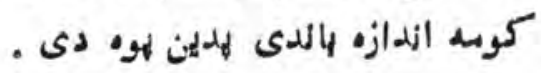

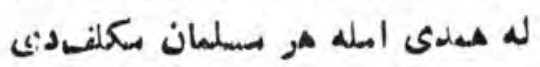

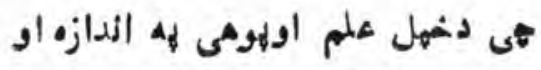

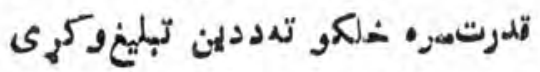
او سمه لاره ورته وبنائى او يوائه تئي

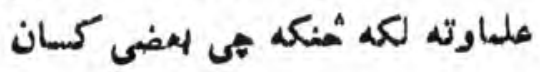
ككر كوى ثى تبليغ القط د علصاز

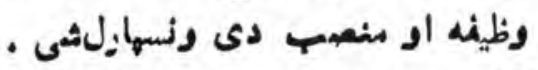

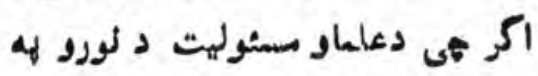
المول دروئد اوستر دى . خمكه موليم

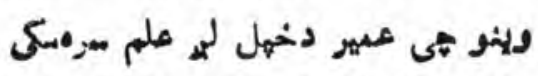

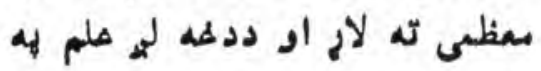

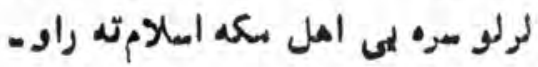

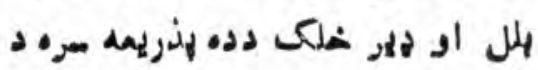
اسلام به دلين سيرف شيو.

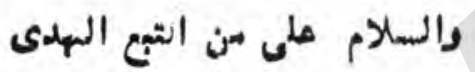

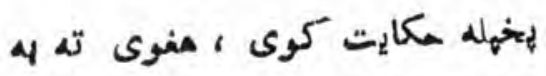

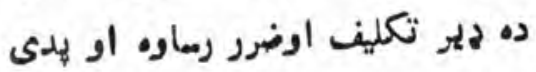

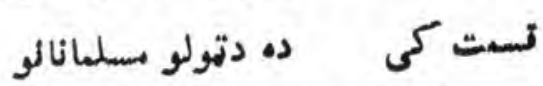

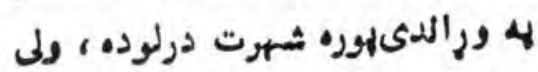

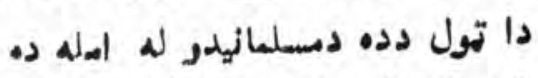

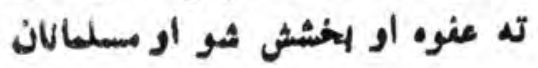

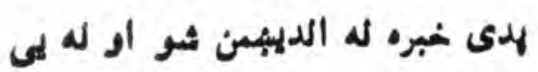

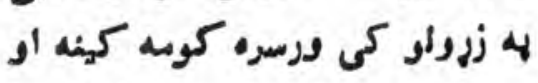

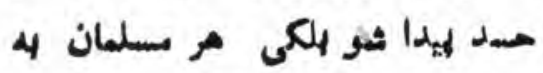
ور سره د ورور به شان مهنه اوستبت ساته مادى او سعنوى ماللى اد بلدئى مرسته او كومكى به شى ورسره كاؤ،

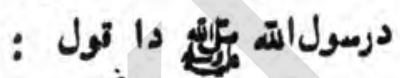

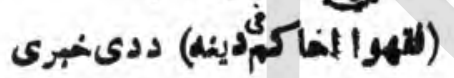

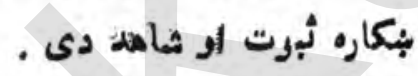

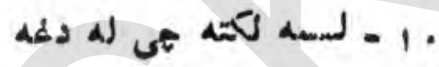

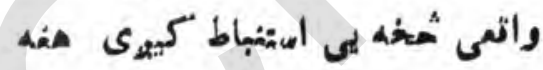

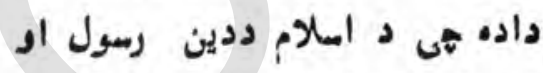

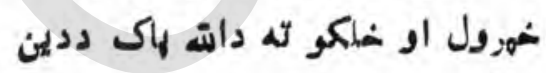

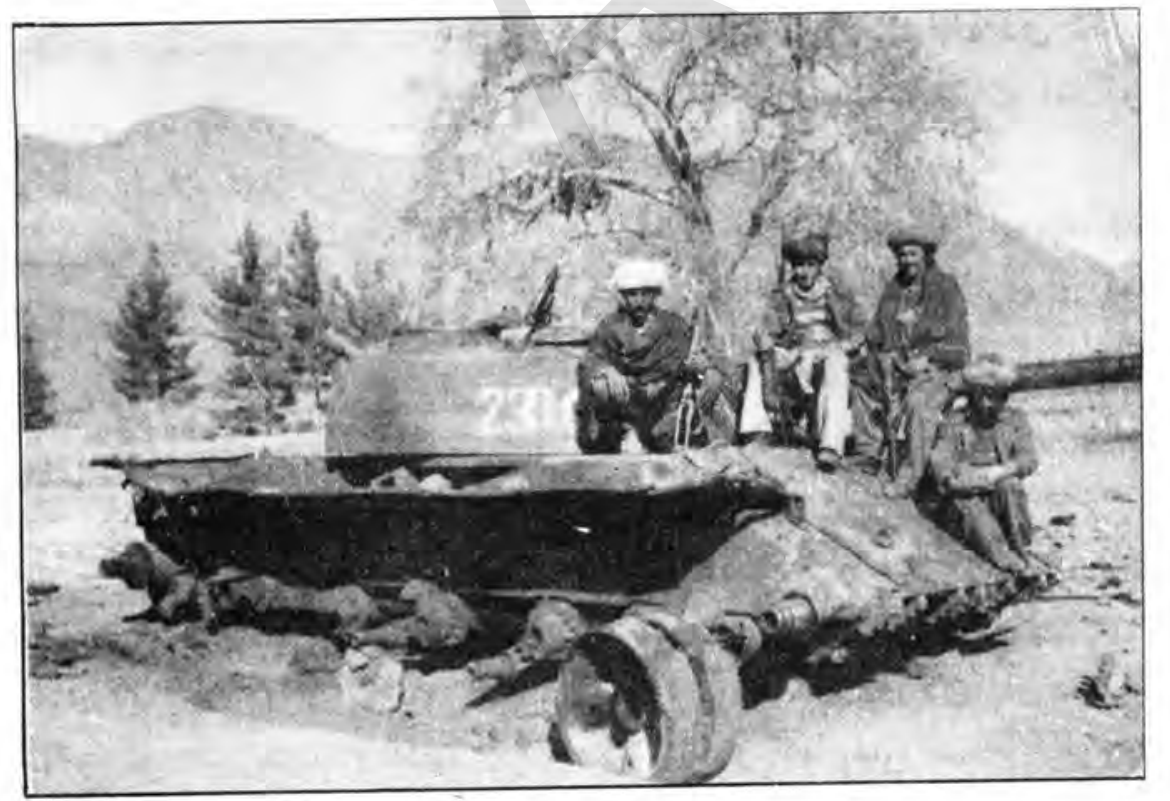

اود بنده -ملى وله بهزٔلى اودبيو اوبلدو

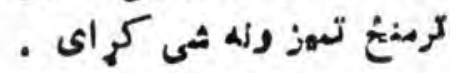

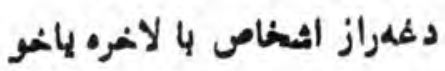

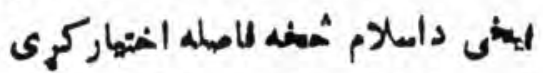

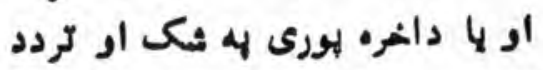

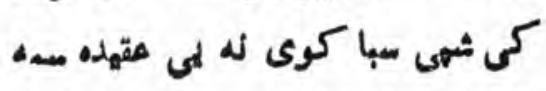

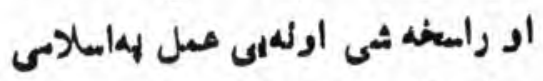

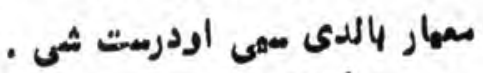

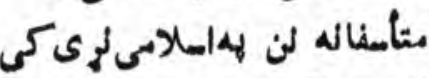

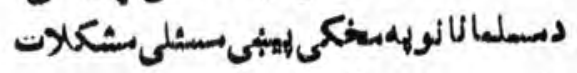

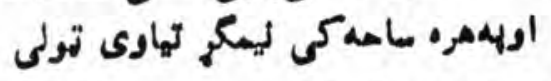

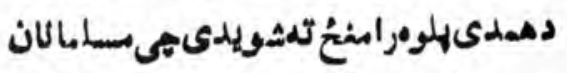
دهمل دلين ذيكمورو اصولو اوامكابو

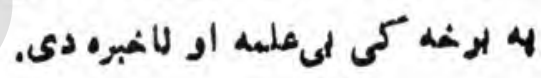

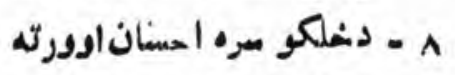
دالدو عفو كول ، دزرولو ثمخه د دماند

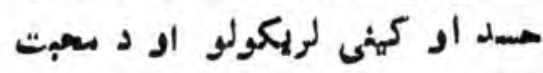
ليداكولو امبابدى.

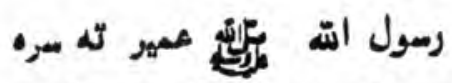

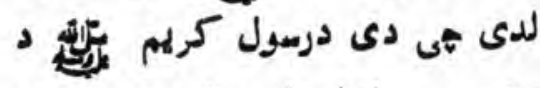

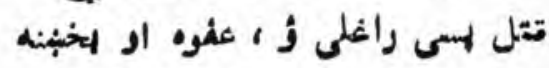

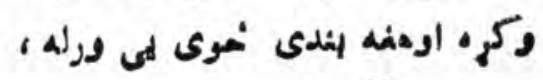

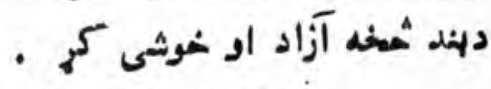

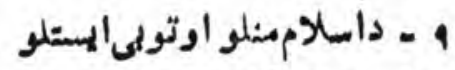
لوبه مئكنى تول كناهونه دموه او

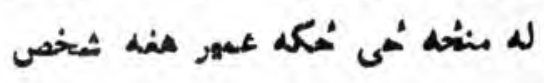

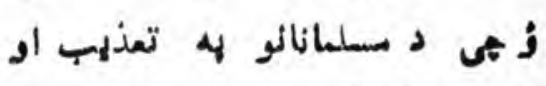

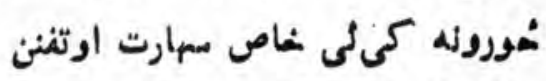

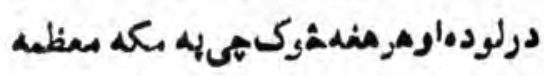
كى له اسلام مشرف شيوى دو ، لكه

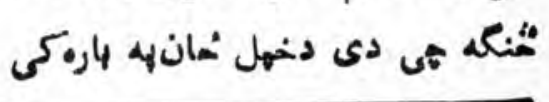


ترجمه وتلخيص : محهد نسيم " فقيزى "
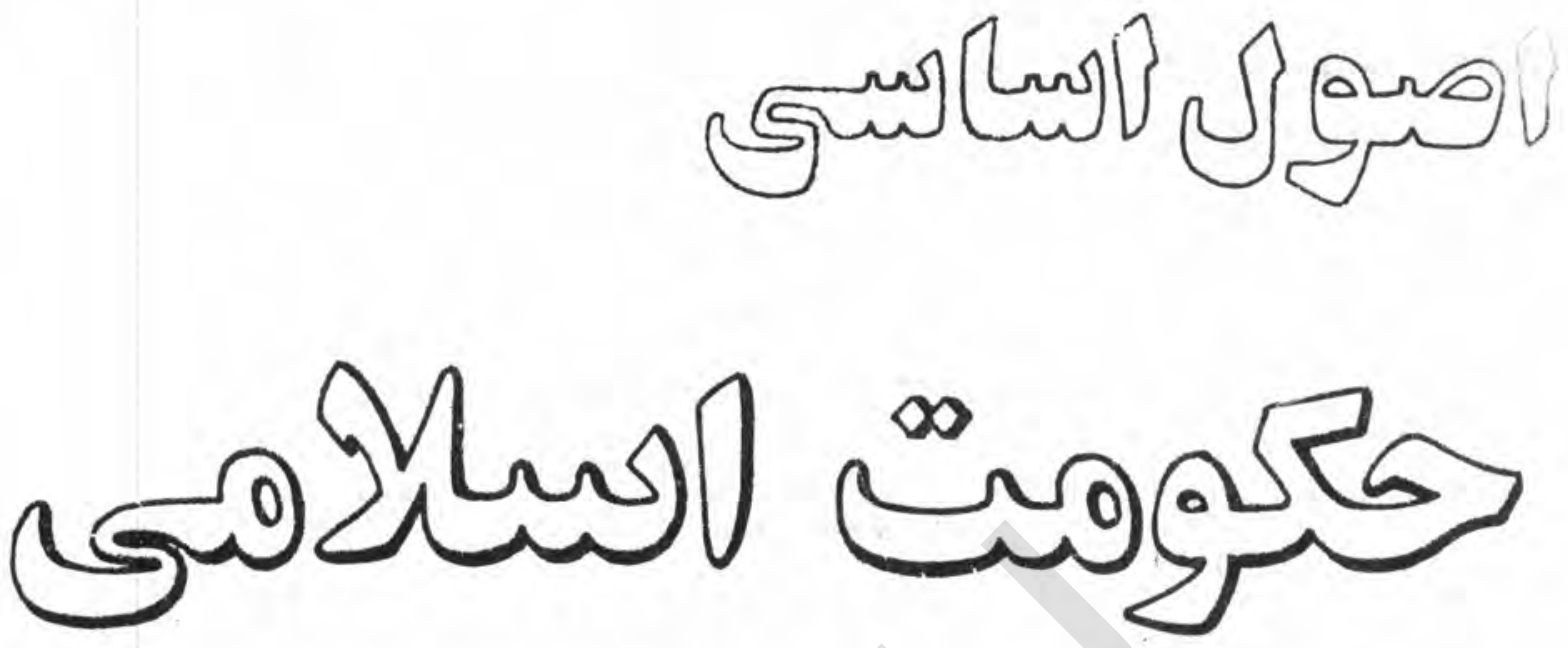

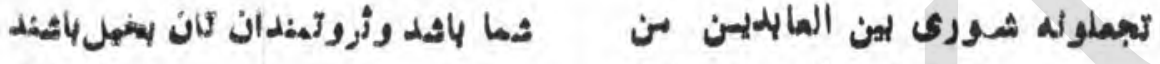

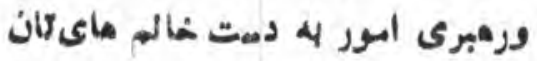

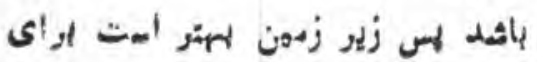

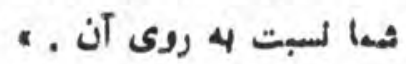

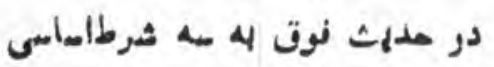

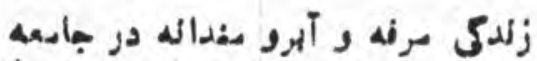

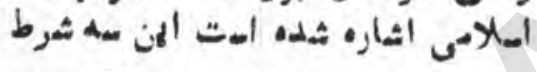

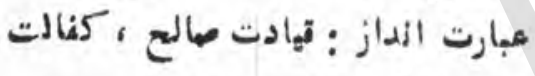

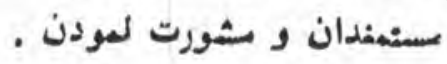

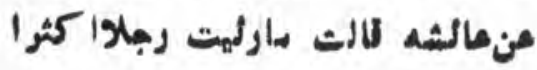

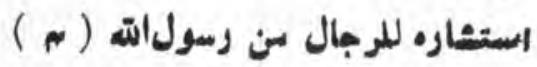

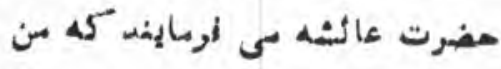

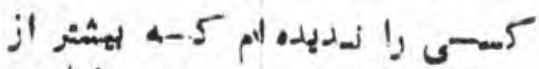

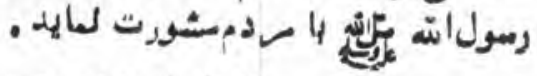

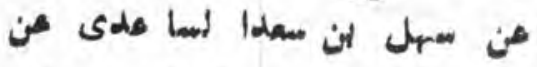

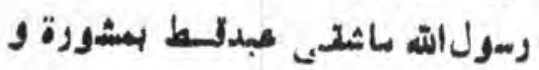

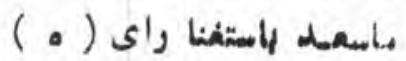

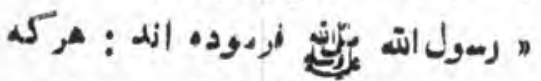

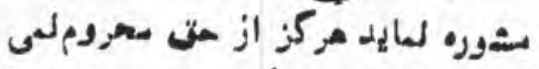

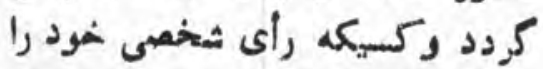

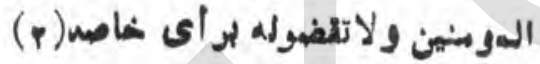

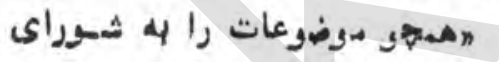

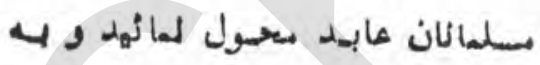
رأى المرا:ى عصل لكنهيد. "

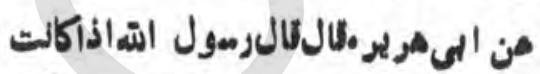

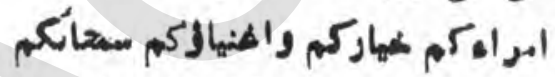

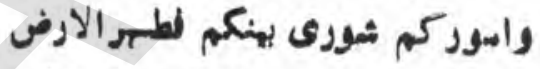

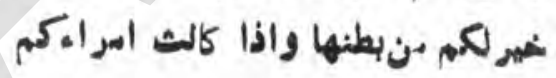

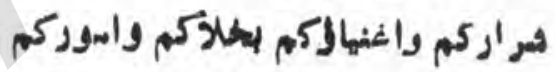

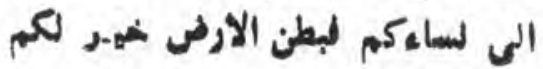

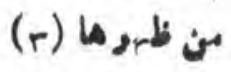

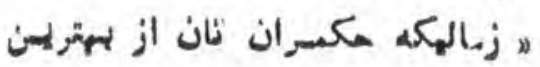

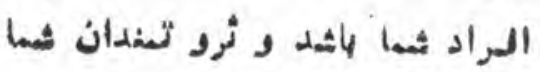
متخاوتمند باشثيد و معاملات و و ابمود زلمدي ار الماس شهورى هل و لمعل

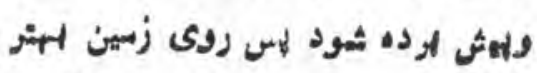

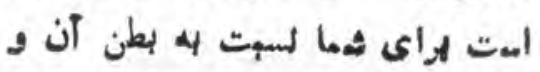

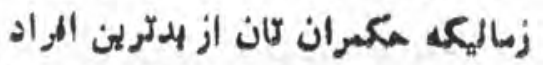

اهادئ لهوى (م) درباره شورى

كن على قال قلت بيا رسولاته ان

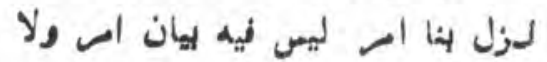

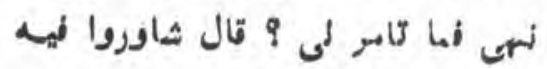

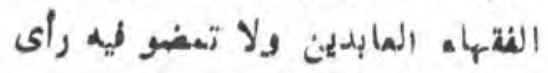

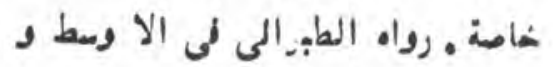

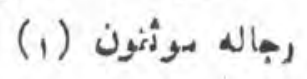

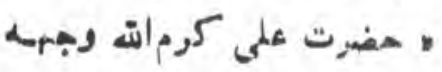

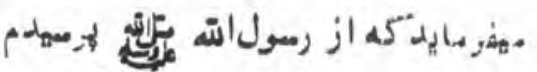

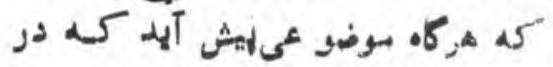
مورد آن له امششده باشدونه لمهيلس

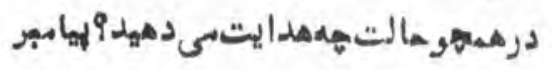

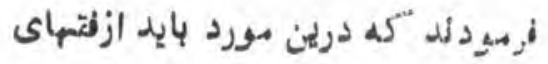

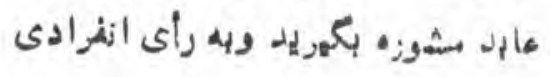

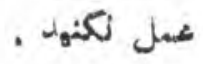
مسهان در لاسيخ عهدانه الهن

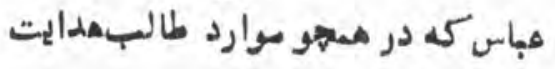

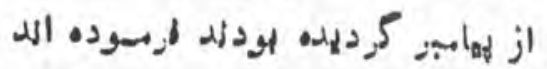




\section{VY}

خدا و سيت رسمول بايند رأى ثما

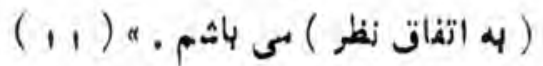
رئمس دولتهق ندارد تاراى شورى را رد نهايد

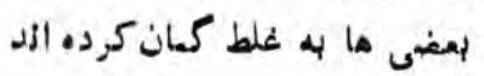

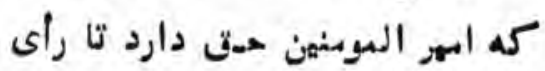
وفيعله شورى را رد و ويتو نمايد ،

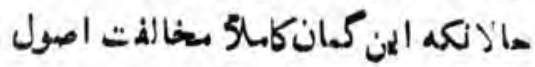

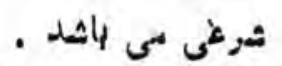

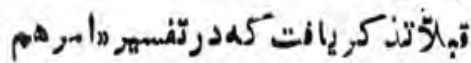

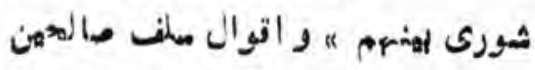

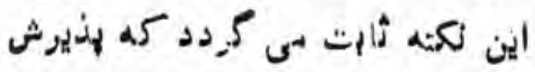

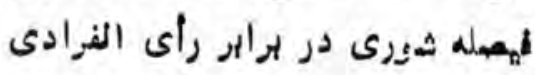

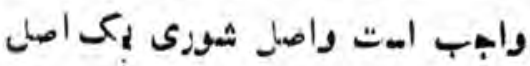

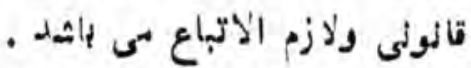

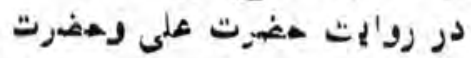

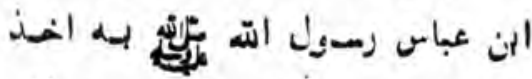

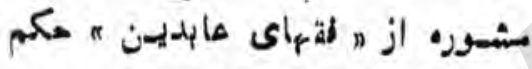

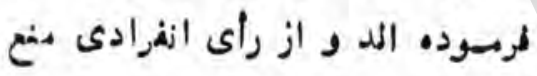

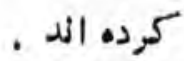

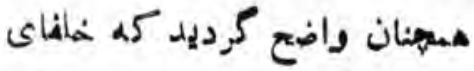

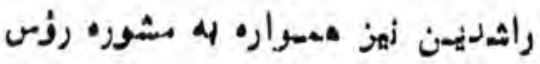

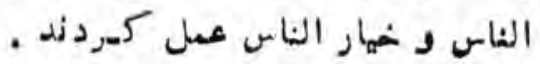
رويعمرثته اسهاسى ترين بمورد اختيلان

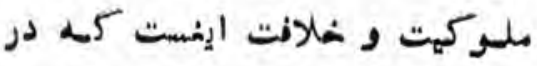

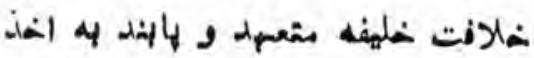

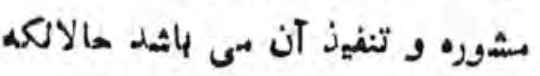
هادثاه رطلق المثان وخود كامهل بوده

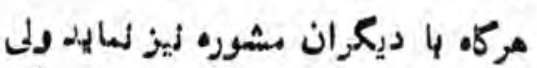

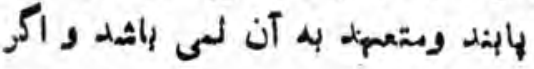

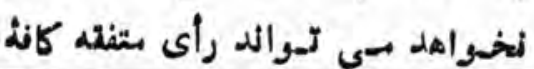

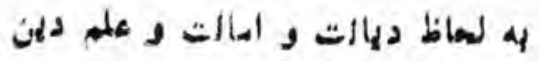

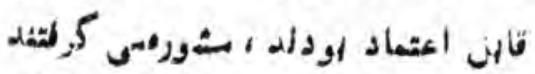

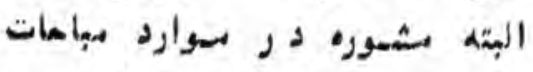

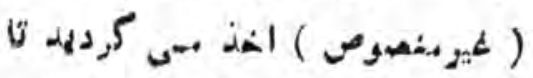

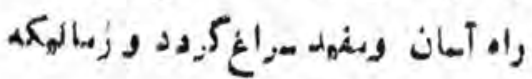

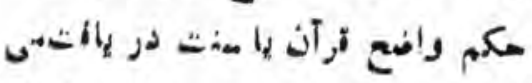

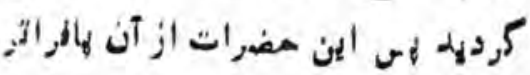

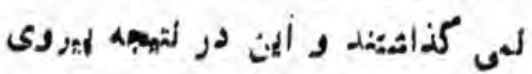

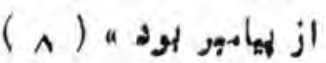

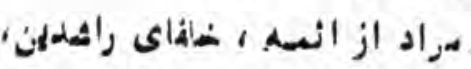

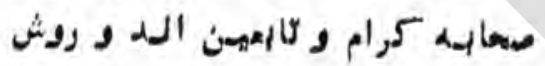

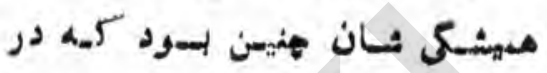

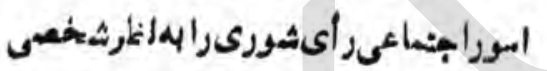

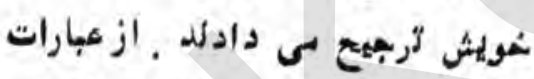

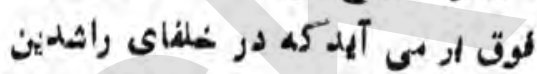

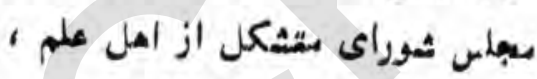

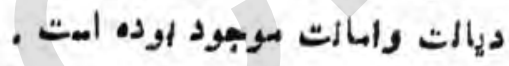

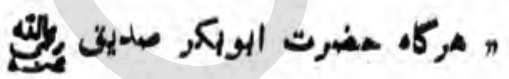

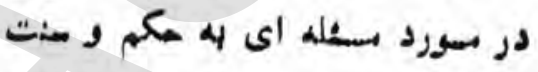

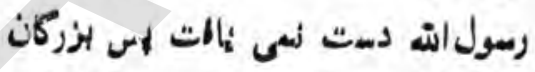

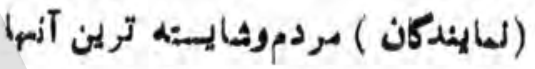

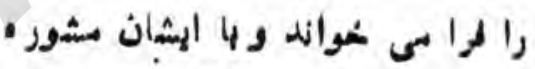
بـ لمود دهركه به الفات آراء لميصله

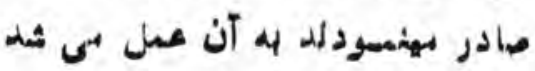

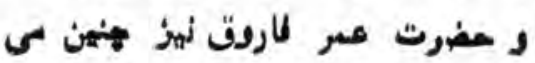

$$
\text { (a) ( ) }
$$

اعضأى مجلس ثورىدر زمان مضرت

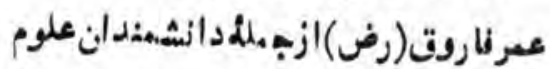

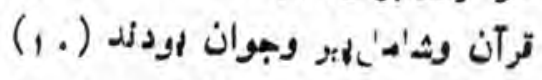

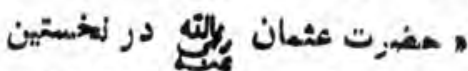

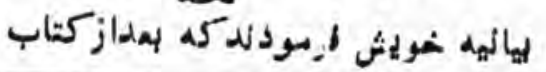

كافى نيدازيد ( بستبد الرأى باثهد ) هركز

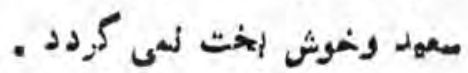

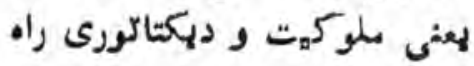
شقاوت و بدانختى و لذظام شوراى راه

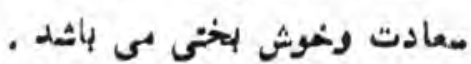

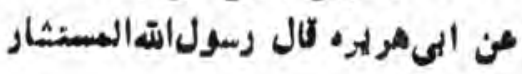

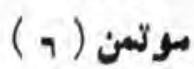
"

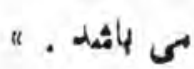
ليعنى عضو شورا بالهد ازلهاظ دولاكت و اسالت كاملكا بورد اعتهاد باثهد زيرا مشوره شمود بكى لوع امبالت

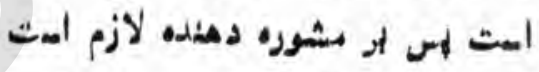

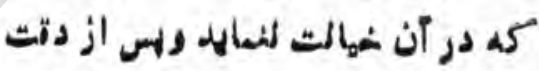

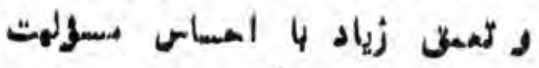

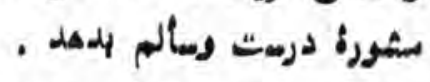

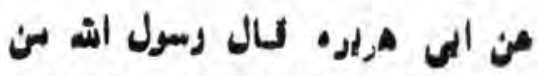

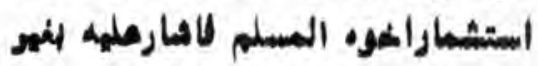

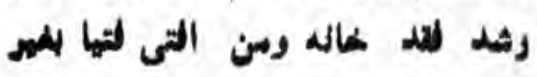

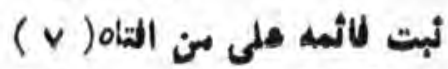

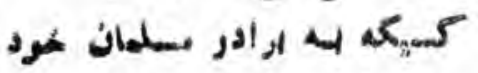

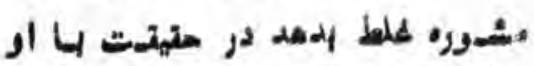

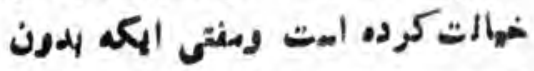

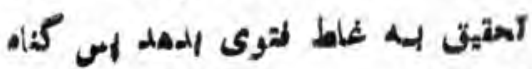

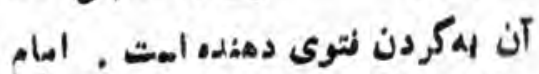

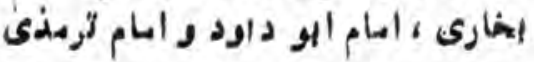

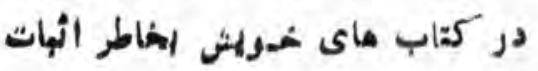
هزورت واهموت ثورىىو شيثوره لاه

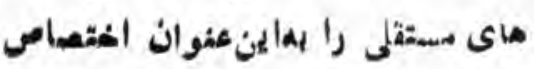

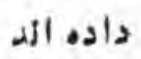

خلفاى راشلهين وشورى

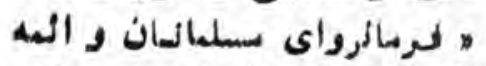

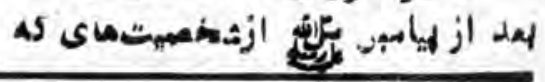




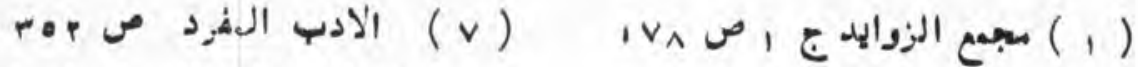

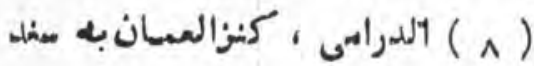

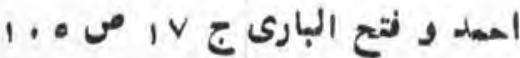

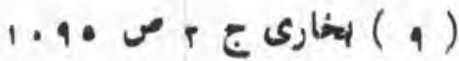
94 94 (1, )

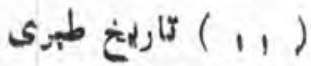
Tा

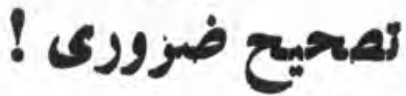

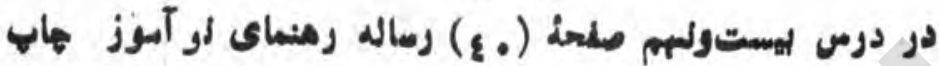

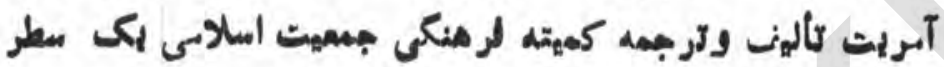
از خطاطى وهاب باز مالدهامت.

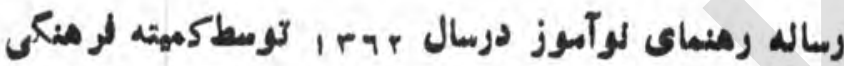

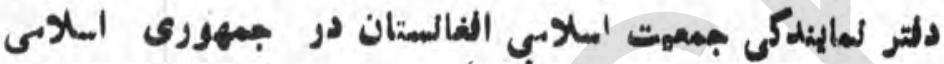

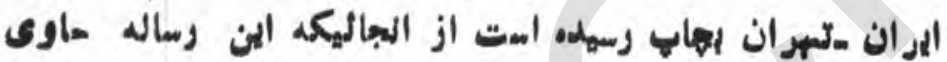

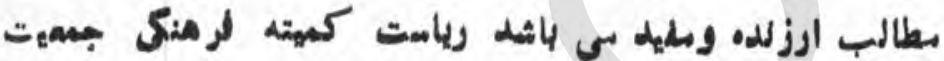

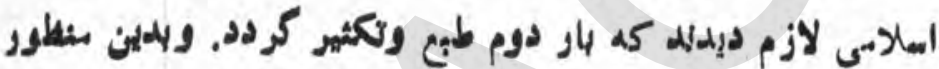

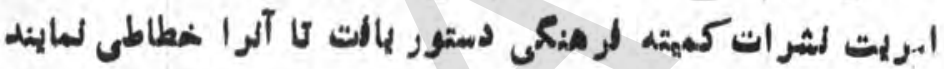

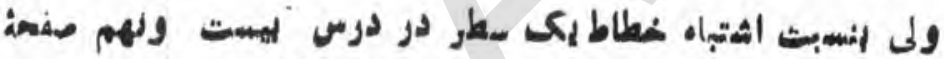

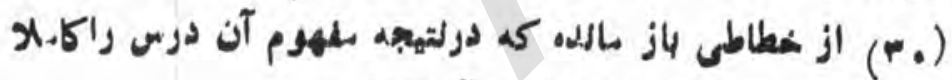

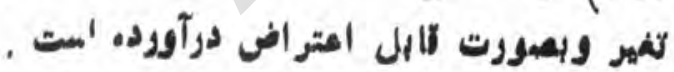

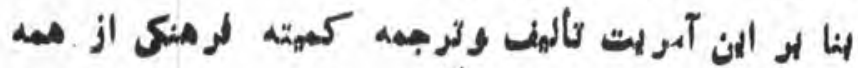

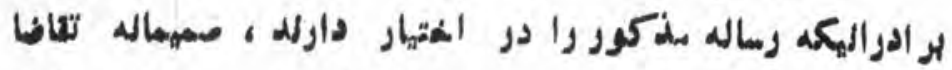

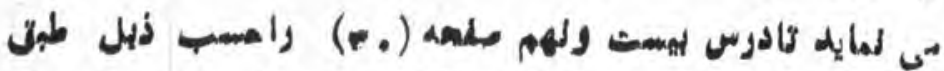

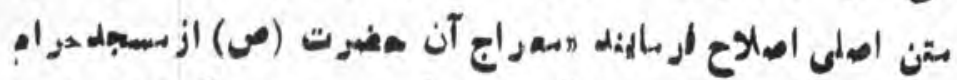

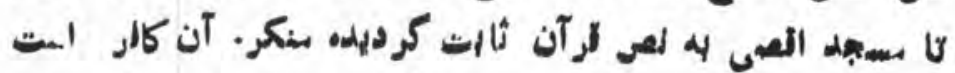

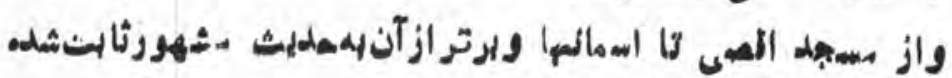

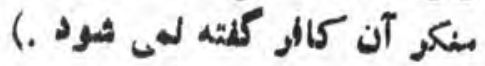
اداره وأليف ولرجمه
ملت را ليز ود نهايد . مايد. دلهل ديكريكمثثابتسى كميد خليفه

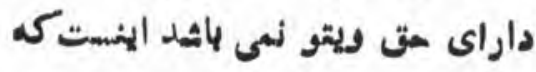
خلينه تموسط مجلس ثدورى التخاب

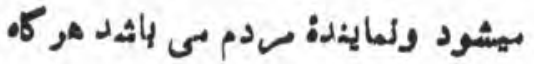
زيصله شورى را رد لماهد در حقيةت به اعتماد مسدم خحاتمه داده است .

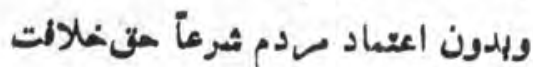

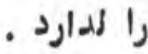

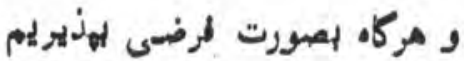
كه خليغه داراى حق وييو بى باثهد

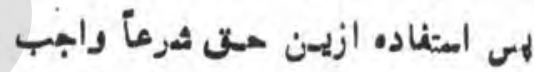

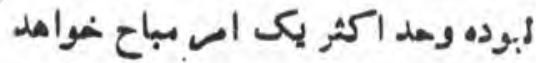

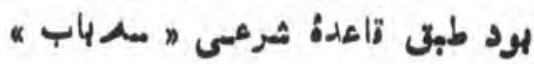

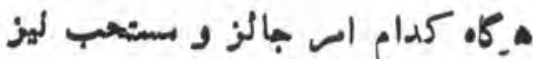

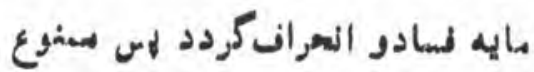

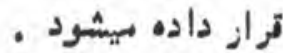

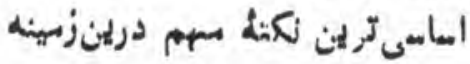

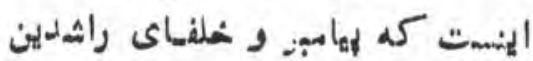

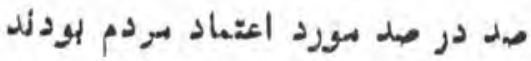

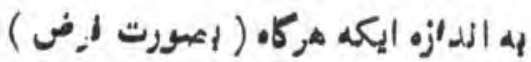

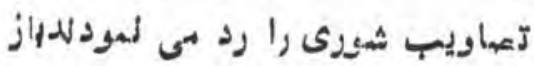

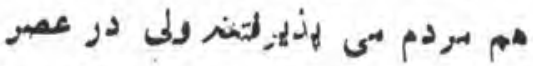

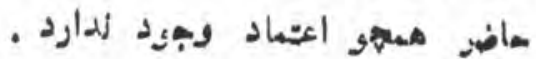

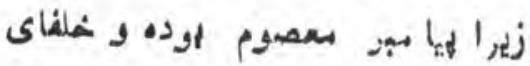

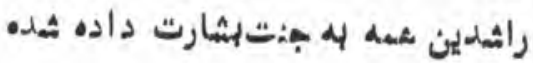

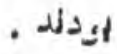


سترجهم: هبدا لتـدير هلطرته لـو يستده: : سولانيا مـودودى
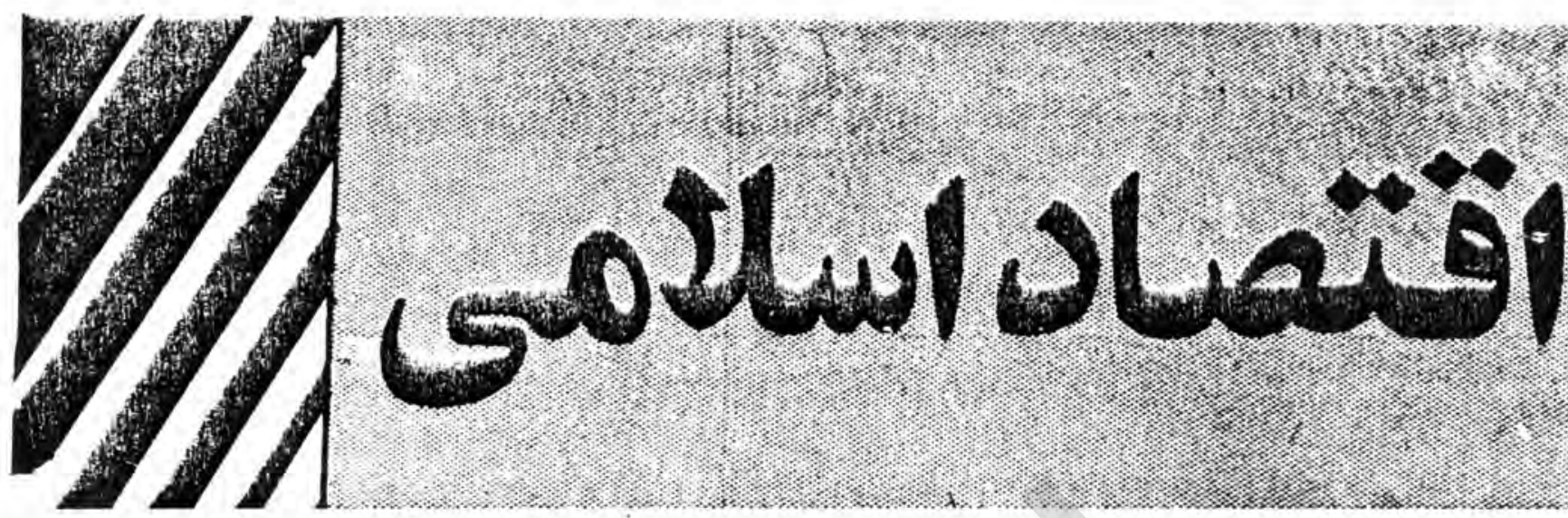

دالبين و سطرلكميلليل والنهار وآن كم من كل ما سالتموه و ان لهدو

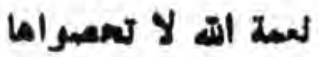

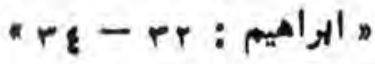

خداوند ذالهيت كم آسمالبه

و زمين را آنريده ، و از آسمان آب دات

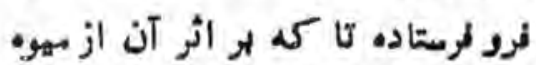

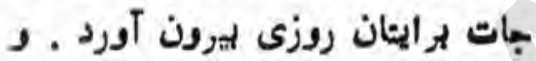

او كثتى ها را درمعيط تسبغير شها

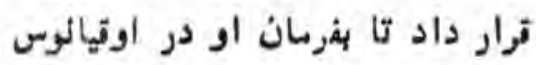

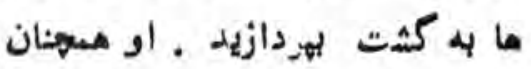

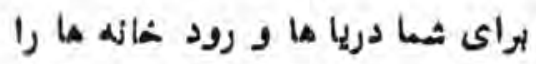
سيخر نمود و ماه و خورثهيد را در

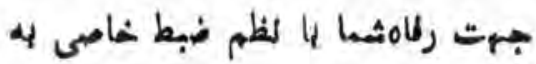
كردش در آورد و شثب و روز را هايند

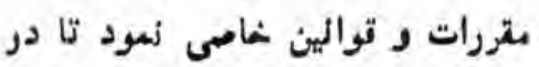

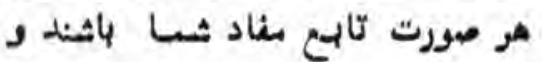
خلاصه آنهه را كم طلب لمودئ لماديد

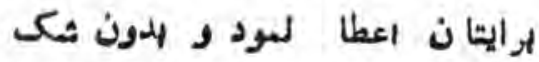

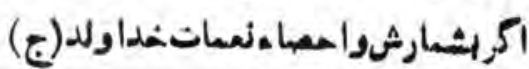

و موالذى مدالارض د بعل

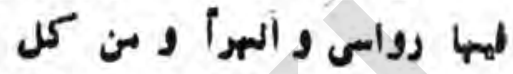
الثرات بعل ليها زوبمن الثنين

$$
\text { "رعد م: رات }
$$

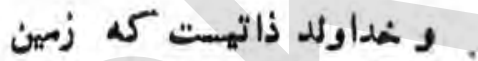

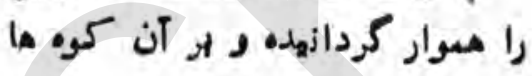

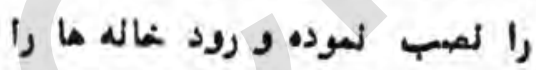

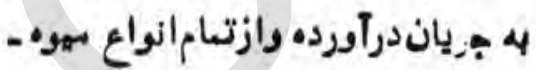

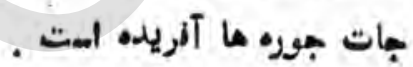

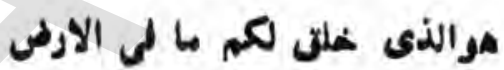

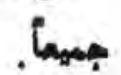

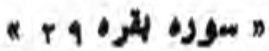

اوست كم زمين و آنهـه در لهر

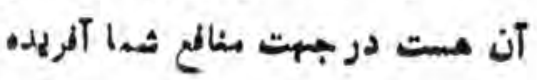
أست

اله الذى خلق السموات و

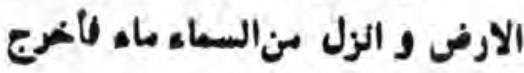
4ه من الثمرات رزلابكم و مسطرلكم

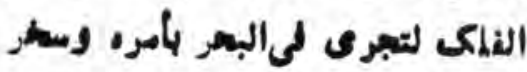

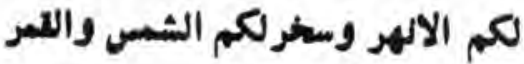

\section{زماليم اقتعادى قرآن}

- مقايت و والمهت ماى عينى : اولين و اساسى ترين هقيتت اقتصادى كه ترآن 4 تأكيد واهثام لمراوان لهان مى دارد آنست كه كنيه منابع و وسايل سماش النسان ، آزريدة

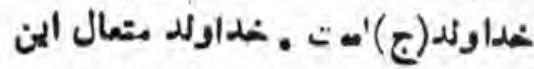

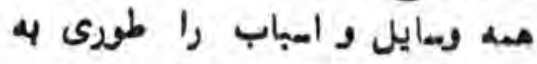
توالهن و ضوايط لطرت امتوار نمود

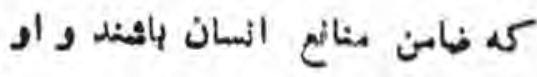
السان رافرصت داد تا ازآن استفاده

$$
\text { ليرد و در آن تعرف لمايد . }
$$

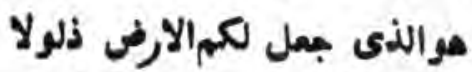

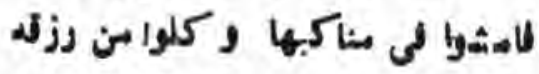

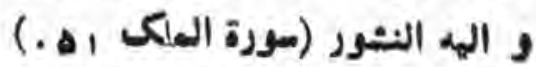

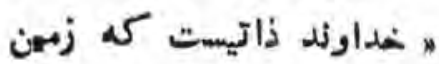
را إراى ثيها رام كردانيده تا دربهمهه

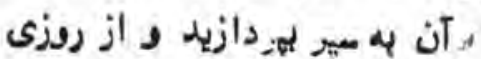

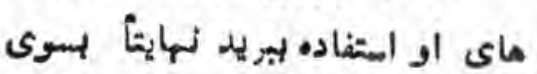

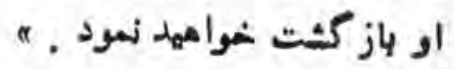


م-ائبات مقدالكيه ت شخهمى

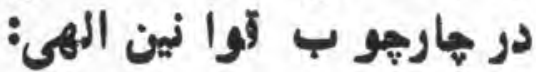

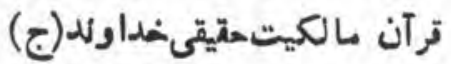
وبرمبنى حدود مقركرده آنمالكهي

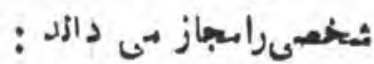
لاتأكلوالهوالكم ايتكم بالباطل الا ان لكون تهارة عن كر الم منكم.

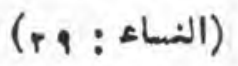

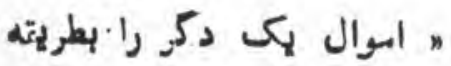

هاى ثا بايز ناتهوريد مكر آنكه 4 رضائيت درمهان شمها تهارت صورت لهائر نانكيرد

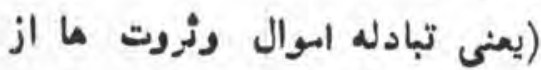

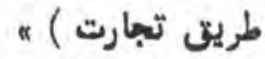

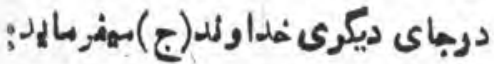

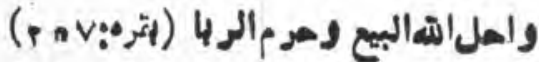

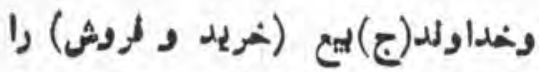
ملال ومود ( اخدذ بهره) ) را هراء

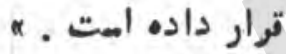
وبه ادامه آن هيند آلت لهد

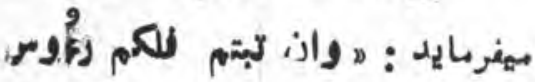

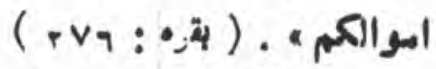
" واكر از سود شوارى توه4 نموديد آنكاه شهما سمتهق رأسالمالة

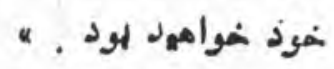

واذا لهائتم بلدين الى اجل

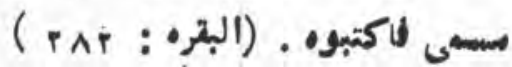

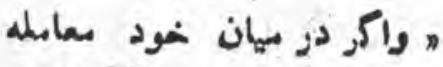
القرض تموديد باله دستاويزات واسئاد

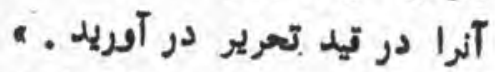

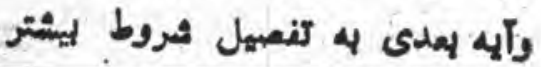

صآلها ( توم مدين ) به هضرت

ثعهب (ع) اظهار داشيتندكم ايثمعيب

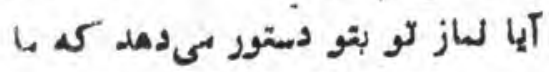

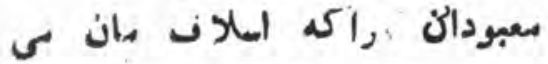
لارستهدند ترك بكونيم ودر اموال و

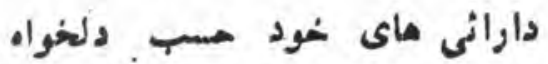
"تصرف ننغانيم 9

قرآن به هيز هانيكه انسان به

صصواب ديد شُود هلال يا هرام قرار

بى دمد عنوان ,كذب" بهيكذارد .

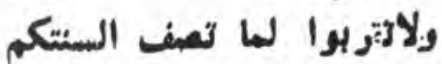

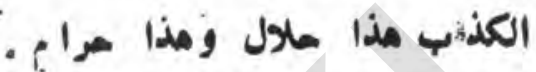

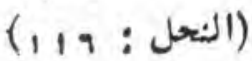

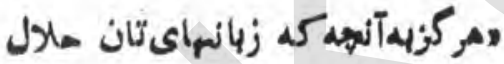

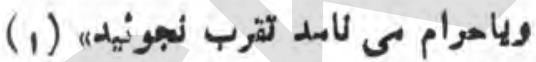

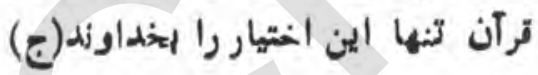
ولانب برحقاودرزمين يعنى بيى كريم

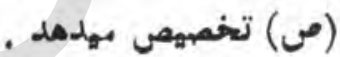

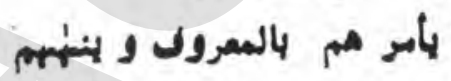

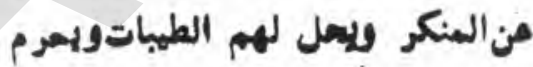
ملهم الطبائث ويغع هنهم امرمم هنم والا هلارلتى كالت عليهم.

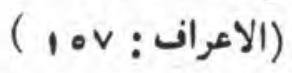

فرمانرمانخداولد (نبى كريم)

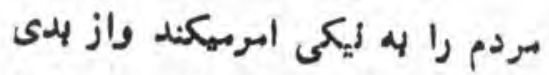

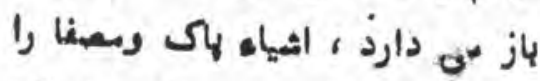

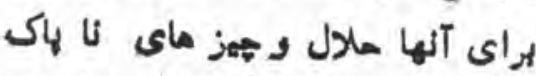
را بو ايثان مرام بنئرداله وآتهارا

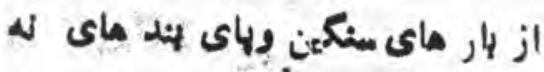

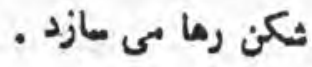

دست هبا زيد زا كام مرخواهيد كثت . ولقد مكنّم لمىالارض وبعلنا

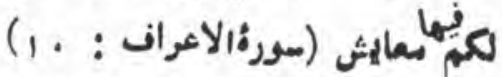
ها ثما را در لهنه زمسين اقتدار بخشهديم و برايتان منايع د ومائل زيليست تهمه ديديم ل...

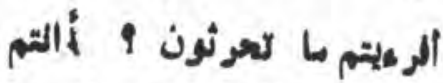
تزرعوله ام لهن الزارعون ـ ( مورة

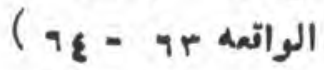

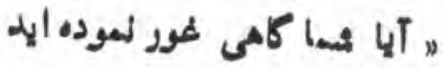

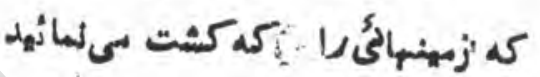

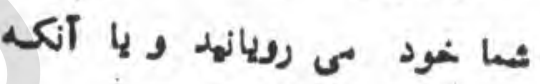

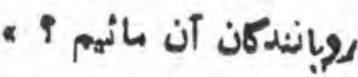

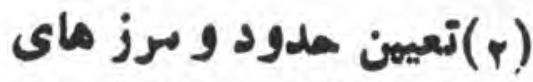

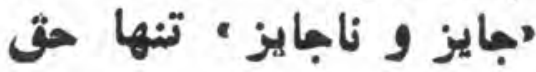

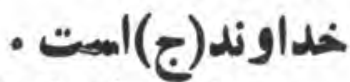

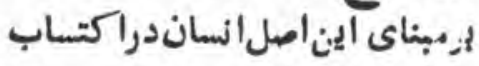

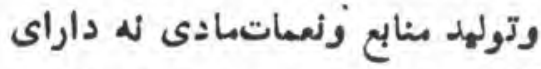

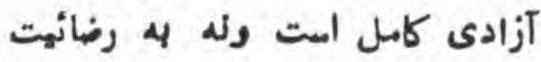

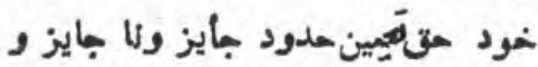

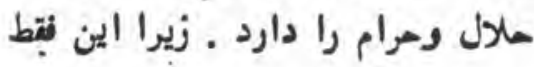

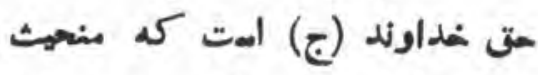

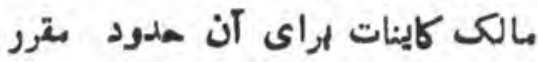

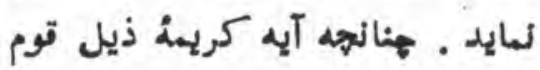

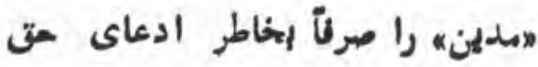
غير سعدود در امر توليد و معبرف

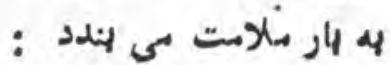

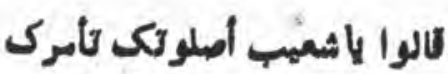

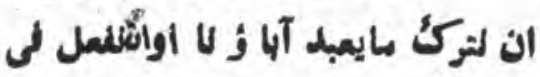

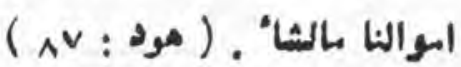




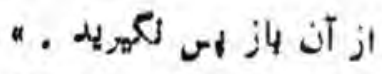

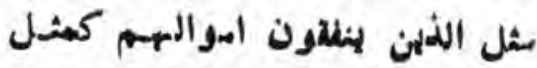

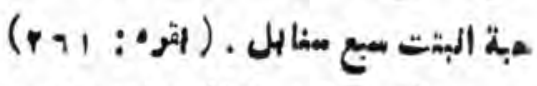
" را درزاهخداولد(ج) يهمبرف بميرهاندل هثال صون آلان هنان اهت كه داله

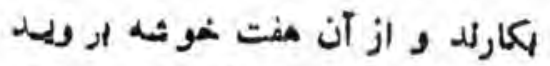

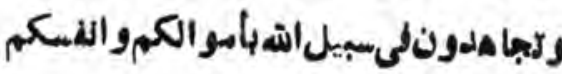

$$
\text { ( سوره العهف: (11) ) }
$$

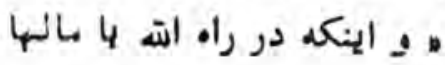

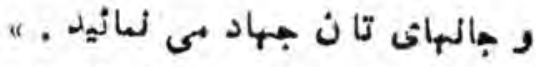

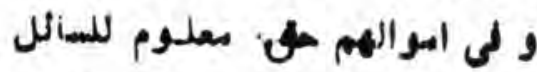

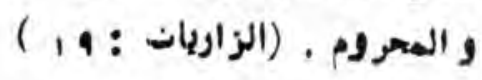

مايلل عا و معرود ديس در

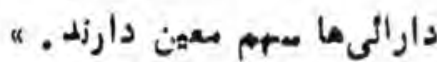
امكاه ومدايلت فوت ، 'لمعولرى

از ميكل مالكيت شخعسى در اسللام است ـ و جائى وبود لددارد كمآيات

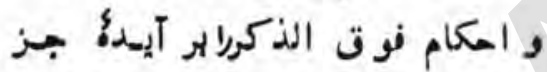
كالكيت شخغيى سمل لمود ويا ايهارة

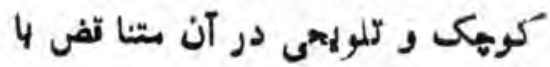
بـاله مالكيت شعضعى "لاش لمود .

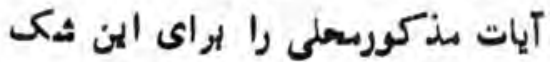

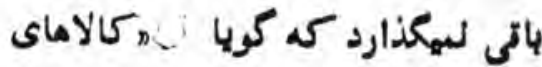
سعرأى ه در سعدوده مقررات سالكيت

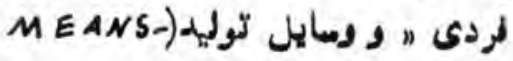
(-ofbro Duct

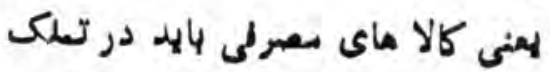

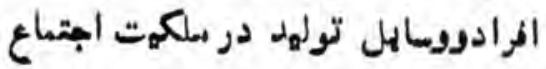

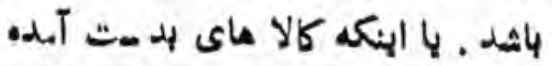

وآكواسله ايوم معطاده ( المام :

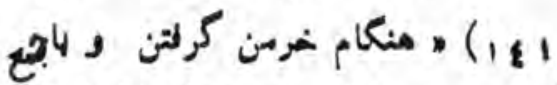

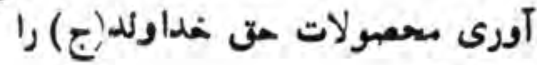

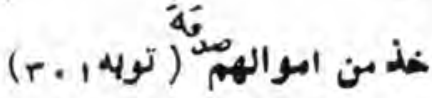

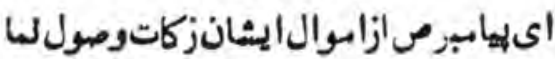
وآلوا اليتمى . . . اموالهم

ولاكاكلوا اموا لهم الى اموالكم لهم

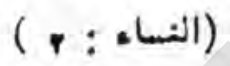

” الموال هدرمردكان را إليشان

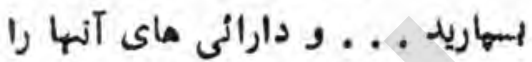

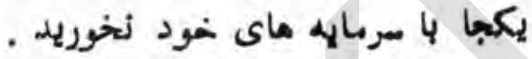

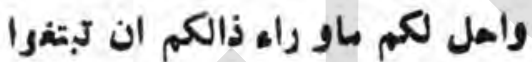

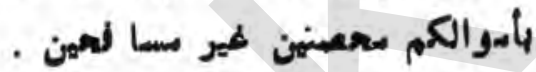

$$
\text { ( النساء : ( ) }
$$

" له المتشناى زلان نحرما ت

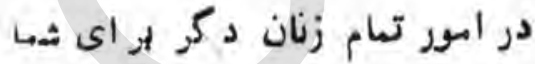

اجهازمداده شده امت تا در الهل اموال

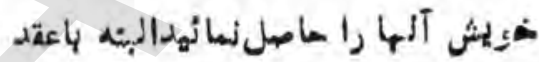

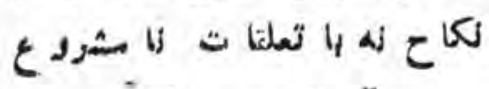

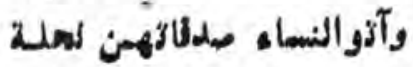

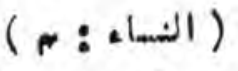

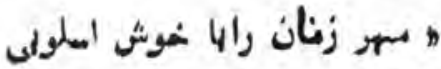

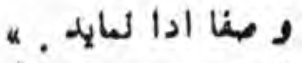

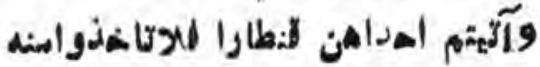

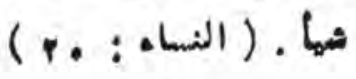

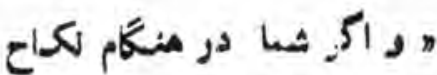

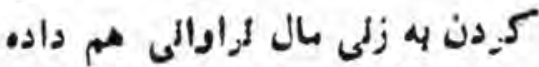

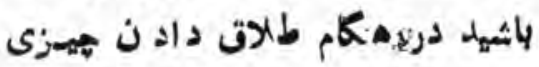

$$
\text { مى لمردازد : }
$$

وان كنتم علىسفر ولم تجدو

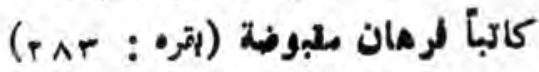

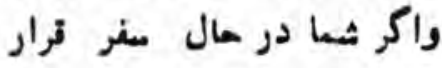
داريد وايزاى تحرير لثمودن دستاويز

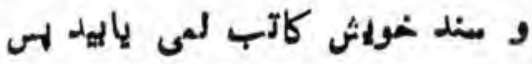

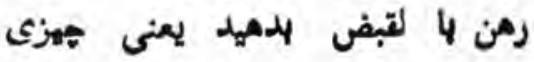

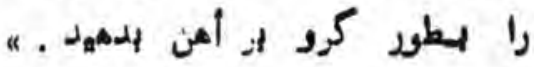
للرجالنعبيب مدا ترك الوالدان

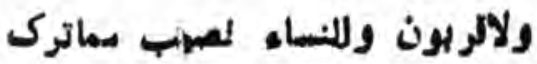
الوالدان والآر الون . هزدان از امهئن هتزوكى

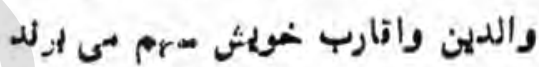
و زلان لهز در امدال متركس والديدين

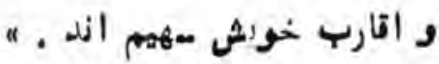

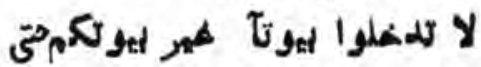
لستالسيا' . ( النور ) : :

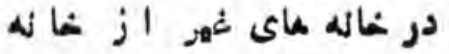

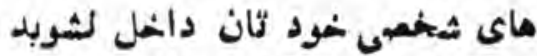

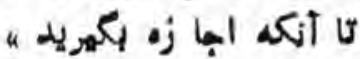

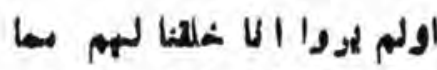
عملت اليدينا المأمألمملها مالكوذ .

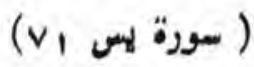

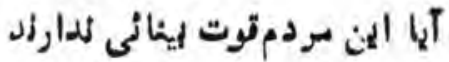

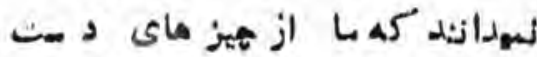

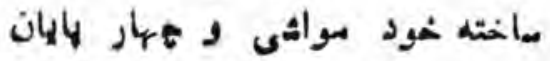

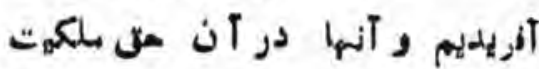
دارند

السارق والسارلة للهلموا الهمهما

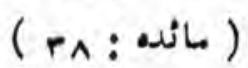

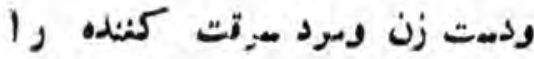


روز تمام روزىها د اتوات زميهن را

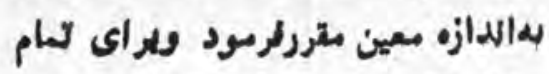

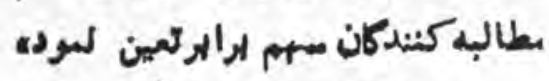

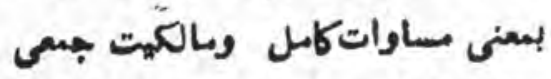

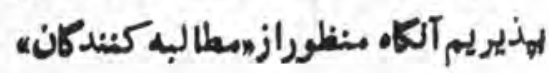

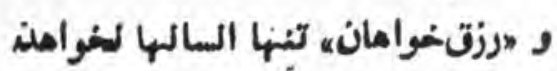

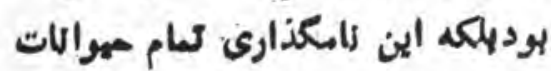

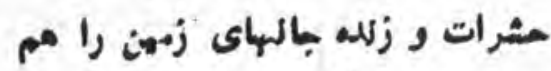

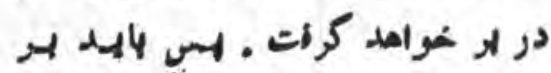

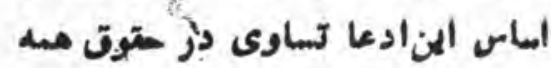
اين جالداران رعائي كردد و دائر.

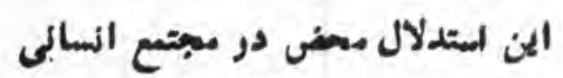

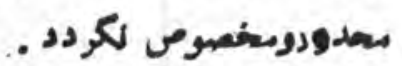

مبهنان تاكيدرآن براي كميى و سساعلت به مستمندان و لاتوالان ن جامعه به الين معنى لهست كدكرياقرآن

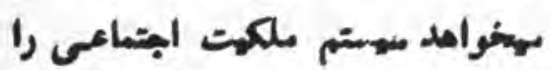

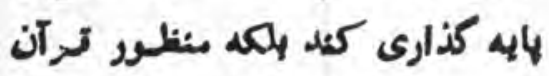
تنها صرفت يكى مقلار اموال و المعهد ثروتئدان جامعه راتى ريخ خروديات

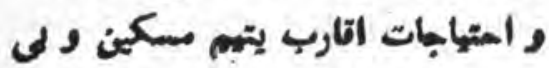

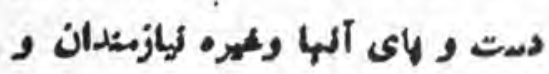

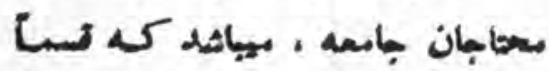
بوسيله حود آلان وتسماً يوسملدودلث

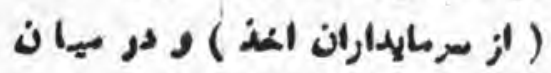

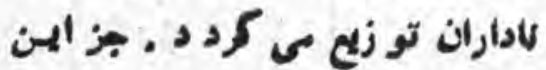
ملف ، الدارهوكنايغ و ورمز واستعاره

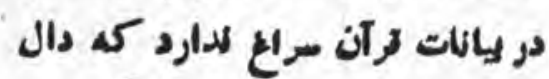

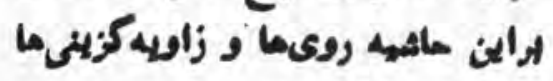
كيال هودازنها بالهد. دكمأهست كم كرآن دربلها مواتع

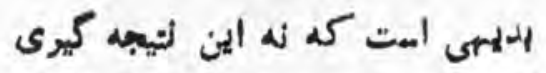

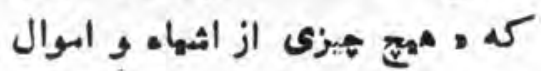

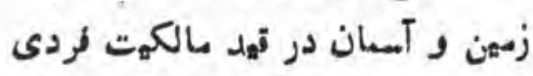

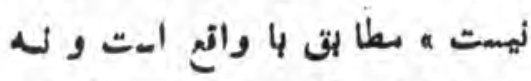

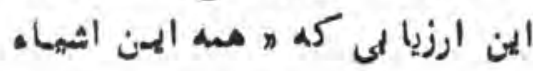

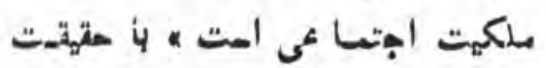

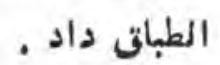

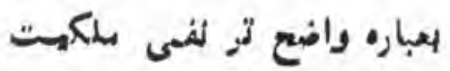

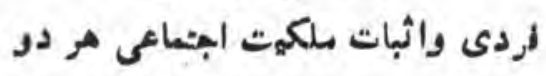

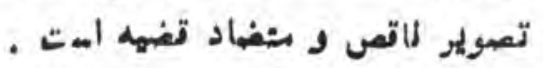

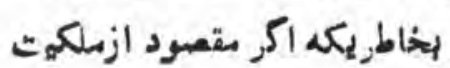

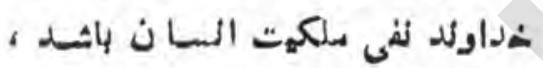

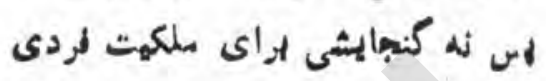

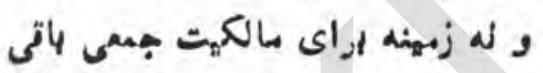

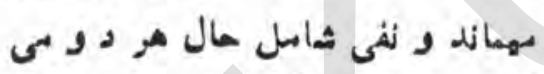

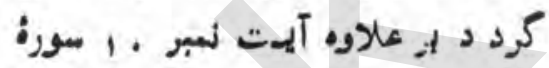

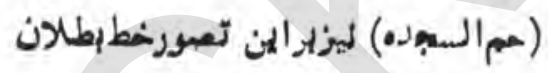

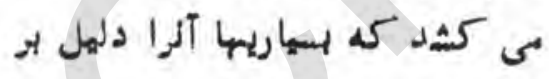

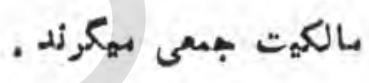

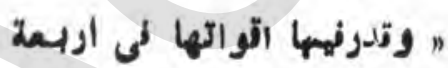

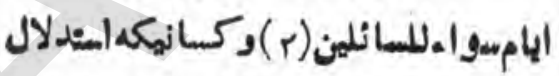
بيكنيد ( ترأن درين آيت بهسماوات

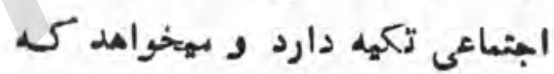
اثوات زمهن (هنأبع زمين) راسساويانه دئه

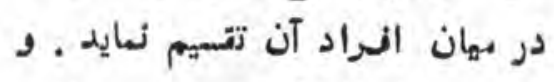

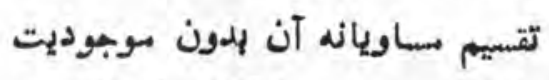

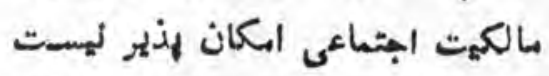
و لذا هدف قرآن درين آيث تثميل الثيل

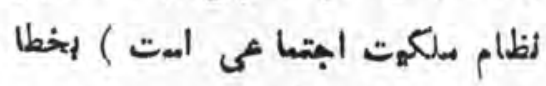

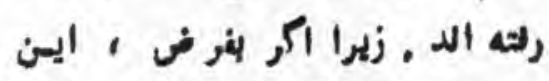

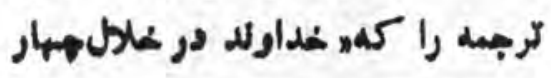

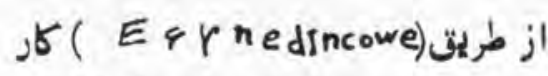

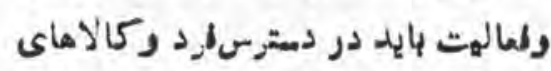
a a errnediucowe (a)

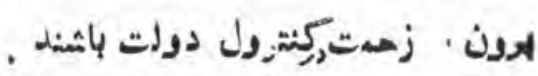
آثماراست كماثيهاء وثردونهايرا

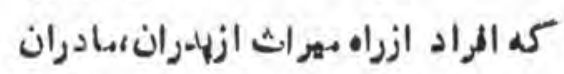
زنان ،هوهران ، برادران ، -خواهران

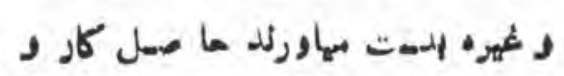
و تلاش آنها ليست هينانهد كماموال

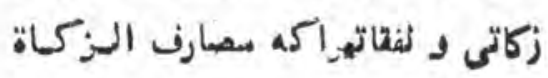

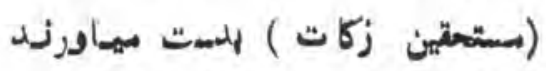

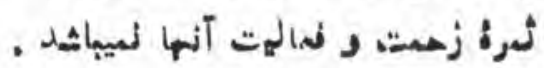

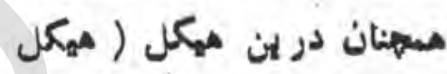
مالميت الردى دراسلام ) نشائلمازين لهين

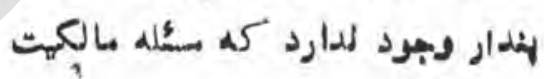

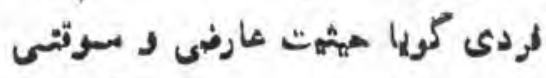

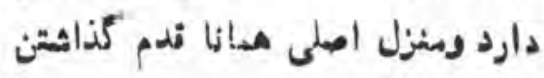

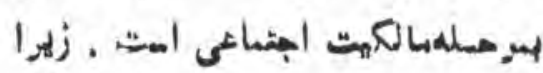

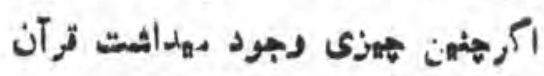

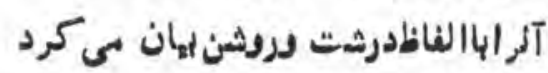

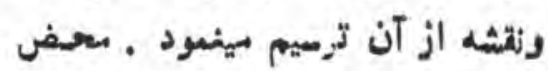

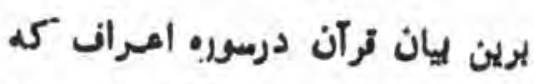

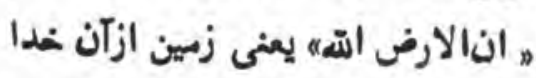

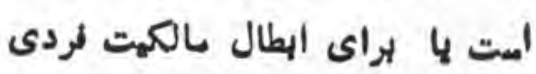
و ائبات ما لكيت جمعى كافى أيست. زيرا ترآن در جاى ديكر أهز

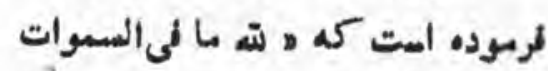

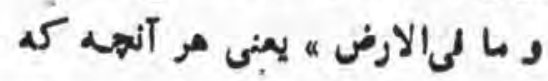

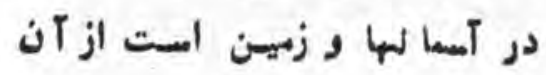

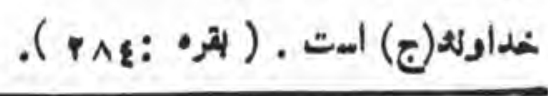




\section{VA}

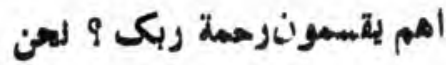

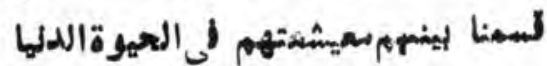

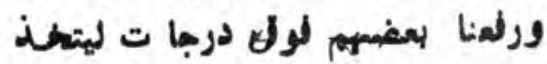

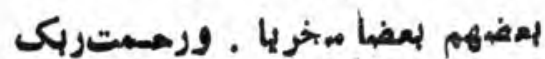
خير

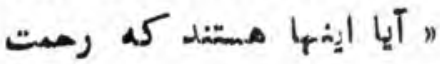
هزئوردكار تو ( نهوت ) را تقسمب مهى

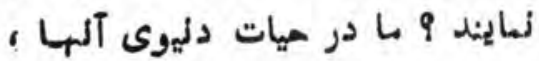
معبشمت آنان را توزيع لمو ده ايم د

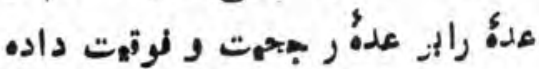

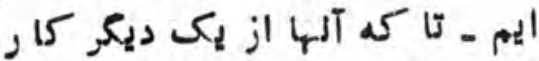

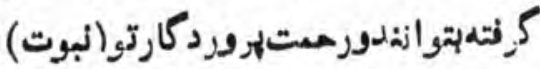
اززّزوت و دارا نى هائى كم اينهـا

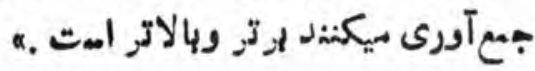
و طوريكهاز مياقآياتيزير ميإيدمخخالفين جيا بهر اكرم بار ما سوا لميكردوند

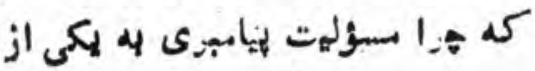
مورمايه داران مكه و ياطائف سمرده. (ص)

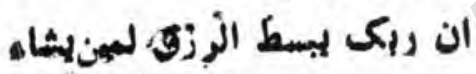

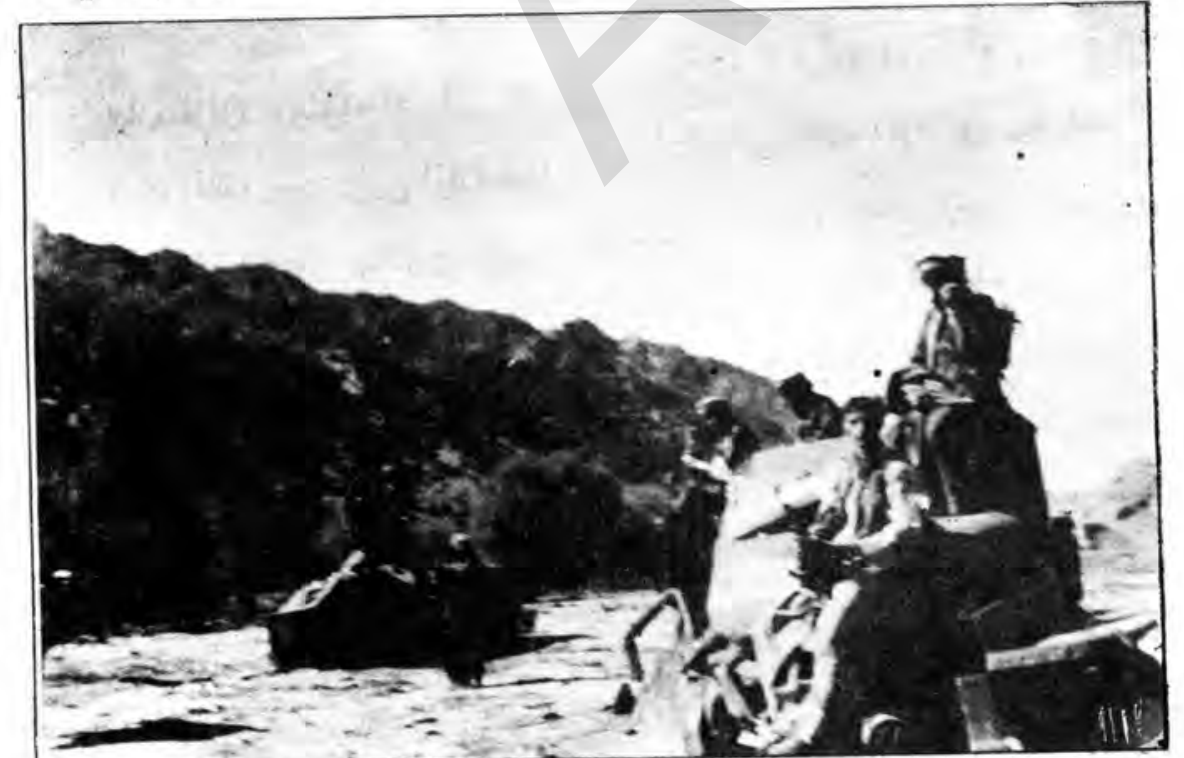

اكر خرورت احساس شود ، دمست 4 ملى كردن بعضى تامهيات و املاكى همهومى ميزنلد كل اجتماعى لهود ن آذظامن مصهالح اجتماع و لردىلودن

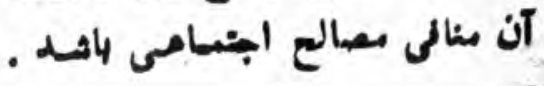
امانفى كلى تصاهب فودى. و تعلى همهومى و رزذيرش امدل كنتسرو ل اجتماع 4 دولت لز تمام لجيه هـا ى اقتعهادى منحيث يرى قاذون كلى و

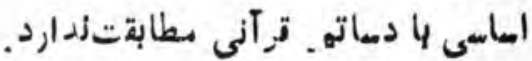
تهذيل غير الطرى و نسابجاى

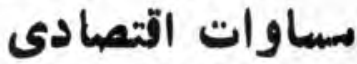
ترآن كريم اين حةهقت رامنيتث

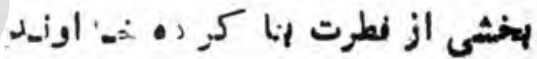
دانسته و مانزلد مهاير اثشيا ى ديرك قائل به تأمين بساوات اقتصادى و توزليع شساويانه تهام وسايل توليد و كالا هايى سولده در ميان تما م افزاد

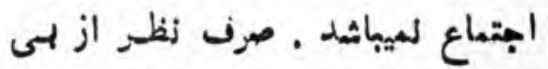

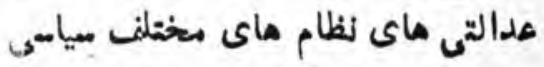

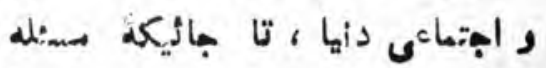

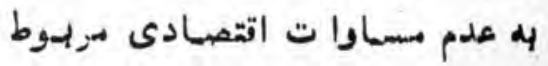

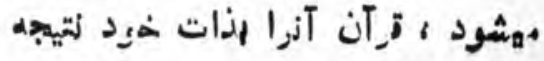
تقسيم و تقديز خداوزيد متعال ودطابق

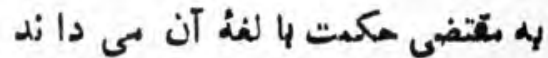

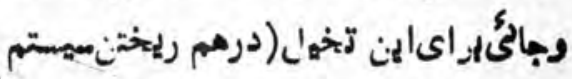
هدم مساوات اتتعهادى .و اماسكذارى مساوات اتقصادى ) درنابه اقتهادى

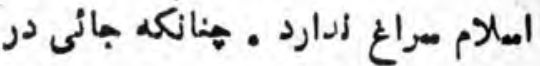
: قرآن هئين بهيخواليم 


\section{va}

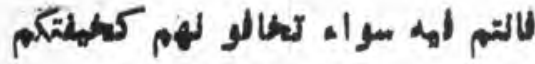

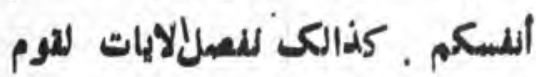

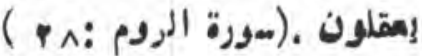
اله متعال لراى تفهمب شما از لله

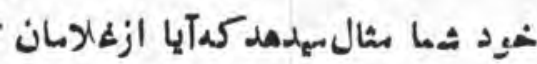

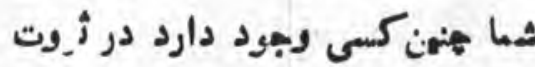

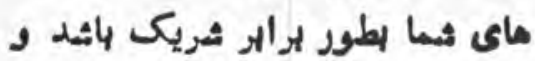

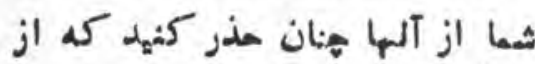

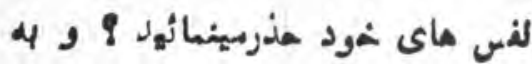

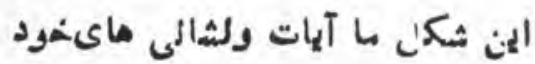

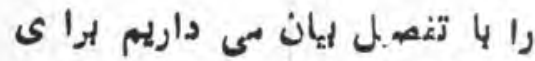

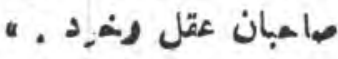

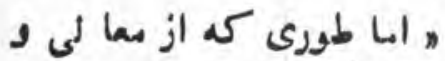

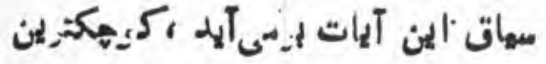

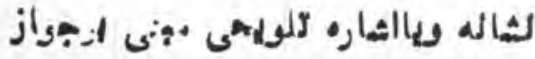

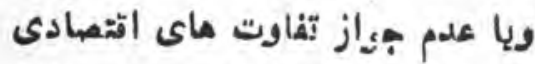

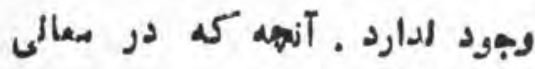

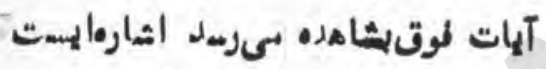

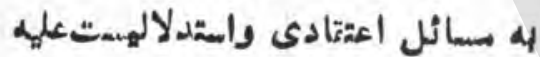

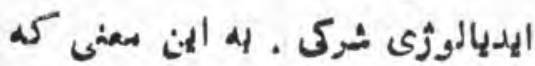

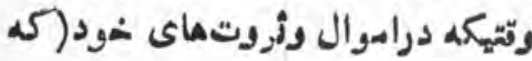

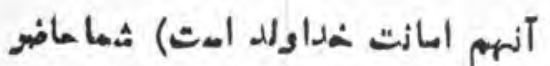

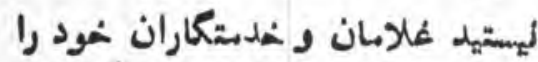

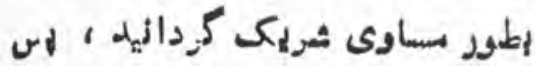

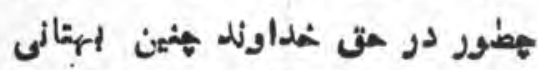

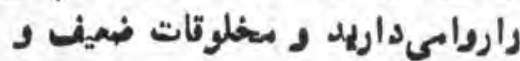

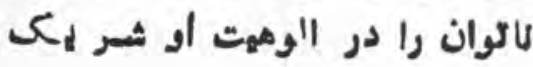
مص كودالهد و

بقيهه درمفه ( IIII)

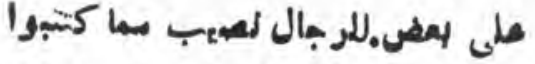

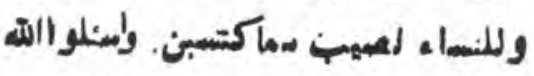
من الفهله اله بكل شى هلهما (النشاء T آيه + (r)

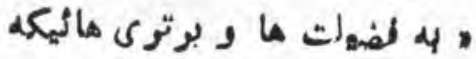

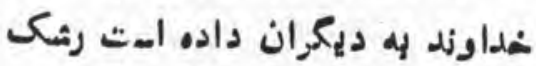

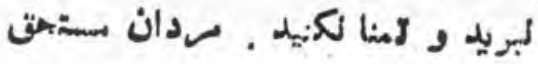

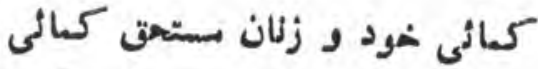

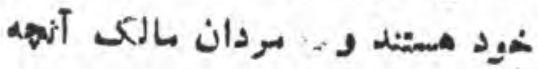

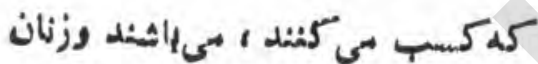

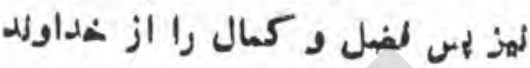

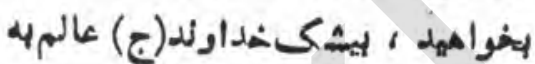

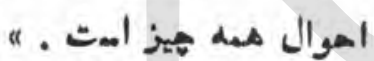

آياتمكه عد: مددم آلرا د دهل بوسساوات توزليع رزقولمسات مادى

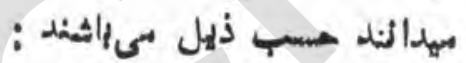

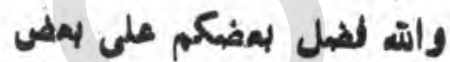

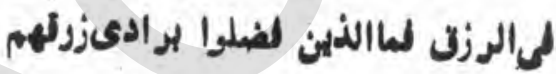

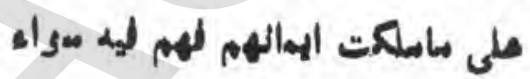

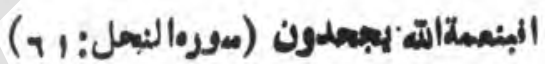

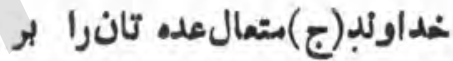
عده ديكر زضهلت بغخشهده است .له كسسايكه مائز اين فضهيلت شيده ازٔد اموال خويش را به غلامان خمود باز

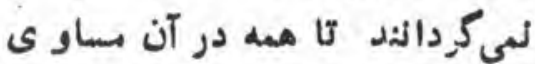

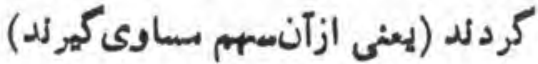

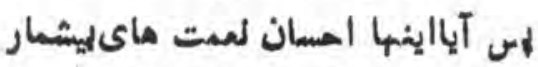

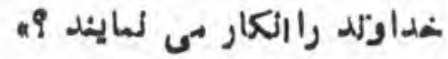

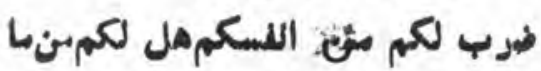

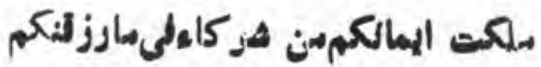

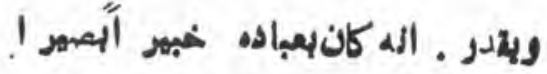

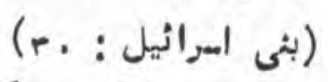

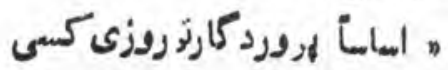

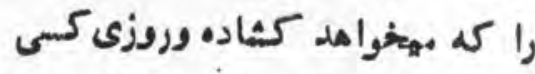

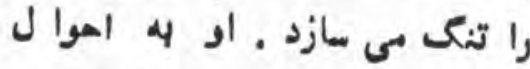

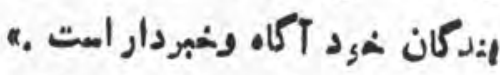

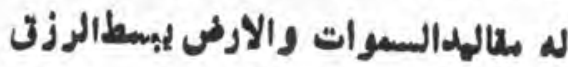

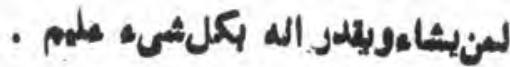
( شموى : (1+ )

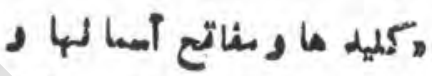

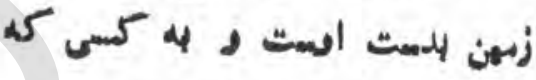

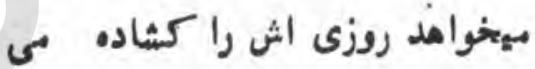

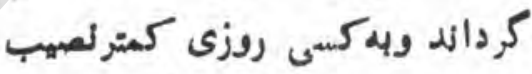

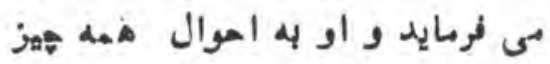

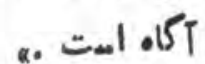

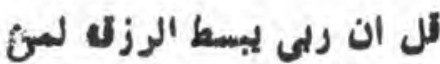

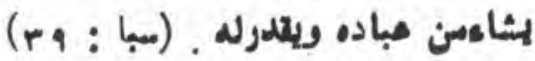

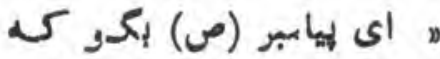

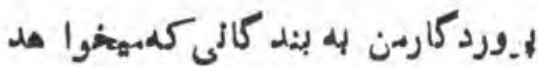
روزى لإاوان نصوب بى فرمايد وبه

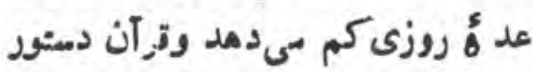
مهدمد كه سدم بايد 4 لهيثا كلى باز

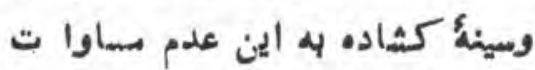

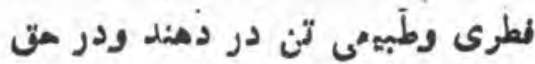

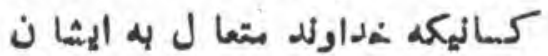

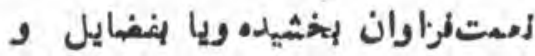
ملكات خاصى نوازيده ،رشكى وحسد

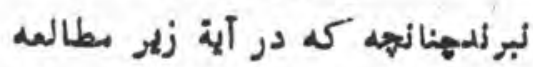

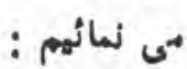
ولاكتمنوا مالفل هانة 


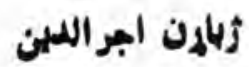

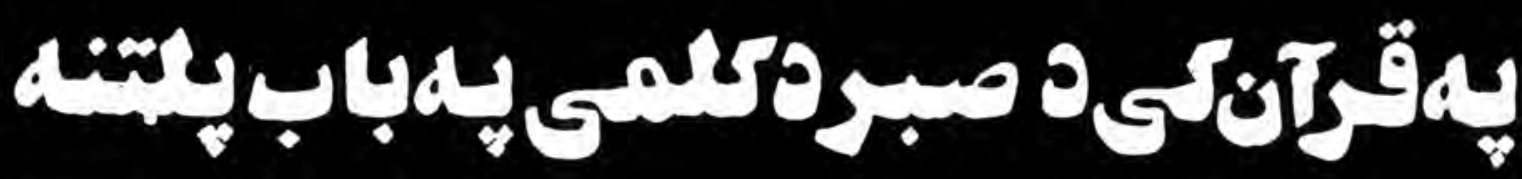

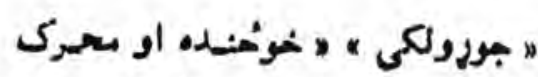

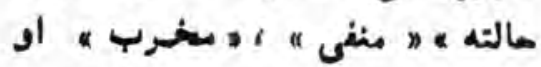

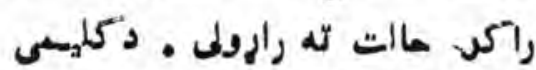

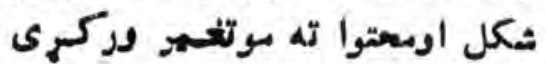

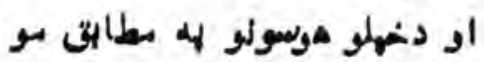

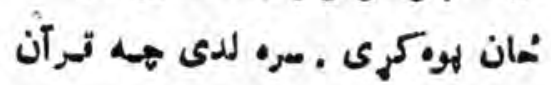

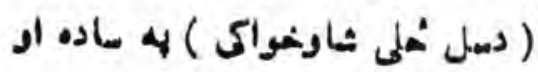

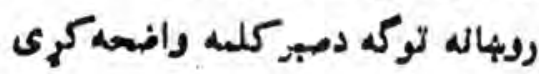

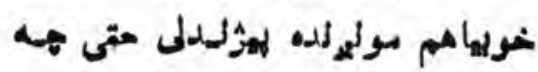

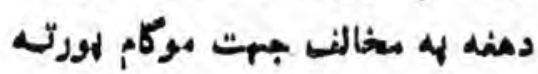

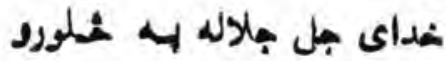

$$
.65
$$

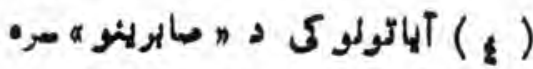

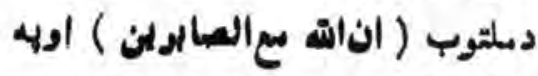

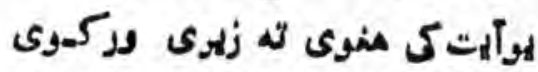

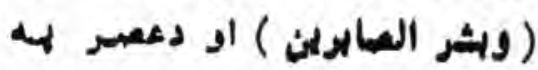

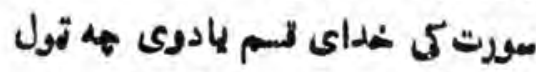

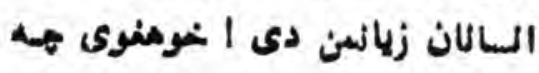
الهان راورى اد صالع همل تر مره

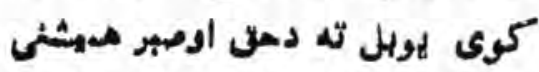

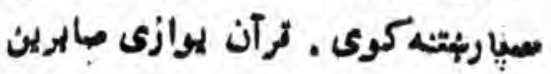

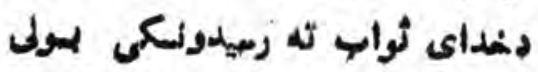

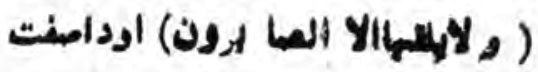

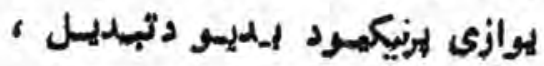

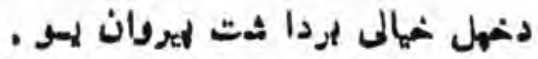

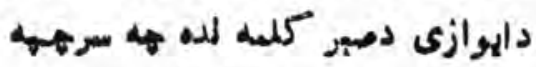

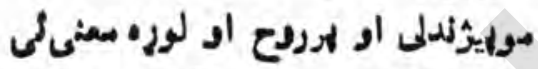

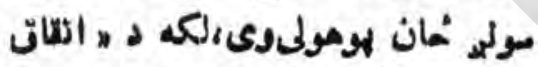

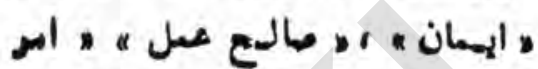

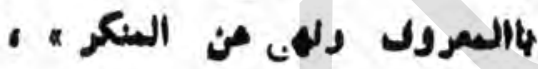

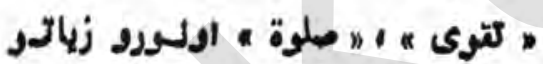

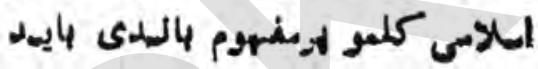
"مان ولاومود دمفوى ربتنى خهرى

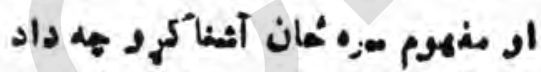

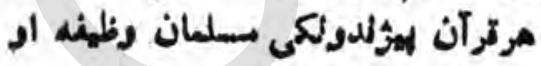

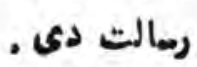

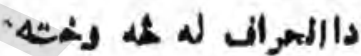
لهيل دوى 9 ... . داله مغه وخته

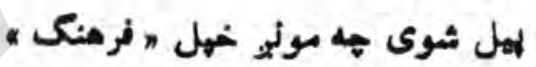

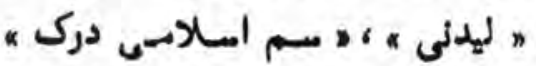
اسلابى زولـد او روميه لح لاصن وركه. . او به ظاهرى دود ، عنعناتي

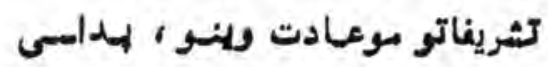
هال كى هـ أومورى وضعهت داسلام دمتهى روع مره --هون كله درلودار

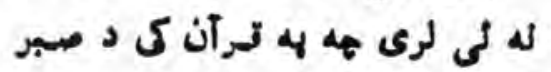

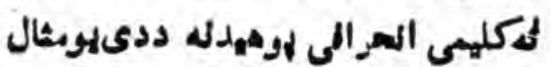

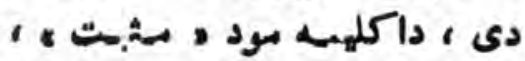

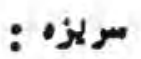
صبروكه بالاخرهكارونه سمييزى ليوماءت بن صبزوكي خموا لثى ...

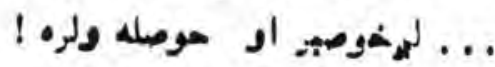

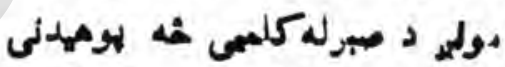

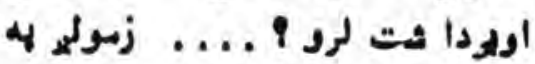
ذهن كى دصبر دكلسم مغهوم هـ دى 19 ... مونه دالثظار، مسنى ، اومعطلى مالت ته صبردايو اودلهيرى او هبهلي

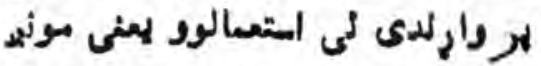

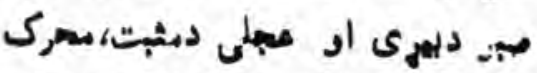

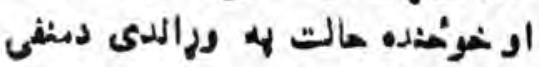

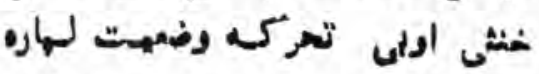

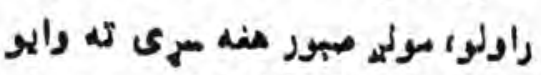

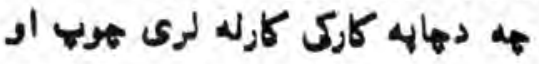

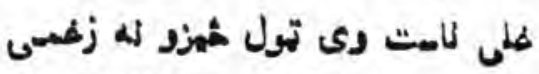

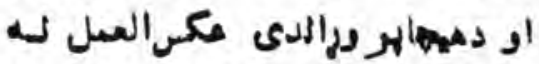

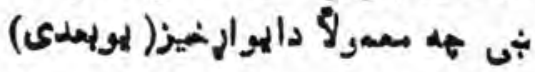

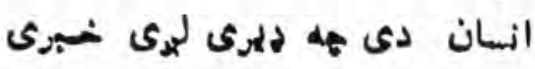

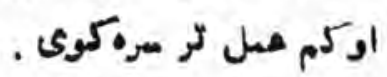

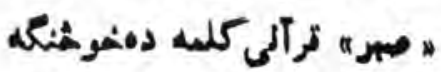

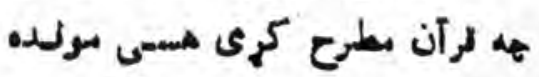

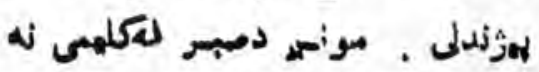




\section{A)}

هريوآيت دسورت دموضوع مخكى آمريك او ورستى آيت سرمسنجود'د زيارياسو

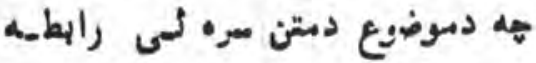
ومومو لياهغوى يوله بله سره مقايسه

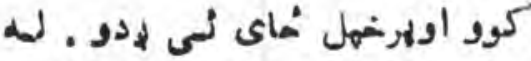
درنو لوسيولكو هيله منيمهيه داليتينه

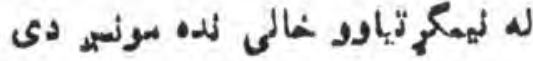
الخهلو احلامى الثتاداتو سرن خهلو

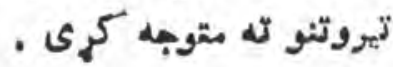

د سثهرتيا كانون ( دتكلمل

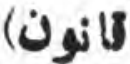

دكله له جيكرمبه ادخونهيله

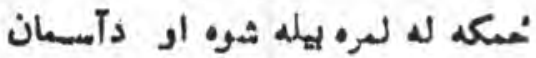

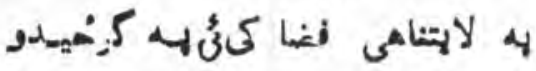

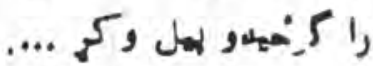

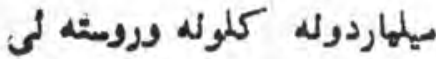
خارجى بوتكى سورثيو ، عازات تولهد

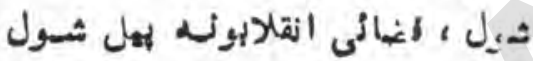

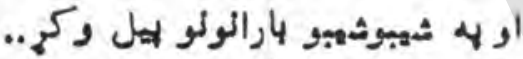

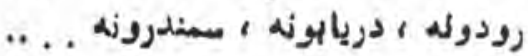
ار هُمكه او بو وينسوله لها زونسي

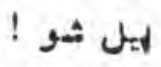

ددريابونو إزغارو ارلمنا كه.

مراهلوكى له خاورو نه يوسلولى ساده

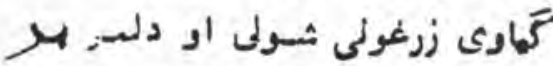

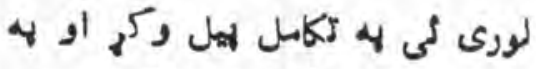

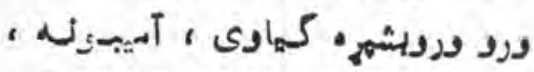

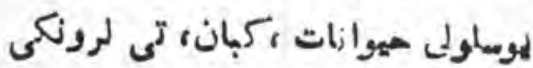

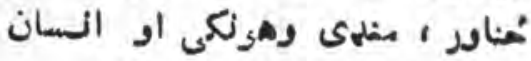

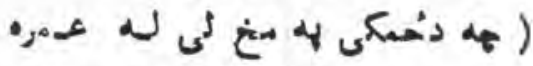

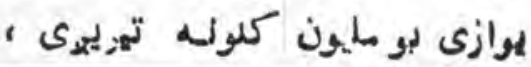

ادكانهالى وعده وزكي شوى ده آيادا

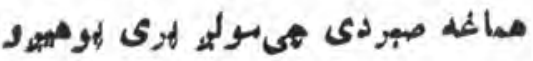

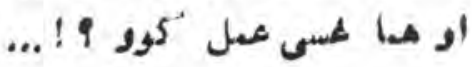

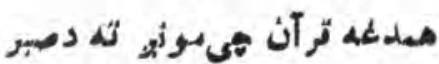
درس راكوى ، خداى ممعادلثقاضمى

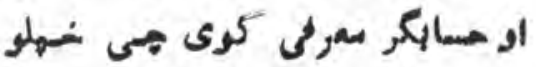

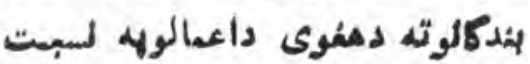

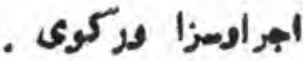

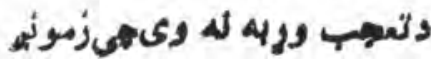

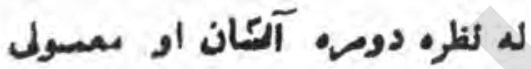
مبرثه ليامم دومه مسطا ز امديت

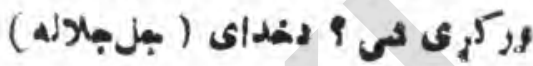

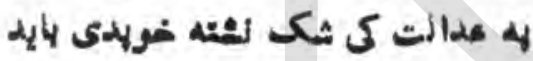

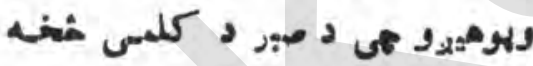

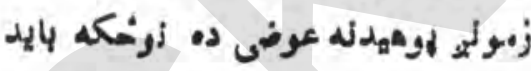

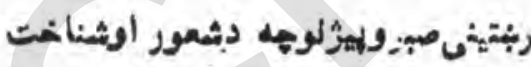

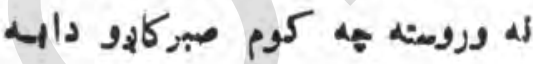

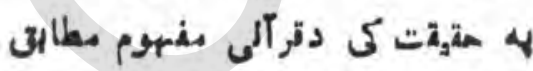

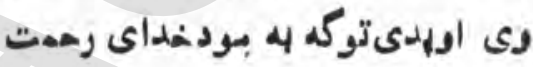

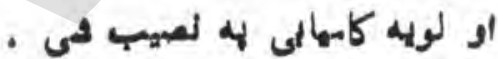

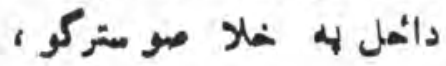
اوريدولكو غوإه ادآزاز مكر قرآنته

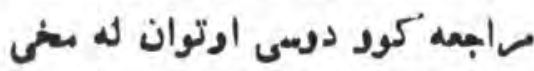

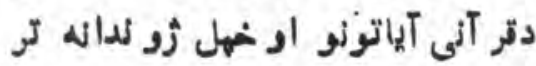

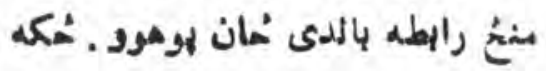
دادهر سملمان وظيفه ده هم خهل

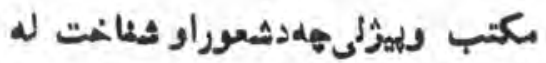
لارى اسلام درك او اهساس كمى . اوس لموله سادمتوكم بوضومات المكات

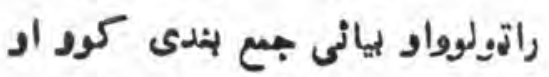

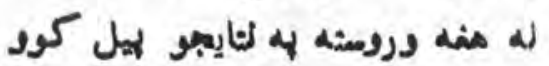

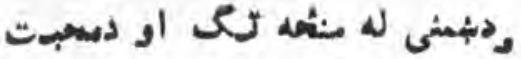

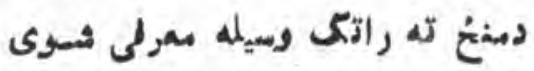
اوخوكى هه دلهسى مفت لرى دلوى ارخى خاوزدلى كنى ( و ما بلقها الا

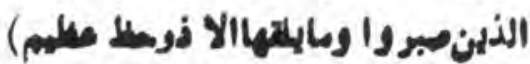

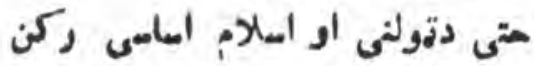

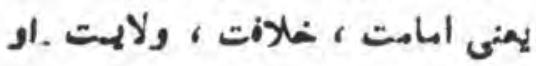

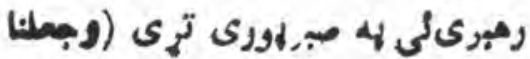

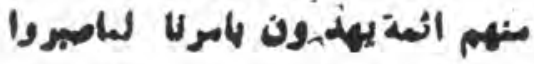

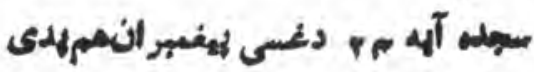
مذتستايل شوبهى دوى ثملى مهرد

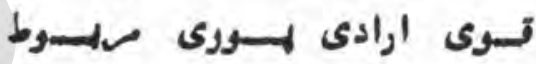
او متكى داسى كمل ثوى ثي الئل

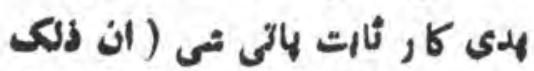

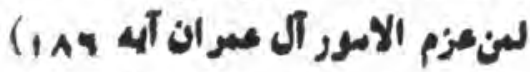

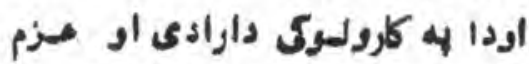

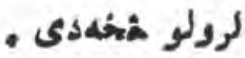

ترتولوبكم لاد اهه مالرئينوته

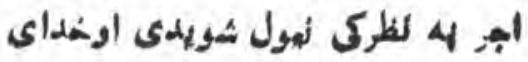

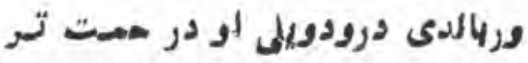

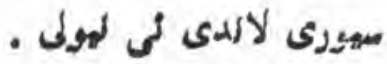

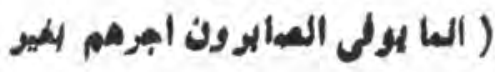

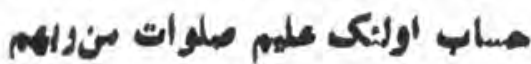

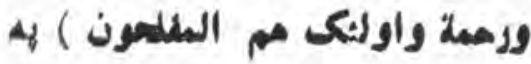

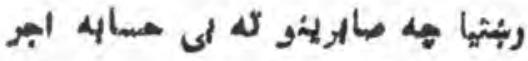

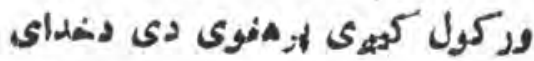
دروء اورميت دى اومصدوى لبريالم دئل

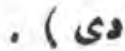
دمبر فمخه هيه شومره هادوله او لهليل شوى او مايرينو ته داجر 


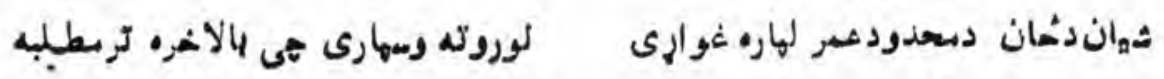

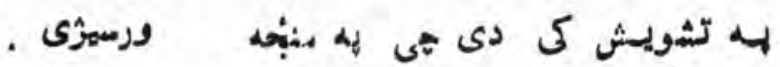
صبر يعنى : دلتكسل هو قالون

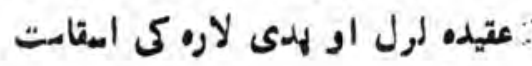

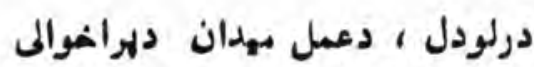

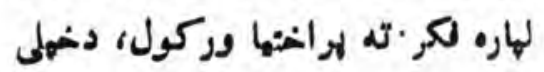

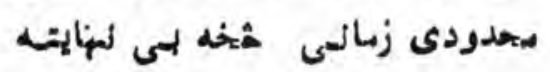

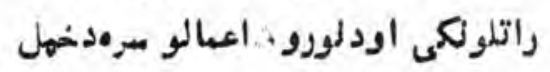

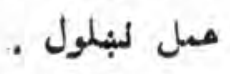

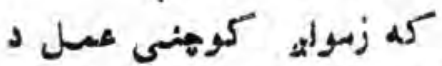

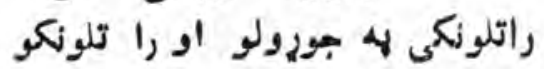

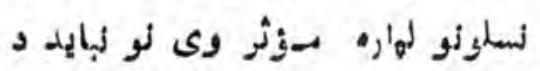

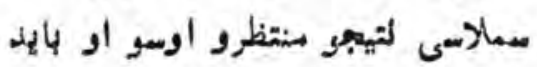

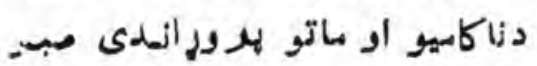

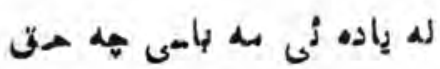

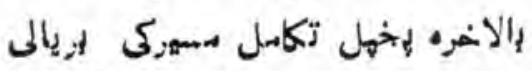

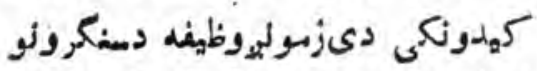

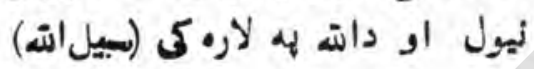

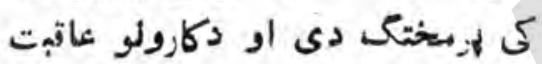

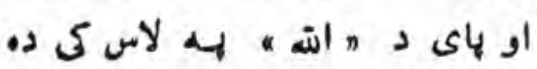

\section{دروسولا لامبر :}

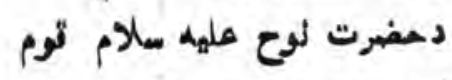

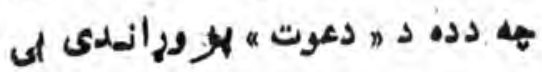

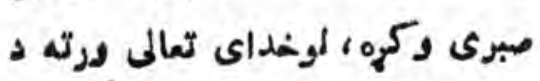

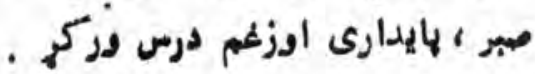

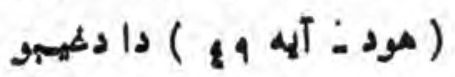

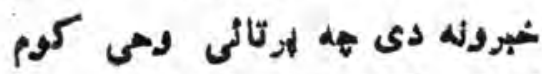

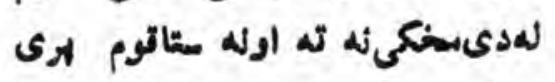
- odanar

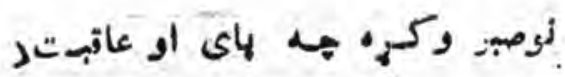

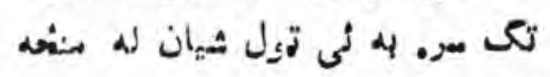

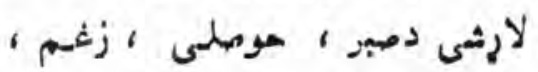

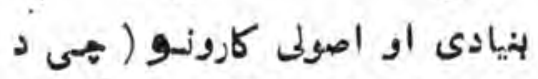

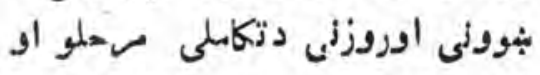

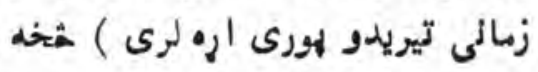
بردs)

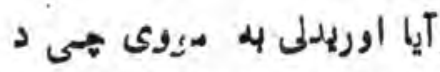

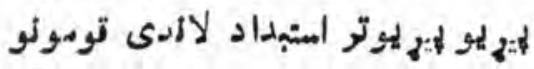
دكسال او آزادى لاره به يوه شئه

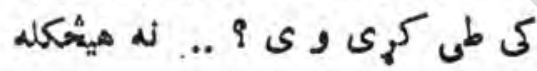

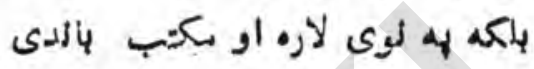

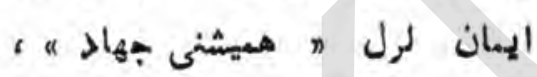

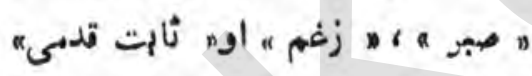

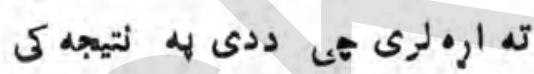

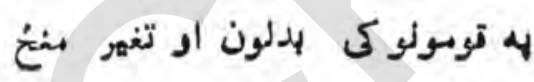
ته راهی

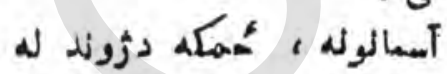

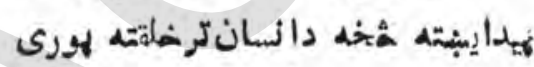

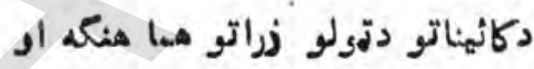

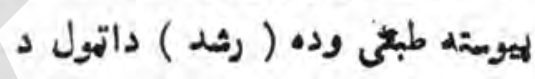

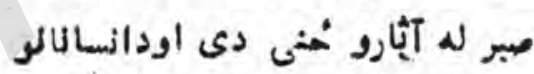

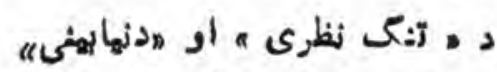

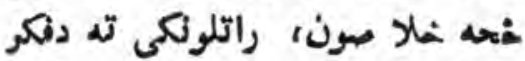

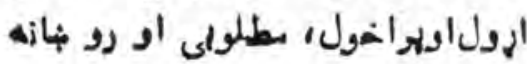

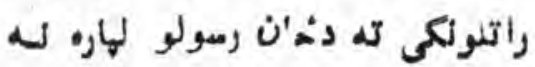

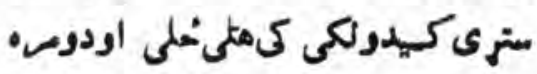

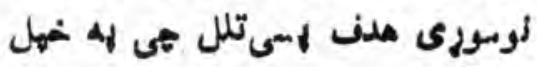

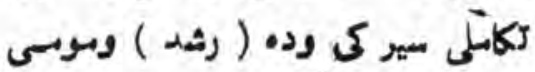

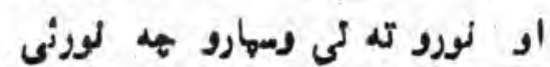

هداسى هال كى جه دُهمكى عمر دو. زره مهلموله كلونو ته رسييدى ) لهيدا

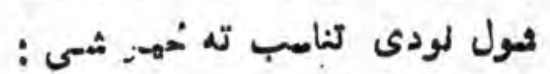

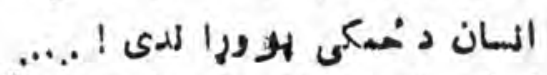

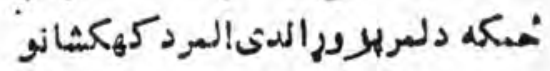

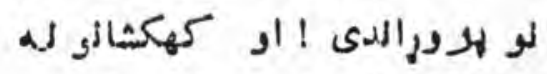

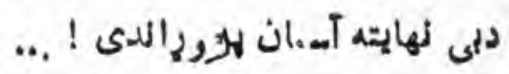

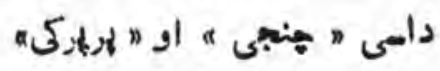

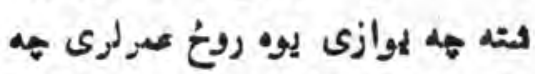

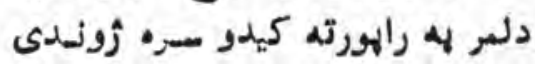

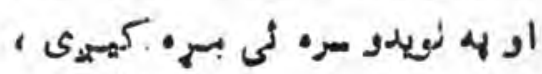

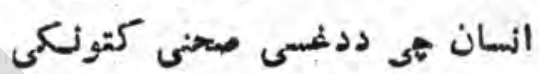

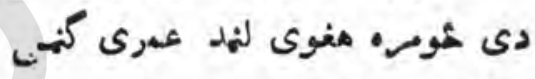

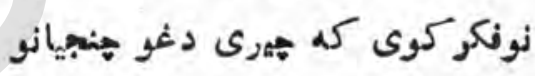

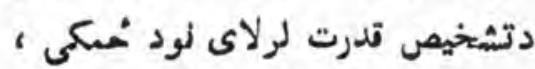

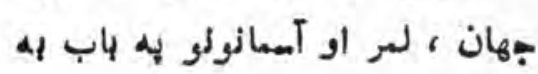

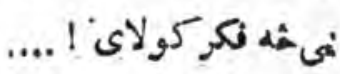
لويدى مهورتكى انسان جهبان

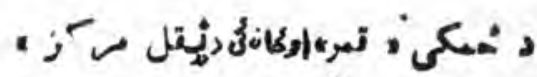

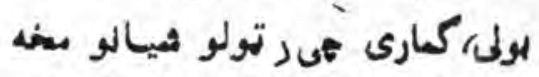

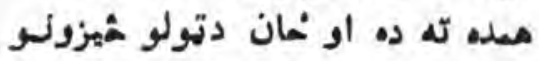

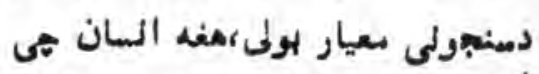

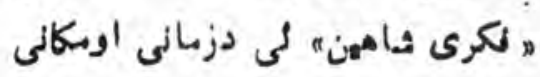
سر ـــاتو له لدنو كى هدالوتنى تدرت

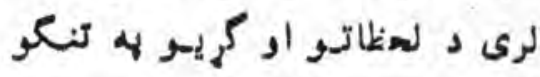

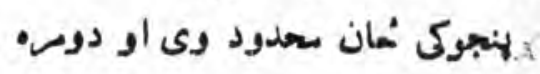

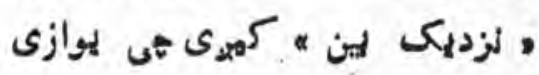

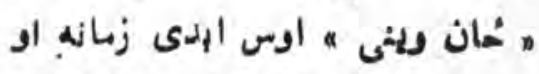

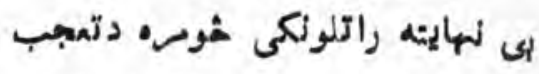
ورده خونه د عهول الـسبان لهاره

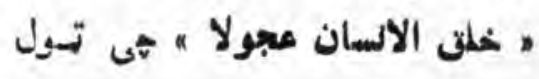


سوره بلد ( ـ ) ) ـ آيات حا

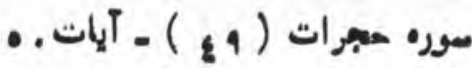

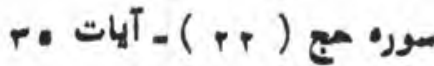

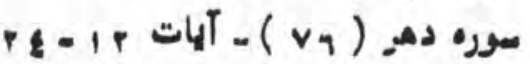

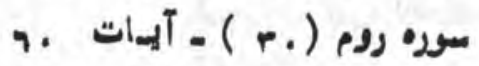

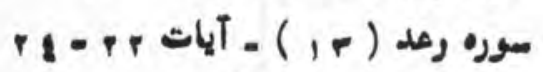

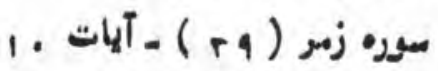

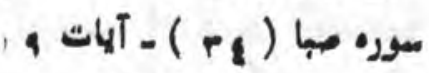

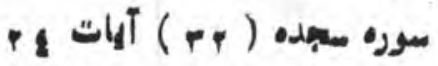

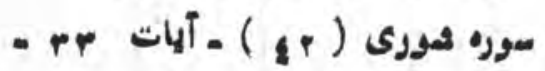
ir

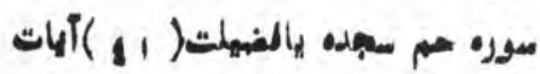
P. $+\varepsilon$

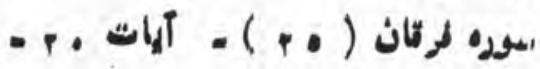

$$
\text { va - ir }
$$

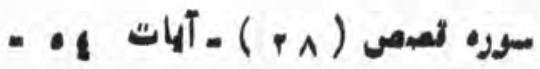
A.

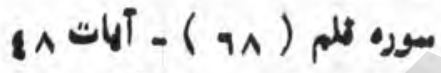

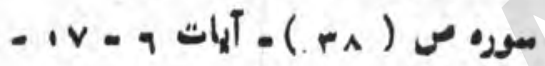
81

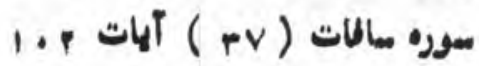

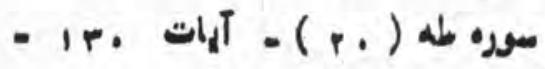

tpp

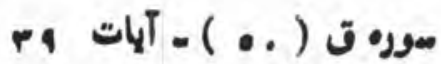

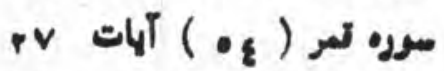

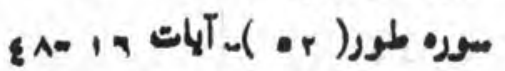

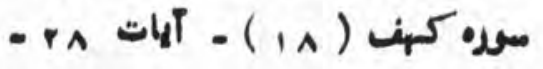
$v_{\Lambda}=v_{0}-v_{4}+4=9 \Lambda=q V$ Ar -

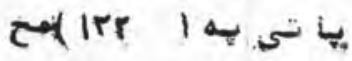

كفار دى دآزار او ربرو لى لاس

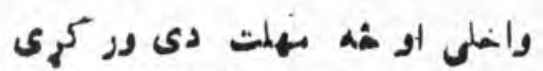

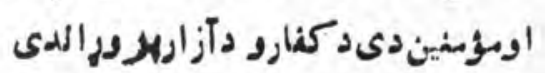

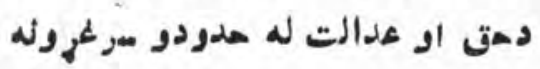

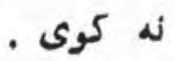

خداى بلجبلاله د "نمودقومه

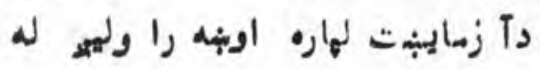

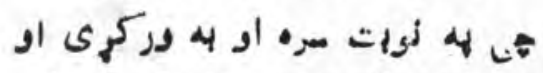

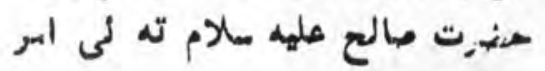

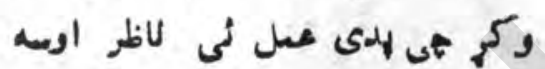

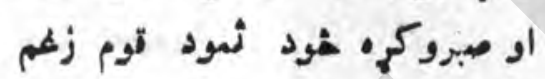

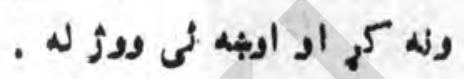

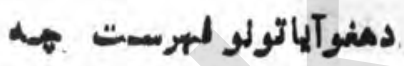

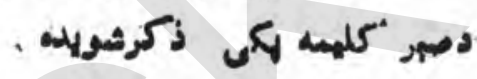

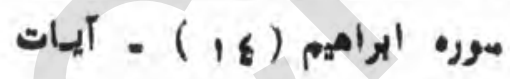
$p 1-1 p=0$

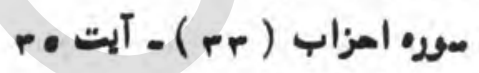

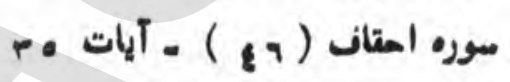

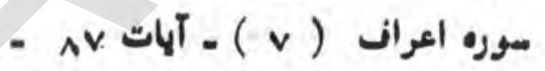
$1 p V-1 \psi \Lambda=1 \% q$

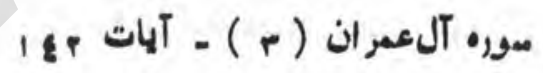
$1 \% \cdot-1+0 .+.-1 \wedge q-169=$

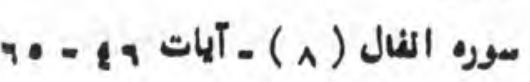
$99=$

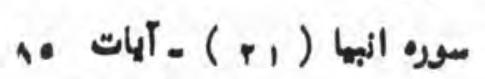

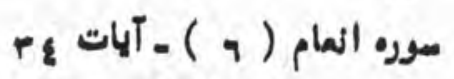

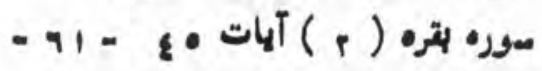
- $21-1 V V-1 V 0-100-104$ •.

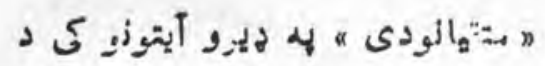

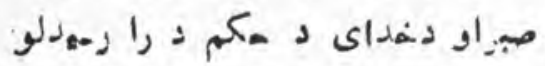

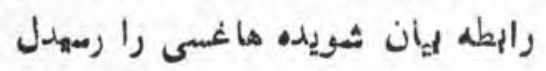

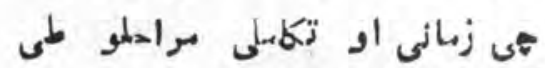

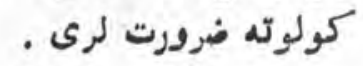

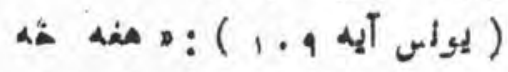

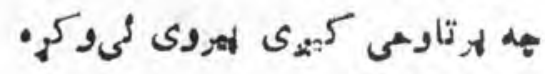

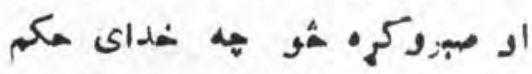

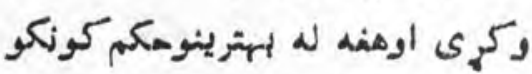

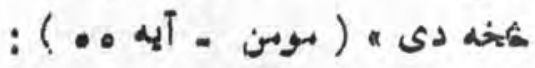

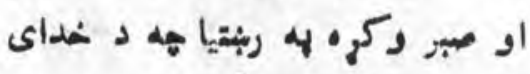

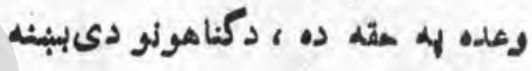

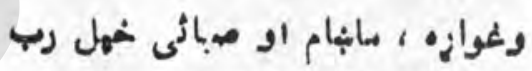

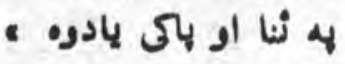

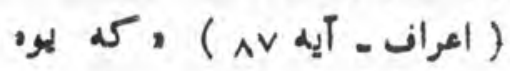

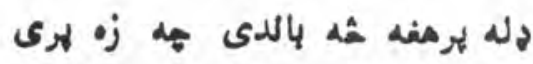

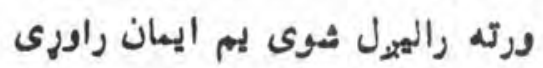

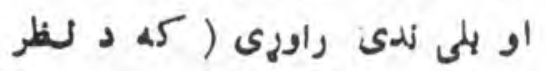

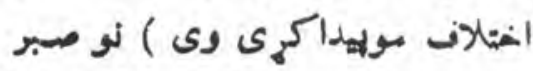

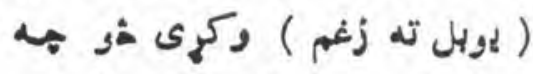

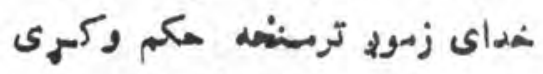

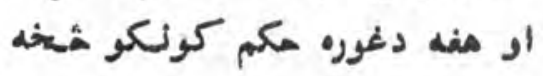
- 62

داد مضرت شعيـب علميه

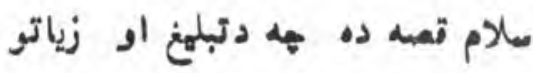

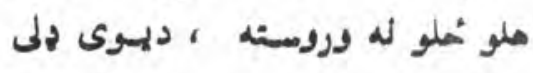

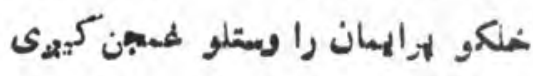

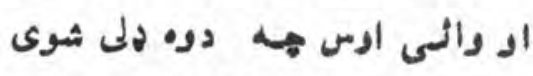

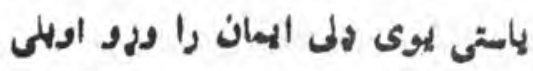

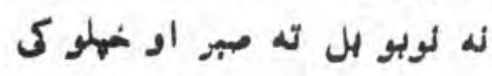

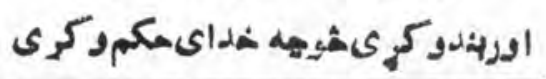




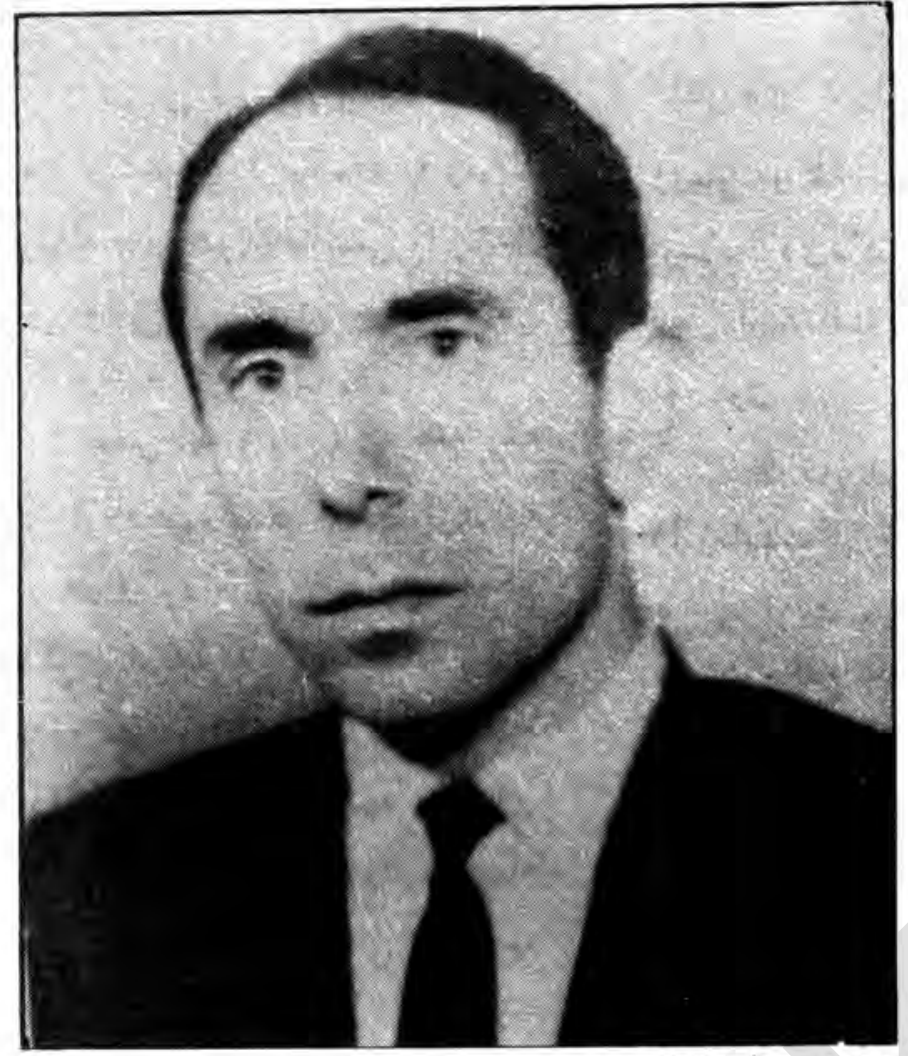

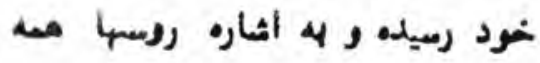

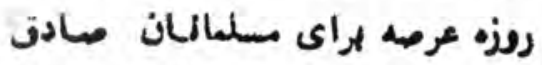
كثور كم هون سد فولادينى دربهاير

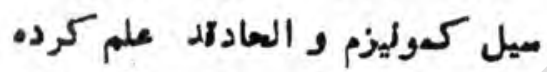
لودند ، تنك ترمى دد .....كمولهزم

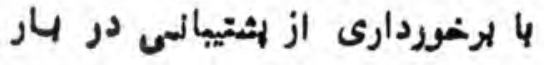
روز تا روز عله دين د عقيده ومشد مات كشيوركستاخ لر مى كرديلد و

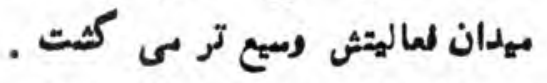

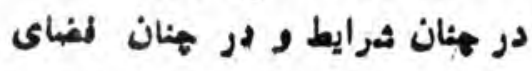

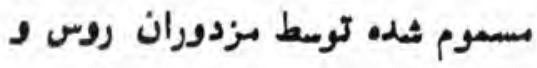
هين و امريكا و الكليس ، كسم تردم

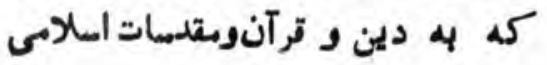
تومهن بى كرد ، روشمنغكر تلمداد

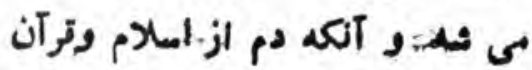

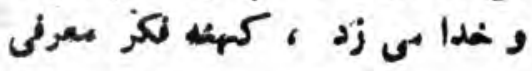

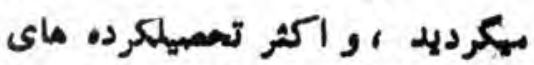

كاثيع الد ، السا الثمار التحلاهي و

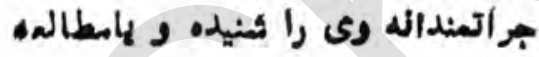

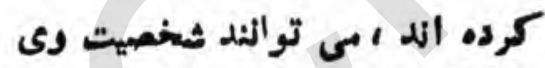

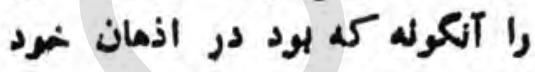
مبهسم سازلد ا من خود مهومثميدا

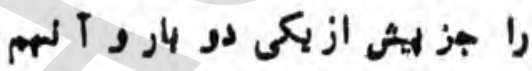

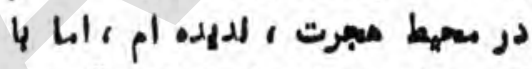

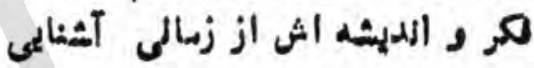
دارم كم مغعلم متحتب الودم وائمار

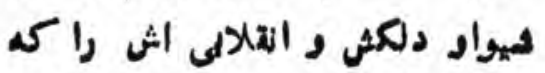

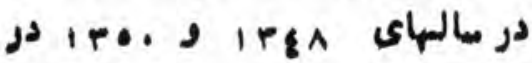

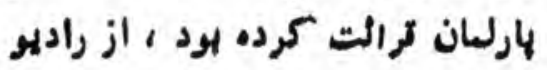
در لآن عالها لطام فاسد ناهر

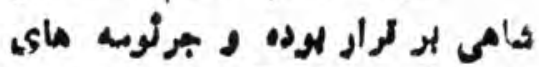

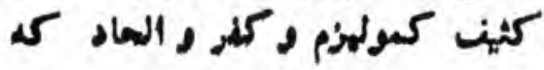

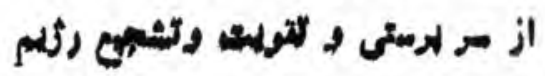

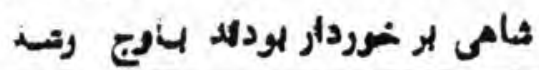

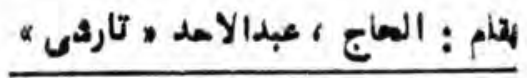
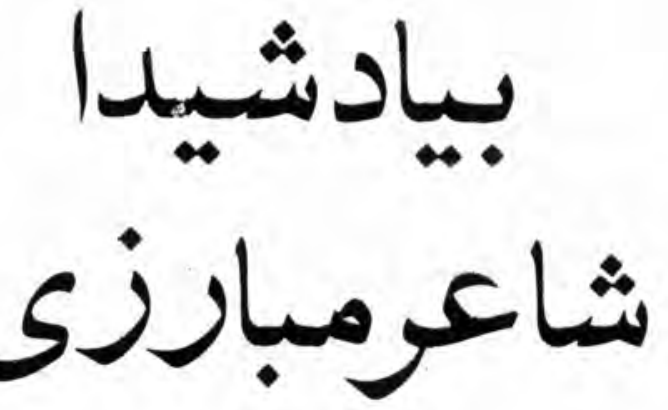

ازخطئفارياب

دو مال وازدىاز ولات ثاعر

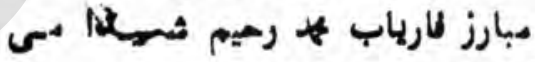

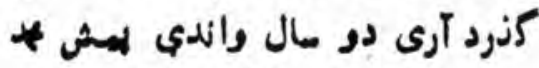

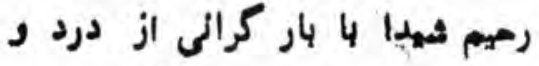

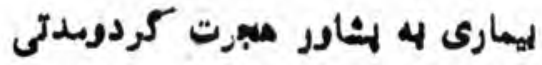

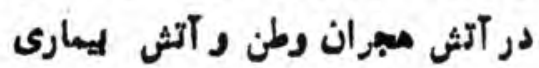
و آتش مواى كرم سعيطمهرتموخت

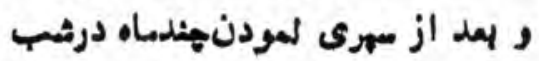
عيد فطر بل سوى عالم بلا رخت ميغر

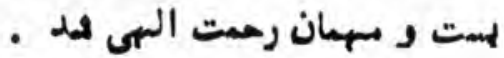

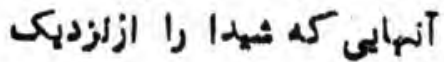

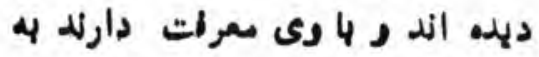

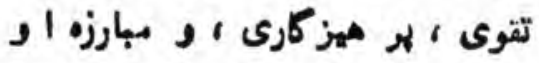

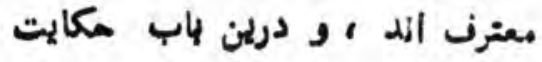

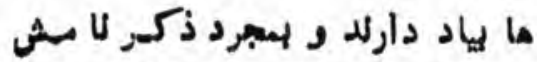

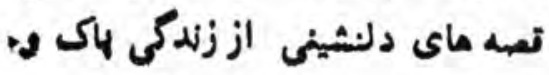

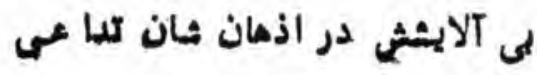

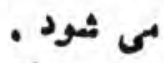
و ألهايمي مم 4 ثيها آثفله 


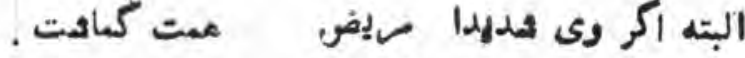

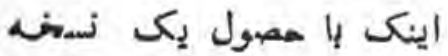

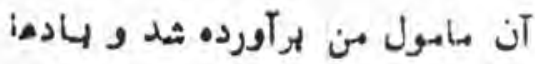

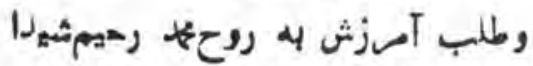

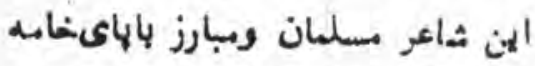
4ه بـر كلمتان الشعار وى مى روئم و به تحليل قستى از دو شعرش سى دي : هودازيمب

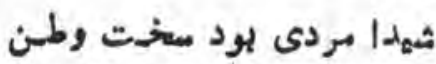

دوست و مسلمان وبههان اندازه أيز

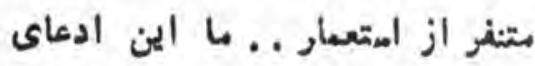

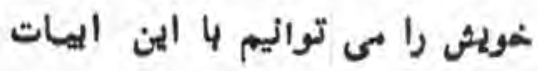
دلنشين وى كه در لهارلعان درارالها

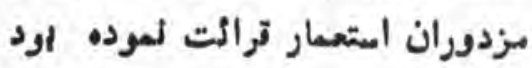
و اكنون در منكر ماى خولينجهاد

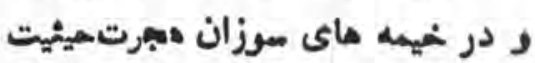

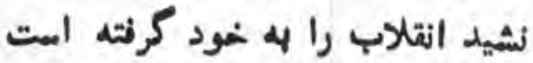

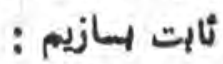

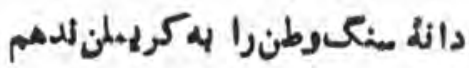

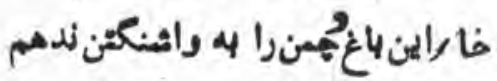

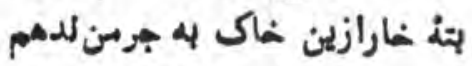

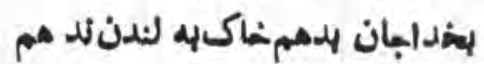
من كه اففانم ر اسلام الود آكينم

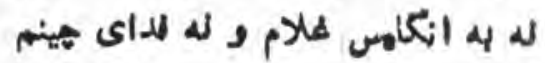

\section{- -}

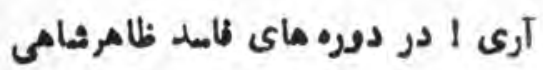

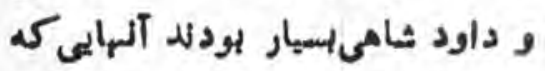

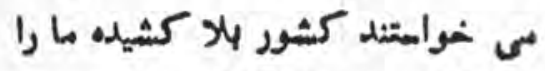

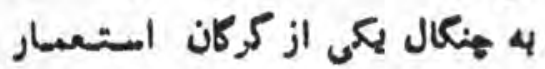

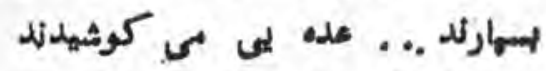

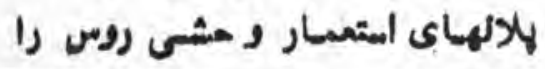

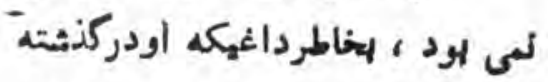

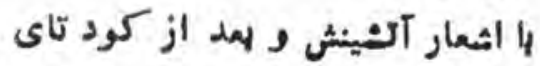

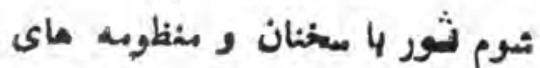
إيشدارش به دور لهاى كمونستهاكذاشبه بود ومى لئاثهت زلده اشنيمكذايتئد ولى مزدور ان روس بالئن المهيد دل

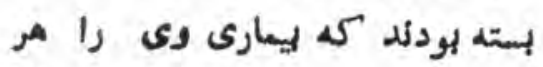
هه زود از لادر خهواهد آوردوايشان

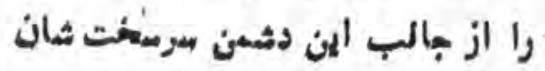

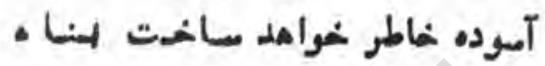

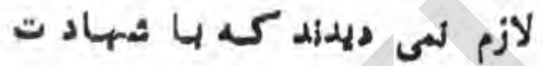

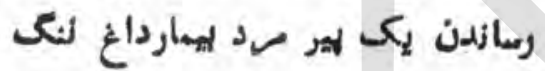

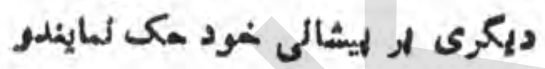

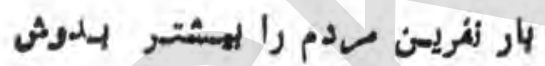
كمشند.

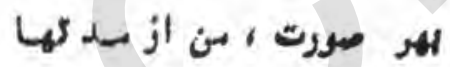

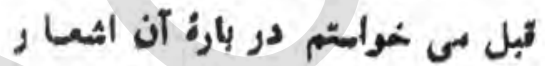

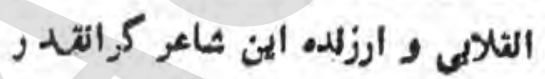
كه هالها تبل در بهارلمان ظاهر شياه

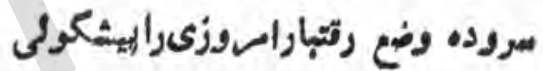
كرده و مكام ضاكن آلوكت را شئهه

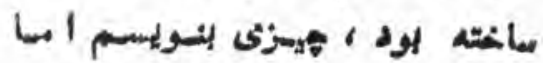

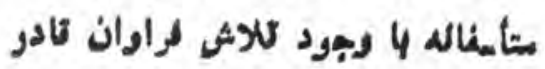

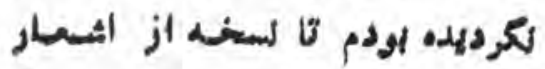

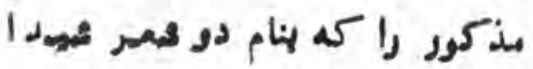

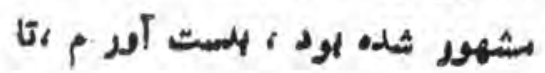

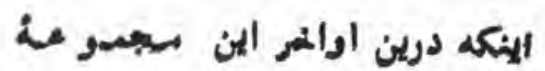

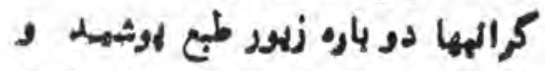

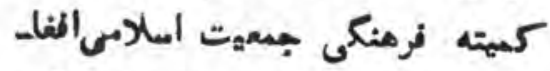

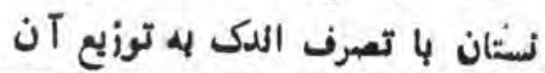

كثور با به افكار غير اهلامى روى

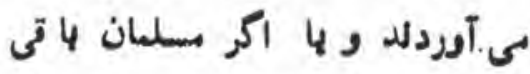

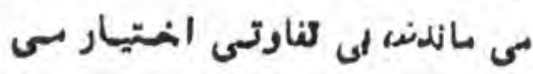
لمودند و ازلرس آنكه متهم بلكمينه

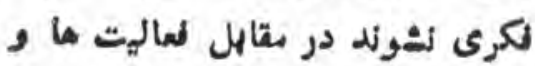

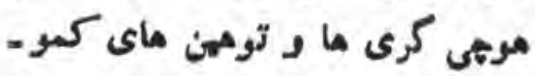

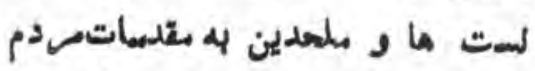
سملمان كشور ، خاسوشى كزى كزيدلد و در برائر صيامت هاي عواسفريبائه

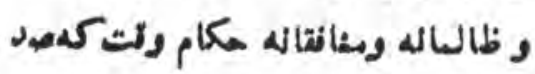

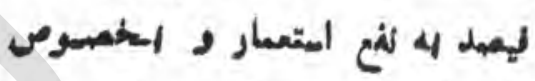

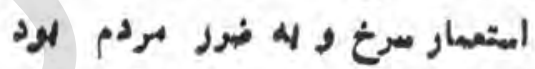

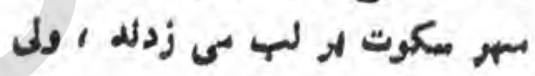

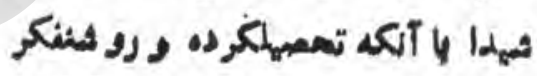

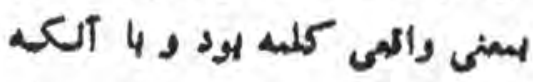

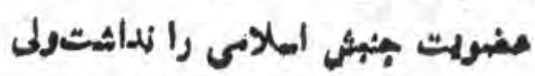

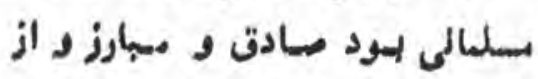

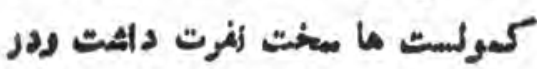

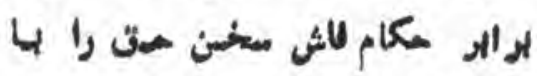

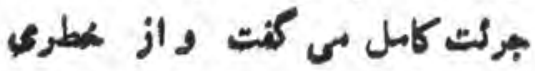

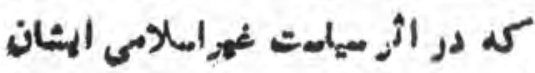
كثور را تهديدمى كرد ، ملتو آلها

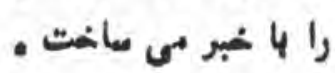
بعد از هلهدرت رمهدف مزدودران

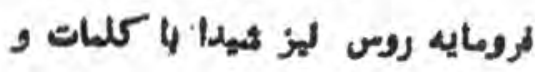

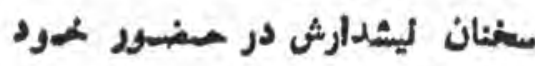

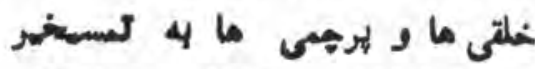

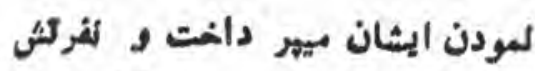
را از كمونيزم و روسباى آدم خوار

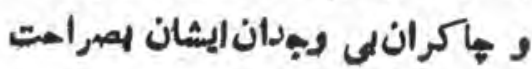
- ايراز سى نمود 


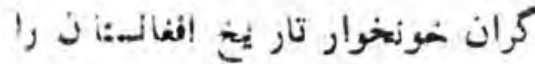

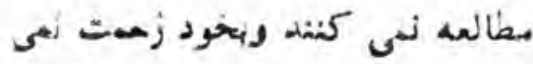

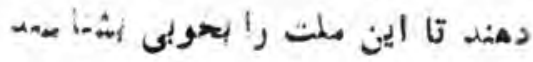

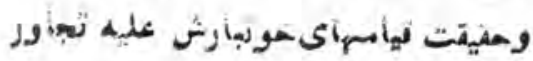

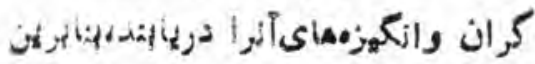

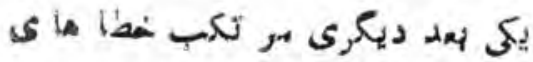

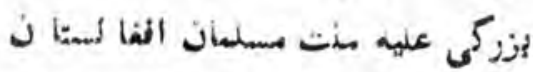

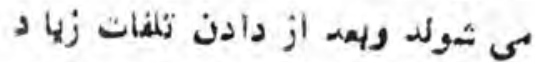
ومتعهل ثمدنشكستهمأى رموا كئده

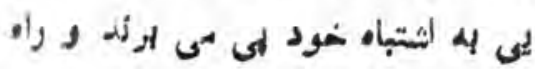

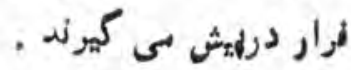

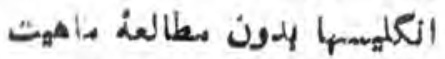

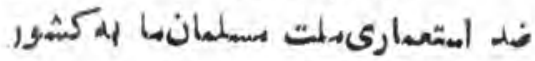

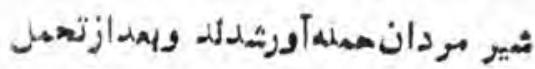

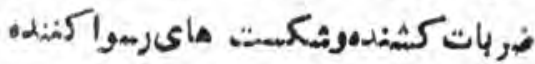

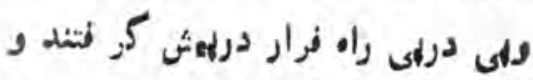

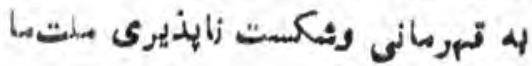

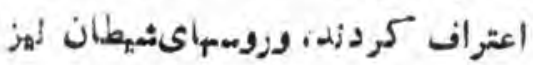

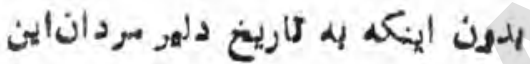

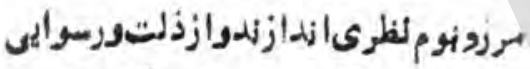

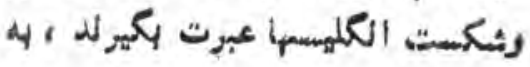

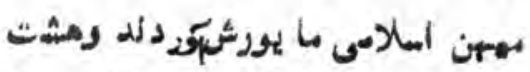

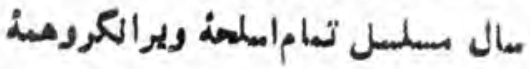
حهله هاي فهيطانى خودرا بكار بردئل تنمكر اين ملت از إعى وجب فهاكي

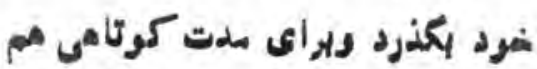

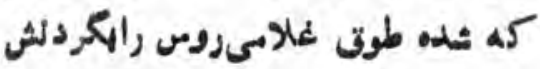

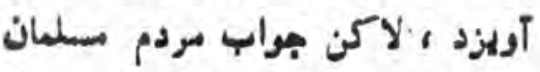

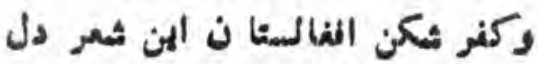

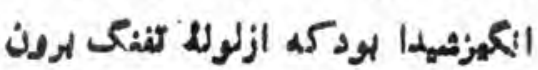

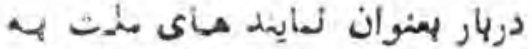

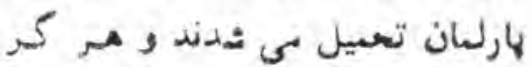
كهاينده هلت لبودألد

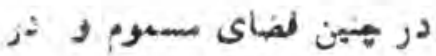

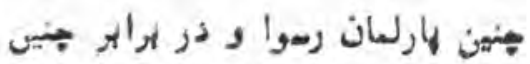

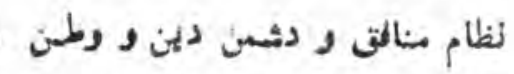

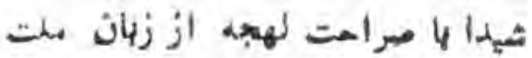

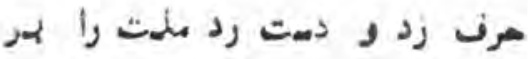
موينه مزدوران استعسار كوفت :

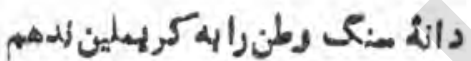

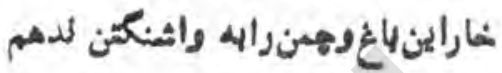

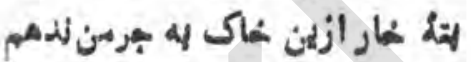

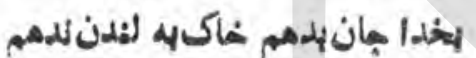

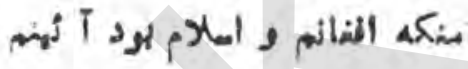

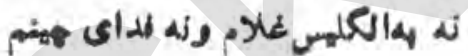

\section{-}

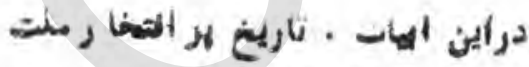
مسلمان الفغانستان خهلاصهثده ابهت.

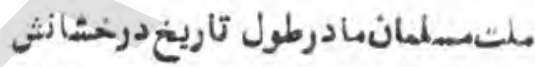

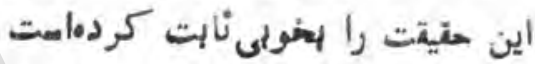
كه دازله سنك وطن وائة خار كشور را به ايكانكان نسى دهد وهاضضر أهت

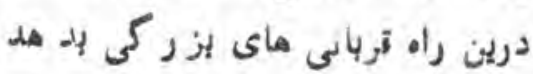

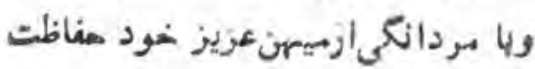

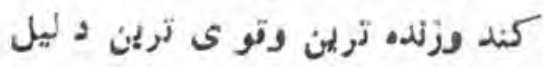
اين ادعا، جهادخمونبارفعلى باهيداران

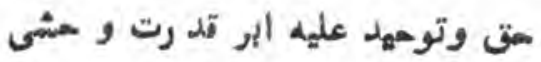

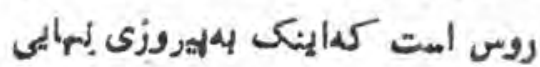

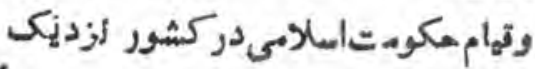

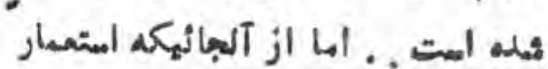

اهنظور بلميدن الفالستان هياده مازلد

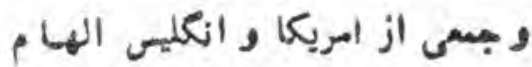

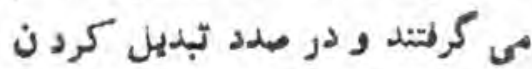

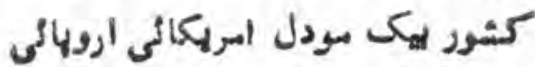

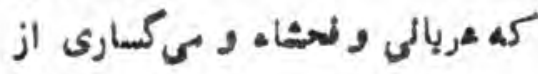
مشيخصات آن اهت ، بودندو كروهى له ساز كاميزم و نثنيزم بى رتصهيدند ,

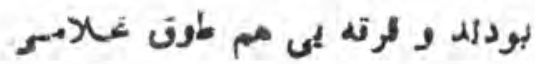

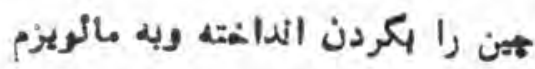

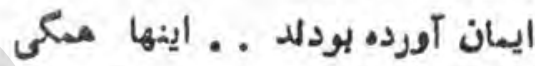

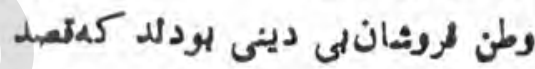
ل بود ى افغائستان و ملت مسلمان

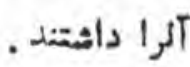
و روز دا روز درسايهنظامهاى

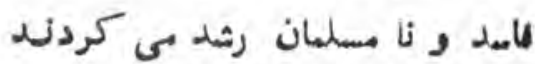
و تقوات مى ثدند ، و و بالب ايثكه متى در بارلهان انغانستانعليه اففا ـ .

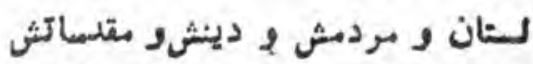

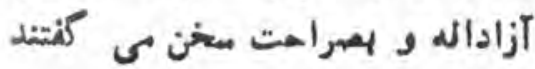

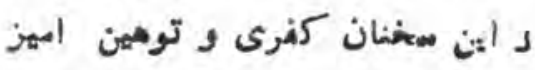

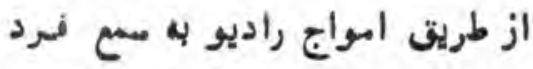

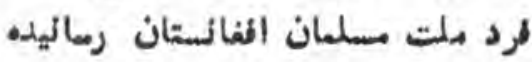

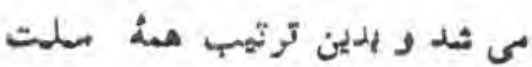

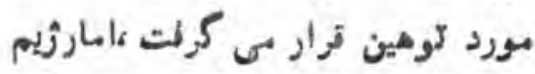

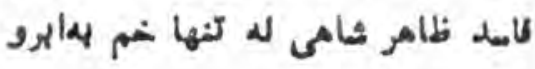

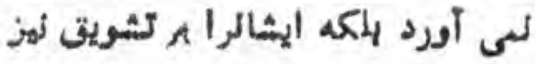

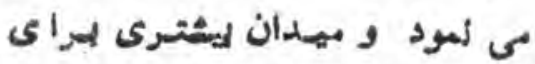

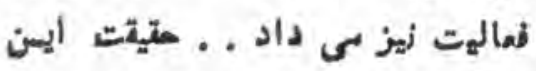

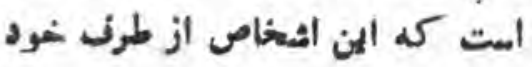




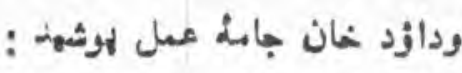

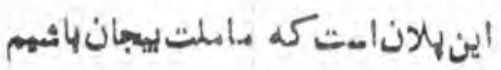

دثمن الكمديكروتوده لادان باشهمب

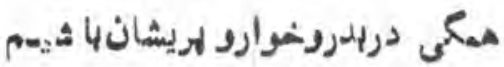

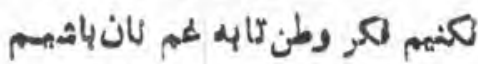

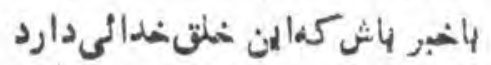

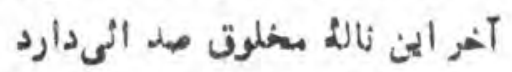
- $\bullet$

دز زمالهمه سلت هاى دلهاروز

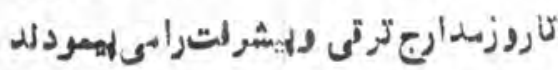

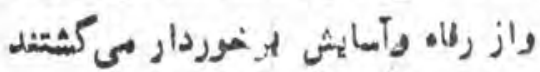

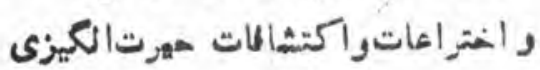

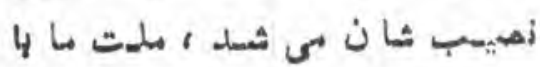

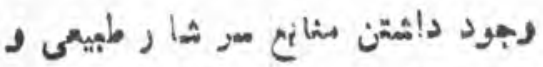

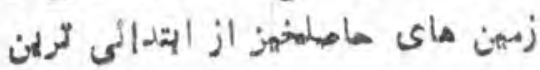

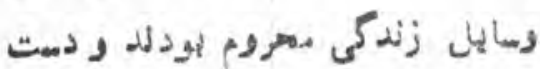

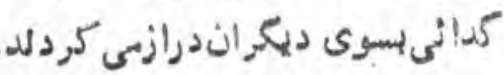

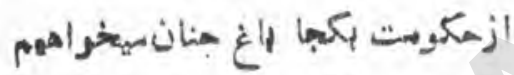

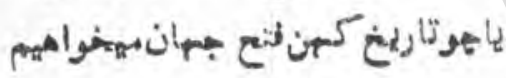

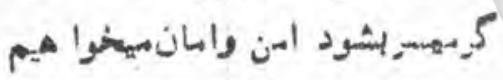

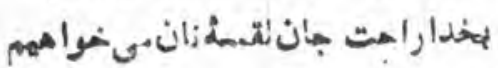

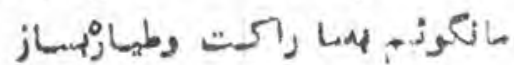

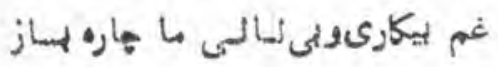

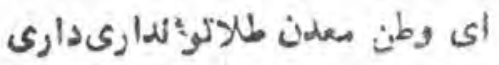

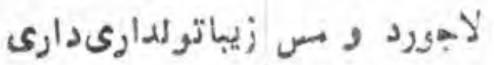

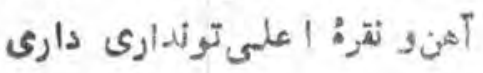

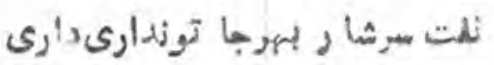

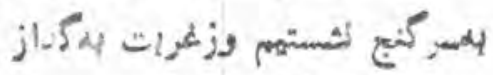

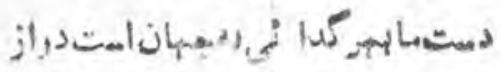

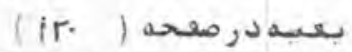

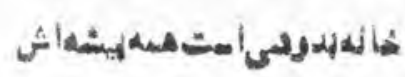

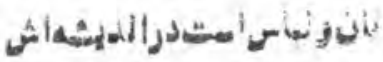

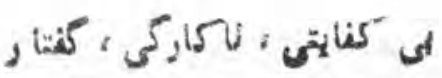

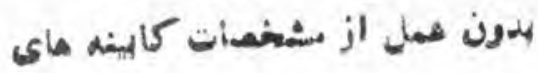

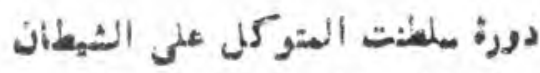

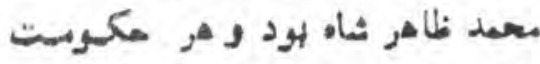

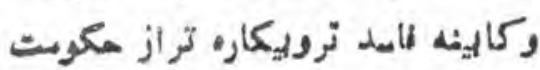

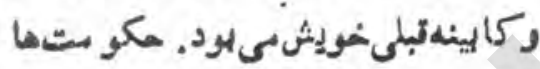

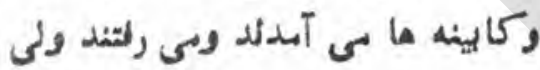

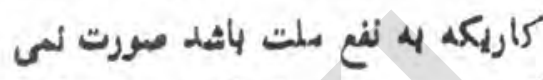

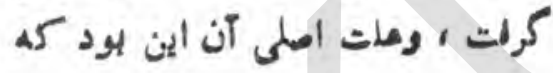

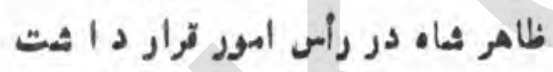

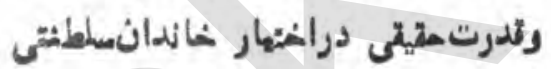

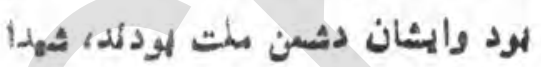

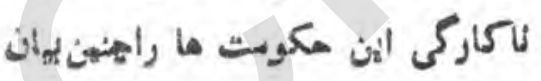
هم كفد :

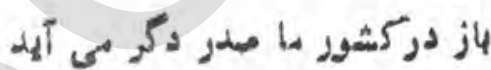

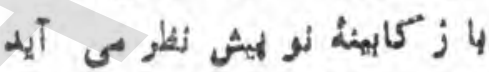

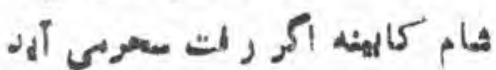

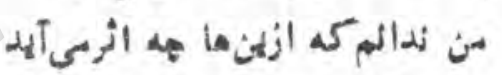

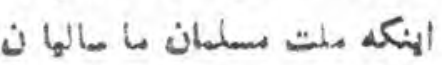
دراز

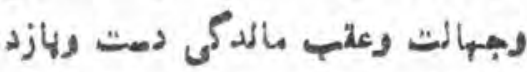

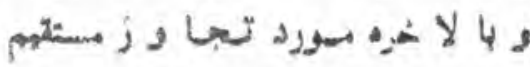

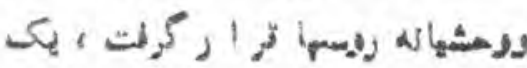

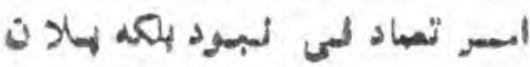

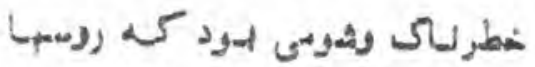

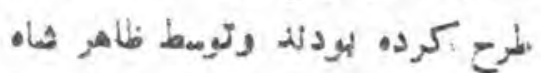

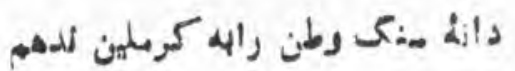

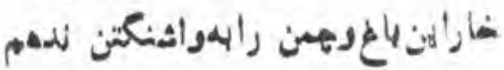

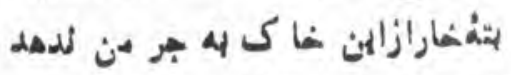

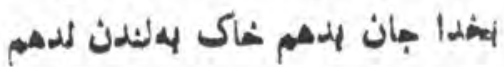

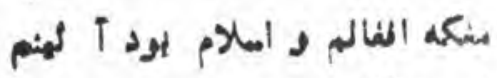

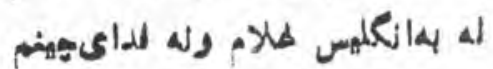

روسما آكر عقل بـ دافعتند از

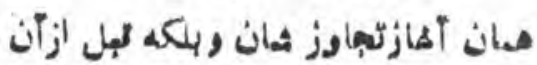

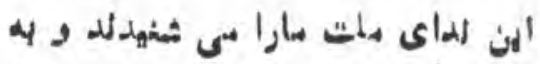

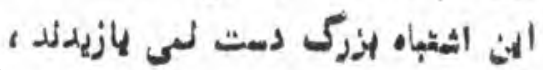

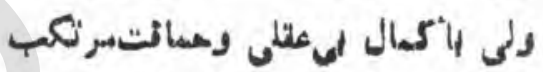

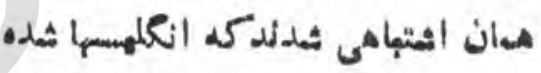

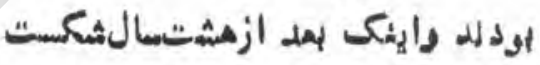

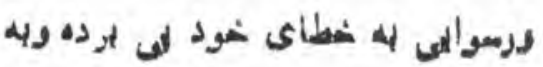

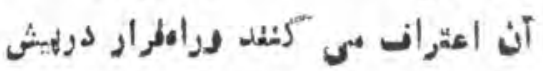
كرالثد انده

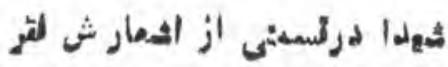

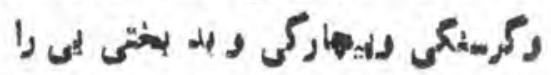

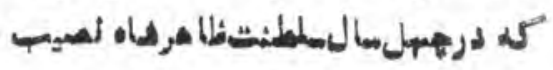

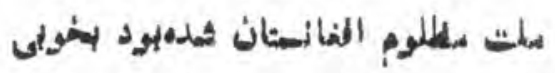

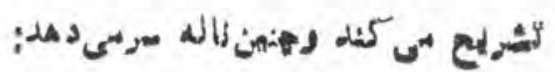

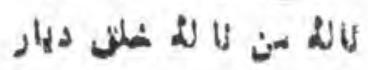

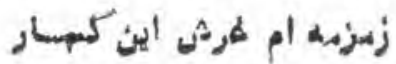

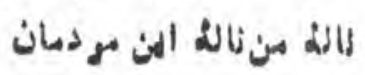

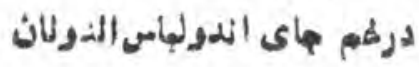

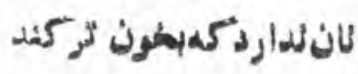

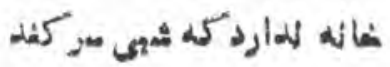

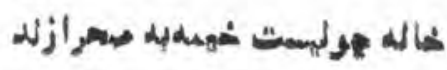

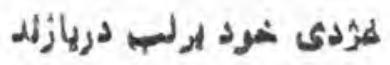




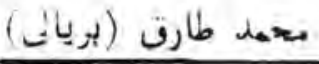 \\ زموز. غوبنته د افغانانو لياره

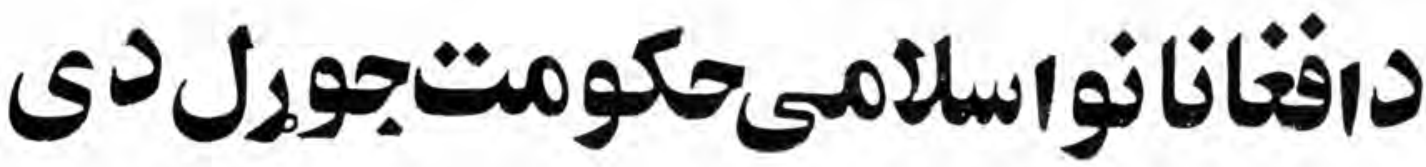

كى نا كام شول نو كوببس نى وركي جه دنوى كلونيالستى او دافغانستان

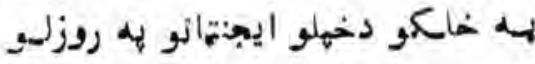

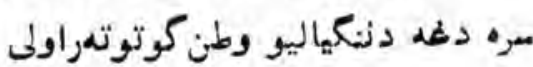
تزخو وكمائ شى خهلو را تلونكي. هراختياغوبتتنو ( Expansionisms )

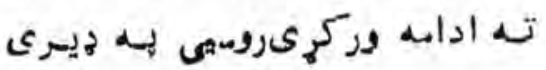

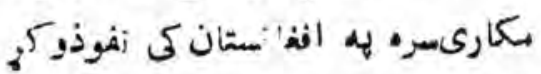

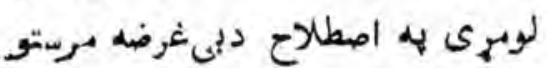

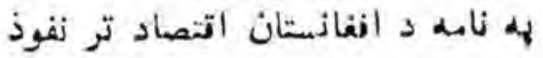

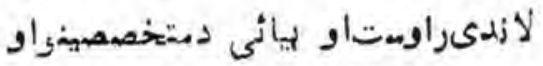

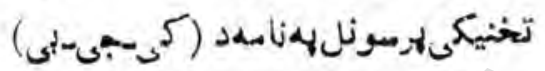
جاسوسانانغانستانته نزه ايستل دهنه

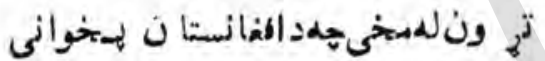

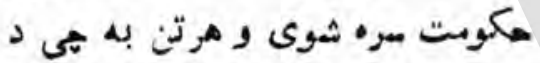

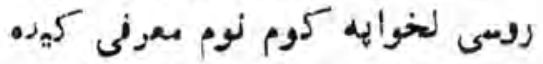

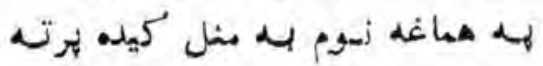

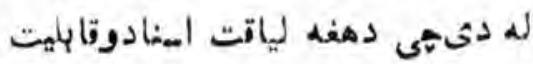

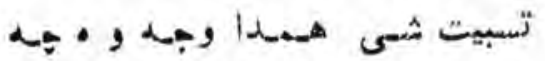

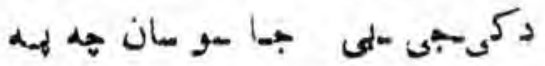

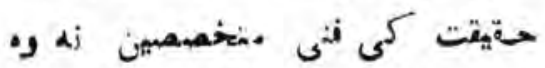

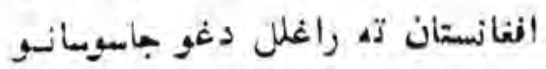
به امطلا ع د متخصصينو وظينه

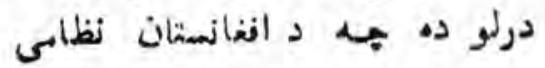

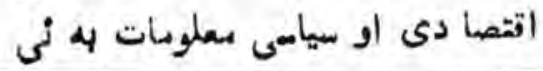

دـ شمال نه تي جنوب او د شرت نح

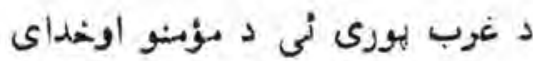

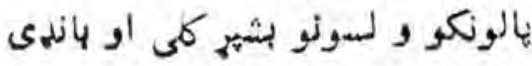

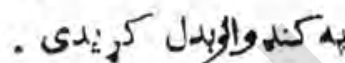

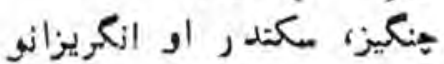

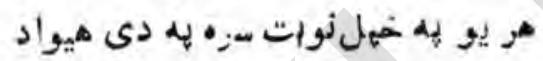
باندى خيل ناروا تيرى سرتهزسولى

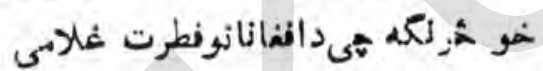

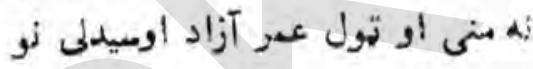

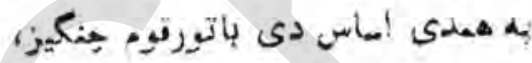

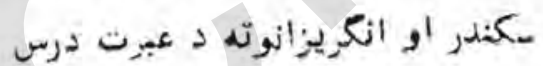

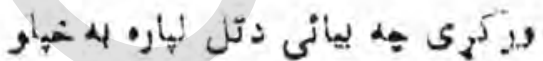

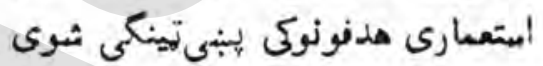

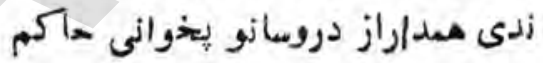

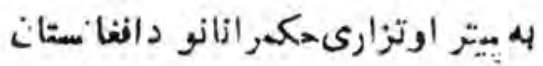

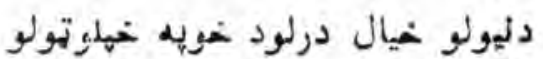
دى غـيثتينوكى نالكام شيوى دوى

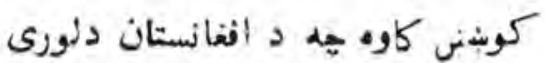

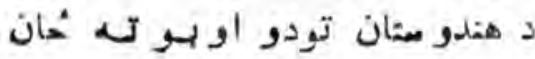

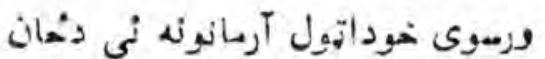
سر. كور تم يوزل .

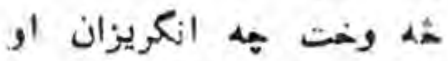

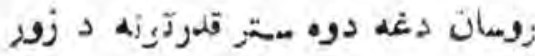

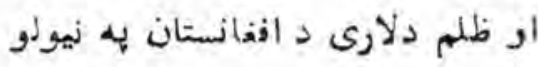

أنوليونواو دمبلمونوتيرتاريخونه

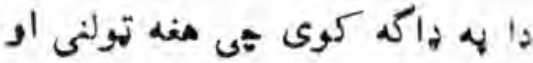

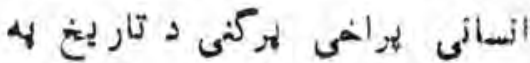

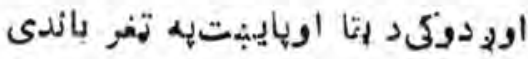

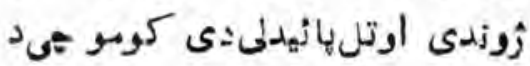

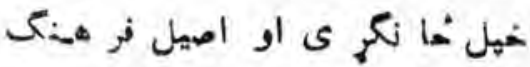

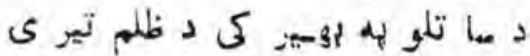

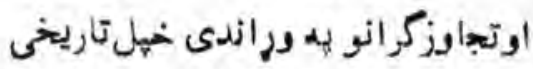

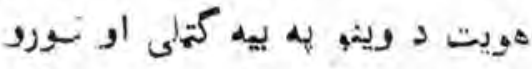

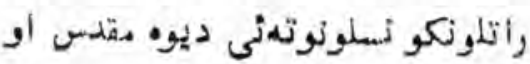

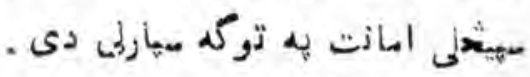

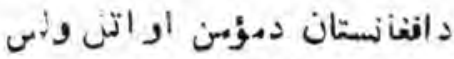

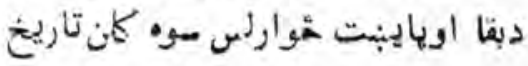

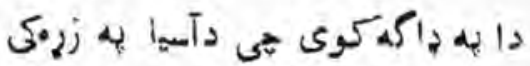
دغه مساهان روزونى اوايهان مإلونيكى

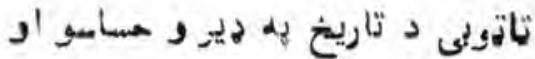

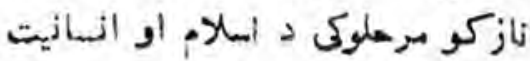

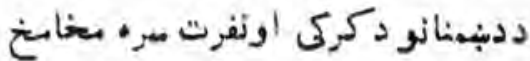

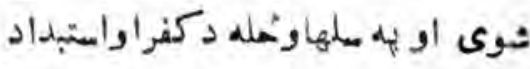

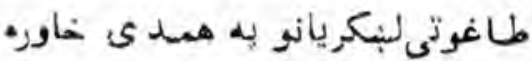

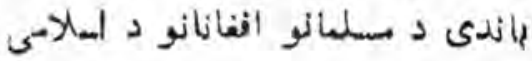

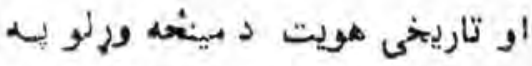

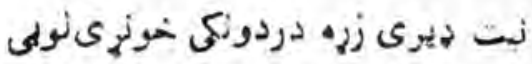

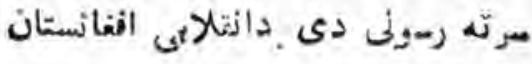


نعيمورى جاسوسان رهبزى كول او 2

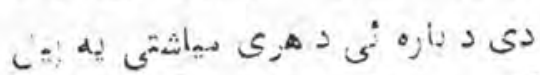

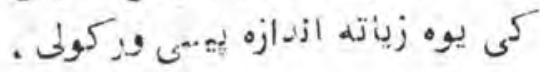

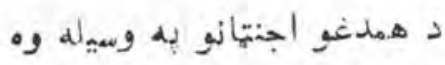

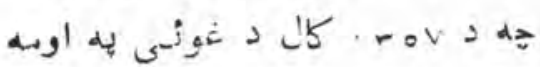

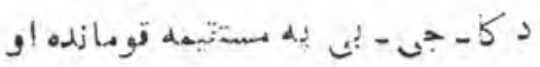

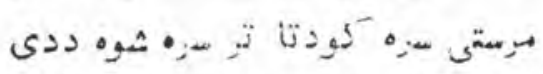

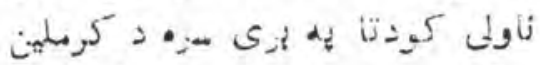

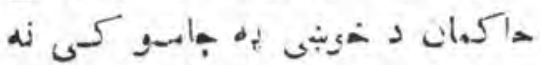

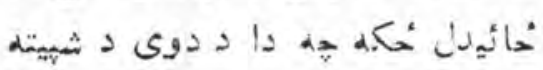

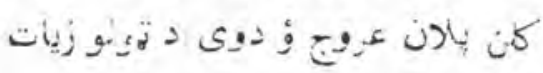

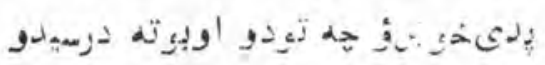

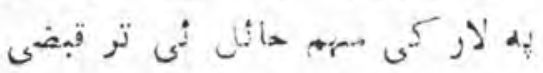

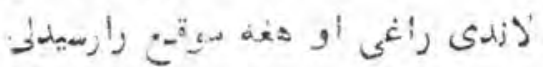

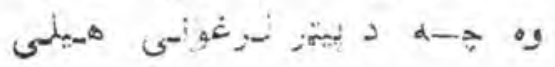

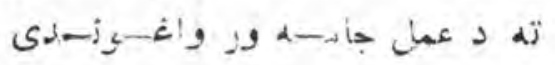

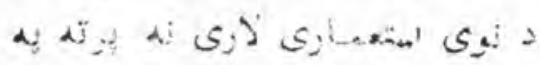

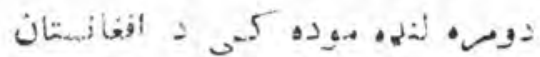

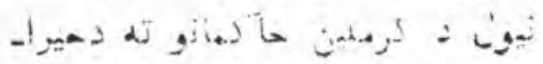
ن

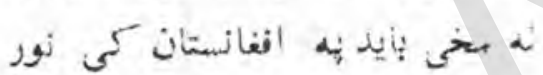
هـ كار شوى واى زيوخكه دوى دنه

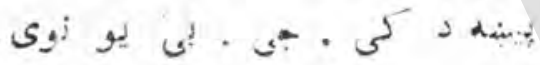

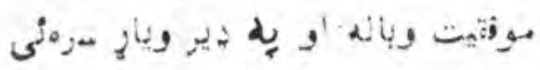

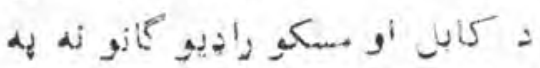

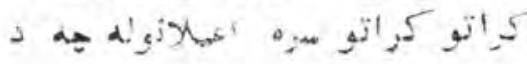
أing iو

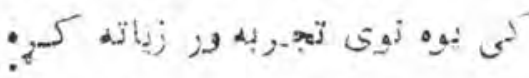

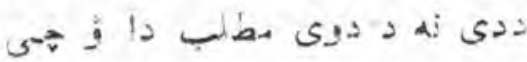

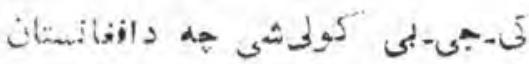

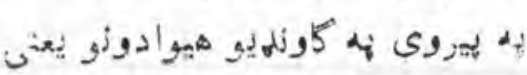

او هفيم نى كحى د د دغو محملينـي

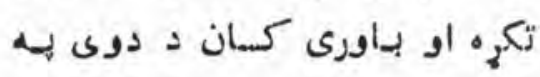

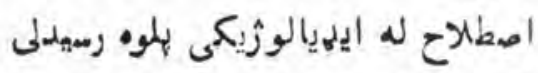

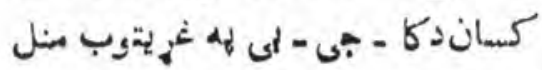

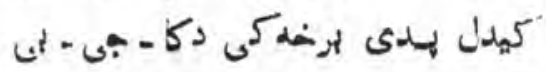

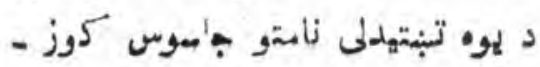

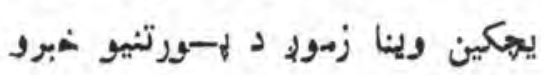

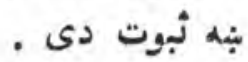

كوزيجكين خهاه دكا - بی - نى يو زأمتو غرى و او مَّ مياثتن نى نى

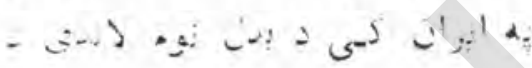
5 ك د

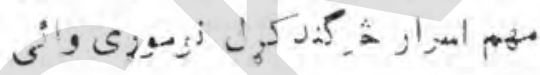

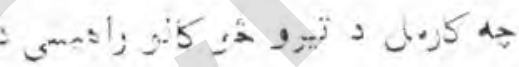
ك-

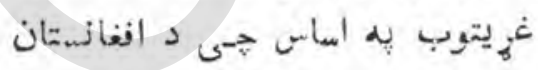

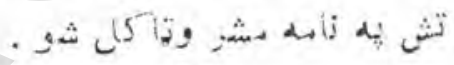

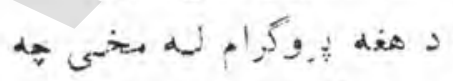

5

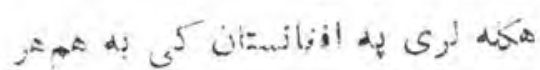

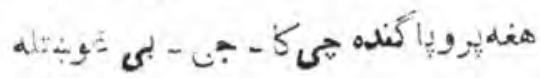

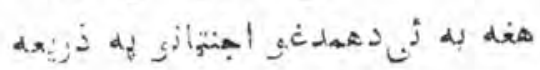

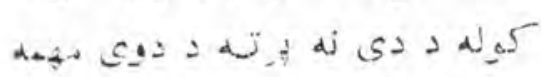

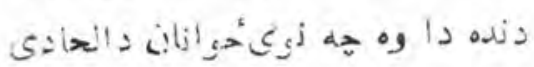

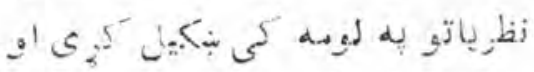

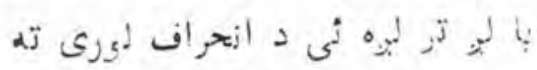

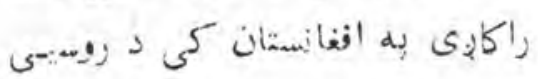

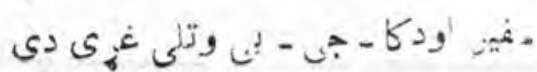

دكرهيين هاكهانوته وخت يه وخت

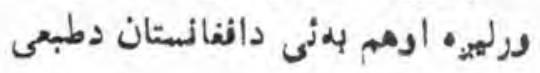

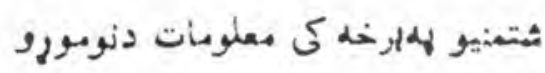
تش به نامه متخصمينو لهوا تهمهد

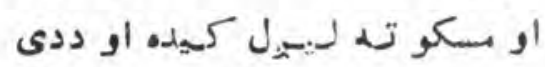

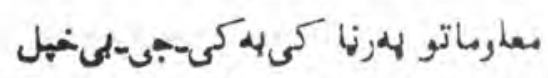

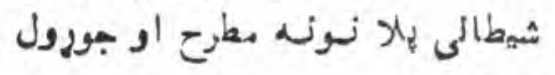

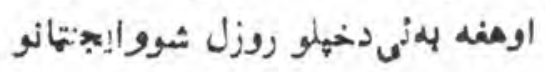

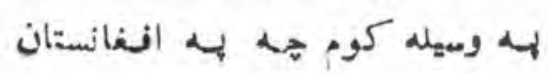
كى ؤ ابلى كون. هـداراز د تعليمى او كنتورى

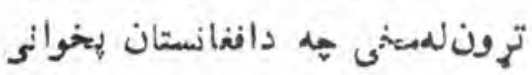

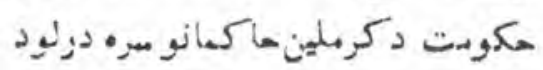
د افغنا نستا ن دهلهـكى تعليمى ادارو او همدا زاز د حربى لهيوهتون زيهات

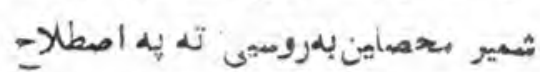

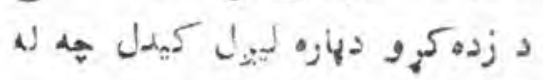

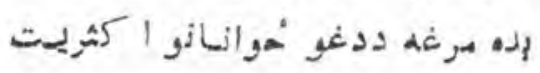

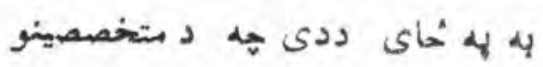
بهتوكم وطنته راستانه شیى دالهاديى نظريىسر هبه خهل ديواد تهر اكرئهيدل.

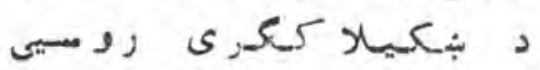
تعليمى نصهأب د مهدى اصل بهل هابم

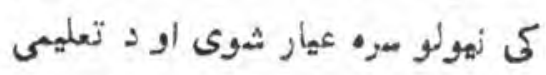

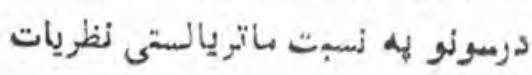

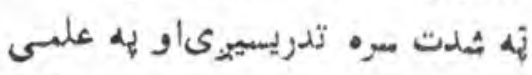

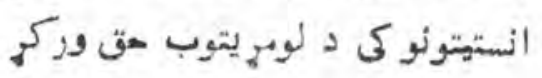
ثوإيدى هـر يسو دتصصن بإيد د شهيل

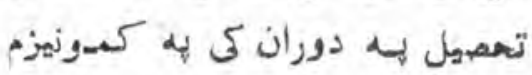

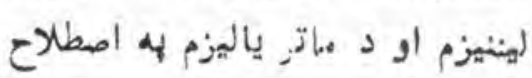

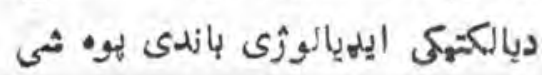




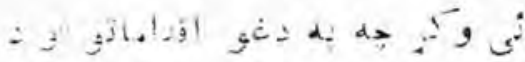

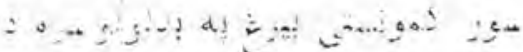

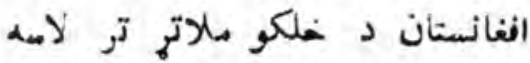

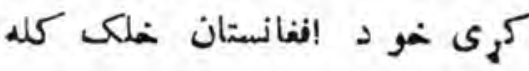

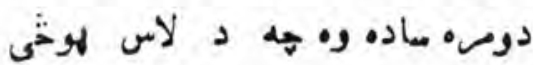

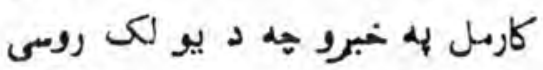

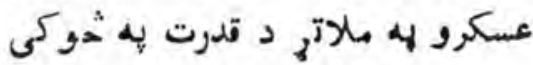

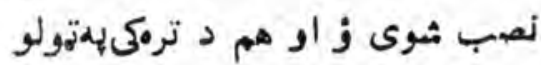
جناياتو اوفاجعو كى ورسره شريك

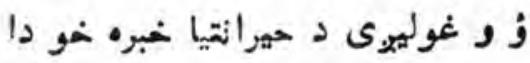

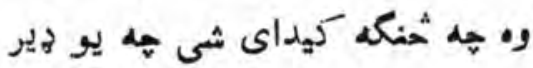

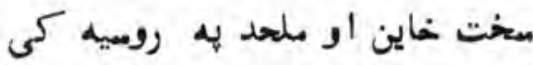

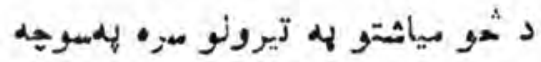

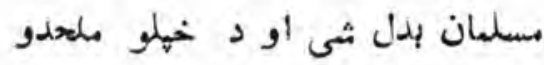

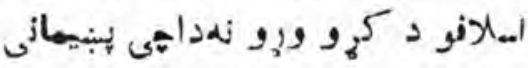

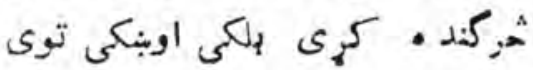

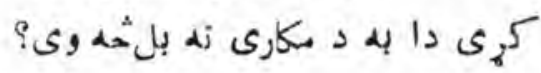
مهدا علت ؤهه بجاهد او باتورافغ'ي

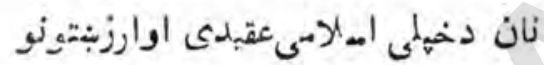

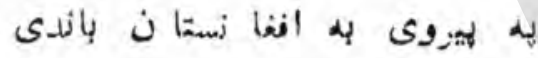

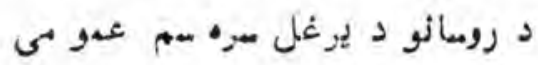

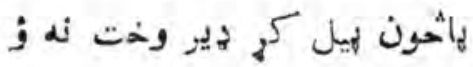

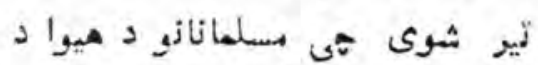

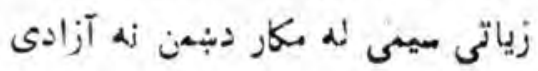
. 15

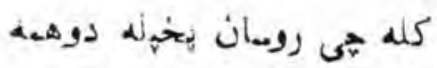

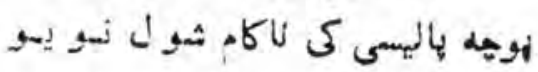

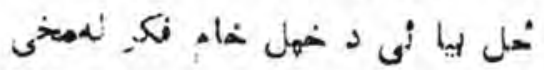

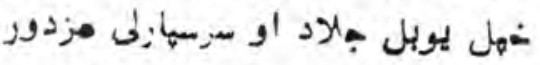

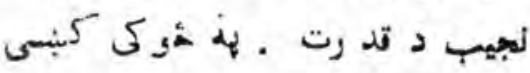

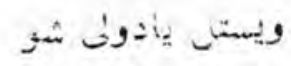

=

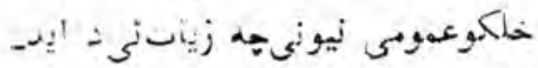

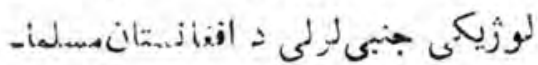

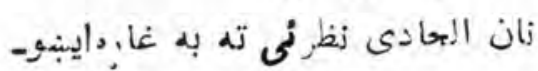

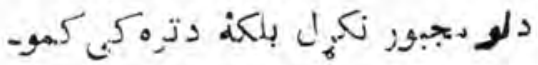

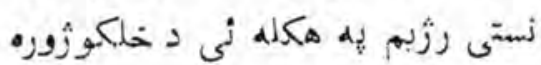

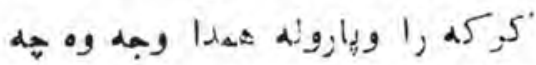

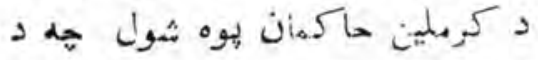

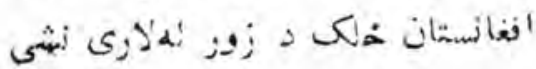

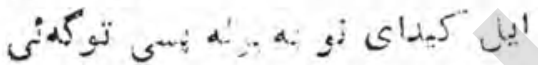
定

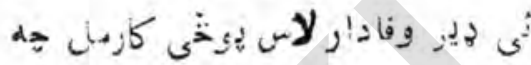

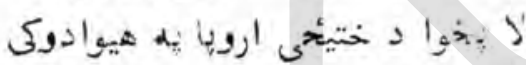
هو

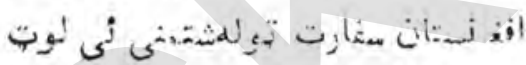

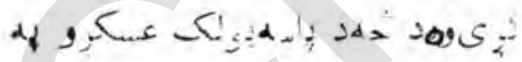

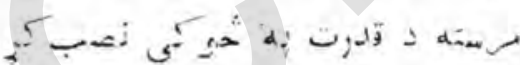

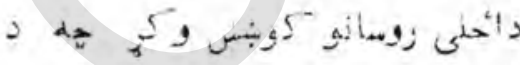
ज

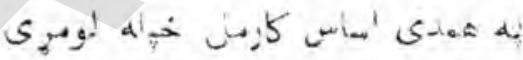

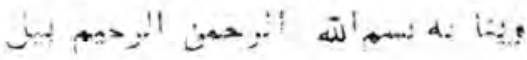
$\therefore$ if

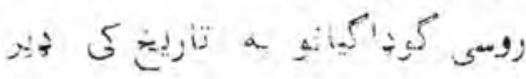

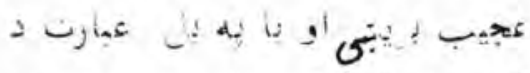

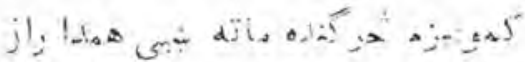

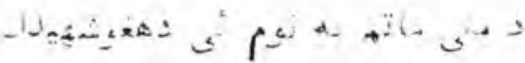

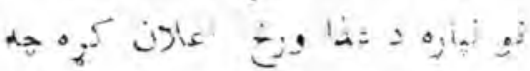

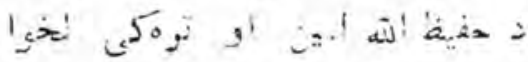

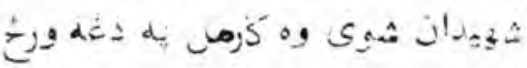

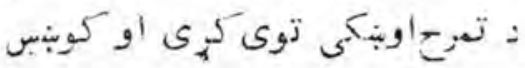

ثائ.

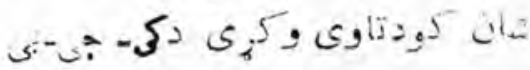

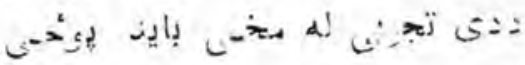

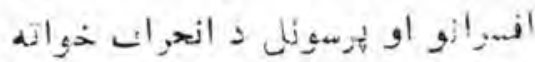

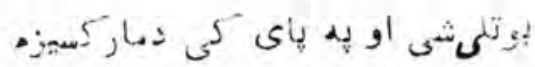

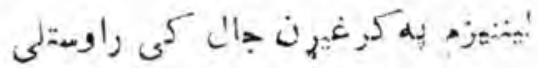

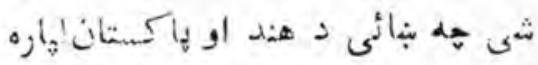
2: हुز "

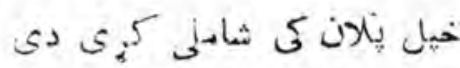

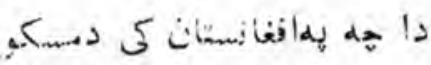

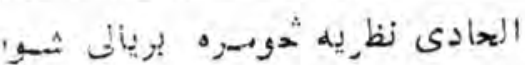

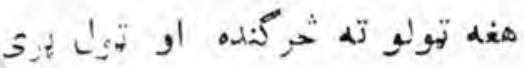

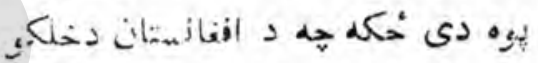

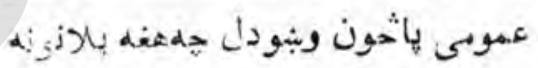

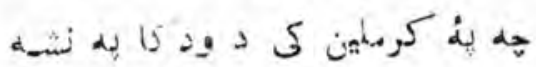

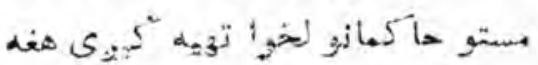

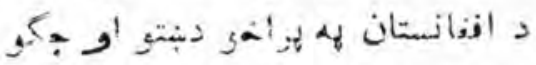

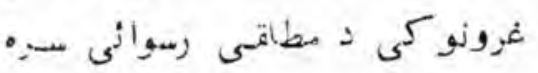

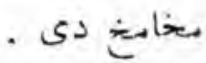
د سرى كونةتا نه وروبمته كى

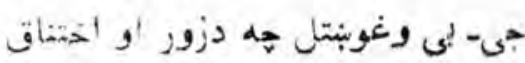

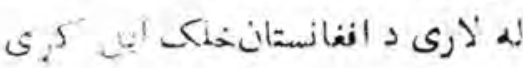

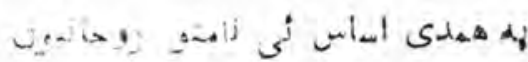

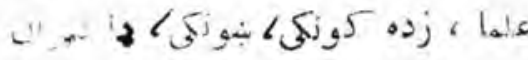
ان.

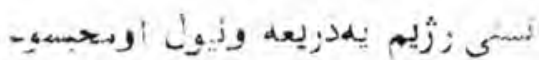

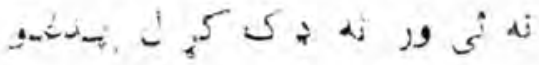

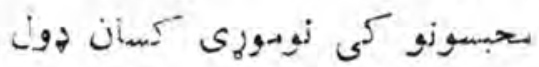

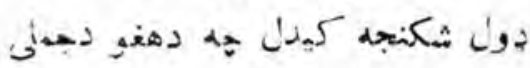

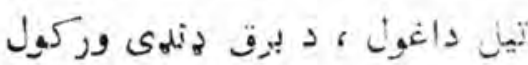

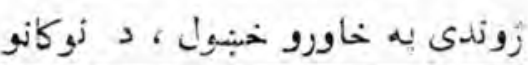




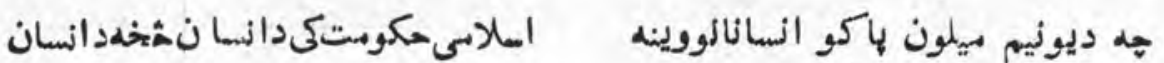
هكومت لرى كييزىاو يوازى دلوى

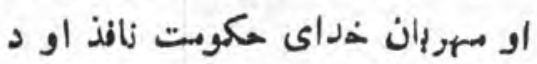

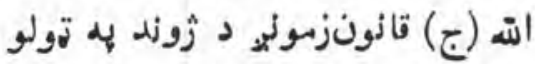

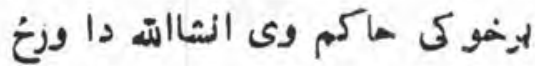

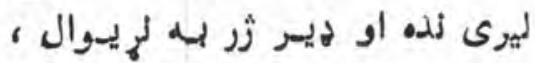

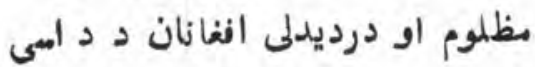
: والسملام ددى دياره توى شوى ضايسع كرى خو د لوى او قدير خدابى إهله مرمثه

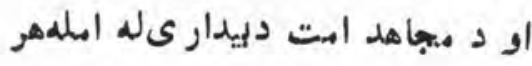

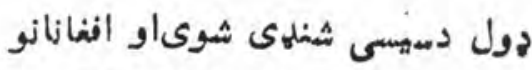

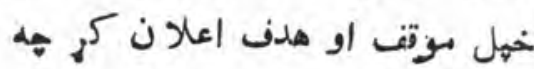

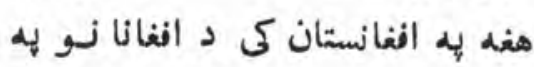

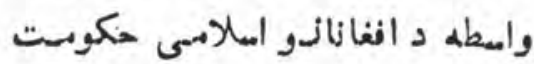

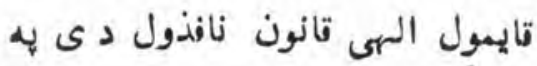

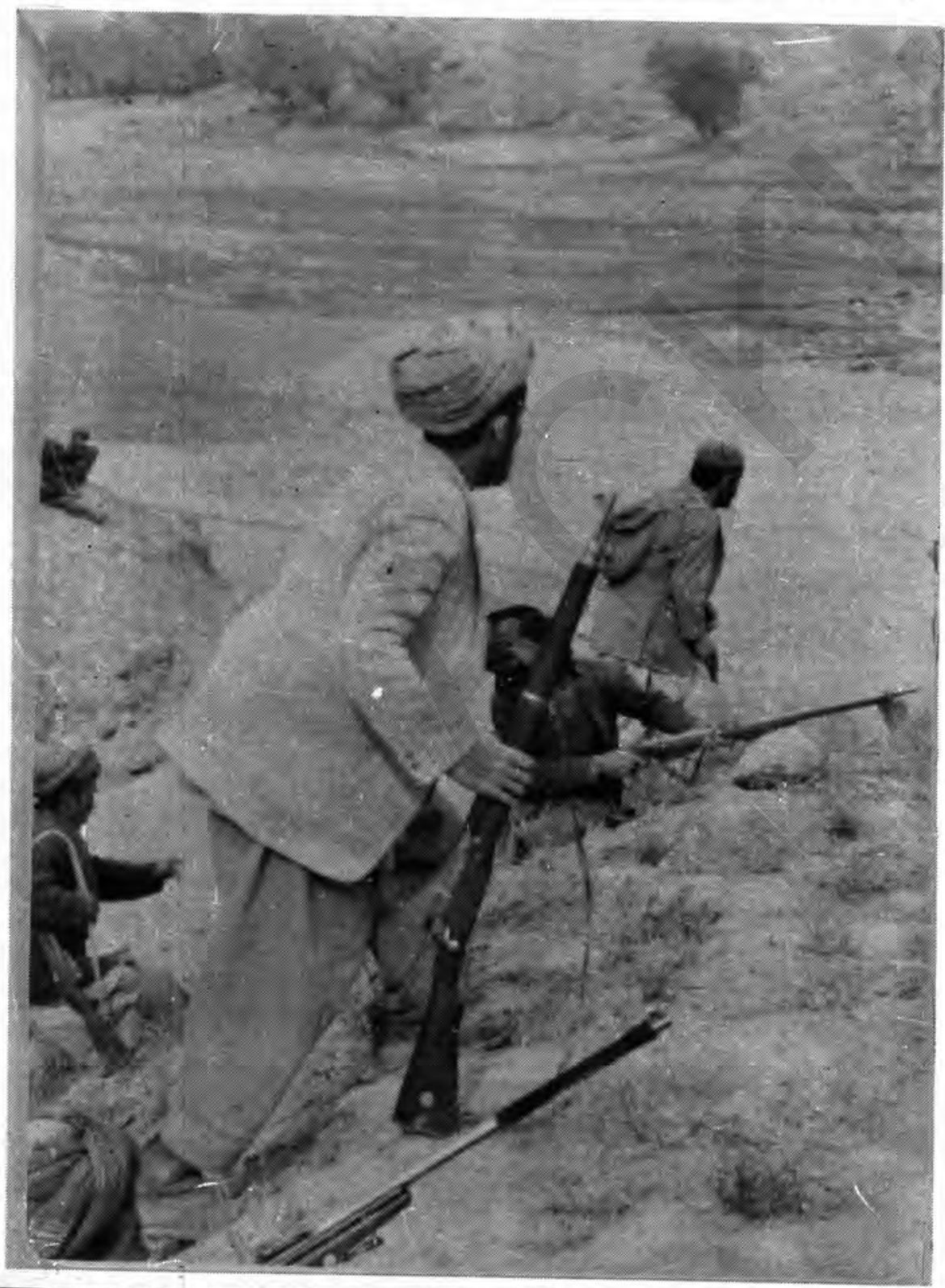

ناؤخو د نجيب دراوستلو سرمجوخت نى له لظامى قوى له زيائه امتفا ده

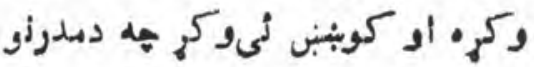
وسلو لهه استعمالولو سره د افغانستان سسلمانان ايل كرى كلى كله جه روسان

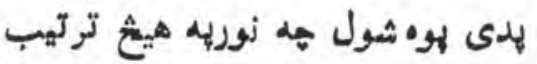
نشى كولايى هيه د الغانستان باتهور اولس د خهلى كاو له قبضسى لالندى

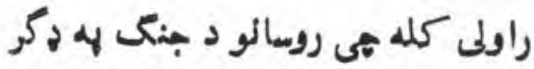
كى د افغانالو طاتت او تمدرت وليدو

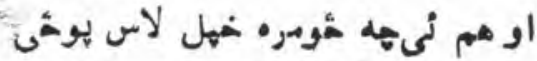

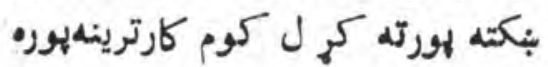

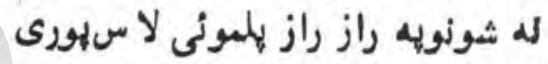

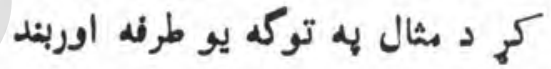
نى اعلان كر، ، د دمعالجه ملى آواز

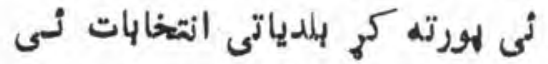

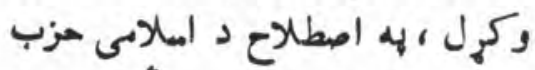

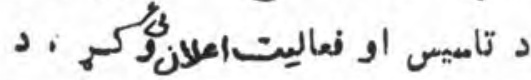

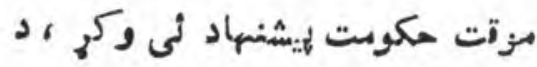

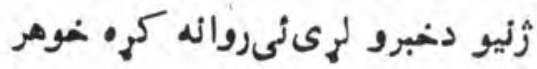

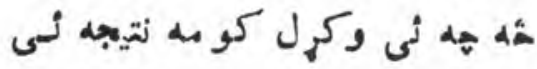

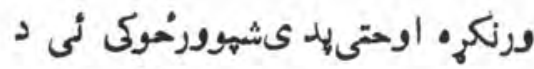

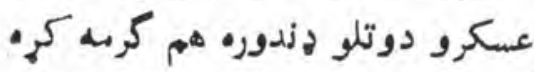

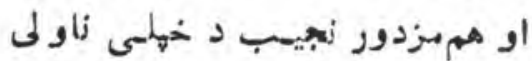

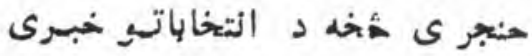

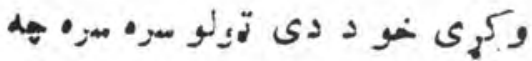

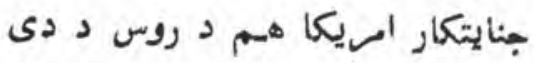

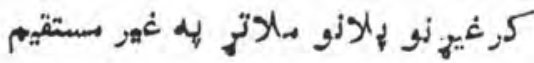
هول اعلان كم او كوبنب نى وكئر

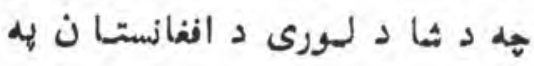
خداى بين اولس سترهمليه اومقصد

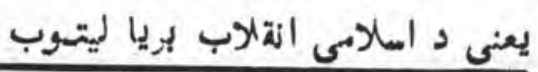


94

شميده من كه ثيوطان زاده را جيو

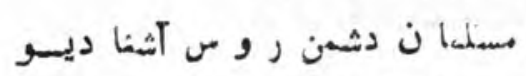

مسخن مـا كفته ضـد لشكر ديـسن ز روى خبث بـا طسن و ز رو رو كمين

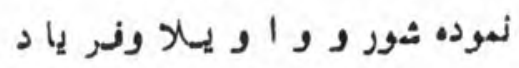

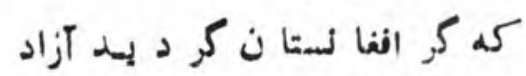

وكر املا م شد حسا كم د در آنبا

هدل كر د د يقيناً و خسع دليا

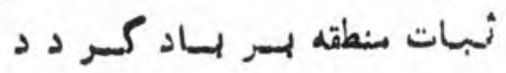

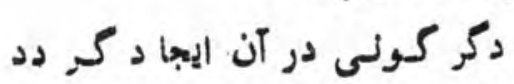

نامة منظوم

مسلس نا ن رها كر د كلد از بيند

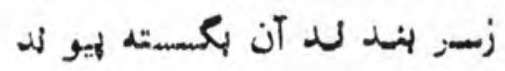

زهواب قترنها لهي-دا ركر د ند

u

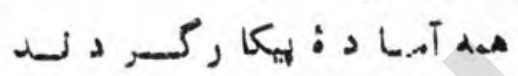

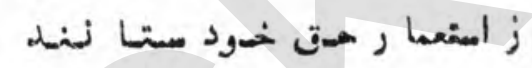

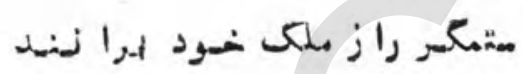

راجيوكاندى

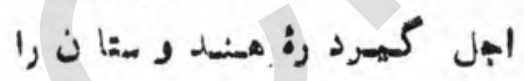

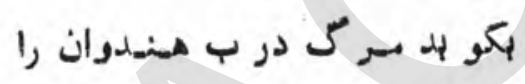

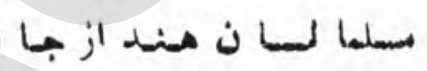

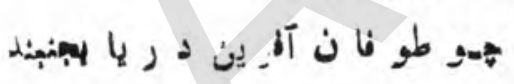

ثمرا رى كثمثه هئد د را لهسو ز مند

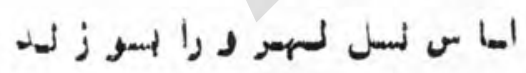

دو 4 ه • تخت وتاج از ما اكهر لد

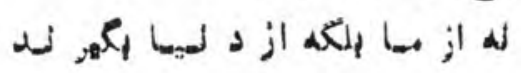

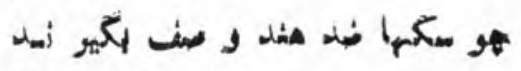

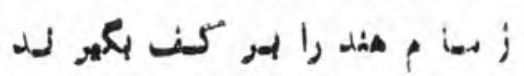

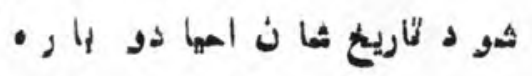

عبدالاهد ,"ارشى"

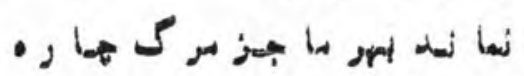

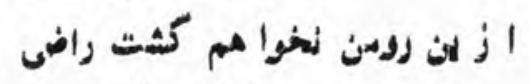

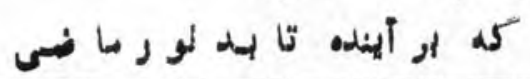




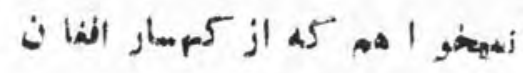

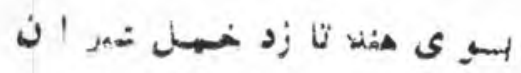

لهنوامهم داد هر كز الن اجاز ت كه در كابل كند فرآن مكومت

هنهن ليهوده كو لي ما ى لسميار

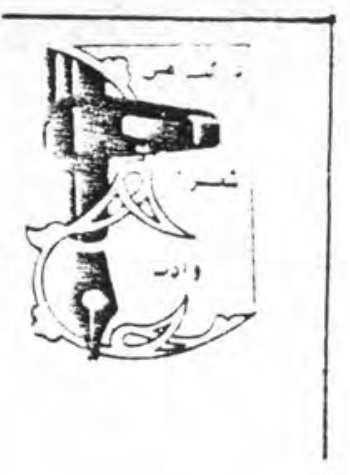

لمو ده آن خدا نشنا س مكار

صبا ایى .تا مسد آلهيسل سهمس

بكو راجيو را !اليكو له از بـا

كه اي هفدوى دون آد بهيطوار

مميشه كار تو مكر است و كشتار

تو ليق لرز لمد آن شميطا ن ما ده

كه مسدم را بكثث از هد زلياده

زيقد وكيمه ميدووزخ لهوالمدهت

سمسمانان هندى را دور آنسعوشت

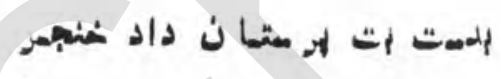

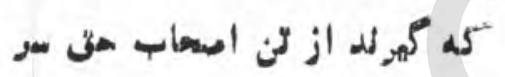

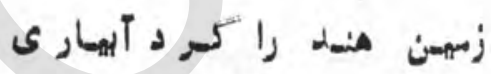

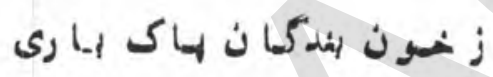

هبسلمان رابه تأون دمهت دلهالمبت

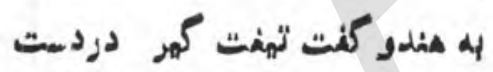

سملها ذ را بكذت از بها لهنهى

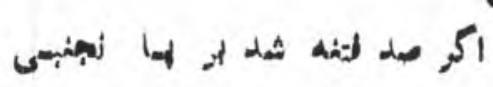

a diئد كفت از ها خهنهونهرق

مرش ابركي وخونش رونهون الرق

لوازش كمرد هئد و راز هند إيث

مسلمالرا هو المعى زد به دل كهيف

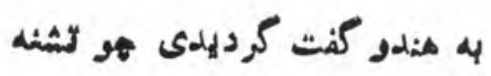

هد: قلمب هسيلما ن را به د ثئه

لبا لب كن زخونش سمالعر و بام 
$9 \varepsilon$

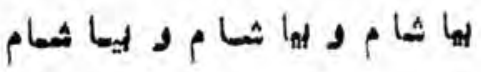

به هئدو داد اجا زه تا به تزوليهر

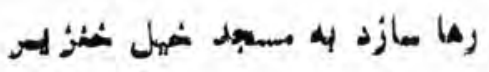

مسلسان ثنا دلاع ازخوايثشثن كرد

تروزسمش لقب آن شيوم زن كرد

نه تيها ريهت خمو ن مؤ منسالهزا

ز ملدها سيك هم بكرات بها نسرا

لدلى دليدى كه انهامش ثهانشيد

له دوزخ باهه رسواله روان ثد

ثلا طم كعرد همون لهكناهـان

4ه رتص أسد درائي دريا همطولان

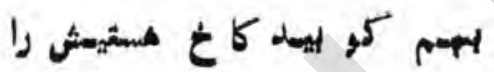

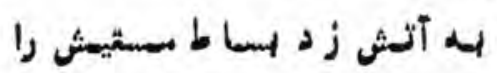

تو مم در راه اد 4 مى كذارى

لالمينكأ لهاى إيها سم كذارى

كو مم درياى شهون خلق نوشى

تو مبم بر قتل موسن سخت كوشى لوش

تو هم هون مادر خمود كيمهتوزى

تو هم خناش و از اعداى روزى

تو مم كركى و روبامى يكى آن

السان مادرت آن ماده شرطان

تو مم هون مادرت مزدور زوسى

غلام ماكىم منفور روسى

تو مم ديوا له تدر ت لير متى

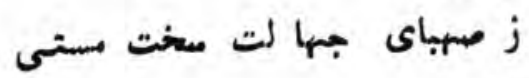

تو مم كم هن: و كم دندان لمايى

هو الديرا به لاكسبتان لهالي

تو مم خوامى كه بلمى اين وطن را

خزان مهازى لهار الين همن را ران 
9.

ترا مم ثكر شاسى مست در سر

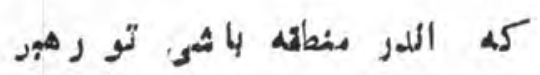

تو حود باشى علام و هاكر روس

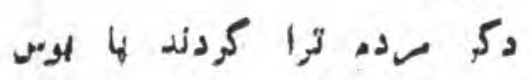

ترا مم لكر تحخيك هرم هست

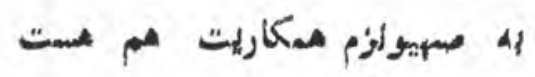

تو هم درنده بإى إز ج:كل كنو

زلى در قلب الهان هيكل كفر

لمرض هون مادرت مستى لهو, كار

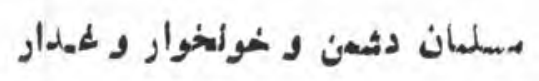

اكر خواهي همو وى رس-وا نهمىى

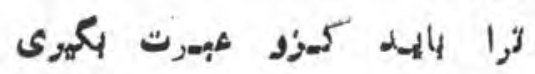

كرت الهر لفش او رلثار باشهد

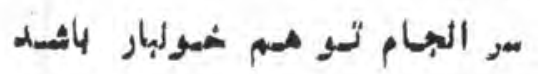

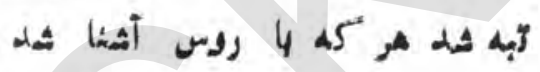

اسهر خشتهم مسلدت وز مخدا لهد

ككن 4 خدرس روسى مهينوايسى

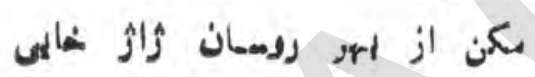

ككئ لهز مساز روسان لاليكونى

ككن له درب روسان شاكروانى

هشو هون مادرت هئشون رومان

مهده عقل از كَف از المسون رومان

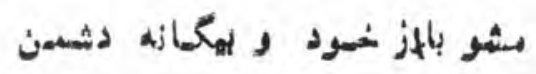

مزئن أو ثمله هائ كمينه داسن

بكن با النقلاب بـا عدادت

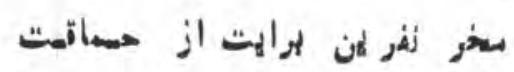

خود را بزن بر سنك شارا

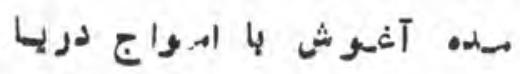

$$
\text { كو كركى از هه } 4 \text { شهران ستهزى }
$$

هرا لا ملت إلغان متهيزى 
47

به نهاثاك ازيه بيدى راه طوفان

جه كولى مشت خمود بر كوهسازان

تو اى حناش كور تيره اقبال

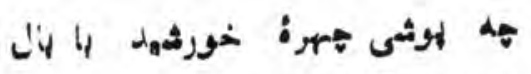

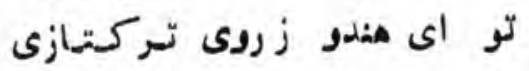

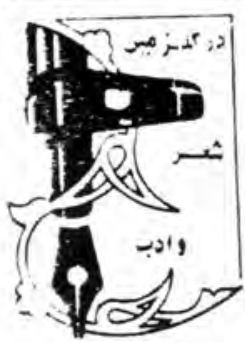

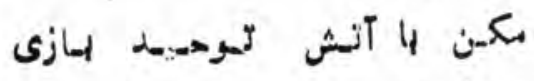

به نان كردن لكوامى كرد خاموش

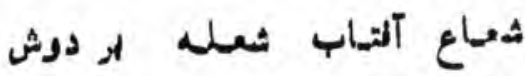

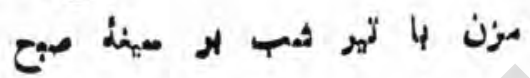

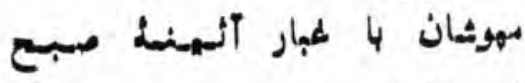

كله ميع اندر كفش شبشهر دارد

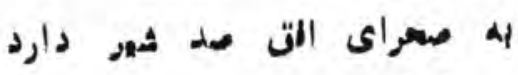

ثرا اي البه 4 الهان مثتئى

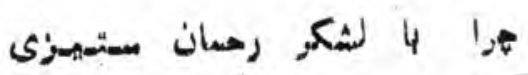

ثرا كر بى كئد كرآن حكومت هرا

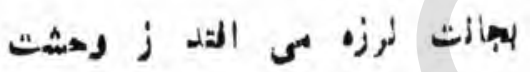

ثرا از هكم الهلاتى م-راسيان

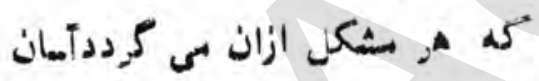

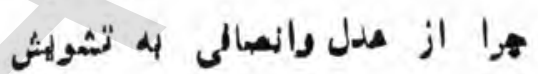

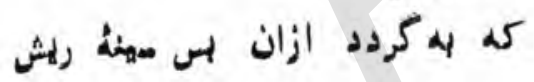

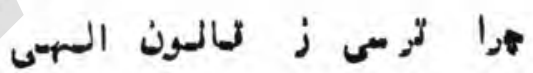

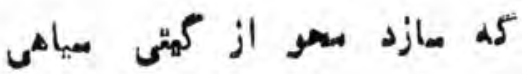

هرا لرزى الهود از لام اسلام

كه ازليضش بلام بهان ميكردد آرام

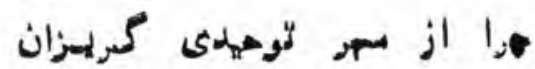

كم دذهيا را لسايهد لمور لهاران

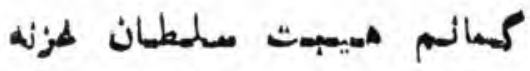

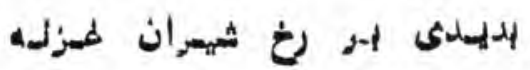

كالم ات ثكنها الرده موشست

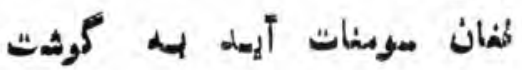


9V

تو خواهى انتقام قرنها

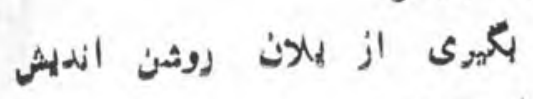

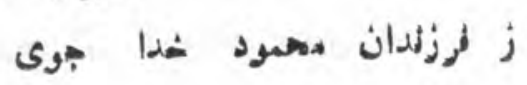

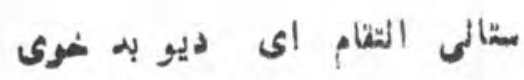

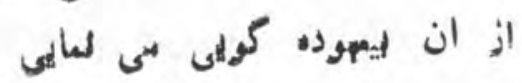

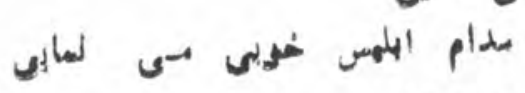

كهى كولى كه كر در ماكىالفان

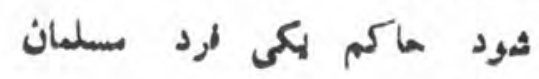

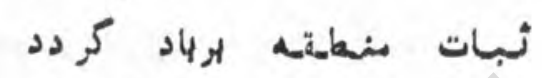
دكر كولى در آن ايبهاد كردد

كمى كوله أخواهم داد اجازه كه كردد زيم روس دوه دمئد بازه

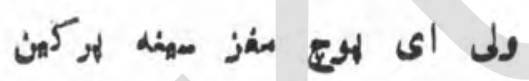

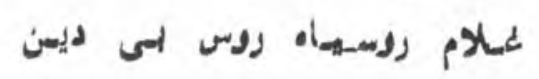

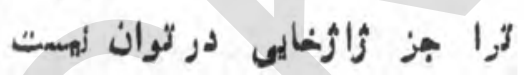

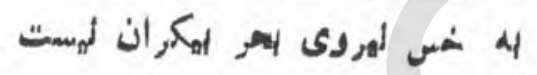

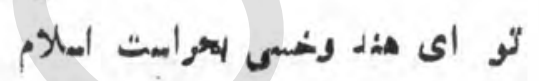

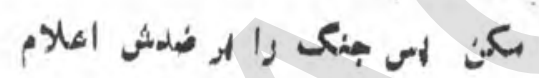

سشو 4 هوج لهد لورش كلا ولئ

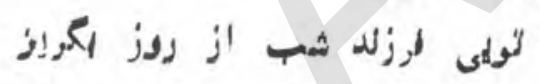

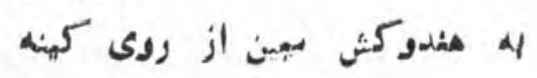

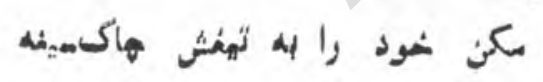

ز بادارن زوسى فهـ-رث أبهوز

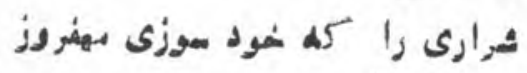

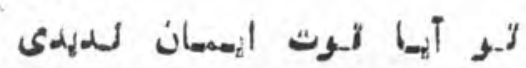

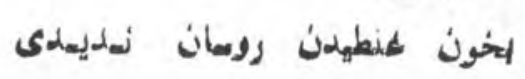

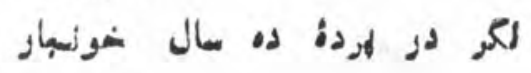

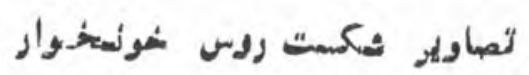

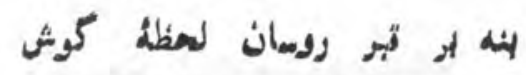

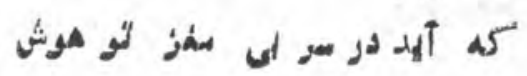


91

هئو ملددا مئائ از تهر ايشان

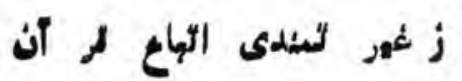

المرس از كوهسار بلمين لا هكا بت هاي بركدهمن ها

لكر مرغار ائن خاكسترنكين

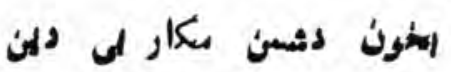

كم شههون ليزه در مّلبش خليد. دل لا لاكش از مهد با درلهن.

ثنو از سوج دريا بانك تكبه |4ه ميثرا هازكم روليده دعشثه

مرى زن در جبهم كي لظظاره ||

هزاران روس را با للب لاره

درينكينسار لنكم زير هرسنى

تن خولين صهل الى دينهليك

له از ده سال بنك لا لهرايه

كريزان كمته روسان ستعر

هو خرسمرغالاينامت اهوال

تو اي روله بها هنها ىينكال

ازلن الس مهكند قرآن مكومت

توكرخوامى مسد كنها سمسومت.

لواى خناش از ومثت بدهجان

كم آمد موكبهمورثهد لانان

تو كركى از سمه شيراكريز

توشاهاكى زراه سوج بر شهز

به سوالانى كماز مولستموجش

به كبسارى كملهيها نيستاوجش

اكر شهير خود اق هيدم لهضواهى

دكر للهس دوى هونردس الهانام

ذليل د روسياه وشوار د لاكام 


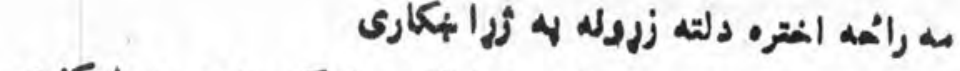

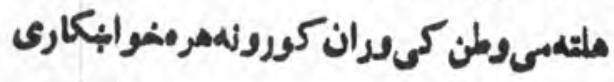
مه رائهاخترن

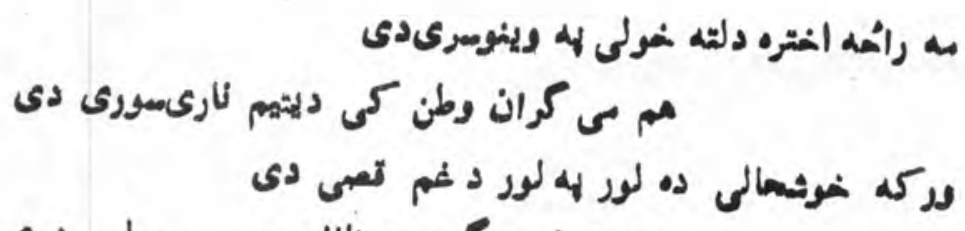

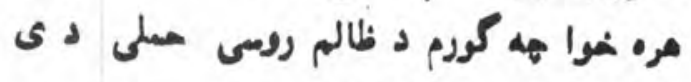

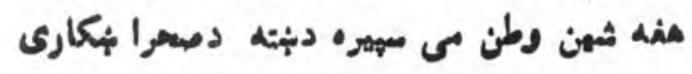

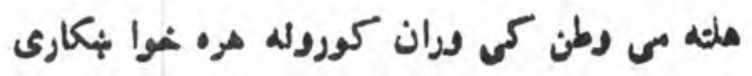

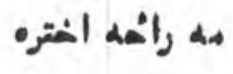

دلوى اختربم منامبت

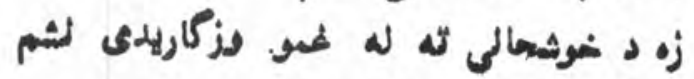

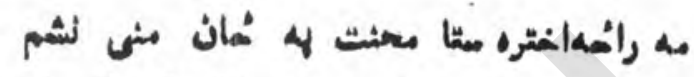

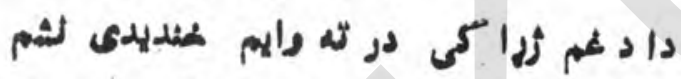

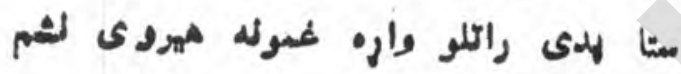

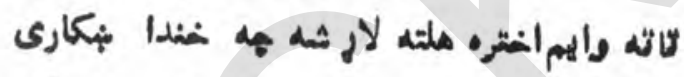

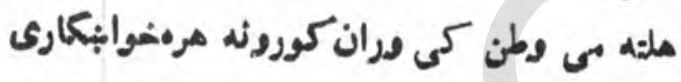

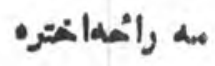

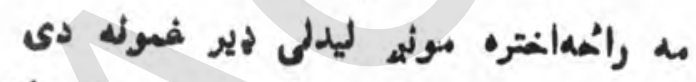

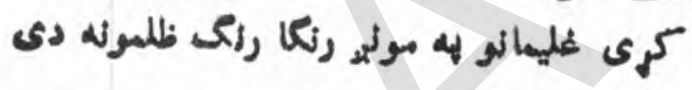

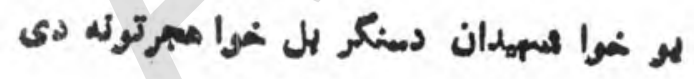

هم مو به زركى د آزادى همت آرما لونه دى هي

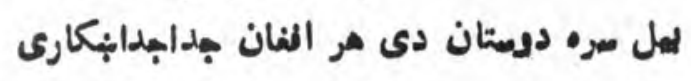

"

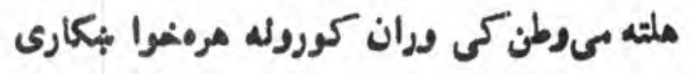

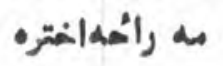

$$
\text { مه رائهاختره د لقه هره خوا ويرونه دى }
$$

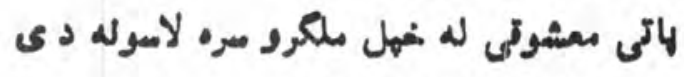

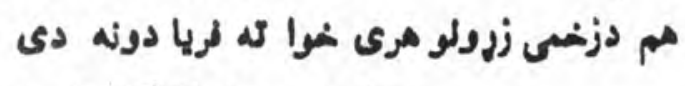

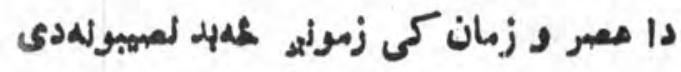


مكه مالنهاريهد خوب خندا لن نا روا بنكارى ملته مى دطن كى موران كورونه مرهخوابكارى هـ رائهه اختره

لوله خداله إته توان دطاعت را كهى

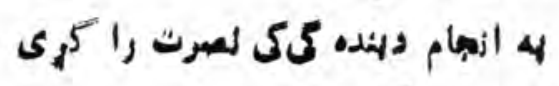

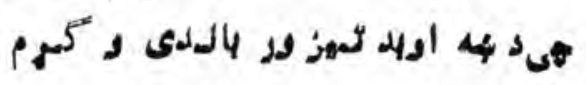

"له مكمهيى ذوالهلاله عكعت رآكرى

زه ليى علدمه إبهم لارده راله وركس.

مناجات ؛

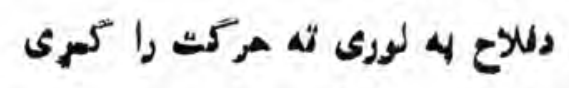

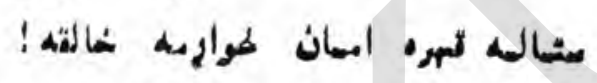

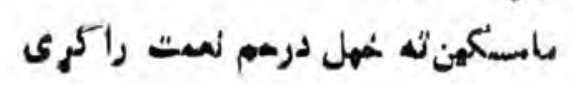

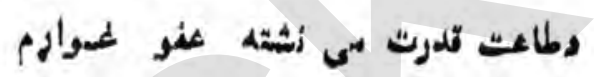

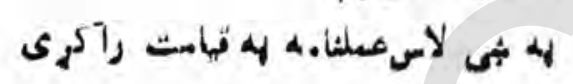

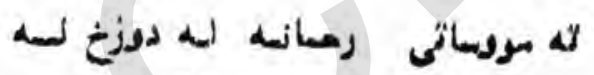

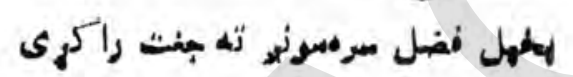

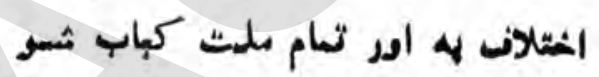

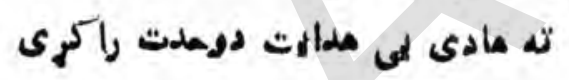

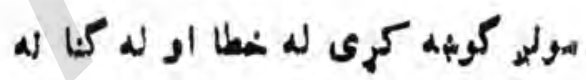

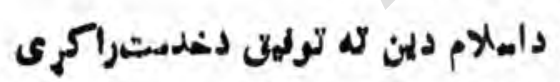

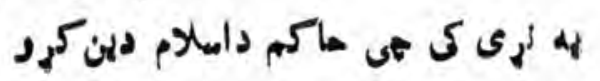

مهد الرثهد

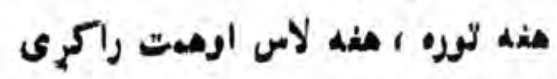

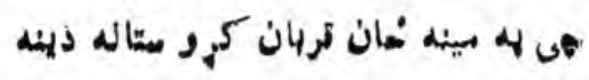

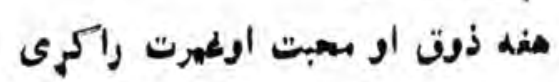

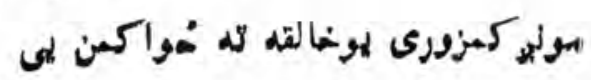

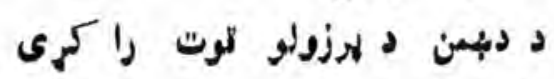

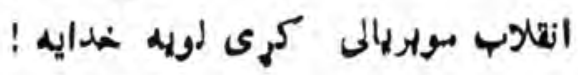

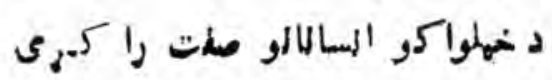




$$
\begin{aligned}
& \text { دطاعوت او دالعاد مانى كرى له لكمى }
\end{aligned}
$$

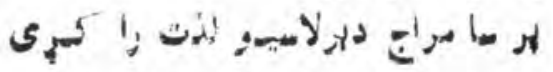

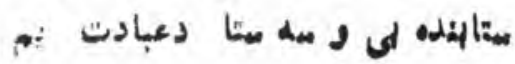

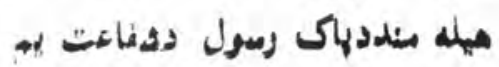
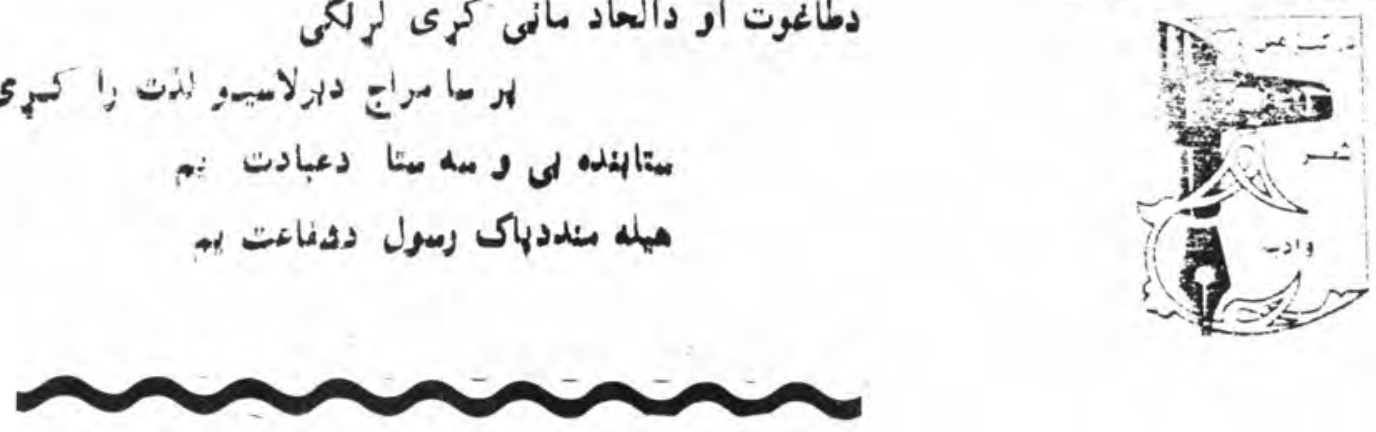

دا الثقلاب به دلهو لوى زولد بهار را ولى

تورى تهارى زيآن خمتيدى سهين سهارراوله

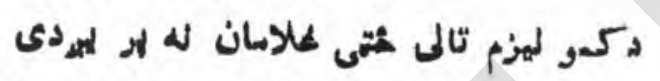

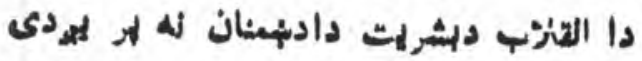

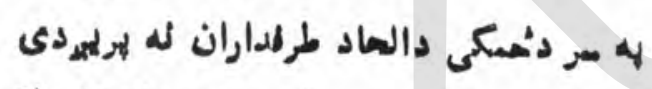

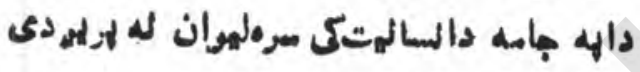

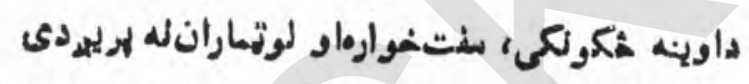

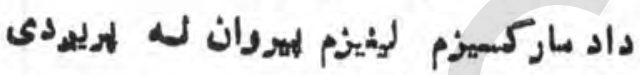

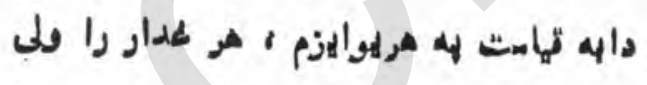

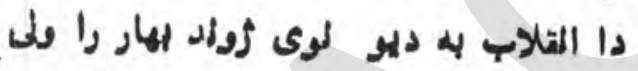

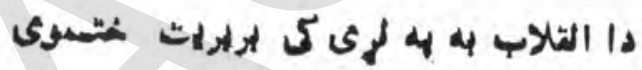

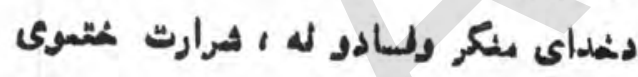

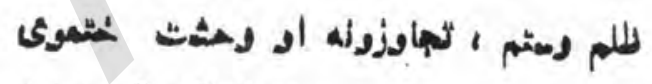

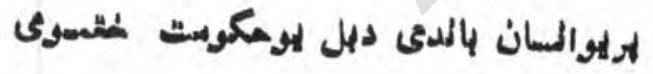

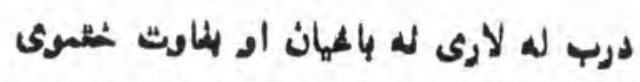

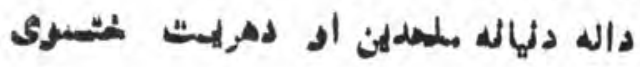

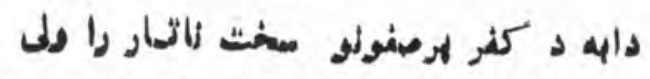

دا الثلاب 4ه دليو لوى ثرولد لهاد رادلى

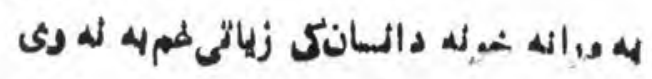

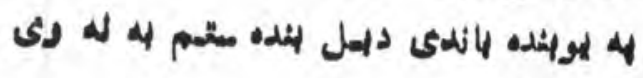

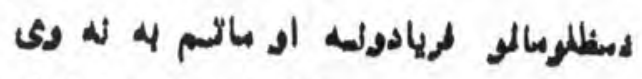

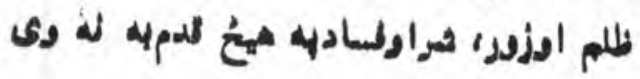


1.Y

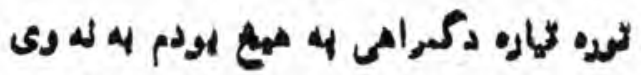

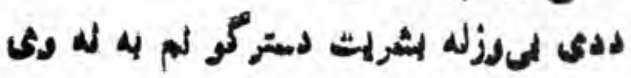

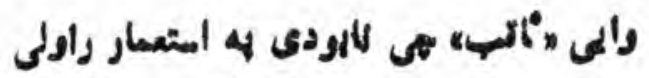
دا أنلاب له دهيو لوى زولدى بهار رالهل

ده هه دلجزى دارد خوب منطلر بغلان

بان و دل كند واله حسن دل ايرلانلان

مد هزار مالى را هاهر است ار ر ركش

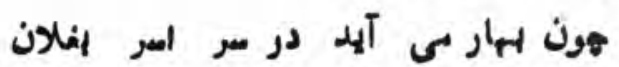

(1)

"اجغنروق" وا إمميرشه كردهرثك كشمهرش

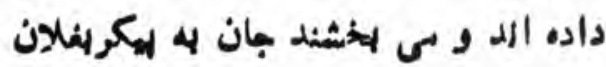

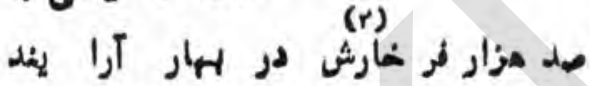

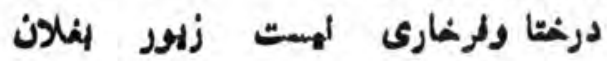

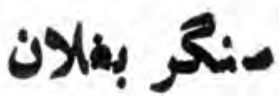

المدرا ب و لهورينش بلهقه الد آذلينش

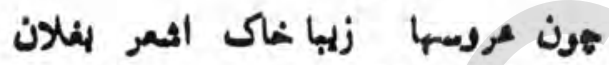

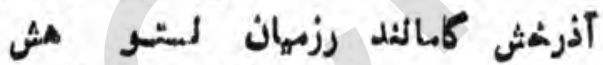

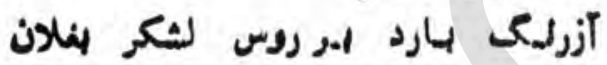

خربه هاى لكولاديسن مشث الهرماكالش

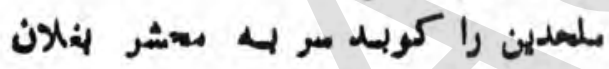

مر كاميده تا الملكى كومشار ستو ارش

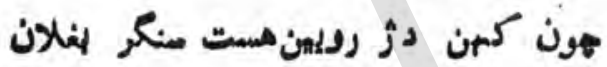

جلال مرمبغنت

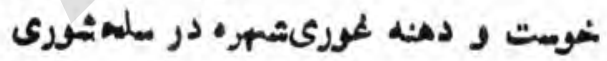

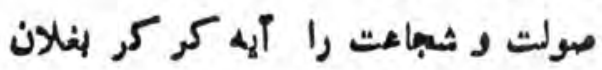

دوثى و دلهرالثى ، رز مهان هنهانش

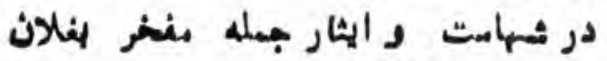

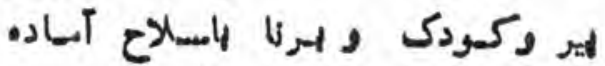

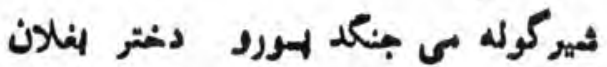

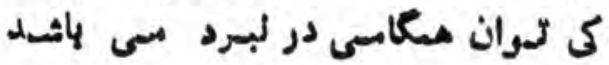

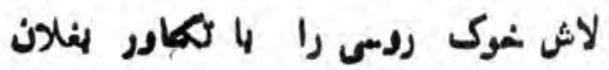

دهت و لامزن ليما روس شهرق شوامىثد

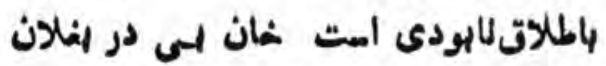


وراه راكت وإم ها ل لشكنى مر الغلان

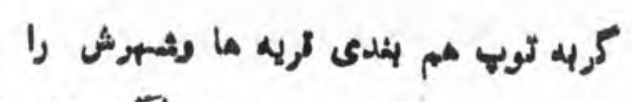

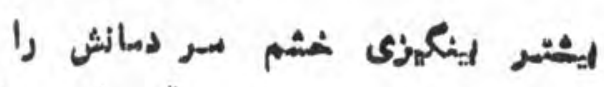

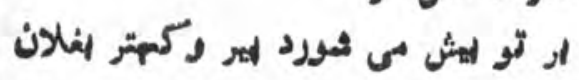

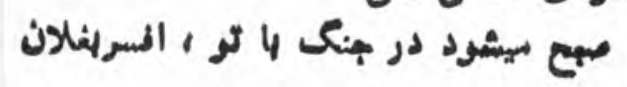

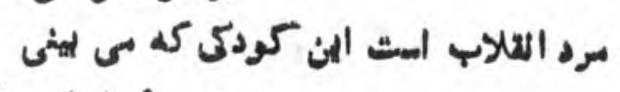

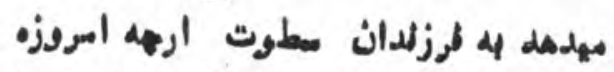

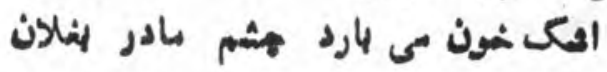

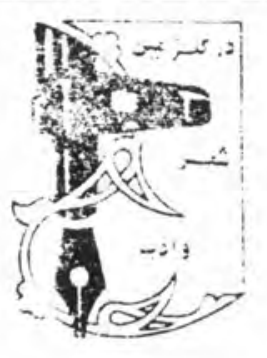

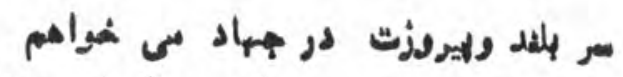

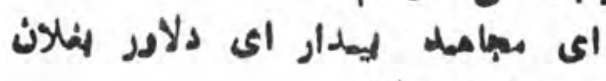

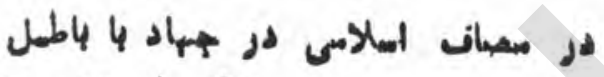

لطف الهزدى داد داليم بلاد بادر لهلان

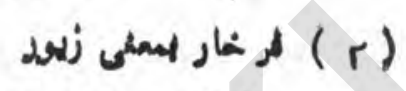

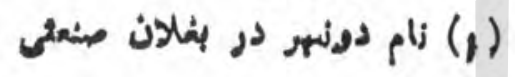

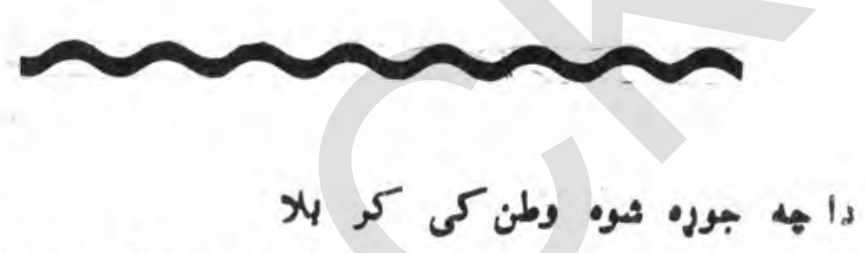

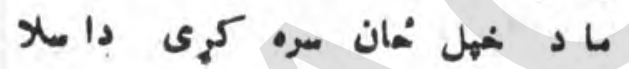

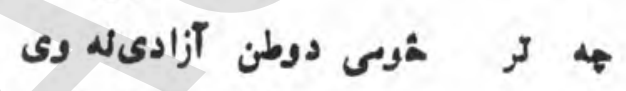

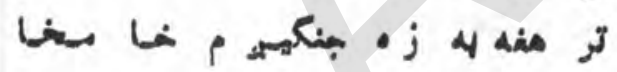

$$
\text { كمه له سرو ولينو كن هرق له دهله لار دم }
$$

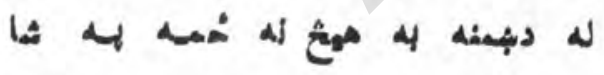

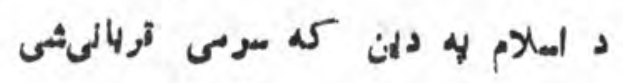

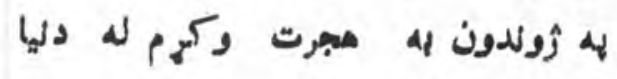

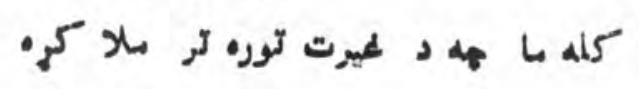

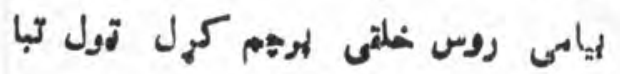

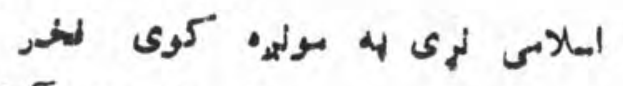

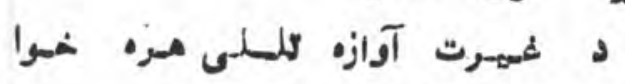

لعل ه n كلستالى a كثندوز وال

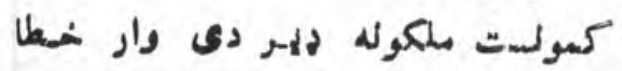

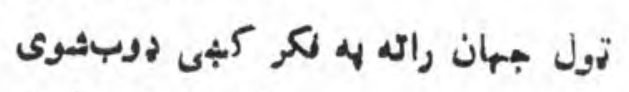




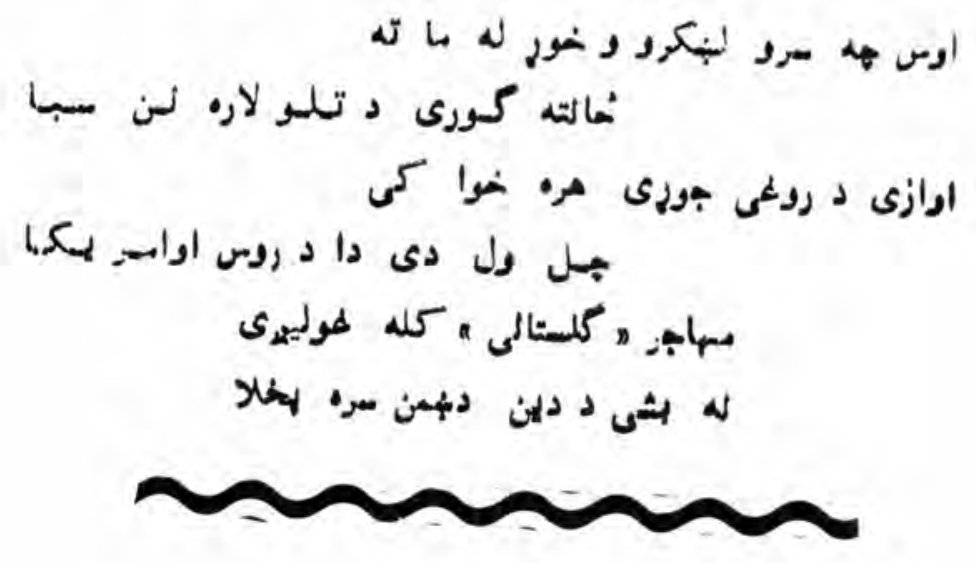

ول المدومكين مغطرم صوحت كزانآلش دورهمهان كرم سوحت

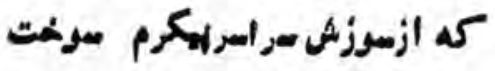

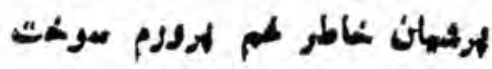

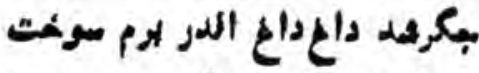

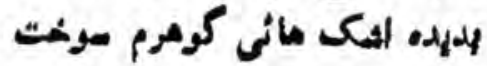

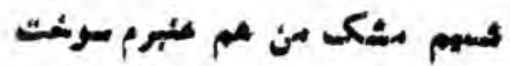

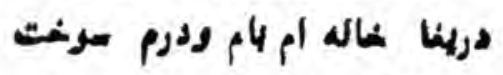

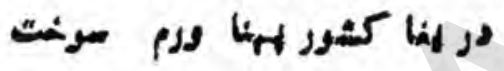

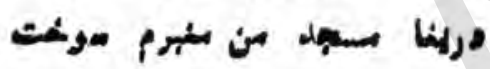

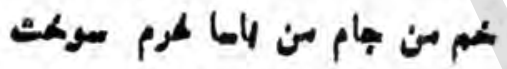

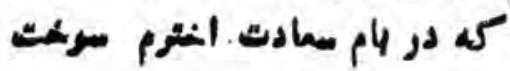

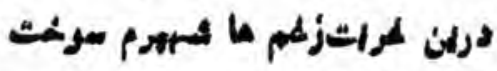
ككولى عثل لازى رهمرم سرخك

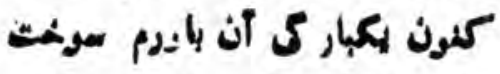

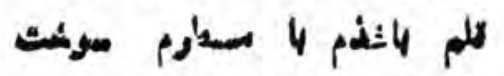

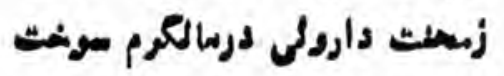

4 ياد كثورم بالوهرم سوشت مكر الدمر دلم آلش لثقاده

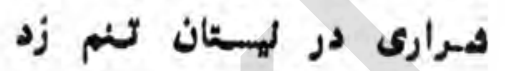

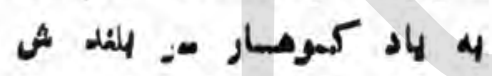

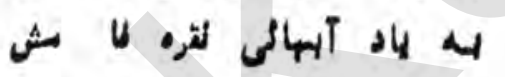

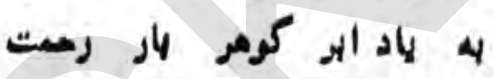

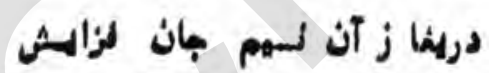
ز طلم ار لوش دليرانكر روس

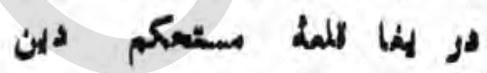

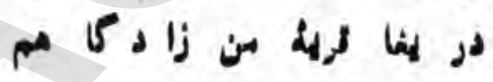

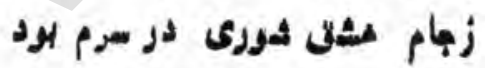

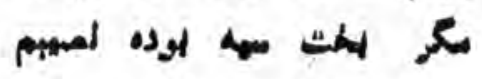

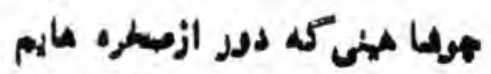

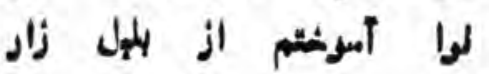

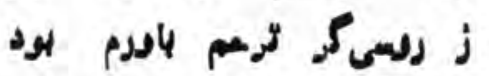

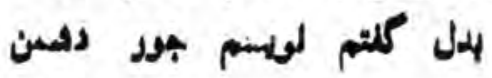

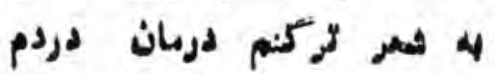

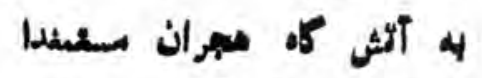

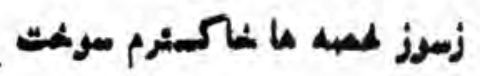

anirar/e/l 


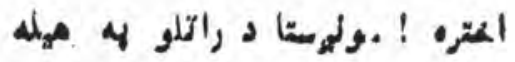

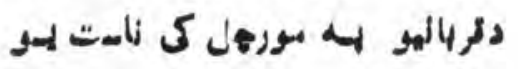

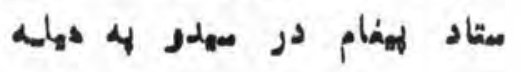

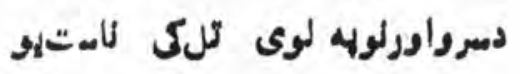

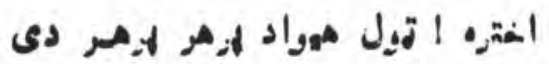

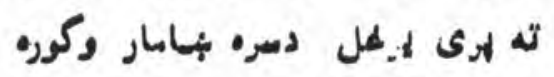

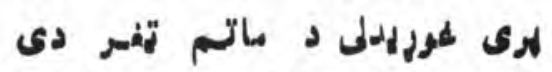

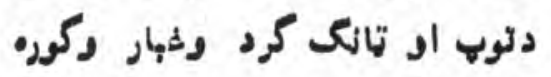

$$
\begin{aligned}
& \text { اخثره } 1 \text { و لينونه سعندوزله بورثول }
\end{aligned}
$$

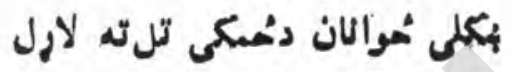

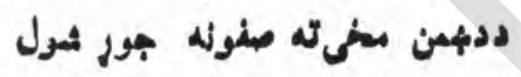

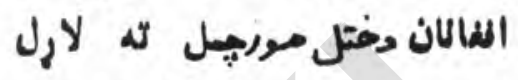

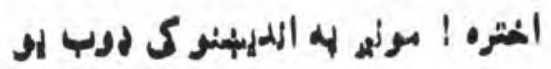

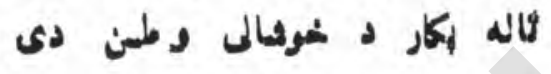

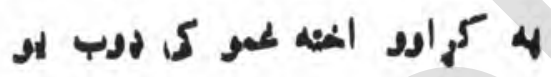

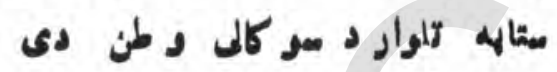

احستره ! رالهه الهفاللان وكوره

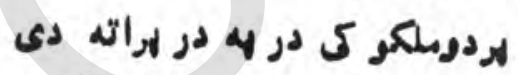

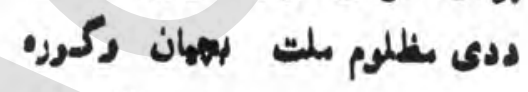

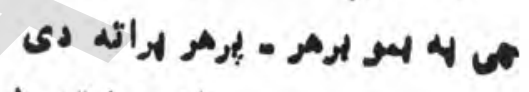

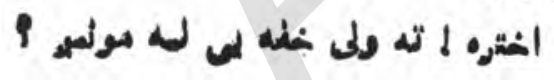

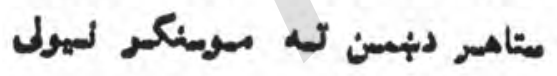

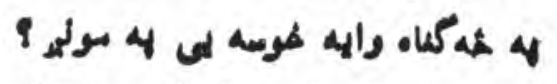

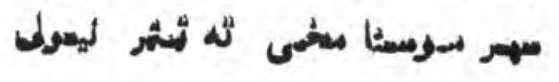

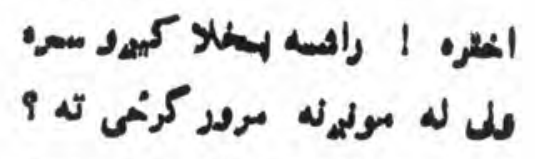

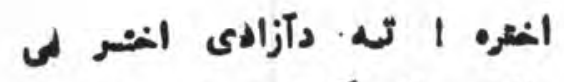

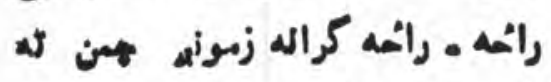

له "له

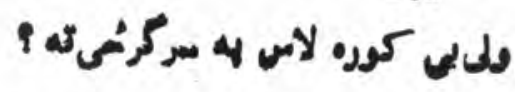

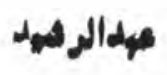

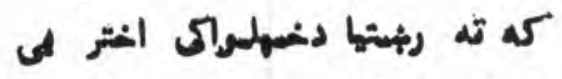

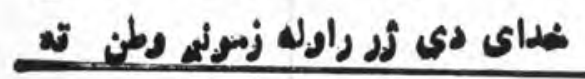




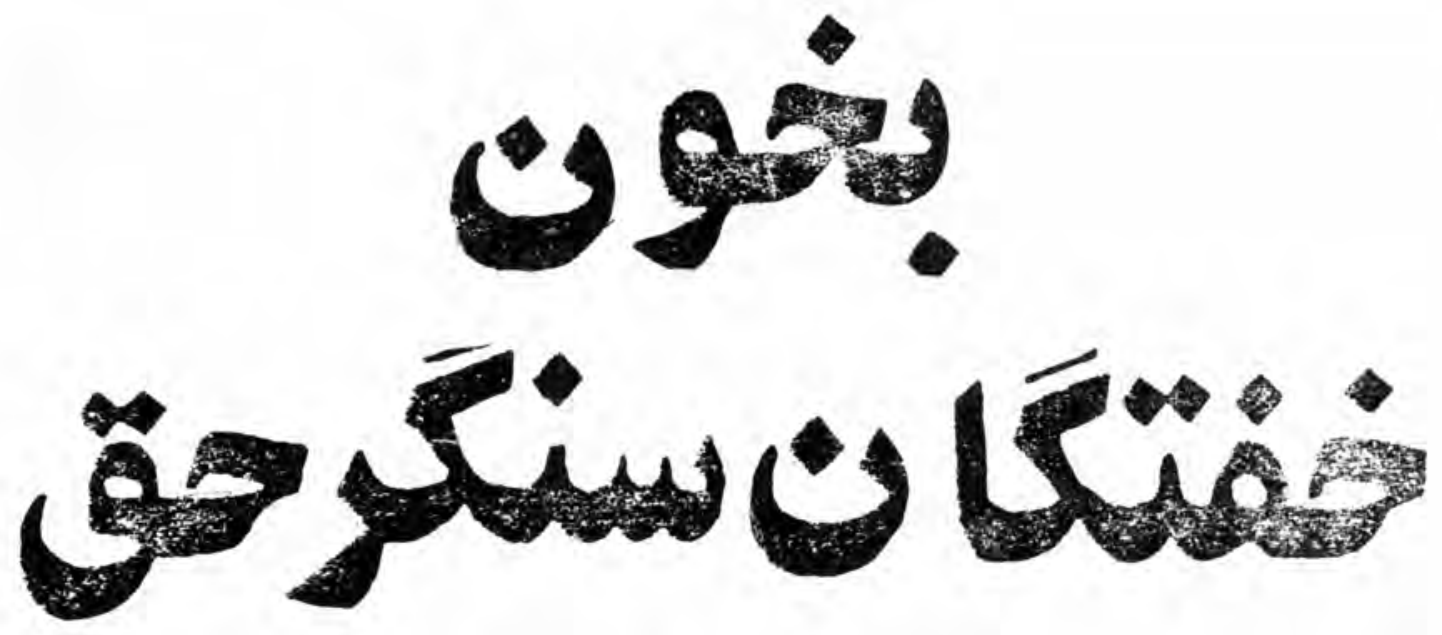

\section{هبهيد ه اكبر}

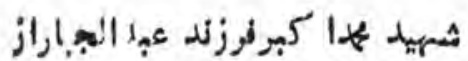

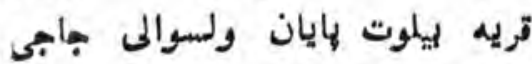

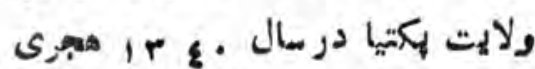

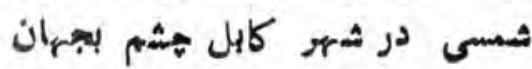

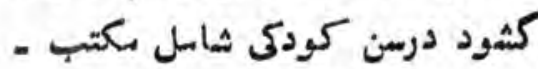

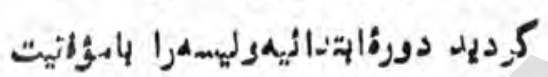

لهايان رسائد هنوز مشعلم مشت يازدهم

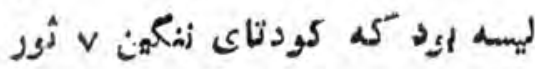

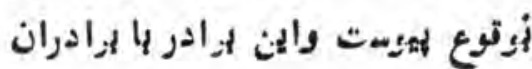

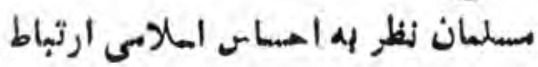

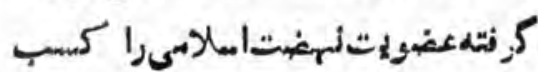

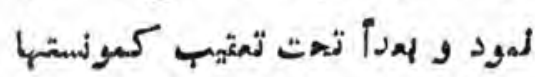

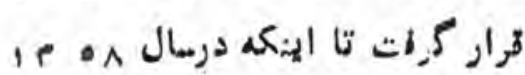

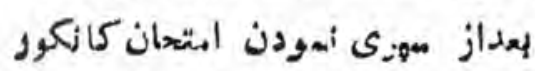

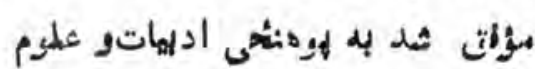

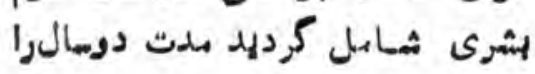

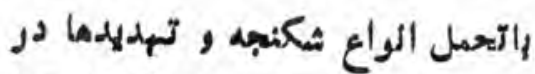

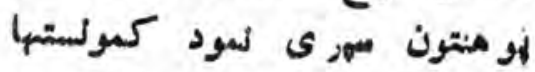

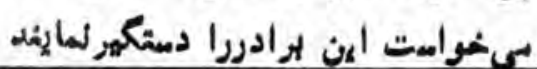

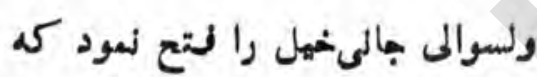
دراجزاى معين عمليات برادرتهربان

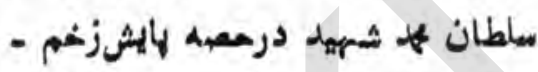

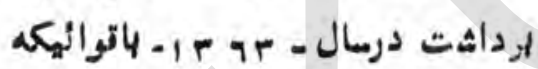

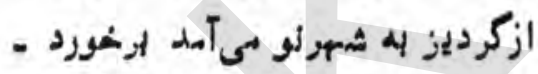

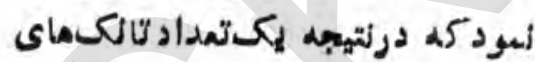

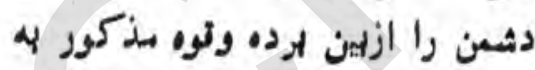

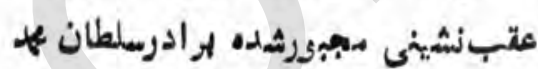

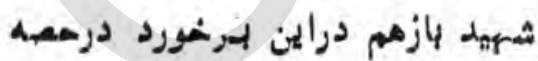

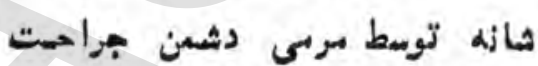
الزدادئ

لعداز صجت ياليى برادر قهربان

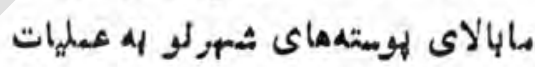

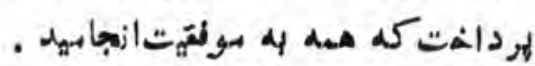
بالآخره برادر قهربان با درفئح

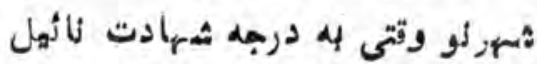

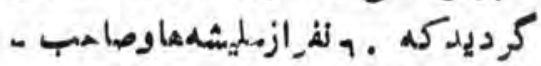
هنصبان رزئم مزدور را مزددارلمود و

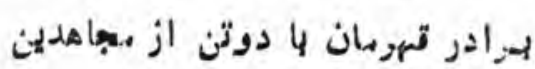

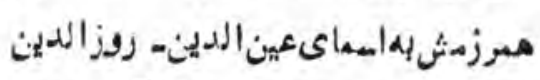

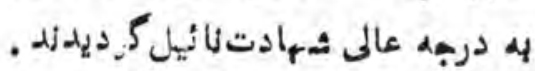
رومش شماد ويادش كادراسي باد كادي
سلطان ما ثميه مشيهور بهملنك

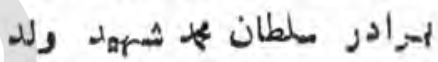

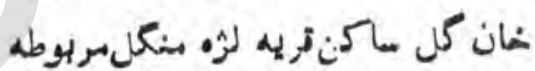

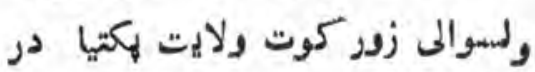

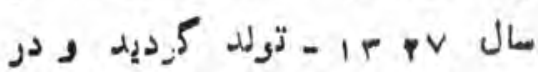
مدارس هملى دروسداينى را آهوشت

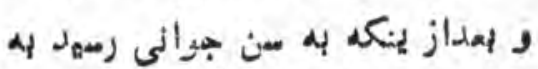

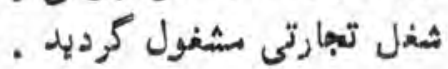

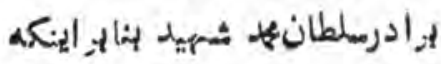

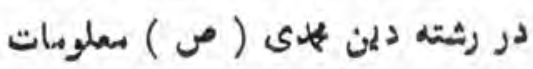

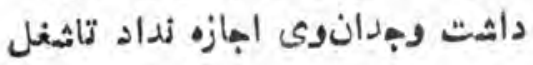

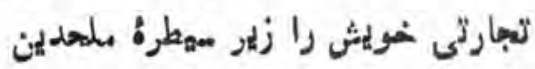

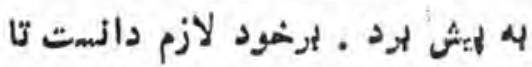
دربةايل رثئم كمونستي مبارزه بمسلحانه راشيروع كيند وى بايرخى ازمهمثهريان

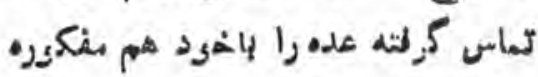
ساخت .

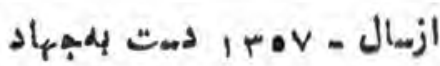

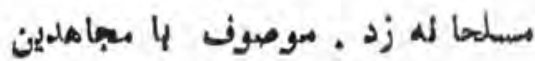
هنطقه اش در اثرتلاش و فيدا كارى له

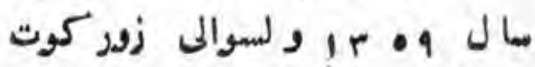


دشامن (9) لهوسمه التيع يهك كعداد

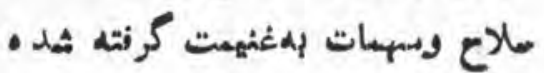

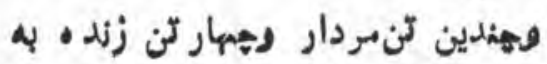
امارت سهاهد ين در آهد كسمه ايسن عميات دو شب وروز ادابه دا شت در جريان معي-ن عدليات تومالددان

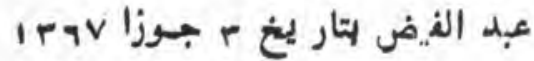

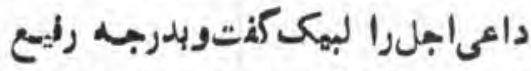
ثهادت نايلآمد.رومش شاد ويادي كراسى باد . كادت

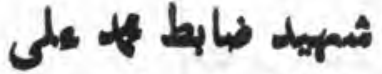

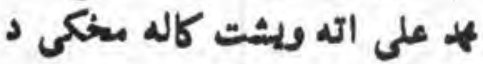

لكتيا ولائت دسيد كرم دولسوالى د

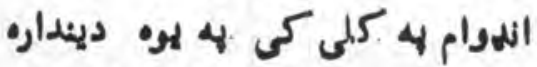

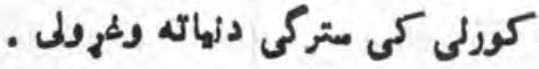

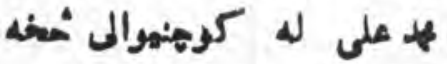

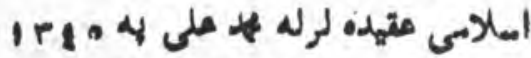

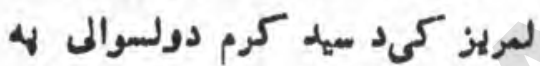

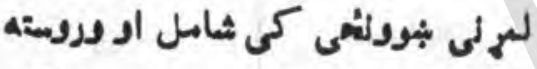

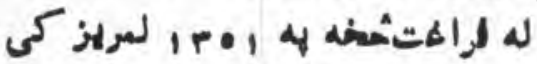

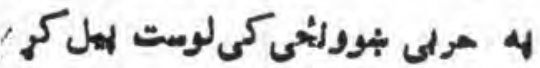

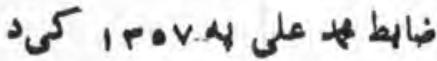

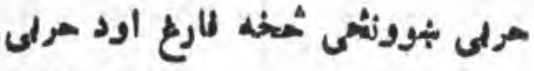

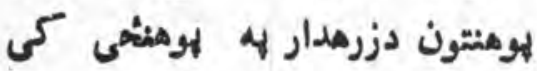

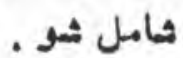

به ميواد كى دكمولزم دلاس

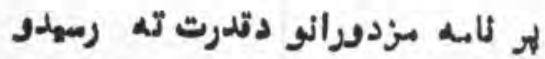

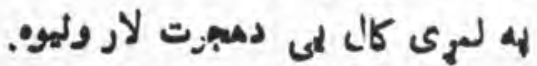

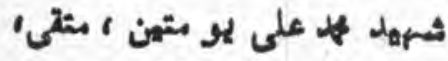

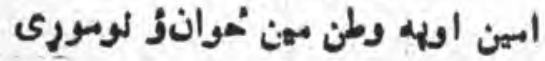

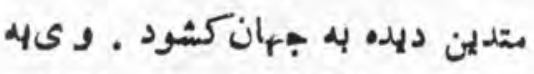

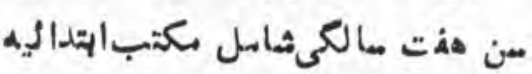

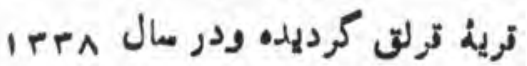

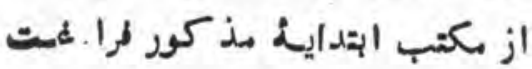
هاهل كرد در جريان دورة تحصهل

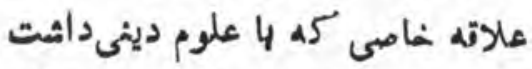
لزد سهوم دا.بلا صاهب عبداته كم هكى از علماء بشههور ونامور هنطقه انودند ، دمعر وف الراكيرى علوم دلينى

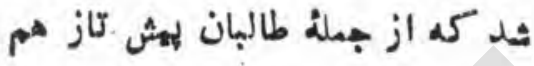
درره مائودد محسوب بهيثد .

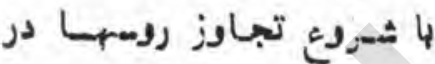

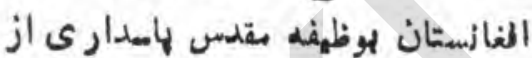
داين وكثور وسدمخولش در جبهذ

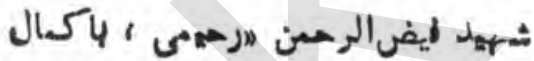
مداتت واخلاص هئدى وتعهلمهزى

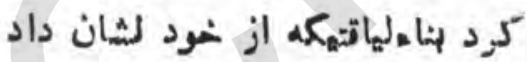

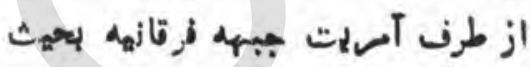

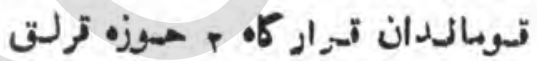
ولسوالى ارثى توظيف كرد يد و 4 اهساس مسوليت ثيديد در برانز وظينه

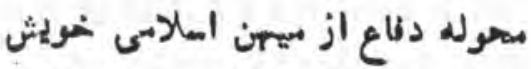

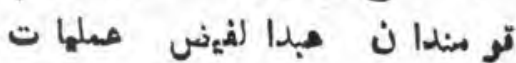
جهادى انهام داد مساد

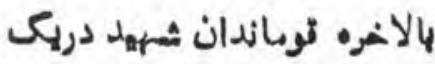

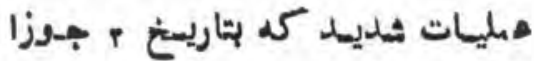

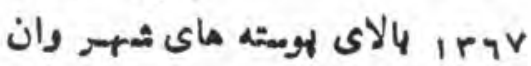

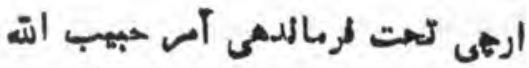
رهمى مهورت كرفت 4 وارد آوردن تافات وخساراتسنكين بالاى مواضي
كبلاك اطلاع كسب كرده به كشيور

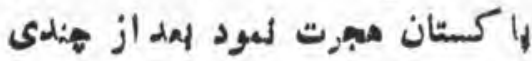

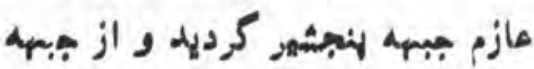

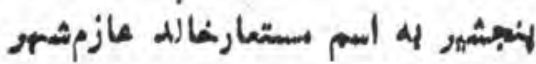

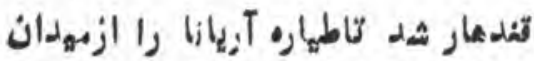

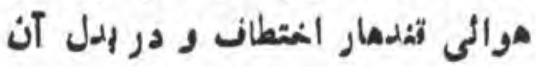

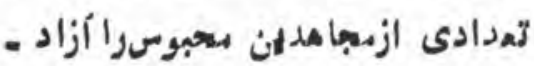

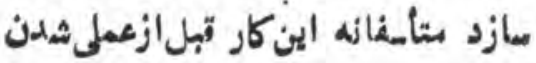

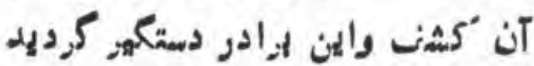

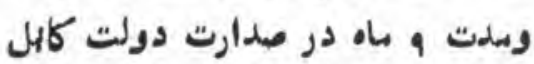

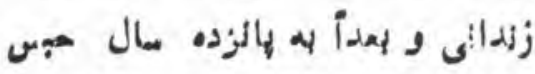

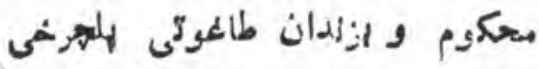
انتقال داده شيد و در زأدانئ كيز آرام

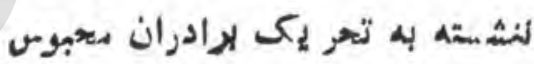

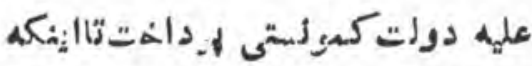

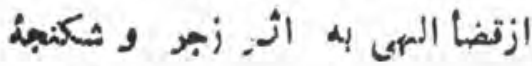

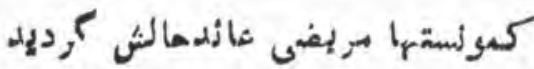

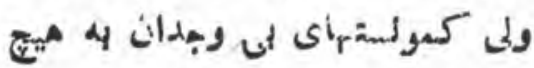

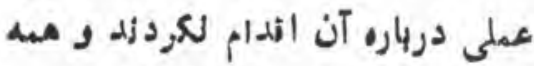

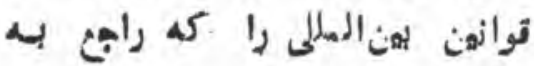

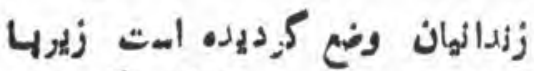

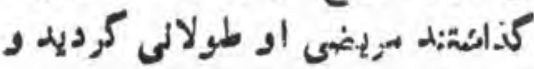

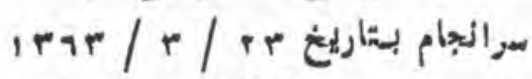
داعى اجلرا لئككثته به رنيق اعلى

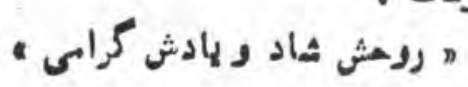
لائدت . لومادان مبد الفيض ثهيهد : توماندان عبد الفيض در مال

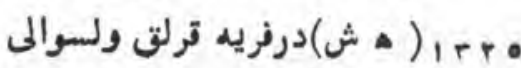

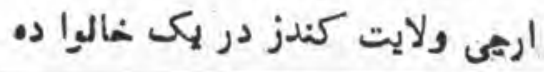


كسب كرد كه اززنسدان كرومدى

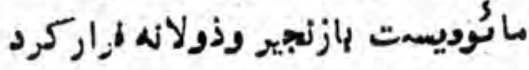
وطى دوره يقدس جهباد دوبار ديكر

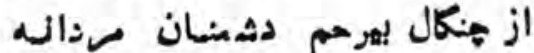

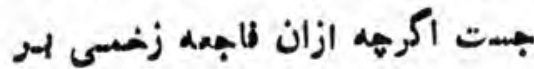

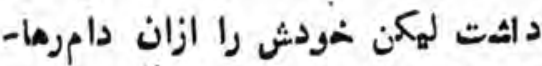

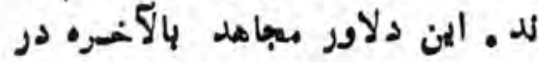

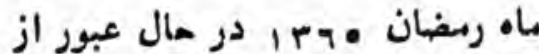

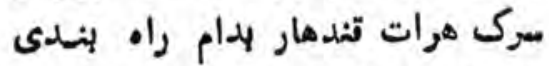

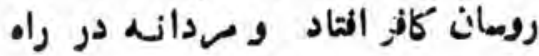

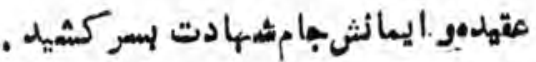
ردمش ثاد

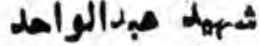

فريسالده شئمل عبدالواحد

كرزلد حابى عبدالقادرساوط جبهات

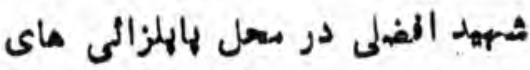

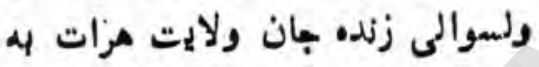

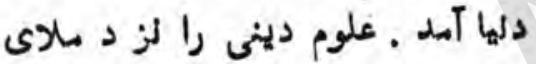

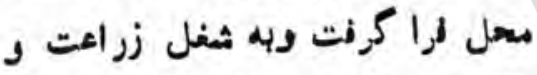

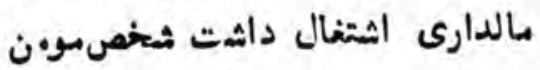
وصداتت كارى ابود كه در اكثر كار

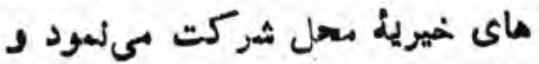

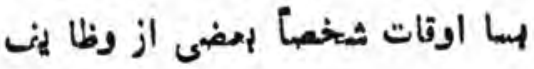

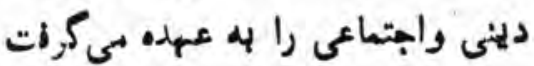

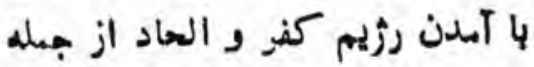

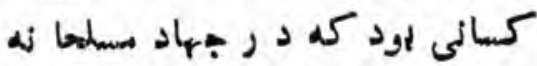

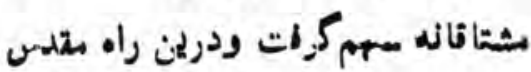
جانثنارى هاى فراوان لمود ـ او 4

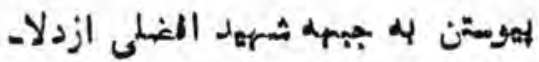
ورا ن اين جبهه محسوب و به به مقام

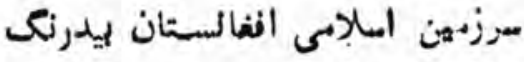

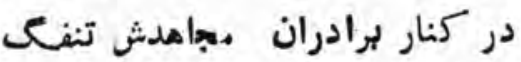

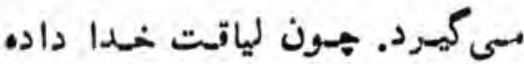
داثيت به الرمالدهى هنصوب ومدتى را درين وظينه مقدس لسر ميكند واز

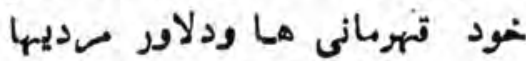
ليهادكار بىكذارد. اوبادثمنان قاطعانه

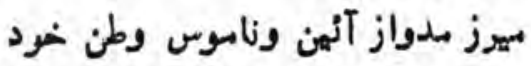

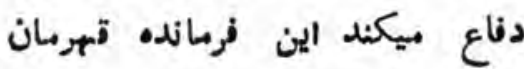

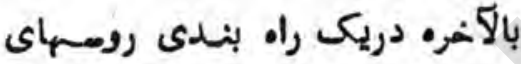

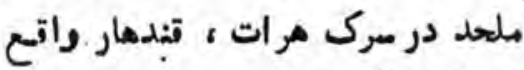

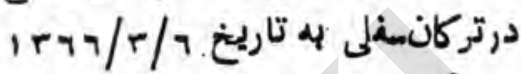

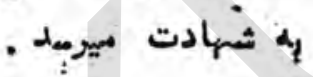

رومث شهاد

\section{شهبيل}

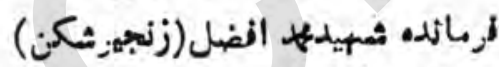

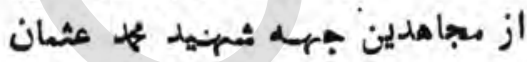

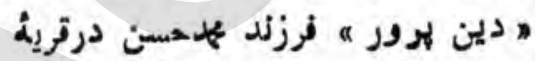

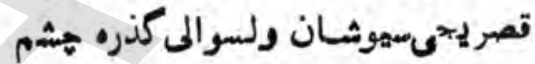

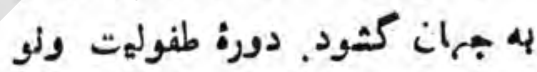

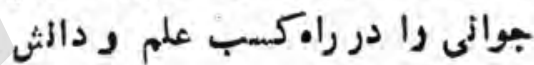

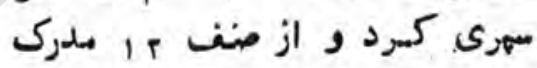

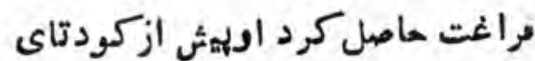

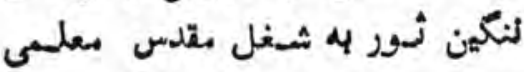

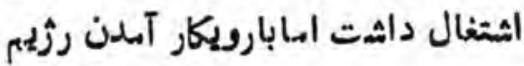

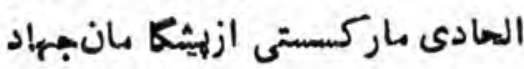

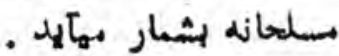
كمتزكسيست كم بنام زنبنيرثمكن.

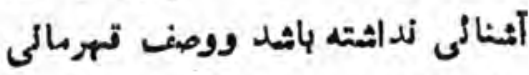
ما ودلاور مدد يهاى اورا نشينيده

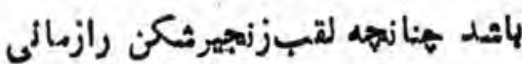

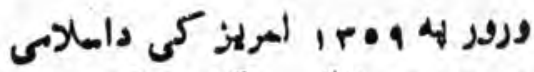

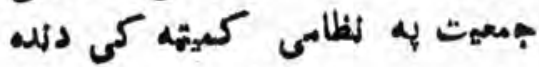

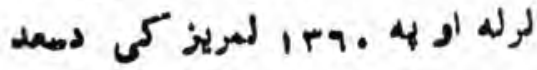

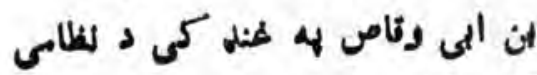
آس آنت لخوا توظيف ثو .

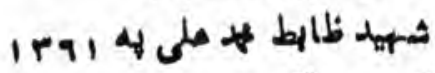

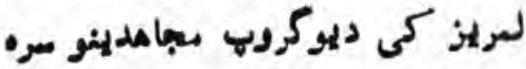
دمر كروب 4 توكم بكتيا ته ستون מ

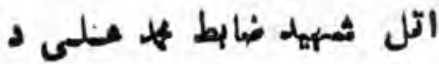

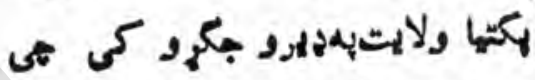

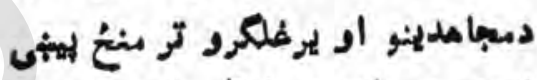

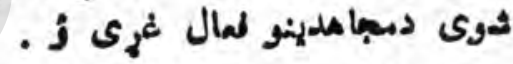

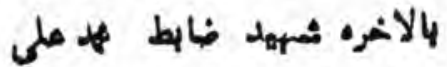
دعلياتو لهاره دتهارى لهولو همانه مأل

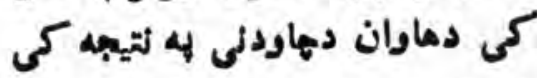

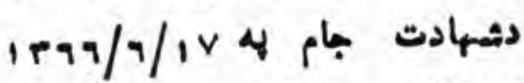

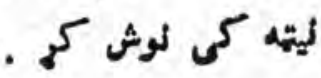

\section{شمبيد هوف صبدالغنى فرمانده شهيد صوفى عبدالغنى فيلى فئل} از فرماند هان جبهه شهيهد ميخ عثمان

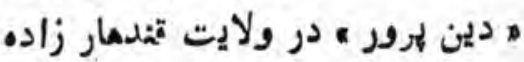

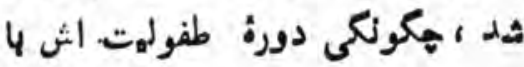

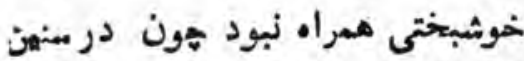

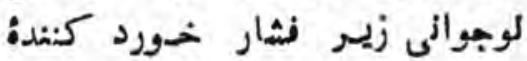

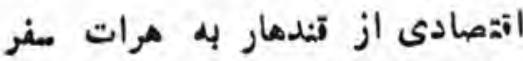

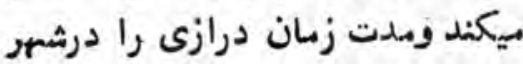
هله شغل دمت فروشى مسى كذراند .

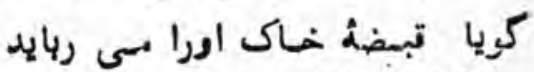

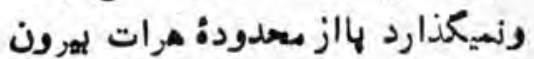
كذارد ـ باهجوم له لهكر طاغوت هرات ليرون 
لا جوانمردانه بزدوران روسى ايسن

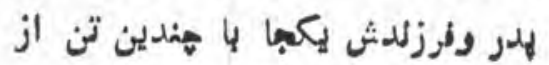

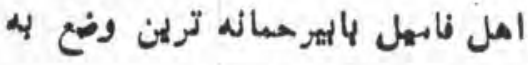

ثمادت رماليده شدئد.

روحشان شادويادثهان كرابى4اد

\section{ثرهيله داكتر فلام سرود}

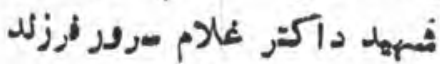

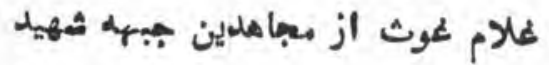

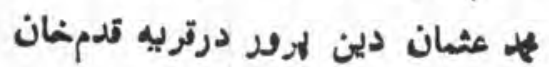

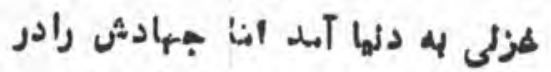

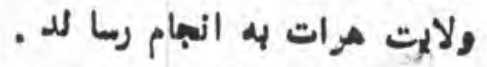

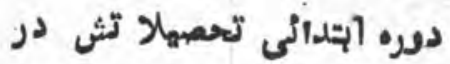

كتيب شنجوار خاله موفقانه لها يان

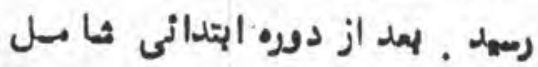
لرمنك مرات كرديل و رو بعداز تكميل

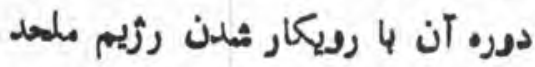
در كثور اهلانى در من برادران

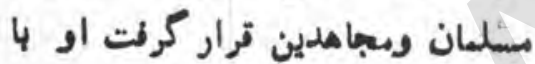

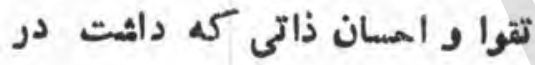

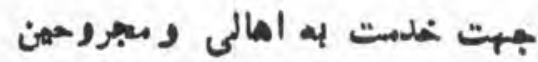

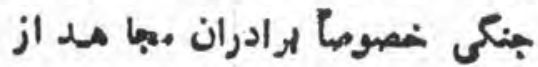

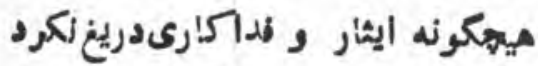

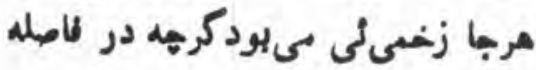
دور با إيى لياده به علاجش بى

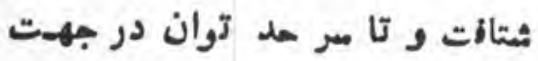
الهبودى و علاجش كوثها إودي الان

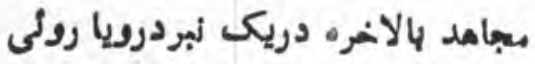

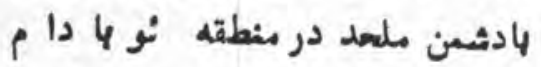

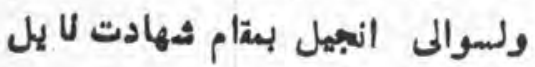

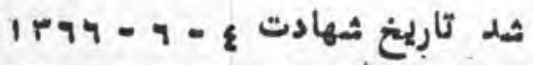

شهيه هولوى لموراسمد

شيهمد مولوى نور احمد فرزلد

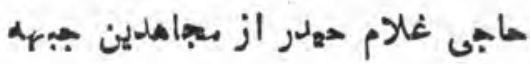

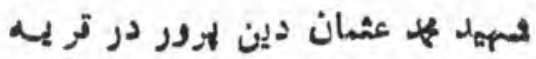
هقاب ولسوالى انبيل هرات به دنيا

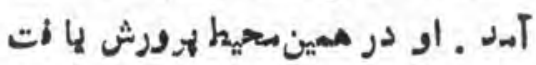

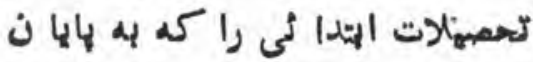
رمانيد شياسل مدرمهه علوم دينى مسبهد

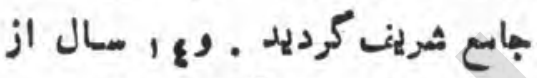

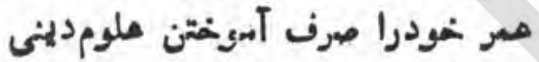

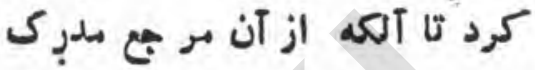
تحصيحلى دريازت نمو د ـ او مرد ى لى

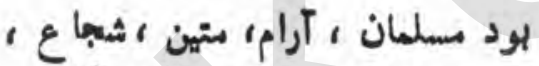

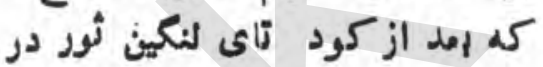

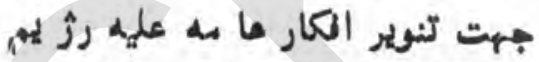

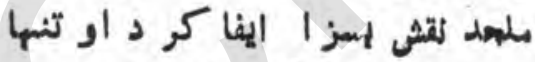

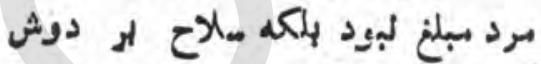

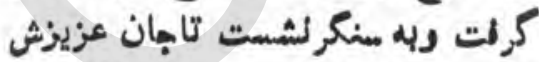

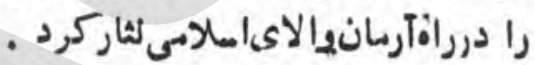

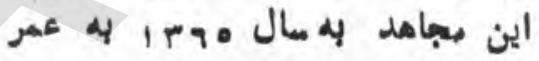

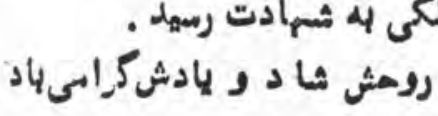

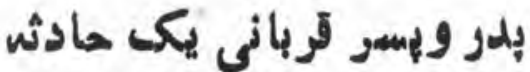

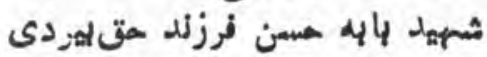
و شهمد عبدالعزيز فرزئد بابه هسن

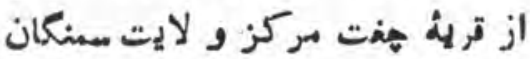

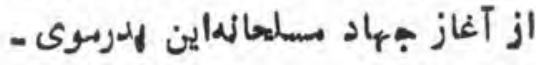
مفيد ولرزند ش سالاحيردوش كر فتيد

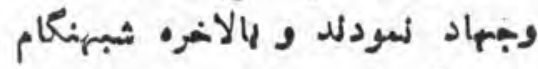
در ماه حوت ع هم ا در يكى توطيه

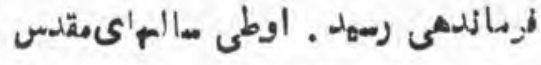

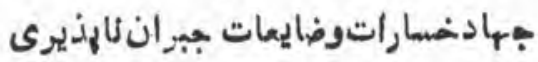

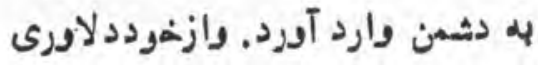

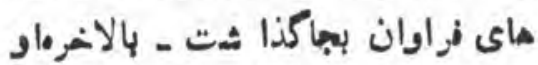
دريكى نبزد رويارولى بادشمن بهدتارئن

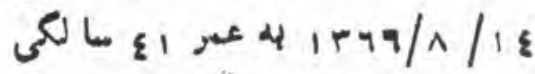

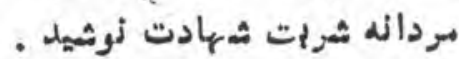
روش شاد و يادشكرامى

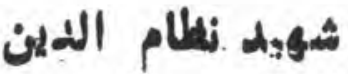
فرمانده ثهمدئظام الدين مشهور

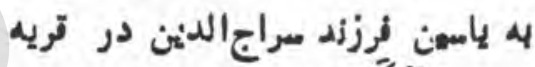

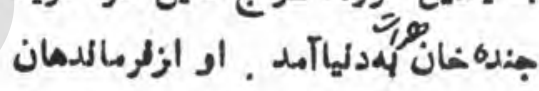

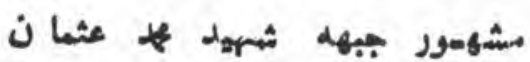

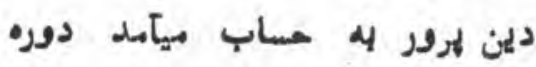
طفوليت را ليزمالند دوره لوجوالي در لهر

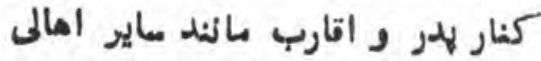
فقير روستا نشين له كثث وزراعت

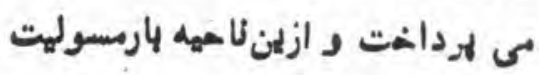
هانوادكى اش را مبكتر ميساخت

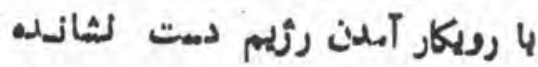
الهادى، أو لمز مانيد ديكر ليرادران مسلسان خون ايهالش لهوش آمده و

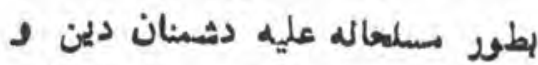
رطن داخل لهكار كرديد. اينمبالهد

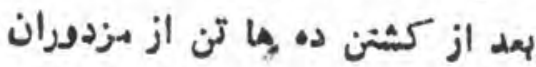

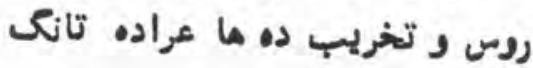

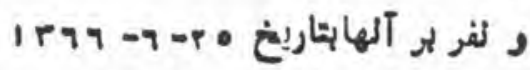

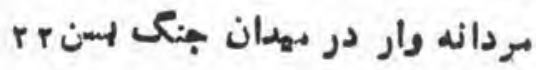

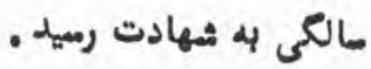
روش دياد 
II.

دمز دور رزيم دمنخُته را تكى

سره مبم ليى دنورو مجاهدينو ترثة:كى

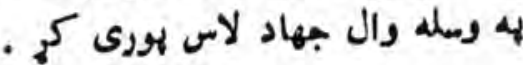
شههد طرهباز د كنرى توادوسره به ديرو جكرو كى دمبهامدينو لمال غرى و و نو

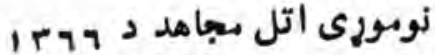

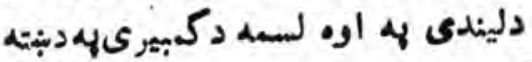

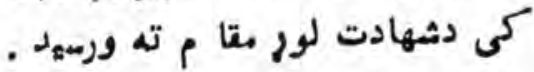
روح يلى بناد

شهيد جانك

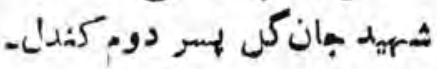

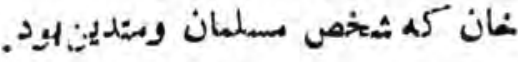

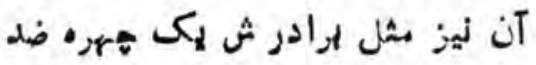

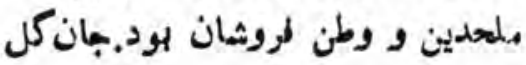

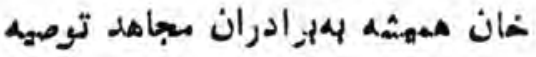
هينمو د كم لهيزوزى از حقى است و هق از ما ست به بمبارزه تا ن دوام

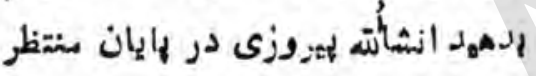

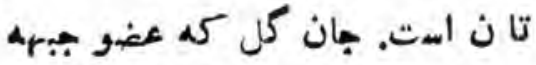

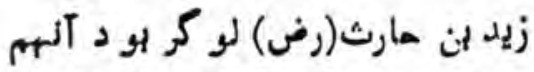

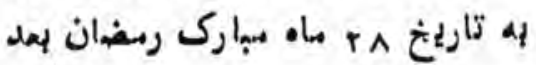

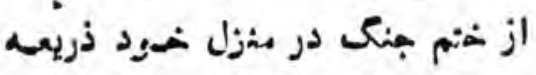

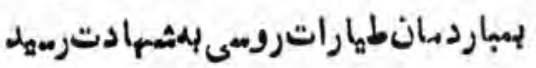
روهث شهاد ويادش كرابى لباد

\section{شهيله معر قاسم}

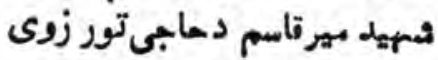
ديكتيا ولايت دخومت د د ولسو الى دئي

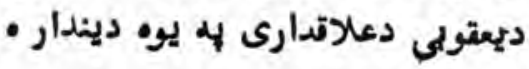
كورنى كى زيوريدلى دى . .
شهيد هـاكرام

ثمهد مطاكرام فرزند اهيوند درمال

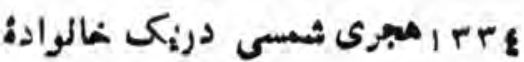

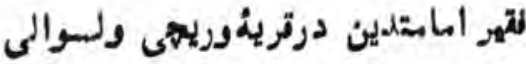
هوست وفرلى ولايت انغلانديده أه جهان كثود . وى تعليهات اليتدائى رادر مكثب بازار بهوايان زمانيذ ودر

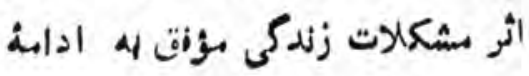
تحعيل نكرديد .

العد از كودتاى كمولمت هايت وتبهاوز روس به مث مجامدينإ.ومت ودر راه جrاد خدمات ومداكازى هاى زيادى را انجام داءتنا إنكه درتهاجم ودمانم كاندولى وإمباردهانانى رهمائدروس

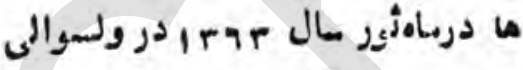
خوست ولزلك بالنج لفز اعضباى

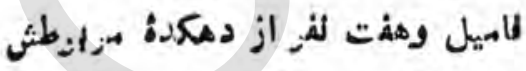

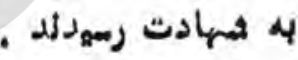

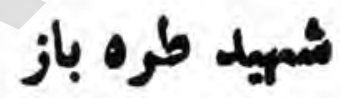

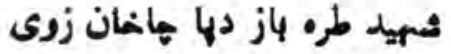
دننكر مار ولاهت دثخى دولسوا لى

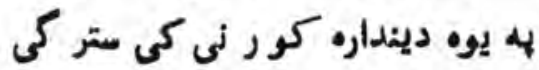

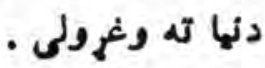

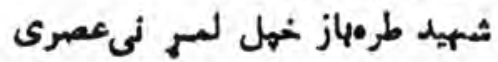
تعليدات دمثكى د ولسوا لى دياسين

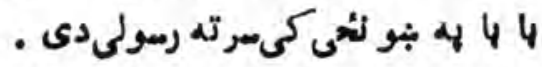

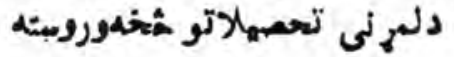
كومورى ور ور ديكى إهمامعبومات

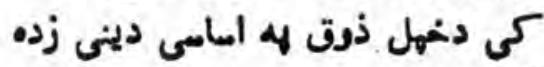
ك.
ثهمه بستم اله

ثميد البماته فرزئد ثـ شرين در تريله نو بادام ولسـوالم الجيـل

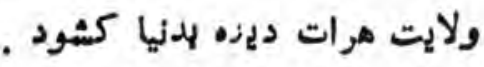

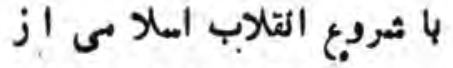
دلباخته ترين عاشقانجهادفى لمبيل الته

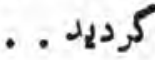

ودر اكثر بنكهاى اطرافثشهر

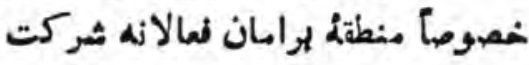

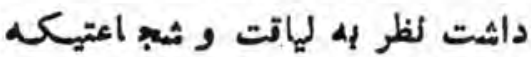

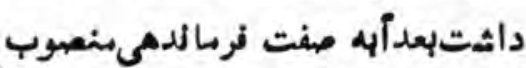

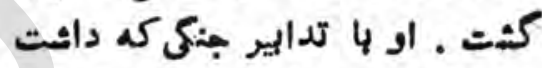

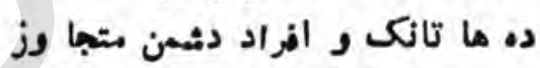

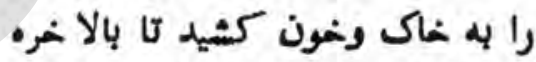
در يكى نبرد خوذين 4 د د مسن خون

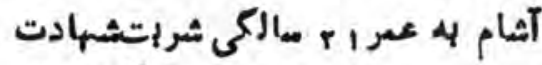
نوشيد ـ. رومثرثاد ويادش كرامى باد

\section{ثهبه عبدالرهيم}

ثميد عبدالرهيم فرز ند صغر

درعلاقه دارى خم آبولايتجوزيجان در يك فاميل مسلسان ديده جبان كشود ودر من هفت ميا لكى ثامل مكتب ايتداتيه آن علاقهدارى كرديد نامبرده هنوز تعصيلاتخويش

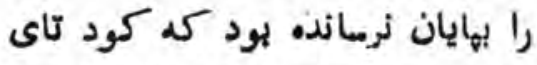

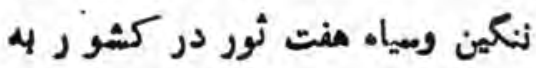
وتوع زيوست موصسوف جهباد را از

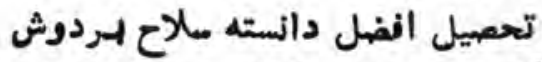

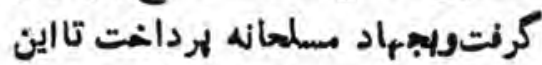
كه در يك لجرد رويازونى 4 دثمن

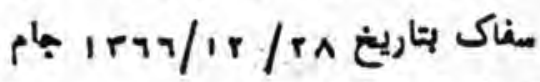

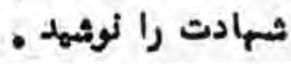


ثبهيد موصوف لمه از لنجهال

جهاد بسلهانه دريكى از عملهيات مات

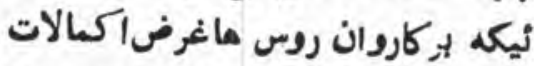
به سوى إبدخشان رمسوار بود ،مدتهانها در كمين بازكثت كاروان در سنكر اوده كهدر بازكثت كاروان رومى از

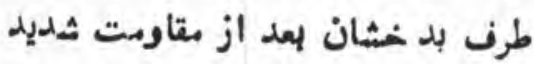

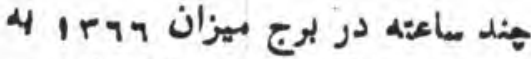

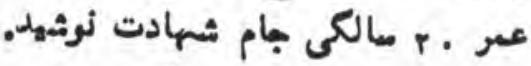

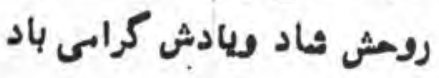

\section{ثيهيد عزيزالله}

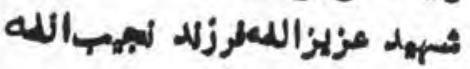

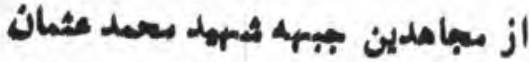

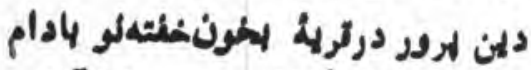

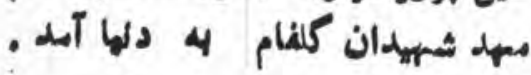
دورة طلفوليت را لزد ملا امام مسبهد

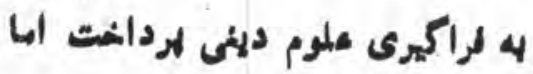

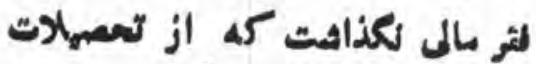

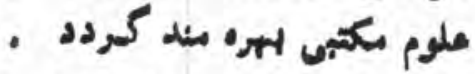

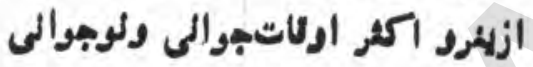

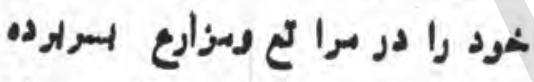

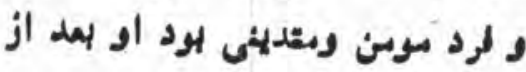

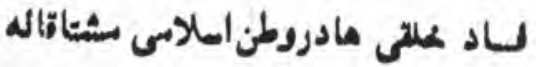

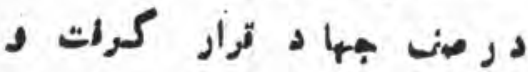

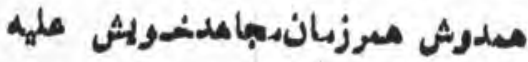

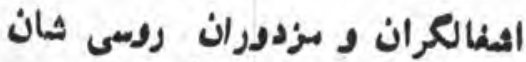

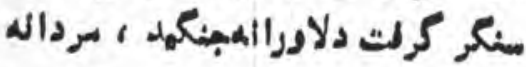

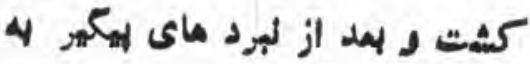

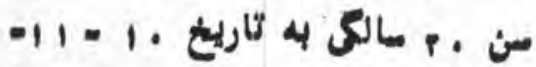
إل
دشمن در داخل شهر تلش عمده اينا

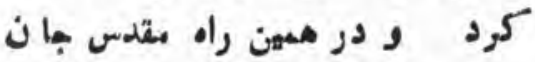
مهر د الهن شهميه عزيسز از شيههداى

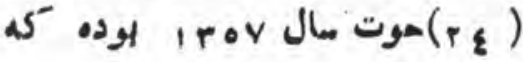
العمر رم سالكى به اين فيض لاهل

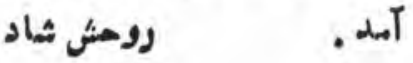
شهيد عبد السلام

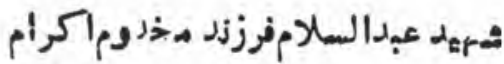

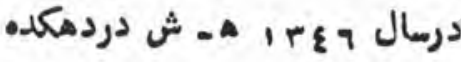
بنام قريه موفى غلام مس بوط مركز ولايت تخار ديده به جrان كثود .

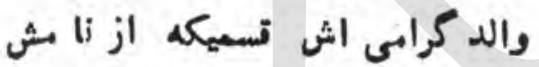

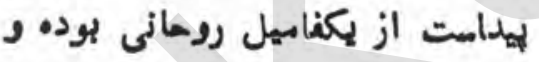
خودشنيزثشخص رومالى وعالميمدين مى الثيد .

بدر بزركوارش لعد از اشغال لهخارا وكشور هاى المالمى آميها ى لنى ميانه توسط رومسباى غارتكر به ديار افغانستان مساجرت نموده در تريلن

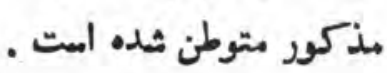

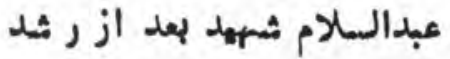
فكرى و ازدياد عمرث تعليمات دينى را از بدر مهريالش فراكرفت . درمال | إج | كه هنوز بانزده مال داثيت

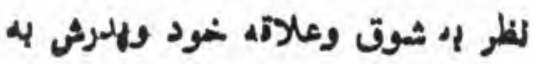
جهاد مقدس اله مفوف مباهدين اليوت مته وعاهه اشفالكران روسىولوكران زرخريد داخلى ثان ابهباد مسلحا نه

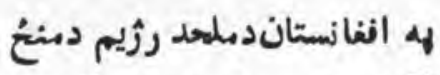

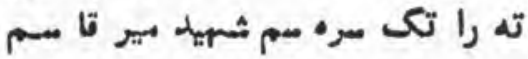

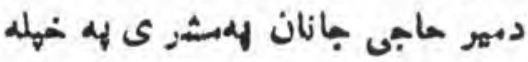

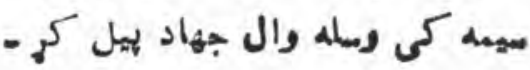

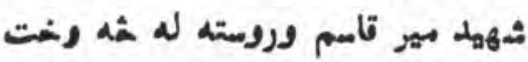

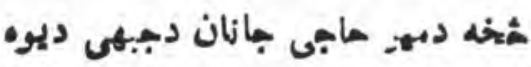

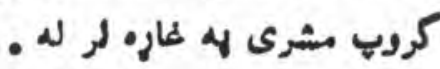

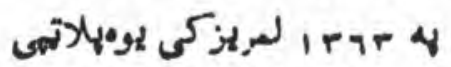

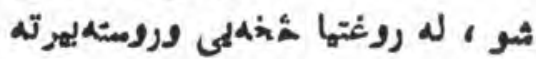

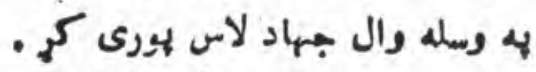

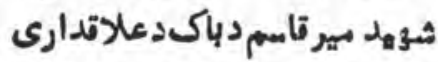

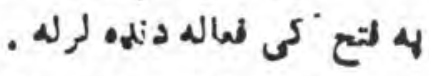

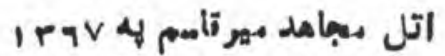

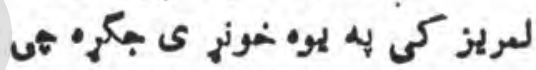

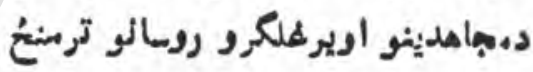

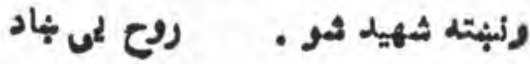

\section{شهيه ثلام رسول}

ثمهيد خلام رمول فرزلدعبداته

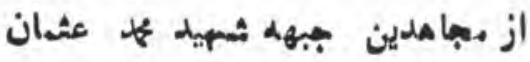

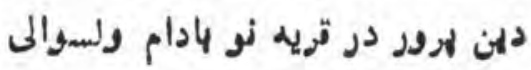

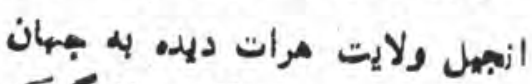

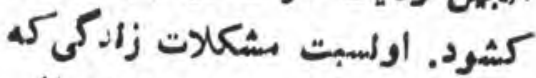

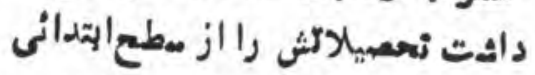

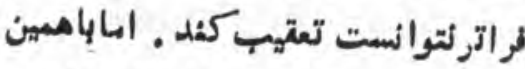

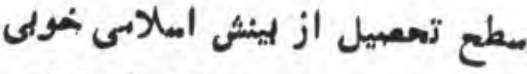

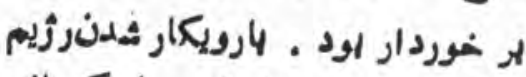

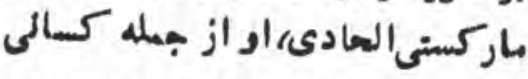

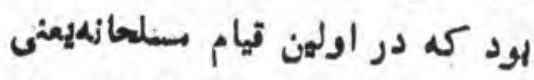

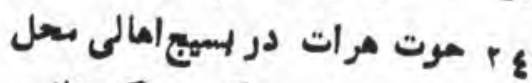
و هركت لهوى لالهكاهرمراكزئطاسى 
مجاهد خوددرجبهه زيلد انوهارث (رف) لوكريهوستو مبارزةهى ادمان

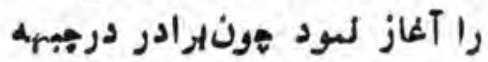
زياد سخاص 4 تلنظيم وجهاديود

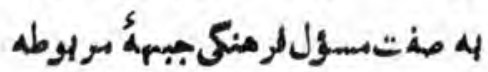

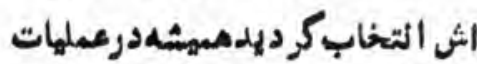

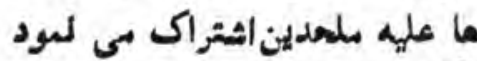

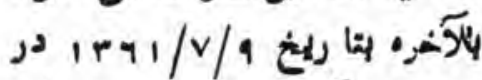

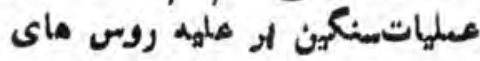

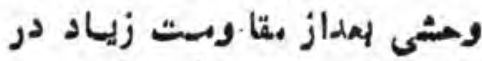

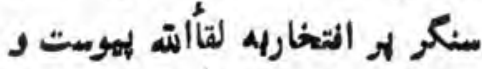
جام شهادت رائوثمده . رومش ثاد و يهادت رالدشكرابى باد

\section{ثهيد هلام غوث}

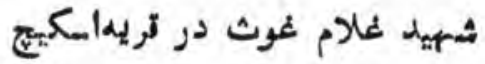

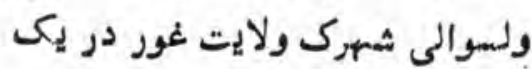

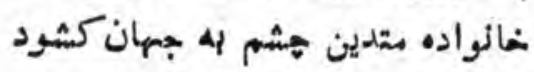

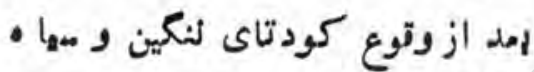

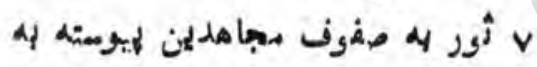

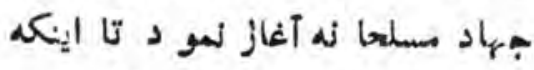

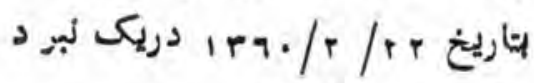

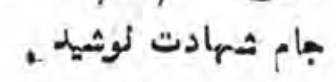

\section{شهيد قربان قليج}

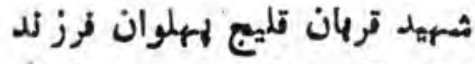

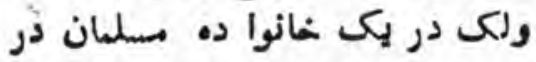
تريه ترنسعلاقه دارى خممآب ولايت

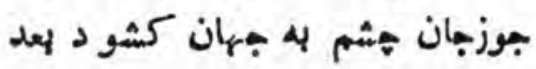

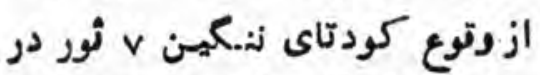

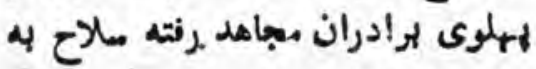

لمودنتحصيالاتدوره ليسه فـاسل كورس خسورد ضايطان كرديد لعد از فراغت كورم لهميث درالم الريدمن در ارد و مؤفلف كزديد 4 اشغال اففالهتان ذريعه روس ماى داى اثفالكر وظيفه را ترك كنته وارد

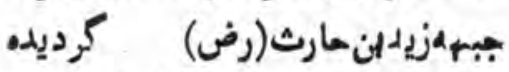
مبارزه به كمونيزم را آغاز لمود و بعد از لعاليتما و مجامدت ماى لهاى

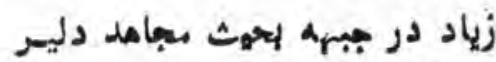

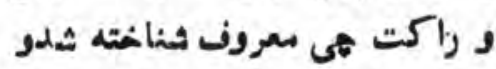
در انهدام تالكىها و وسايط نقلهم قوايى بزدور و كفر سمسم لعـال ميكركات بلاخره در يـك عنلهات

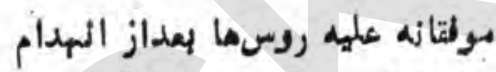

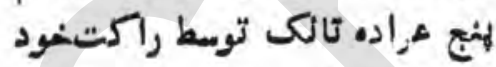

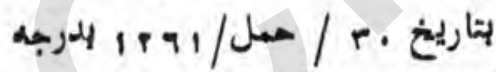
عالىشهادتوآرماندير إينشودروسيد. النا له و النا الهه راجعون .

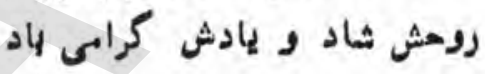

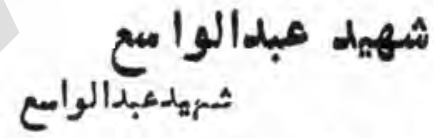

له عبدالشكور در مسا ل Ar A ه ، ش دريكى فاميل مقدين و شمدا

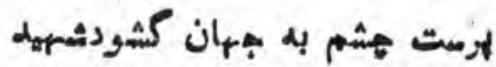
مبدا لواسب دورةتحصيمالات مثومسطهرا

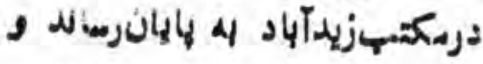

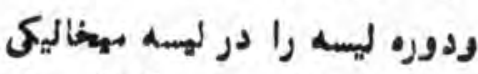

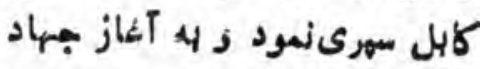
بسملمانهدر افغالستان به به برادران

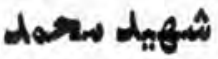

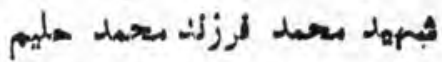

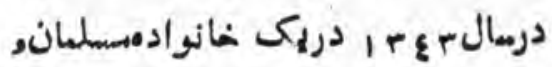

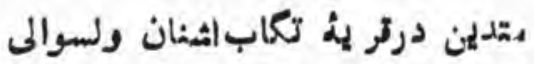

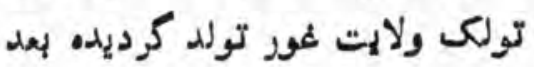

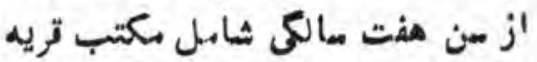

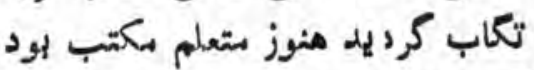

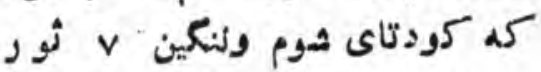

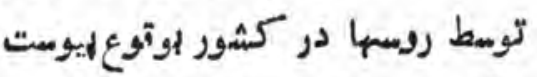
ديكر اين هرادر جهاد را از تهصهل

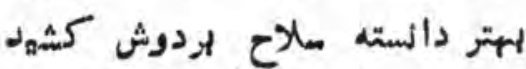
و راهى سنكر مت عليه أأطل كرديد و در هندين عمليات اثشتراك ورزيله و در يكى از مصلياتها مبروح

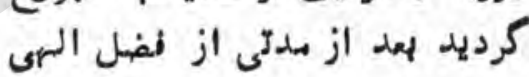

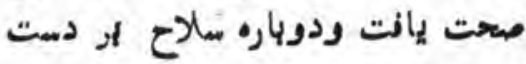

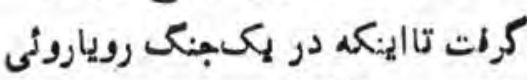

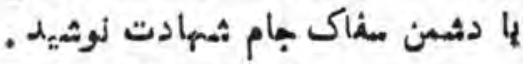

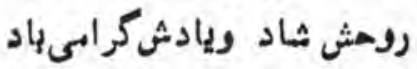

\section{ثيهيد ضابط زعهدتالته}

الرادر شهميد خابط لعمت الته

خاورى سشهورهه " لالده درسال

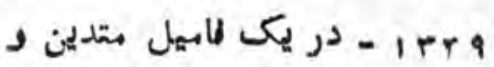

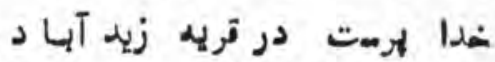
ولسوالى شآغه ولايت لوكر متولد

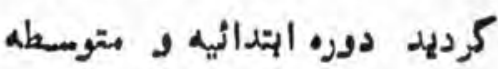
را در مكتب زيلد آياد به بانيسان رمائد و دوره لميسه را دم رلعهمه

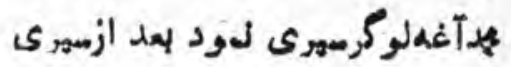


بهاد مقلدس خود خسارات جيران

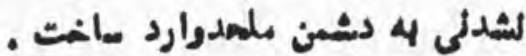

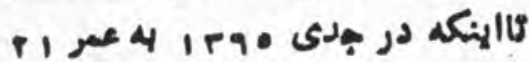

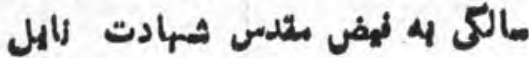
.

\section{روش هاد}

\section{شهيه ميو شيس}

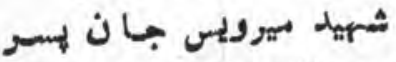

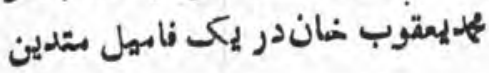
و مسلدان مسابوط قريله زيد آبلاد

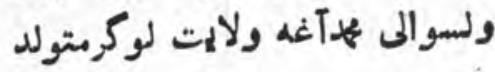

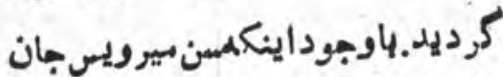
از مثت سال تهاوز لمى كرد ولىاحساسـات ايمانى او وادارش

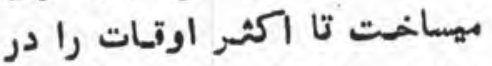

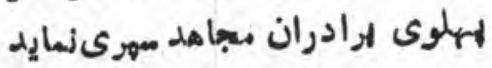
و در م جنك و مبارزن بيها موزد

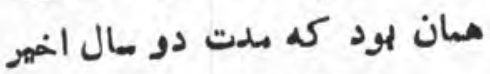

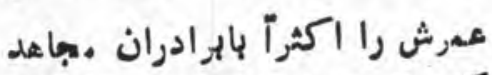

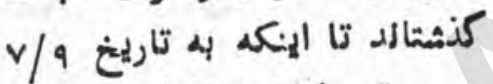

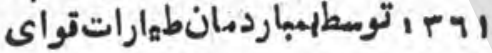
روسجه درجه مقامرفيعشهادتزائل كرديدرومثثماد ويانش ركرابه دباد

\section{لمبهد المهاله}

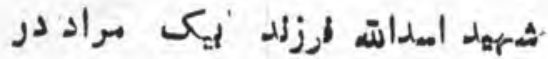
مال اعس ا (هش)درترية تاجكهاى ولسموالى ارثى ولايت كندوز دريكى هانواده بتدلين وعلم دوست ديده

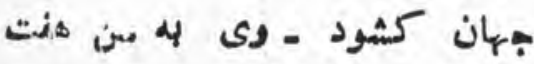

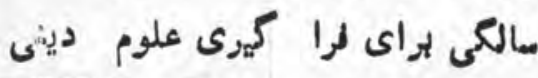

\section{شهيه ياركل}

ارادر شمهي ياركل ولدكمدل. خان سجاهد بايمانجببهزيد انهمارث

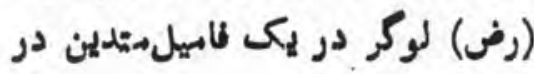

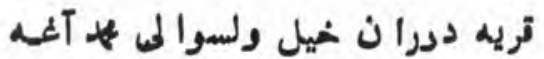
رلايت لوكر هشم به جبهان كثود. و تعلهمات إئدائى خهود را دروبكتب

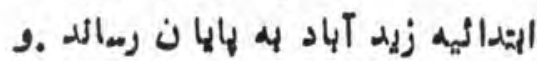
به آغاز جهاد مسيلماله در الفغالستان

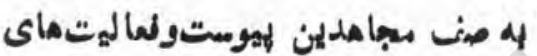

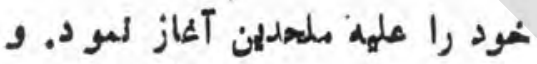

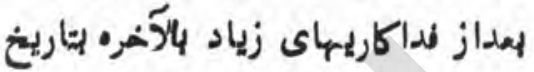

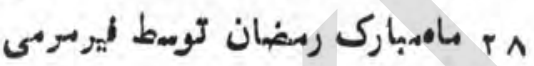

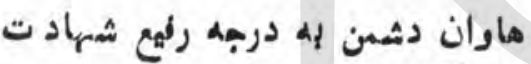
كايلكرديد.

رومش شاد ريادش كرابى باد

\section{ثمهيد مبلدالقدوس}

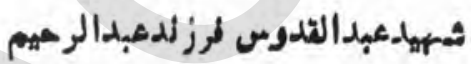

از مبهاهدين جبهه متحعد عثشان دئن لهرور در قريله لوبادام ولسوالمىالجهل رلايت مرات ديده به بهان كثيود. از كودكى دلباخته مسبهد ولهازيود ومديثهبا اتزركان درمفوف لمازديده

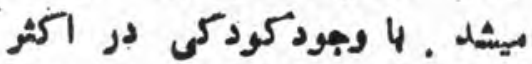
كار ماى زرا عتى بلهدر لهيرشمكار

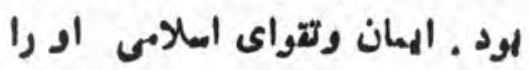

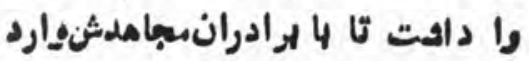

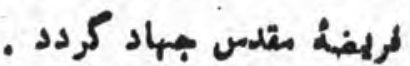

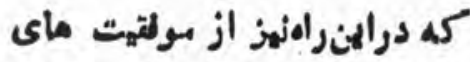

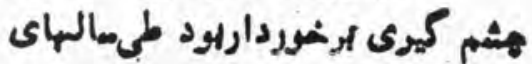

دمتكرفت ودريثندين عبلماتاثتراكى ورزيد تا اينكه در ريك نبزد هادشمني

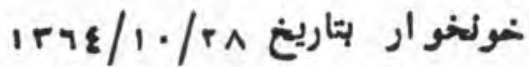
جام شهادت نوشيد . رومش ثاد ويادشي كرامى لاد ناد

\section{شهيد عبد الطلا هو}

ثههد عبدا لظاهر فرزلدهج اكهي

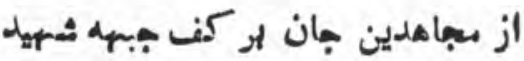
\$ عثان دين لهور در قريه نوبادام ولسوالى انجيل ولايت مرات بددنيا

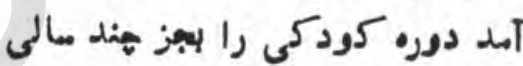

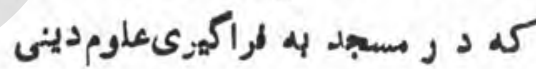

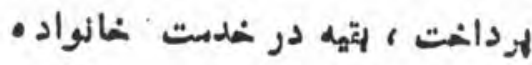

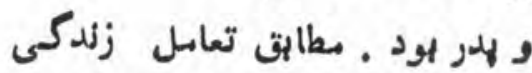

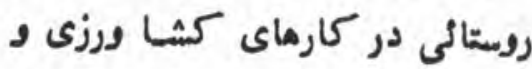

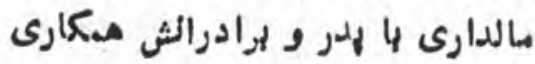

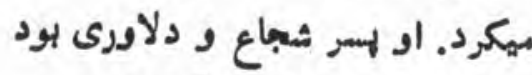

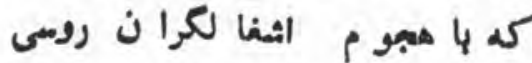

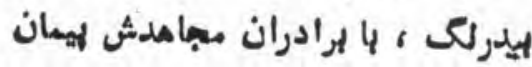

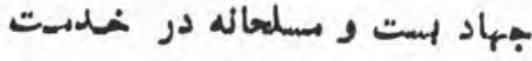
القلاب اسلامى قراركركت ـ دردوره

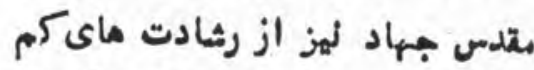

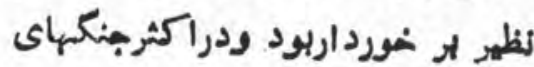

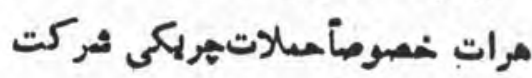

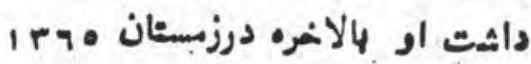

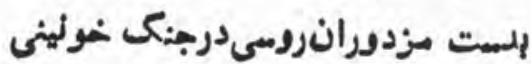

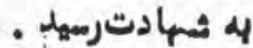
رومش ثماد 
دهمنان املام و وطن وارد ماخت.

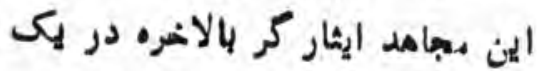

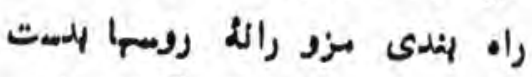

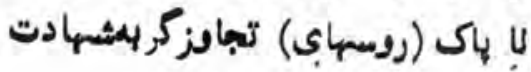

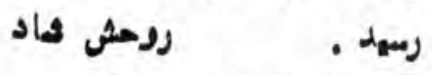

\section{ثهيله ميه|}

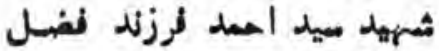

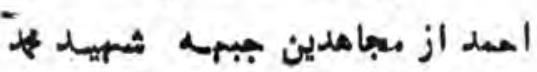
ثثمان دين هرور از مريوطات جبهه

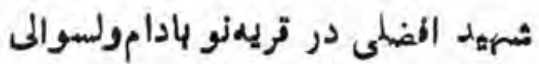
انجيل ولائت مرات در خانواده فتير

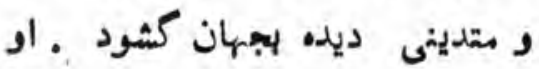

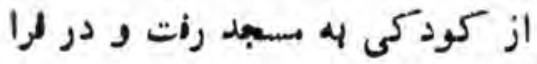

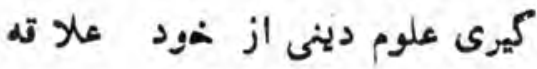
فراوان لثان بيداد وتتى بلدر بهرش

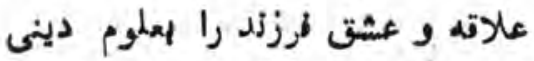
اهساسكزد او رانزد مولوى لرهاهبان يزرى طلبه ساخت و او او ليز باثهوت ر عالاقه فزاواندر كسب علوم مقدس

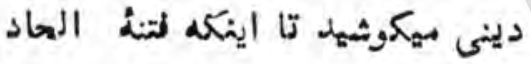
دركشور انتاد و وبهاد مسلحانه علهه كفر اعلام ثيد ـاين شايق دور ديدار

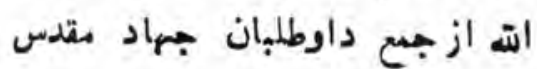

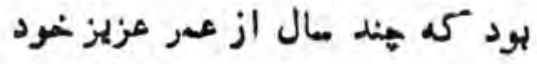

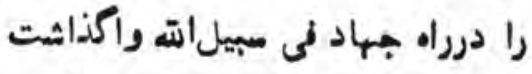

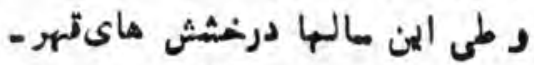

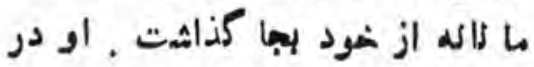

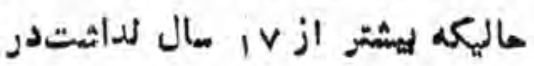

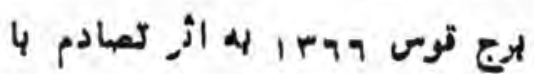

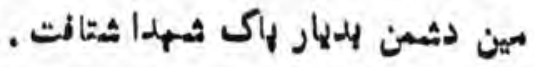
روشش شاد
هثم به دنها كثئود از انجانيكه

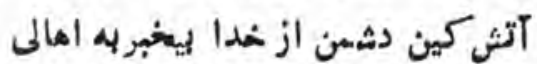

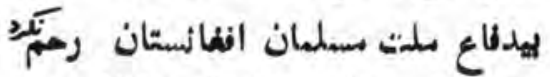
ولاجوان مددانه هزاران هزارازمردم ليدمان ليدفاع را فتط بهرم عقيده وائسان

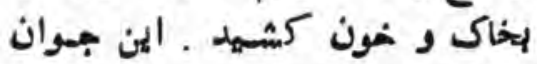

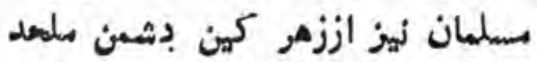

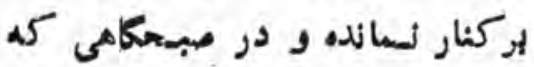

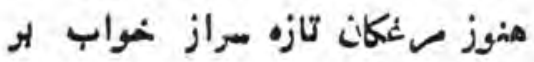
داشته ولغنه حيات سر داده ليودند

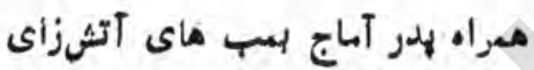

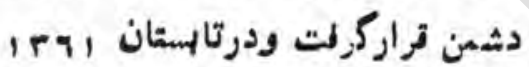

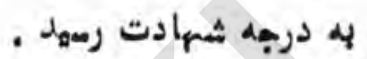
روش ثـ ماد

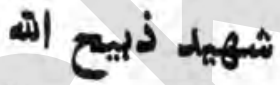

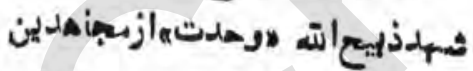

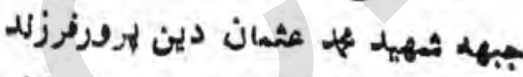

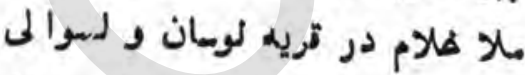

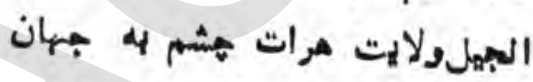
كثود . از دوران كودمكى ثيخص

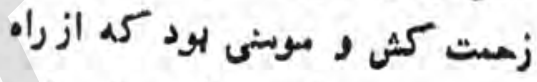

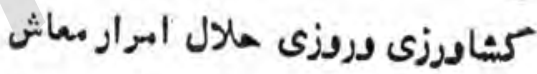

بعد از كودتاى نثكين ثور د . نهكرد

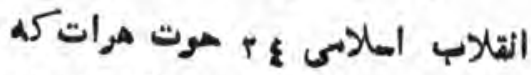
جهاد مسلحاله عليه رذابم كفروالحاد هرات

اعلام شد از اولهن داوطلبان جباد

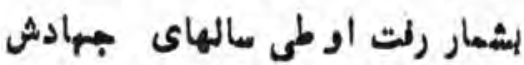

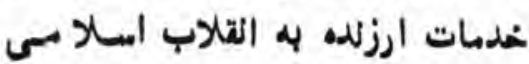

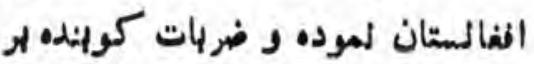

كزد ماساى نمود ملا جمال الدين

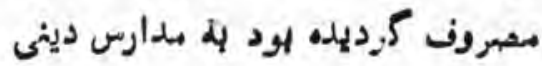
در ولسوالى ارثىى دربدرسهُ خيالان ولإي كنيدز ثزد علهاء دينى

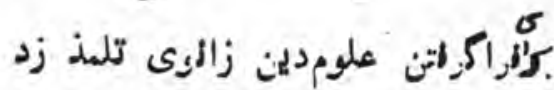
ودراين وتت كوتاى ثنكمين (v) ثور روسى دركثيور بوتوع ليهوتئ

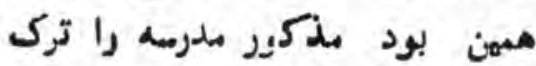

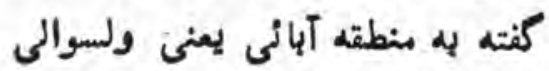
ارثى بازكثت آنجوان عزيز وبادرد ايخاطر دماع از مقدسات دينى وتهاه مهت ارضى كشيور املانى شمويش ملاح عازدوش كشيد وزاهى منكر كرديده اوظهفه هقدس لهاسدارى از دين كشور وبردم خويش درقطار

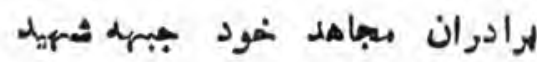
لمض الرعمن باكمالصداقت واخلاص مشفول كرديدهشت ميال تام باكسال صداقت واخلا ضمندى لحظة آرام تكرفته درسيكر كرم بهاد درائكار

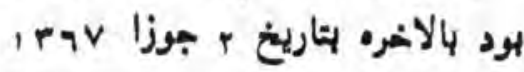

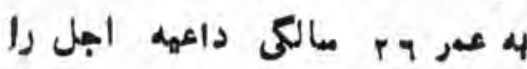
لبهم كثته بدربه رفيع ثبهادت كلاكل كرديد رومش شاد لهادش كراس بردي

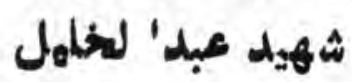

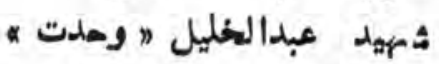
فرزلد بعراج الدين از مجاهدين جبهه

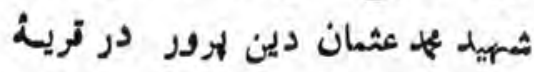
نوبادام ولسوالى انجيل ولايتهرات 


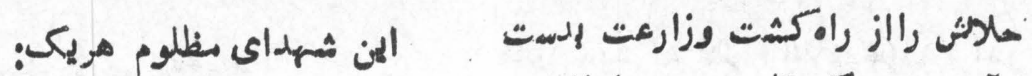

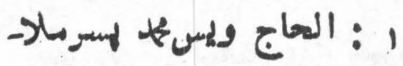

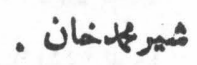

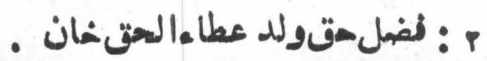

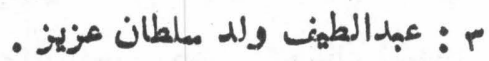

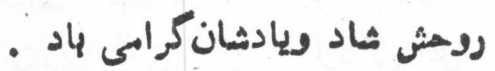

\section{شمبهد عبد الجهليل}

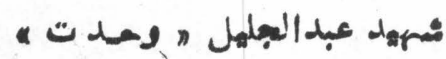

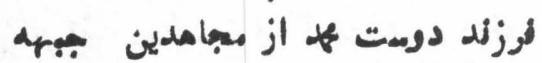

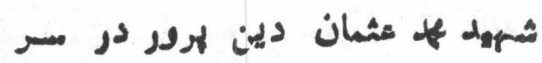

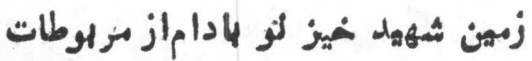

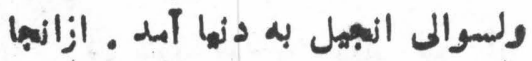

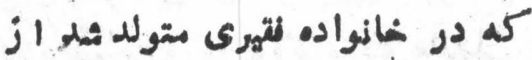

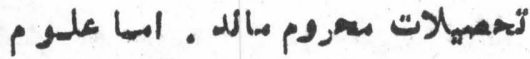

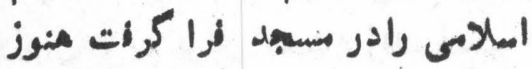

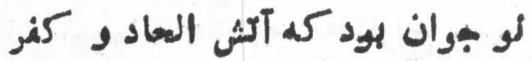

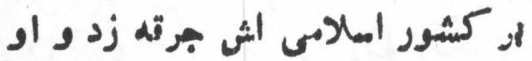

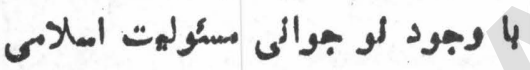

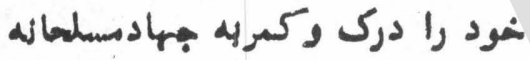

تهومانى أين لو جوانمسلمان

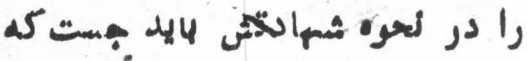
از جبهه و توماكدالش مبقت مى كميرد

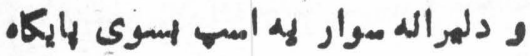
دثمن كافر مى تازد لاكه تيو ابل بلهاز

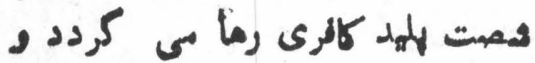

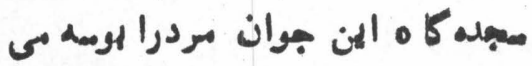

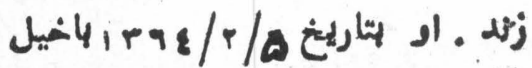

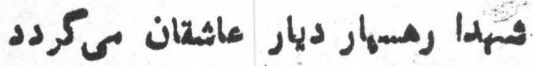

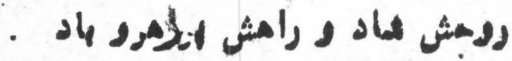

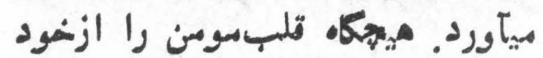

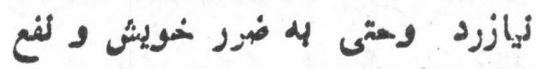

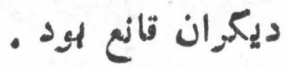
اوبا يسر نو بوانسش لكسبا درد

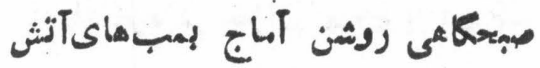

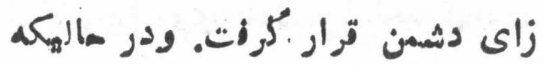

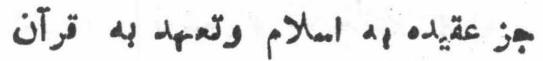

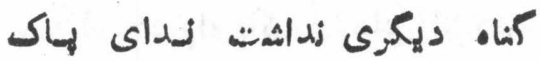

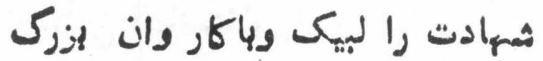

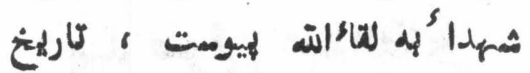

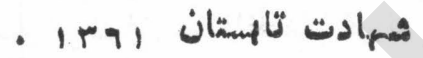
رومش ثهاد

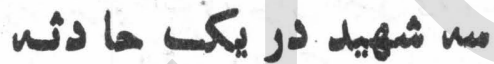

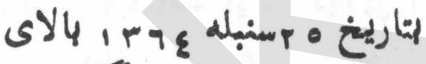

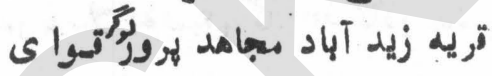
متجاوز روس هجوم وششثيانه لموده

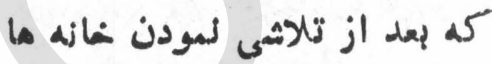

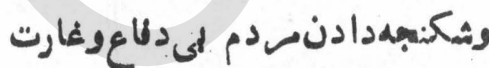
لمودن اموال ثهخصى مرددمهنطقه

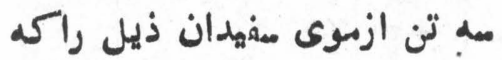

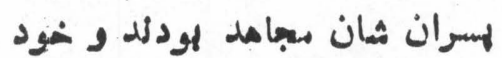
ثمان ليز در محدست مباهدمدين قرار دايشتيدلاجوان مرداله بعدازثكنبهه هاى زيلاد توسمط برهيه دو تن آلهها را زئده و زغبى زيو خاك لمسوده و دمت ماى يايك تن را له عقب وله

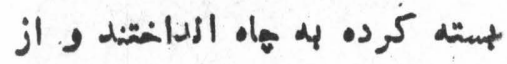
هقب آن بم دمتى را بمهاه مهوالهـ

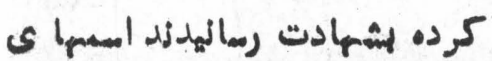

\section{شهريه قبه الواسح}

ش كه در قاميل ديندار ومنها لهومت

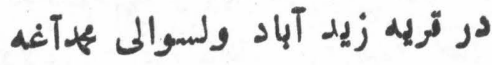
لوكر متولد كرديده بود دوره ليسه و تحعمهال ت متوسطمرا در مكتب زيله آباد مثزئى نموده و دورهليسه را در .كثب ثالوى كابل بهيايان رمالدد وبعد از الشغال وطن متجبوب

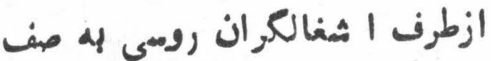

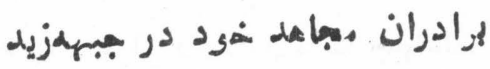
ان سارث(رض) لوكريوميوت وليعد ازمبارزهوحهداقت درمهن دمجامهدئن

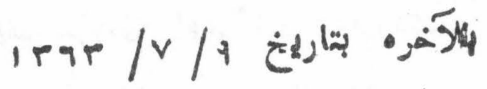
العد از إكىعمليات منزل ثمانتحت همباردمان ثهديد الهمنالكمران قرار

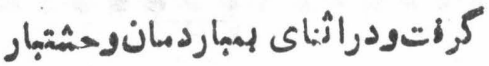

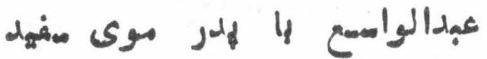

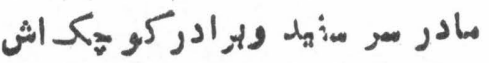
بلدربهه والايى شهادت رسيدند.

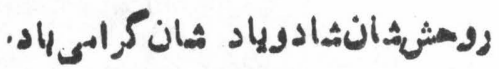

\section{شهيمه بعراج الده الدين}

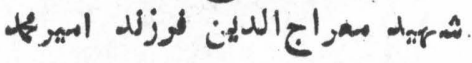

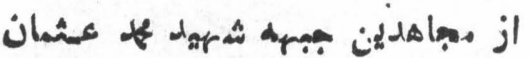

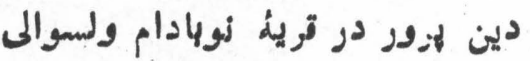

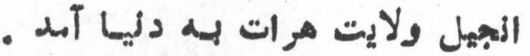
مددؤسن و.متدينى بهد كه ازمةتّديان

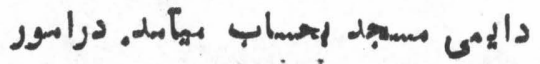

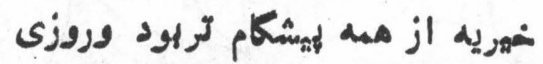


آتاب انقلاب املانى كركثور جلوه

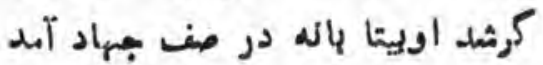
ودر راه جهاد از هيهكونه إيهار

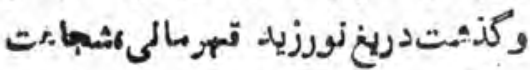

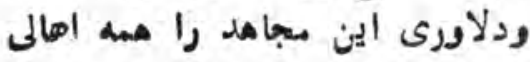

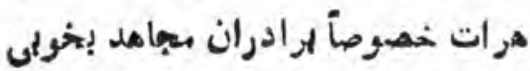
مى دانيد اود'راق اخلاق هميده ودرمساشرت باسمدم بتواضع وفروتن

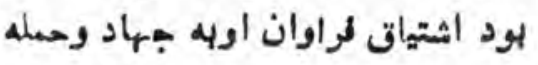

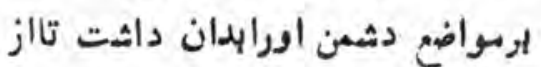

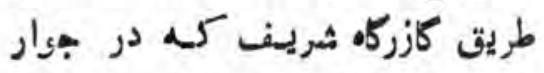
فرقه vا قرار دارد عمليات :هبادى

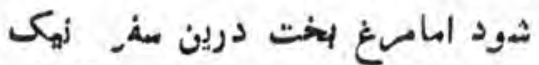
هنظر باوهمبال نبود ودرمدل كرزكا.

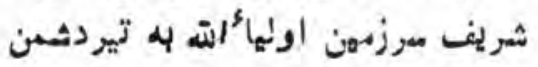
كافر به لقاهاتهايوست ـ تاريخشهبادت

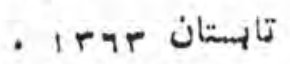

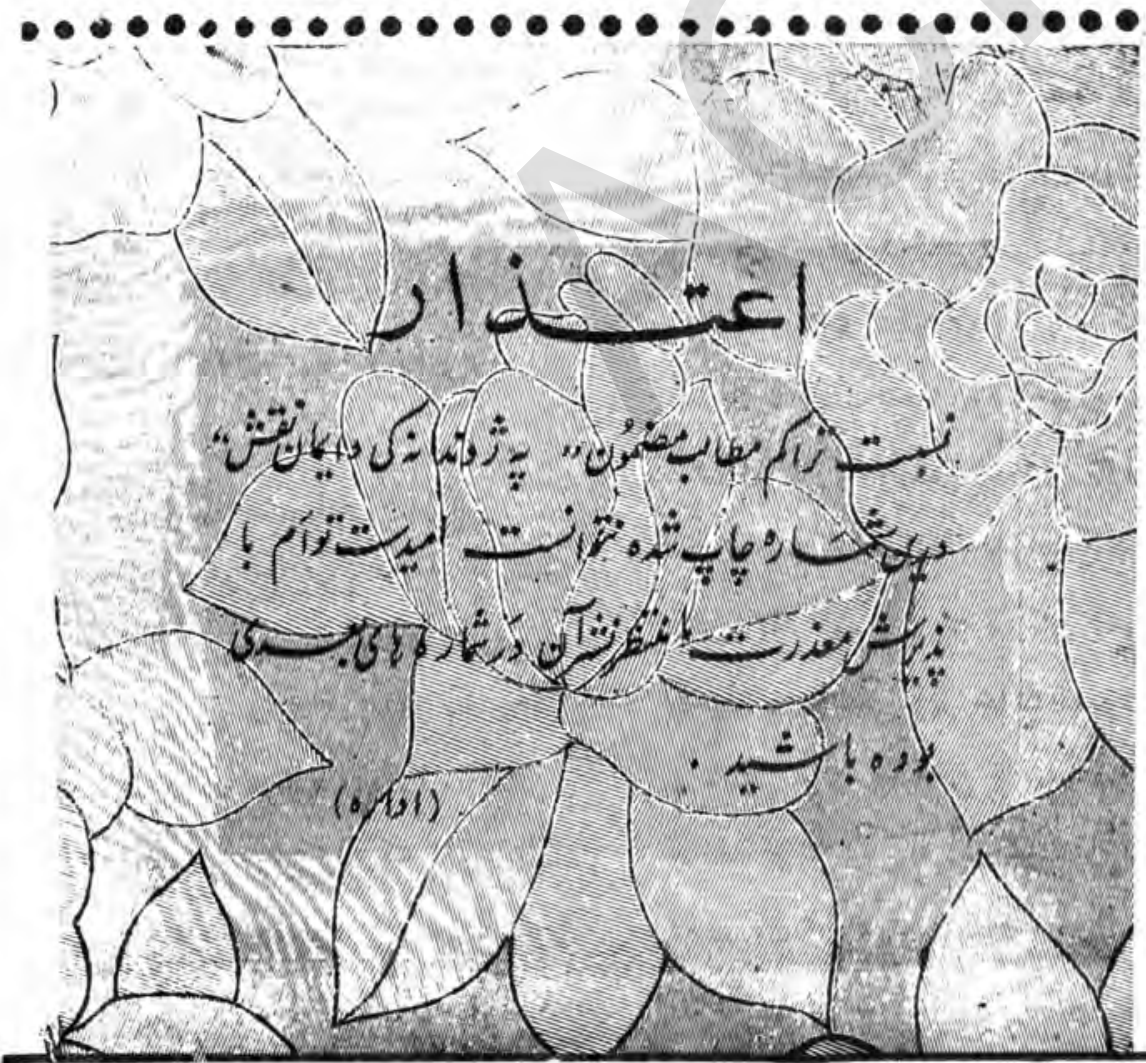

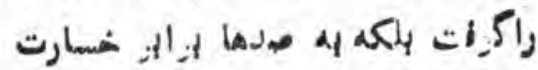

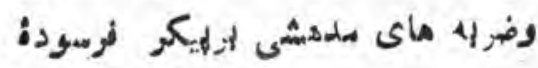

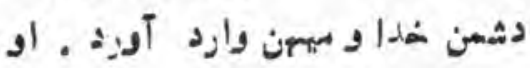
ليز بالاخره در شخزان مجهم 1 دريكى

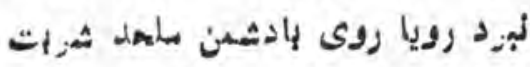

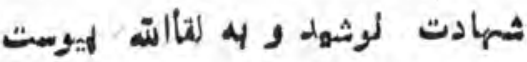

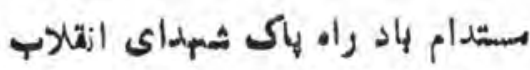

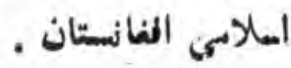

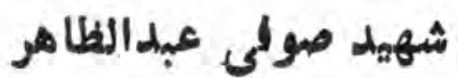
ثمهيد صوفى عهد الظاهر فرزلد فيلد

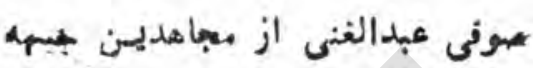

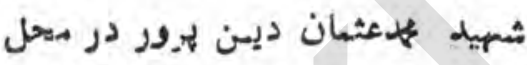
كارته مسإوطات ولسوالى انجيل ولايت هر:ات بدنيا آهد ايام كودىى را نزد هدر وملا به سبق كذر اند تادر خشش اليد

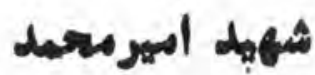




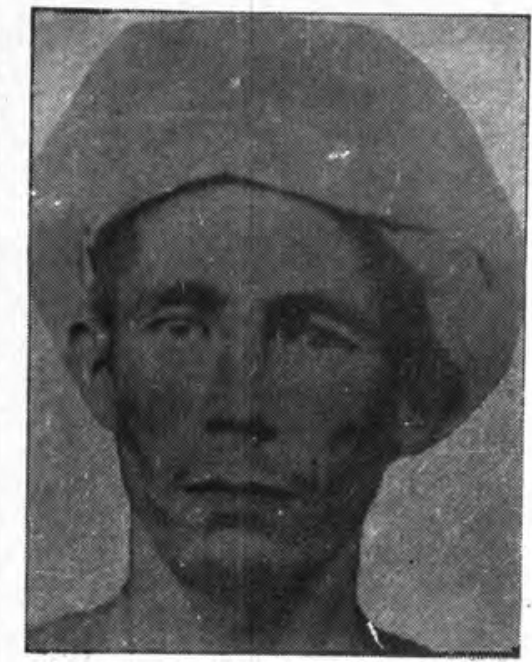

كلومالدان عبد النيض شهمه :

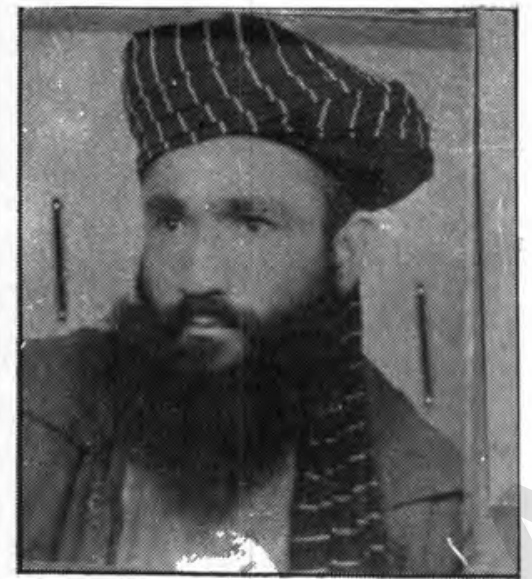

شهيه

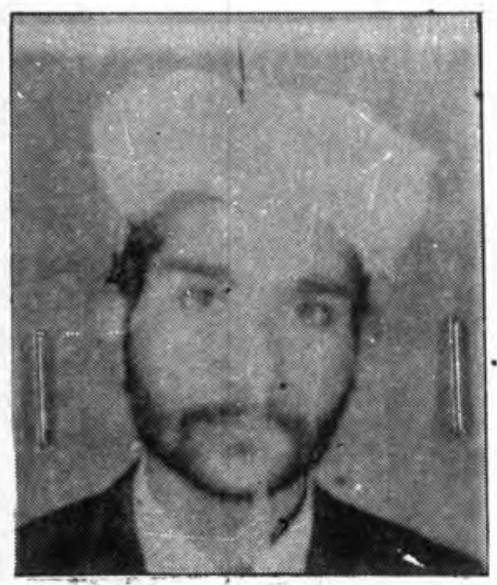

ثمهيد مولوى لورامهد

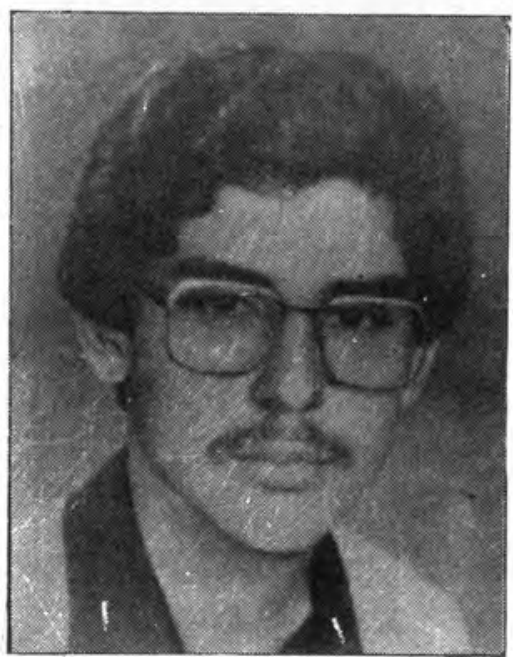

كهبيد هـ اكبر

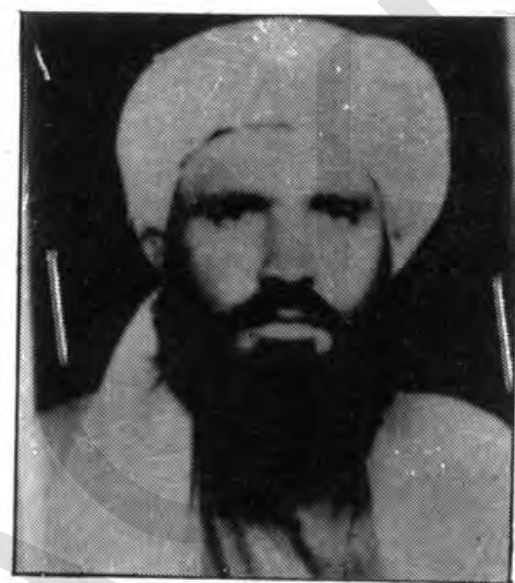

شهيد صوفى عبدالفنى

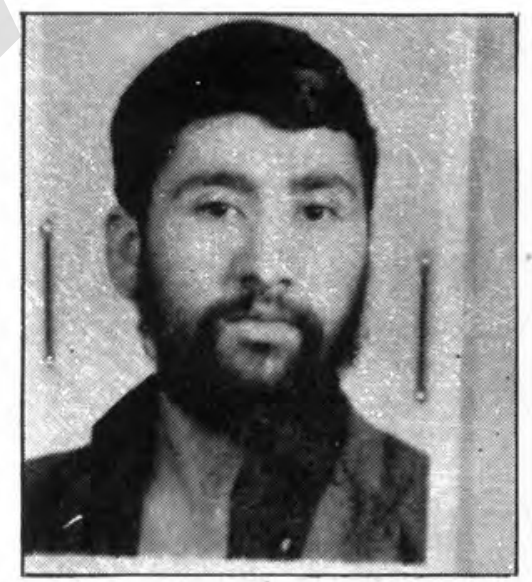

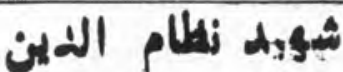

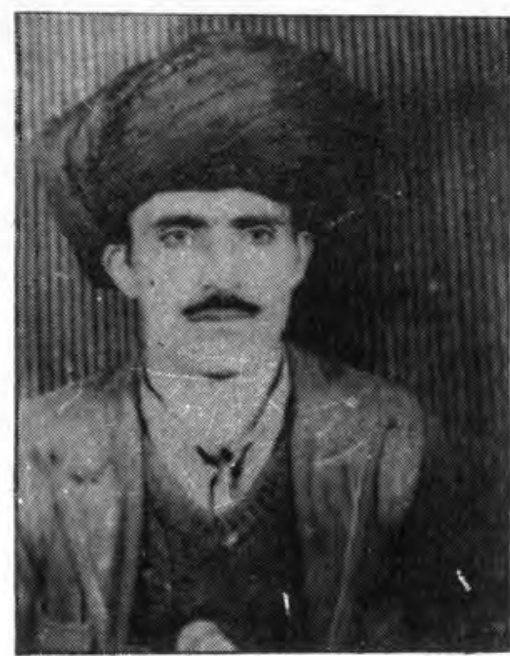

ملطان * شعيد سشهور بهملنك
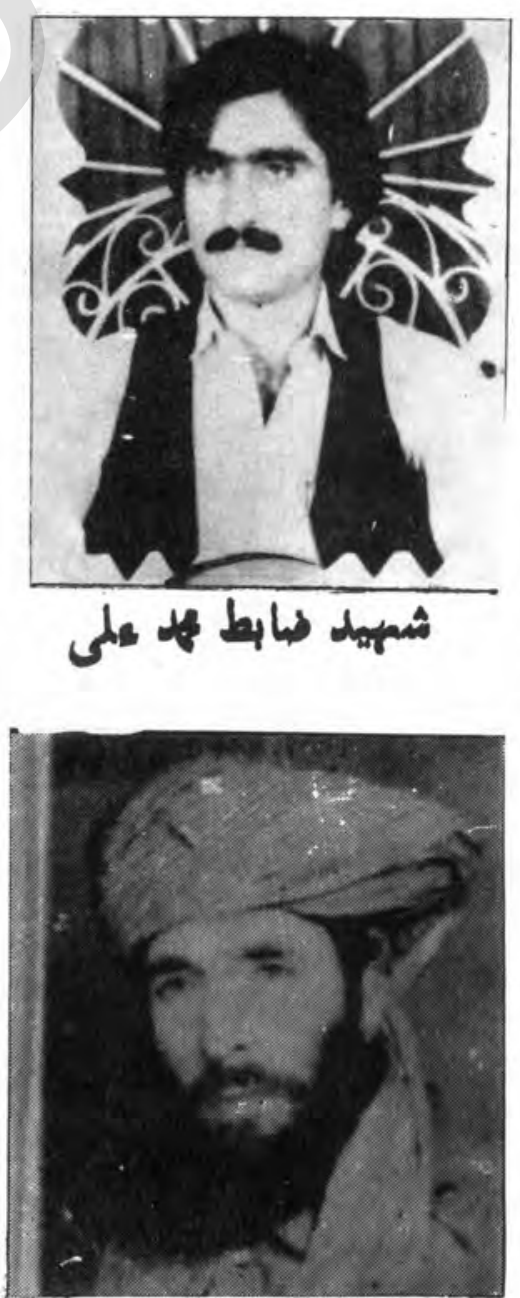

شهمه مبدالواهد 
111

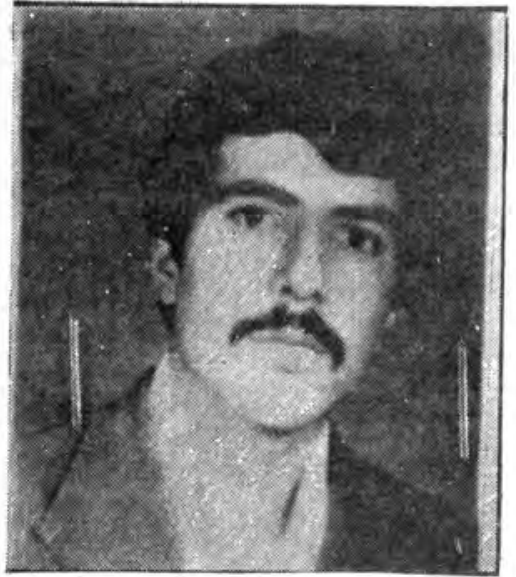

شهيد داكتر غلام سوور

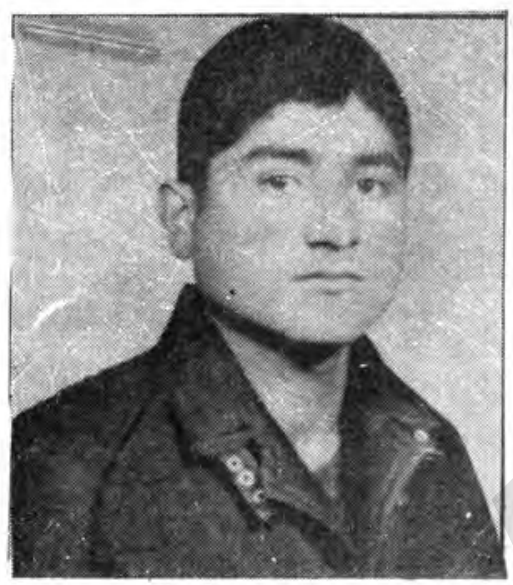

شهم هماكرام

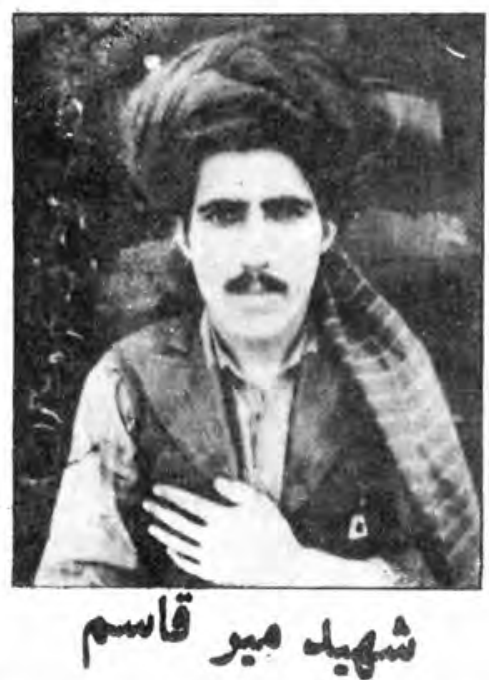

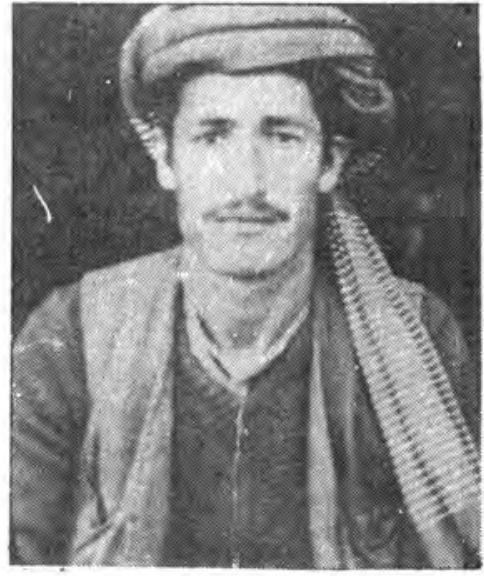

شهميد عبدا لعزيز

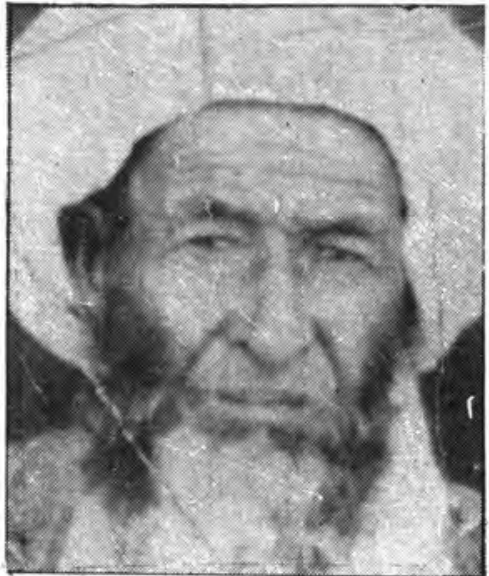

شهيد بابه مسن

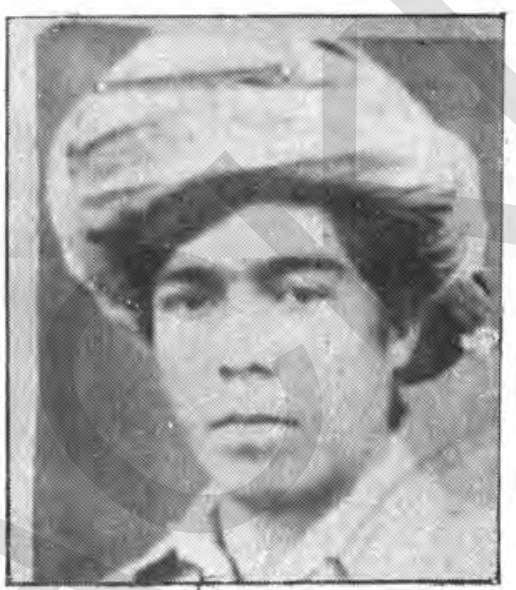

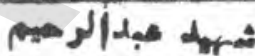

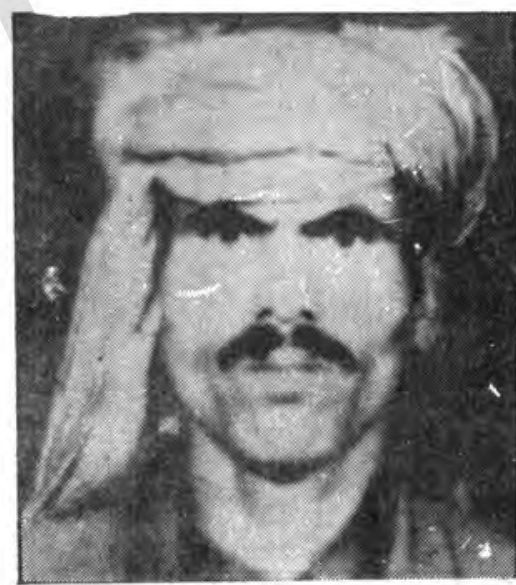

شهميه جانكل

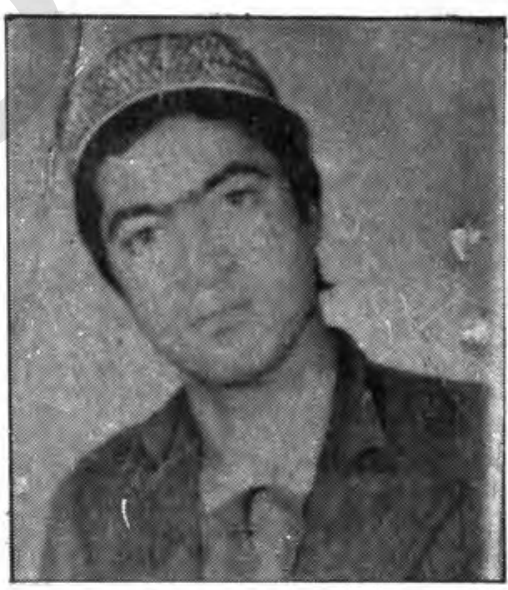

Dil

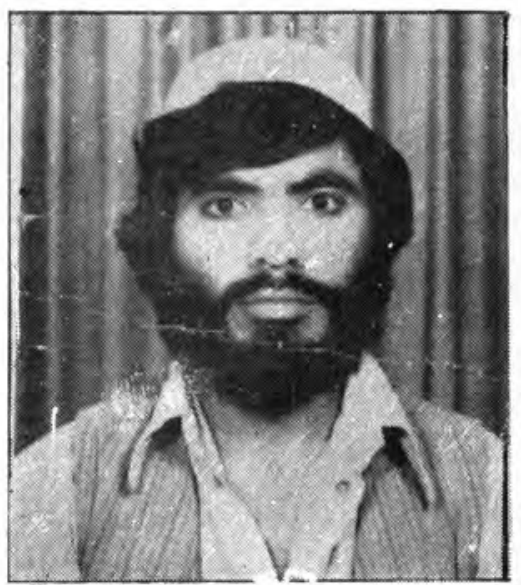

مهيد طره باز 


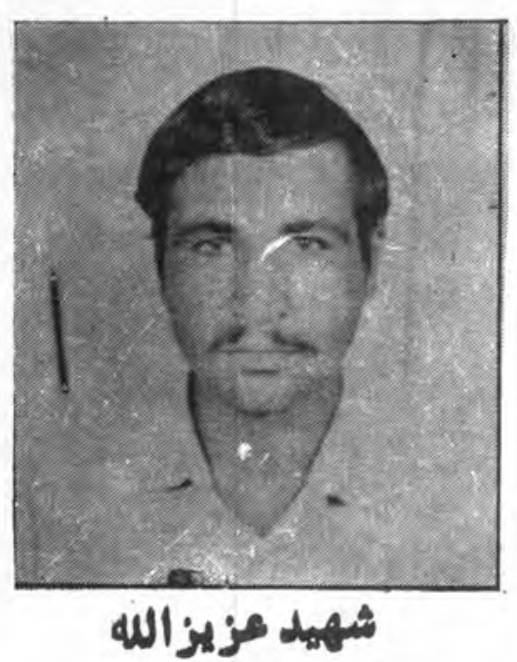

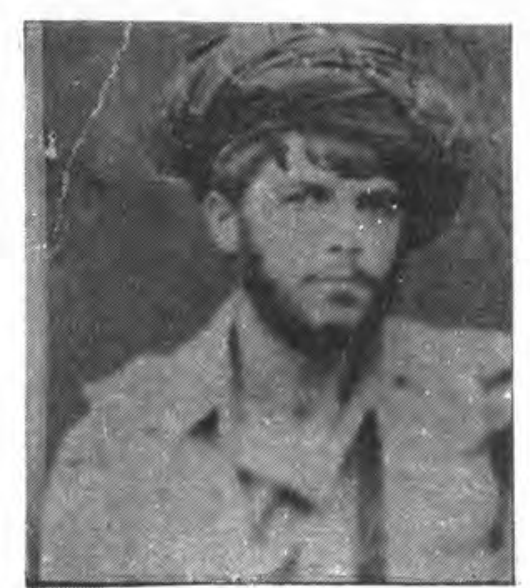

مهيد هبد السلام

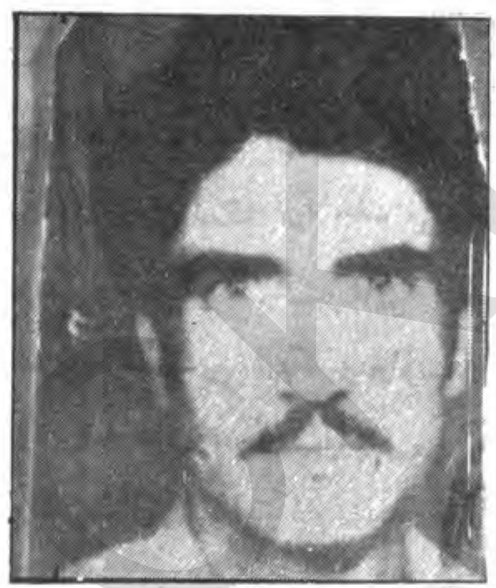

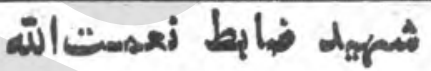

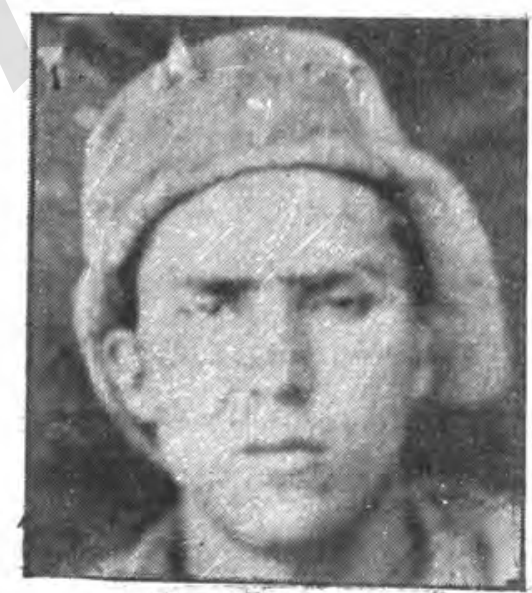

شهيد قوبان قليج
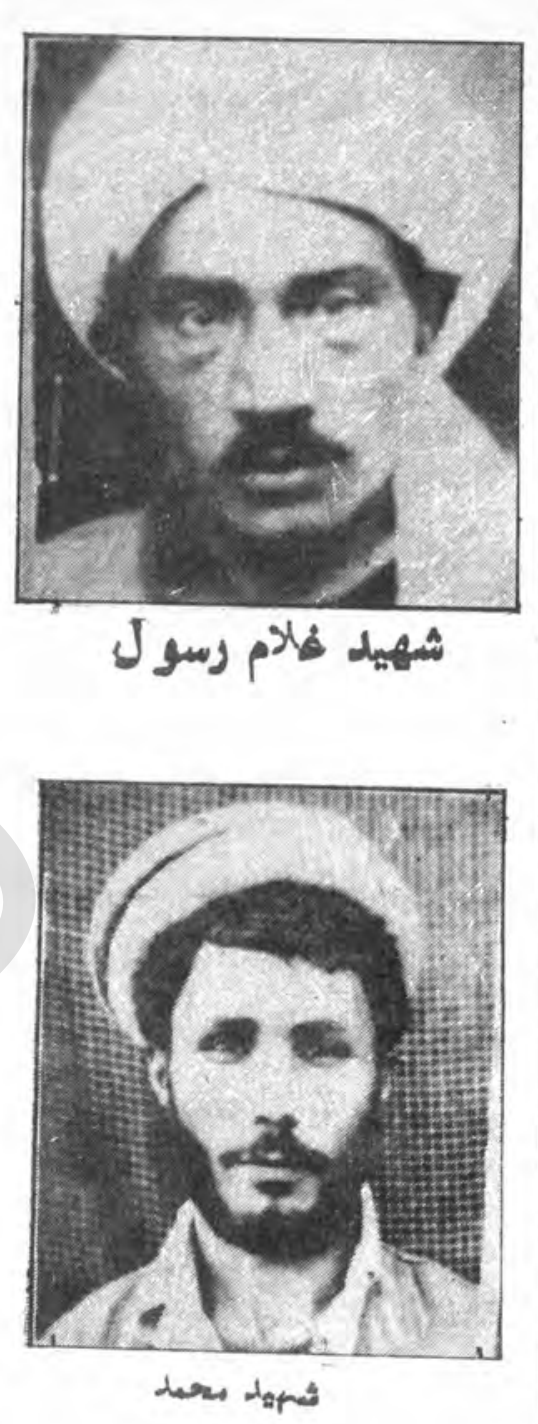

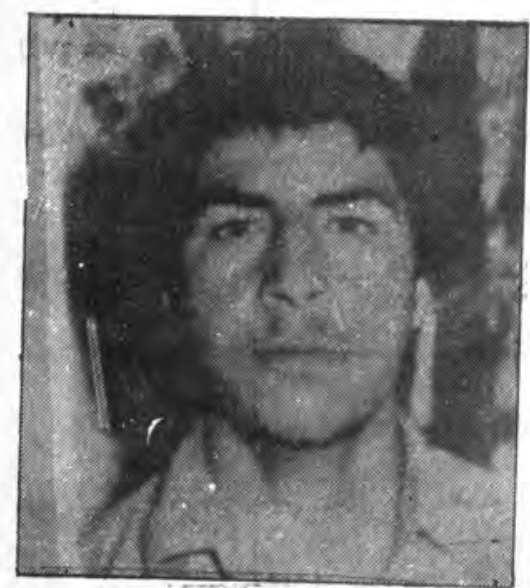

ثهيد عبد الطا هو 
Ir.

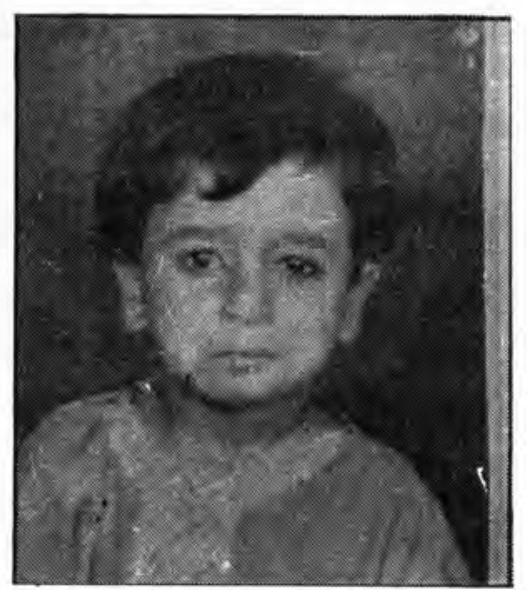

شهيد نسيرويس

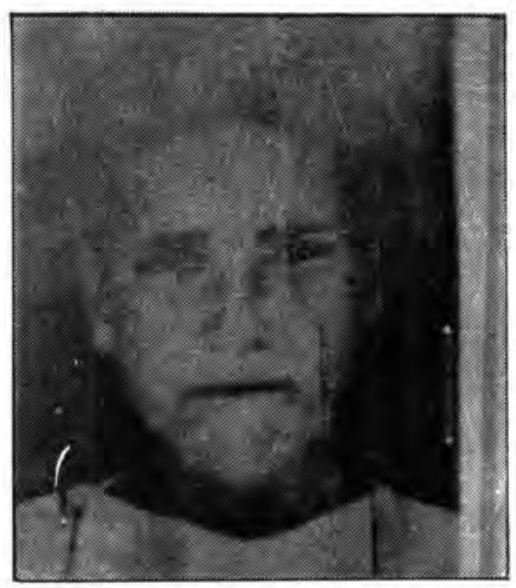

ثهيه تبدالقدوس

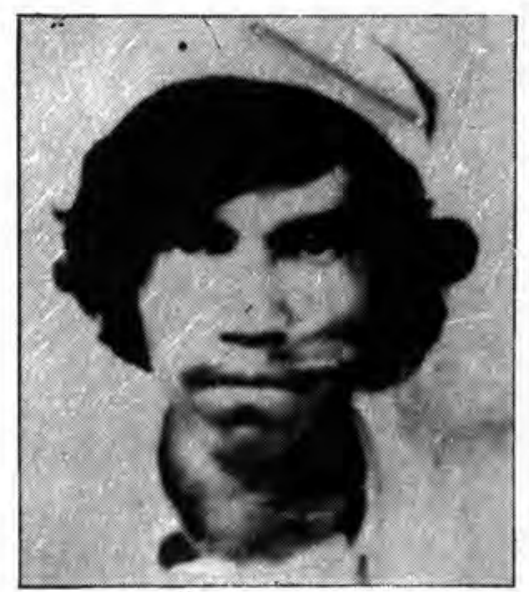

شهيد

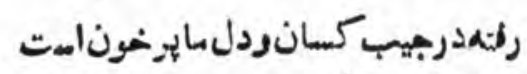

آخر قرض ندائم شخداياهـون ناست

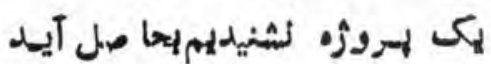

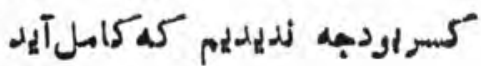

لآيه در ثمسارة آينده.

- -10
كرضها كم اكثرأ بشكل مساسان آلات واشياى غير ضرورى لرداخت بىثيد

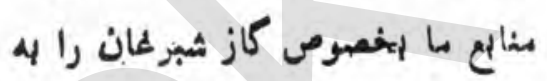

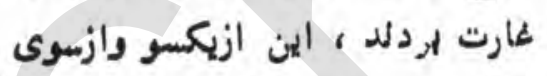

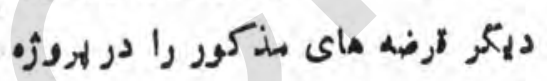

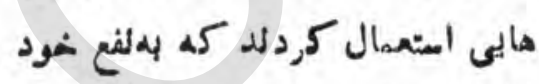

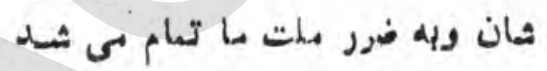
ودر لهملوى آن به بهاله ايزعه ايسن

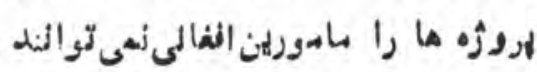

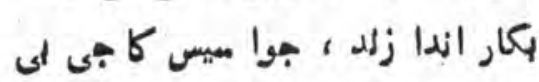

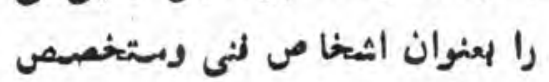

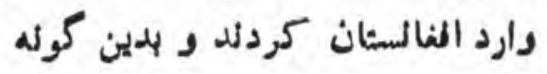
روز تا روز در ماهات مشتلف زندكى

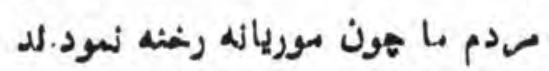

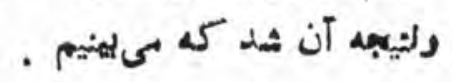

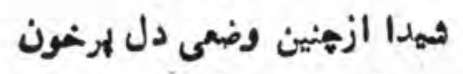

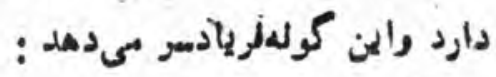
ترض ايندالر ماتابهزاربلميونامت واتيت

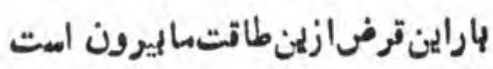

\section{بياد ديدا شاعر. ...}

يكى از زهر نكهاى رذيالانداستشمار

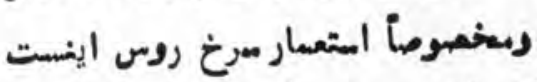

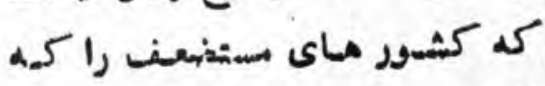

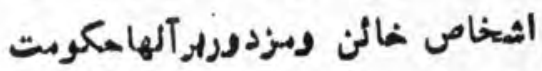

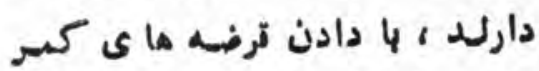

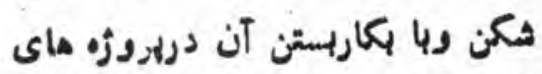

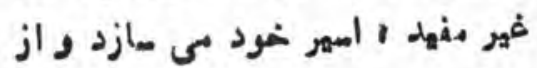

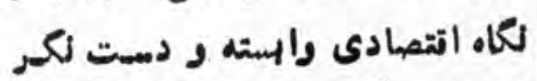

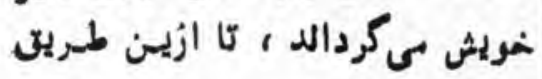

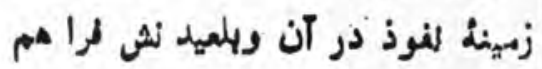
كردد . روسها در مهل ما ل ملطنت مرا لبا كلساد وخيالت وجنايت ظاهرثاه ازنين روش شهطا كى كار كر فتند و

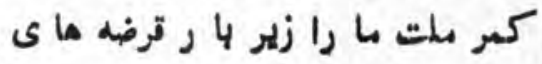

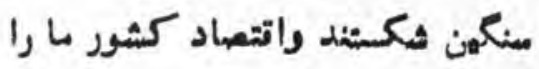

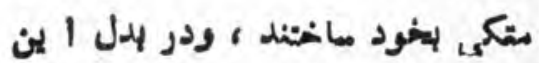


الفاظ آيث ازين قرار اهت : لمارليعل

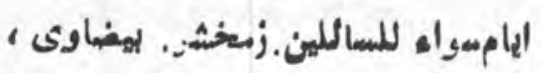

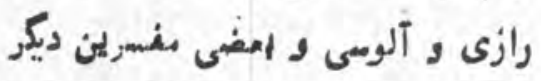

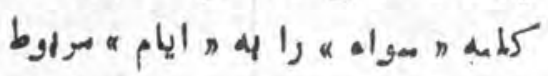

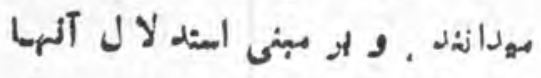

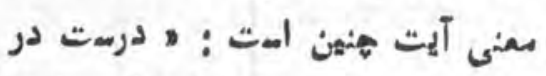

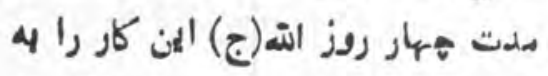

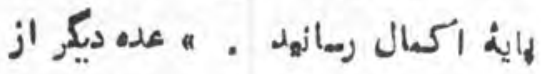

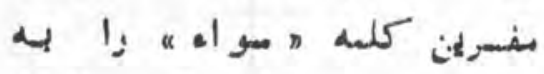

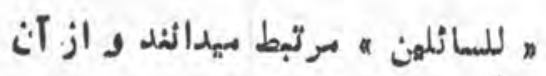

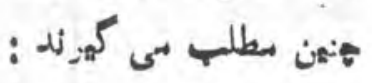
" مهيسا بـزاى تمام مطالبه

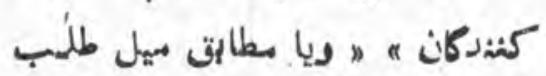

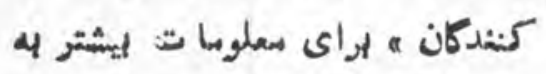

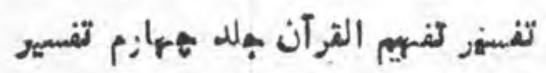
آيه (هم السبهده) مراجعه فرمائيد .

الهادوو...

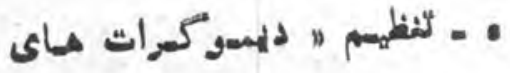

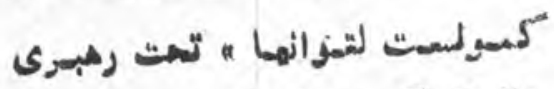

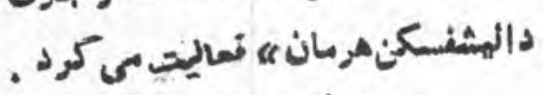

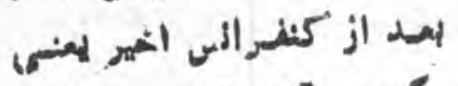

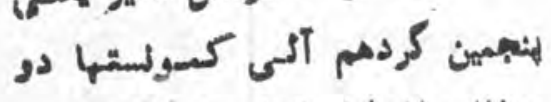

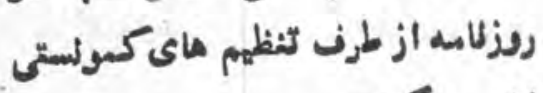

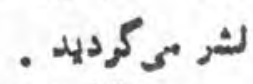

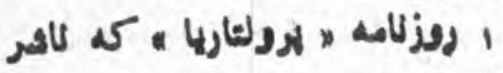

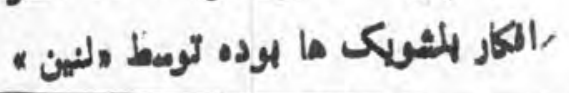

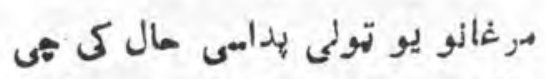

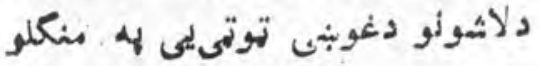
كى وى او يوله بل مبره جنكيدونكى دونى اد له شور او زوي اخته وو دجنرال سهل هام شُماتنهوار اوه. جنرالسيل لومثو بيى د ديرش

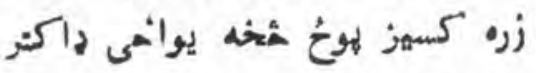

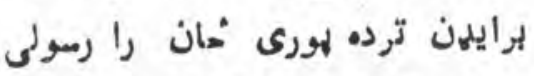

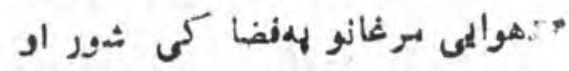

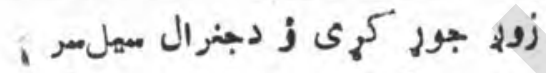

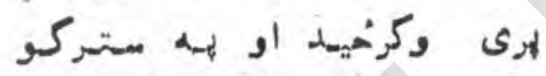

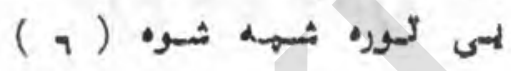
اقتصاد اسلامى ... (1) آبه فون 4 جزم وتاكيد لهراين وهم سهر بى كوبد كم انسانها

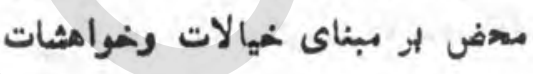
اله تحريم وتحليل هميزى فيعله كنيد

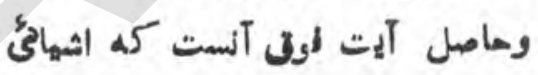

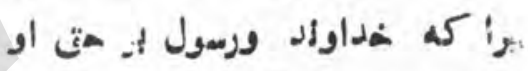

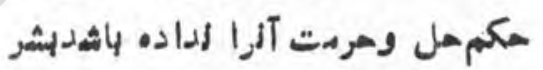

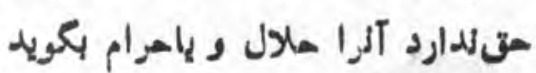

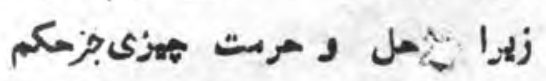

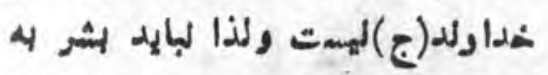
آن تومل جوائد وله خهداوند (ج)

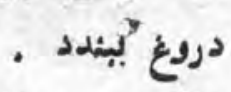

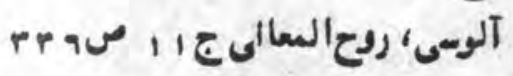

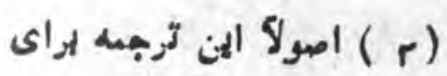

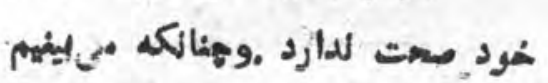

... غار

دجنرال سول دمقر تر سخى به

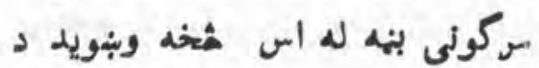

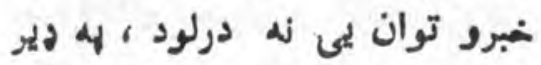

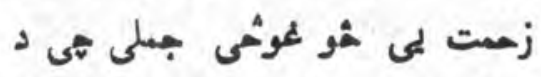

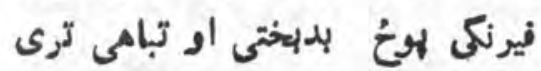

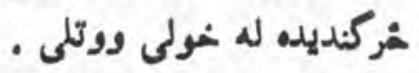
دجنرال سهل لارى له نهوله

كى وجى وى لهه وار خطا او نبتى لهن

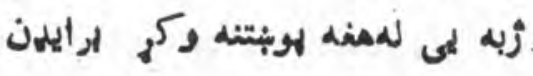

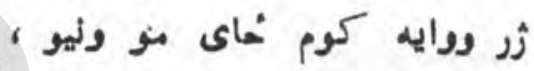

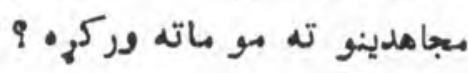
زمواءلبنكرى وزى دى لباس نلرى ؟

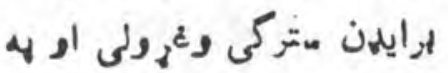

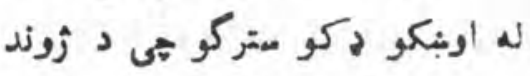

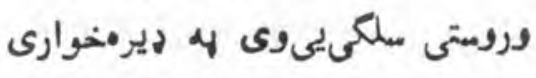

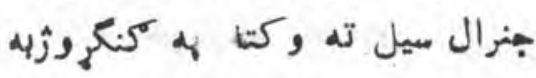

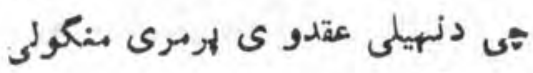

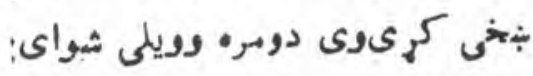

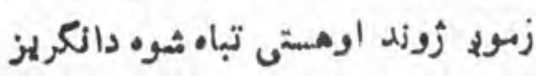

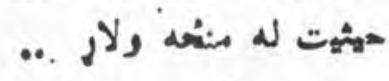

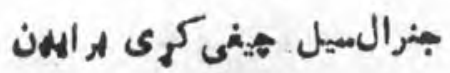

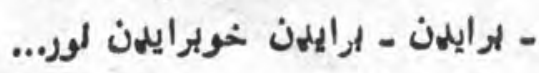
جنرالسيل جاريهانراو عوبيتل هى جار وومى كولدى دماتى خورل

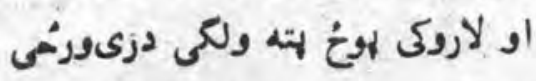

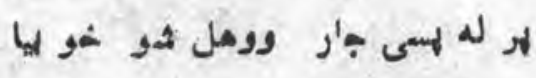

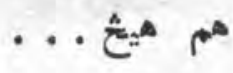
له دريو ورثمو وروستيه دهوالمى 
در اخهر بكبارديكر لمرار مى

كردد ك5ه مردم آكه و لهيذار ما در

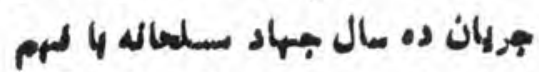

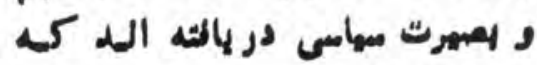
دروعماى علعنوى و منسات درولهين

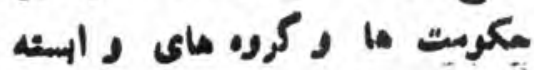

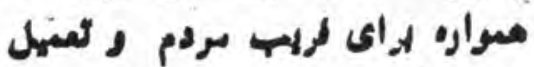

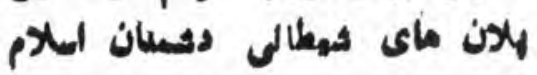

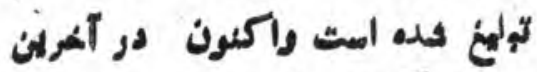

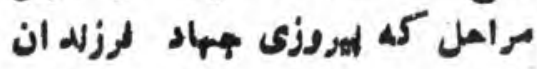

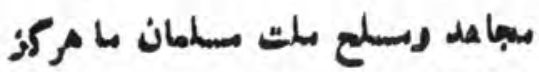

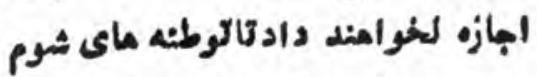

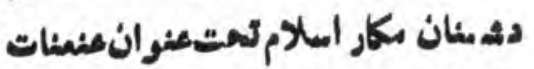

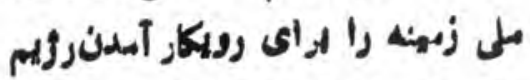

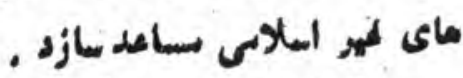

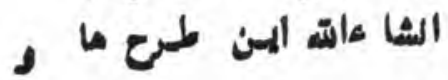

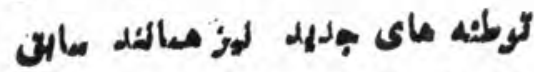

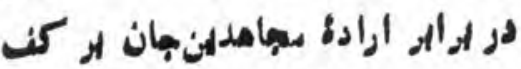

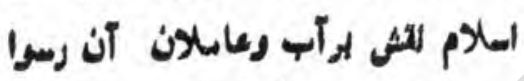

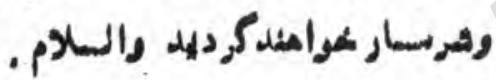

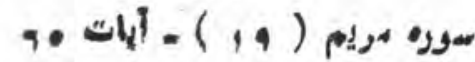

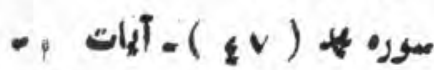

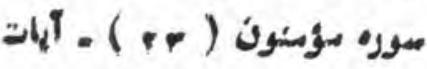

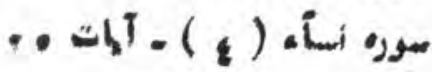

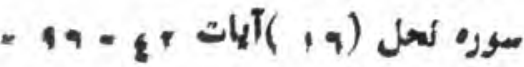

$142-1,2=1$,

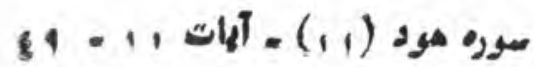

110

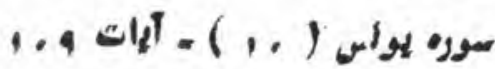

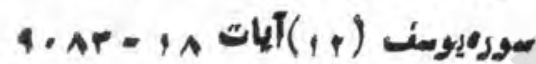

\section{... vgiad ot ess.}

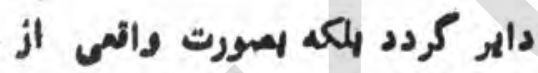

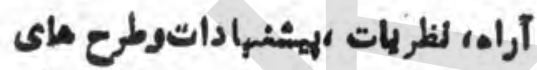

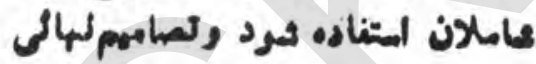

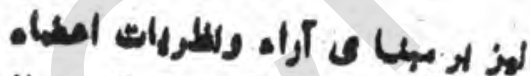

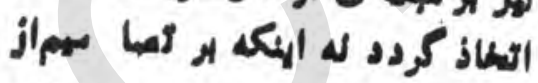

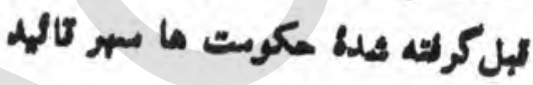

زمه شود

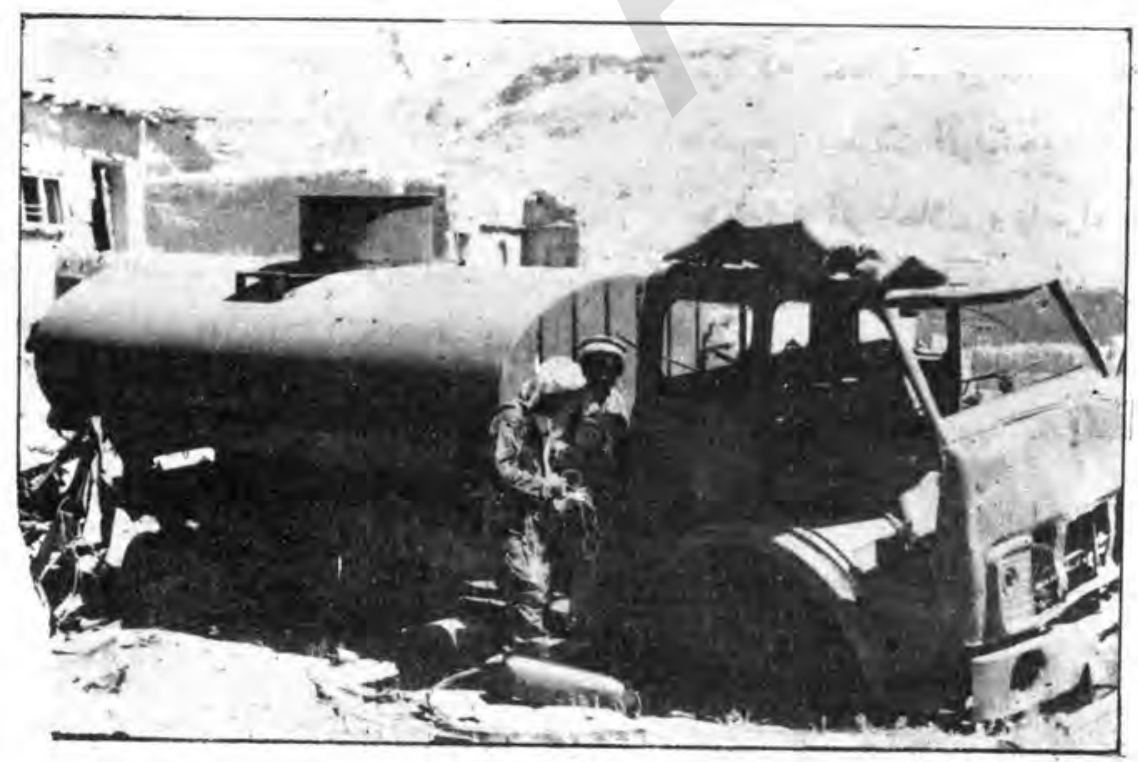

الهودى وزلينولهيف الهودى وكامهنيف

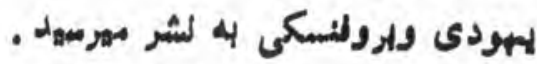

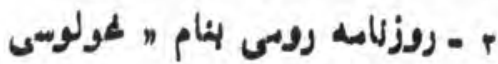

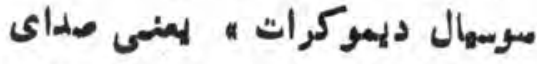
اشثراكي د دايهوكرات كسه از طرن

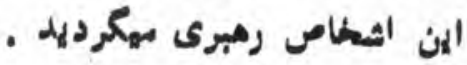
| سارتوف لهودى . " ـ اكسرود لبهودى .

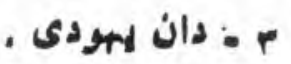

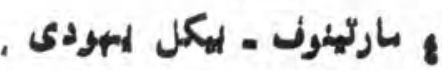
•.

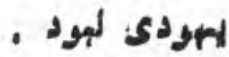

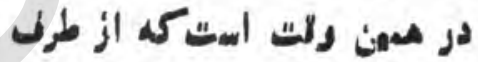

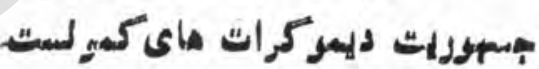

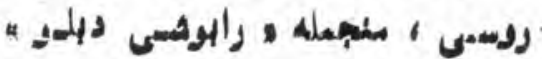

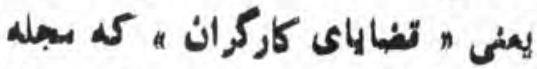

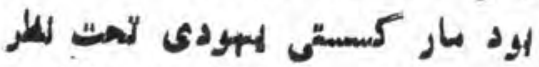

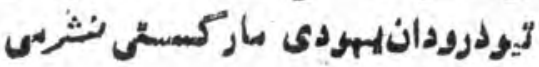

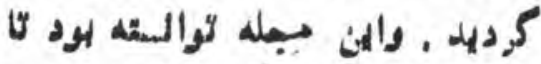

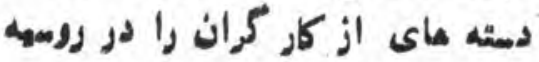

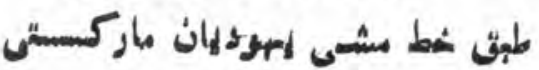

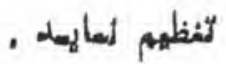

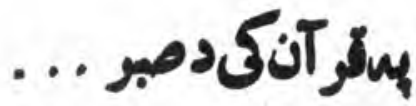
موروه عصر ( r.1 ) آليات م

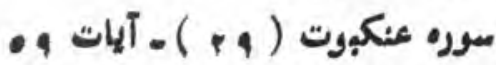

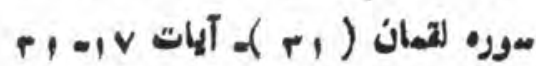

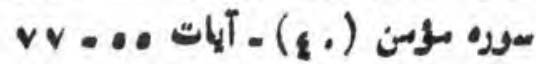

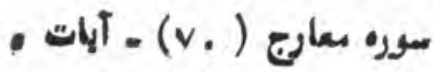

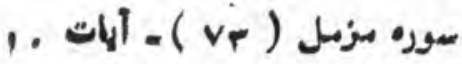

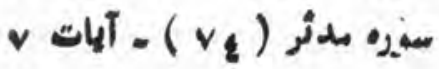




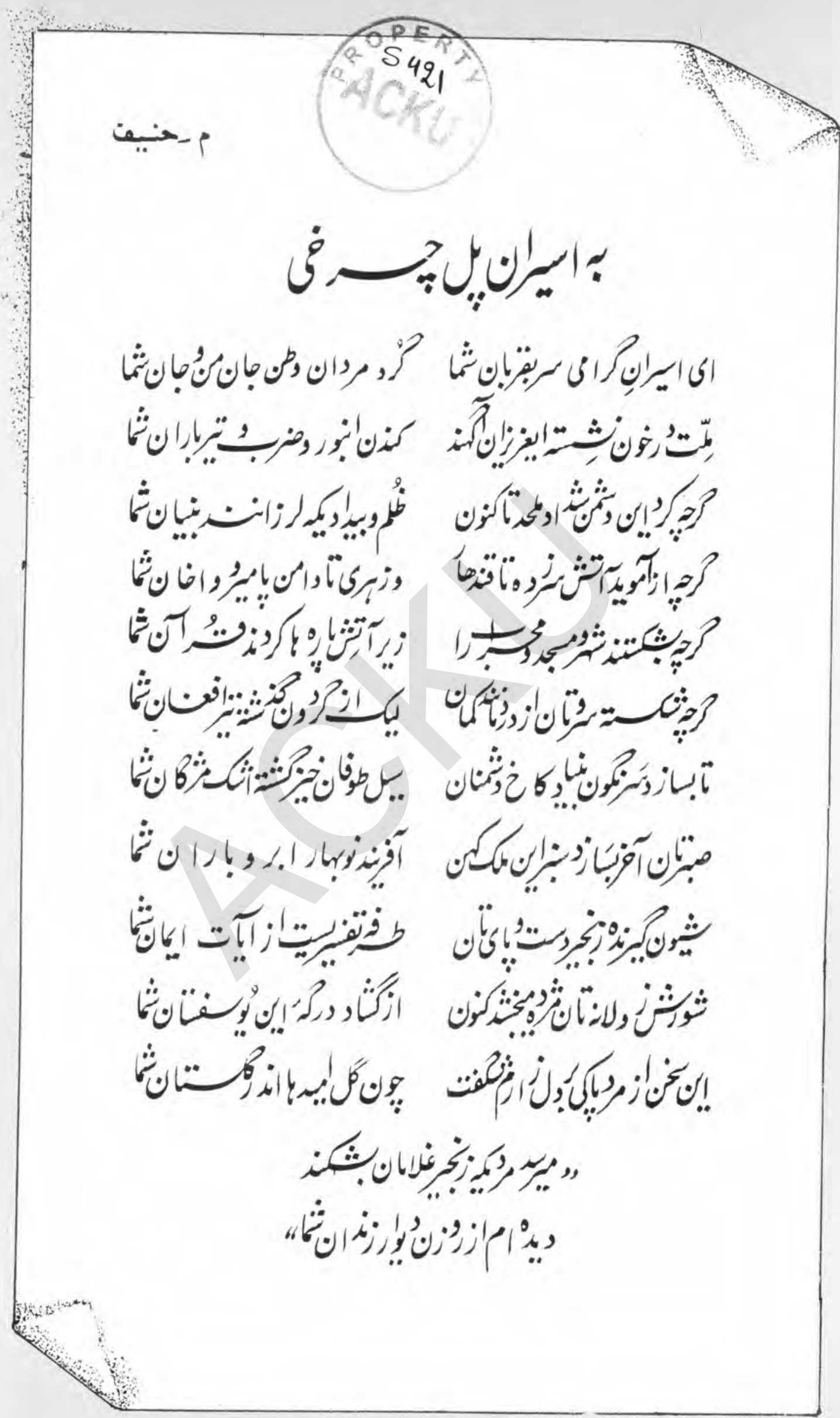

تصوير هاى روى ـ عقب جلد از : مؤز نشراتى افغان (مدياسنتر) 

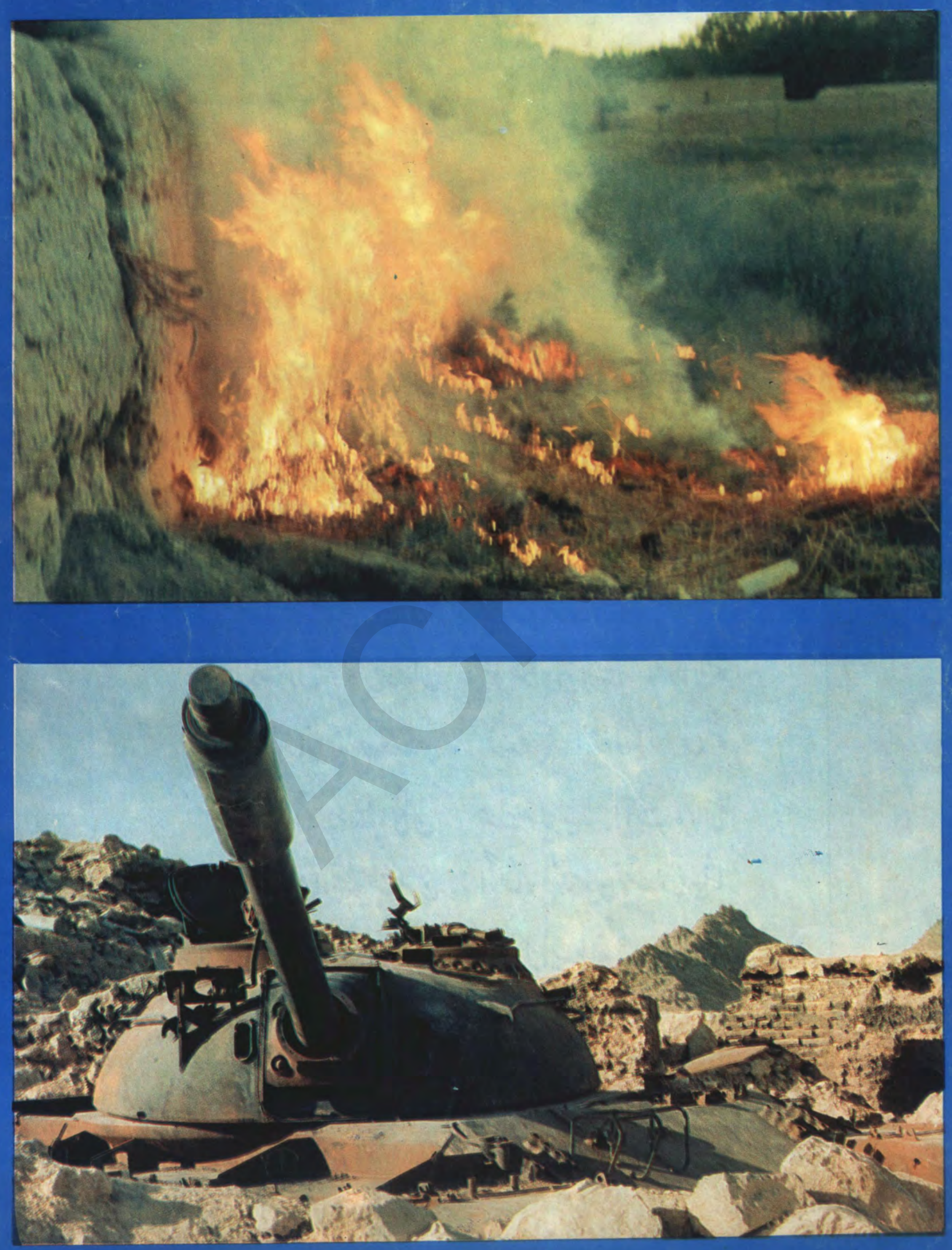